Universidade de São Paulo

Instituto de Física

\title{
Apropriação da linguagem científica por parte dos alunos em uma sequência de Ensino de Física Moderna
}

\author{
João Freitas da Silva
}

Orientadora: Prof. Dra. Anna Maria Pessoa de Carvalho

Dissertação de mestrado apresentada ao Instituto de Física, ao Instituto de Química, ao Instituto de Biociências e a Faculdade de Educação da Universidade de São Paulo, para a obtenção do título de Mestre em Ensino de Ciências.

Comissão Examinadora:

Profa. Dra. Anna Maria Pessoa de Carvalho (USP)

Profa. Dra Deise Miranda Vianna (UFRJ)

Prof. Dr. Mauricio Pietrocola Pinto de Oliveira (USP) 


\title{
FICHA CATALOGRÁFICA \\ Preparada pelo Serviço de Biblioteca e Informação do Instituto de Física da Universidade de São Paulo
}

\author{
Silva, João Freitas da
}

Apropriação da linguagem científica por parte dos alunos em

uma seqüência de ensino de física moderna - 2009.

Dissertação (Mestrado) - Universidade de São Paulo.

Instituto de Física e Faculdade de Educação

Orientadora: Profa. Dra. Anna Maria Pessoa de Carvalho

Área de Concentração: Ensino de Ciências e Matemática

Unitermos: 1. Ensino e Aprendizagem; 2. Física Moderna;

3. Linguagem. 
"Meu amor, disciplina é liberdade compaixão é fortaleza ter bondade é ter coragem" Legião Urbana 


\section{Agradecimentos}

Agradeço a Deus pelas oportunidades e pela sabedoria em saber aproveitá-las.

Com certeza o primeiro passo para este momento foi dado quando minha mãe, antes mesmo da escola, me apresentou ao "incrível mundo da escrita e leitura", quando as histórias em quadrinhos me fascinavam e incentivavam para que eu aprendesse logo a ler e escrever para desfrutar desse mundo fantástico.

Depois veio a escola, onde aprendi a respeitar os professores em seu difícil trabalho e admirar a quantidade de informações e interações que são possíveis nesse ambiente. E por fim, o universo acadêmico, onde fui apresentado ao estimulante mundo da pesquisa.

Portanto não posso deixar de agradecer:

Aos meus pais Durvalina e Manoel e a minha irmã Aparecida que constituíram minha base de formação e até hoje acompanham meus passos, agora com a presença dos sobrinhos Tiago e Milena e do cunhado Osvaldo.

Aos meus professores com os quais tive contato, em maior ou menor grau, mas que sempre deixaram alguma contribuição para minha vida escolar e pessoal.

À minha esposa e companheira Zélia, por todo apoio e paciência, principalmente nos momentos em que me encontrava em dificuldade.

À minha orientadora Anna Maria que, além da indiscutível contribuição com seus conhecimentos sobre a pesquisa acadêmica e suas valorosas críticas em busca sempre de um trabalho melhor, ainda teve paciência e me amparou e animou em momentos que me encontrava em dificuldades.

Àqueles que me incentivaram a acreditar na possibilidade de um Mestrado: professor Maurício Pietrocola que também forneceu valorosas contribuições na qualificação, e os amigos Émerson, também companheiro de LaPEF, professora Marines, colega de profissão, e Paula, ex-aluna e hoje colega acadêmica.

Ao professor Josias Paiva, companheiro de LaPEF e de tantos trabalhos, que permitiu a gravação de suas aulas e ao longo do trabalho contribuiu com suas observações e comentários.

Ao Júlio, colega de LaPEF, que ajudou muito durante a fase de gravação das aulas. As aventuras para conseguirmos chegar à escola.

À Cristina, pela importante contribuição com as transcrições.

À professora Nobuko, por toda sua atenção sempre que precisei e pelas contribuições durante a qualificação. 
Aos professores com os quais tive um contato direto durante o Mestrado: Alberto Villani, Anna Maria Pessoa de Carvalho, Luiz Carlos de Menezes, Nobuko Ueta, Osvaldo Pessoa, Silvia Trivelatto e Suzana Salém.

Ao Daniel e demais colegas de curso.

Valeu pela colaboração Daise e Jennifer e claro, Geane pela revisão.

A todos os colegas do LaPEF que sempre contribuíram com suas críticas e sugestões ou mesmo com apoio e também serviram de inspiração pelos trabalhos que desenvolvem: Alex, André, Cândida, Carla, Cristina, Dani, Guilherme, Ivã, Jackson, Jorge, Lucia, Luciana, Maxweell, Nelson, Nicole, Rogério, Valéria e Wellington. Também pelos momentos de descontração. André, Josias, Maxwell e Wellington, agradeço também pelos nossos raríssimos, mas importantes momentos de lazer com jogos de vôlei, basquete e futebol.

Realmente só posso dizer: Obrigado a todos! 


\section{Resumo}

Silva, J. F. da. Apropriação da Linguagem Científica por parte dos alunos em uma sequência de Ensino de Física Moderna. 2009. Dissertação (Mestrado) - Instituto de Física e Faculdade de Educação, Universidade de São Paulo, São Paulo, 2009.

Nesta pesquisa analisamos duas atividades práticas, envolvendo alunos do terceiro ano do Ensino Médio, que fazem parte de uma sequência de Ensino de Física Moderna. Na primeira das atividades, os alunos observam e analisam os espectros da luz proveniente de determinadas lâmpadas com o auxílio de espectroscópios construídos com redes de difração provenientes de pedaços de $\mathrm{CD}$, e na outra, buscam identificar quais elementos químicos estão presentes em algumas estrelas, comparando espectros hipotéticos destas com os espectros de alguns elementos químicos.

Na Sequência de Ensino adotada, essas atividades estão localizadas exatamente no momento de transição entre a Física Clássica e a Moderna e servem para introduzir o Modelo Atômico de Bohr e a quantização dos níveis de energia como explicação para os espectros de emissão e absorção da luz.

Buscamos analisar "se" e "caso ocorra" como os alunos se apropriam das linguagens científicas e de termos técnicos durante a realização das duas atividades práticas, bem como a presença de indicadores da Alfabetização Científica. Também procuramos analisar as estruturas das argumentações presentes na aula. Por fim, analisamos o envolvimento dos alunos com as atividades.

Para tanto, fizemos uma revisão sobre as linguagens científicas, destacando a linguagem verbal/oral, a gestual e de manipulação e sobre estrutura de argumentação no Ensino de Ciências baseados no Modelo de Toulmin (1958), Van Eemeren et al. (1987) e adaptações para esses modelos em trabalhos como os de Jiménez Aleixandre (1998), Villani e Nascimento (2003), Capecchi (2004) e Carmo (2006).

As análises foram feitas a partir das transcrições das aulas gravadas em DVD.

Tais análises remetem à importância das linguagens científicas e das argumentações para acompanhamento do processo cognitivo em sala de aula. Indicam também a importância que deve ser dada às linguagens para compreensão do processo ensino-aprendizagem, bem como a necessidade de perguntas que estimulem a argumentação por parte dos alunos.

Palavras-chave: Ensino e Aprendizagem, Física Moderna e Linguagens. 


\begin{abstract}
Silva, J. F. da. Appropriation of scientific language by students in a sequence of Teaching
\end{abstract} of Modern Physics. 2009. Dissertação (Mestrado) - Institute of Physics and School of Education, University of São Paulo, São Paulo, 2009.

In this research we analyze two practical activities, involving students from the third year of high school, which are part of a sequence of Teaching of Modern Physics. In the first activity students observe and analyze the spectra of light from certain lamps with the aid of spectroscope diffraction networks built with pieces of a CD. The second one seeks to identify which elements are present in some stars, comparing theoretical spectra of it with the spectra of some chemical elements.

Following the Education adopted, these activities are located exactly at the transition between the Classical and Modern Physics and are useful to introduce the Atomic Model of Bohr and quantization levels of energy as an explanation for the emission and absorption of the spectra of light.

We examined whether, and if it occurs, as students are aware of scientific language and technical terms during the performance of both practical activities and the presence of indicators of scientific literacy. We also seek to analyze the structures of the arguments in the class. Finally, we analyzed the involvement of students with the activity.

Thus a scientific language review was made highlighting the verbal/oral language, the gestural and handling ones and on the structure of argument in science education based on the Toulmin Model (1958), Van Eemeren et al. (1987) and adaptations to these models in studies such as Jiménez Aleixandre (1998), Birth and Villani (2003), Capecchi (2004) and Carmo (2006).

The tests were made from transcripts of lessons recorded on DVD.

These tests refer to the importance of language and scientific arguments for the monitoring of cognitive process in the classroom. They also show the importance of languages to understand the teaching-learning process and the need for questions that encourage reasoning by students.

Keywords: Teaching and Learning, Physics and Modern Languages. 
1. Capítulo I - Problemas, objetivos e delimitação de estudo...............................................08

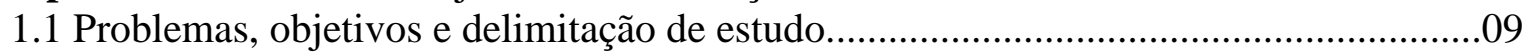

1.2 Grupo de pesquisa LaPEF (Laboratório de Pesquisa em Ensino de Física)...................18

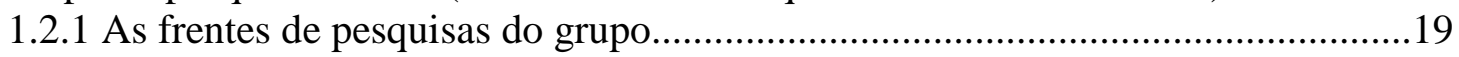

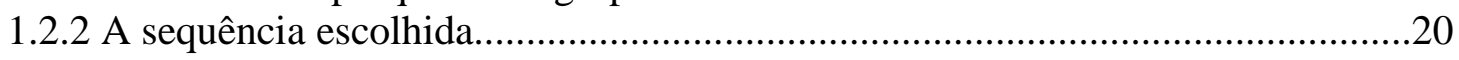

2. Capítulo II - Conceitos Físicos importantes da sequiência de Ensino e sua contextualização

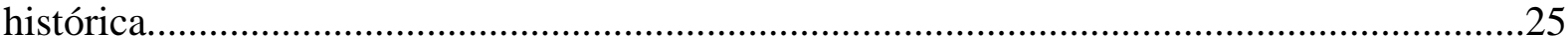

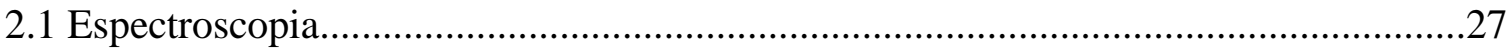

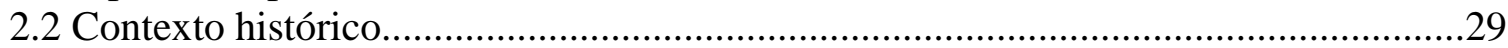

2.3 Espectros de absorção e espectros de emissão.............................................................

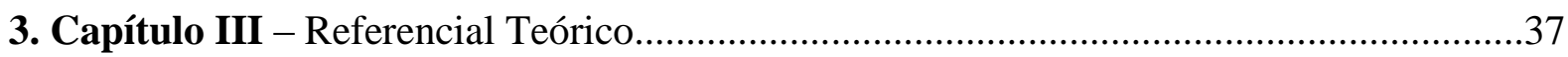

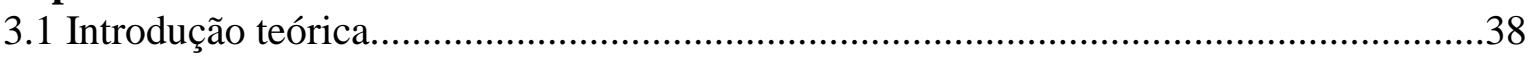

3.1.1 A importância da linguagem na Ciência e no Ensino..............................................38

3.1.2 Linguagens da Ciência no Ensino....................................................................41

3.1.3 Argumentação no Ensino de Ciências....................................................................51

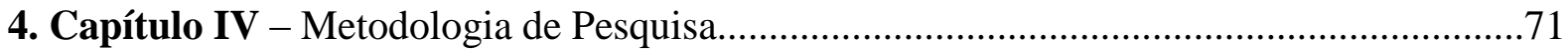

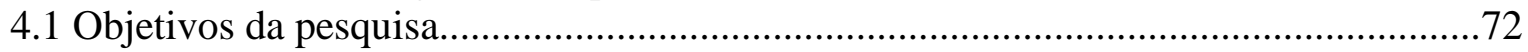

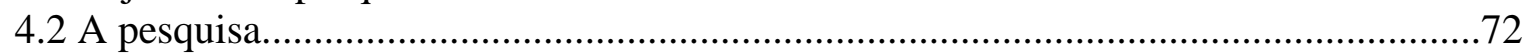

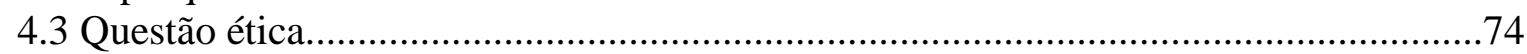

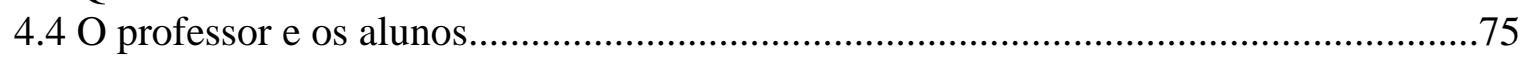

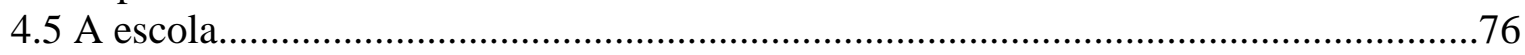

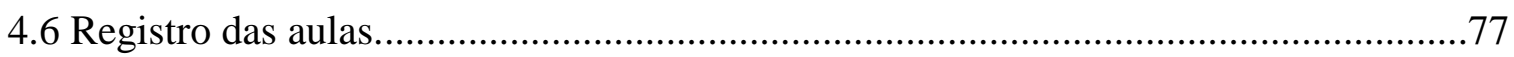

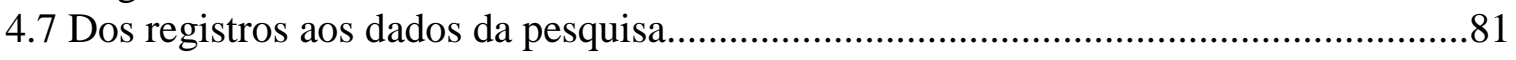

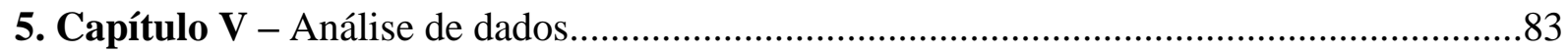

5.1 Análise de dados e os instrumentos utilizados para essa análise ..................................84

5.2 Episódio 1 - atividade de observação das lâmpadas e seus espectros..............................88

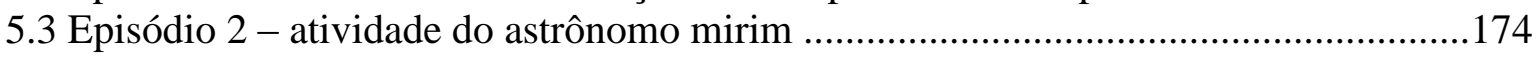

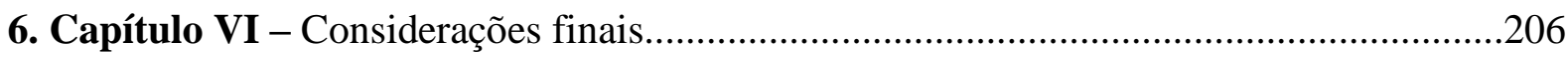

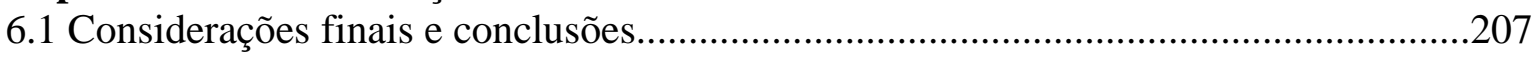

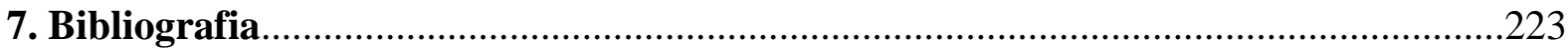

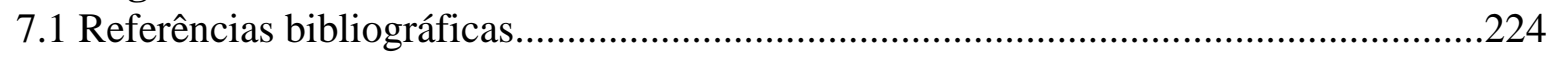

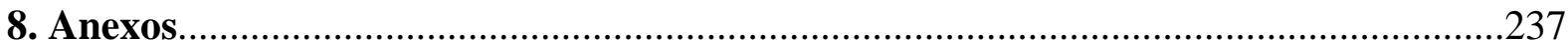

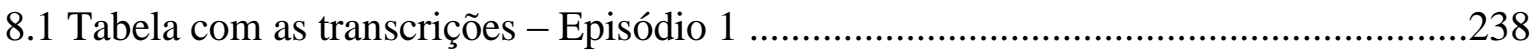

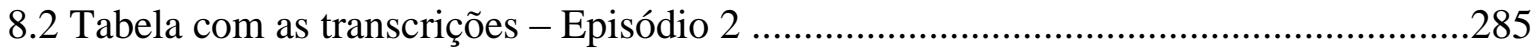

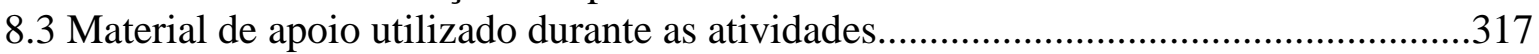

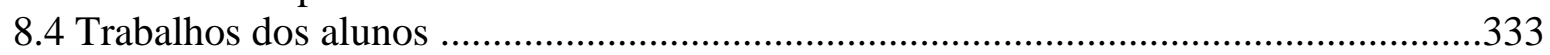


Capítulo I - Problemas, objetivos e delimitação de estudo 


\section{Problemas, objetivos e delimitacão de estudo}

Com essa pesquisa objetivamos verificar "se" e "como" os alunos se apropriam da linguagem científica partindo de conceitos falados ou de outras formas de linguagem científica e se essa apropriação pode ser um indicativo de evolução conceitual em uma sequência de ensino de Física Moderna para o Ensino Médio que trabalhe com a realização de atividades experimentais e/ou práticas.

Também temos como objetivo verificar se essas atividades práticas apresentam algum tipo de contribuição para essa apropriação da linguagem científica e para evolução conceitual, caso ela ocorra.

$\mathrm{Na}$ escolha da seqüência de aulas a ser analisada levamos em consideração o conteúdo, a forma como este seria trabalhado e o fato de ser uma proposta de trabalho para o Ensino Médio da rede pública.

Em relação ao conteúdo, nós poderíamos trabalhar com qualquer área de física, mas particularmente, consideramos interessante e relevante a Física Moderna para o Ensino Médio e a maneira como essa transposição vem sendo realizada, por se tratar de um tema atual e pouco trabalhado no Ensino Médio.

A verificação sobre como os alunos se apropriam das linguagens científicas, caso ela ocorra, em relação a um tema que é praticamente novo na cultura escolar, além de ser instigante, pode trazer contribuições para a compreensão do processo ensino-aprendizagem na busca pela inserção da Física Moderna nas aulas de Ensino Médio.

A escolha de atividades práticas que buscam aproximar o aluno do cotidiano das pesquisas foi levada em consideração, embora não represente a realidade vivida pelos pesquisadores.

Havia o conhecimento de um trabalho realizado por um grupo de professores do Ensino Médio coordenado pelo professor Dr. Maurício Pietrocola, na Faculdade de Educação da USP, voltado para transposição didática de uma física mais contemporânea para alunos da rede pública. Optamos por entrar em contato com o grupo para verificarmos a possibilidade de acompanhamento de algumas aulas elaboradas a partir desse trabalho, com a finalidade de desenvolvermos nossa pesquisa.

Já há algum tempo trabalhos e estudos como os apresentados nos PCN Ensino Médio (1999); Pietrocola (2003); Brockington (2005); Oliveira (2006) têm sinalizado a importância e a necessidade de atualização de currículos do Ensino Médio, levando até à sala de aula questionamentos e estudos mais contemporâneos. 
Para o Ensino Médio meramente propedêutico atual, disciplinas científicas, como a Física, têm omitido os desenvolvimentos realizados durante o século XX e tratam de maneira enciclopédica e excessivamente dedutiva os conteúdos tradicionais. Para uma educação com o sentido que se deseja imprimir, só uma permanente revisão do que será tratado nas disciplinas garantirá atualização com o avanço do conhecimento científico e, em parte, com sua incorporação tecnológica. (PCNEM, p. 209).

De acordo com Brockington (2005), nas últimas décadas, os avanços científicos e tecnológicos têm despertado interesse nos jovens em assuntos com temas voltados à Ciência, de um modo geral, e a Física particularmente tem contribuído muito para o desenvolvimento da Medicina e das Engenharias, porém no Ensino Médio, o Ensino de Ciências está muito distante do acompanhamento desse desenvolvimento e dessas contribuições.

Um dos fatores apontados para contribuição desse quadro é a defasagem em termos de conteúdo do atual currículo trabalhado em sala de aula e as notícias divulgadas pelas mídias atuais sobre descobertas científicas. Embora, como citado anteriormente, os próprios PCNEM sinalizem a necessidade de inserção da Física Moderna, isso ainda está distante da cultura escolar existente, o que acaba resultando numa prática pedagógica descontextualizada e distante da realidade atual. Por sua vez isso atrapalha a compreensão por parte dos alunos em relação à necessidade de se estudar Física, disciplina esta que muitas vezes se resume a aulas baseadas em fórmulas e equações matemáticas, sem considerar os aspectos histórico, social e cultural que ela desempenha.

\footnotetext{
E quem se pretende formar com o ensino de Física? Partimos da premissa de que no ensino médio não se pretende formar físicos. O ensino dessa disciplina destina-se principalmente àqueles que não serão físicos e terão na escola uma das poucas oportunidades de acesso formal a esse conhecimento. Há de se considerar, então, dois aspectos do ensino de Física na escola: a Física como cultura e como possibilidade de compreensão do mundo. (Orientações Curriculares para o Ensino Médio, 2006, p. 53).
}

Brockington (2005) também comenta a importância da disciplina de Física para formação do cidadão e como uma das únicas formas de contato formal com a ciência mais atual e presente no dia a dia:

Por fim, é preciso ressaltar a questão do caráter terminal do Ensino Médio. Este caráter último da formação média não se faz presente apenas para 
aqueles que terão a oportunidade de ingressar na Universidade. O Ensino Médio é a última oportunidade de contato com a ciência para a grande maioria dos estudantes. Mesmo entre aqueles que eventualmente seguirão cursos universitários, muitos são os que não abraçam carreiras das áreas científico-tecnológicas.

Como o Ensino Médio passa a ser a única forma de escolarização formal em Física, ao não se tratar de FMC priva-se o futuro cidadão, em face de tudo que foi discutido anteriormente, de tomar conhecimento desta nova maneira, criada pelo homem, de compreender e prospectar a realidade. (Brockington, 2005, p. 15).

Essa importância e necessidade de um ensino de Física mais contemporâneo e de acordo com as situações mais atuais contribuíram para a escolha do conteúdo presente nas aulas a serem analisadas.

Pietrocola (2003) cita em seu projeto "Atualização dos Currículos de Física no Ensino Médio de Escolas Estaduais: A Transposição das Teorias Modernas e Contemporâneas para sala de aula" alguns trabalhos relacionados à inserção da Física Moderna no Ensino Médio:

- $\quad$ Arruda e Villani (1998) desenvolvem na UEL (Universidade Estadual de Londrina) um projeto conjunto entre professores do Departamento de Física e professores do Ensino Médio, visando elaboração de propostas para inserção de Física Moderna no currículo de Física no Estado do Paraná;

- $\quad$ Ostermann et al. (1999) descrevem o processo de introdução e análise dos resultados obtidos do tópico "partículas elementares e interações fundamentais" em uma escola de Porto Alegre;

- Costa \& Santos (1999), em seus trabalhos dedicados à formação continuada de professores no Estado de Rio de Janeiro, sugerem a exploração de artefatos do cotidiano para que em seguida possam ser desenvolvidos temas atuais como laser, holografia, caos e fractais, relatividade e radiação;

- Cavalcanti (1999) propõe uma transposição a partir do tema Raios Cósmicos, utilizando a mídia com uma abordagem histórica da evolução das ideias e dos experimentos na Física;

- Custódio Pinto (1999), por meio de um levantamento, realiza um estudo e elaboração de materiais didáticos associados à inserção da Física Quântica no Ensino Médio. 
Ostermann et al (1998) realizou uma pesquisa onde em uma de suas etapas verifica a opinião de professores de Física, pesquisadores em ensino de Física e pesquisadores Físicos sobre quais os temas de Física Contemporânea deveriam ser desenvolvidos no Ensino Médio em escolas brasileiras por meio de sua inclusão no currículo.

Nessa etapa citada, os respondentes deveriam sugerir, de acordo com suas opiniões, quais tópicos de Física Moderna deveriam constar e ser efetivamente trabalhados no currículo do Ensino Médio, obtendo-se os seguintes resultados: Mecânica Quântica (63\%), Relatividade Restrita (50\%), Estado Sólido (40\%) e Física das Partículas (38\%).

Baseados nessa pesquisa, Pietrocola (2003) juntamente com o seu grupo de pesquisa optaram por iniciar o projeto pela área da Mecânica Quântica. Dentro dessa área escolhida, propuseram-se a enfocar o tema "interação radiação-matéria", por meio dos tópicos: Modelo atômico de Bohr, Quantização de Energia, Processos de emissão-absorção de energia e Dualidade onda-partícula, por acreditarem ser propício aos objetivos do projeto, pois o tema:

- $\quad$ Localiza-se na fronteira entre Física clássica e Física Moderna;

- Fundamenta o entendimento de uma série de fenômenos físicos (emissão e absorção de radiação) e de produtos tecnológicos (cristais líquidos, laser, células fotoelétricas etc.);

- $\quad$ Favorece a construção de modelos sobre o mundo microscópico;

- Oportuniza o entendimento de alguns princípios básicos da Física Moderna e Contemporânea (quantização da energia, relação massa-energia, relatividade do tempo etc.).

Esses tópicos citados anteriormente permitem abordar fenômenos físicos e artefatos tecnológicos como o laser, espectros de radiação, equipamentos de diagnóstico médico (radiografias, tomografia, ressonância magnética), fissão e fusão nuclear, centrais nucleares, toca-CDs, forno de micro-ondas.

É nesse contexto e com esse tema que realizaremos nossa pesquisa. 
Em relação à forma de trabalhar os conteúdos e metodologia, também são apontadas algumas dificuldades no tratamento desses assuntos mais atuais devido ao fato de existir um número ainda discreto de materiais elaborados para esse público.

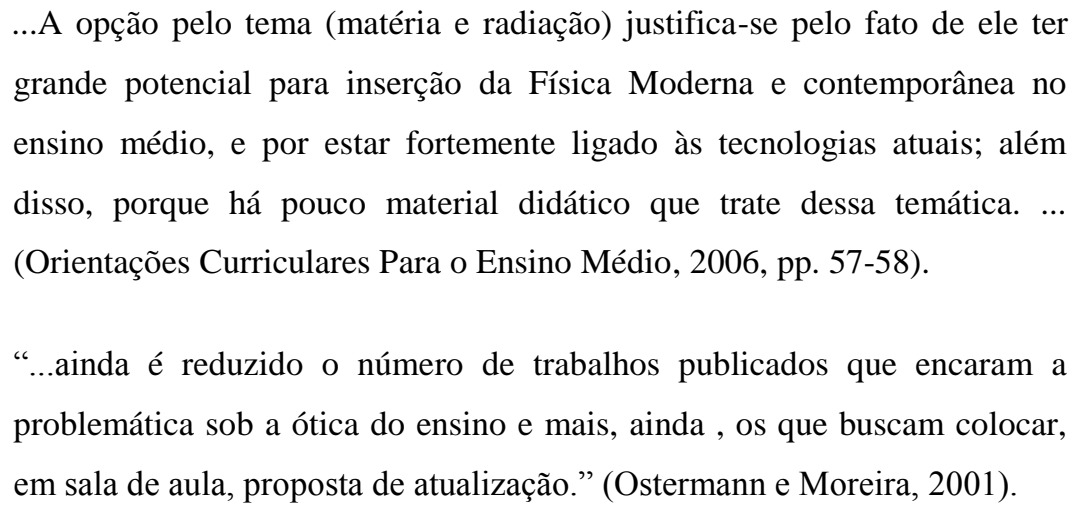

Assim consideramos uma grande oportunidade a possibilidade de realizarmos a pesquisa com um grupo envolvido com a pesquisa em Ensino de Física, já com um material e uma proposta organizada e estruturada para o Ensino Médio.

Outro aspecto importante está relacionado à maneira como discutir assuntos mais atuais sem utilizar apenas cálculos muito complexos que muitas vezes aparecem de forma desarticulada, representando situações artificiais e desvinculados de seu significado físico efetivo, ou abstração exagerada que acaba por não trabalhar a parte prática e exemplos concretos. Tais observações sinalizam para necessidade de utilização de outros recursos além de aulas expositivas. Tais questionamentos também instigaram a escolha por esse assunto atual.

$\mathrm{O}$ ensino de Física tem-se realizado freqüentemente mediante a apresentação de conceitos, leis e fórmulas, de forma desarticulada, distanciados do mundo vivido pelos alunos e professores e não só, mas também por isso, vazios de significado. (PCNEM, p.229).

A questão do formalismo matemático é relevante a ponto de Custódio (1999), a partir de suas pesquisas, apontar dificuldades presentes no ensino de Física Quântica no Ensino Médio e sugerir que tal dificuldade pode ser "contornada" pela utilização da História da Ciência, apontando para um ensino com foco mais qualitativo e menos formal.

Acreditamos que o formalismo matemático é importante sim, porém ele deve possuir significado para os alunos. É pouco provável que uma proposta que parta da utilização de muito formalismo matemático, que os alunos não possuem nem dominam, seja bem sucedida 
no Ensino Médio na disciplina de Física. Dessa forma a utilização de outras estratégias e metodologias, buscando uma conciliação entre a parte conceitual e o formalismo matemático acessível à realidade dos alunos se faz necessária. De qualquer forma, é um assunto que ainda está longe de ser considerado consenso e que ainda vai gerar muitas pesquisas e discussões na área de Ensino.

Pietrocola (2003) afirma que de uma forma geral existe um consenso por parte das pesquisas acadêmicas em relação à necessidade e importância da introdução da Física Moderna no Ensino Médio, porém em relação à maneira como essa introdução deve ser feita, várias propostas são apresentadas, mas ainda não existe um consenso entre elas.

Embora existam várias pesquisas acadêmicas que procuram avaliar estratégias de ensino de conteúdos Modernos e Contemporâneos no Ensino Médio, os resultados obtidos até agora não permitiram a formulação ou destaque de um modelo de ensino eficiente na transposição didática de conteúdos de Física Moderna e Contemporânea para este ensino.

Não sabemos se existe realmente uma forma mais indicada, mas acreditamos que devemos trabalhar com uma gama de opções de forma que o próprio professor, escola ou instituições oficiais ligadas ao ensino possam optar por uma delas de acordo com seu próprio planejamento, objetivos e limitações. Porém, que essas opções possam contar sempre com a elaboração de atividades voltadas à aprendizagem do aluno.

Partimos do princípio que a elaboração de atividades capazes de envolver os alunos e propiciar uma aprendizagem efetiva é de extrema importância para o desenvolvimento do Ensino de Ciências. O projeto de transposição didática de Física Moderna e Contemporânea para o Ensino Médio do qual pretendemos acompanhar algumas aulas e atividades se propõem a desenvolver e trabalhar com atividades elaboradas, buscando esse envolvimento e aprendizagem.

O interesse por saber programar atividades de aprendizagem manifesta-se como uma das necessidades formativas básicas dos professores. Inclusive aqueles que orientam seu ensino como uma transmissão de conhecimentos já elaborados, consideram muito conveniente poder completar suas explicações com algum tipo de atividade dos alunos. Esse interesse cresce, é lógico, quando se pretende organizar a aprendizagem como uma construção de conhecimentos por parte dos alunos. (Carvalho e Pérez, 1995, p. 42). 
O trabalho dos autores aqui citados é voltado para um ensino construtivista, o que não corresponde necessariamente à proposta das aulas que acompanharemos, embora no projeto algumas propostas, como utilização de textos históricos, de experiências de demonstraçãoinvestigativa, de laboratório aberto e uso de questões e problemas abertos, tenham se baseado na proposta de um projeto anterior: "Melhoria da qualidade de ensino de Termodinâmica, no Ensino Médio de escolas públicas estaduais: 98/1078-1" com caráter de ensino construtivista. De qualquer forma eles destacam a importância da elaboração e trabalho com atividades que envolvam os alunos.

Dessa maneira, em relação à forma como o conteúdo seria trabalhado, achamos interessante a escolha de uma sequência com atividades práticas onde os alunos realizassem algum tipo de trabalho e pudessem interagir em pequenos grupos, com os demais grupos e com o próprio professor. Partimos do princípio que atividades práticas que permitam interações com as atividades e com outros alunos, principalmente se possibilitarem levantamento de hipóteses, expressar opiniões, realizar análises e emitir opiniões, contribuem de forma significativa para apropriação da linguagem científica.

Para Carvalho et al. (1995) “As atividades ocupam um papel fundamental num ensino que tem por objetivo proporcionar condições ao aluno para que ele construa seu conhecimento". Para isto, a atividade deve estar acompanhada de situações problematizadoras, questionadoras e de diálogo, envolvendo, portanto, a resolução de problemas e levando à introdução de conceitos. (Carvalho et al., 1999, p. 42).

Kanbach, Laburu e Silva (2005) afirmam que atividades práticas passaram a ter ampla difusão em meados da década de sessenta, através de projetos de origem americana como PSSC (Physical Science Study Committee), BSSC (American Biological Science Curriculum Study), CHEMS (Chemical Educational Material Study) entre outros, e que a partir de então esse tema tem sido estudado por vários pesquisadores de Ensino de Ciências.

Como conseqüência disto, passou-se a ter um consenso entre pesquisadores e professores, de que as atividades práticas são importantes para o processo de construção do conhecimento em Física, Química e Biologia. Mas embora exista este consenso da importância das aulas experimentais, a partir da segunda metade da década de oitenta, encontra-se na literatura relatos descrevendo que as aulas práticas vêm cada vez menos sendo utilizadas no Brasil. (Kanbach, Laburu, Silva, SNEF, 2005). 
Realizaram ainda, em seu trabalho, um levantamento sobre vários autores e suas pesquisas sobre o tema. Dentre os quais destacam:

- $\quad$ Pessoa (1985) discute que com atividades práticas consegue-se colocar o aluno diante de um fenômeno que ele pode investigar com seus próprios recursos mentais. Para ele essas atividades despertam o interesse dos alunos, sugerindo problemas, fazendo distinção entre os vários fatores que causam um determinado efeito, proporcionando dados para confirmar ou refutar hipóteses e para oferecer situações novas nas quais se possa utilizar o aprendido. Sinaliza que o laboratório fechado e sem manutenção e a falta de tempo para a preparação das aulas e em muitos casos a formação dos professores dificultam a realização de atividades;

- Axt (1991) descreve que as atividades práticas aproximam o ensino de ciências das características do trabalho científico e ainda contribuem para aquisição de conhecimento e desenvolvimento mental dos alunos, citando inclusive uma observação de Piaget "as crianças em idade de cursar ciências têm seus raciocínios operando sobre situações com significado concreto". Argumenta ainda que aulas experimentais podem gerar conflitos cognitivos, quando os alunos se encontram diante de situações que não conseguem explicar com suas concepções. Aponta ainda a formação do professor e a falta de materiais como os grandes responsáveis pela não utilização de atividades empíricas;

- Thomaz (2000) aponta que o fato de os professores terem uma postura errada da natureza da ciência e de não saberem o papel do laboratório no Ensino de Física dificultam o trabalho com atividades;

- Borges (2002) realiza críticas em relação à forma como as atividades práticas são tradicionalmente usadas. Descreve também algumas razões para o não uso de atividades experimentais, como o fato de não existirem atividades já preparadas para o professor, falta de recursos para a compra de materiais, falta de tempo para o professor preparar e planejar suas atividades e uma postura equivocada quanto à natureza da Ciência;

No seu próprio trabalho, Kanbach, Laburu e Silva (2005) mostram que a questão de falta de equipamentos e infra-estrutura não é um fator determinante para não utilização de atividades práticas. Apontam outros que não aparecem na literatura, mas podem 
influenciar no comportamento e atitude do professor, como a interação dos alunos com aulas experimentais e utilização de aulas práticas pelos professores de outras disciplinas com mesma turma que o professor de física.

Porém, nestas pesquisas, é praticamente um consenso que a formação do professor é extremamente importante para o bom desenvolvimento de uma aula, inclusive daquelas que envolvam atividades práticas.

...faz-se necessária uma profunda revisão da formação - inicial e permanente - dos professores, estendendo a mesma às aquisições das pesquisas sobre aprendizagem das Ciências ... (Briscoe, 1991). (Carvalho e Pérez, 1995, p. 10).

...até recentemente os estudos centravam-se nas características do bom professor ou nas "diferenças entre bons e maus professores" (Ausubel, 1978), ao passo que hoje a questão se coloca em termos de quais são os conhecimentos que nós, professores, precisamos adquirir. Este aspecto é, sem dúvida, importante e supõe uma superação de concepções essencialistas (um bom professor "é" ou "nasce" como tal) que indicavam ineficazes políticas de seleção mais que processos de formação. (Carvalho e Pérez, 1995, p. 17).

No caso de nossa pesquisa, a situação em relação ao preparo e capacitação do professor é ainda mais delicada, pois se trata de um assunto que não possui muitos trabalhos e materiais elaborados para professores ou alunos do Ensino Médio e que ainda não está inserido na cultura escolar.

É importante ressaltar que a atualização do currículo não pode ser desvinculada da preocupação com a formação inicial e continuada de professores. Não basta introduzir novos assuntos que proporcionem análise e estudos de problemas mais atuais se não houver uma preparação adequada dos alunos das licenciaturas para esta mudança e se o profissional em exercício não tiver a oportunidade de se atualizar. (Oliveira, 2006).

Oliveira (2006) discute em sua dissertação que a maior parte dos professores que leciona hoje em dia em escolas públicas não possui uma formação específica em Física. e a maioria não trabalha com temas relacionados com a Física Moderna.

Dessa forma, tivemos uma preocupação especial na busca de um professor ou professores dispostos a colaborar com a pesquisa e que estivesse trabalhando com o algum 
tema voltado para Física Moderna. Considerando que também pretendíamos trabalhar com uma seqüência de atividades práticas, era necessário um professor com perfil relacionado a esse tipo de aula e metodologia e que não se sentisse inseguro ou incomodado com a presença de pesquisadores e câmeras de filmagem em suas aulas.

Por esses motivos, o conhecimento de um grupo trabalhando com a transposição didática de Física Moderna para o Ensino Médio de escolas públicas, e com professores que buscam alterar a concepção da relação ensino-aprendizagem, habituados a trabalharem com atividades e metodologias diferenciadas, tornou-se uma excelente opção para a pesquisa que pretendíamos realizar.

Consideramos importante também o fato de ser uma proposta para o Ensino Médio público, pois, dessa forma, poderíamos trabalhar com condições próximas às de muitos colégios. Isso permite em alguns aspectos especularmos se as análises a serem realizadas possibilitam uma extrapolação ou pelo menos uma indicação de que ocorre nas salas de aula, de uma forma geral, em termos de apropriação de linguagem científica.

Quando fizemos essa opção também pensamos nas implicações do cotidiano escolar e das condições reais de trabalho das escolas (número de aulas, locais de trabalho, aulas suspensas e outros) para essa sequência de aulas. Situação que é relevante quando pensamos em estrutura ensino-aprendizagem e que pode representar um rico material de pesquisa.

Dessa maneira, preocupamo-nos em estabelecer relações entre os conteúdos trabalhados em sala de aula e a maneira como são trabalhados com aspectos da cultura científica, relacionados à linguagens da ciência em escolas da rede pública do Estado de São Paulo.

Buscamos salientar aqui os motivos e considerações que nos levaram a delimitar o estudo de caso, praticamente apontando três fatores essenciais: a escolha do conteúdo e tema, a maneira como esse conteúdo será trabalhado em sala de aula e, por fim, a escolha da escola

pública. É certo também que os três fatores estão intrinsecamente relacionados, de forma que, ao comentarmos um deles, acabamos, por vezes, associando a outro.

\section{Grupo de pesquisa do LaPEF (Laboratório de Pesquisa em Ensino de Física)}


O Laboratório de Pesquisa em Ensino de Física situa-se na Faculdade de Educação da USP e conta com pesquisadores universitários, alunos de doutorado, mestrado, iniciação científica e professores da rede pública.

O grupo que entramos em contato para realização de nossa pesquisa trabalha com um projeto financiado pela FAPESP denominado "Atualização dos currículos de Física no Ensino Médio de escolas estaduais: a transposição das teorias modernas e contemporâneas para a sala de aula: 2003/00146-3” sob coordenação do professor Dr. Maurício Pietrocola.

Este projeto tem como objetivo propor a atualização dos currículos de Física por meio do ensino de conteúdos da Teoria Quântica, desenvolver representações científicas do mundo microscópico possíveis de serem trabalhadas com alunos do Ensino Médio e avaliar a efetividade de estratégias utilizadas para o ensino destes conceitos.

O grupo produz, aplica e avalia atividades de Ensino Médio sobre temas da Física Moderna e Contemporânea que possam ser trabalhados em condições da realidade atual dos colégios públicos.

Faz parte das atividades do grupo um encontro semanal toda terça-feira no LaPEF para elaborarem, discutirem, estudarem e analisarem o desenvolvimento do projeto, sempre interessados na busca de resultados mais satisfatórios.

\section{$\underline{\text { As frentes e pesquisas do grupo: }}$}

O trabalho de pesquisa do grupo contava basicamente com três frentes em 2006:

$1^{\text {a) }}$ Dualidade Onda-Partícula - foram desenvolvidas praticamente duas versões: uma que trabalha primeiramente alguns assuntos da Física Clássica para depois entrar nos conceitos mais contemporâneos, e outra que aborda desde o início a parte contemporânea;

$\left.2^{a}\right)$ Física de Partículas;

$3^{\text {a }) ~ R e l a t i v i d a d e . ~}$

A primeira frente (dualidade onda-partícula) foi desenvolvida desde o início do projeto, aplicada com várias turmas do Ensino Médio, já passou por diversas revisões e encontra-se em fase final de aperfeiçoamento; a segunda (física de partículas) já foi aplicada em turmas de duas escolas e no ano de 2006 foi aplicada praticamente por todos os professores envolvidos no projeto; a terceira frente estava em fase de desenvolvimento por alguns integrantes do grupo e ainda não havia sido aplicada em nenhuma turma. 
Para nossa pesquisa, acompanharemos a primeira frente com a versão que trabalha alguns conceitos da Física Clássica antes de iniciar os assuntos e temas mais contemporâneos.

Os tópicos abordados em dualidade onda-partícula são: fenômenos elétricos e magnéticos, campos (elétrico, magnético e gravitacional), interação eletricidade e magnetismo, fenômenos ondulatórios, ondas eletromagnéticas, espectroscopia da luz, modelo atômico de Bohr, quantização de energia, processos de emissão - absorção da energia, efeito fotoelétrico, interferômetro de Mach-Zehnder, dualidade onda-partícula.

\section{A sequência escolhida:}

A sequência escolhida faz parte da primeira frente que é subdividida em blocos numerados a seguir:

I - Os modelos no cotidiano da Física,

II - Ondas e partículas,

III - Introdução às propriedades magnéticas e elétricas da matéria,

IV - Breve discussão sobre campos: elétrico, magnético e gravitacional,

V - O campo eletromagnético e a indução eletrostática,

VI - Ondas mecânicas e a luz como onda eletromagnética,

VII - Luz: cor e visão,

VIII - Espectroscopia,

IX - O modelo atômico de Bohr,

$\mathrm{X}-\mathrm{O}$ efeito fotoelétrico,

XI - Dualidade Onda-Partícula.

A seguir apresentamos um pouco da ideia geral proposta para o curso e de cada bloco para em seguida dar mais ênfase aos blocos que escolhemos para pesquisa.

Como já citado anteriormente, essa proposta percorre um caminho mais histórico e trata de assuntos da física clássica antes de iniciar propriamente a parte mais contemporânea.

- No Bloco I é discutida a importância e como são construídos os modelos na ciência e suas evoluções através dos tempos de acordo com as necessidades de novas explicações e conforme o surgimento de novos fatos que exijam novos modelos ou reformulações naqueles já existentes.

- No Bloco II é apresentada aos alunos de uma forma geral a ideia do que vem a ser onda e do que vem a ser partícula, já que o objetivo do curso é discutir a questão da dualidade onda e partícula. 
- No Bloco III são discutidas propriedades elétricas e magnéticas da matéria, os tipos de eletrização, a ideia de domínios magnéticos e materiais que interagem com fenômenos elétricos ou magnéticos.

- No Bloco IV são discutidos os campos: elétrico, magnético e gravitacional apresentando suas principais características, como a ação à distância, a diminuição da intensidade com a distância, a representação geométrica e o caráter vetorial. Observa-se aqui a importância de destacar a transferência de energia por meio do campo, sem enfatizar o conceito de forças. Há também a preocupação de mostrar que o campo gravitacional é associado à massa; o elétrico à carga e o magnético aos domínios e todos se coexistem, ou seja, existe uma preocupação para que não fique a ideia de que o campo seja gerado por algo, mas sim existe simultaneamente a ele.

- No Bloco V é discutida a experiência de Oersted (corrente elétrica induzindo variação de campo magnético) e a experiência de Faraday (variação de campo magnético induzindo o surgimento de corrente elétrica). Aqui, além das aplicações que surgiram com essas descobertas, é discutida a ideia da interação eletricidade e magnetismo por meio das variações dos campos elétricos e magnéticos.

- No Bloco VI é trabalhada a ideia de onda eletromagnética e os fenômenos a ela associados de um modo geral, levando-se em consideração a possibilidade de o aluno não ter estudado ondas de forma adequada antes, os fenômenos são discutidos também a partir de ondas mecânicas. Aqui a luz surge como o principal exemplo de onda eletromagnética a ser estudado no momento e é apresentado aos alunos o modelo ondulatório para luz e suas consequências.

- $\quad$ No Bloco VII observa-se a luz, discutindo-se a questão das cores e da visão, coloração por reflexão e por transmissão, a importância do nosso olho, a mistura de cores por pigmentação e por luzes e a ideia de cargas e campos para entender a luz como onda eletromagnética.

- No Bloco VIII é analisada a construção de um espectroscópio simples com redes de difração de CD (como forma de decompor a luz), o estudo da espectroscopia de uma forma básica e os espectros de lâmpadas e do sol. Aqui começam as discussões sobre os espectros de emissão e de absorção da luz. 
- No Bloco IX temos a utilização de modelos que justifiquem e expliquem a existência dos espectros de emissão e de absorção da luz. Trabalha-se o modelo atômico de Bohr e seus postulados para explicar as linhas espectrais.

- No Bloco X é discutido o efeito fotoelétrico e o abalo no modelo ondulatório da luz, apresentando um fenômeno no qual ela se comporta estritamente como partícula. Aqui é lançada a questão de como em alguns casos a luz tem comportamento que só pode ser explicado se ela for considerada como onda e em outro apenas se for explicada como partícula.

- No Bloco XI é discutida efetivamente a questão da dualidade ondapartícula para luz, através do interferômetro de Mach-Zehnder e levando-se em consideração algumas interpretações possíveis para o fenômeno da dualidade: a interpretação ondulatória, a interpretação corpuscular, a interpretação dualista realista e a interpretação da complementaridade de Bohr.

Destacamos a seguir mais detalhadamente os blocos VIII e IX que fazem parte da sequência que pretendemos analisar: Espectroscopia e Modelo Atômico de Bohr.

No Bloco VIII é trabalhada a construção de um espectroscópio com canos de pvc ou cartolina e pedaços de CD. Com o espectroscópio em mãos, os alunos recebem um roteiro de observação utilizando o mesmo. Os alunos observam a luz emitida por várias lâmpadas levadas pelo professor, também em casa e na rua, além do próprio sol. Analisa-se a explicação de como funciona um espectroscópio, seja ele constituído por uma rede de difração (como no caso do $\mathrm{CD}$ ) ou o espectroscópio com prismas, destacando a vantagem de se utilizar um ou outro.

Com as observações, o professor trabalha com os alunos:

$\checkmark \mathrm{O}$ espectro contínuo - em que as imagens obtidas se superpõem parcialmente, dando origem a uma única faixa colorida e a passagem de uma cor para outra não se faz bruscamente. É feita de uma forma gradual, formando as sete tonalidades conhecidas como as cores do arco-íris (ocorrendo devido à luz que incide no espectroscópio apresentar todas as cores do espectro eletromagnético):

$\checkmark$ O espectro de raias (ou bandas) - quando não temos todas as cores na formação da imagem e as que aparecem estão separadas por regiões escuras (devido à luz que chega ao espectroscópio ser constituída apenas por um número discreto de luzes monocromáticas); e como ocorre a "separação das 
cores" através do espectroscópio. Neste bloco também são trabalhadas algumas características de algumas lâmpadas.

No Bloco IX temos uma continuação direta da parte de espectroscopia e depois da atividade de observação das diferentes lâmpadas com o espectroscópio e a observação que existem diferentes espectros característicos para cada lâmpada ou para cada elemento. É realizada uma atividade para investigar os espectros de emissão e absorção no site http://astro.if.ufrgs.br/rad/espec/espec.htm da Universidade Federal do Rio Grande do Sul. Com esta atividade, os alunos podem trabalhar mais o conceito de espectros de emissão e absorção e respondendo as questões propostas pelo professor tentar notar e descrever as semelhanças entre esses espectros para o mesmo elemento químico, como, por exemplo, o Hidrogênio e o Hélio. Nesta atividade, o aluno descobre que pode conhecer do que é feito uma estrela, mesmo que ela esteja a milhões de anos-luz de distância, através da espectroscopia.

Em seguida, é realizada a atividade "Astrônomo mirim" na qual os alunos tentam identificar os elementos presentes numa estrela hipotética, com o uso de uma folha que recebem com espectros de diferentes elementos químicos e transparências numeradas que correspondem a espectros simplificados de estrelas hipotéticas. Com uma comparação cuidadosa, entre os materiais recebidos, os alunos podem identificar os elementos presentes na estrela.

Em seguida, com ajuda de um texto de sistematização, é retomada a discussão sobre espectros de emissão e absorção, a origem das linhas espectrais utilizando a ideia de átomo e luz e apresentando o modelo atômico de Bohr e seus postulados para explicar os espectros atômicos.

A escolha específica dessa sequência foi motivada pelo fato de ela aparecer num momento de transição da física clássica para física mais contemporânea, pois é nessa sequência que surge a necessidade de adequação de modelos ou utilização de novos modelos para explicar os espectros de emissão e absorção. A sequência trabalhada pelo professor segue uma linha cronológica mais linear, partindo de conceitos da física clássica até chegar a ideias mais contemporâneas, chegando até a questão da Dualidade onda-partícula. Portanto, estas atividades apresentam uma importância estratégica dentro da proposta de ensino mostrada e poderiam representar um rico material para pesquisa.

Como mencionado anteriormente, nossa atenção foi particularmente voltada para atividades práticas com participação dos alunos, portanto as atividades de análise dos espectros das lâmpadas e do astrônomo mirim representaram o foco de nossa coleta de dados. 


\section{Consideracões sobre o pesquisador:}

Licenciado em Física pelo Instituto de Física da USP, professor da rede privada e pública estadual.

Sempre envolvido com atividades voltadas ao Ensino de uma forma geral e, principalmente, relacionadas ao Ensino de Física, participei dos projetos: "Termodinâmica um Ensino por Investigação”, coordenado pela Professora Dra. Anna Maria Pessoa de Carvalho e do Projeto “Atualização dos currículos de Física no Ensino Médio de escolas estaduais: a transposição das teorias modernas e contemporâneas para a sala de aula", coordenado pelo professor Dr. Maurício Pietrocola.

Durante o período que trabalhei com o professor Maurício, fiz parte da equipe de professores que aplicavam a proposta de ensino e que contribuíam para elaboração do projeto.

A participação e envolvimento direto com o projeto e a preocupação com a melhoria da qualidade de ensino e busca por novas informações também foram fatores que contribuíram para escolha dessa pesquisa. 


\section{Capítulo II - Conceitos Físicos importantes da sequência de Ensino e sua contextualização histórica}




\section{Conceitos físicos importantes da Sequência de Ensino e sua contextualizacão histórica}

A sequência de ensino adotada no projeto "Dualidade Onda-partícula" parte de alguns conceitos clássicos como o de campos (gravitacional, elétrico e magnético), de propriedades elétricas e magnéticas da matéria, da relação entre eletricidade e magnetismo, até a ideia de campo eletromagnético, incluindo indução eletrostática e ondas eletromagnéticas chegando ao modelo de luz como onda eletromagnética. Só depois desta sequência, chegamos a uma física mais contemporânea com conceitos quânticos com o modelo atômico de Bohr, do efeito fotoelétrico (a luz é apresentada como partícula, fóton) e da dualidade onda-partícula, propriamente dita.

Na transição entre essas abordagens está exatamente a sequência de ensino referente à espectroscopia da luz, que é o foco desta pesquisa.

Dentro da proposta do projeto, o tema sobre espectroscopia foi escolhido como um possível caminho a ser percorrido para se chegar à discussão e apresentação do modelo atômico de Bohr com a introdução de novos conceitos e questões, e também, as atividades aqui desenvolvidas procuram mostrar aos alunos alguns dos aspectos do trabalho realizado pelos cientistas de uma forma motivadora.

Para tanto, duas atividades merecem destaque nesta sequência: a observação dos espectros de luz emitidos por diferentes fontes e a manipulação de diferentes espectros na atividade "brincando de astrônomo".

Na primeira, os alunos observam espectros da luz emitida pelo Sol e por diversos tipos de lâmpadas na sala de aula e também numa pesquisa de campo onde observam inclusive espectros de anúncios luminosos, através de um espectroscópio de rede de difração montado por eles, ou fornecido pelo professor. Com a ajuda do professor (orientador), os alunos são levados a perceber a diferença entre os espectros observados chegando à percepção da existência de representações contínuas e discretas.

$\mathrm{Na}$ segunda atividade, os alunos recebem uma folha com os padrões de diferentes elementos químicos e transparências diversas com espectros simples representando estrelas utópicas. Cada grupo deve identificar em cada "estrela" quais os elementos existentes através da comparação dos espectros da "estrela" com os dos elementos padrões que recebeu. Assim, com essa atividade, os alunos conhecem um aspecto das pesquisas em astrofísica, servindo inclusive para tratar de um assunto de uma área de pesquisa mais atual. Com essas atividades 
trabalha-se com espectros de emissão e absorção que propiciaram historicamente a evolução do modelo atômico de Bohr.

O objetivo aqui foi apresentar alguns conceitos e ideias dentro de um contexto para discutirmos um pouco sobre seus aspectos históricos e conceituais que serão de grande valia no entendimento da sequiência de ensino utilizada e na compreensão dos diálogos estabelecidos entre professor e alunos durante a mesma.

O texto a seguir sobre espectroscopia e contexto histórico foi baseado nos trabalhos de Dulcidio Braz Júnior - Física Moderna - tópicos para o Ensino Médio (2002) e nos textos dos seguintes endereços eletrônicos: http://astro.if.ufrgs.br/rad/espec/espec.htm; Universidade Federal Fluminense - Laboratório de Plasma e espectroscopia atômica http://www.if.uff.br/plasma/espectroscopia.htm, último acesso em março de 2009; Schlumberger Excellence in Educational Development - apoiando o desenvolvimento comunitário por meio da educação http://www.seed.slb.com/pt/scictr/watch/fullerenes/spectro.htm, último acesso em março de 2009.

\section{$\underline{\text { Espectroscopia }}$}

A espectroscopia pode ser definida como uma área da física e também da química, que estuda as emissões da luz ou de qualquer outra onda eletromagnética pela matéria, como raios $\mathrm{X}$ ou $\Upsilon$. Cada elemento químico possui um espectro de cores característico como se fosse uma "impressão digital” que serve para identificação do elemento.

Devemos destacar aqui também que não é só o átomo que possui espectro característico, mas também o núcleo e as moléculas. Desta forma, através da emissão e da absorção de radiação eletromagnética em frequências definidas, por uma ou várias substâncias, é possível por meio da análise espectral, uma identificação dos elementos presentes, ou seja, uma identificação do átomo, do núcleo e/ou das moléculas.

Sabe-se que as ondas eletromagnéticas estão associadas ao comprimento de onda $(\lambda)$ e a frequência (f) e a energia do fóton é dada pela relação $E=$ h.f, em que h é uma constante determinada por Planck e que recebeu seu nome. Esta relação nos mostra que frequências elevadas correspondem a maiores energias. 
Como a velocidade de uma onda eletromagnética é dada pela relação $\mathrm{c}=\lambda$.f, podemos notar que existe uma relação inversa entre as grandezas comprimento de onda e frequência.

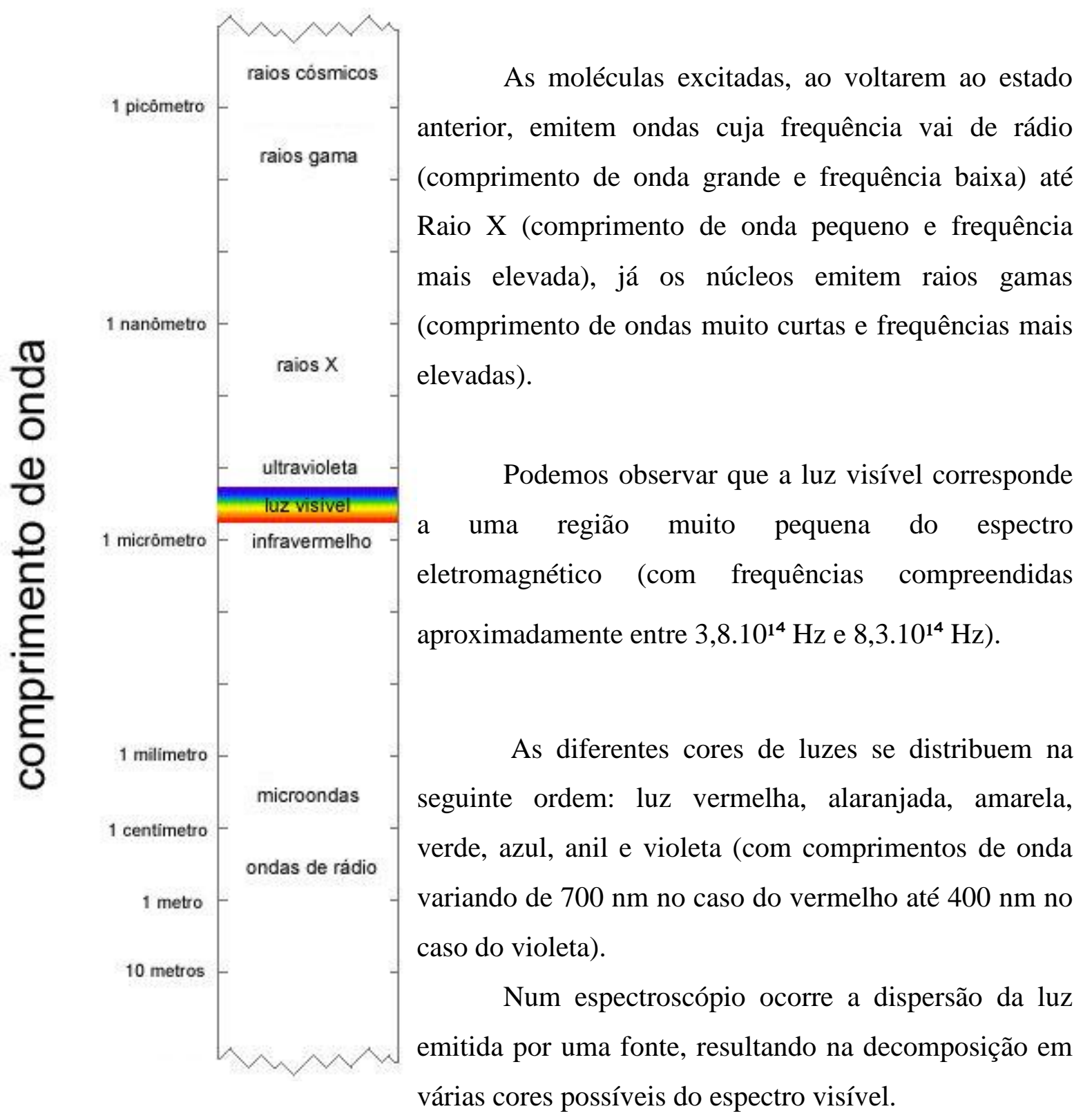

Fonte da imagem: http://www.seed.slb.com/pt/scictr/watch/fullerenes/spectro.htm

A dispersão da luz depende do elemento óptico utilizado no espectroscópio, que pode ser um prisma no qual temos o fenômeno da refração em destaque, ou uma rede, em que o fenômeno da difração aparece em destaque.

Observação: A rede de difração apresenta uma resolução maior que a do prisma.

Quando a luz branca passa por um espectroscópio, observam-se imagens coloridas que se superpõem parcialmente, sem uma separação nítida entre as cores numa faixa colorida 
denominada espectro contínuo. A passagem de uma cor para outra não se faz bruscamente, ela é gradual com as sete cores que vão do vermelho ao violeta (conhecidas como cores do arcoíris) do chamado espectro visível.

Se a luz que passa pelo espectroscópio for formada por um número discreto de luzes monocromáticas, teremos imagens de acordo com o número de cores que compõem essa luz e as cores serão separadas por regiões escuras, formando um espectro de raias (ou bandas).

Podemos dizer que a análise espectral é uma ferramenta importante para a detecção e análise de moléculas e elementos, pois apresenta uma sensibilidade muito boa e normalmente trabalha com uma quantidade mínima de uma substância na sua identificação; pode ser realizada em grandes distâncias por isso é utilizada na astronomia.

\section{Contexto histórico}

Historicamente os espectros dos elementos foram descobertos por Gustav Robert Kichhoff e Robert Wilhelm Busen em meados do século XIX. Com a análise espectral, Bunsen conseguiu descobrir o césio, estudar seus derivados e fixar uma relação com o sódio e potássio, descobrindo também o rubídio. Essa análise passou a ser utilizada pelos químicos no estudo dos elementos e permitiu, no campo da física, o surgimento de um novo ramo na astrofísica.

Algumas décadas antes, Joseph Fraunhofer, procurando melhorar as objetivas das lunetas astronômicas, se dedicou ao estudo dos desvios de raios luminosos e dos prismas. Ao repetir as experiências de Newton, ele colocou um prisma para decompor a luz e com uma luneta obteve uma visão mais nítida do espectro.

Uma luz com distribuição uniforme de intensidade, independentemente do comprimento de onda, tem espectro contínuo. Um exemplo de luz com espectro contínuo é a luz solar, porém, em 1814, Fraunhofer descobriu que o espectro da luz solar é cortado por inúmeras linhas escuras, que hoje são denominadas de linhas de Fraunhofer. Ele mostrou que esse fenômeno era devido a uma propriedade da atmosfera solar, onde ocorre uma absorção seletiva. Mediu também as posições relativas das linhas, designando-as por letras que são utilizadas até hoje.

Fraunhofer realizou outras importantes constatações e entre as linhas escuras observadas por ele, para o espectro da luz solar, estava a linha D, a partir da qual Kirchhoff e Bunsen realizaram seus estudos. 
Kirchhoff e Bunsen estabeleceram que cada elemento químico possui um espectro correspondente bem definido, independente da natureza do composto do qual faz parte. Em 1856, Bunsen inventou o bico de gás que hoje leva seu nome. Ao colocar um elemento químico sobre a chama do gás, as cores emitidas eram as da substância e não as da chama. Kirchhoff com o auxílio de um prisma conseguiu uma distinção melhor destas cores. Observaram então, que os espectros emitidos por sólidos ou gases incandescentes são contínuos, já os espectros emitidos por gases rarefeitos são linhas (discretos) e as cores, o número de linhas e suas respectivas posições permitem a caracterização do elemento. Desta forma, concluíram que, para determinar os elementos presentes em uma substância sólida, basta vaporizá-la sobre uma chama.

Dessas experiências resultaram três leis empíricas da espectroscopia:

$1^{\circ}$ ) Um corpo opaco quente, sólido, líquido ou gasoso, emite um espectro contínuo.

$\left.2^{\circ}\right)$ Um gás transparente produz espectro de linhas brilhantes (chamado espectro de emissão). O número e a posição dessas linhas servem para identificar os elementos presentes no gás.

$3^{\circ}$ ) Se um gás em temperatura baixa for colocado na presença de um sólido em alta temperatura, que está emitindo um espectro contínuo, notaremos a presença de linhas escuras formando o espectro (chamado espectro de absorção). O número e a posição dessas linhas também servem para identificar os elementos existentes no gás.

Vale destacar o experimento de Kirchhoff, auxiliado por Bunsen, e que se refere ao espectro de absorção.

Ao colocar um pouco de sal de cozinha (cloreto de sódio) numa chama, encontraram uma luz amarela e, ao observarem o espectro desta, perceberam uma linha amarela característica do sódio, e quando repetirem o experimento com uma maior precisão, verificaram que se tratava na verdade de duas linhas muito próximas, o dubleto de sódio, que posteriormente foram associadas a comprimentos de ondas diferentes, embora muito próximos.

Notaram também que a luz emitida por um sólido incandescente, por exemplo, que apresenta um espectro contínuo ( $1^{\text {a }}$ lei empírica da espectroscopia), ao atravessar um recipiente contendo sódio em sua forma gasosa, em temperatura mais baixa que o sólido, deixa de apresentar um espectro contínuo ( $3^{\mathrm{a}}$ lei empírica da espectroscopia).

Além disso, observaram que na região do amarelo apareciam duas linhas escuras exatamente na posição correspondente às linhas brilhantes quando analisamos apenas o espectro do sódio, sem a presença do sólido incandescente. 
Assim, conseguiram explicar a linha escura (que passou a ser identificada pela letra D), observada por Fraunhofer ao analisar o espectro solar, considerando o Sol uma esfera sólida ou um gás muito denso rodeado por uma atmosfera que tenha sódio em sua forma gasosa: o gás absorve a radiação correspondente à sua constituição, que normalmente seria vista se o elemento fosse colocado em uma chama. Em outras palavras, absorve a radiação com comprimento de onda específico do elemento que constitui o gás.

Desta forma, muitas informações sobre as estrelas podem ser obtidas pela análise de seus espectros.

Historicamente podemos citar alguns fatos importantes relacionados a essa área de pesquisa:

- Em 1776, o físico e químico inglês Henry Cavendish (1731-1810) realizou a identificação do elemento hidrogênio;

- Em 1860, Giovanni Battista Donati (1826-1873) deu grande impulso à observação de espectros estelares;

- Em 1862 o astrônomo sueco Anders Jonas Angström (1814-1874) identificou as linhas do elemento hidrogênio no Sol;

- Em 1868, o astrônomo inglês Sir Joseph Norman Lockyer (1836-1920) a fím de observar um eclipse do Sol, previsto para 18 de agosto do mesmo ano, juntamente com outros cientistas, constatou a presença de uma linha escura que inicialmente chegou a ser confundida com a linha D de Fraunhofer, porém, mais tarde, ao verificar que se tratava de outra linha, passaram a chamá-la de D3. Ao comparar com os espectros dos elementos conhecidos até então, constataram que se tratava de um novo elemento existente apenas no Sol já que não correspondia às linhas de espectro de nenhum dos elementos que conheciam. Desta forma deram-lhe o nome de hélio, do grego hélios, Deus do Sol;

- Em 1895, o químico inglês Sir William Ramsay (1852-1916) descobriu a presença do elemento hélio na Terra ao analisar o espectro de um minério de urânio contendo uma linha exatamente como a que Lockyer encontrou no espectro do Sol.

A espectroscopia foi importante inclusive filosoficamente indo contra a visão positivista do francês Auguste Comte, que acredita que todo conhecimento vem da observação de fatos e jamais de especulações que não sejam comprovadas pelos sentidos.

Conforme citados anteriormente, Kirchhoff e Bunsen notaram a presença de linhas escuras nos espectros correspondentes às radiações absorvidas pelos gases mais frios que a 
fonte incandescente da luz denominados espectros de absorção. Perceberam também a presença de linhas brilhantes referentes a radiações emitidas pelo gás de acordo com os elementos que o constituem e que são denominados espectros de emissão.

Mas como explicar essas emissões e absorções de forma discreta? Como explicar esses processos? Estas questões contribuíram para o desenvolvimento dos modelos atômicos, aperfeiçoando-os.

O texto a seguir sobre espectros de emissão e absorção foi baseado nos trabalhos de Dulcidio Braz Júnior (2002) e nos textos dos seguintes endereços eletrônicos: http://astro.if.ufrgs.br/rad/espec/espec.htm último acesso em março de 2009; Universidade Federal Fluminense - Laboratório de Plasma e espectroscopia atômica http://www.if.uff.br/plasma/espectroscopia.htm, último acesso em março de 2009.

\section{$\underline{\text { Espectros de absorcão e espectros de emissão }}$}

No início do século XX, eram comuns os experimentos utilizando as técnicas de espectroscopia para determinação dos elementos, mas não tínhamos uma explicação razoável para a existência dos espectros descontínuos.

Nessa época, por volta de 1911, já existia o modelo atômico proposto por Rutherford no qual os átomos são constituídos por um pequeno núcleo, com carga elétrica positiva, e rodeado por elétrons com carga elétrica negativa.

Os elétrons não poderiam permanecer parados ou seriam atraídos para o núcleo graças à interação elétrica ou interação coulombiana, afinal cargas de sinais opostos se atraem, e assim, Rutherford apresentou em seu modelo elétrons que estariam girando em torno do núcleo em órbitas circulares.

O modelo proposto por Rutherford ainda não resolvia o problema, pois de acordo com a teoria clássica do eletromagnetismo e com os estudos de Maxwell, cargas aceleradas emitem radiação, ou seja, energia. No caso, os elétrons girando em órbitas circulares, mesmo considerando o movimento como circular uniforme, apresentam aceleração centrípeta e desta forma, deveriam irradiar energia, perdendo a estabilidade de suas órbitas e se aproximariam do núcleo espiralando até um colapso final.

Durante sua queda em direção ao núcleo, os elétrons deveriam girar cada vez mais rápidos e assim a frequência a eles associada mudaria de forma contínua e deveria ser 
detectada uma onda equivalente a espectros contínuos e não raias discretas como eram observados nos experimentos.

Em 1913, Niels Bohr propôs algumas correções para o modelo de Rutherford para o átomo de Hidrogênio, por meio de alguns postulados:

$1^{\circ}$ ) Os elétrons giram ao redor de um núcleo atômico graças à interação elétrica entre eles;

$2^{\circ}$ ) Os elétrons não possuem uma infinidade de órbitas possíveis e podem ocupar apenas algumas órbitas específicas, com raios bem determinados (órbitas onde o momento angular orbital L é um múltiplo inteiro de h);

$3^{\circ}$ ) Os elétrons que giram em qualquer uma das órbitas possíveis não emitem radiação eletromagnética, portanto a energia total permanece constante e a estabilidade do núcleo atômico está garantida;

$4^{\circ}$ ) Os elétrons emitem radiação eletromagnética apenas quando mudam seu movimento de forma descontínua para ocupar umas das outras órbitas possíveis.

Podemos destacar aqui que apenas o $1^{\circ}$ postulado está de acordo com as previsões teóricas da época. Em outras palavras, de acordo com as previsões da chamada Física Clássica, convém lembrar que um postulado é “...princípio ou fato reconhecido, mas não demonstrado; princípio que se admite sem discussão, mas que não é tão evidente...” (Dicionário brasileiro Globo, 1992).

De acordo com o modelo de Bohr, os elétrons só podem ocupar órbitas com energia específica definindo um esquema de níveis de energia característico do átomo de Hidrogênio. O salto para outros níveis e a freqüência emitida no mesmo depende da diferença de energia entre os níveis. Desta forma, a energia é quantizada, o que explica a descontinuidade no processo.

Se o elétron absorver energia, poderá saltar para uma das órbitas mais externas dentre aquelas possíveis e, se emitir energia, saltará para uma das órbitas mais internas ou menos energética, dentre aquelas possíveis também.

Essas previsões do modelo de Bohr estão de acordo com outras teorias importantes desenvolvidas na época como a que Einstein utiliza a ideia de Planck sobre quantização para explicar o efeito fotoelétrico Planck (h), propõe que a emissão ou absorção de energia é diretamente proporcional à frequência de radiação (f) associada a pacotes denominados quanta de luz (ou fótons): $\mathrm{E}=$ h.f (Tipler 1995).

Interessante também destacarmos que já existiam análises matemáticas para o espectro de hidrogênio antes do modelo proposto por Bohr. Em 1884, o sueco Johann J. Balmer, 
professor de Ensino Médio na Suécia, já tinha proposto uma série numérica (chamada posteriormente de série de Balmer), que descrevia o espectro de hidrogênio na faixa do visível, porém ela servia para determinar alguns comprimentos de onda de algumas linhas e não explicava a existência do espectro descontínuo.

Analisando as nove primeiras raias do espectro de hidrogênio, Balmer notou que existia uma relação entre os comprimentos de onda das mesmas e representou essa relação através da seguinte expressão matemática:

$\lambda=3646 \mathrm{n}^{2} / \mathrm{n}^{2}-4$ no qual $\lambda=$ comprimento de onda referente a cada uma das raias e n é um número inteiro relacionado a cada raia do espectro, ou seja, serve para especificar uma linha dentro das séries e no caso do hidrogênio $n=3$ para primeira raia observada, $n=4$ para segunda raia e assim por diante.

A partir do trabalho de Balmer, outras fórmulas empíricas surgiram para descrever os espectros de outros elementos.

O físico suéco Johannes Robert Rydberg, em 1890, reescreveu a expressão proposta por Balmer da seguinte maneira: $1 / \lambda=R\left(1 / 2^{2}-1 / n^{2}\right)$ em que $R$ é uma constante com valor aproximado de $1,10.10^{7} \mathrm{~m}^{-1}$ (posteriormente chamada de constante de Rydberg). A expressão proposta por Rydberg pôde ser generalizada como: $1 / \lambda=\mathrm{R}\left(1 / \mathrm{m}^{2}-1 / \mathrm{n}\right)$ onde $\mathrm{m}$ é um número inteiro que especifica as séries à qual a linha, ou raia, pertence. No caso da série de Balmer, temos $\mathrm{m}=2$ e $\mathrm{n}=3,4,5, \ldots$ ou seja, $\mathrm{n}$ sempre maior que $\mathrm{m}$.

O trabalho de Rydberg foi importante ao prever que existiam outras séries para outros valores possíveis de $\mathrm{m}$.

Em 1906, Theodore Lyman descobriu novas raias do espectro de hidrogênio na faixa referente ao ultravioleta e, em 1908, Friedrich Paschen descobriu outra série de raias agora na faixa correspondente ao infravermelho. Para série de Lyman a expressão de Rydberg é válida com $\mathrm{m}=1$ e para série de Paschen idem com $\mathrm{m}=3$.

No desenho a seguir, estão representadas as séries de Balmer, dentro da faixa do visível, de Lyman na faixa do ultravioleta e de Paschen na faixa do infravermelho.

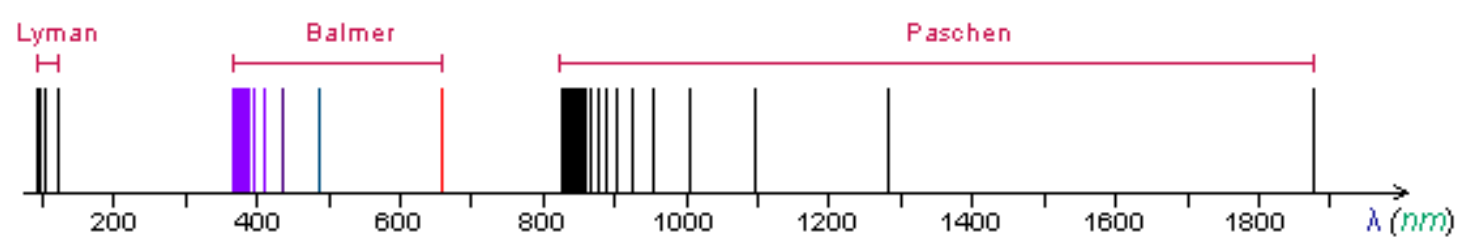

Fonte da imagem: http://www.if.ufrgs.br/ betz/iq_XX_A/espRad/aEspRadText.htm 
Como já mencionado anteriormente, essas séries possibilitavam a determinação dos comprimentos de onda para as raias conhecidas do hidrogênio, mas de forma alguma explicavam a formação desses espectros, ou seja, existia uma descrição, porém não uma explicação, apenas foi possível com o modelo atômico de Bohr.

Com o modelo de Bohr, como se explicam os espectros de absorção e emissão?

Com base nos textos de Braz Junior (2002) e no texto apresentado no site http://astro.if.ufrgs.br/rad/espec/espec.htm último acesso em março de 2009, respondemos a questão anterior:

\section{Espectro de absorção:}

Se o gás hidrogênio é atravessado por um feixe de luz, seus elétrons podem absorver energia na forma de fótons. O detalhe é que não são fótons de qualquer energia que serão absorvidos, apenas aqueles que possuam exatamente a energia, ou freqüência, necessária para que o elétron salte de um nível de energia para outro de acordo com o modelo de Bohr.

Neste caso, o elétron absorve energia e realiza o que denominamos de salto quântico, indo para um nível mais externo e ficando mais energético.

Como o hidrogênio absorve fótons com energias ou frequências específicas da luz que passa através dele, se registramos o espectro, teremos linhas escuras, que representam exatamente as frequências dos fótons absorvidos pelo hidrogênio, e o chamado espectro de absorção.

\section{Espectro de emissão:}

Quando o hidrogênio de algum modo foi excitado de forma que um elétron já ocupe uma órbita mais externa, este elétron pode voltar para sua órbita inicial, mais interna, desde que emita um fóton com energia ou frequência exata para que essa transição ocorra.

Neste caso, o hidrogênio emite fótons com energias ou frequências específicas para que o elétron realize o salto quântico para uma órbita mais interna. Se registrarmos seu espectro, poderemos notar a presença de linhas brilhantes, que correspondem exatamente às frequências dos fótons emitidos pelo hidrogênio, e teremos o chamado espectro de emissão.

Os espectros de absorção e de emissão apresentam linhas que correspondem a mesma posição, pois estão associadas a mesma frequência ou mesma variação de energia (que podem ser representados pela relação $\mathrm{f}=\Delta \mathrm{E} / \mathrm{h}$ ) para que o salto quântico seja realizado. A diferença 
está no fato que as linhas escuras representam os fótons que foram absorvidos da luz pelo gás no espectro de absorção e as linhas brilhantes representam os fótons que foram liberados pelo gás no espectro de emissão.

\section{Espectro de absorção}

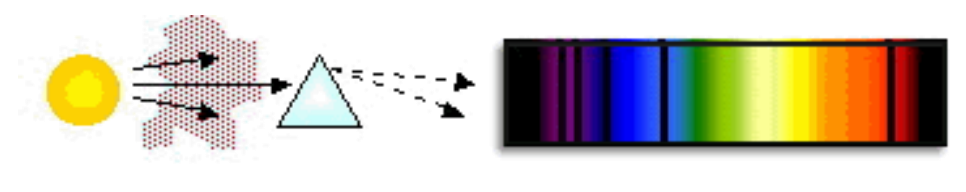

Espectro de emissão

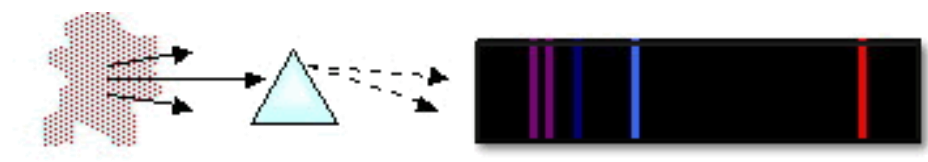

$\boldsymbol{4}$

Espectro contínuo

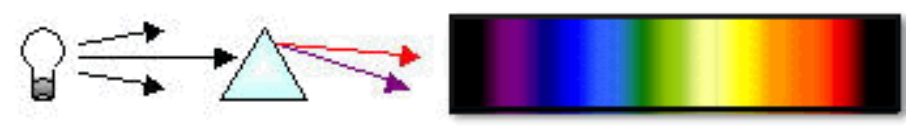

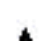

Fonte da imagem: http://astro.if.ufrgs.br/rad/espec/espec.htm 
Capítulo III - Referencial Teórico 


\section{Introducão teórica}

\section{A importância da linguagem na Ciência e no Ensino}

O papel da linguagem na ciência inserido no processo de ensino e aprendizagem de Ciências recebe maior importância ainda quando consideramos os trabalhos de autores como Driver et al. (1994), que apresenta o conceito de enculturação, e Lemke (1992), que destaca a apropriação do discurso científico como característica da aprendizagem de Ciências (Villani e Nascimento 2003).

De acordo com o trabalho de Driver, os processos de ensino e aprendizagem de ciências são uma enculturação somente quando o aluno se apropria da cultura científica, ou seja, a aprendizagem por parte do aluno ocorre à medida que ele consegue compreender e utilizar parte da linguagem, dos métodos e das práticas da cultura científica que, juntamente com a cultura que já possui, cria novas visões de mundo e amplia as que já possuía (Driver et. al., 1999; Mortimer e Machado, 1996; Capecchi e Carvalho, 2002; Capecchi, 2004; e Carmo, 2006).

Este conceito de enculturação se contrapõe ao de aculturação, em que os conhecimentos apresentados pelo professor e obtidos no ambiente de aula suprimem a cultura do aluno. Toda a bagagem de conhecimentos e cultura obtidas anteriormente seriam substituídas pelas novas informações e conhecimentos, fato este que vem preocupando muito alguns pesquisadores e autores na área de Ensino em Ciências.

Cabe destacar que trabalhos como o de Mortimer (1994), ao estudar a evolução do conceito de átomo com estudantes de química do Ensino Médio, mostram que a aculturação não ocorre ou é muito difícil de ocorrer, pois se verificou que os alunos podem apresentar mais de uma interpretação sobre o mesmo conceito e que elas podem coexistir em sua mente, podendo, com a orientação do orientação do professor, usá-las da melhor forma possível de acordo com o contexto. Tal fato também aparece em evidência em situações do dia-a-dia, no qual o conceito de calor possa aparecer como substância e utilizado pelo mesmo aluno numa situação de ensino de Ciências como energia relacionada à movimentação das moléculas, conforme cita Carmo, 2006.

Tal relato nos leva à conclusão que no processo de ensino aprendizagem de Ciências prevalece a enculturação em contrapartida à aculturação, ou seja, o aluno é capaz de adquirir 
novos conhecimentos e cultura sem eliminar as que já possuía e a partir desta nova situação saber utilizar a que for mais adequada de acordo com a situação em que se encontra, seja ela uma aula de Física na sua escola ou uma conversa informal com seus amigos num momento de descontração.

Desta forma, também notamos a importância da aquisição de conhecimentos científicos de forma que o aluno seja capaz de expressar opiniões e emitir valores sobre situações que envolvam um conhecimento mais específico da área e, somado aos conhecimentos que já possuía, as novas informações permitem uma visão mais crítica e participativa na sociedade.

Os Parâmetros Curriculares Nacionais sugerem dois aspectos do ensino de Física nas escolas: a Física como cultura, na qual devemos considerar que muitos alunos têm na escola uma das poucas oportunidades de acesso formal ao conhecimento físico, e como possibilidade de compreensão do mundo.

O trabalho de Lemke fala também de apropriação do discurso científico, ou seja, o aluno ser capaz de utilizar ou relacionar a fala ou a escrita de acordo com o raciocínio e a lógica, próprios da ciência.

Sabendo quando e como utilizá-las de acordo com o contexto para produzir significados específicos, indicando um crescimento em relação ao discurso que já possuía e não simplesmente uma pulverização da capacidade discursiva anterior, temos de certa forma, um enriquecimento do discurso em vez de uma simples substituição do que já existia.

Tanto no processo de enculturação quanto na apropriação do discurso científico, reconhecemos que a Ciência e suas áreas de conhecimento são constituídas por leis, teorias, conceitos, postulados e princípios constituindo uma grande estrutura. Portanto, existe a necessidade de uma linguagem própria, capaz de tornar possível seu aprendizado e seu conhecimento (Villani e Nascimento, 2003).

A linguagem de uma forma geral pode ser definida como todo sistema que se utiliza de signos, visando o estabelecimento de comunicação.

A linguagem é considerada aqui como a capacidade humana de articular significados coletivos e compartilhá-los, em sistemas arbitrários de representação, que variam de acordo com as necessidades e experiências da 
vida em sociedade. A principal razão de qualquer ato de linguagem é a produção de sentido. (PCNEM, p. 125).

A linguagem pode ainda ser dividida em linguagem verbal, língua falada ou escrita, a que se vale da palavra, e linguagem não-verbal, como gráficos e tabelas, gestos e manipulação de materiais didáticos.

A linguagem no Ensino de Ciências transcende a fala e a escrita e conta também com atividades visuais, gestuais e de manipulação.

Da mesma forma que a ciência utiliza-se de diversas linguagens ao mesmo tempo, o ambiente e contexto numa atividade de Ensino devem permitir ao aluno a utilização das linguagens de forma significativa e integrada. Podemos dizer que a compreensão e domínio destas linguagens e como se relacionam entre si é uma competência essencial para a prática científica e também para o ensino de ciências.

Vale ressaltar, portanto, que a linguagem é de extrema importância nos processos de ensino e aprendizagem e ao mesmo tempo apresenta certa complexidade:

[...] assumimos que o papel da linguagem nos processos de ensino e aprendizagem de ciências é complexo e possui intrinsecamente um caráter dual: por um lado, a linguagem é um objeto do processo de aprendizagem de ciências, mas por outro, a linguagem é um instrumento de mediação do seu processo de ensino. (Villani e Nascimento, 2003, p. 2).

Desta forma, quando consideramos a linguagem como objeto do processo de aprendizagem de ciências, o professor deve ter domínio dos conteúdos, conceitos e particularidades a serem trabalhados em sala de aula destacando sua importância bem como o ensino e aprendizagem da própria linguagem científica. Isto traz uma responsabilidade por parte do professor em sistematizar e ensinar os termos e as formas de organização e significação deste conhecimento.

Quando consideramos a linguagem como instrumento de mediação do processo de ensino, alunos e professor devem apresentar certo sincronismo para produzirem significados comuns para os diversos conceitos, leis, teorias e princípios dentro da sistematização do conhecimento científico escolar, de forma que a linguagem utilizada deve ser compartilhada por todos os envolvidos no processo a partir das situações de conhecimento contextualizadas e desenvolvidas no ambiente escolar. 
Por isso, faz-se necessário para o desenvolvimento de nosso trabalho de pesquisa um estudo sobre as linguagens da Ciência no Ensino.

\section{Linguagens da Ciência no Ensino}

O ensino vem dedicando bastante atenção à linguagem, e podemos considerá-la como a utilização de sistemas arbitrários de representação de forma articulada produzindo significados coletivos que são compartilhados, cujo principal objetivo é a busca por sentido (PCNEM, p. 125), ou seja, “... sistema de sinais empregados pelo homem para exprimir e transmitir suas idéias e pensamentos;(...); qualquer meio de exprimir o que se sente ou se pensa;..." (Dicionário brasileiro Globo) na busca de obtenção de significados.

Seguem algumas linguagens no ensino de ciências.

A linguagem verbal sempre recebeu destaque nos estudos sobre construção de conhecimentos em situações de ensino aprendizagem. É um importante e eficiente instrumento de investigação em pesquisas com abordagens sócio-culturais, em que são abordadas interações discursivas. Muitas vezes o professor utiliza a linguagem verbal como forma de interação e para disponibilizar o conhecimento num plano social. Dentro de relações dialógicas, alguns estudos sobre a linguagem verbal em sala de aula ganharam destaque:

Edwards e Mercer (1987) descrevem em seu trabalho como o professor estrutura e guia o discurso em sala de aula, visando à introdução de conceitos e à interação com os alunos. Conforme Capecchi (2004), estes autores identificaram formas de intervenção pedagógicas que dependiam do nível de controle e direcionamento adotado pelo professor. As intervenções apresentadas, considerando um nível decrescente de controle por parte do professor, incluem as seguintes ações: extração/obtenção de contribuições dos alunos; reforço de conhecimento como compartilhado e significativo; extraçãolobtenção de contribuições por meio de pistas; paráfrase de contribuições de alunos; revisão e exposição direta.

Já nos trabalhos de Lemke (1998), são apresentados padrões de discurso, classificados como estratégias de diálogo e estratégias de monólogo. Alguns inclusive se sobrepõem aos obtidos por Edwards e Mercer. Dentro das estratégias de diálogo, por exemplo, Lemke identificou o que chamou de série de questões do professor que assim como a intervenção: extração/obtenção de contribuições dos alunos por meios de pistas (Edwards e Mercer 1987), refere-se a um discurso diretivo baseado no padrão IRF. 
O padrão IRF, em que o professor Inicia o diálogo, o aluno Responde e o professor dá um Feedback com a função de avaliar as respostas dos alunos. Conforme cita Lemke (1997), esse padrão é muito utilizado em pesquisas que visam interações em sala de aula (Sinclair e Coulthard, 1975, e Mehan, 1979) e estes tiveram o seu caráter estritamente avaliativo questionado no trabalho de Mortimer e Machado (1997). Esse questionamento foi fundamentado, por Mortimer e Machado (1997), no conceito de dialogismo de Bakhtin e na teoria sobre dualismo funcional de um texto de Lotman (1988).

Ao analisarem interações discursivas em um determinado episódio de Química, os autores notaram que o padrão IRF caracterizava boa parte das interações, porém sua utilização nem sempre estava associada a um processo de transmissão de conhecimentos prontos por parte da professora. Em alguns casos, de acordo com o feedback, o padrão foi associado a um processo de construção conjunta de novos significados, em que o feedback da professora incentivava os alunos a expressar suas idéias em vez de avaliar as contribuições dos alunos.

Observaram também que o padrão IRF indicava uma alternância entre uma postura avaliativa e elicitativa por parte da professora que pode determinar o sucesso ou o fracasso de um processo de mudança conceitual.

Capecchi e Carvalho (2002 (a) 2002 (b)) observaram diferenças na utilização do padrão IRF ao trabalharem com crianças pequenas do Ensino Fundamental e com alunos do Ensino Médio. Essa diferença ocorreu devido às séries iniciais do ensino fundamental não terem entrado em contato com nenhum conhecimento sistematizado sobre os fenômenos estudados nas aulas. Isso fez com as professoras adotassem o padrão elicitativo. Já com os alunos do Ensino Médio, os conhecimentos básicos que eles traziam foram levados em consideração, proporcionando a utilização de uma alternância entre o padrão elicitativo e avaliativo.

Capecchi (2004) também destaca que Scott (1997), baseado nos trabalhos de Bakhtin, construiu um modelo para descrever a narrativa de ensino, em que explorou os seguintes aspectos relacionados entre si: formas de intervenção do professor; natureza dialógica e de autoridade do discurso; conteúdo do discurso e intervenções pedagógicas de suporte.

Capecchi (2004) adota uma perspectiva sociocultural em sua pesquisa sobre ensino e aprendizagem de Ciências, baseada na definição de Lemke (2001), considerando que Ciência, 
educação em Ciências e pesquisa sobre educação em Ciências são atividades sociais humanas e culturais.

A pesquisa de Capecchi (2004) procura focar como os aspectos da cultura científica são disponibilizados no plano social da sala de aula com atividades experimentais, observando as interações entre professor e alunos em uma sequência de aulas de Física. Para tanto, procura observar que ações costumam ser empregadas nessas aulas e como elas contribuem para construção de significados.

A partir dessa perspectiva, também utiliza a linguagem verbal em seu trabalho, destacando inclusive os dois primeiros aspectos do trabalho de Scott (1997), citados anteriormente:

Em relação às formas de intervenção do professor, Capecchi relata que Scott (1997) identificou cinco categorias, distribuídas em três grupos de acordo com os objetivos de ensino. Segue uma tabela com essas categorias:

\begin{tabular}{|l|l|l|l|l|}
\hline \multicolumn{5}{|c|}{ Narrativa de Ensino } \\
\hline $\begin{array}{l}\text { Desenvolver conhecimento } \\
\text { científico }\end{array}$ & $\begin{array}{l}\text { Dar suporte à construção } \\
\text { de significados por parte dos } \\
\text { alunos }\end{array}$ & $\begin{array}{l}\text { Manter } \\
\text { narrativa }\end{array}$ \\
\hline $\begin{array}{l}\text { Desenvolver a } \\
\text { linha conceitual: }\end{array}$ & $\begin{array}{l}\text { Desenvolver a } \\
\text { linha } \\
\text { epistemológica }\end{array}$ & $\begin{array}{l}\text { Promover } \\
\text { conhecimento } \\
\text { compartilhado }\end{array}$ & $\begin{array}{l}\text { Verificar } \\
\text { entendimento } \\
\text { dos alunos }\end{array}$ & $\begin{array}{l}\text { Manter } \\
\text { narrativa }\end{array}$ \\
Seldar idéias \\
idéias
\end{tabular}

Intervenções pedagógicas na narrativa de ensino (Scott, 1997)

Em relação ao segundo aspecto natureza dialógica e de autoridade do discurso, temos a diferenciação entre os dois discursos. No discurso de autoridade, as contribuições do professor estão relacionadas à transmissão de informações, restringindo as opções de diálogo, 
enquanto que no discurso dialógico, os alunos são estimulados a debaterem e apresentarem suas idéias.

Capecchi (2004) cita também os trabalhos de Mortimer e Scott (2000, 2002 e 2003), no qual desenvolvem um modelo abrangente para descrição de dinâmicas discursivas envolvidas na construção de significados em sala de aula, levando em consideração tanto o papel das intervenções do professor quanto das contribuições dos estudantes. Trabalharam com cinco categorias relacionadas entre si, subdivididas em três grupos: foco do ensino, abordagens e ações.

O foco de ensino aplica-se tanto ao conteúdo desenvolvido quanto às intenções pedagógicas do professor durante as interações.

A abordagem está relacionada à maneira como o professor conduz sua interação com os alunos que pode ser feita de uma forma mais autoritária, em que sua fala prevalece sem deixar espaço para fala dos alunos, ou de uma forma dialógica: as falas dos alunos são consideradas durante as interações.

As ações referem-se à implementação das ideias científicas em sala de aula, por meio de ações propriamente ditas. Destacam-se aqui os padrões de discurso empregados pelo professor e os tipos de intervenção conforme tabela a seguir:

\begin{tabular}{|l|l|}
\hline Aspectos da análise & \\
\hline Foco do ensino & $\begin{array}{l}\text { 1. Intenções do professor } \\
\text { 2. Conteúdo }\end{array}$ \\
\hline Abordagem & \begin{tabular}{l} 
3. Abordagem comunicativa \\
\hline Ações
\end{tabular} \\
& 4. Padrões de interação \\
& 5. Intervenções do professor \\
\hline
\end{tabular}

Estrutura analítica para interações de ensino propostas por Mortimer e Scott 
Capecchi (2004), considerando o foco de sua pesquisa e a estreita relação entre os aspectos abordados na estrutura analítica proposta nos trabalhos de Mortimer e Scott (2000, 2002 e 2003), destaca três das cinco categorias:

1. Intenções do professor - os autores identificaram intenções relacionadas aos propósitos pedagógicos do professor, inseridos numa abordagem sociocultural de ensino e aprendizagem, baseados na construção de significados a partir de idéias levantadas pelos alunos, mas considerando-se a introdução de uma nova cultura por meio de suporte oferecido pelo membro mais experiente que é o professor. As intenções identificadas foram criar um problema; explorar e trabalhar com a visão dos estudantes; introduzir e desenvolver a estória científica; guiar trabalho dos estudantes com idéias científicas e dar suporte a internalização; guiar estudantes na aplicação e expansão do uso de idéias científicas e transferir aos mesmos a responsabilidade por seu uso; manter a narrativa (onde o professor procura manter a continuidade do discurso e ajudar os estudantes a seguir o desenvolvimento da estória científica).

2. Conteúdo - procuram identificar a linguagem social predominante nas interações: cotidiana e científica. Considerando que a linguagem científica é o objetivo maior do ensino, os autores identificaram três abordagens da mesma: descrição, explicação e generalização, bem como as formas de embasamento para construção delas: empírica e teórica.

3. Abordagem Comunicativa - de acordo com o tipo de interação discursiva entre alunos e professor, os autores destacaram a distinção entre um monólogo e um diálogo conforme o número de locutores na interação, o que permitiu a classificação da fala como não-interativa (monólogo) ou interativa (diálogo). Também destacaram o predomínio da fala do professor ou da fala conjunta entre professor e alunos na interação, levando à classificação da fala como discurso de autoridade ou dialógica. Desses destaques foram obtidos quatro tipos de abordagens comunicativas:

- $\quad$ interativa/de autoridade (pode ser relacionada à estratégia de obtenção de contribuições dos alunos por meio de pistas de Edwards e Mercer (1987));

- $\quad$ interativa/dialógica (pode ser relacionada à estratégia de obtenção de contribuições do professor, de Edwards e Mercer (1987)); 


\section{- não-interativa/de autoridade correspondente à aula expositiva tradicional;}

- não-interativa/dialógica pode ser relacionada à estratégia de parafrasear as contribuições dos alunos, identificada por Edwards e Mercer (1987) e também as estratégias de revisão.

Capecchi (2004) utilizou ou tomou como base esses estudos, entre outros, para elaboração de instrumentos de análise de discursos principalmente no que se refere à linguagem verbal.

Com os trabalhos citados, podemos ver a importância e o interesse que a linguagem verbal desperta nas pesquisas em Ensino de Ciências e para compreensão de processos de ensino aprendizagem que envolvam interações discursivas em sala de aula.

$\mathrm{Na}$ nossa dissertação, trabalhamos a linguagem verbal, com destaque à oralidade, relacionada tanto aos alunos quanto ao professor, nas interações ocorridas em relações sociais desenvolvidas em sala de aula. Já a escrita aparece quando o professor faz uso da lousa e em alguns poucos momentos pelos alunos, isto na sequência que estamos analisando.

Embora seja reconhecidamente importante a linguagem verbal, por si só não é suficiente para compreensão do processo de construção de significados. Temos, portanto, a necessidade do estudo das diversas linguagens da ciência para obtermos essa compreensão de forma mais eficiente.

Podemos dizer que as linguagens oral e escrita apresentam limitações para explicar determinadas situações necessitam de auxílio e complementação por parte de outras linguagens.

Estudos e pesquisas que descrevem o papel das linguagens em aulas de Ciências têm destacado a importância das várias linguagens e a forma como elas se relacionam e se completam, contribuindo para uma maior precisão na compreensão das interações ocorridas nos processo de ensino-aprendizagem e na construção de conceitos em sala de aula e ampliando as possibilidades de comunicação.

A linguagem gestual aparece como importante mediadora no processo de comunicação, principalmente entre a linguagem verbal e o mundo. Capecchi (2004) destaca 
Roth (2002a) com seu trabalho, mostrando que os gestos como linguagem representam um dos aspectos centrais da cultura. Estes gestos assumem um papel de mediação entre linguagem e o mundo, partindo da manipulação e manuseio de objetos, evoluindo para gestos simbólicos e finalmente representam uma linguagem descritiva e teórica viável.

Em sua tese, Capecchi (2004) também cita Crowder (1996), cujos estudos indicam os gestos como instrumentos utilizados pelos estudantes na construção de significados. De acordo com Crowder, os gestos aparecem durante o processo de construção de explicações por parte dos estudantes de forma a ajudá-los com previsões, revisões e coordenação de elementos de um modelo explicativo, mas destaca que no caso de descreverem um modelo já memorizado, a função dos gestos é mais enfática do que construtiva. Por isso, eles servem para destacar ou repetir o que já foi expresso pela linguagem verbal.

Em relação aos conteúdos, Crowder (1996) denomina-os de icônicos (representando atributos concretos entre os objetos); metafóricos (representando conteúdos abstratos) e dêiticos (com função indicativa). A autora observou três funções associadas a esses gestos: representar ideias veiculadas por outras linguagens, de uma maneira redundante; enfatizar ou estender significados apresentados pela linguagem oral e por fim veicular conteúdo.

Podemos dizer que a linguagem por meio dos gestos aparece algumas vezes de forma redundante em relação à linguagem oral, outras vezes, de forma enfática ou complementar, e também como importante aspecto na criação de significados. Portanto, em nosso trabalho estaremos atentos aos gestos tanto do professor quanto dos alunos durante as interações presentes na sequência a ser analisada.

Devemos também prestar atenção ao caráter social dos gestos e sua contextualização. Na linguagem gestual permanece a noção de convenção: há gestos idênticos com significados diferentes, dependendo de cada cultura.

\section{Conforme enfatizam os PCNEM:}

“Os gestos, as posturas e as expressões faciais são criados, mantidos ou modificados em virtude de o homem ser um ser social e viver num determinado contexto cultural. Isso significa que os indivíduos têm uma forma diferenciada de se comunicar corporalmente, que se modifica de cultura para cultura. E o indivíduo, por sua vez, aprende a fazer uso da expressões corporais, de acordo com o ambiente em que se desenvolve 
como pessoa. Isso quer dizer que todo movimento do corpo tem um significado, de acordo com o contexto. (PCNEM, p. 160)".

A linguagem de manipulação também é discutida no trabalho de Capecchi (2004) que cita a pesquisa de Franks e Jewitt (2001) e apresentam como significativas as ações sobre objetos concretos presentes nas atividades de ensino aprendizagem que são estruturadas, transformadoras, comunicativas e geradoras. Aqui eles diferenciam a ação de comportamento (relacionado a interesses e motivações e também a processos psicológicos superiores). Os autores se baseiam no conceito de atividade de Leontiev, em que, por exemplo, numa atividade que envolva manipulação de objeto concreto, teremos um sujeito humano, uma meta representada pelo objeto e entre eles um instrumento mediador (ou ferramenta). Este instrumento mediador pode ser a linguagem verbal, em suas formas oral e escrita, mas também a manipulação e o uso dos objetos e instrumentos.

Os autores concluem que quando os alunos conseguem perceber que pequenas ações fazem parte de um contexto maior de padrões de ação possíveis em uma aula, temos uma evidência de aprendizagem. Portanto, a ação física de manipulação, ao lado da linguagem verbal, também é importante na construção de significados.

$\mathrm{Na}$ seqüência de ensino que analisaremos, temos atividades onde alunos manipulam objetos, fato que evidencia o nosso interesse por esta forma de linguagem.

A linguagem matemática é constituída por diferentes linguagens como aritmética, geométrica, algébrica, lógica e gráfica, sendo que esta última geralmente é expressa por meio de tabelas, diagramas, gráficos e esboços (Klüsener, 1998). Pode ser considerada uma forma híbrida que possibilita a integração entre a linguagem verbal com as representações visuais, de acordo com Carmo (2006).

Carmo (2006) destaca em seu trabalho que a linguagem é constituída ao mesmo tempo por um componente verbal-tipológico e um matemático-gráfico-operacional-topológico, o que de acordo com as ideias apresentadas por Lemke, ao se integrarem, permitem a inserção no mundo da ciência. A integração ocorre ao se combinar discurso verbal, expressões matemáticas, representações gráficas, visuais e operações motoras e de manipulação. 
Esta característica dessa área de conhecimento, de acordo com Lemke, está relacionada à materialidade dos processos físicos, que ultrapassa os limites de comunicação e representação da linguagem verbal, sendo mais orientada para classificação do que a descrição de relações de interação. Necessitamos, então, da matemática para auxiliar na construção de explicações científicas.

Em seu trabalho, Carmo (2006) apresenta também as características dos aspectos tipológicos e topológicos de acordo com seus estudos baseados nas pesquisas de Lemke:

Os recursos tipológicos estão associados a classificações relacionadas a categorias discretas (Lemke, 1998), que geralmente apresentam a idéia de oposição uma em relação à outra, como quente e frio, longe e perto, momento angular e momento linear etc. Dizemos que são relativos à comunicação/representação de diferenças: classificação, predominando, portanto, na linguagem verbal.

Já os recursos topológicos estão associados a variações contínuas ou quase contínuas sobre alguma propriedade de objetos materiais, são os significados contidos nas proporções entre os entes que construímos. Nesse tipo de recurso, são descritas variações contínuas (ou quase) do objeto de estudo ou análise e que de alguma forma são proporcionais ou possuem algum tipo de dependência funcional, como: tamanho, forma, distância, proporção, densidade, velocidade, densidade etc. Destacam-se aqui também, desenhos, gráficos, gestos e outros tipos de representações visuais. Os aspectos topológicos são relativos à comunicação/representação de interações: relação, representados em processos visuais e motores. Mostram a relação entre duas ou mais grandezas, por exemplo.

Outra diferença entre os recursos tipológicos e topológicos, segundo Lemke (2002), é que o primeiro é basicamente qualitativo enquanto o segundo é quantitativo.

Podemos ter os dois recursos concomitantemente como nas representações gráficas, que apresentam um caráter de continuidade proveniente de modos visuais e motores, mas também uma gramática implícita na leitura das mesmas, proveniente da linguagem verbal. É o que Lemke classifica como híbridos semióticos presentes nos conhecimentos científicos, ou seja, simultaneamente e essencialmente verbais (tipológicos) e matemáticos (topológicos).

Lemke coloca em evidência o caráter híbrido do conhecimento científico: 
“...Para fazer ciência, para falar ciência, para ler e escrever ciência, é necessário lidar com e combinar em formas regradas discurso verbal, expressões matemáticas, representações gráfico-visuais e operações motoras no mundo 'natural' (incluindo humano como natural) . (Lemke, p. 3, tradução Capecchi , 2004).”

Outras leituras também são apresentadas por Carmo (2006) considerando a matemática como linguagem no ensino de ciências, o que tem como conseqüência o fato de ela deixar de ser uma tradução direta da natureza e passar a ser uma expressão de pensamentos humanos, mas também possuidora de características próprias como a precisão, a universalidade e a lógica dedutiva (possibilidade de se fazer previsões). Além disso, serve como instrumento de raciocínio e permite comparações, apresentando, desta forma, uma função estruturante, conforme Pietrocola (2002), em relação à física, por exemplo:

\footnotetext{
“[...] a Matemática, enquanto linguagem, empresta sua própria estruturação ao pensamento científico para compor os modelos físicos sobre o mundo. Essas são, em última instância, estruturas conceituais que se relacionam ao mundo, mediadas pela experimentação" (Bunge, 1974) (Pietrocola, op. cit., p. 106). Carmo 2006.
}

Existe um pressuposto que a linguagem matemática impregna os conceitos físicos, tendo como objetivo construir interpretações do mundo real.

Na sequência que iremos analisar, a linguagem matemática se apresenta na forma de tabelas, gráficos, esquemas e/ou desenhos que o professor ou alunos podem utilizar para sistematizar um pensamento, demonstrar um raciocínio ou tentar organizar ideias.

Conforme Carmo (2006), as diferentes linguagens e seus recursos podem: Cooperar quando duas ou mais linguagens atribuem o mesmo significado ao mesmo fenômeno, representando funções semelhantes (Márquez et al., 2003); Especializar quando duas ou mais linguagens atribuem um significado para um conceito ou fenômeno, realizando funções distintas (Márquez et al., 2003). Tanto as cooperações quanto a especializações podem ocorrer no decorrer de uma comunicação de acordo com a necessidade do contexto.

As pesquisas aqui citadas sobre as diferentes linguagens empregadas em sala de aula têm contribuído para compreensão dos papéis representados por elas na construção de significados, o que nos leva a outras considerações e estudo importantes para o desenvolvimento de nosso estudo e pesquisa.

Seguem considerações sobre o papel da Argumentação nas salas de aula. 
Em seus trabalhos Sasseron e Carvalho (2008), apresenta alguns indicadores que apontam destrezas que devem aparecer quando se deseja trabalhar com o processo de conhecimento voltado para formação de uma Alfabetização Científica. Entre esses indicadores cita:

- $\quad$ Seriação de informações: quando se determinam bases para uma ação investigativa. Pode ser uma lista de dados a serem trabalhados.

- $\quad$ Organização de informações: ocorre quando se discute como um trabalho foi ou será organizado.

- $\quad$ Classificação de informações: mostra-se quando se busca conferir hierarquia às informações, o estabelecimento de uma ordem e distinção entre as informações obtidas.

- Levantamento de hipóteses: acontece quando são feitas suposições sobre determinado assunto ou tema. Pode aparecer como pergunta também.

- $\quad$ Teste de hipóteses: quando testamos suposições. Pode ocorrer com a manipulação de materiais ou por meio de atividades de pensamento baseadas em conhecimentos prévios.

- $\quad$ Justificativa: aparece quando uma afirmativa ganha uma garantia.

- $\quad$ Previsão: surge quando uma ação ou fenômeno é antecipado por meio de associação com certos acontecimentos.

- $\quad$ Explicação: quando se busca relacionar informações e hipóteses já elaboradas.

Esses indicadores podem ser identificados por meio das linguagens científicas.

\section{Argumentação no Ensino de Ciências}

Ao falarmos em linguagem relacionada à construção de significados não podemos deixar de falar no conceito de argumentação.

De acordo com Villani e Nascimento (2003), temos:

A argumentação, ampliando o conceito de Van Eemeren et al. (1987) para o contexto das interações discursivas em sala de aula de ciências, é uma atividade social, intelectual e de comunicação verbal e não verbal utilizada para justificar ou refutar uma opinião sobre um assunto de ciências. (Villani e Nascimento, op. cit., 2003). 
Um dos aspectos importantes destacados aqui é o conceito de argumento como atividade social por meio das interações discursivas e que depende, portanto, do contexto no qual está inserido. Um enunciado ou comunicado poderá ser considerado um argumento ou não de acordo com a situação na qual aparece.

Um enunciado que apareça de forma isolada, a princípio, pode não representar um argumento, já quando estiver inserido em um discurso e submetido a um determinado contexto e for constituído por um ou mais posicionamentos com a intenção de obter a aprovação de um ponto de vista particular, será considerado como argumento.

Outro aspecto importante é que o argumento existe quando a linguagem é utilizada para justificar ou refutar uma ideia, um conceito ou uma opinião numa aula de ciências.

Dentro desta perspectiva, um gesto, por exemplo, que de forma isolada não apresente nenhum significado, poderá, dentro de um contexto, indicar uma ênfase a um comentário, ou mesmo uma negação e, assim, ser considerado um argumento, contribuindo para construção de significados, seja de forma a justificar ou negar a ideia apresentada.

A importância da contextualização para construção de argumentos no ensino de ciências também é destacado por Candela (1998). A autora ressalta em seu trabalho a relação dialética entre o contexto criado e os significados construídos em uma situação de ensino. Enfatiza a forma como a interação discursiva em torno do conteúdo vai construindo dialeticamente um contexto argumentativo que propicia elaborações de outras aproximações ao significado. Observou que, conforme práticas discursivas são incentivadas durante as aulas, os alunos vão se apropriando de novas formas de se expressar, com mais confiança, independência de ideias e atitudes científicas baseadas na postura do professor.

Em seu trabalho, a autora procurou identificar características do discurso argumentativo em sala de aula e concluiu que situações de conflito representam uma forma de envolver os alunos na busca de recursos discursivos para validação de seus argumentos sobre os conteúdos de ciências. Destaca que a diversidade de argumentos sempre será mais rica que opiniões uniformes e com certeza essa diversidade só pode ser observada com uma contextualização das relações sociais para construção de argumentos.

Ainda em relação à contextualização, Capecchi; Carvalho e Silva (2002) enfatizam que uma mesma afirmação pode ter diferentes significados em diferentes contextos, o que 
deve ser levado em consideração em análises que buscam informações sobre discursos argumentativos em sala de aula.

Villani e Nascimento (2003) destacam ainda a relação entre argumentação e opinião e usam a definição de Philippe Breton (1996) de que a opinião é um conjunto de crenças, de valores, de representações de mundo e da confiança nos outros que um indivíduo forma para ser ele mesmo. Por isso, a opinião está em constante evolução, dependente dos outros.

Quando a opinião aparece como um ponto de vista possível ou como confrontação de vários pontos de vista, ou seja, quando é utilizada por intermédio da linguagem para convencer um ou mais interlocutores, ela será considerada um argumento.

Consequentemente, podemos interpretar que um argumento ocorre quando uma opinião é utilizada na tentativa de persuadir um ou mais interlocutores sobre determinado ponto de vista a respeito de uma situação: quando se tenta convencer outros que determinado ponto de vista é correto (justificando) ou não (refutando).

Vamos utilizar alguns turnos de fala de um determinado episódio apresentado no trabalho de Villani e Nascimento (2003) para exemplificar o conceito aqui apresentado sobre opinião e argumento.

O episódio se desenvolve num momento em que determinadas alunas do primeiro ano do Ensino Médio, em aulas de um laboratório didático de Física, se encontram assentadas em bancadas interagindo com materiais de análises. O episódio tem início com a leitura de uma questão apresentada por um roteiro; "Você acha que a velocidade (em $\mathrm{km} / \mathrm{h})$ dos impulsos nervosos é mais próximo de 1,10, 100 ou 1000, isto é, qual é a ordem de grandeza desta velocidade?). Essa questão se refere a uma tarefa específica que é estimar o valor da velocidade dos impulsos nervosos.

Segue a tabela de análise apresentada pelos autores:

\begin{tabular}{|l|l|l|l|l|}
\hline Turno & Locutor & Enunciado & Elemento da & Componen- \\
De & argumentação & tes dos \\
fala & & & argumentos \\
\hline
\end{tabular}




\begin{tabular}{|c|c|c|c|}
\hline 136 & LUMA & $\begin{array}{l}\text { A velocidade média de } \\
\text { reação de uma pessoa está mais } \\
\text { perto de um / dez / cem ou mil } \\
\text { quilômetros por hora? [LUMA lê } \\
\text { esta questão no roteiro de prática } \\
\text { para o grupo] }\end{array}$ & \\
\hline 137 & BIA & $\begin{array}{l}\text { 1- Eu acho que está mais } \\
\text { próximo de mil / }\end{array}$ & Opinião \\
\hline 137 & BIA & 2 - é muito rápido & Argumento \\
\hline 138 & LUMA & $\begin{array}{l}\text { Qual é a ordem de } \\
\text { grandeza desta velocidade? / } \\
\text { [LUMA lê esta questão no roteiro } \\
\text { de prática para o grupo num tom } \\
\text { baixo de voz] dez elevado a três / } \\
\text { mil é dez elevado a três / é } \\
\text { quando você tá falando a ordem } \\
\text { de grandeza você não pode falar } \\
\text { mil não / é para falar que é dez } \\
\text { elevado a três /// então a gente vai } \\
\text { colocar, achamos que está mais } \\
\text { próximo de mil e sua ordem de } \\
\text { grandeza é dez elevado a três }\end{array}$ & $\begin{array}{l}\text { Posicionamento } \\
1 \\
\text { (confirmação, } \\
\text { segurança) }\end{array}$ \\
\hline
\end{tabular}

Reprodução do quadro 5: episódio 22 - subturma B (Villani e Nascimento 2003).

No momento apenas nos interessa olhar para a classificação em "opinião" e "argumento".

No turno de fala 137-1 quando Bia diz "Eu acho que está mais próximo de mil/” ela expressa uma opinião de acordo com o que acredita. Essa fala não tem como objetivo 
explícito tentar convencer alguém. Já no turno 137-2 quando diz “é muito rápido" também temos uma opinião de Bia, porém aqui, esta opinião expressa na linguagem oral, tem o objetivo explícito de convencer os demais interlocutores a respeito de sua fala anterior, aparece como uma justificativa para sua fala anterior, sendo, portanto, classificada como um argumento.

Dizemos então que todo argumento contém pelo menos uma opinião e a opinião pode existir sem ser necessariamente um argumento, ela precede este.

Os autores ainda destacam a distinção entre opinião e informação, sendo que a primeira possui um caráter mais subjetivo, e a segunda, por sua vez, destaca-se pela busca de objetividade.

Capecchi; Carvalho e Silva (2002) utilizam categorias elaboradas por Driver e Newton (1997) a partir do padrão de Toulmin (1958) para identificação de componentes de argumentos dos alunos numa análise de duas cenas dentro de um episódio de ensino extraído de uma sequência de aulas, na qual alunos do primeiro ano do Ensino Médio estudam o funcionamento do forno de micro-ondas. É interessante notarmos que, com essas categorias, os argumentos passam a ter níveis de qualidade baseados na sua complexidade e também na complexidade das interações entre diferentes ideias.

A seguir temos uma tabela com as categorias desenvolvidas por Driver e Newton (1997) para análise da argumentação dos alunos a partir do modelo de argumento de Toulmin:

\begin{tabular}{|l|c|}
\hline Tipo de Argumento & Nível \\
\hline Afirmação isolada sem justificativa & 0 \\
\hline Afirmações competindo sem justificativas & 0 \\
\hline Afirmação isolada com justificativa & 1 \\
\hline Afirmações competindo com justificativas & 2 \\
\hline
\end{tabular}




\begin{tabular}{|c|c|}
\hline Afirmações competindo com justificativas e qualificadores & 3 \\
\hline Afirmações competindo com justificativas respondendo por refutação & 3 \\
\hline Fazer julgamento integrando diferentes argumentos & 4 \\
\hline
\end{tabular}

Estas categorias foram criadas dentro de uma proposta de desenvolvimento de argumentos em sala de aula, visando a uma enculturação em ciências e considerando o aspecto de construção coletiva do conhecimento científico. Baseado nesse aspecto, as categorias valorizam a presença de teorias conflitantes e as sínteses nas discussões em sala de aula.

Se compararmos as categorias de Driver e Newton (1997) com os conceitos de argumento e opinião de Villani e Nascimento (2003), notaremos que o "nível 0" afirmação isolada sem justificativa corresponde à definição de opinião, enquanto que os demais níveis já correspondem a argumentos, com níveis de elaboração diferentes.

Em seu trabalho, Capecchi; Carvalho e Silva (2002) destacam que a utilização isolada das categorias de Driver e Newton (1997) não seria suficiente para análise, pois não permitiria que fossem estabelecidas diferenças entre os tipos de justificativas utilizadas pelos alunos em suas falas: todas elas receberiam a mesma classificação e não teríamos distinção entre uma justificativa baseada no senso comum e outra, em conhecimentos adquiridos na escola. Para evitar tal acontecimento, utilizaram o padrão de Toulmin (1958) para identificação de elementos constituintes de argumentos individuais.

\section{$\underline{\text { Modelo de Toulmin }}$}

Conforme citado, o modelo de Toulmin (1958), que representa um dos aspectos de seus trabalhos, foi adaptado e vem sendo amplamente utilizado em estudos na área de pesquisa em Educação e tem se mostrado um importante e eficiente instrumento de análise na investigação sobre a argumentação dos alunos em aulas e situações de ensino de Ciências.

Muitos pesquisadores utilizaram o modelo de Toulmin em seus trabalhos e investigações de forma a contribuir significativamente para sua consolidação como um importante instrumento de análise adaptado a diversas situações de ensino. Alguns trabalhos 
utilizaram o modelo com algumas adaptações ou ainda em conjunto com outros instrumentos de análise, mas sempre enfatizando a sua importância. Dentre esses trabalhos, foram citados aqui Driver e Newton (1997); Jiménez Aleixandre (1998), Capecchi \& Carvalho (2000); Capecchi; Carvalho e Silva (2002); Villani e Nascimento (2003); Capecchi (2004) e Carmo (2006).

Villani e Nascimento (2003) apresentam no artigo "A argumentação e o Ensino de Ciências: uma atividade experimental no laboratório didático de Física do ensino médio" um estudo em que destacam os argumentos de alunos do Ensino Médio como indicador da utilização da linguagem mediadora entre os conhecimentos científico escolar e cotidiano.

Modificaram o modelo de Toulmin (1958) e o modelo de Van Eemeren et al. (1987) para análise de argumentação adaptando-os para situações discursivas de ensino de Ciências.

O modelo de Toulmin é uma ferramenta poderosa para identificar a estrutura de argumentos científicos. Este modelo pode mostrar o papel das evidências na elaboração de afirmações, relacionando dados e conclusões através de justificativas de caráter hipotético. Também pode realçar as limitações de uma dada teoria, bem como sua sustentação em outras teorias. O uso de qualificadores modais ou de refutações pode indicar uma compreensão clara do papel dos modelos na ciência e a capacidade de ponderar diante de diferentes teorias a partir das evidências apresentadas por cada uma delas. Se os alunos puderem entrar em contato com argumentos completos, prestando atenção nestas sutilezas, possivelmente estarão compreendendo uma importante faceta do conhecimento científico. (Capecchi \& Carvalho; 2000).

Podemos dizer que o modelo desenvolvido por Toulmin para análise de argumentos permite a identificação de elementos básicos que o compõem e a forma como esses elementos se relacionam.

O modelo também mostra o papel das evidências na elaboração de afirmações, relacionando dados e conclusões por meio de justificativas de caráter hipotético e realça as limitações de uma determinada teoria, assim como sua sustentação em outras. Um modelo pode, por exemplo, ser útil na explicação de determinada situação ou fenômeno, mas em outras situações, ele pode não contribuir muito, sendo necessária a presença de outro modelo mais abrangente. 
Segundo o modelo de Toulmin, a estrutura básica de um argumento é constituída pelos seguintes elementos:

$$
\begin{aligned}
& -\quad \text { o dado (D); } \\
& \text { - } \quad \text { a justificativa (J); } \\
& \text { - } \quad \text { a conclusão }(\mathrm{C}) .
\end{aligned}
$$

Com esses três elementos fundamentais podemos ter um argumento: "a partir do dado (D), já que Justificativa (J), então conclusão (C)".

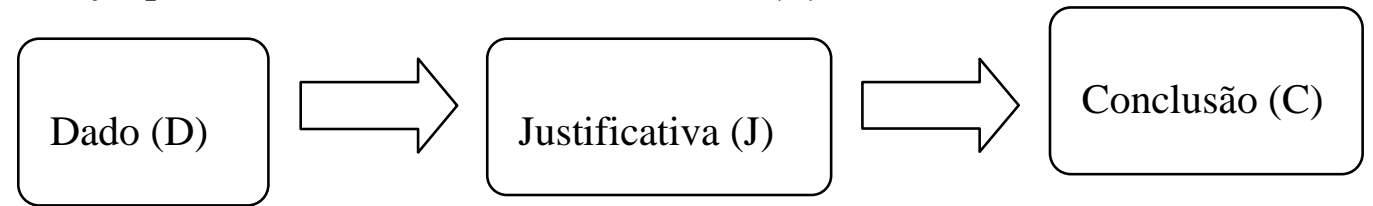

Estrutura básica de um argumento segundo modelo de Toulmin.

Além desses três elementos, o modelo de Toulmin comporta ainda outros para que o argumento seja considerado completo.

Quando a estrutura argumentativa apresenta também especificações das condições necessárias para que uma dada justificativa seja válida, temos os chamados qualificadores modais (Q), que servem para indicar um "peso", uma "escala" para as justificativas, ou seja, permitem que seja estabelecida uma comparação para a validade das mesmas.

Já quando aparecem elementos que determinam condições de oposição à justificativa e que mostrem que ela não seja válida ou capaz de sustentar uma conclusão, temos o elemento refutação $(\mathrm{R})$.

Os qualificadores modais e a refutação complementam a ligação entre dado e conclusão sinalizando a atuação da justificativa, que por sua vez apresenta um caráter hipotético que pode ser complementado pelo elemento conhecimento básico(B), apoiando a justificativa pelo conhecimento de caráter teórico, procedente de fontes distintas. Ele fundamenta a justificativa com base em alguma autoridade, uma lei científica, por exemplo.

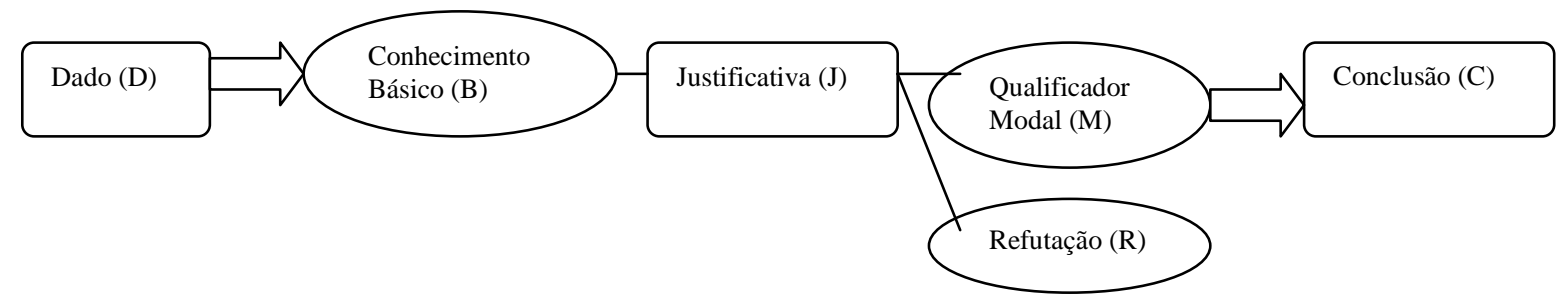

Estrutura completa de um argumento segundo modelo de Toulmin. 


\section{Modelo de Toulmin ampliado por Jiménez Aleixandre}

Algumas limitações são apontadas em relação ao modelo de Toulmin (1958) por Driver e Newton (1997), sinalizando para uma necessidade de adequação ou ampliação do modelo. Segundo os autores, o modelo não conduz a julgamentos sobre a verdade ou adequação do argumento, sendo necessária a incorporação de conhecimento específico à análise. Outro aspecto a ser abordado é que a argumentação acaba aparecendo de forma descontextualizada e seus aspectos interacionais não são explicitados, e enquanto discurso, sujeito a influência dos contextos linguísticos e pela situação na qual está inserido.

Consequentemente, a necessidade de interpretação do texto e algumas considerações devem ser observadas com muita atenção: a mesma afirmação ou posicionamento podem apresentar significados diferentes de acordo com o contexto em que se apresentem; declarações implícitas e de relevância para a estrutura do argumento podem ser informadas por meio do contexto; para identificar componentes e/ou as características de um argumento são necessários exames de longas seções do texto, já que as conversas em sala de aula não se desenvolvem necessariamente de forma linear; outras formas de linguagem, além da oral devem ser observadas atentamente, como a gestual, por exemplo, pois podem apresentar e constituir elementos essenciais de um argumento.

Nessa linha de raciocínio, Jiménez e Aleixandre et al. (1998) apresentaram em seus trabalhos uma ampliação do modelo de Toulmin com a criação de subcategorias específicas em relação ao elemento dado (D).

O dado (D) em relação à natureza de sua procedência, seja ela teórica ou experimental, pode ser caracterizado como: um dado fornecido (DF) que é aquele disponibilizado pelo professor, livro texto, roteiro de experimento etc.; ou dado obtido (DO) que são dados que os alunos conseguem por meio de uma atividade experimental, por exemplo, e que recebem a classificação de dado empírico (DE), ou por hipóteses elaboradas por eles sendo classificados como dado hipotético (DH). 


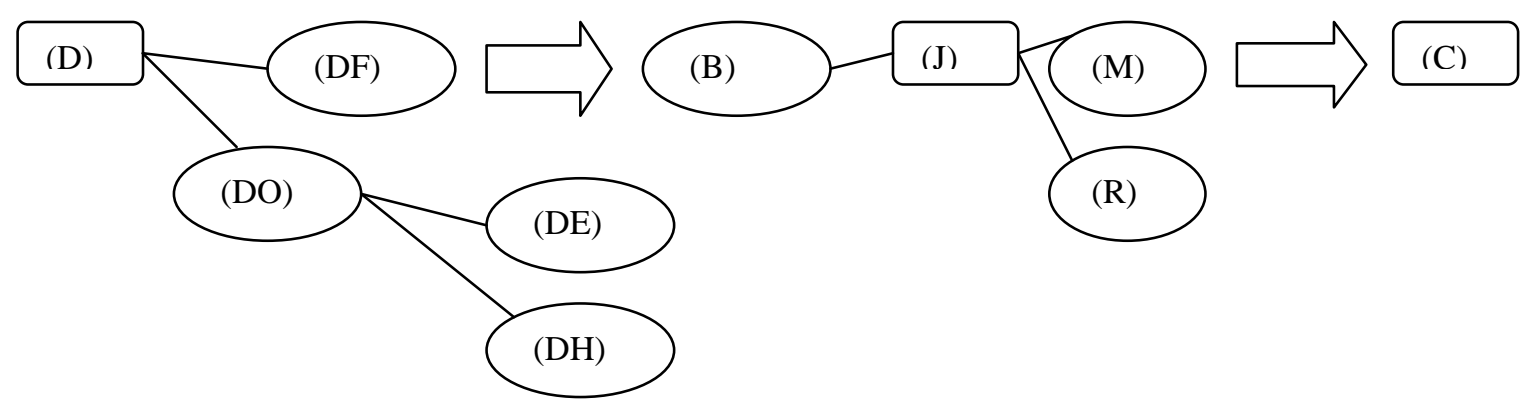

Estrutura completa de um argumento segundo o modelo de Toulmin ampliado com as categorias Dado Fornecido (DF), Dado Obtido (DO) e as subcategorias Dado Empírico (DE) e Dado Hipotético (DH) propostos por Jiménez Aleixandre (1998).

$\underline{\text { O modelo de argumentação de Van Eemeren et al. (1987) adaptado por Villani e Nascimento }}$ (2003) para análise de situações discursivas em Ciências

Os autores levaram em consideração o fato que as aulas analisadas por eles não foram planejadas para desenvolver a argumentação dos alunos, e acharam necessário utilizar o modelo adaptado de Van Eemeren (1987) para ampliar ou modificar as categorias do modelo de Toulmin.

A adaptação teve como objetivo identificar no discurso dos alunos enunciados que estivessem inseridos no contexto de uma argumentação. Esta adaptação pode ser utilizada em situações discursivas entre dois ou mais interlocutores.

O modelo considera um contexto particular que se encontra em contínua mudança e não como uma entidade estática. Os argumentos dos alunos estão inseridos neste contexto e podem apresentar significados diferentes em relação a seu aceite ou refutação quando se encontrarem em contextos diferentes.

Neste modelo temos:

Um ou mais locutores $(S)$ com objetivo de justificar ou refutar determinado ponto de vista valendo-se de um discurso $(D)$, inserido num contexto, expressando uma opinião $(O)$. Por outro lado temos um ou mais ouvintes $(L)$ que tentam interpretar o discurso $(D)$. 


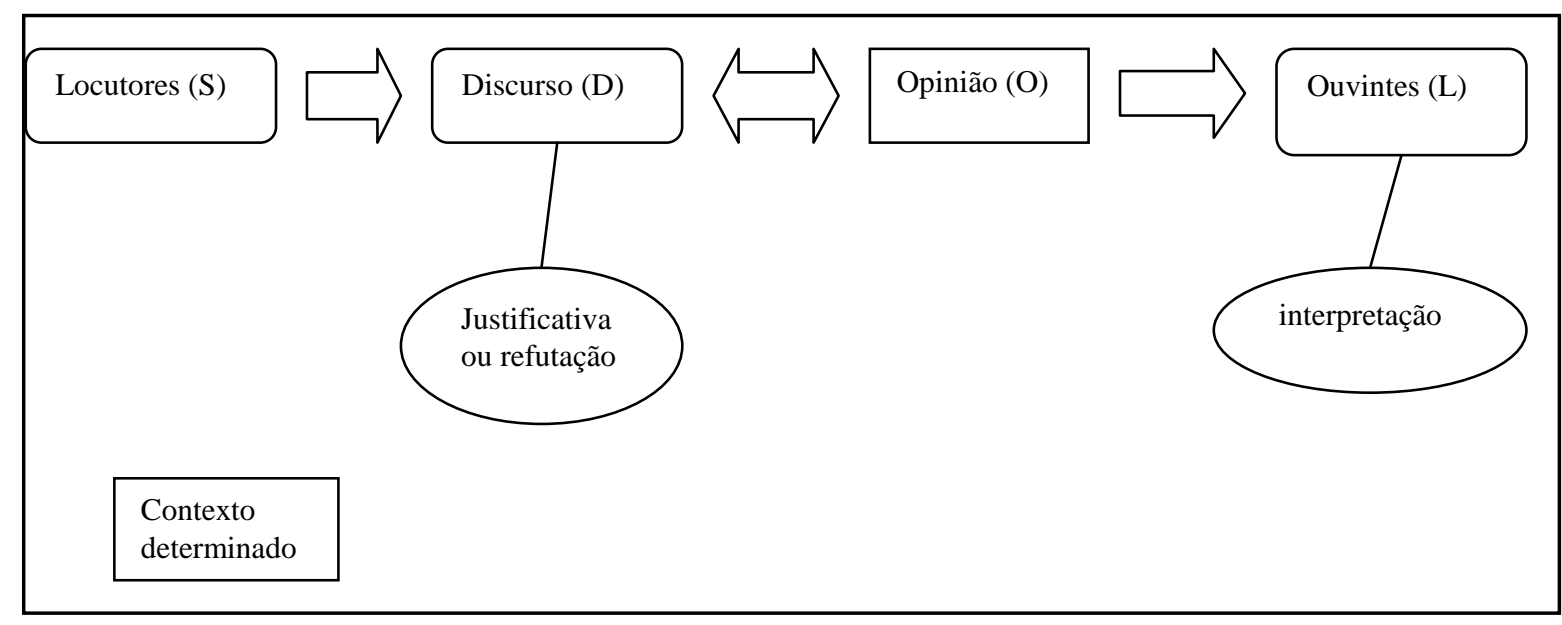

Ao interpretar o discurso (D), os ouvintes (L) procuram avaliar no discurso interpretado ( $\left.D^{\prime}\right)$ se o ponto de vista interpretado ( $\left.O^{\prime}\right)$, ou seja, a interpretação que o ouvinte faz da opinião $(O)$, é compatível ou não com o contexto em que estão inseridos.

Os interlocutores têm a intenção de verificar também se a opinião $(O)$ expressa pelo locutor $(S)$ corresponde à interpretação da opinião $\left(O^{\prime}\right)$ expressa no discurso elaborado pelos ouvintes ( $\left.D^{\prime}\right)$ de acordo com a interpretação que tiveram.

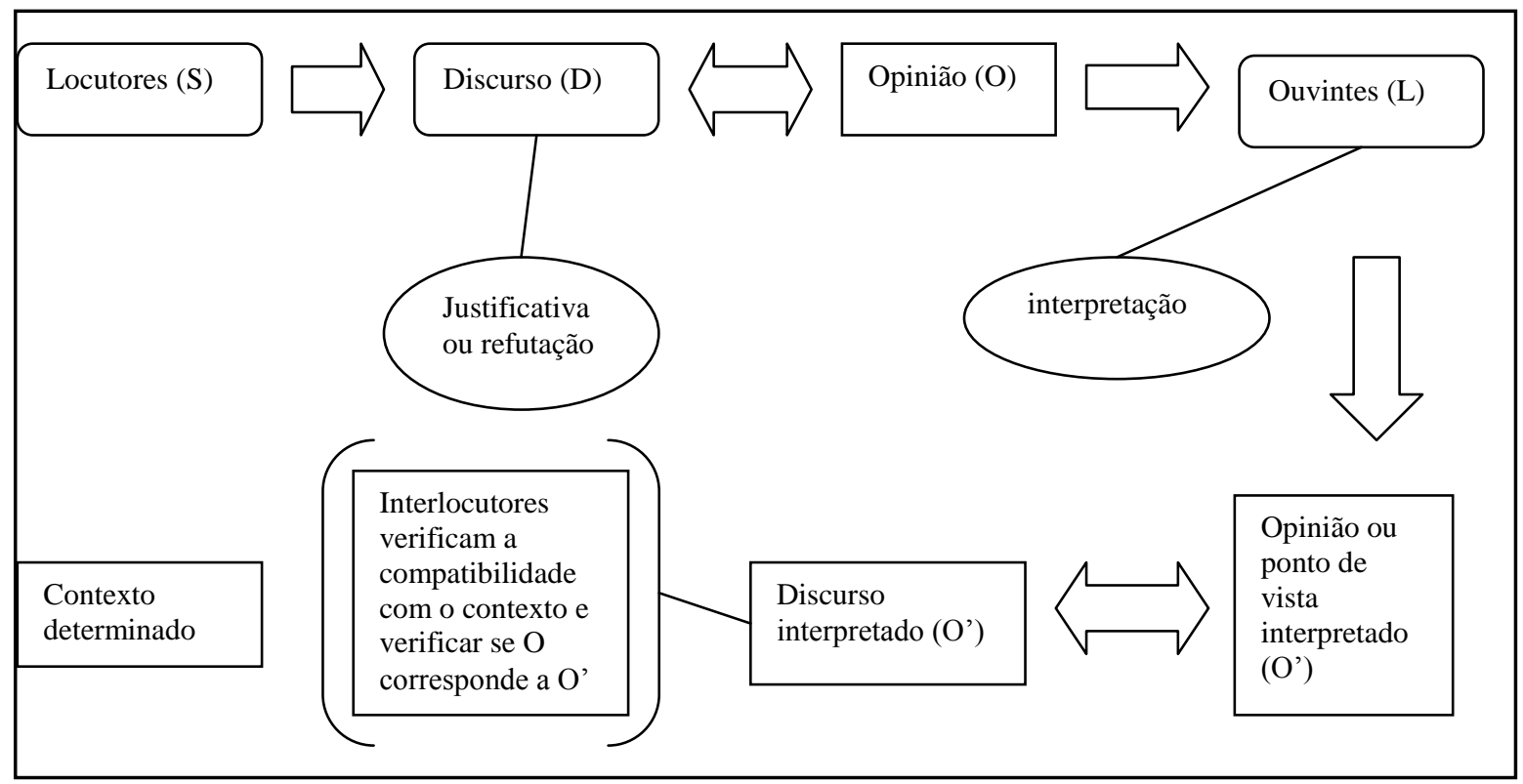

Temos a opinião expressa pelos locutores $(L)$ e também um ou mais argumentos $(A 1, A 2, \ldots A n)$ relacionados a um conjunto de posicionamentos $C(P 1, P 2, \ldots P n)$ assumidos em função do contexto. 
Os posicionamentos são explicitados por meio de um enunciado (Eo) quando estão diretamente relacionados à opinião $(O)$.

Já quando a relação entre eles é indireta, ocorrendo por meio dos argumentos, são explicitados por meio de enunciados denominados $\left(E_{1}, E_{2}, \ldots E n\right)$ e são consideradas "formas sofisticadas" que o Locutor $(L)$ utiliza para convencer o ouvinte $(L)$ sobre sua opinião $(O)$.

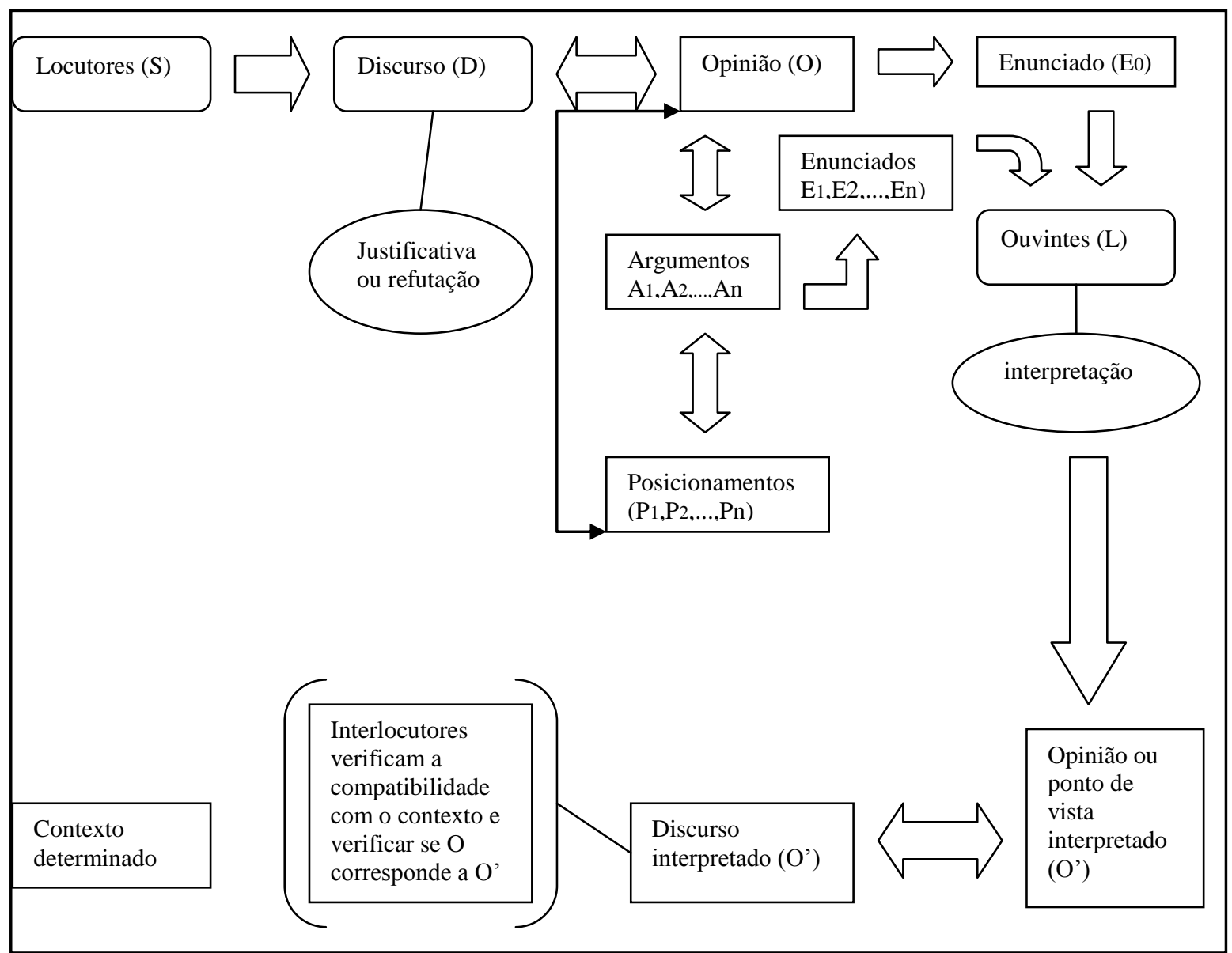

Até aqui, os autores consideram a linguagem verbal quando falam dos enunciados $\left(E_{0}, E_{1}, E_{2}, \ldots E n\right)$, mas eles também consideram em seus estudos que o discurso argumentativo é composto também pela linguagem não verbal como atitudes e gestos relacionados às opiniões, aos argumentos e ao conjunto de posicionamentos $C(P 1, P 2, \ldots P n)$, na tentativa de convencer os ouvintes $(L)$ de que a opinião $(O)$ deve ser considerada justificada ou refutada.

Quando os ouvintes $(L)$ emitem juízo de valor e opinião em relação ao discurso formulado $(D)$ pelos locutores $(S)$, temos o discurso interpretado ( $\left.D^{\prime}\right)$.

Quando o discurso interpretado ( $D^{\prime}$ ) é elaborado a partir da interpretação da opinião interpretada $\left(O^{\prime}\right)$, ele é constituído pelo enunciado (E0'). E quando é elaborado a partir dos argumentos interpretados $\left(A 1^{\prime}, A 2,, \ldots A n\right.$ ') pelos ouvintes $(L)$, o discurso é constituído pelos enunciados $\left(E 1^{\prime}, E 2{ }^{\prime}, \ldots E n '\right)$. 
O ouvinte $(L)$ ao emitir sua interpretação também pode ter como base posicionamentos interpretados ( $P 1$ ', $P 2$ ',...Pn') e pode utilizar-se da linguagem não-verbal como os gestos.

Nesse processo ou na interface entre o discurso argumentativo produzido $(D)$ e a interpretação do discurso argumentativo ( $\left.D^{\prime}\right)$, temos os interlocutores formando juízo em relação à opinião expressa e ao contexto em questão, o que resulta em modificações em relação ao aceite, modificação ou abandono da opinião, conforme Villani e Nascimento (2003).

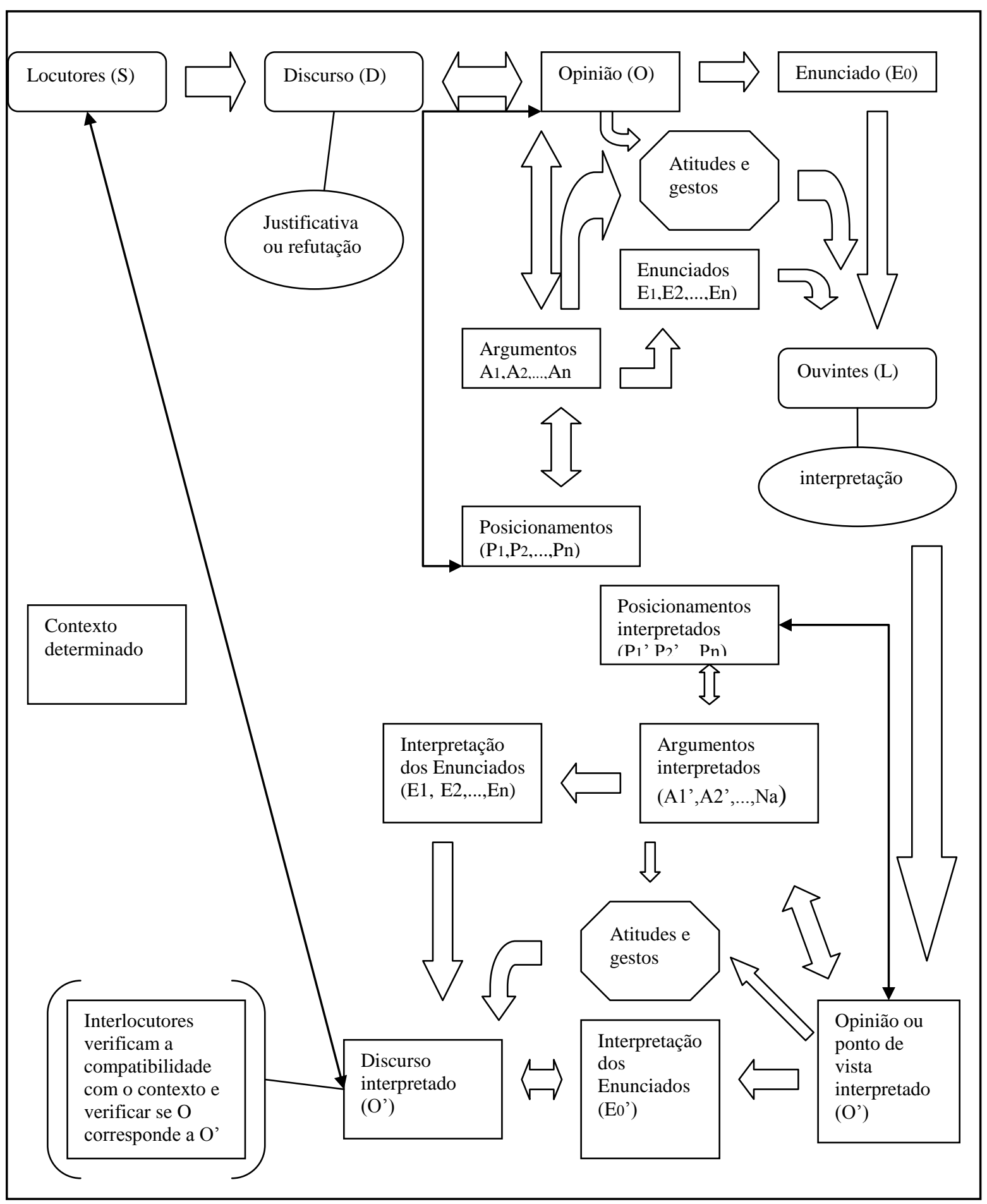


Os autores ainda apresentam em seu trabalho outras categorizações que utilizaram para os tipos de interação, definindo o ato intencional, do principal protagonista de uma ação, em transformar os demais participantes em interlocutores ou interagir diretamente com um elemento presente no contexto de forma dialógica (Bouda e Wel-Baris, 2001). Segue um quadro com os tipos de interação que utilizaram:

\begin{tabular}{|c|c|}
\hline Tipo de interação & símbolo \\
\hline Professora/Turma & $(\mathrm{P} / \mathrm{T})$ \\
\hline Professora/Grupo & $(\mathrm{P} / \mathrm{G})$ \\
\hline Professora/Aluno ou Aluno/Professora & $(\mathrm{P} / \mathrm{A})$ \\
\hline Aluno/Aluno (alunos de um mesmo grupo) & $(\mathrm{A} / \mathrm{A})$ \\
\hline Aluno/Aluno (alunos de grupos diferentes) & $(\mathrm{Ax} / \mathrm{Ay})$ \\
\hline $\begin{array}{c}\text { Aluno/Material Empírico (O material Empírico corresponde aos } \\
\text { (A/ME) } \\
\text { equipamentos e materiais específicos que compõem a atividade experimental) }\end{array}$ \\
$\begin{array}{l}\text { Aluno/Material Analítico (O material Analítico corresponde aos materiais } \\
\text { que auxiliam os alunos a efetuar as atividades de rotina de laboratório, tais como } \\
\text { a calculadora, folhas de papel milimetrado e caderno de laboratório) }\end{array}$ \\
\hline
\end{tabular}

Este descritor mostra alguns tipos de interação numa aula de laboratório. Trabalharam também com outro descritor em relação à configuração espacial de interação, definido de acordo com a ocupação do espaço físico interativo do laboratório didático pelos participantes. Veja as características das configurações identificadas.

\begin{tabular}{|c|c|}
\hline $\begin{array}{c}\text { Configur } \\
\text { ação espacial }\end{array}$ & Caracterização \\
\hline$(\mathrm{C} 1)$ & $\begin{array}{c}\text { Os alunos encontram-se, em grupos, nas bancadas, enquanto a professora } \\
\text { permanece de pé no centro da sala. }\end{array}$ \\
\hline$(\mathrm{C} 2)$ & $\begin{array}{c}\text { Os alunos encontram-se assentados ou em pé, trabalhando nas bancadas e a } \\
\text { professora se encontra assentada em sua mesa no centro do laboratório. }\end{array}$ \\
\hline$(\mathrm{C} 3)$ & $\begin{array}{c}\text { Um ou mais alunos/alunas de outros grupos ficam de pé em frente à bancada de } \\
\text { trabalho do grupo observado. }\end{array}$ \\
\hline
\end{tabular}




\begin{tabular}{|c|c|}
\hline (C4) & $\begin{array}{r}\text { Os alunos/alunas estão nas bancadas e a professora em pé diante da bancada do } \\
\text { grupo observado. }\end{array}$ \\
\hline (C5) & $\begin{array}{r}\text { É uma configuração livre, onde normalmente os alunos se encontram em pé, } \\
\text { fora das bancadas de trabalho, e realizam uma atividade experimental ou fazem medidas } \\
\text { de grandezas físicas dentro e fora do laboratório. }\end{array}$ \\
\hline
\end{tabular}

Podemos verificar que novas categorias são criadas e novos descritores são utilizados de acordo com alguns modelos já existentes e baseados nas interações que ocorrem nas aulas ministradas.

\section{$\underline{\text { Argumentação utilizada pelos professores em sala de aula }}$}

Nosso trabalho visa principalmente o discurso e argumento dos alunos para verificarmos "se" e "como" eles se apropriam da linguagem científica, porém já vimos que a contextualização e todos os tipos de interações devem ser levados em consideração, inclusive as que ocorrem com o professor.

Nesse sentido, Monteiro e Teixeira (2004) apresentam um trabalho onde o foco de análise está na maneira como as professoras organizaram suas falas para dirigir uma atividade didática e de que forma essas falas organizadas interferem na construção dos argumentos dos alunos. As atividades que utilizam em seus estudos são do "conhecimento físico" desenvolvidas com três diferentes turmas das séries iniciais de três diferentes escolas do Ensino Fundamental.

Embora o estudo apresentado pelos autores seja para um caso específico cujas atividades visam ao desenvolvimento da argumentação de alunos do Ensino Fundamental para que se apropriem da linguagem científica, e esteja focado no discurso do professor, verificamos que alguns aspectos apresentados neste trabalho podem ser úteis no tipo de análise para as atividades que estamos estudando.

Os autores apresentam categorias elaboradas por Compiani (1996) baseadas nas formas interativas mais gerais do processo discursivo em sala de aula na tentativa de compreender melhor o papel da fala dos alunos e do professor. Seguem as categorias: 
- Solicitação de informações: apresenta como característica a necessidade que os envolvidos no processo interativo têm de obter explicações ou esclarecimentos, que por sua vez interferem nos rumos do diálogo. É dividida em clarificação, quando falta clareza às ideias expostas, e em explicação, que é solicitada quando não existirem ideias para explicar determinado fato.

- Fornecimento de informações: representa uma ação indutiva do professor sobre o raciocínio dos alunos. Também apresenta uma divisão: exposição direta, quando o professor apresenta uma ideia, sem chances de muitos questionamentos por parte dos alunos, e fornecimento de pistas, em que o professor apresenta elementos que mantenham o aluno numa determinada trajetória de raciocínio previamente planejada, de forma a conduzi-lo à resolução de um problema. $\mathrm{O}$ autor destaca ainda uma postura intermediária que denominou remodelamento, neste, o professor aprimora alguns pontos de vista apresentados pelos próprios alunos, visando aproximá-los da visão científica.

- Re-espelhamento: momento no qual o professor encoraja a fala do aluno, por exemplo, ao repetir com ênfase ou gesticular favoravelmente, atribui legitimidade e reforça a ideia do aluno.

- $\quad$ Problematização: ocorre com uma atitude intencional, seja do professor ou do aluno, de investigar, estudar ou provocar reflexões na resolução de um problema. Nesta categoria, o autor apresenta também as contraposições, que são ideias que representam contradições ou geram conflitos importantes durante as aulas.

- Re-estruturação: acontece durante a reorganização das proposições que aparecem durantes as interações discursivas, representando uma sistematização parcial ou final das ideias discutidas durante as interações. Temos aqui a recapitulação, que aparece na sistematização final, com o objetivo de generalizar ideias, concluindo determinado assunto.

- Recondução: é quando o professor retoma a pertinência das discussões. $\mathrm{O}$ autor destaca que neste momento o professor avalia os rumos do discurso para verificar se está existindo evolução dentro da proposta de diálogo ou se existe necessidade de intervenção para retomada das discussões. 
Outra abordagem que os autores utilizam é baseada nos trabalhos de Boulter e Gilbert (1995), que propõem uma classificação em relação à fala do professor e resulta em três tipos de argumentação: retórica, socrática e dialógica.

$\mathrm{Na}$ argumentação retórica, o professor apresenta uma série conectada de declarações para sustentar uma opinião. Aqui a opinião e ideias dos alunos não são levadas em consideração, e temos uma tentativa de persuasão por parte do professor. Representa um processo de transmissão de conhecimento na qual o professor é o transmissor e os alunos os receptores passivos. O termo "retórico" foi atribuído por Kuhn (1993).

$\mathrm{Na}$ argumentação socrática, o professor procura conduzir os alunos através da utilização de questões dirigidas que podem ser reformuladas de acordo com as respostas iniciais dos alunos até a obtenção da resposta ou idéia esperada. Utiliza-se uma metodologia de ensino por condução. Nesta categoria, a abordagem do professor não é independente das ações dos alunos, o professor, após uma indagação, espera determinada resposta dos alunos e se esta não aparece, ele reformula ou faz outros questionamentos a partir do discurso apresentados por eles. O professor busca conduzi-los às ideias cientificamente aceitas que julga corretas e precisas.

$\mathrm{Na}$ argumentação dialógica, o professor visa à construção de um consenso entre os alunos, permitindo que eles possam criar, expressar e discutir suas questões de acordo com suas investigações. Aqui o professor não é mais o transmissor de informações e passa a assumir o papel de orientador e mediador que permite o compartilhamento de ideias entre os alunos e com ele próprio. Utiliza-se da estratégia de confrontação de ideias para resolução de problemas a partir de determinadas regras expostas de forma clara. Aqui os alunos participam de forma ativa.

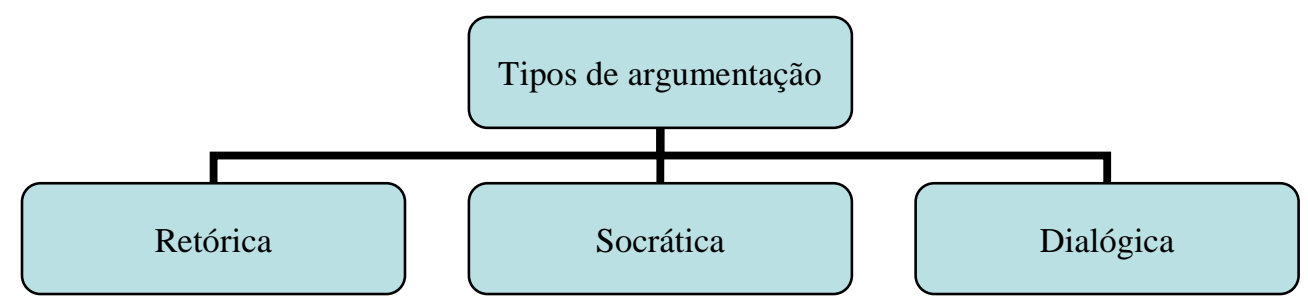

Tipos de argumentação utilizados pelos professores em sua prática em sala de aula. conforme Boulter e Gilbert (1995). 
Os autores utilizaram essas definições tendo como referência os trabalhos de Boulter e Gilbert (1995) e também utilizaram elementos do trabalho de Compiani (1996) para elaborarem subcategorias com o objetivo de caracterizar mais especificamente as falas do professor, ou seja, utilizaram dois referenciais para construção de sua ferramenta de análise.

Dessa forma, acrescentaram a categoria retórica às subcategorias contextualização e exposição.

A contextualização, também chamada direcionamento, ocorre quando o professor, utilizando atitudes discursivas, procura envolver o aluno com o tema a ser desenvolvido em sala de aula. De acordo com um planejamento prévio, o professor busca oferecer condições para que os alunos possam, por meio das atividades realizadas, aprender o conceito a ser ensinado. Apesar da atitude passiva dos alunos, toda a ação do professor é elaborada com o objetivo explícito de desafiá-los e envolvê-los com o tema a ser trabalhado e estudado.

Já na exposição, o professor utiliza seu discurso fornecendo subsídios para que o aluno compreenda o assunto trabalhado. O professor tem o papel ativo de encaminhar e organizar questões quando julgar necessário para que os alunos tenham condições de realizar as tarefas propostas.

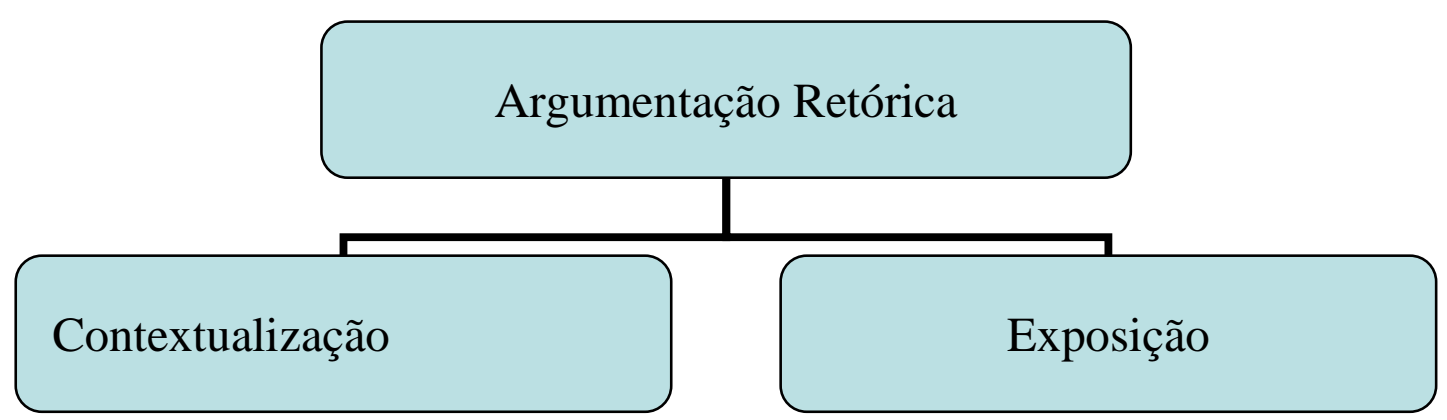

Esquema baseado em Boulter e Gilbert (1995) com subcategorias elaboradas por Monteiro e Teixeira (2004)

Em relação à categoria socrática, os autores definiram as seguintes subcategorias: fornecimento de pistas, remodelamento, re-espelhamento e elucidação.

O fornecimento de pistas representa o discurso do professor que visa a um direcionamento do raciocínio dos alunos. Pode ser feito por meio de explicações ou pelo 
oferecimento de elementos, e até mesmo perguntas que possam conduzi-los à resposta desejada.

O remodelamento representa o discurso do professor que destaca ideias apresentadas pelos próprios alunos, fornecendo-lhes maior precisão, riqueza de detalhes e preenchendo lacunas conceituais dos alunos aproximando-os da visão e linguagens científicas.

O re-espelhamento ocorre pela fala do professor autorizando ou reprovando a fala dos alunos. A autorização acontece, por exemplo, quando o professor repete com ênfase a ideia do aluno ou com um gesto favorável à mesma. Já a reprovação surge com uma negativa ou até mesmo com a espera por outras respostas, indicando que aquela não é a mais adequada.

A elucidação é a fala do professor que ocorre a partir de questões apresentadas pelos alunos e que não são compreendidas por todos. Tem como objetivo tornar claras e inteligíveis as ideias apresentadas para todos.

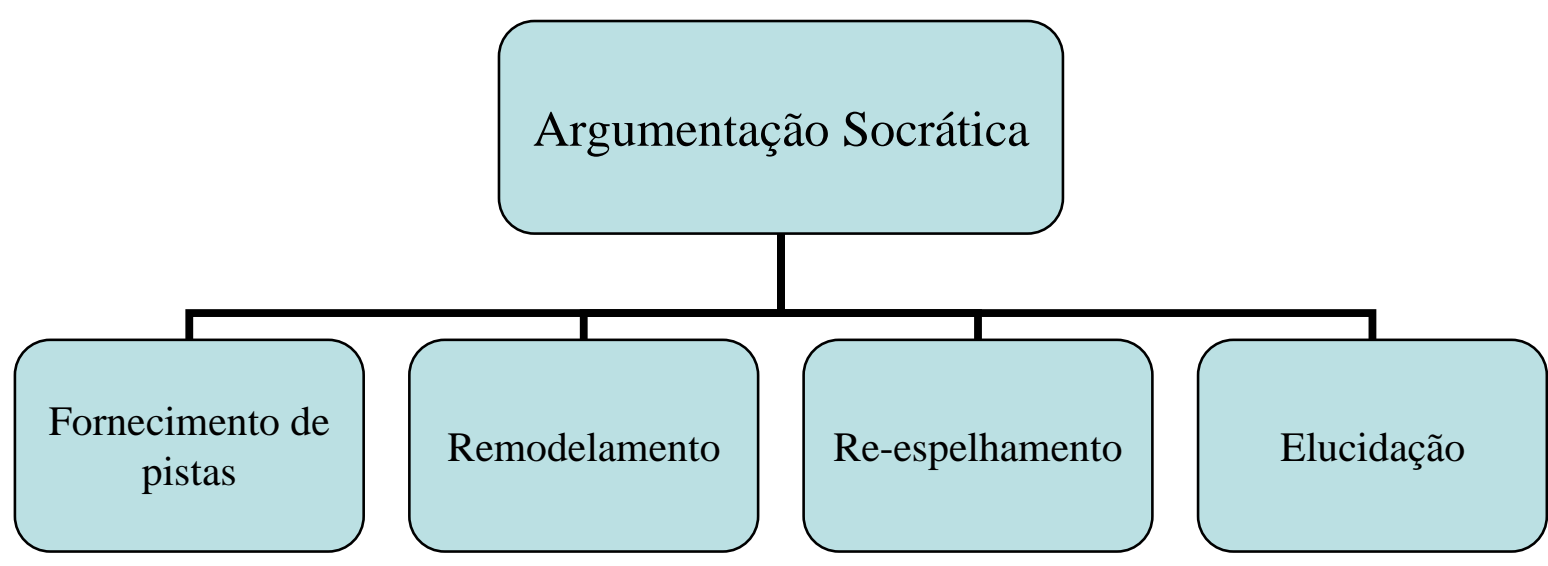

Esquema baseado em Boulter e Gilbert (1995) com subcategorias elaboradas por Monteiro e Teixeira (2004)

Já a categoria dialógica recebeu o reforço das subcategorias: instigação, contraposição, organização, recapitulação, recondução e fala avaliativa.

A instigação é a fala do professor que estimula os alunos a exporem suas ideias e iniciarem as interações em sala de aula.

A contraposição é fala do professor que mostra contradições nos argumentos utilizados pelos alunos, ou que gera conflitos entre ideias apresentadas no contexto de sala de aula. Isso também estimula mais interações entre eles. 
A organização representa a fala que sistematiza ideias provenientes dos alunos, permitindo que concordem ou discordem e estimulando novas interações na sala de aula. É neste momento que surge a articulação das ideias apresentadas durante as discussões.

A recapitulação é a fala que sintetiza todas as ideias discutidas pelos alunos. Representa o momento conclusivo que encerra os debates.

A recondução aparece quando a fala do professor retoma o desenvolvimento das discussões pertinentes, a fim de regular e definir limites em relação às falas que não contemplem os objetivos propostos para aula.

A fala avaliativa é a que ocorre quando o professor tenta entender a lógica utilizada pelo aluno ao expor determinada afirmação. Para tanto, a fala do professor é utilizada de forma a questionar os alunos sobre os fundamentos que utilizou para expressar sua afirmação.

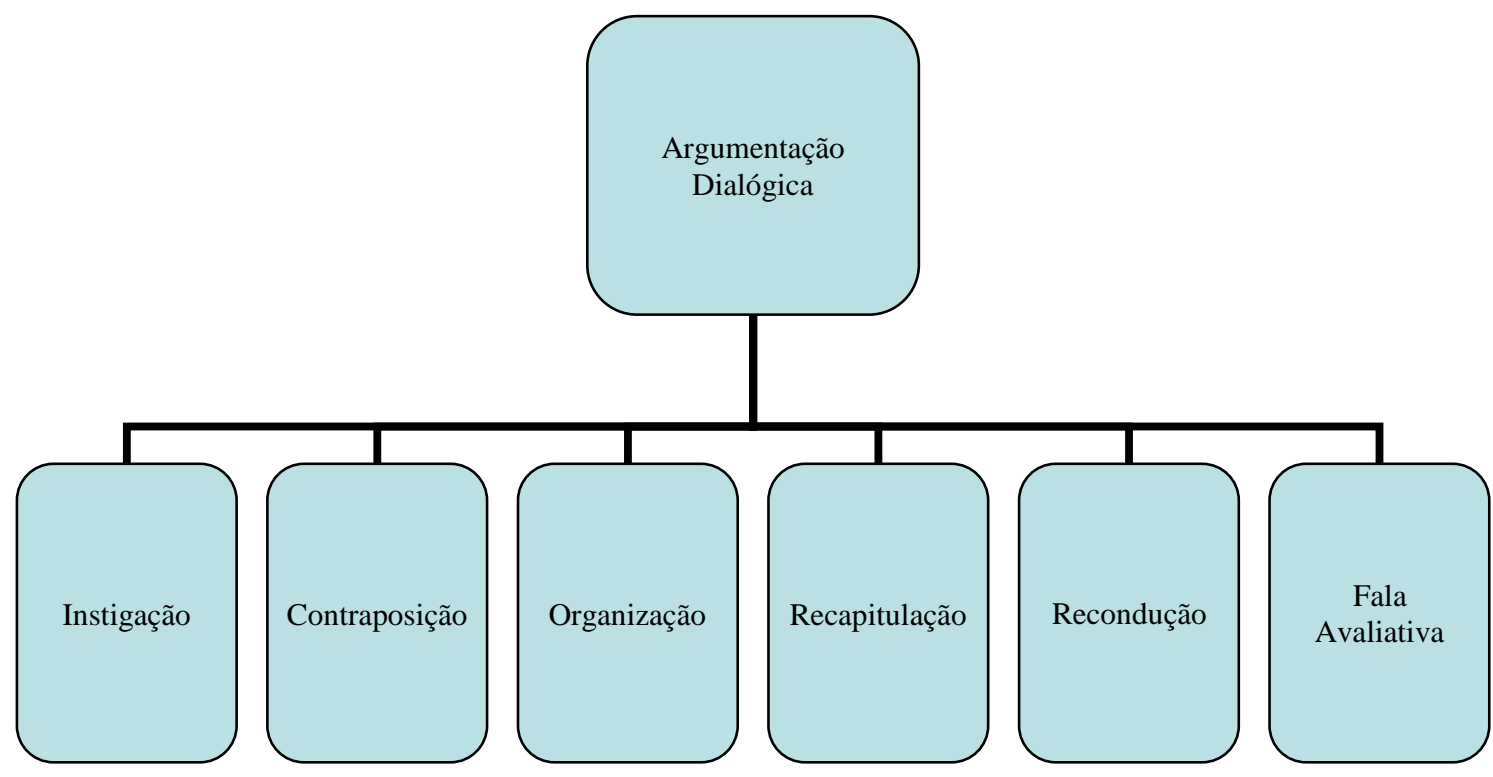

Esquema baseado em Boulter e Gilbert (1995) com subcategorias elaboradas por Monteiro e Teixeira (2004) 


\section{Capítulo IV - Metodologia de Pesquisa}




\section{Metodologia de pesquisa}

\section{$\underline{\text { Objetivos da pesquisa }}$}

Conforme mencionado no capítulo I, o objetivo da pesquisa é verificar "se" e "como" os alunos se apropriam da linguagem científica a partir de conceitos falados ou de outras formas de linguagem científica, e se essa apropriação pode ser um indicativo de evolução conceitual em uma sequência de ensino de Física Moderna para o Ensino Médio que trabalhe com a realização de atividades experimentais e/ou práticas. Portanto, estaremos interessados nas interações que ocorrem em sala de aula, principalmente as que ocorrem entre os próprios alunos.

Estaremos atentos às diferentes linguagens utilizadas durante a realização das atividades e da aula como um todo, assim como no desenvolvimento das próprias atividades, pois também procuramos verificar se elas contribuem de alguma forma para a apropriação da linguagem científica, caso ela ocorra.

\section{$\underline{\text { A pesquisa }}$}

Essa pesquisa é qualitativa, já que iremos interpretar a fala, a escrita, os gestos e as ações de professores e alunos em sala de aula, além de suas interações com os materiais das atividades.

Lüdke e André (1996), ao apresentar as pesquisas qualitativas dentro de uma visão etnográfica, apresentam algumas de suas principais características, e Carvalho (2005) discute cada uma delas com o objetivo de caracterizar de forma consistente uma proposta metodológica para pesquisas mais direcionadas aos processos de ensino e de aprendizagem em ciências, que apresentam algumas diferenças em relação a pesquisas etnográficas. Destacamos a seguir as características apresentadas por Lüdke e André (1996) seguida das observações realizadas por Carvalho (2006): “A pesquisa qualitativa tem o ambiente natural como sua fonte direta de dados e o pesquisador como seu principal instrumento" (Lüdke e André, p. 11-13, 1996). Existe aqui uma diferença fundamental, embora tenhamos a sala de aula em seu ambiente natural, como fonte de dados e esses serem predominantemente descritivos, o pesquisador não é o principal instrumento, apesar de sua grande importância, pois comandará a câmara e decidirá sobre o que vai ser visto. $\mathrm{O}$ principal instrumento passa a ser o vídeo que colherá as imagens que posteriormente serão analisadas. 
- "A preocupação com o processo é muito maior do que com o produto"

Lüdke e André (1996).

Neste caso, o processo é tão importante como o produto. Buscamos entender o processo de ensino, porém a aprendizagem obtida pelos alunos em relação aos conteúdos ensinados também é importante Carvalho (2006).

- “A análise dos dados tende a seguir um processo indutivo" Lüdke e André (1996).

- "Os pesquisadores não se preocupam em buscar evidências que comprovem hipóteses definidas antes do início dos estudos” Lüdke e André (1996).

Nem sempre essas duas características são válidas. São:

“... as hipóteses pensadas e estruturadas anteriormente que orientam o nosso olhar sobre o objeto investigado. Nossos conhecimentos prévios, nossos referenciais teóricos e principalmente nossa visão de mundo definem o que queremos ou podemos observar" (Gonçalves, 1997, p. 107). Carvalho 2006, p. 13-48.

A diferença fundamental entre os dois casos está nos objetivos que se pretendem alcançar. Quando os problemas que dão origem às pesquisas realizadas por professores são percebidos durante as aulas e depois são debatidos e transformados em questões, refletindo sobre o seu próprio trabalho realizado em sala de aula, a análise tende a seguir um processo indutivo, pois os questionamentos saem da prática e não partem de hipóteses definidas antes dos estudos.

Porém, quando o pesquisador vai a campo com o problema bem delimitado, sabendo o que vai observar, buscando evidências que comprovem ou não suas hipóteses iniciais, o processo deixa de ser indutivo. Aqui os pesquisadores pretendem estudar o "como" para chegar ao "por que" os alunos aprendem, alcançando os conteúdos, habilidades e competências determinadas nos planejamentos de ensino e, portanto, eles têm grande influência da literatura em pesquisa de Ensino de Ciências e das revisões bibliográficas já realizadas pela comunidade científica.

- “As abstrações formam-se ou se consolidam basicamente a partir de inspeção dos dados num processo de baixo para cima". 
Carvalho (2005) cita que em algumas pesquisas realizadas por seu grupo, as abstrações formaram-se e se consolidaram a partir da análise dos dados, não num processo de baixo para cima e sim pela interação entre os referenciais teóricos e os dados obtidos (Carvalho 2004, Nascimento 2003, Capecchi 2004, Abrahão e Carvalho 2003). Já em outros casos, depararam-se com fenômenos que muitas vezes não estavam preparados teoricamente para analisar, fato este que acabou resultando em novas teses e pesquisas. De qualquer forma fica evidente que podemos nos deparar com situações bem diferenciadas e que precisam ser analisadas com calma.

Podemos partir dos conceitos apresentados por Lüdke e André (1996), mas não podemos esquecer-nos de adequá-los à pesquisa em Ensino de Ciências, conforme Carvalho (2005).

Destacamos também que se trata de um estudo de caso, onde pesquisamos atividades de ensino aprofundando nas relações professor/aluno/conteúdo e aluno/aluno/conteúdo, numa sequência de aulas de Física Moderna no Ensino Médio.

Optamos por uma sequência com atividades práticas, uma vez que esse tipo de estratégia tende a facilitar as interações dialógicas em sala de aula.

\section{Questão ética}

Como utilizamos registros em vídeo na nossa pesquisa em sala de aula, necessitamos de muito cuidado com a exposição de imagens tanto do professor quanto dos alunos.

Discutimos amplamente com o professor colaborador essas questões e também explicamos detalhadamente aos alunos quais os objetivos das filmagens.

O próprio projeto “Atualização dos Currículos de Física no Ensino Médio de Escolas Estaduais: A Transposição das Teorias Modernas e Contemporâneas para sala de aula" solicita uma autorização da escola para utilização de máquinas fotográficas e filmadoras durante as aulas e com o objetivo de utilizar essas imagens puramente para divulgação de material científico e de pesquisa.

Após a permissão da escola, ainda solicitamos uma autorização por escrito de cada aluno para o uso de imagem e respeitando o direito daqueles que não querem suas imagens divulgadas, mesmo que em divulgações de caráter científico. Um detalhe de extrema importância é que sem a autorização não podemos exibir as imagens. 
A questão ética da pesquisa está muito presente nas discussões atuais e consideramos de grande relevância para relação pesquisador, escola, professor e alunos.

\section{$\underline{\text { O Professor e os alunos }}$}

Na ocasião das filmagens e acompanhamento da sequência de aulas escolhidas, que foram realizadas em 2006, o professor contava com uma experiência de aproximadamente treze anos de magistério, sempre lecionando a disciplina de Física.

O referido professor, que representaremos pela letra "P" nas transcrições, participava, na época, do projeto "Atualização dos Currículos de Física no Ensino Médio de Escolas Estaduais: a Transposição das Teorias Modernas e Contemporâneas para sala de aula" FAPESP 2003/00146-3 desde o início do mesmo no ano de 2003.

Após entrarmos em contato com o professor e apresentarmos nossa proposta de pesquisa e o interesse em trabalharmos com a sequência de espectroscopia da luz, o próprio professor sugeriu uma turma para acompanharmos as aulas. O critério de escolha foi praticamente a compatibilidade de horários e a possibilidade de que a classe chegasse ao assunto que pretendíamos acompanhar. O fato de serem duas aulas consecutivas também contribuiu para escolha.

Mantínhamos contato direto com o professor para sabermos exatamente que assuntos eles estavam trabalhando e para planejarmos nossas gravações em áudio e vídeo.

As aulas que acompanhamos eram ministradas às sextas-feiras no período das 21 horas e 30 minutos até às 23 horas.

A turma escolhida para acompanharmos foi um $3^{\circ}$ ano do Ensino Médio, indicado como $3^{\mathrm{a}}$ série turma $\mathrm{D}$.

Assim como toda classe do Ensino Médio, esta turma possuía um total de 45 alunos matriculados, sendo que em média 3 a 6 alunos pediram transferência durante o ano letivo. Também é um fato que a frequência média foi de aproximadamente vinte e cinco alunos, portanto um pouco mais que $50 \%$ do universo total de matriculados, o que representa uma média comum a todas as disciplinas. Porém, deve-se destacar que os alunos frequentes eram praticamente os mesmos e comprometidos com todas as atividades propostas pela escola e professores.

Devido à localização da escola, a maior parte dos alunos vem do trabalho e assiste às aulas, antes de retornar para seus lares, já que não daria tempo de passarem em casa antes, nem de chegarem a tempo hábil em outras escolas mais próximas de seus lares. Em algumas 
aulas existiu a necessidade de se trabalhar com duas séries juntas devido a fatores extraordinários como dispensa de alunos antes do horário de saída, para preparação da escola que realizaria atividades aos sábados. Então, em alguns casos, como descreveremos mais detalhadamente na sequência de aulas filmadas, chegamos a trabalhar com a presença dos alunos da $3^{\circ}$ série $\mathrm{G}$, que também estavam realizando a mesma sequência de atividades e apresentavam um perfil parecido com o dos alunos da $3^{\mathrm{a}}$ série $\mathrm{D}$.

\section{$\underline{\text { A Escola }}$}

As aulas que acompanhamos foram ministradas na Escola Estadual João Evangelista Costa, situada na Avenida Cupecê, 2672, na cidade de São Paulo. Nesta localização existe um corredor que representa uma das principais vias de acesso à rodovia Imigrantes e ao município de Diadema, portanto muitos alunos que retornam de seus serviços param antes de chegarem a seus lares para acompanharem as aulas em tempo hábil.

A escola funciona em três períodos: das sete horas às doze horas e trinta minutos (matutino); das treze horas às dezoito horas e vinte minutos (vespertino) e das dezenove horas às 23 horas (noturno). Cada aula do período matutino e vespertino correspondem à cinquienta minutos e no período noturno elas correspondem a quarenta e cinco minutos. O período da tarde é destinado aos alunos do Fundamental II e os períodos da manhã e noite são frequentados por alunos do Ensino Médio.

A escola possui 16 salas de aula, uma sala de informática, uma sala de vídeo, uma biblioteca, uma quadra oficial coberta e um espaço adaptado como quadra menor e um laboratório de Ciências.

A sala de informática possui 10 computadores ligados em rede, 20 cadeiras para os alunos trabalharem direto com as máquinas e 10 cadeiras em torno de duas mesas, caso o professor tenha que levar 30 alunos de uma vez para esta sala. Os computadores possuem conexão em banda larga com acesso à Internet.

A sala de vídeo possui 45 cadeiras, uma TV 29 polegadas e duas caixas de som, um amplificador, um vídeo cassete e um aparelho de reprodução de DVD.

A biblioteca é adaptada em uma área equivalente a duas salas de aula, em uma metade ficam os livros e na outra as mesas para os alunos realizarem suas pesquisas, o que pode ocorrer em horário de aula ou período alternativo.

O laboratório de Ciências apresenta uma área equivalente a uma sala e meia de aula, com duas bancadas ao longo de todo seu comprimento, com tomadas em diversos pontos e 
cinqüenta banquetas para os alunos sentarem quando necessário. Existe outra bancada com altura menor onde estão instaladas duas cubas de pia ao longo de toda parede lateral e abaixo dela ficam armários. Sobre esta última bancada ficam as vidraças, cobertas por cortinas, que foram fornecidas pelo projeto FAPESP 2003/00146-3 do qual o professor de física aqui mencionado participa, cuja particularidade é que elas praticamente não deixam entrar luz do meio externo.

O laboratório conta ainda com um quadro negro, um rack onde ficam um computador conectado a uma televisão 29 polegadas que funciona como monitor para o micro. Essa televisão e micro são materiais fornecidos pelo mesmo projeto e ficam emprestados à escola sob responsabilidade do professor que participa do mesmo.

O laboratório, a sala de vídeo e a biblioteca ficam num prédio separado das salas de aula. É o prédio 2 da escola e conhecido pelos que participam do ambiente escolar como “sítio" por possuir áreas não pavimentadas atrás de suas salas.

Existiam alguns alunos trabalhando na biblioteca e sala de vídeo por meio de um programa do governo estadual de incentivo ao primeiro emprego.

As salas de aulas possuíam basicamente um quadro negro e próximas a este, uma mesa e uma cadeira para o professor, e carteiras e cadeiras enfileiradas para os alunos, porém esta disposição de carteiras podia ser modificada de acordo com a necessidade da atividade a ser realizada em cada aula. Havia poucas tomadas e nem todas funcionavam, porém existiam tomadas no corredor também, o que possibilitava o uso delas com a ajuda de uma extensão.

A sequência de aulas que acompanhamos foram realizadas no laboratório de ciências e na própria sala de aula.

\section{$\underline{\text { Registros das aulas }}$}

Considerando que o objetivo da nossa pesquisa é verificar como os alunos se apropriam da linguagem científica por meio das linguagens da ciência que utilizam durante a realização das atividades nas interações que ocorrem em sala de aula, seja entre os membros do mesmo grupo, entre os diferentes grupos ou com o professor, e que contribuições essa sequência de ensino com atividades práticas podem proporcionar para evolução conceitual dos mesmos. A principal forma de registro das informações foi por meio de gravação em áudio e vídeo, além das notas de campo.

O vídeo e áudio foram extremamente importantes, pois não tínhamos como prever os momentos essenciais para nossa pesquisa, o que se tornou possível após inúmeras vezes que 
assistimos às gravações. Também o fato de precisarmos analisar os gestos e manipulações juntamente com as falas, tornou-se essencial a utilização das filmagens.

Nas nossas gravações, utilizamos três câmaras, duas delas ficaram fixas em determinados grupos de alunos e uma terceira gravando a participação do professor e sua interação com a sala de aula. Com as duas câmaras fixas nos dois grupos, objetivou-se principalmente analisar as interações que ocorrem entre integrantes do mesmo grupo e, num segundo momento, a interação com os demais grupos e com o professor. Já a câmara que filmava o professor e a sala como um todo teve como objetivo principal captar as interações entre professor e alunos.

As duas câmaras fixas dos grupos foram manipuladas por mim em um grupo e por um aluno de iniciação científica, que colaborou durante o registro dos dados, em outro grupo. Simultaneamente a terceira câmara estava fixa em um ponto da sala onde pudesse filmar o professor e atuava ligada no automático.

A ideia de utilizarmos câmaras em dois grupos distintos serviu também para evitar eventuais problemas, como no caso em que um dos equipamentos apresentasse algum tipo de falha ou o próprio pesquisador tivesse algum tipo de dificuldade técnica, prejudicando a qualidade das gravações. Além disso, o fato de ter dois grupos filmados resultou em uma quantidade maior de dados a serem analisados, e consequentemente, a uma dificuldade mais ampla na transcrição e análise dos dados.

Embora as imagens fossem muito importantes, o áudio também foi essencial para transcrições e análise da linguagem falada, por isso, nos dois grupos analisados, utilizamos microfones fixos com receptores de forma que o som já saísse digitalizado junto com o vídeo na própria câmara. Já a fala do professor foi captada com o uso das câmaras que estavam nos grupos e com a própria filmadora que estava captando a interação entre o professor e sala.

A utilização dos microfones fixos nos grupos com receptores foi uma vantagem, assim o áudio foi obtido em sincronia com a imagem da filmadora e facilitou a transcrição e a própria análise dos dados e a qualidade do som foi superior. Eliminou-se também boa parte dos ruídos e captando de forma mais clara e definida as falas do grupo em questão, porém se o receptor ou o microfone apresentassem alguma falha, o áudio da filmadora não estaria funcionando e só teríamos a imagem, comprometendo a análise dos dados.

Após as filmagens, digitalizamos os filmes das câmaras que utilizavam fitas de forma a tornar mais fácil a análise dos dados e garantir que estes não fossem danificados. No nosso caso, utilizamos três tipos diferentes de filmadora, duas delas eram com fitas e uma com 
DVD, portanto a digitalização contribuiu até para a uniformidade na hora da análise dos dados.

É importante destacar aqui a necessidade que tivemos em estarmos atentos à utilização dos equipamentos para que não fôssemos surpreendidos de última hora, detalhes que podem parecer sem muita importância, mas podem atrapalhar totalmente a gravação. A seguir, destacamos algumas observações importantes que fizemos sempre antes das filmagens:

- verificar se existe alguma bateria a ser recarregada ou se há a necessidade de comprar novas baterias;

- $\quad$ verificar se existem fontes suficientes e se elas não apresentam nenhum tipo de problema;

- $\quad$ o número e os tipos de cabos devem ser adequados aos equipamentos e a utilização de cabos reservas é uma medida para evitar imprevistos;

- levar para filmagens sempre extensões extras, pois o local pode não contar com número de tomadas suficientes para todo o equipamento;

- mesmo durante a filmagem, ficar atento se os equipamentos estão funcionando adequadamente, inclusive os receptores de áudio;

- testar os equipamentos com algumas horas de antecedência para, no caso de algum problema, tentar solucioná-los com tempo adequado e de forma mais tranquila.

Também tivemos que estar atentos ao local onde realizamos as filmagens, no nosso caso, algumas sequências na própria sala de aula, outras no laboratório de ciências da escola, e o conhecimento prévio das condições das tomadas e da disponibilidade física do ambiente foram de grande importância e, para tanto, a contribuição e o apoio do professor foram fundamentais ao acesso a essas informações.

É importante discutir com o professor colaborador os objetivos de nossa pesquisa, mesmo porque a implementação da proposta de ensino depende diretamente de seu engajamento. Segundo Erickson (1998), o sujeito de uma pesquisa fica muito mais ansioso quando não sabe os propósitos da mesma, bem como o que é esperado dele. (Carvalho, 2006).

Qual a melhor posição para as câmeras, a disposição dos grupos filmados, a melhor posição para câmara fixa que filmou o professor, qual o tempo efetivo de aula, as atividades 
extras classe que podem interferir nessas aulas, foram questionamentos feitos antes das filmagens.

Precisamos ter em mente também que a sala de aula e a própria escola possuem um comportamento dinâmico e, embora necessários todos os cuidados citados, ainda encontramos situações inesperadas com as quais tivemos que lidar de forma racional para buscar soluções que não comprometessem nosso trabalho de pesquisa.

Outra questão importante é a isenção de participações e intervenções na aula por parte do pesquisador. Muitas vezes a simples presença de filmadoras e equipamentos de áudio e vídeo pode inibir ou até mesmo alterar o comportamento regular dos alunos. Para evitar que isso ocorra, ou pelo menos minimizar a situação, gravamos aulas teste para que os alunos pudessem se acostumar com nossa presença.

O primeiro cuidado é acostumar a classe com a pessoa que vai gravar e com a função da gravação. Assim devemos iniciar as gravações algumas aulas antes das planejadas para a obtenção de dados de tal modo que os alunos e professor já vejam essa função como parte da aula, e toda a curiosidade já tenha sido acalmada. (Carvalho, 2006).

Carvalho (2006) discute a interferência da câmara de vídeo em sala de aula considerando dois pontos de vista: o prático e o teórico. De acordo com o ponto de vista prático destaca que a interferência é mínima e uma aula bem estruturada que envolva intelectualmente os alunos é mais atrativa que uma gravação. Também destaca que a gravação de algumas aulas antes das planejadas pode acostumar os alunos e professores em relação à presença do pesquisador e das câmaras, que de certa forma, passam a fazer parte do cotidiano da sala de aula, não despertando mais curiosidade. Entretanto, comenta a importância do pesquisador tomar cuidado para não interferir nas aulas.

Do ponto de vista teórico, ressalta que não temos como não interferir de forma alguma. Sempre certa interferência existirá, assim como todo e qualquer instrumento interfere no fenômeno a ser estudado. Porém, enfatiza que mesmo com essa intervenção mínima, o ganho com a utilização dos vídeos é enorme, pois permitem superar as limitações do que o observador perceberia sem gravações em processos de ensino e aprendizagem, resultando a uma mudança de paradigma em pesquisas de ensino.

Erickson (1982) considera a utilização de gravações em vídeo como um início de estudo de pesquisa interacional, permitindo relatos de ações em tempo real, e um importante instrumento para estudo analítico de relações sociais. Cita também os limites da capacidade 
de armazenar informações pela mente humana e a vantagem de se poder utilizar o vídeo várias vezes permitindo reflexões a cerca de toda uma sequência, para em seguida analisar as partes (considera as ações dos indivíduos como subsistemas do sistema total de um grupo de ação).

Cita ainda quatro estágios nessa análise: revisão geral do evento; identificação dos segmentos mais importantes do evento; identificação de aspectos da organização de um importante momento particular no evento e as ações dos indivíduos.

As aulas testes tiveram como objetivo também verificar possíveis falhas do equipamento ou no manuseio dos mesmos por parte dos pesquisadores e, com certeza, serviu para direcionar as gravações que vieram a seguir, em termos de posicionamento de câmaras e dos microfones e até mesmo com relação à postura e ao posicionamento dos pesquisadores. Estas aulas serviram do mesmo modo para ajudar a contextualizar a pesquisa, mostrando a parte imediatamente anterior àquelas que analisamos para nossa pesquisa.

\section{$\underline{\text { Dos registros aos dados da pesquisa }}$}

Para Erickson (1998), qualquer tipo de registro realizado em campo não pode ser considerado dado em sua forma bruta, e sim fonte para dados potenciais. Os registros só se transformam em dados a partir do olhar do pesquisador em busca de respostas para suas questões.

Temos de ter consciência que as gravações não são dados de uma pesquisa, muito pelo contrário, como uma aula é um fenômeno bastante complexo, uma mesma gravação pode servir para estudarmos mais de um problema tendo por base mais de um referencial teórico. (Carvalho, 2006).

Carvalho (2005) ressalta como um aspecto importante das transformações das gravações de vídeos em dados para as pesquisas o fato de podermos ver e rever as aulas quantas vezes forem necessárias com o intuito de permitir às pesquisas uma coleção de novos dados que jamais seriam registrados por nenhum observador, por mais atento que ele fosse. Esse registro de múltiplas facetas dos fenômenos que ocorrem em sala de aula possibilita o diálogo com outros pesquisadores e especialistas, resultando em trabalhos interdisciplinares com abordagens teórico-temáticas diversas.

Outro passo importante para transformação das gravações em dados é a seleção dos episódios de ensino, que são "momentos extraídos de uma aula, onde fíca evidente uma 
situação que queremos investigar" (Carvalho et al., 1993). É um recorte feito na aula, uma sequência selecionada a situações-chaves que estejam relacionadas com as perguntas do pesquisador e que são resgatadas.

Os episódios podem não ser contínuos, ou seja, a sequência analisada é interrompida, continuando em minutos ou mesmo em aulas posteriores. Nesse caso o episódio é subdividido em cenas. Compete ao pesquisador montar diversas cenas de um episódio para dar sentido aos seus dados.

...as discussões em sala de aula não são retilíneas sendo que temos de tomar consciência da dificuldade da construção do conhecimento pelos alunos e da lentidão com que se processam as mudanças dos conhecimentos espontâneos para os científicos, das idas e vindas tanto das participações dos alunos como a dos professores. (Carvalho, 2006).

O próximo passo é integrar os dados empíricos com os referenciais teóricos, que serão responsáveis pela sustentação às observações realizadas, consolidando a fidedignidade do pesquisador. Essa integração começa a ser feita durante a primeira tentativa de classificação dos episódios.

Essa fidedignidade das medidas é alcançada quando os episódios analisados são apresentados a um grupo de discussão ou para uma série de juízes com o objetivo de uma maior precisão dos dados obtidos. 
Capítulo V - Análise de dados 


\section{Análise de dados e os instrumentos utilizados para essa análise:}

A fim de contemplar nossos objetivos, realizaremos análises de episódios baseados em alguns referenciais e utilizando algumas categorias que foram usadas em outros trabalhos e até mesmo adaptando ou criando novas categorias de acordo com a necessidade e particularidades desse caso.

O foco de nosso trabalho está nas interações realizadas pelos alunos e na utilização que eles fazem das diferentes linguagens. Também estamos atentos à atividade realizada e à contribuição que pode trazer nesse processo.

Para tanto, utilizaremos alguns instrumentos e indicativos para facilitarem a visualização e identificação do que está acontecendo, bem como auxiliarem a própria análise dos dados.

Dentre eles enumeramos alguns aqui:

Para facilitar a visualização da disposição dos alunos e professor na sala, utilizaremos um descritor indicado por Villani e Nascimento (2003):

\begin{tabular}{|c|c|}
\hline $\begin{array}{c}\text { Configuração } \\
\text { espacial }\end{array}$ & Caracterização \\
\hline C1 & Os alunos encontram-se assentados, em grupos, nas \\
& $\begin{array}{l}\text { bancadas enquanto o professor permanece em pé parado ou percorrendo } \\
\text { a sala e conversando com todos. }\end{array}$ \\
\hline C2 & Os alunos encontram-se assentados ou em pé, trabalhando nas \\
& bancadas e o professor encontra-se manuseando a caixa de lâmpadas. \\
\hline C3 & Um ou mais alunos/alunas de outros grupos ficam em pé diante \\
& Os alunos/alunas estão nas bancadas e o professor em pé diante \\
\hline C4 & da bancada do grupo observado. \\
\hline C5 & Os alunos estão nas bancadas e o professor está passando em \\
\hline
\end{tabular}




\begin{tabular}{|l|l|}
\hline & \begin{tabular}{l} 
outros grupos. \\
\hline C6
\end{tabular} \\
& $\begin{array}{l}\text { Uma configuração livre, em que os alunos encontram-se fora das } \\
\text { bancadas de trabalho, realizando alguma atividade ou simplesmente } \\
\text { caminhando pela sala. }\end{array}$ \\
\hline
\end{tabular}

Esse descritor nos permitirá visualizar o que está acontecendo dentro do espaço físico onde a aula está se realizando.

Outro descritor apontado no trabalho dos mesmos autores acima mostra se o tipo de interação que está acontecendo é entre aluno e professor, alunos do mesmo grupo, alunos de grupos diferentes ou alunos e materiais e um que acrescentamos, entre professor e materiais:

\begin{tabular}{|l|c|}
\hline Tipo de interação & símbolo \\
\hline Professor/Turma & (P/T) \\
\hline Professor/Grupo & (P/G) \\
\hline Professor/Aluno ou Aluno/Professora & (A/A) \\
\hline Aluno/Aluno (alunos de um mesmo grupo) & (Ax/Ay) \\
\hline $\begin{array}{l}\text { Aluno/Aluno (alunos de grupos diferentes) } \\
\text { equipamentos e materiais específicos que compõem a atividade } \\
\text { experimental) }\end{array}$ & (A/ME) \\
\hline $\begin{array}{l}\text { Aluno/Materiais que auxiliam os alunos a efetuar as atividades de rotina de } \\
\text { laboratório, tais como a calculadora, folhas de papel milimetrado e caderno } \\
\text { de laboratório) }\end{array}$ & (A/MA) \\
\hline $\begin{array}{l}\text { Professor/Material (O professor demonstra como utilizar o material } \\
\text { ou ele mesmo utiliza para demonstrar algum fato importante ou ainda } \\
\text { manipula o material empírico para que os alunos coletem dados ou } \\
\text { realizarem suas observações) }\end{array}$ & (P/MA) \\
\hline
\end{tabular}


Com este descritor, podemos também ter uma visualização do que ocorre no espaço físico onde se realiza a aula, analisar os discursos e comunicações ocorridas e principalmente determinarmos se ocorrem as interações que estão mais voltadas para o foco de nosso trabalho (entre alunos e entre alunos e materiais).

Verificamos a existência ou não de argumentos. E, no caso, em que eles aparecem, analisaremos como são construídos e a relação das linguagens verbais e não verbais com essa construção, conforme algumas referências encontradas em Capecchi (2004) e Carmo (2006).

Para análise da estrutura de argumentação, utilizaremos como referência o modelo de Toulmin (1958) e verificaremos se existe a presença dos seguintes elementos: Dado(D), Conhecimento Básico (B), Justificativa (J), Qualificador Modal (M) ou Refutação (R) e a Conclusão (C).

Estaremos atentos também à necessidade de se considerar o contexto em que a argumentação aparece, e o fato de essas aulas não terem sido necessariamente planejadas para desenvolver a argumentação.

Para isso usaremos também as adaptações e ampliações do modelo de Toulmin (1958) realizadas ao longo de vários anos e estudos como os de:

- Jiménez Aleixandre (1998) que acrescenta as subcategorias Dado Fornecido (DF) e Dado Obtido (DO) que ainda pode ser subdividido em Dado Empírico (DE) e Dado Hipotético (DH);

- $\quad$ Ou ainda as adaptações realizadas por Villani e Nascimento (2003) a partir do modelo de Van Eemeren (1987), que passam a considerar basicamente a seguinte estrutura: Inseridos em um contexto, temos os Locutores (S) que por meio de um discurso tentam refutar $(\mathrm{R})$ ou justificar $(\mathrm{J})$ uma opinião $(\mathrm{O})$ ou ponto de vista para os ouvintes (L) que tentam interpretar o discurso (D) e, por sua vez, podem produzir uma opinião interpretada (O') que também pode ser expressa por um discurso interpretado (D'). Nesse modelo os interlocutores procuram verificar a correspondência entre a opinião $(\mathrm{O})$ e a interpretação da opinião (O’).

O foco do trabalho está nas interações entre os alunos principalmente, porém a fala do Professor é extremamente importante e também estamos atentos a ela, inclusive no tipo de discurso adotado.

Utilizamos também nessa análise indicadores da Alfabetização Científica (Sasseron e Carvalho, 2008) com o objetivo de verificarmos como e se os alunos vão se apropriando da Linguagem Científica:

- $\quad$ Seriação de informações. 
- $\quad$ Organização de informações.

- $\quad$ Classificação de informações.

- Raciocínio lógico.

- Raciocínio proporcional.

- Levantamento de hipóteses.

- Teste de hipóteses.

- Justificativa;

- Previsão;

- $\quad$ Explicação.

Na nossa estrutura de análise procuramos observar praticamente:

$\circ \quad$ As linguagens da ciência.

○ $\quad$ Argumentação.

○ Indicadores de Alfabetização Científica.

○ Apropriação de termos técnicos.

○ Envolvimento dos alunos com a atividade.

○ Conceitos.

Destacamos que utilizamos as transcrições com o grupo cuja gravação ficou melhor e utilizamos as outras para melhorar as transcrições em momentos coletivos em que ocorriam interações com a sala toda.

Acompanhamos alunos do $3^{\circ} \mathrm{G}$ do Ensino Médio, mas na atividade de observação dos espectros das lâmpadas, os alunos do $3^{\circ} \mathrm{D}$ também participaram. Devido a problemas de ordem estrutural da escola, os alunos foram dispensados nas últimas aulas, então para não perderem essa atividade, o professor adiantou as aulas dos alunos do $3^{\circ} \mathrm{G}$, permitindo que acompanhassem os alunos do $3^{\circ} \mathrm{D}$ até o laboratório onde a atividade foi realizada. Como o espaço era grande, a quantidade de alunos não atrapalhou o bom andamento da aula. As duas séries estavam no mesmo momento dentro da proposta de ensino.

Consideramos para nossas análises a atividade dos espectros das lâmpadas como Episódio 1 e que foi dividido em momentos, e a atividade do astrônomo mirim como Episódio 2 que também foi dividido em momentos. 


\title{
Episódio 1 - atividade de observação de lâmpadas diversas para identificação de seus espectros
}

\author{
Momento 1 - início da aula \\ Ver tabela de transcrição e análise (anexo p. 238).
}

\section{Descricão da aula:}

A parte inicial da aula é utilizada pelo professor para fornecer informações gerais sobre a atividade a ser realizada, bem como organização da sala e verificação de quem construiu o espectroscópio e quem realizou a atividade de campo solicitada como tarefa em aula anterior.

Já os alunos estão preocupados em manusear o espectroscópio, primeiro de uma forma independente do professor e depois mais atentos às falas do mesmo. Segue uma descrição mais detalhada desse início:

Do turno de fala 01 ao 11, notamos o professor explicando que os alunos deveriam construir os espectroscópios naquele momento e que ele também levou alguns, no caso de alguém não ter conseguido fazer. Já os alunos do grupo observado conversam independentemente da fala do professor e manipulam constantemente os espectroscópios e tentam terminar os que não estão prontos.

No turno de fala 12 o professor cobra a pesquisa de campo que foi solicitada na aula anterior. Em seguida aproveita para informar que aqueles que não fizeram deverão fazer em sala.

P: Alguns fizeram. Os que fizeram, por favor, me passem. Os que não fizeram, nós faremos aqui. Nós vamos aproveitar já a experiência...

No turno de fala 17 o professor avisa que tem algumas lâmpadas para observação. Conclui nos turnos 22 e 24 onde relata os tipos de lâmpadas: mista, mercúrio, fluorescente compacta, incandescente e dicróica. No turno 23 um aluno não identificado questiona se não tem um tipo de luz amarela:

Ani: Tem amarelo a, professor?

É importante notarmos que é a primeira vez que um aluno se dirige diretamente ao professor, pois até o momento os alunos do grupo, mesmo que estivessem prestando atenção à 
fala do professor estavam mais preocupados com a manipulação dos espectroscópios. Também chama a atenção que esta pergunta provavelmente foi feita em virtude da pesquisa solicitada em aula anterior na qual o professor sugeriu que observassem as luzes dos postes de rua, tanto dos postes com luz branca quanto dos postes com luz amarela. Podemos perceber tal fato também por meio dos turnos 80 a 83 onde A1, A3 e A5 relatam as observações que fizeram na pesquisa de campo:

\section{A3: Ô Gabi! Saiu olhando na rua?}

A1: Não, só olhei no postezinho lá perto de casa, só que é branca, amarela não tinha mais nada.

A5: Da varanda do meu quarto pegou uma "luzona” amarela assim ó!

A1: Já pensou aí ó, indo lá embaixo na outra rua que eu não conheço ninguém?

Quando A1 fala que só olhou no poste perto de sua casa "só que é (luz) branca, (luz) amarela não tinha mais nada." faz uma referência à sugestão do professor para pesquisa de campo.

Após a fala do professor indicando as lâmpadas que observarão e a pergunta de Ani no turno 23, A2 comenta que não tem a lâmpada amarela e que esta observação deveria ter sido feita em casa mesmo (turno 25). Do turno 25 ao 34, as falas dos alunos são simultâneas às do professor, porém elas estão diretamente relacionadas, ou seja, eles estão atentos ao que o professor está falando. Inclusive A4 no turno 26 solicita silêncio por meio de gesto característico levando o dedo a boca. Os alunos continuam manipulando o espectroscópio, manuseando cadernos e anotando seus nomes nos seus espectroscópios.

Em relação aos objetivos da atividade, o professor destaca nos turnos 38, 40 e 41 que verificarão os espectros das lâmpadas que tentarão reproduzir a claridade da luz solar, mas cada qual com uma especificidade. No turno 105, o professor também comenta que, quem não realizou a pesquisa, deverá fazê-la agora e mesmo quem fez, deverá tentar corrigir os possíveis erros cometidos, melhorando suas observações com essa atividade em sala de aula.

No turno 41 o professor questiona sobre quem fez o espectroscópio e se dirige ao grupo em questão no turno 62. Do turno 43 ao turno 59, temos uma forte interação entre os alunos do grupo que tentam organizar suas anotações nos espectroscópios e nos cadernos. Chama a atenção que no turno 52, A2 já está olhando para o alto com o espectroscópio, mesmo sem solicitação do professor.

Já no turno 79 o professor pergunta sobre quem fez a pesquisa. Temos uma conversa entre os alunos do grupo sobre a pesquisa que realizaram, conforme citado anteriormente dos turnos 80 a 83 . Neste instante chama a atenção que dos turnos 87 a 93 os alunos conversam e 
brincam pela primeira vez, desvinculados da aula, mas logo em seguida A1 questiona a quantidade de lâmpadas para o professor e os alunos do grupo voltam a manipular os espectroscópios. No turno 99, A4 questiona se o professor possui luz vermelha para que ele termine sua pesquisa numa referência à determinada luz solicitada na pesquisa de campo e obtém resposta do professor no turno 100 que diz não ser necessário apresentar todas as lâmpadas sugeridas na atividade.

No turno 117, A3 indica no espectroscópio a região onde a observação deve ser feita.

A3: Aqui ó, você olha por aqui.

No turno 119 o professor fornece ao grupo alguns espectroscópios que ele fez e já no turno 121, A4 utiliza um destes e busca o lado correto do espectroscópio para observar a lâmpada do teto. No turno 123, vários alunos do grupo observam as lâmpadas do teto, trocam os espectroscópios e continuam as observações. No turno 125, o professor avisa para todos que devem observar com os espectroscópios que fizeram e com os que ele trouxe também definindo qual deles é o melhor para as observações da atividade, porém como dissemos os alunos do grupo já estavam fazendo isso.

Nos turnos 127 e 132, o professor explica que deverão anotar os mesmos dados solicitados na tabela fornecida para pesquisa que realizaram como tarefa. No turno 134, lembra e reforça aos alunos que deverão anotar o nome da lâmpada e o tipo de espectro, ou seja, informando se é contínuo ou discreto.

Os alunos continuam a manipular os espectroscópios.

\section{Análises:}

Mesmo sendo a parte inicial da aula, podemos notar alguns fatos relevantes:

Os alunos do grupo apresentam um grande envolvimento com a atividade, mesmo no início, quando eles parecem não prestar muita atenção à fala do professor, estão empenhados em manipular os espectroscópios e a partir do turno 23 os alunos demonstram mais atenção em relação à fala do professor, o que foi iniciado com uma pergunta de Ani.

Até o final desta sequência, mesmo manipulando os espectroscópios e mexendo com os cadernos, eles demonstram atenção às informações fornecidas e solicitadas pelo professor. Somente durante um rápido momento os alunos do grupo conversam e brincam com coisas desvinculadas à atividade, tal fato é observado somente entre os turnos 87 e 93.

Em relação às linguagens, notamos por parte dos alunos, em virtude da natureza da atividade, o predomínio da manipulação dos espectroscópios (ou dos materiais utilizados para 
construí-los), seguidos da manipulação de materiais (como cadernos e roteiros) que ocorrem praticamente durante todo esse início de aula.

A linguagem oral também aparece num primeiro momento entre alunos do grupo e posteriormente numa interação com o professor, quando também fazem questionamentos sobre as atividades, porém predominam as interações orais entre alunos do grupo durante o restante dessa etapa. Exemplos de interação por meio da linguagem oral entre alunos do grupo:

Turno 04: A1: Dá um pedacinho para o Maurício.

Turno 15: A4: Enxergou Ricardo?

Turno 80: A3: Ô Gabi! Saiu olhando na rua?

Turno 81: Al: Na, só olhei no postezinho lá perto de casa, só que é branca, amarela não tinha mais nada.

Exemplos de interação por meio da linguagem oral entre alunos e professor:

Turno 23: Ani: Tem amarelo aí professor? (praticamente o início das interações com o professor).

Turno 99: A2: Tem luz vermelha aí? Só falta esse para mim.

Turno 100: P: Não precisa ter todos.

A linguagem gestual também é utilizada pelos alunos, seja num pedido de silêncio como no caso de A6 no turno 26, ou para complementar uma fala como no caso de Aba que, no turno 82, utiliza gestos abrindo os braços para indicar o "tamanho" da luz amarela que conseguiu ver da varanda de seu quarto.

Turno 82: A5: Da varanda do meu quarto pegou uma "luzona” amarela assim ó!

Outro exemplo ocorre no turno 129, quando A1 diz que não consegue ver pelo espectroscópio e balança a cabeça negativamente, complementado sua fala.

Turno 129: A1: Não dá para ver nada.

Os gestos também são utilizados em outros momentos para indicar posição de algo como no turno 115, ou para indicar quem realizou determinada ação como no turno 114.

Embora utilizada em menor escala, a linguagem gestual está presente.

Em relação à apropriação de termos técnicos não notamos os alunos utilizando nenhum termo técnico, mesmo a palavra "espectroscópico", não é utilizada por eles, apesar de estarem manipulando constantemente os vários espectroscópios existentes na sala.

As palavras "contínuo" e "discreto" aparecem pela primeira vez, no turno 134, quando o professor lembra o que os alunos deverão anotar durante a observação das lâmpadas. A 
ausência dessas duas palavras pode ser entendida pelo momento da aula e pelo fato de não serem questionados ainda sobre os tipos de espectros.

Em relação a conceitos envolvidos, não temos nenhum comentário por parte dos alunos e nem por parte do professor. O que também consideramos normal em vista do momento e dos objetivos dessa etapa da aula.

Com relação à argumentação, podemos notar que não existem questionamentos ou questões que levem à elaboração de argumentos por parte dos alunos. Apenas no turno 81 temos um exemplo de argumentação básica seguindo o Modelo de Toulmin (1958), quando A1 explica que observou apenas a luz do poste perto de sua casa (dado) e, portanto, só conseguiu ver um tipo de luz, no caso, a branca (conclusão). No turno 83, explica que não saiu na rua para procurar o poste que tivesse luz amarela por não conhecer ninguém da rua (justificativa). Tal fato só ocorreu em virtude do questionamento de A3, no turno 80, onde pergunta se A1 saiu para observar as lâmpadas na rua.

Em relação aos indicadores de alfabetizacão científica, observamos que só existe o indicador organização que aparece em duas formas: organização para realização da atividade e organização para observação com os espectroscópios.

Em virtude do momento inicial da aula e da natureza da atividade, o indicador "organização para realização da atividade" predomina tanto em virtude dos comandos do professor, quanto das falas e ações dos próprios alunos, que tentam terminar os espectroscópios, ficam atentos às instruções do professor e realizam suas anotações.

O indicador "organização para observação com os espectroscópios", embora apareça em menor quantidade, é relevante, pois mostra o interesse dos alunos pela observação e também iniciativa por parte dos mesmos, já que começaram a observar antes que o professor fizesse alguma solicitação específica. Essa iniciativa pode estar associada à pesquisa de campo solicitada na aula anterior. Tal fato tem início no turno de fala 52 quando A2 olha para o alto através do espectroscópio. No turno 117, A3 fala apontando a região do espectroscópio onde a observação deve ser feita:

Turno 117: A3: Aqui ó, você olha por aqui.

No turno 121, A4 pede para ver com determinado espectroscópio que o professor colocou na bancada e coloca o espectroscópio nos olhos, depois vira o mesmo e coloca o dedo em um dos seus lados, em seguida, vira novamente e põe o dedo na outra extremidade e finalmente observa a lâmpada no teto.

Turno 121: A4: "Deixa eu” ver, “deixa eu” ver este aqui! 
Neste turno temos um ótimo exemplo de manipulação do espectroscópio a fim de buscar a melhor posição para realização da observação.

No turno 123 os alunos A1 e A3 juntamente com outros alunos do grupo também olham com o espectroscópio em direção às lâmpadas do teto. No turno 124, os alunos do grupo manuseiam e trocam os espectroscópios entre si e realizam novas observações das lâmpadas do teto.

Somente após esses turnos citados o professor no turno 125 sugere que os alunos verifiquem qual o melhor espectroscópio para realizarem suas observações. Lembrando que as falas dos turnos 123 ao 125 ocorrem praticamente ao mesmo tempo.

Turno 125: P: Pessoal, eu coloquei mais alguns sobre a mesa, dependendo da observação que vocês já fizeram com os seus, tenta aí com outro primeiro... (inaudível)... o que estiver melhor você faz a observação...

Após a sugestão do professor ainda percebemos no turno 127, A3 observar a lâmpada utilizando o espectroscópio que estava com A1 e A4 continuar observando atentamente com o seu espectroscópio.

No turno 128, A1 vira e observa pelos dois lados do espectroscópio e em seguida passa para o aluno a sua esquerda. Pela sua fala e gestos nos turnos 128 e 129 percebemos este espectroscópio não ficou bom.

Turno 128: Al: Esse aqui não é de CD não hein? O Leonardo que pegou para fazer.

Turno 129: A1: Não dá para ver nada.

Sendo que neste último turno A1 ainda balança a cabeça negativamente indicando certa frustração por não conseguir ver.

Outra observação importante nessa etapa é que o descritor "organização para observação com os espectroscópios" é mais notado pela manipulação do espectroscópio do que pela linguagem oral.

\section{Outras informacões relevantes:}

No turno 86 um aluno de outro grupo vem até este, pega uma cadeira e senta entre A3 e A4 e ali permanece durante todo esse início de aula.

Praticamente todos do grupo falam ou participam da manipulação dos materiais e do espectroscópio, com destaque para A3 e A4. 


\section{Episódio 1 - atividade de observação de lâmpadas diversas para identificação de seus espectros}

\section{Momento 2 - observação da $1^{\text {a }}$ lâmpada (fluorescente compacta) e $2^{\mathrm{a}}$ lâmpada (incandescente)}

Ver tabela de transcrição e análise (anexo p. 248).

\section{Descrição da aula:}

Nesta parte da aula, o professor realiza uma troca rápida de uma lâmpada para outra com o objetivo de que os alunos percebam as diferenças básicas entre os espectros delas. Realizando essa troca rápida da $1^{\mathrm{a}}$ para $2^{\mathrm{a}}$ lâmpada, o professor procura destacar as diferenças entre os espectros discretos e contínuos bem como explicar aos alunos o que devem observar e considerar para classificá-los. Devido à troca rápida o professor acaba retornando para $1^{\text {a }}$ lâmpada para que os alunos realizem as observações com mais atenção, porém veremos essa descrição na próxima etapa. Aqui vamos analisar a primeira observação com a lâmpada fluorescente compacta e a observação com a lâmpada incandescente.

Merece destaque também o fato de que na observação da $2^{\mathrm{a}}$ lâmpada o professor solicita que os alunos identifiquem e anotem a maior e a menor "banda do espectro de cores", ou seja, qual a cor aparece com um tamanho maior ou menor no espectro observado.

Em relação aos alunos, notamos que eles estão atentos à observação, mas ao mesmo tempo, estão preocupados com as anotações que devem fazer. Começam a classificar os espectros, mas com dúvidas.

O envolvimento por parte dos alunos é grande, principalmente quando observam a $2^{\mathrm{a}}$ lâmpada.

Notamos também certa dificuldade para identificarem determinadas cores dos espectros observados.

Para facilitar nossa análise dividimos esse momento em etapas distintas:

- Do turno 142 ao turno 182 - observação da $1^{\text {a }}$ lâmpada (fluorescente compacta) buscando a identificação do tipo de espectros;

- Do turno 182 ao turno 266 - observação da $2^{\mathrm{a}}$ lâmpada (incandescente) buscando a identificação do tipo de espectros; 
- Do turno 267 ao final dessa etapa - observação da $2^{a}$ lâmpada buscando a identificação das cores que aparecem mais (largas) ou menos (largas) no espectro observado.

Segue uma descrição mais detalhada dos momentos citados:

\section{Do turno 142 ao turno 182:}

No turno 142 as luzes da sala são apagadas e a lâmpada fluorescente é acesa em uma das bancadas. No turno 146, o professor vai até a bancada onde está a lâmpada acesa e alguns alunos comentam que ele está na frente da mesma.

No turno 150 o professor explica que vai recolher o trabalho no final da aula, portanto alguém de cada grupo deve anotar as observações. Em seguida, no turno 153, o professor classifica a lâmpada como fluorescente compacta e solicita que classifiquem o tipo de espectro da mesma como contínuo ou discreto.

A3, simultaneamente à fala do professor no turno 150 , começa a relatar as cores que está enxergando mesmo sem ser solicitado:

Turno 151: A3: Violeta, verde, verde-claro. Laranja. Vermelho. Não, azul não "to" vendo.

No turno 153 o professor informa que estão observando uma lâmpada fluorescente compacta e em seguida solicita a classificação do espectro em discreto ou contínuo.

No turno seguinte, A3 responde prontamente que o espectro é contínuo, mas não apresenta nenhuma justificativa para sua classificação. Outros alunos afirmam que é discreto sem apresentarem justificativas também. Os alunos do grupo demonstram também uma preocupação em relação a quem está anotando as observações;

Turno 159: A5: Anota aí Raxixi.

Turno 160: A3: Ô Gabi você está aí anotando?

A1 gesticula com a cabeça de forma negativa e A4 no turno 163 avisa que está realizando as anotações.

Com o objetivo de apresentar justificativas para as classificações, o professor pergunta se os alunos conseguem enxergar todas as cores (as sete do arco-íris - espectro eletromagnético).

Turno 166: P: Aparecem todas as cores? As sete aí?

Em seguida vários alunos respondem que não é possível.

O professor explica que isso é uma característica de um espectro que não é contínuo.

Turno 168: P: Então isso já é um indício que o espectro não é contínuo.

Enquanto o professor fala, A5 continua citando as cores que está enxergando. 
Turno 169: A5: Roxo, azul e verde. Roxo, azul e verde.

O professor continua explicando como diferenciar um espectro do outro, porém, devido ao excesso de ruído e conversas na sala, ele é obrigado a pedir silêncio, buscando uma organização para que os alunos tenham condições de analisar o tipo de espectro a partir das informações que ele está fornecendo. Em seguida, de forma mais tranqüila, o professor destaca que a presença de linhas entre as cores do espectro indicam que o espectro é discreto.

Turno 173: P: Você vê uma tarja colorida e nesta tarja se aparecem linhas ou quadros reforçados com destaque maior, mais intenso parecem várias linhas, então este espectro é discreto.

Após essa fala o professor solicita novamente a classificação do espectro e vários alunos respondem que é discreto e tal classificação é confirmada em seguida pelo professor. Neste momento, seria interessante uma questão para que os alunos explicassem o motivo por terem classificados como discreto, pois apesar das explicações recentes por parte do professor, não podemos afirmar se esta resposta correta foi realmente baseada nas mesmas.

No turno 178, A4 pergunta para A1 se é o azul que ela está anotando. Neste momento A3 comenta novamente que não está vendo o azul.

Turno 179: A3: Azul, eu não to vendo azul.

Essa fala reforça o que foi dito pelo próprio A3, no turno 151, e mostra uma dificuldade na observação e identificação de determinadas cores. A4 demonstra certa indignação com essa dificuldade de A3.

No turno 182 o professor fala sobre a percepção da diferença dos espectros e troca a lâmpada.

Neste momento predominam as interações Professor/Turma e Aluno/Aluno (mesmo grupo).

Os alunos iniciam suas classificações, mas sem apresentarem justificativas.

\section{Do turno 182 ao turno 266:}

No turno 182 o professor inicia troca de lâmpadas. O pouco tempo utilizado para análise da $1^{\mathrm{a}}$ lâmpada é explicado pela intenção do professor em destacar a diferença entre os espectros dessas lâmpadas.

Esse momento da aula é utilizado para observação e identificação do espectro de uma lâmpada incandescente.

Logo no turno 184 um aluno não identificado demonstra sua preocupação com as anotações que precisa fazer. 
Turno 184: Ani: Professor, tem que anotar o nome das cores professor?

Trata-se de um momento da aula em que vários alunos falam ao mesmo tempo.

No turno 189 o professor solicita que observem a lâmpada e avisa que depois colocará a $1^{\text {a }}$ lâmpada novamente. Em seguida, destaca a necessidade de observarem as diferenças entre os dois tipos de espectro. Do turno 191 ao turno 196, os alunos demonstram grande envolvimento e euforia com a realização da atividade. Também temos uma constante manipulação dos espectroscópios com os alunos buscando um melhor posicionamento para observação, como no caso de A1 que, no turno 196, inclina-se para frente para observar melhor a lâmpada.

No turno 194 o professor afirma que este espectro é contínuo, mas não justifica sua afirmação.

No turno 198, A4 pergunta o nome (tipo) da lâmpada.

Turno 198: A4: Como chama essa lâmpada?

A resposta correta vem com A5:

Turno 199: A5: Incandescente.

Porém, A3 parece estar confuso sobre o tipo de lâmpada.

Turno 200: A3: Lâmpada incandescente..., ou não? Você não sabe?

Turno 201: A4: É lâmpada amarela.

Neste instante temos uma confusão no grupo. Quando A4 fala que é lâmpada amarela provavelmente está se referindo a uma das lâmpadas que eles tiveram que observar na atividade de campo. Em seguida A4 classifica o espectro da lâmpada.

Turno 202: A4: Espectro contínuo.

Logo em seguida A3 discorda com a classificação e pela primeira vez apresenta uma justificativa para sua afirmação.

Turno 203: A3: Não, não é contínuo, não “aparece” todas as cores. Contínuo é quando "aparece" todas.

Temos aqui um exemplo de argumentação segundo o Modelo de Toulmin (1958): A3 apresenta um dado ao afirmar que não é contínuo, em seguida apresenta uma justificativa afirmando que "não aparece todas as cores", e por fim apresenta uma conclusão ao afirmar que é contínuo quando aparecem todas as cores. É a primeira vez que um aluno justifica e explica sua classificação, ou seja, apresenta sua fala na forma de um argumento, mesmo que em sua estrutura básica.

Nesta fala chama a atenção A3 dizer não enxergar todas as cores, pois foi exatamente ele que nos turnos 151 e 179 avisa não ter conseguido identificar o azul. Embora tenha 
utilizado uma explicação correta para sua resposta, ela está errada. A explicação para o erro pode ser a dificuldade em identificar todas as cores com o espectroscópio, já que ele demonstrou dificuldade para enxergar o azul.

No momento seguinte, o professor explica como os alunos devem utilizar o espectroscópio para realizarem suas observações. É um momento que o professor passa de uma fala em baixo tom para uma fala voltada a toda sala.

Turno 204: P: Põe o lado do plástico da lente encostado no olho. E o fundo aponta para lâmpada.

Turno 212: P: Aí mais ou menos onde você está segurando na lateral aparece uma tarjinha colorida...

Essa fala demonstra uma preocupação do professor com a maneira como os alunos estão realizando as observações. Durante esse comentário vários alunos falam ao mesmo tempo.

No turno 217 o professor pergunta qual o espectro da lâmpada.

Em seguida A3 demonstra indecisão ao começar a responder que é contínuo, e antes de terminar a palavra, afirma que é discreto.

Turno 218: A3: Conti... é discreto!

O professor insiste para que observem as cores que estão presentes no espectro para responderem corretamente.

Turno 219: P: Você tem que dizer nesse espectro que cores aparecem aí.

Em seguida, A4 solicita que o professor deixe a lâmpada acesa mais um pouco para que ele realize as anotações e pede para A3 verificar quais as cores que aparecem. É um momento de grande agitação na sala, os alunos falam entre si e gesticulam muito uns com os outros.

Do turno 224 ao turno 238, temos um fato interessante, pois enquanto o professor explica que a luz da lâmpada incandescente é uma luz branca (turno 225), porque é composta por todas as cores do espectro, citando quais são essas cores: luz vermelha, alaranjada (turno 229), amarelo, verde, azul, anil e violeta (turno 233), reforçando inclusive que o espectro contínuo deve apresentar todas essas cores (turno 235), A3 continua realizando suas observações para indicar as cores para A4. Primeiramente A3 cita violeta e azul (turno 224), verde claro (turno 226), amarelo que afirma ser "meio vermelho" (turno 228), até que finalmente consegue distinguir o vermelho e o laranja (turno 230).

Turno 230: A3: Vermelho, alaranjado! Laranja. Primeiro é o laranja, depois o vermelho. 
Turno 231: A4: Laranja e vermelho?

Turno 232: A3: É.

E finalmente no turno 238, após o professor repetir as cores do espectro, A3 concorda que as cores são essas mesmo e afirma que conseguiu ver todas.

Turno 238: A3: "Podes crê", é vi... é isso mesmo.

É importante lembrarmos que A3 é o mesmo aluno que apresentou dificuldades para enxergar o azul anteriormente (turnos 151 e 179) e classificou erroneamente o espectro da lâmpada incandescente, argumentando não possuir todas as cores (turno 203), ou seja, apresentou uma justificativa correta para sua classificação, porém sua observação não foi correta, já que não havia enxergado todas as cores.

Também notamos que A3, do turno 224 ao turno 228, cita as seguintes cores: vermelho, laranja, amarelo, verde, azul e violeta sem mencionar o anil. Inclusive a definição do anil é uma dúvida para A4 também.

Turno 239: A4: Que cor é anil?

No momento deste questionamento A4 está com o espectroscópio no olho observando a lâmpada. Tal questionamento leva o professor a falar das tonalidades do azul.

Turno 242: P: Olha o azul, ele tem uma tonalidade que nós...

Turno 244: P: ...na linguagem comum nós diríamos que ele, (inaudível)... um pouco mais claro. Então o azul e o azul claro.

Essa explicação do professor leva a outro questionamento por parte de A4:

Turno 245: A4: Anil é o azul piscina?

Isso leva o professor a dar uma resposta mais direta:

Turno 247: P: $O$ anil é o azul escuro.

Temos nessa sequência um bom exemplo de interação dialógica no discurso entre professor e aluno.

No turno 251 o professor diz que os alunos devem anotar o nome da lâmpada e ele mesmo confirma que é incandescente, e também o seu espectro que ele deixa como pergunta. A resposta dos alunos ainda reflete uma dificuldade para classificarem, pois A4 afirma que é contínuo (turno 256), porém outro diz ser discreto (turno 257). O professor confirma que é contínuo (turno 258). Durante a fala do professor, no turno 251, A3 e A4 continuam comentando e discutindo sobre as cores observadas, enquanto os demais alunos do grupo estão olhando novamente para lâmpada com o espectroscópio. 
Ainda sobre os tipos de espectro o professor chega a perguntar no turno 263 se tem todas as cores, porém não conseguimos ouvir as respostas dos alunos, pois vários falam ao mesmo tempo.

Nesse momento da aula continuam as interações P/T e A/A e temos algumas interações P/A, mas que em geral o professor utiliza como informação para toda a sala, podendo ser caracterizada como $\mathrm{P} / \mathrm{T}$. Continuamos com os descritores organização e classificação, mas temos também um exemplo de justificativa e explicação no turno 203.

\section{Do turno 267 ao turno 349:}

No turno 267 em diante continuamos com a lâmpada incandescente, porém agora o foco da observação é outro: o professor quer saber qual a cor que se destaca mais no espectro observado (a mais larga) e qual se destaca menos, por isso selecionamos essa parte do episódio como um momento distinto.

Turno 267: P: As duas últimas anotações do quadro. Qual é a maior banda?

O professor faz referência ao quadro que os alunos utilizaram para realizar as anotações da pesquisa de campo.

No turno 269 o professor explica que por maior banda os alunos devem procurar a mais larga e já afirma que o vermelho representa a maior banda.

Turno 269: P: No caso a mais larga. Vermelho.

Nesse momento um aluno não identificado (turno 270) e A3 (turno 271 e 273) discordam do professor, afirmando que a maior banda é representada pela cor verde. Não temos resposta do professor.

No turno 274 o professor associa a ideia de maior banda com maior distribuição de frequências, ou seja, a frequência da cor vermelha é a que aparece mais distribuída no espectro observado. Os alunos não fazem referência à palavra frequência, porém continuam afirmando que o verde também deve constar como maior banda. A1 e A5 reforçam a fala de Ani e A3. A1 chega a destacar que as duas cores possuem larguras parecidas.

Turno 275: A1: Professor, mas o verde também tem.

Turno 278: A1: O verde e o vermelho "tá" na média.

Turno 281: A5: É o verde.

No turno 276 Ani reforça a fala de A1 no turno 275 e A3 continua afirmando que é a cor verde (turnos 279 e 280). 
Mesmo com os alunos do grupo questionando sobre qual é a maior banda dos turnos 270 até 281, o professor não apresenta uma resposta para eles. Nesse momento o professor parece mais preocupado com a classe e com o fato de que todos devem fazer as anotações.

Já no turno 282 o professor questiona qual é a menor banda e desta vez ele não diz qual.

Turno 282: P: Qual é (inaudível)... o que aparece menor?

No turno 283 vários alunos respondem ao mesmo tempo, alguns dizem que é o amarelo, outros dizem que é o verde.

A3 parece fazer uma confusão em relação à pergunta, pois continua dizendo que é o verde (turno 284), o que representaria uma incoerência, já que anteriormente ele estava afirmando que o verde possuía a maior banda. Analisando as falas seguintes, entendemos que na verdade A3 ainda estava falando da maior banda, pois vários alunos afirmam que a menor banda é o amarelo (turno 286), e A2 fala diretamente para A3, afirmando que a menor é o amarelo, quando este responde:

Turno 288: A3: É não, o amarelo é o menor.

A2 confirma que é isso mesmo o que estão procurando no momento:

Turno 289: A2: É o que aparece menos.

No turno seguinte A3 concorda que estão procurando a menor banda neste instante, porém indica que é a cor laranja.

Turno 290: A3: Ah menor. Menos é o La... La... o laranja.

Turno 291: A3: Ô. Menos aparece é o laranja.

A fala de A3 no turno 291 é direcionada para A4 que está realizando observações com o espectroscópio. Em seguida um Ani chega a afirmar para o professor que é realmente a cor laranja que aparece menos no espectro e vários alunos confirmam esta fala.

Diante da resposta o professor solicita que anotem qual a maior e a menor banda. Temos vários alunos falando ao mesmo tempo, alguns risos e brincadeiras entre os alunos.

No turno 302, A1 questiona se a menor banda é o laranja ou amarelo. No turno 311, A4 afirma que a menor é a cor laranja e é acompanhado por vários alunos, porém em seguida A3 (turno 314) diz que é o amarelo, contradizendo sua fala anterior (turno 294). Tal fato pode indicar também uma dificuldade que A3 possui para identificar as cores do espectro nessa faixa de frequências (vermelho, laranja e amarelo).

Diante da fala de A3, A4 demonstra certa irritação e afirma que a menor banda é a cor laranja. 
Turno 315: A4: "É laranja Ricardo. Pára, é laranja, por que cê ta falando amarelo veio?!"

Por sua vez A3 continua dizendo que é a cor amarela.

Turno 316: A3: É amarelo! Amarelo! É amarelo.

Diante do impasse A1 encontra uma explicação para a confusão:

Turno 317: A1: "Ô Ricardinho, é porque o amarelo e o laranja tão junto."

Quando diz que a cor amarela e a cor laranja estão juntas, A1 na verdade está dizendo que estas cores correspondem a uma faixa muito próxima e por isso fica difícil distingui-las, o que acaba gerando a confusão e a dificuldade para A3.

Temos aqui um exemplo de argumento construído coletivamente: uma divergência na definição de cores (dado) por meio da observação de A3 e A4, uma explicação por parte de A1 dizendo que o motivo é o fato dessas cores aparecerem juntas (justificativa) por isso A3 está confuso (conclusão).

Após a explicação de A1, A3 concorda e gesticula muito, demonstrando irritação com a dificuldade encontrada (turnos 318 e 319). Porém, em seguida, A4 pergunta quem tem certeza (sobre a menor banda) e isso traz a polêmica de volta, pois A5 afirma que é a cor laranja (turno 321), porém A3 retorna com a idéia que é a cor amarela (turno 322). Demonstrando um pouco de impaciência com a polêmica, A4 afirma que já anotou a cor laranja e vai deixar dessa forma (turno 323). A discussão segue até o turno 328 quando A4 chama o professor, porém não obtém retorno e não chegam a um consenso.

Durante o final dessa discussão o professor explica que na próxima aula vai apresentar todas as cores possíveis do espectro (turnos 327 e 329).

A partir do turno 330, quando A2 questiona A3 e A4 se estão fazendo as anotações como se fossem grupos diferentes, temos uma discussão interna sobre qual das anotações vão entregar ao professor. A4, sabendo que A1 também tinha anotado, decide que não precisarão mais de suas anotações, porém A3 discorda por acreditar que todo o trabalho que tiveram deve ser aproveitado também. A discussão segue até o turno 352 e aparentemente o grupo fica com as anotações de A1, apesar de A3 continuar protestando.

Durante essa discussão o professor apresenta algumas falas, porém em baixo tom e não conseguimos compreender. Já no turno 339 o professor pergunta para toda a sala se já pode trocar a lâmpada e, como resposta, um aluno solicita que espere mais um pouco (turno 340). Os alunos do grupo manipulam constantemente seus cadernos e folhas. Praticamente toda a sala está conversando também. 
No turno 350 o professor solicita novamente que os alunos observem e anotem. No turno 352, A3 e A2 estão novamente com o espectroscópio olhando para a lâmpada. No turno 357, A1 elogia um espectroscópio:

Turno 357: A1: Ah a do Léo é da hora.

Em seguida, A2 passa o espectroscópio elogiado para A1.

A5 solicita que o professor mostre a primeira lâmpada de novo (turno 354), solicitação reforçada por A3 (turno 356).

O final da observação da lâmpada incandescente é muito agitado e no turno 358 o professor retira a lâmpada colocando outra logo em seguida (turno 363).

\section{Análises:}

Durante a observação das duas lâmpadas, notamos um grande envolvimento com a atividade por parte dos alunos. Podemos observar que logo no início, enquanto o professor ainda comenta que no final da aula irá recolher o trabalho (turno 150), os alunos já começam a observar a lâmpada com o espectroscópio e a falarem as cores, mesmo sem um pedido específico para isso.

Praticamente durante todo o período de observação dessas lâmpadas, os alunos manipulam os espectroscópios e realizam observações com eles. Temos registro de A3 e A2 com o espectroscópio olhando para a lâmpada até o turno 352, e de A2 passando um espectroscópio para A1 no turno 357.

Outros exemplos de observação com o espectroscópio ocorrem nos seguintes turnos: o já citado 150, em que os alunos observam e falam as cores; no 154, quando A3 diz que o espectro da lâmpada (fluorescente) é contínuo; no 173, enquanto o professor explica que espectros que possuem linhas são discretos, vários alunos continuam olhando para lâmpada e realizando suas anotações e comentando uns com os outros; já no turno 180, enquanto discute com A3 sobre as cores observadas, A4 olha fixamente com o espectroscópio. Todos esses turnos correspondem à observação da lâmpada fluorescente compacta.

No caso da lâmpada incandescente podemos destacar os turnos: 196, quando os alunos observam a lâmpada com seus espectroscópios e A1 até inclina-se para frente buscando uma melhor posição para realizar sua observação; turno 211, A4 observa com seu espectroscópio; turno 215, quando A3 consegue enxergar o espectro com a ajuda do professor, demonstra uma expressão de felicidade por ter conseguido, chegando a comemorar, porém sem tirar o espectroscópio do olho e continuando na mesma posição de observação; no 238, A3 gesticula com um sinal de positivo e continua observando com o espectroscópio; no turno 239, quando 
A4 pergunta qual é a cor é anil, fala com o espectroscópio ao olho, observando a lâmpada; no 254 enquanto A3 e A4 falam ao mesmo tempo em que o professor, os demais alunos do grupo estão observando com o espectroscópio de novo. Mesmo quando o professor questiona sobre qual é a maior banda (turno 267), temos alguns alunos observando a lâmpada; no 279, A3 fala olhando com o espectroscópio novamente; no 291, A3 fala com A4 enquanto este realiza uma observação com o espectroscópio.

Outros exemplos de momentos de manipulação do espectroscópio foram encontrados nos turnos: 260, quando o professor entrega um espectroscópio para um aluno; 275, no momento em que A1 fala tirando o espectroscópio do olho; 351, quando A4 coloca na bancada o espectroscópio que estava utilizando; e turno 357, quando A2 passa seu espectroscópio para A1.

Outro indicador de envolvimento dos alunos com a atividade é a preocupação que apresentam com as anotações e registro que precisam fazer, conforme o turno 152 quando A5 questiona quem está anotando. Ou entre os turnos 159 e 165 quando os alunos do grupo discutem quem está anotando, até A4 assumir que está realizando essa função. No turno 170, quando A1 comenta que fez errado, após explicação do professor (turno 166 e 168), ou seja, ela estava atenta à explicação dele. Já no turno 178, A4 fala para A1, enquanto ela escreve no caderno.

No turno 184 Ani pergunta ao professor se é necessário anotar os nomes das cores. Do turno 185 ao 188 estão preocupados que o professor saia da frente da lâmpada para observarem e com o momento de troca das lâmpadas.

No turno 230, A3 fala os nomes das cores que está observando pelo espectroscópio para que A4 anote em seu caderno.

Do turno 330 ao 352 os alunos do grupo discutem sobre as anotações realizadas. A1 fica responsável pelas anotações que serão entregues, bem como com o registro dos números dos alunos envolvidos. A3 não concorda com A4 e prefere deixar suas anotações em favor das anotações de A1.

Outro aspecto que podemos destacar como demonstrativo do interesse dos alunos é o fato que praticamente todos os turnos apresentam falas ou atitudes relacionadas à realização da atividade. Só observamos algumas brincadeiras do turno 358 ao 363 que não estão relacionadas à atividade, o que é normal, pois é o momento de troca da lâmpada depois de intensas observações e discussões. Ou em pequenos momentos de brincadeiras ao longo das observações como nos turnos 300 e 301. 
Também observamos certa euforia dos alunos com a atividade. Alguns turnos destacam mais tal fato, como no turno 194, quando o professor afirma que o espectro da lâmpada incandescente é contínuo, vários alunos falam ao mesmo tempo e é nítida a euforia dos mesmos. Essa atitude parece estar relacionada com o fato de observarem a diferença entre o espectro dessa lâmpada (incandescente) com a anterior (fluorescente compacta), o que pode ser notado no turno 191:

Turno 191: A3: É mesmo! Vai esse é linha reta ó!

Enquanto fala A3 vai gesticulando, A4 e A5 também demonstram sua satisfação:

Turno 195: A4: Esse é da hora!

Turno 196: A5: Esse é garantido.

O mesmo A3 demonstra muita alegria quando o professor explica como devem observar dentro do espectroscópio para enxergarem os espectros da lâmpada (turno 212) e pergunta se conseguiram ver (turno 214):

Turno 215: A3: É. Uh, uh!!!

Neste momento, além de comemorar, A3 demonstra expressão de felicidade e continua observando com o espectroscópio sem tirá-lo do olho.

Por fim consideramos indicativos de envolvimento com a atividade:

O cuidado com a melhor forma de realizar as observações, como no turno 196 quando A1 inclina-se para frente a fim de melhorar sua observação;

A preocupação com as características dos espectros discretos e contínuos presente no turno 203 na fala de A3 que explica uma das características do espectro contínuo: Turno 203: A3: Não, não é contínuo, não aparece todas as cores. Contínuo é quando aparece todas.

Empenho na observação e identificação das cores presentes em cada espectro, como nos turnos 151 com A3, 169 com A5, 178 com A4, 179 com A3, 203 com A3, do turno 224 ao 238 com A3. Também destacamos a dúvida que tiveram para identificarem determinadas cores, como o anil que exigiu uma explicação por parte do professor (turnos 242, 244 e 247) após questionamento de A4 (turno 239), A3 (turno 243) e A4 (turno 245).

$\mathrm{O}$ momento que o professor afirma que a maior banda presente no espectro da lâmpada incandescente é o vermelho (turnos 269 e 274) também mostra envolvimento dos alunos que questionam tal dado, afirmando que o verde também merece essa classificação (turnos: 270, 271, 273, 275, 276, 278 ao 281), fato que pode ser resumido com a fala de A1 no turno 278: A1: O verde e o vermelho tá na média. 
A dificuldade de A3 distinguir o amarelo do laranja no espectro para classificação da menor banda. A3 afirma que a cor amarela representa a menor banda, enquanto outros alunos afirmam que é a cor laranja (turno 283 ao 326), motivo que leva a uma intensa discussão no grupo. A1, atenta às falas dos companheiros de grupo, parece ter a explicação para dificuldade de A3: Turno 317: A1: Ô Ricardinho, é porque o amarelo e o laranja tão junto. A1 reforça sua fala por meio de gestos. Mesmo concordando com ela em relação ao fato de aparecerem muito próximas A3 continua considerando a cor amarela como a menor banda.

Em relação às linguagens, continuamos com grande destaque para manipulação dos espectroscópios e em menor escala manipulação de materiais como cadernos. A manipulação dos espectroscópios ocorre do início ao fim com objetivo de realizarem as observações e praticamente é feita por todos os alunos do grupo, e também percebemos o mesmo comportamento por parte de outros alunos da classe. Já a manipulação de materiais como caderno ocorre durante momentos em que estão realizando as anotações e no caso desse grupo A4 e A1 são os que mais realizam essa manipulação.

Por ser uma atividade de observação, consideramos normal o destaque para linguagem de manipulação dos espectroscópios, mas conforme destacamos no item "envolvimento com a atividade", o interesse dos alunos e a dedicação dos mesmos contribuíram para o predomínio dessa linguagem.

A linguagem oral também tem seu destaque nessa sequência de observações, principalmente nas interações entre alunos do mesmo grupo (A/A) e professor e turma (P/T) com alguns momentos de interações mais específicas entre professor e aluno (P/A).

Percebemos uma interação dialógica nas falas dos alunos por meio de perguntas ao professor, solicitações ou ainda questionamentos sobre as afirmações do mesmo.

Como exemplos de perguntas realizadas, temos os turnos 236, quando A4 pergunta quais são as cores do espectro contínuo; 239, quando A4 pergunta o que é (a cor) anil, após a fala do professor que citou esta como uma das sete presentes no espectro contínuo e turno 245, situação em que A4 questiona se anil corresponde ao azul piscina.

Exemplos de solicitações: turno 181, momento em que A3 pede licença ao professor para observar a lâmpada ou no turno 354, quando A5 pede que o professor coloque a primeira lâmpada para observarem novamente.

Como exemplo de questionamento temos os turnos 270, 271, 273, 275, 276, 278,279, 280 e 281 , em que os alunos não concordam com a fala do professor ao afirmar nos turnos 269 e 274 que a maior banda é representada pela cor vermelha. Nessa sequência os alunos 
afirmam que a maior banda é representada pela cor verde e que essa cor merece destaque ao lado da vermelha como maior banda. Este fato pode ser exemplificado com os turnos 275 e 278.

Turno 275: A1: Professor, mas o verde também tem.

Turno 278: A1: O verde e o vermelho "tá" na média.

Já nas interações A/A destacamos a sequência em que A4 afirma que a menor banda é representada pela cor laranja, discordando dos demais alunos do grupo que dizem ser a amarela, criando uma polêmica interessante no grupo, inclusive com uma explicação proposta por A1 no turno 317.

Turno 317: A1: Ô Ricardinho, é porque o amarelo e o laranja tão junto.

A polêmica praticamente vai do turno 290 ao 324 e, embora a dúvida permaneça, representa um momento rico no qual os alunos expressam suas opiniões de forma espontânea e representando uma interação dialógica também.

A linguagem gestual aparece pouco relacionada à atividade propriamente dita, mas podemos destacar dois turnos:

Turno 191: A3: É mesmo. Vai, esse é linha reta ó!

Aqui A3 parece perceber a diferença entre o espectro da lâmpada que está observando (incandescente) com relação à lâmpada anterior (fluorescente) e quando diz "é linha reta...", parece afirmar que as cores aparecem juntamente sem interrupções de uma para outra e, ao erguer a mão direita, parece utilizar esse gesto para reforçar sua afirmação.

Turno 317: A1: Ô Ricardinho, é porque o amarelo e o laranja tão junto.

A1 fornece uma possível explicação para o fato de A3 considerar a cor laranja como representante da menor banda, os outros consideram a cor amarela. Enquanto fala, A1 gesticula com as mãos indicando proximidade (das cores).

Nos dois exemplos temos os gestos cooperando com a linguagem verbal (Carmo, 2006).

Os demais gestos aparecem mais indicando emoções dos alunos, como alegria e frustrações.

Em relação à apropriação de termos técnicos, notamos que as palavras "discreto" e “contínuo" são utilizadas pelos alunos, já que nessa sequência o professor solicita a classificação dos espectros das lâmpadas observadas. A primeira solicitação do professor ocorre no turno 153:

Turno 153: P: Esta lâmpada fluorescente compacta. Segunda coisa, o espectro aqui é discreto ou contínuo? 
Em seguida no turno 154, A3 classifica como contínuo e no turno 156, A2, como discreto. Ambas as falas não apresentam justificativas.

Nos turnos 166 e 168 o professor associa a presença de todas as cores (as sete do arco íris) ao espectro contínuo e nos turnos 171 e 173, associa a presença de linhas ao espectro discreto.

No turno 176, em resposta ao questionamento do professor no turno 175, vários alunos respondem que é discreto. No turno 202, A4 afirma que o espectro da lâmpada que está observando é contínuo, porém apenas no turno 203 que A3 afirma que não é contínuo e apresenta uma justificativa para sua fala:

Turno 203: A3: Não, não é contínuo, não aparece todas as cores. Contínuo é quando aparece todas.

Consideramos essa fala importante, pois é um indício de que o aluno se apropriou da palavra e também de seu significado de acordo com a explicação fornecida pelo professor nos turnos 166 e 168. Ao mesmo tempo mostra que ele não utiliza a presença ou ausência de linhas para realizar sua classificação.

Temos outros momentos que os alunos utilizam os termos "discreto" ou "contínuo", porém sem justificativas: o próprio A3 no turno 218, e alunos não identificados nos turnos 256,257 e 259.

Com isso notamos uma incorporação e apropriação desses termos por parte dos alunos, porém não temos como afirmar se ocorreu uma apropriação de seu significado, exceto por A3, que demonstrou utilizar uma característica dos espectros para realizar sua classificação.

No turno 267 o professor apresenta um novo termo técnico ao perguntar qual a maior banda, explicando que ela seria a mais larga (turno 269), ou seja, a maior distribuição de frequências do espectro (turno 274). Logo a seguir também pergunta qual que aparece menor (turno 282) e volta a utilizar o termo maior e menor banda no turno 298.

Os alunos por sua vez utilizam apenas o termo "menor", como nos turnos 288, 299 e 302:

Turno 288: A3: É não, o amarelo é o menor.

Turno 299: Ani: Para, para. Fala o menor aí, gata.

Turno 302: A1: Menor é o laranja ou o amarelo? Decide gente!

Também utilizam "aparece menos", como nos turnos 289 e 291:

Turno 289: A2: É o que aparece menos.

Turno 291: A3: Ô. Menos aparece é o laranja. 
O termo "maior ou menor banda" aparecem apenas nos turnos 295, 306 e 311 sempre com A4:

Turno 295: A4: A maior banda é qual?

Turno 306: A4: Qual é a maior (banda)?

Turno 311: A4: Laranja é a menor... banda.

O termo "distribuição de frequências" não é utilizado pelos alunos.

Em relação a conceitos envolvidos, não notamos referência explícita se tratam a luz como onda ou partícula. Quando o professor fala sobre "maior distribuição de frequências no espectro" (turno 274), ele parece remeter ao conceito de luz como onda, porém os alunos não demonstram nenhuma reação em relação a isso e nem o professor retoma tal ideia.

Com relação a argumentação, notamos que na maior parte do tempo os alunos classificam ou respondem algum questionamento sem apresentarem justificativas. Por vezes apenas expressam opiniões, mas também obtivemos exemplos de argumentação básica, conforme o modelo de Toulmin (1958):

$1^{\circ}$ exemplo:

Turno 203: A3: Não, não é contínuo, não aparece todas as cores. Contínuo é quando aparece todas.

Aqui a sequência "dado, justificativa e conclusão" aparece invertida, mas identificamos facilmente uma argumentação com elementos básicos: A3 apresenta primeiro sua conclusão ao afirmar que não é contínuo (o espectro), em seguida apresenta o dado (obtido por meio de sua observação) que não aparecem todas as cores e por fim temos a justificativa, quando afirma que (o espectro) contínuo é no aparecimento de todas as cores.

Utilizando aqui também as categorias e subcategorias propostas por Jiménez Aleixandre (1998) que ampliam o modelo de Toulmin, podemos classificar o dado como obtido e empírico, já que foi por meio de sua observação com o espectroscópio que A3 observou que não apareciam todas as cores.

Podemos utilizar aqui também, de uma forma mais geral, o modelo de Van Eemeren et al. (1987) adaptado por Villani e Nascimento (2003), pois A3 (Ouvinte) apresenta um discurso interpretado (O’) a partir do discurso do professor (Locutor) apresentado nos turnos 166 e 168 quando associa a presença de todas as cores ao espectro contínuo e nos turnos 171 e 173, associando a presença de linhas ao espectro discreto.

Notamos que A3 utilizou em sua fala o discurso do professor apresentado nos turnos 166 e 168 quando associa a presença das cores ao tipo de espectro, porém o aluno não utiliza a presença de linhas para realizar sua classificação. Como comentamos anteriormente, o aluno 
justificou corretamente sua afirmação, no entanto seus dados estavam errados, pois o aluno apresentou dificuldades em enxergar todas as sete cores do espectro. Caso utilizasse a ideia das linhas separando as cores, provavelmente o mesmo questionaria sua própria classificação, porque ela seria conflitante com sua observação. Como não fez isso, podemos dizer que, após a fala do professor (discurso (D) do locutor (L)) e dentro de um contexto de observações com o espectroscópio, por parte de A3 e de outros alunos do grupo e mesmo da sala como um todo na qual os alunos apresentam suas opiniões e classificações, temos um discurso interpretado (O’) por parte de A3. Interessante notarmos que no contexto citado, o aluno assimilou uma parte da fala do professor para classificação dos espectros, porém o mesmo parece não ter ocorrido ainda com a outra parte. Essa fala representa uma interpretação do aluno para as afirmações do professor.

$2^{\circ}$ exemplo:

Turno 317: Al: Ô Ricardinho, é porque o amarelo e o laranja tão junto.

Nesse turno A1 apresenta uma explicação para opinião diferente de A3 em relação aos demais alunos na definição de qual seria a menor banda da lâmpada observada. Enquanto os demais alunos afirmam ser a cor laranja, A3 garante que é a cor amarela.

A1 justifica essa divergência de A3 pelo fato das cores laranja e amarela aparecerem juntas, o que pode ter gerado dificuldade para identificação de uma ou outra, ou seja, que exatamente termina a faixa laranja e começa a amarela.

Aqui podemos identificar uma argumentação: o dado é a observação feita por A1 onde notou a proximidade das duas cores, portanto trata-se de um dado obtido e empírico (Jiménez Aleixandre, 1998); a justificativa é o fato da cor laranja e a amarela aparecerem muito próximas, A3 destaca isso em sua fala e reforça por meio de gestos com a mão indicando proximidade; a conclusão é apresentada de forma implícita "é porque o amarelo e o laranja tão junto (por isso você está confundindo e discordando da opinião dos demais alunos)", constituindo dessa forma um exemplo de argumentação básica, segundo o modelo de Toulmin (1958).

Sobre os indicadores de alfabetização científica, observamos que o indicador organização aparece em grande destaque ao lado do descritor classificação, já que nesta etapa da aula os alunos começam a classificar os tipos de espectros e também qual a maior ou menor banda (a cor que ocupa a maior faixa de frequência no espectro observado). Surge também o indicador justificativa duas vezes demonstrando respostas mais elaboradas por parte dos alunos. 
O indicador organização aparece nas seguintes formas: "para realização da atividade", "organização para observação com os espectroscópios" e surge agora "para classificação dos espectros" e também "para classificar a cor que representa a maior ou menor banda do espectro observado" e por fim "buscando associação de variáveis".

Em virtude da própria natureza da atividade, consideramos normal que o indicador “organização para realização da atividade" apareça de forma bem acentuada, afinal os alunos estão preocupados com as anotações que devem fazer e como devem entregá-las ao professor.

Como exemplos desse tipo de organização, temos os turnos: 152, 159 ao 165. Percebemos que os alunos do grupo demonstram preocupação com quem está registrando as observações; 184 quando um Ani pergunta ao professor se precisam anotar o nome das cores; 198 no momento que A4 procura identificar o tipo de lâmpada; 207 e 208, A1 procura identificar o número de A5; 222 quando A4 solicita que repitam as cores para fazer suas anotações e o mesmo aluno solicita calma para anotar as cores azul e verde claro no turno 227; 299 um Ani pede para repetir qual é a menor banda; do 308 ao 310, A3 pede ao professor que espere que terminem suas anotações antes de trocar a lâmpada; do 330 ao 353 os alunos do grupo discutem sobre quem são os integrantes do grupo e depois sobre qual das anotações vão utilizar se as de A1 ou as de A4, o que gera certa polêmica, porque A3 prefere utilizar as anotações de A4 enquanto o restante do grupo, inclusive o próprio A4, prefere utilizar as anotações de A1, situação esta que acaba prevalecendo.

Como a atividade é uma prática para observação dos espectros das lâmpadas apresentadas, é normal que durante toda a realização da atividade tenhamos alguns momentos dedicados à "organização para observação com os espectroscópios" em que os alunos buscam realizar suas observações. Como exemplos, temos os turnos: 181, A3 solicita que o professor mude de posição, pois está atrapalhando sua observação; 185, um Ani repete a solicitação de A3; 186,A5 reforça o pedido de ambos; 188,A5 pergunta se (o professor) já mudou a lâmpada; 216 quando Ani pergunta se pode olhar (direto) na lâmpada; 220, A4 solicita que o professor não apague a lâmpada; 308 a 310, A3 e Ani pedem ao professor que os espere terminar as observações, e 354 quando A5 solicita que o professor recoloque a primeira lâmpada (fluorescente compacta).

Nesse momento da aula o professor solicita classificações. Uma das solicitadas é sobre o tipo de espectro, portanto temos organização "para classificação dos espectros" como nos turnos 178 e 179, A3 e A4 discutem sobre as cores que estão vendo para classificarem os espectros; nos 224, 226, 228, 230 e 231, A3 e A4 tentam também organizar as cores que estão vendo para realizarem sua classificação; 236 onde A4 pergunta quais cores precisam ser 
observadas para classificar o espectro como contínuo; já nos 239, 243 e 245, A4 e A3 fazem perguntas sobre que cor é o anil, já que o professor citou esta cor como uma das sete que devem estar presente para que o espectro seja contínuo (turno 237).

Outra classificação é sobre as bandas (tamanhos) das cores presentes no espectro, motivo que leva à "organização para classificação das bandas", como nos turnos: 295 quando A4 solicita qual a maior banda; 302 em que A1 procura, com o grupo uma definição sobre qual seria a menor banda a cor laranja ou a amarela; 306, A4 questiona qual a maior; 319, A3 organiza sua ideias após explicação de A1 para sua divergência com o restante do grupo sobre a classificação da menor banda.

No caso da "organização buscando associação de variáveis", temos como exemplo o turno 191 no momento em que A3 associa a presença de linhas retas, na sua observação, ao tipo de espectro (Turno 191: A3: É mesmo. Vai esse é linha reta!’).

O indicador "classificação" tem destaque nesse momento da aula pois a própria atividade solicita isso. Essa classificação pode estar relacionada ao tipo de espectro lâmpada e também à identificação da maior ou menor banda do espectro observado. Portanto, teremos "classificação do tipo de espectro" e "classificação do tamanho da banda do espectro". É interessante notar que seja para definir o tipo de espectro, o tamanho da banda ou para identificação das cores presentes, temos também “classificação das cores".

Em relação ao tipo de espectro temos como exemplos: no turno 154 quando A3 diz que o espectro é contínuo enquanto faz sua observação com o espectroscópio; 156, A2 afirma que é discreto; 169 quando A5 cita as cores roxa, azul e verde; no 176 vários alunos afirmam que é discreto; 202, A4 diz que é contínuo; 203, logo em seguida à fala de A4, A3, além de afirmar que não é contínuo, fornece uma explicação para classificação dele; 218, A3 começa a classificar o espectro como contínuo e em seguida afirma que é discreto; 256 Ani afirma que é contínuo; 257 Ani1 afirma que é discreto; 259 Ani1 refaz sua classificação após o professor afirmar que é contínuo e repete a fala do mesmo.

Em relação ao tamanho da banda do espectro obtemos como exemplos: 270 Ani afirma que é o verde a maior banda, mesmo após o professor ter afirmado no turno 269 que seria a cor vermelha; 271, A3 também afirma que é o verde, discordando explicitamente do professor; 273, A3 confirma sua afirmação; 275, A1 chama o professor e diz que o verde também tem a maior distribuição de frequiências, após o professor ter afirmado que o vermelho teria a maior distribuição no turno 274. Neste momento notamos que ao falar “também”, A1 concorda que o vermelho também apresenta uma grande distribuição de frequências; 276 Ani repete a fala de A1; 278, A1 confirma sua opinião de que o verde e o 
vermelho podem ser classificados como as maiores bandas; 279, A3 afirma que é o verde; 280, A3 inconformado repete sua afirmação que é o verde; 281 A5 também afirma que é o verde; 283 após o professor perguntar qual é a menor banda vários alunos respondem que é o amarelo, verde e amarelo novamente; 284, A3 afirma ser o verde, e neste instante notamos que A3 provavelmente está fazendo confusão, pois em turnos anteriores ele afirmava ser o verde a maior banda, portanto provavelmente ele não prestou atenção no que os demais alunos já estão respondendo qual é a menor banda; 286 vários alunos afirmam que é o amarelo; 287, A2 também afirma que é a cor amarela; 288, A3 discorda que seja a cor amarela; 290 após A2 explicar que estão classificando a "que aparece menos", ou seja, a menor banda, A3 desfaz sua confusão, porém em vez da cor amarela ele afirma ser a laranja; 291, A3 afirma com convicção que é a laranja; 292 Ani também afirma ser a laranja; 293 vários alunos repetem a afirmação de A3 e Ani; 294, A3 repete ser a cor laranja a menor banda; 302, A1 solicita uma definição se a menor banda é a cor amarela ou laranja para que ela faça sua anotação; 306 A4 solicita que repitam qual a maior banda; 311, A4 afirma que a menor banda é a laranja; 312 vários alunos afirmam que é a laranja; 313 alguém afirma que é a amarela; 314, A3 começa a dizer que é a cor laranja e depois afirma que é a amarela; 315, A4 se mostra indignado com A3 por este considerar o amarelo como a menor banda e diz que o correto é considerar a laranja; 316, A3 repete três vezes que é o amarelo em resposta ao A4; 321, A5 afirma que é o laranja; 322, A3 discorda novamente e afirma ser o amarelo; 323, A4 afirma ser o laranja e avisa que já anotou essa cor, fato este que leva a uma pequena discussão entre A3 e A4 sobre o que deveriam deixar anotado; 326, A3 continua afirmando que é o amarelo.

A "classificação das cores" pode ocorrer seja para identificação das mesmas no espectro observado, seja para classificação dos espectros ou ainda para definição da menor ou maior banda, e como exemplos desses casos, temos: 157, A1 observa a cor azul; 169 A5 identifica o azul, roxo e verde; 224, A3, após solicitação de A4, diz as cores que está observando: violeta e azul; 226, A3 dá continuidade a sua resposta identificando o "verde claro"; 228 A3 diz que está vendo também a cor amarela, porém meio avermelhada; 230, A3 diz que vê também o laranja e o vermelho, primeiro o laranja e depois o vermelho.

O indicador "justificativa" aparece duas vezes mostrando respostas mais elaboradas por parte dos alunos: 203 A3 afirma que o espectro não é contínuo e justifica sua afirmação dizendo que não aparecem todas as cores e contínuo é quando aparecem todas elas; 317, A1 justifica a divergência de A3 com os demais alunos do grupo em classificar a cor que 
representa a menor banda, afirmando que as duas cores aparecem muito próximas, por isso A3 está com dificuldade para identificá-las.

\section{Outras informacões relevantes:}

Predominam as interações P/T e A/A, mas também aparecem momentos com P/A, porém, em geral, o professor utiliza esses momentos para socializar a dúvida ou informação com o restante da sala.

Os alunos se mostram à vontade para realizarem suas observações e mesmo seus questionamentos, quando discordam do professor que a maior banda seria representada apenas pela cor vermelha e afirmam que a cor verde merece esse destaque também, isto mostra um tipo de interação dialógica que aparece neste momento da aula. 


\section{Episódio 1 - atividade de observação de lâmpadas diversas para identificação de seus espectros}

\section{Momento 3 - nova observação da $1^{\text {a }}$ lâmpada (fluorescente) \\ Ver tabela de transcrição e análise (anexo p. 260).}

\section{Descricão da aula:}

Neste momento da aula, o professor utiliza novamente a primeira lâmpada (fluorescente compacta) para observação, após os alunos terem realizado uma análise mais detalhada dos espectros da lâmpada anterior (incandescente). Lembramos que ele utilizou essa lâmpada rapidamente com a finalidade de que os alunos percebessem a diferença entre o espectro dela com o espectro da lâmpada incandescente, ou seja, a diferença entre os dois tipos de espectros: fluorescente com espectro discreto e incandescente com espectro contínuo.

Uma rápida observação e análise da lâmpada fluorescente foi realizada entre os turnos 145 e 181. Já com a lâmpada incandescente, é feita uma análise mais detalhada e agora o professor retorna à primeira lâmpada.

Esse momento da aula pode ser dividido em quatro etapas distintas:

- $\quad$ Apresentação da lâmpada e postura inicial dos alunos diante da atividade (do turno 364 ao 367).

- Determinação e identificação do tipo de espectro da lâmpada e os possíveis motivos para essa classificação (do turno 368 ao 410).

- Estabelecimento de uma relação entre o tamanho da fenda do espectroscópio e a imagem obtida com ele (do turno 411 ao 454).

- Identificação da cor que representa a menor e da cor que representa a maior banda (do turno 455 ao 488).

Basicamente temos uma novidade nessa análise que é a tentativa do professor em relacionar o tamanho da fenda do espectroscópio com a imagem obtida por ele.

Segue uma descrição mais detalhada dos momentos citados:

Do turno 364 ao 367: 
Consideramos o turno de fala de 354 a 367 como um momento distinto, pois é quando o professor apresenta a nova lâmpada a ser analisada e por mostrar a postura e envolvimento inicial dos alunos em relação à atividade.

Neste episódio, temos apenas a interação Professor/ Turma o que é natural, pois é o momento em que ele apresenta o novo tipo de lâmpada.

Chama-nos atenção também que no turno 366 um aluno não identificado dá sua opinião sobre o tipo de lâmpada que estão trabalhando, mesmo sem ter sido solicitado tal atitude, e que leva à confirmação e reforço por parte do professor legitimando a fala do aluno. O mesmo fornece uma informação e o professor a confirma.

Esse fato parece indicar uma tendência a uma relação mais dialógica durante a observação. Os alunos também demonstram envolvimento com a atividade e grande interação no manuseio do espectroscópio. Praticamente todos eles estão com um observando a lâmpada, com exceção de A7 que também olha para lâmpada, mas sem o espectroscópio.

Após a observação da lâmpada incandescente, os alunos parecem empenhados em prestar muita atenção na nova observação da lâmpada fluorescente.

Neste episódio temos uma situação de organização para observação da lâmpada, portanto é um episódio no qual basicamente identificamos o indicador "organização".

\section{Do turno 368 ao 410:}

Consideramos o turno de fala de 368 a 410 como uma segunda etapa, pois quando se discute o tipo de espectro dessa lâmpada e os possíveis motivos para que tenha esse espectro, predomina uma relação professor/turma. Muitas vezes os alunos respondem aos questionamentos do professor ou simplesmente relatam o que estão observando, mas de uma forma geral para que todos ouçam. Porém, podemos notar uma grande interação entre os alunos do mesmo grupo, quando questionam, afirmam e expressam seus pontos de vista com espontaneidade.

Logo no primeiro turno deste momento, A3 comenta o que está vendo enquanto o professor ainda dá informações sobre a lâmpada. Isso ocorre até o turno 373 e, nesta sequência de turnos, os alunos do mesmo grupo (A3, A4 e A7) interagem entre si. Podemos observar neste momento uma relação dialógica bem caracterizada na abordagem comunicativa.

A3 indica um novo fato em relação à observação da lâmpada anterior: o surgimento do preto (lembrando que com a lâmpada anterior tínhamos todas as cores juntas do vermelho ao 
azul). Destaca A3 também o fato de ser "pontilhado" e usa o gesto com o braço num movimento para cima e para baixo na tentativa de verificar se os outros alunos estão entendendo o que ele fala. O mesmo fornece uma informação e utiliza os gestos para reforçar sua afirmação. Podemos dizer que a linguagem gestual coopera com a oral (Carmo, 2006).

A4 por sua vez revela surpresa por essa demonstração e juntamente com A7 reforçam e confirmam a informação de A3.

É um momento em que basicamente os alunos estão se organizando para a atividade, porém, ao dizer que está enxergando "Tudo pontilhado sabe?”, A3, apesar de não ser solicitado, está classificando sua observação, ainda que de forma intuitiva.

Do turno 374 ao 388, professor e alunos discutem o tipo de espectro e as razões para que se apresente na forma observada.

Nesse momento os alunos interagem com o professor e entre integrantes de grupos diferentes na construção e elaboração de suas ideias. É um processo de construção coletiva.

No turno 374 o professor questiona como é o espectro da lâmpada observada neste instante. Aqui o professor tentar organizar a observação e a discussão, ao mesmo tempo em que busca uma classificação para o tipo de espectro observado.

A4 afirma que o espectro é discreto, em seguida, vários alunos reforçam sua afirmação. Eles expressam sua opinião, mas não a justificam. Temos então a presença do indicador "classificação".

No turno 378 o professor por não ter obtido a justificativa pergunta qual o motivo de terem dado aquela resposta.

Em seguida, os alunos apresentam suas justificativas de uma forma coletiva, constituindo uma estrutura simples de argumentação. A justificativa veio da observação que representa um dado Empírico (D) e a partir do que observaram diferente nesta lâmpada em relação à lâmpada anterior e às informações fornecidas pelo professor, quando realizaram a observação anterior e que representa um Dado Fornecido (DF).

Os motivos apresentados para justificar a classificação do espectro como discreto são: o fato das cores aparecerem separadas, não aparecerem todas as cores e aparecerem "umas bolinhas", ou seja, a figura reproduzida no espectroscópio era no formato de várias bolinhas. Os alunos demonstram saber algumas diferenças entre os dois tipos de espectro, embora nenhum comentário seja feito em relação ao que isso poderia significar de fato.

É interessante notar como os alunos utilizam o termo "discreto" de maneira mais espontânea. De qualquer forma é um momento de destaque, pois o indicador "justificativa" 
aparece para mostrar uma resposta elaborada em termos de apropriação da linguagem científica e da alfabetização científica.

No turno 385 o professor reforça a informação que não aparecem todas as cores e solicita mais informações demonstrando que ainda queria mais detalhes por parte dos alunos.

A3 e A4 destacam que a imagem formada no espectroscópio lembra uns quadradinhos, e A3 destaca que estão pulando e reforça essa informação por meio de gestos, movimentando o braço para cima e para baixo. Novamente temos a linguagem gestual cooperando com a oral (Carmo, 2006). Nesse momento ele parece reforçar sua atitude no turno 371:

Turno 371: A3: Tudo pontilhado sabe? (Quando fala para A4, gesticulando com o braço para cima e para baixo.)

Ocorreu também uma mudança de sua descrição substituindo o "pontilhado" por quadradinhos, buscando ser um pouco mais específico.

Um aluno reforça a questão das cores estarem separadas no turno 388. Aqui os alunos se esforçam para tentar responder ao professor, mas de forma a organizar as observações, sem avançar em termos de explicação.

Do turno 390 ao 395, A3 e A4 estabelecem um diálogo no grupo a respeito do que estão observando. A3 demonstra dúvidas em relação ao que observa, mais especificamente em relação ao que enxerga após o "verde claro". Outro detalhe interessante é o fato do A4 afirmar que não está vendo nada e em seguida trocar o lado de observação do espectroscópio procurando melhorar sua observação. Notamos um exemplo de interação com o material empírico neste turno 391.

Nesse ínterim o professor, não obtendo nenhuma informação nova, questiona se estão vendo linhas bem definidas nas imagens formadas no espectroscópio, turno 393, e no turno 396, reformula seu questionamento ao perguntar se dá para ver o formato da lâmpada na imagem obtida.

Um aluno de outro grupo responde que sim, e outros alunos destacam novamente o fato de as imagens aparecerem separadas. No turno 400 um aluno não identificado chega a tentar uma explicação para a separação, porém não conclui sua fala.

No turno 402 o professor pergunta novamente se é possível enxergar o formato da lâmpada, nesse momento A4 demonstra sua dúvida em relação a esse fato e questiona A3. Antes da resposta de A3, vários alunos afirmam que dá. Após as afirmações dos alunos, o professor pergunta especificamente para um aluno se é possível ver linhas, retomando seu questionamento do turno 393.

A resposta obtida é que sim, porém não acompanhada de justificativa ou explicação. 
Do turno 383 até o final deste episódio predomina o indicador "organização" em que buscam discutir como realizar a observação, o que se deve inclusive às perguntas do professor e natureza da atividade no momento.

\section{Do turno 411 ao 454:}

Esse momento caracteriza-se basicamente pela interação Professor/turma. Lembramos que o foco da pesquisa é voltado para os alunos, porém é importante notarmos o diálogo com o professor.

A situação analisada refere-se a dois momentos distintos: no primeiro, o professor tenta contribuir para que os alunos percebam o formato da fenda dos espectroscópios que estão utilizando, e num segundo, que relacionem esse formato com a imagem dos espectros observados: aqueles que têm o espectroscópio com a fenda grande conseguem ver o formato das lâmpadas separadas (turno 437), e os que têm com a fenda pequena, veem linhas separando as cores dos espectros (turno 440). Para isto, o professor utiliza perguntas buscando uma organização e classificação por parte dos alunos em relação ao formato da fenda e ao espectro observado.

O professor segue com uma série de questionamentos e aqui não percebemos interação entre os alunos e nem a presença de discurso dialógico. Dessa forma identificamos basicamente os indicadores "organização" e "classificação" nesse episódio, principalmente em relação aos alunos que tentavam responder aos comandos do professor. Apenas no turno 442, A1, ao relatar (organizar) sua observação, parece tentar explicar sua própria fala quando diz que cada cor fica em um lugar distinto na imagem.

O professor tenta estabelecer uma relação entre o tamanho da fenda e a imagem formada e conclui com as seguintes informações nos turnos de fala:

Turno 437: P: Vamos lá. Vamos. Quando o espectroscópio tem a fenda muito grande, muito aberta, dá para ver aí o formato da lâmpada.

Turno 440 P: Quem tem o espectroscópio com a fenda muito fina, então você vai ver linhas no meio do espectro.

A partir do turno 451 o professor passa a questionar sobre quais as cores que se destacam mais e as que se destacam menos. Os alunos respondem de acordo com suas observações e interpretações e continuam manipulando o espectroscópio durante todo o episódio. 
Os alunos parecem conseguir observar o espectro como o professor queria, porém não temos indicativo neste episódio de que eles estão associando a imagem ao tamanho e formato da fenda.

Ao falar das cores que aparecem mais, parece que a intenção do professor é, num momento posterior, falar sobre as diferentes frequências que compõem a luz, de qualquer forma, isto não fica evidente neste momento da atividade.

No turno de fala 449, o professor busca substituir uma notação comum para notação científica ao propor a troca de "maior banda" pela "mais intensa", porém os conceitos parecem estar confusos. Ao se falar de "maior banda", pode ser uma referência ao fato de aparecerem várias frequências e destacar entre elas qual é a predominante, ou seja, um número de frequências diferentes e destacar qual delas (cor) aparecem mais. Talvez haja uma relação entre a largura da banda (frequência) e a intensidade (da energia), e o professor queira destacar isso mais tarde, mas pode acarretar uma confusão na assimilação dos conceitos por parte dos alunos.

\section{Do turno 455 ao 488 :}

Nesta sequência o professor continua a questionar sobre quais as cores que se destacam mais e as que se destacam menos.

Os alunos respondem de acordo com suas observações e interpretações e demonstram dúvidas nas definições das cores. Em momento algum eles utilizam uma forma de argumentação mais elaborada, apenas respondem sem justificativas.

Continuam manipulando o espectroscópio durante todo o episódio. Porém, o que distingue esta sequência da anterior são os tipos de interações, pois há interações entre os alunos novamente, o que não aconteceu anteriormente.

Um fato interessante é que A4 demonstra possuir uma dúvida sobre qual a cor que se destaca menos (a menor banda), porém não pergunta ao professor e solicita que A3 pergunte ao professor depois da aula quando estiverem sozinhos na sala. Essa atitude chama a atenção, porque as interações predominantes foram as de professor e turma nesse episódio.

Em relação ao conceito e conteúdo, o professor, ao falar da cor que aparece mais, já tinha utilizado o termo mais intenso no lugar de maior banda, porém os alunos continuam utilizando apenas o que aparece mais ou menos. Isto indica que neste momento os alunos ainda não se apropriaram desse termo específico. A apropriação da linguagem está sendo 
construída, mas ainda de forma básica. E a confusão entre frequência e intensidade ainda aparece, embora os alunos não demonstrem estar atentos a isso.

Em relação aos indicadores da Alfabetização Científica, predomina a presença do indicador "organização". A manipulação de materiais é uma linguagem que também se destaca neste momento da atividade. Tal fato parece coerente com a natureza da atividade e seu atual momento.

\section{Análises:}

Em relação ao envolvimento com a atividade, notamos logo no início desse momento que um Ani apresenta sua classificação para o tipo de lâmpada que estão observando no turno 366, mesmo sem ter sido solicitado tal classificação. Esse fato leva o professor a confirmar que a lâmpada é fluorescente como o aluno disse e legitimar sua fala. A mesma demonstra que o aluno está atento à realização da atividade.

A manipulação dos espectroscópios também é intensa durante todo esse momento da aula e isto denota o interesse dos alunos na realização da atividade.

Na sequencia de turnos do 370 ao 373 , A3, A4 e A7 demonstram surpresa e interesse nas observações que estão realizando e no fato de enxergarem a cor preta entre as cores dos espectros:

Turno 370: A4: Nossa!

Turno 371: A3: Tudo pontilhado sabe? (A3 gesticula com os braços para cima e para baixo enquanto fala com A4.)

Turno 372: A4: Aparece preto velho.

Turno 373: A7: É $\hat{o} !$

É uma sequência importante também, pois pela reação dos alunos e suas falas, fica nítido que eles perceberam uma diferença importante entre o espectro observado no momento (fluorescente compacta) em relação ao anterior (incandescente).

Outro indicativo de interesse na atividade aparece quando o professor pergunta no turno 379 por que eles classificaram o espectro como discreto e os alunos respondem justificando que é discreto por não aparecerem todas as cores e também devido às cores estarem separadas, utilizando para suas respostas basicamente os argumentos apresentados pelo professor no momento anterior a este.

$\mathrm{Na}$ maioria dos turnos continuamos notando falas relacionadas a atividades. São poucos os turnos em que surgem brincadeiras, como na sequência em que o professor pergunta o formato da fenda do espectroscópio (turno 411). Elas aparecem respectivamente 
nos turnos 411, 414 e 417, servindo até como um momento de descontração para sala, porém, com as perguntas do professor sobre o tamanho e formato da fenda, os alunos retomam sua atenção e interesse na atividade.

Notamos que em alguns momentos vários alunos falam ao mesmo tempo, o que acaba prejudicando a explicação do professor, como ocorrem nos turnos 441 e 443, em que o professor interrompe sua explicação para reclamar do barulho. Neste instante observamos que, enquanto o professor busca sistematizar suas ideias, alguns alunos continuam observando os espectros da lâmpada e realizando anotações e comentários paralelos à fala do professor; mesmo num momento de dispersão em relação à explicação do professor, os alunos estão atentos à atividade. É evidente que isso dificulta a fala do professor e mesmo a compreensão da explicação, porém destacamos que até num momento de muita conversa paralela a atenção está voltada para atividade.

Consideramos aqui também indicativos de interesse e envolvimento com a atividade:

A preocupação com a melhor forma de realizar as observações como no turno 391 quando A4 reclama que não consegue ver nada e em seguida inverte o lado de observação do espectroscópio. No turno 471, A4 sugere que o professor coloque as duas lâmpadas (fluorescente que estão olhando e a incandescente) juntas para observarem as diferenças, sugestão que é repetida por A5 nos turnos 472, 476 e 479. Sabemos que isso não é viável na prática, até mesmo porque os alunos provavelmente não conseguiriam identificar exatamente qual espectro estariam observando, mas é interessante notarmos o interesse dos alunos na busca pela distinção entre os dois tipos de espectros.

Outro exemplo de preocupação com a observação aparece no turno 442, e A1 explica para A6 como deve realizar sua observação com o espectroscópio, indicando em que lugar deve olhar dentro do espectroscópio para enxergar as cores separadas ou as lâmpadas separadas e cada uma representando uma cor.

O pedido de silêncio feito por Ani nos turnos 436 e 447 para que prestassem atenção à fala do professor.

A constante manipulação dos espectroscópios como nos turnos 367, 389, 391, 408, 436, 437, 462, 465, 474, 479, 483 e 487.

Em relação às linguagens, verificamos que a manipulação dos espectroscópios continua de forma intensa e também temos alguns exemplos de manipulação de materiais. A manipulação dos espectroscópios ocorre praticamente durante todo esse momento da aula e praticamente por todos os alunos do grupo, com exceção de A7 que no turno 367 parece olhar 
para lâmpada, mas não utiliza o espectroscópio para isso. Nesse mesmo turno os demais alunos estão com o espectroscópio no olho observando a lâmpada fluorescente mesmo sem um pedido explícito do professor para tal ação.

Como citado no item "envolvimento com a atividade", temos outros exemplos de manipulação do espectroscópio e ocorre nos turnos 367, 391, 408, 436, 437, 462, 465, 479, 483 e 487. Destacamos o turno 391 e A4 afirma que não está vendo nada:

Turno 391: A4: Nossa não dá para ver nada.

Logo após esse comentário, A4 troca o lado de observação do espectroscópio buscando, ao manipular o material, uma melhor forma de realizar suas observações.

Merece destaque também a sequência do turno 411 ao 436, quando o professor questiona sobre o tamanho e formato da fenda do espectroscópio e os alunos vão respondendo, e mesmo assim vários alunos continuam com o espectroscópio nos olhos observando a lâmpada. Lembramos que apenas no turno 437 o professor começa a explicar a relação entre o tamanho da fenda e a imagem obtida por ela.

No turno 462, A5 chama a atenção para a forma que segura o espectroscópio. No turno 474 um aluno ao lado de A1 larga o espectroscópio na bancada e passa a mão na cabeça demonstrando sinais de cansaço. Mesmo no final desse momento da aula, A3 no turno 487 pega o espectroscópio que estava na bancada e realiza novas observações (turno 487), ou seja, a manipulação dos espectroscópios se tornou uma importante linguagem para os alunos se expressarem.

Verificamos também, em menor intensidade, a manipulação de materiais como cadernos. No turno 439 enquanto o professor fala sobre qual a imagem que obtemos no espectroscópio com a fenda grande, A5 realiza suas observações com o espectroscópio e anota em seu caderno. No turno 458 enquanto identificam a cor que aparece menos no espectro observado, A4 realiza anotações em seu caderno, o mesmo ocorrendo com A1 no turno 465 .

A linguagem oral aparece principalmente em interações P/T, com algumas interações P/A, pois nesses casos o professor sempre procura socializar a informação para toda a classe, e também alguns momentos de A/A. Nesse momento os alunos acabam respondendo aos questionamentos do professor e não temos muitos exemplos de interações mais dialógicas como na análise da lâmpada incandescente.

Os alunos utilizam a linguagem oral para expressar o que estão vendo, como no turno 372:

Turno 372: A4: Aparece preto, velho. 
E também para responderem diretamente a um questionamento do professor como no turno 382, A3 explica ao professor o porquê de ter classificado o espectro como discreto:

Turno 382: A3: Não aparece todas as cores.

Outro exemplo de utilização da linguagem oral que merece destaque é o turno 394:

Turno 394: A3: Depois do verde claro pula. E o lilás aparece um quadradinho do lilás.

Aqui A3 descreve o que observa no espectroscópio, destacando que no espectro observado logo depois do verde ocorre um salto e só aparece um quadradinho ao lado, provavelmente querendo dizer que entre o verde e a próxima cor aparece um trecho escuro, que é uma característica do espectro discreto.

Por fim, destacamos um momento importante de utilização da linguagem oral no turno 442:

Turno 442: Al: Bem no cantinho ali ó. (inaudivel). As corezinhas, cada cor fica num lugar (inaudível)... As lâmpadas, são várias lâmpadas uma de cada cor.

Temos A1 explicando para A6 a posição em que as imagens se formam no espectroscópio ("Bem no cantinho") e que cada cor aparece num lugar distinto, isto é, separada.

A linguagem gestual manifesta-se de forma mais relacionada à atividade, muitas vezes cooperando com alguma informação fornecida verbalmente. Destacamos os seguintes turnos:

Turno 371: A3: Tudo pontilhado sabe?

Ao descrever como está vendo o espectro, A3 gesticula com o braço para cima e para baixo para reforçar a ideia de que é "pontilhado". A linguagem gestual coopera com a linguagem oral, reforçando a informação fornecida (Carmo, 2006).

Turno 387: A3: Uns quadradinhos assim ó pulando.

Após A4 afirmar que vê alguns quadradinhos, A3 confirma sua observação e utiliza novamente gestos com o braço para cima e para baixo para indicar que eles estão "pulando", segundo sua observação.

Turno 395: A4: “Tesc, tesc”... Não tem essa...

A4 afirma oralmente que não concorda com A3 e gesticula de forma negativa para enfatizar seu sentimento de contrariedade.

Turno 469: A3: Professor, dá um tempinho, por favor.

Neste instante o professor havia solicitado que os alunos fossem um pouco mais rápidos para trocar a lâmpada, e A3 pede para ele esperar e com isso também utiliza um gesto 
característico em atividades esportivas cujo significado é um pedido de tempo. Ela utiliza o gesto para reforçar a ideia de que necessita de mais tempo para suas observações.

Em relação à apropriação de termos técnicos, quando o professor pergunta o tipo de espectro da lâmpada (turno 374), A4 e vários alunos utilizam o termo "discreto" com espontaneidade e respondem corretamente à indagação do professor de por que seria um espectro discreto. Isso leva a crer que neste momento da aula eles conseguem definir bem quais as características dos tipos de espectro, embora não garanta que tenham facilidades em observá-las na prática.

O professor procura destacar que no espectro discreto aparecem linhas entre as cores do espectro, porém num primeiro instante os alunos afirmam que aparece "tudo pontilhado" (turno 371), "preto" (turno 372), “tem uns quadradinhos", “estão separados" (turnos 387 e 394) e somente no turno 410, A8 responde que dá para ver linhas, entretanto após pergunta específica do professor:

Turno 409: P: Bobe! Dá para ver linhas, Bobe?

Turno 410: A8: Dá para ver linhas.

Neste momento da aula não temos outras falas que utilizem o termo "linha" para indicar a separação das cores do espectro discreto.

No turno 449 o professor começa a perguntar qual seria a maior banda e depois resolve substituir o termo "banda" por "intensidade". Novamente parece existir certa confusão de conceitos.

De qualquer forma, reparamos que os alunos utilizam "a que aparece mais" e "a que aparece menos", sem nem notar a possível confusão de conceitos. E o próprio professor, logo no turno seguinte, também utiliza esses termos:

Turno 451: P: Qual é a mais intensa? O que aparece mais, o que aparece menos?

Embora estejam contentes e intensamente manipulando o espectroscópio e respondendo perguntas sobre ele, inclusive sobre o tamanho de sua fenda, os alunos continuam não utilizando esse termo e somente no turno 458, A4 utiliza o termo:

Turno 459: A4: Aires, não tem meu espectroscópio para ver.

No que diz respeito aos conceitos envolvidos, observamos que os alunos parecem ter assimilado bem as características que definem o espectro contínuo e o discreto, porém em nenhum momento fazem referência ao que poderia ser responsável por um tipo ou outro de espectros. 
Como dissemos anteriormente no turno 449, ao perguntar qual a maior banda e em seguida trocar o termo "maior banda" por "mais intensa", parece existir certa confusão de conceitos.

Com a maior banda, o professor parece querer identificar qual cor se evidencia mais, ou qual faixa de frequência se destaca no espectro de cores, e por intensidade, podemos entender a frequência que possui mais energia, o que não seria necessariamente a cor que apareceria mais. Lembramos que as frequências aumentam do vermelho para o violeta. Os alunos não percebem a confusão e isso não atrapalha suas observações, pois continuam procurando a (cor) "que aparece mais e a que aparece menos".

Também não comentam sobre a luz observada para que possamos verificar se estão considerando-a como onda ou partícula.

Sobre argumentacão chamamos a atenção para o turno 374 quando o professor pergunta o tipo de espectro, obtendo como resposta que o espectro é discreto (A4 e vários alunos fornecem essa resposta) nos turnos 376 e 377. Em seguida, o professor faz uma pergunta:

\section{Turno 379: P: Por que é discreto?}

Essa pergunta é extremamente importante, pois permite observarmos o que os alunos pensam e a elaboração de uma estrutura de argumento por parte dos mesmos.

Turno 380: A4: Porque não aparece todas as cores.

Pela resposta de A4 notamos uma estrutura básica de argumentação segundo o modelo de Toulmin: A conclusão aparece na afirmação que o espectro é discreto no turno 376, e a justificativa para tal afirmação é que não aparecem todas as cores, conforme sua observação com o espectroscópio que representa o dado, no caso um dado obtido e empírico (Jiménez Aleixandre, 1998).

No turno 382, A3 repete a afirmação de A4, constituindo a mesma situação de argumentação.

No turno 381 vários alunos apresentam outra justificativa para classificarem o espectro como discreto.

Turno 381: Val: Porque tá separado.

Por essa resposta temos: a conclusão na afirmação que o espectro é discreto no turno 377, e a justificativa para tal afirmação é que as cores estão separadas, fato constatado por meio de observação com os espectroscópios que representam um dado obtido e empírico (Jiménez e Aleixandre, 1998). 
Nos turnos 383 e 384, A4 e A3 justificam usando a ideia que existem umas bolinhas nos espectros observados; em seguida, o professor repete que não aparecem todas as cores e pergunta o que mais poderia justificar o espectro como discreto:

Turno 383: A4: (inaudível) e as bolinhas lá.

Turno 384: A3: Vai aparecer umas bolinhas.

Turno 385: P: Não aparecem todas. O que mais?...

Em seguida, A4 e A3 reformulam suas falas e substituem o termo "bolinha" por "quadradinho" e um aluno não identificado, logo depois da fala de A3 afirma que as cores estão separadas.

Turno 386: A4: Tem uns quadradinhos.

Turno 387: A3: Uns quadradinhos assim ó pulando. A3, ainda utiliza gestos movimentando o braço para cima e para baixo para enfatizar sua afirmação.

Turno 388: Ani: É tá separado não é?

Essa sequência também constitui um exemplo de argumentação básica segundo Toulmin (1958): a conclusão foi apresentada no turno 376 e 377 com a afirmação que o espectro é discreto, e justificativa é apresentada por A4, A3 e Ani quando afirmam num primeiro momento que aparecem umas bolinhas, depois que aparecem uns quadradinhos e, por fim, que as cores estão separadas. Tais justificativas são apresentadas por meio de observação com os espectroscópios que representam um dado obtido e empírico (Jiménez e Aleixandre, 1998).

Destacamos nesta sequência a importância das perguntas do professor e a construção coletiva da argumentação numa relação dialógica apresentada.

Ao falar que aparecem umas bolinhas e uns quadradinhos, A3 e A4 parecem ter percebido os espectros com o formato das lâmpadas separadas, inclusive a fala de Ani é coerente com tal raciocínio, porém seria necessário uma pergunta para verificarmos se este foi realmente o caso.

Podemos utilizar aqui também, de uma forma mais geral, o modelo de Van Eemeren et al. (1987) adaptado por Villani e Nascimento (2003), pois as falas de A4, A3 , Val e Ani (Ouvintes) apresentam um discurso interpretado (O') a partir do discurso do professor (Locutor) apresentado nos turnos 166 e 168, quando associa a presença de todas as cores ao espectro contínuo e nos turnos 171 e 173, associando a presença de linhas ao espectro discreto. Tal discurso foi apresentado no momento anterior enquanto observavam a lâmpada incandescente. 
No momento anterior os alunos relacionaram a classificação do tipo de espectro pela presença ou ausência das cores. Embora não falem exatamente das linhas como o professor, eles falam da separação das cores, ou seja, no discurso interpretado, eles apresentam duas características que permitem classificar o espectro como contínuo: o fato de não aparecerem todas as cores e de aparecerem cores separadas.

No discurso interpretado, depois de todo o contexto de observações e comentários de vários alunos e do professor, os alunos substituem o termo "linha" entre as cores pela informação que elas estão separadas. Isso pode ter ocorrido também pelo fato de que com a fenda grande os alunos podem ter enxergado as cores separadas e ainda no formato da lâmpada, o que dificultaria a observação de "linhas" entre as cores.

O professor ainda insiste na explicação com linhas e somente no turno 410, A8 afirma ter visto linhas quando o professor faz uma pergunta direta para ele.

No turno 401 Ani afirma que os espectros estão separados “por causa disto", porém não apresenta a justificativa.

$\mathrm{Na}$ sequência desse momento da aula, o professor questiona sobre o tamanho e o formato da fenda do espectroscópio e faz uma associação com a forma da imagem obtida e por fim questiona novamente sobre quais cores aparecem mais e quais aparecem menos. Não existem situações que levem ao desenvolvimento de argumentos por parte dos alunos, mas notamos um avanço em relação à observação com a lâmpada incandescente, pois os alunos apresentam, com a ajuda do professor, argumentos para classificação do espectro observado.

Em relação aos indicadores de alfabetizacão científica, continuamos com os alunos organizando, classificando e com alguns exemplos de justificativas.

Temos o indicador organização nas seguintes formas:

$\checkmark \quad$ Organização para realização da atividade: os alunos continuam se preparando para a atividade como um todo. Neste momento esse indicador aparece com menor intensidade, afinal os alunos já fizeram outras observações antes, mas ainda temos como exemplos: turno 418 quando A4 pergunta para A3 se ele anotou (no caderno); 460 quando novamente A3 solicita que anotem (as cores); 465 momento em que A2 pergunta ao professor se depois devem verificar o que aparece menos e por fim 471 quando Ani solicita ao professor que coloque uma lâmpada por vez para realizar suas observações.

Organização para observação com os espectroscópios: os alunos buscam a melhor forma para realizarem as observações. Embora já tenham realizado outras observações anteriormente, ainda encontramos exemplos importantes nesse momento: no turno 392, A3, após reclamação de A4, que não via nada, indica que olhe depois do verde claro, 394 
novamente A3 reforça sua observação, afirmando que depois do verde claro só aparece um quadradinho do lilás, ou seja, não existe outra cor na sequência; 442, A1 gesticula com as mãos e indica que dá para enxergar as cores separadas e no formato da lâmpada num "cantinho" do espectroscópio. Neste instante A1 deixa claro que realizou uma boa observação e quer compartilhar com seus amigos do grupo; 461, A5 mostra como se segura o espectroscópio.

Organização para classificação dos espectros: como faz parte da atividade classificar o espectro como contínuo ou discreto, temos os turnos: 368 em que A3 nota a presença da cor preta diferente do que notara no espectro da lâmpada incandescente; 371 A3 afirma que aparece tudo pontilhado (separado); 372, A4 também afirma que aparece o preto; 383, A4 nota presença de "bolinhas"; 384, A3 confirma a observação de A4 em relação às "bolinhas"; 386 e 387, A4 e A3, respectivamente, substituem o termo "bolinha" por "quadradinho"; 388 Ani diz que aparecem separadas (as cores) embora no final apresente um tom de interrogação.

Organização para classificar a cor que representa a maior ou menor banda do espectro observado: após relacionar o tamanho e formato da fenda com a imagem do espectro formada, o professor solicita aos alunos que identifiquem qual a maior e a menor banda no turno 451. Comparado com o momento anterior, essa classificação é feita de forma muito rápida, pois o professor realiza logo a troca da lâmpada. Temos como exemplo dessa organização os seguintes turnos: 480 e 486, A4 com um pouco de irritação questiona um posicionamento final do grupo sobre qual é a menor banda.

Organização buscando associação de variáveis: dos turnos 416 ao 435, os alunos respondem a questionamentos do professor sobre o tamanho e formato da fenda dos espectroscópios e, embora não percebam, essas perguntas e respostas constituem uma estratégia do professor que busca associar o tamanho da fenda com a imagem formada no espectroscópio: Turno 437: P: “Vamos lá. Vamos. Quando o espectroscópio tem a fenda muito grande, muito aberta, dá para ver aí o formato da lâmpada."; Turno 440: P: "Quem tem o espectroscópio com a fenda muito fina então você vai ver linhas no meio do espectro.".

$\mathrm{O}$ indicador classificação aparece novamente em duas formas:

$\checkmark \quad$ Classificação do tipo de espectro - ocorre na parte inicial desse momento da aula quando o professor solicita essa classificação no turno 374. Temos como exemplos os turnos: 376, A4 afirma que é discreto; 377 vários alunos afirmam que é discreto também. No turno 379 o professor pergunta os motivos por classificarem como discreto e novas classificações não são apresentadas. 
Classificação relacionada ao tamanho da banda dos espectros - aqui os alunos classificam quais as cores que representam a maior e a menor banda do espectro observado. Temos como exemplos os turnos: 452 e 453 quando A3 e A4, respectivamente, afirmam ser o verde claro, porém não indicam se estão classificando como a menor ou maior banda; 455, A5 afirma que azul é a cor que aparece mais (a maior banda); 456, A3 nega a observação de A5; 458, A7 diz que é o verde claro, pela sequência de falas entendemos que classifica o verde claro como a maior banda; 457, A3 afirma que a menor banda é representada pela cor lilás; 470, A3 afirma que é o violeta; 473 Ani repete que é o violeta. Notamos que os alunos de novo apresentam dificuldades na classificação e definição das cores que observam.

$\checkmark \quad$ Observamos ainda algumas classificações diferentes como o tipo de lâmpada utilizada para observação nos turnos iniciais desse momento.

O indicador justificativa aparece explicitamente nos turnos 380, 381 e 382 quando A4, vários alunos e A3 respondem ao professor o motivo pelo qual classificaram o espectro como discreto. A presença do indicador "justificativa" contribui para que tenhamos uma resposta mais elaborada constituindo um exemplo básico de argumentação segundo o modelo de Toulmin. Aqui eles usam como justificativa o fato de não aparecerem todas as cores, como já aparecera antes na classificação do espectro da lâmpada incandescente e acrescentam a ideia de as cores aparecerem separadas.

\section{Outras informaç̃es relevantes:}

Predominam as interações $\mathrm{P} / \mathrm{T}$, mas com alguns momentos aparecendo P/A e também A/A. Nesse momento da aula os alunos estão atentos aos questionamentos do professor e não apresentam ideias ou fatos diferentes àqueles que estão relacionados aos questionamentos.

Notamos que a apropriação das linguagens e a busca pela construção de significados ocorrem coletivamente considerando mais a classe como um todo do que por interações internas do grupo.

Temos uma grande participação de A3 e A4 no grupo que estamos acompanhando.

Um fato interessante é que A4 demonstra possuir uma dúvida sobre qual a cor que se destaca menos (a menor banda), porém não pergunta ao professor e solicita que o A3 pergunte ao professor depois da aula quando estiverem sozinhos na sala. Essa atitude chama a atenção, pois as interações predominantes foram as de professor e turma nesse episódio. 


\section{Episódio 1 - atividade de observação de lâmpadas diversas para identificação de seus espectros}

\section{Momento 4 - observação da $3^{\text {a }}$ lâmpada (mista) \\ Ver tabela de transcrição e análise (anexo p. 267).}

\section{Descricão da aula:}

Neste momento da aula o professor utiliza uma lâmpada mista. Esta lâmpada apresenta inicialmente um tipo de espectro (contínuo), e à medida que vai aquecendo outro tipo (discreto), tal situação leva a uma preocupação por parte do professor para que os alunos anotem rapidamente o espectro observado no início da aula. Esta observação ocorre após terem observado uma lâmpada com espectro contínuo (incandescente) e uma com espectro discreto (fluorescente compacta).

Este momento da aula pode ser dividido em quatro etapas distintas:

- Rápida classificação do espectro no início da observação e o professor fornece pista que existe algo mais nessa lâmpada (do turno 489 ao 517).

- Retomada sobre quais tipos de lâmpada possuem espectro discreto e quais possuem contínuo; classificação do espectro à medida que a lâmpada está aquecendo e com ela aquecida (do turno 518 ao 577).

- O professor tenta ajudar os alunos na percepção que o espectro observado mudou para discreto (do turno 578 ao 635).

É a primeira vez que os alunos observam uma lâmpada que muda seu espectro ao longo da observação, conforme vai aquecendo.

\section{Do turno 489 ao 517:}

Consideramos o turno de fala de 489 a 517 como uma etapa distinta, pois nesta sequência de turnos o professor apresenta a nova lâmpada e solicita uma classificação do espectro, enquanto os alunos, além de responderem à solicitação do professor, questionam sobre qual o tipo de lâmpada estão observando.

Logo no turno 489 o professor solicita que observem rapidamente o espectro da lâmpada, e no turno 498 pede que os alunos anotem a resposta que deram. Essa atitude do 
professor é explicada pelo tipo de espectro observado mudar com o aquecimento da lâmpada (mista), porém não é percebido pelos alunos.

Na sequência de turnos de 489 a 498, os alunos respondem que o espectro é contínuo, mas também estão preocupados em identificar o tipo de lâmpada. Os indicadores de alfabetização científica presentes são apenas de organização, seja para observação ou classificação, e de classificação, seja para identificação do tipo de espectro ou do tipo de lâmpada. Na classificação do tipo de espectro os alunos respondem que é contínuo e conseguem a confirmação do professor no turno 498, porém não explicam e nem justificam essa classificação. O professor também não realiza nenhum questionamento solicitando justificativas ou explicações.

Nesta sequência de turnos de fala praticamente todos os alunos respondem que o espectro é contínuo, apenas um aluno não identificado questiona o fato de ser contínuo (turnos 496 e 497), porém também não justifica seu questionamento.

No turno de fala 500, A2 pergunta explicitamente ao professor o tipo de lâmpada, cuja resposta aparece no turno 504 quando o professor afirma que a lâmpada é mista. Enquanto isso A5 retoma sua fala do turno 492 no turno 501 ao afirmar "que é luz de poste amarelo".

A classificação feita por A5 parece ser baseada numa comparação com um dos tipos de luz que observou na atividade proposta pelo professor na qual os alunos deviam observar os espectros de várias lâmpadas fora da escola antes dessa atividade. De qualquer forma ele não faz nenhuma referência explícita a essa atividade e nem justifica sua comparação.

Após a resposta do professor afirmando que a lâmpada é mista, A5 questiona se além de mercúrio existe a presença de outro elemento na lâmpada (turno 505). O professor responde no turno 507 que existe outra "coisa" presente.

No turno 508, A1 parece utilizar uma associação baseado na palavra "mista", para entender que tipo de lâmpada é essa:

Turno 508: A1: Então se a palavra é mista...

Porém, não conclui seu raciocínio e parece ser completado por A4:

Turno 509: A4: Então, não enxergo espectro nenhum?

Apesar de colocar na forma de questionamento, A4 associa o fato de a lâmpada ser mista à diferença na observação do espectro em relação às observações anteriores. Esta situação chama a atenção, pois é uma contraposição em relação à observação prática que estão fazendo, porque enxergam o espectro contínuo nesse momento. De qualquer forma representa uma estrutura básica de argumento a partir de um dado (informação de que a lâmpada é mista), chega-se à conclusão de não seria possível a visualização do espectro (dessa lâmpada). 
A justificativa utilizada pelo aluno é a própria informação de que a lâmpada é mista. Também é importante ressaltar que foi construída por dois alunos.

Porém, essa ideia é refutada por A3 que, observando a lâmpada com seu espectroscópio, afirma que o espectro é contínuo: baseado em sua observação, não aceita a justificativa de A4. Aqui o aluno parece associar sua observação com as falas de A1 e A4, o que representaria uma configuração básica de argumentação, mas não chega a explicitar que sua observação é que justifica a sua negação em relação à ideia apresentada.

Do turno de fala 512 ao 517, observamos um aluno citar as cores que estão vendo e isso parece gerar um pouco de confusão, visto que o professor não solicitou tal informação no momento. Também notamos os alunos buscando por melhores condições para realizarem suas observações.

\section{Do turno 518 ao 577:}

Na sequência de turnos de fala de 518 a 577, o professor tenta retomar com os alunos quais os tipos de lâmpada apresentam espectro discreto e quais apresentam espectro contínuo baseado nas observações anteriores. Em seguida solicita a retomada da observação para que verifiquem novamente o espectro da lâmpada. A ideia é que os alunos percebam a mudança do espectro para discreto. Entretanto, os alunos demonstram confusão em suas respostas.

De um modo geral os alunos respondem corretamente quais tipos de lâmpadas estão associados aos espectros discretos e contínuos, porém, ao serem questionados sobre o espectro da lâmpada mista, eles parecem um pouco confusos em relação ao que observam. Os alunos começam a raciocinar que a lâmpada mista deve ter os dois espectros, mas não parece claro que primeiro observam um tipo para depois verem o outro.

No turno 552 o professor pergunta qual lâmpada tem espectro discreto, e os alunos respondem nos turnos a seguir: 555, A2 afirma que a fluorescente, apontando com o dedo para lâmpada; 556 vários alunos repetem a afirmação de A2; 557 um aluno não identificado repete que é a lâmpada fluorescente e acrescenta que possui gás.

O professor confirma estas falas no turno 558 e pergunta qual lâmpada apresenta espectro contínuo. A3 responde no turno 559 quando afirma que é a lâmpada de filamento, o que logo em seguida é confirmado pelo professor no turno 560. Ainda neste turno, o professor também declara que a lâmpada é mista e pergunta o que tem dentro dela. No turno 561 um aluno não identificado afirma que a lâmpada possui gás e filamento e é repetido por vários alunos no turno 562. 
Em seguida, o professor tenta explicar no turno 563 que a lâmpada possui filamento e, ao ser aceso, vai esquentando o gás para que entendam que, no início, tínhamos um espectro contínuo relacionado ao filamento da lâmpada e conforme este foi aquecendo o gás, passamos a ter um espectro discreto relacionado ao gás da lâmpada.

Essa sequência de raciocínio não foi totalmente assimilada pelos alunos, e como exemplo temos a fala de A3 nos turnos 564: A3: Quando tem gás espectro contínuo quando apaga a luz... e turno 565: A3: ... agora é filamento... espectro contínuo e discreto ... E (inaudivel).

Com a fala de A3 percebemos claramente a confusão, quando afirma que, inicialmente, a lâmpada que possui gás apresenta espectro contínuo (o primeiro que observaram nessa lâmpada) e depois com filamento o espectro seria discreto. Basta lembrarmos que a própria A3 havia respondido, no turno 559, que a lâmpada com filamento apresentava espectro contínuo.

Apesar dos esforços do professor nesta sequência de turnos, os alunos não demonstram entender seu raciocínio.

\section{Do turno 578 ao 635:}

No turno 578 o professor pergunta quantas cores os alunos estão observando e após respostas dos mesmo, pede para identificarem as que se destacam mais (turno 582). No turno 600 questiona se algumas das cores aparecem "espalhadas". Enquanto respondem, os alunos continuam tentando classificar o tipo de espectro observado. No turno 619 temos a seguinte afirmação do professor: P: Tem uma parte que é discreto, tem aí bem definido, tem uma parte que é (inaudivel).

Com essa fala e pela sequência de perguntas, podemos dizer que o professor tenta destacar que nesse instante da observação os alunos devem enxergar um espectro discreto devido à presença do gás e que este espectro é bem definido, porém algumas cores aparecem "espalhada" ao fundo por causa da presença do filamento que continua aquecido e possui espectro contínuo.

Apesar da fala do professor, percebemos a confusão por parte dos alunos nos turnos: 620, A4 afirma que não está vendo nada (do que o professor fala no turno 619); 621, por sua vez, A3 afirma o que está vendo e que na imagem estão aparecendo umas "flechinhas"; 622, A3 indica que a cor violeta é a "mais forte"; 623 um aluno não identificado acha que (o espectro) é contínuo; nos turnos seguintes A3 continua falando das cores que aparecem "mais 
fortes", no 626 o mesmo fala que a banda mais larga é a "verde forte", já no 627 diz que o vermelho é o "mais fraco"; 628, A1 confirma que (o espectro) é discreto.

Nesse momento o professor não fecha a discussão sobre o tipo de espectro observado.

\section{Análises:}

Em relação ao envolvimento com a atividade, logo no início deste momento, notamos uma preocupação por parte dos alunos com o tipo de lâmpada observada: turno 490, A1 pergunta o tipo de lâmpada e no 492, A5 diz que é luz de "poste amarelo"; 500 A2, pergunta diretamente ao professor que tipo de lâmpada estão observando; no 501, A5 repete que é "luz de poste amarelo"; e no 504, finalmente, o professor afirma que é mista.

Os alunos também se mostraram envolvidos com a atividade ao responderem as perguntas do professor sobre quais os tipos de espectros estão observando e sobre os tipos de lâmpadas que estão associados aos dois espectros. Neste último caso os alunos responderam de forma correta e provavelmente baseados nas observações que fizeram com as lâmpadas anteriores, isto mostra um envolvimento em relação à atividade como um todo.

Como indicativos de envolvimento com a atividade, temos ainda:

$\checkmark$ A constante manipulação dos espectroscópios, como no turno 563 enquanto o professor tenta explicar a mudança dos espectros em relação ao filamento aquecido e depois ao aquecimento do gás, alguns alunos continuam observando a lâmpada com o espectroscópio ao passo que outros realizam anotações nos cadernos. Outro exemplo ocorre no turno 586 quando A3 solicita que A4 anote sobre a lâmpada fluorescente em uma parte específica do caderno e em seguida volta a olhar para lâmpada com o espectroscópio. Praticamente durante todo esse momento os alunos realizam observações com o espectroscópio para darem ou reforçarem suas respostas.

$\checkmark$ A partir do turno 622 até o turno 627 quando A3 classifica a maior e a menor banda do espectro, reparamos que ela faz isto sem uma solicitação específica do professor neste instante da aula.

$\checkmark$ Busca de melhores condições para realizar a observação como no turno 515, em que A3 solicita ao professor licença para que ela possa realizar sua observação. No turno 537 após A5 ter dito que o espectro é contínuo, A1 afirma ver um verde e um amarelo "meio separados", e no turno 539 um aluno não identificado confirma essa observação e indica como "ali" o lugar onde podem verificar esse fato.

Porém, neste momento da atividade, notamos que os alunos começam a demonstrar sinais de cansaço, como nos turnos: 553 quando A2 fala que seus olhos estão doendo; 573, A4 
comenta que está com dor de cabeça; 629 quando A5 diz estar cansado de ficar sentado tanto tempo. Este cansaço não prejudica o envolvimento dos mesmos com a aula, com exceção de A4 que parece ter sua participação reduzida em relação aos momentos anteriores, em compensação A3 tem um destaque ainda maior nesse momento da aula.

Com relação às linguagens, a manipulação dos espectroscópios continua de forma intensa e também temos alguns exemplos de manipulação de materiais. Como exemplos de manipulação dos espectroscópios, podemos citar os turnos: 511 quando A3 discorda da afirmação de A4 no turno 509, que afirma não enxergar espectro nenhum devido ao fato da lâmpada ser mista, aqui A3 afirma que o espectro é contínuo enquanto observa a lâmpada com seu espectroscópio; no 535, A1 afirma que o espectro é contínuo, porém destaca que tem algo diferente, concluindo no turno 537, que o verde e o amarelo estão meio separados. Durante esta fala ele observa segurando o espectroscópio com uma mão e gesticulando com outra; 539 mesmo com vários alunos falando ao mesmo tempo, eles continuam com o espectroscópio no olho realizando observações; 563 enquanto o professor explica os tipos de espectros relacionados às lâmpadas, os alunos continuam com o espectroscópio realizando suas observações. Outros exemplos de manipulação podem ser encontrados nos turnos: 572, 586, 594 quando A4 também passa a observar com o espectroscópio, sendo que ele tinha passado um tempo apenas anotando as observações de A3; 604 e 614.

Como exemplos de manipulação de materiais, basicamente temos os alunos realizando anotações nos seus cadernos como nos turnos: 499 em que A4 reclama por ter observado sem querer, em seguida abaixa seu espectroscópio e realiza suas anotações; 563 durante a explicação do professor e enquanto vários alunos realizam a observação com os espectroscópios, outros anotam; 564 quando A3 fornece sua explicação para A4 anotar; 570 a situação se repete com A3 falando e A4 anotando; 572, A4 continua anotando; do turno 575 ao 577, A3 indica no caderno o local onde A4 deve anotar que a lâmpada é incandescente, mostrando uma preocupação para que as anotações sejam feitas de forma correta; 585, A3 continua observando A4 realizar as anotações; 586 novamente A3 aponta para uma região específica do caderno para que A4 anote que a lâmpada é fluorescente, nesse instante A3 volta a olhar par a lâmpada com o espectroscópio e A4 olha também, mas sem o espectroscópio e para de realizar suas anotações momentaneamente.

Estas manipulações de materiais e dos espectroscópios mostram uma preocupação dos alunos para realização da atividade bem como envolvimento com a mesma.

Da mesma forma, é importante destacar que nesse momento os alunos já não apresentam grandes dificuldades de manipulação dos espectroscópios, já conseguem olhar 
pelo lado mais adequado e não fazem questionamentos indicando dificuldades em enxergar o espectro dentro do espectroscópio, portanto temos uma evolução em relação à manipulação dos espectroscópios e observação dos espectros.

A linguagem oral aparece principalmente nas interações $\mathrm{P} / \mathrm{T}$, visto que na maior parte desse momento os alunos respondem a questionamentos do professor e recebem informações sobre os tipos de espectros da lâmpada, mas temos também algumas interações A/A e Ax/Ay, principalmente quando estão relatando suas observações e fazendo suas anotações.

Como alguns exemplos importantes de linguagem oral para realização da atividade, podemos destacar os turnos: 490 e 500, quando A1 e A2, respectivamente, indagam o tipo de lâmpada que estão observando; 492 e 501, A5, ao afirmar que é luz de poste amarelo, ele parece indicar que associou essa lâmpada a uma que observou em seu trabalho de campo. Isso mostra que eles estão procurando associações e relações entre as observações; 493, 494 e 495, um aluno não identificado e vários alunos fornecem a primeira classificação como contínuo; 496 e 497, outro aluno não identificado discorda dessa classificação, mas não apresenta justificativas; após o professor afirmar que a lâmpada é mista no turno 507, A1, A4, A5 e A3 expressam verbalmente suas ideias sobre o espectro da mesma nos turnos 508 a 511.

$\mathrm{Na}$ sequência o professor tenta explicar os espectros da lâmpada oralmente, proporcionando uma interação essencialmente oral também durante todo esse momento. Basicamente é por meio da linguagem oral que conseguimos perceber o que os alunos estão observando ou pensando. Por exemplo, no turno 535, A1 afirma ver que o espectro é contínuo, porém no turno 537 ele diz observar o verde e o amarelo meio separados. Embora tenha respondido contínuo, o próprio aluno apresenta uma característica do espectro discreto ao indicar que o espectro não é mais o mesmo que observou no início desse momento da aula.

Também é por meio da linguagem oral que percebemos a confusão que A3 faz ao tentar associar o espectro observado aos elementos da lâmpada:

Turno 564: A3: Quando tem gás espectro contínuo quando apaga a luz...

Turno 565: A3: ... agora é filamento... espectro contínuo e discreto ... E (inaudivel).

A própria aluna A3 tinha respondido ao professor no turno 559 que a lâmpada de filamento apresenta espectro contínuo e nesse instante ela demonstra confusão ao afirmar que, quando possui gás, a lâmpada deve apresentar espectro discreto. Esses turnos de fala demonstram que os alunos não conseguiram acompanhar totalmente o raciocínio utilizado na explicação do professor, ou ainda não tiveram tempo de assimilar essas informações.

Quando o professor questiona se a imagens estão aparecendo bem definidas no turno 593, A3 utiliza o termo "fleshinho" que parece indicar uma imagem clara. 
Nos turnos 606 e 607 alguns alunos afirmam que o espectro é contínuo e no turno 609 outro aluno diz ser discreto. No turno 611, A2 utiliza o termo "discretínuo" para dizer que existem os dois espectros. Embora utilize um termo como brincadeira, A2 demonstra estar convencido da presença dos dois tipos de espectro, apenas não faz referência se notou um por vez ou se está observando o discreto e com um espectro contínuo "espalhado" ao fundo como sugere o professor nessa sequência. Neste instante da aula, caberia uma pergunta para procurar saber o que de fato estão observando.

A linguagem gestual continua aparecendo de forma mais relacionada à atividade, mas aparece poucas vezes nesse momento da aula, muitas vezes cooperando com alguma informação fornecida verbalmente. Destacamos os seguintes turnos: 530 após o professor perguntar se o espectro observado ainda é contínuo, Ani responde que sim e acena positivamente com a cabeça reforçando sua fala; nos 535 e 537, A1 classifica o espectro observado como contínuo, mas afirma que a cor verde e a amarela estão meio separadas e, para reforçar essa ideia da separação, acena e gesticula com os dedos da mão direita enquanto continua observando com o espectroscópio; 628 novamente A1 classifica o espectro, agora como discreto, e acena sua cabeça num gesto de positivo para A6.

Neste instante os gestos aparecem mais como uma forma de reforçar aquilo que foi dito verbalmente.

Em relação à apropriação de termos técnicos, observamos que na análise da lâmpada no instante inicial, os alunos, em sua grande maioria, classificam corretamente o espectro como contínuo, porém não justificam tal classificação e nem temos perguntas que levem a isso. No turno 511, A3 discorda do raciocínio de A4 quando ele diz que por ser uma lâmpada mista não enxergariam espectro nenhum. Ao discordar, A3 enfatiza que o espectro é contínuo enquanto realiza sua observação com o espectroscópio, mas não apresenta justificativas também.

No turno 518 o professor afirma que a lâmpada tem gás e pergunta se o espectro é discreto ou contínuo, em seguida no turno 519, A3 afirma que é contínuo e no 520 vários alunos repetem essa afirmação. Essa resposta está errada, conforme fala do professor, no turno 521, que afirma ser discreto, porém, como não tivemos nenhuma pergunta, não podemos afirmar se os alunos não associaram a lâmpada de gás ao espectro discreto ou se responderam pela observação inicial que fizeram, quando de fato o espectro era contínuo, antes do aquecimento do gás.

$\mathrm{Na}$ sequência o professor afirma que a lâmpada possui filamento e pergunta novamente se o espectro é discreto ou contínuo. Desta vez muitos alunos respondem 
corretamente afirmando ser contínuo no turno 524. O professor por sua vez solicita classificação para o espectro que estão observando nesse instante e obtém respostas diferentes: nos turnos 526 e 528, A4 afirma que o espectro é contínuo, no turno 527, A3 classifica como discreto.

O professor retoma o questionamento perguntando, agora, como era o espectro quando começaram a observação (turno 529) e pede para verificarem se ainda é contínuo. Ani responde afirmando que é contínuo no turno 530, enquanto A5 questiona sobre a diferença dos dois espectros:

Turno 531: A5: Quem sabe a diferença discreto e contínuo lá?

A pergunta de A5 mostra a dificuldade que está encontrando para classificar o espectro e parece mostrar também que o aluno não assimilou muito bem as características dos dois espectros. Nesta ocasião A3 e A4, respectivamente, nos turnos 532 e 534, começam a falar da presença do gás, porém não concluem seu raciocínio.

No turno 536, A1 afirma que é contínuo, porém apresenta uma ressalva com a preposição "mas". Essa ressalva é explicada no turno 537 no qual afirma que o verde e o amarelo estão meio separados, o que é uma característica do espectro discreto, fato que colocou em dúvida sua própria afirmação.

Turno 535: A1: É contínuo mas tem um...

A preposição "mas" traz uma ideia de contrariedade ou contraponto para sua afirmação.

Turno 537: A1: ... Um verde e um amarelo meio separadinho.

A separação das cores representa a contrariedade, já que esta é uma característica do espectro discreto.

No turno 542 o professor pergunta novamente se o espectro da lâmpada é discreto ou contínuo e vários alunos respondem que é discreto. Em seguida, provavelmente procurando maior convicção na afirmação, o professor faz o seguinte questionamento:

Turno 545: P: Vocês não falaram que o espectro da lâmpada é contínuo?

Porém, a pergunta parece confundir os alunos, pois no turno 546, A5 responde que é contínuo, no 547 outro aluno responde que temos os dois tipos de espectro ao mesmo tempo e A5 no 548 afirma novamente que é contínuo.

O professor parece mudar de estratégia e no turno 549 diz que a lâmpada é mista e pergunta o que ela está misturando. A2 responde discreto e contínuo no turno 551. 
A partir do turno 552 o professor tenta associar o tipo de lâmpada com o espectro observado, depois de confirmar que realmente temos a mistura do espectro discreto e contínuo conforme fala do aluno no turno 551:

Turno 552: P: O discreto e o contínuo. Que tipo de lâmpada tem ... espectro ... discreto?

A2 responde no turno 555 que é a lâmpada fluorescente. E vários alunos repetem essa afirmação no turno 556 e um aluno não identificado confirma a informação no turno 557:

Turno 557: Ani: Lâmpada fluorescente. A que tem gás, professor.

Turno 558: P: Que tem gás no interior. Que tipo de lâmpada tem espectro contínuo?

Após confirmar a resposta dos alunos, o professor pergunta qual tipo de lâmpada possui espectro contínuo. No turno 559 A3 afirma que é a lâmpada de filamento. Em seguida, o professor confirma a fala de A3 e apresenta outro questionamento:

Turno 560: P: Que tem filamento. Essa lâmpada é mista, o que que ela tem dentro?

Um aluno não identificado responde que possui gás e filamento com muitos alunos confirmando essa fala, respectivamente, nos turnos 561 e 562. No turno seguinte o professor explica que no início da observação o filamento foi aceso e aqueceu o gás no interior da lâmpada e chama a atenção também ao brilho da lâmpada que fica diferente com o aquecimento.

Em seguida, observamos a fala de A3 que tenta organizar suas ideias, porém demonstra confusão para seguir o raciocínio do professor:

Turno 564: A3: Quando tem gás espectro contínuo quando apaga a luz...

Turno 565: A3: ...agora é filamento...espectro contínuo e discreto...E (inaudivel).

Na fala de A3 vemos que ela associa a presença de gás ao espectro contínuo, porém a mesma aluna no turno 559 associa a presença do filamento na lâmpada com o espectro contínuo e demonstra neste instante uma confusão. De fato quando "apaga" (a luz da sala) para realizarem as observações, temos gás na lâmpada e o espectro realmente é contínuo, porém a aluna não parece ter entendido que no início o espectro que vemos é do filamento que acende e aos poucos vai esquentando o gás, para aí sim vermos o espectro deste que é discreto. Em sua fala ela parece inverter essa ordem de fatos, pois coloca o gás como responsável pelo primeiro espectro e depois o filamento para justificar a presença dos dois espectros.

No turno 566, A5 confirma a fala do professor sobre a claridade da lâmpada ter sido modificada após o aquecimento do gás. 
No turno 568 o professor pergunta qual o espectro da lâmpada estão observando no momento. A3 chega a falar "gás e filamento", mas não classifica. Não obtendo respostas, o próprio professor afirma que o espectro é discreto no turno 572.

Nos turno 574 a 577 observamos A3 preocupada com as anotações que estão sendo feitas por A4. A3 pede a ele que anote que a lâmpada de filamento é a incandescente.

Podemos dizer que neste momento da aula os alunos utilizam os termos "discreto" e “contínuo" de forma espontânea, porém não justificam suas classificações. No entanto, apenas podemos falar que A5 no turno 531 demonstra ter dificuldades para identificar as características de cada tipo de espectro, e A1 nos turnos 535 e 537, apesar de classificar o espectro como contínuo, parece perceber que a separação das cores que está observando no momento é contrária a essa classificação.

Já a associação dos tipos de espectros com os tipos de lâmpadas e com as observações que estão realizando não foi completa e gerou algumas confusões ao longo da sequência de turnos de fala descritos acima.

A partir do turno 578 o professor parece ter a intenção de ajudar os alunos a perceberem que, além do espectro discreto que estão vendo em destaque, existe "ao fundo" um espectro mais “espalhado" que é o contínuo associado ao filamento.

Turno 578: P: Quantas cores vocês estão vendo nesse espectro?

Temos um aluno respondendo que vê quatro e outros afirmam enxergar até cinco cores. A5 chega a citar as cores que está vendo no turno 581:

Turno 581: A5: Eu tô vendo azul, verde, laranja, vermelho, azul e roxo (inaudível). A5 só não enxergou a cor amarela e a cor anil, porém não faz nenhuma referência ao tipo de espectro observado. Já no turno 585, A5 afirma que está vendo “um monte de cores".

Nos turnos 590 e 593 o professor pergunta se todas as cores aparecem bem definidas. A maioria dos alunos responde que não como no turno 594; A2 afirma que a cor azul não está bem definida (turno 595); um aluno não identificado chega a citar o anil que foi uma das cores ausentes nas citações anteriores (turno 596); outro aluno não identificado chega a afirmar que todas elas aparecem bem definidas (turno 597); um terceiro aluno não identificado diz que está vendo cores mais claras (turno 598), e por fim A3 diz que vê uns "fleshinhos" que parecem ser referência ao "flash" de uma máquina fotográfica e remete à ideia de claridade.

No turno 600 o professor questiona se algumas cores aparecem espalhadas. Nas respostas alguns alunos indicam a cor vermelha, outros a verde, a verde - clara e amarela. Neste instante, embora não tenha sido solicitado, alguns alunos acabam classificando o 
espectro como discreto e outros como contínuo: é nessa sequência que A2 utiliza o termo "discretínuo" numa forma de indicar a presença dos dois tipos de espectros.

Finalmente, no turno 619, o professor parece definir o que esperava que os alunos vissem ao afirmar que temos o espectro discreto bem definido e outra parte mais clarinha e não bem definida que representa o espectro contínuo. No turno 620, A4 diz que não consegue ver nada, porém A3 no turno 621 comenta que está vendo sim, inclusive cita novamente os "fleshinhos". Logo temos uma mistura de situações, pois alguns alunos destacam a cor que aparece mais forte, alguns classificam o espectro como discreto, outros como contínuo, um aluno fala da (lâmpada) fluorescente e finalmente no turno 632 o professor pergunta se pode apagar essa lâmpada.

A dificuldade na observação e identificação dos tipos de espectros da lâmpada mista levaram também a uma dificuldade na determinação, se os alunos, além de assimilarem o uso dos termos técnicos, assimilaram também seus significados e se conseguem fazer associações.

Merece destaque ainda o turno 626:

Turno 626: A3: A banda mais larga é a verde forte e ...

Mesmo sem ser solicitado explicitamente, A3 identifica qual a cor que aparece mais no espectro e utiliza o termo "banda mais larga" mostrando ter se apropriado deste termo.

Em relação aos conceitos envolvidos, percebemos que os alunos ficaram um pouco confusos em relação às características que definem o espectro contínuo e o discreto devido a suas observações e aos questionamentos feitos pelo professor. De qualquer forma, em nenhum momento fazem referência ao que poderia ser responsável por um tipo ou outro de espectros.

Nesta sequência não temos comentários do professor em relação à maior banda ou intensidade da mesma. Também não comentam sobre a luz observada.

Sobre argumentacão chamamos a atenção para o turno 508 em que, após o professor ter afirmado que a lâmpada é mista (turno 507), A1 inicia seu raciocínio:

Turno 508: A1: Então se a palavra é mista...

A1 tenta associar a palavra "mista" com o que devem observar na lâmpada, porém não completa seu raciocínio, o que acaba acontecendo por meio da indagação de A4 no turno 509:

Turno 509: A4: Então não enxergo espectro nenhum?

Embora na forma de uma indagação, A4 apresenta uma conclusão para a fala de A1. Esta conclusão está errada, tanto que A3 discorda de A4 no turno 510, afirmando que o espectro é contínuo, mesmo não apresentando justificativas para sua afirmação.

Aqui temos um exemplo de estrutura de argumentação baseada no modelo de Toulmin (1958) construído coletivamente pelos alunos do grupo: temos um dado que, segundo a 
classificação de Jiménez Aleixandre (1998), pode ser classificado como um dado fornecido, no caso pelo professor, ao afirmar que a lâmpada é mista no turno 507, já A4 apresenta sua conclusão no turno 509 e diz não enxergar espectro nenhum. A justificativa utilizada por ele para essa conclusão foi a afirmação de A1 ao deixar a ideia que a palavra "mista" deveria ter um significado em relação ao espectro observado. Então (A1) não enxerga espectro nenhum porque é (a lâmpada) mista.

No turno 511, A3 discorda da conclusão de A4 e afirma que o espectro é contínuo. Temos aqui uma refutação: um elemento de oposição à justificativa e, consequentemente, à conclusão.

A4 concluiu que por ser uma lâmpada mista não enxergaria nenhum espectro. A4 parece ter raciocinado da seguinte maneira: já que a lâmpada é mista, então deve ter os dois espectros e um deve anular o outro, portanto não enxergaria nenhum espectro; porém A3 discorda, afinal está observando a lâmpada e enxergando um espectro contínuo. A observação que ela realiza representa um dado obtido e empírico (Jiménez Aleixandre, 1998) que contrapõe o raciocínio de A4.

Temos nessa sequência um exemplo de argumentação com mais elementos constituindo uma forma mais elaborada de argumento.

Durante a observação o professor tenta associar o tipo de lâmpadas que os alunos observaram aos espectros obtidos em cada uma delas. No turno 531, A5 pergunta sobre a diferença entre o espectro contínuo e o discreto, e A3 esboça uma tentativa de resposta, mas não é clara sua fala. A pergunta de A5 poderia ter levado a uma estrutura básica de argumentação, mas não obteve retorno.

Nos turnos 535 e 537 temos uma fala interessante de A1 em termos de argumentação:

Turno 535: Al:É contínuo, mas tem um...

Turno 537: A1: ... Um verde e um amarelo meio separadinho.

A1 apresenta uma classificação na forma de conclusão ao afirmar que o espectro é contínuo, essa afirmação tem por base sua observação com o espectroscópio que representa um dado obtido e empírico, porém não justifica porque fez essa afirmação. Portanto, a estrutura básica de argumentação de Toulmin não existe devido à ausência de uma justificativa. Em sua fala A1 utiliza a preposição "mas" que remete à ideia de contrariedade, afirma que é contínuo, mas algo parece indicar o contrário. Em seguida, percebemos que o fato de as cores (verde e amarela) aparecerem separadas leva à utilização da preposição "mas", pois a separação das cores representa uma característica dos espectros discretos. Podemos dizer que A1 refuta a própria classificação por meio de sua observação com o 
espectroscópio que representa um dado obtido e empírico, inclusive A1, enquanto observa com o espectroscópio, utiliza uma mão para gesticular, procurando reforçar a ideia de que as cores estão separadas e a justificativa para sua contrariedade é exatamente o fato de a cor verde aparecer separada da amarela.

Apesar de classificar como contínuo, ele observa características do espectro discreto. Nesta sequência podemos observar que no contexto geral dos dois turnos de fala temos um exemplo de argumentação, mas com alguns elementos implícitos.

No turno 564 temos A3 explicando o que entendeu sobre os tipos de lâmpadas e os espectros associados a elas e sobre o espectro da lâmpada que estão observando:

Turno 564: A3: Quando tem gás espectro contínuo quando apaga a luz...

Turno 656: A3: ... agora é filamento ... espectro contínuo e discreto ... E (inaudível).

Percebemos um exemplo de argumentação (Toulmin, 1958), embora em ordem inversa: o dado é obtido e empírico (Jiménez Aleixandre, 1998) por meio da observação com o espectroscópio que é o que enxergam "quando apaga a luz", no início da observação; a justificativa é o fato de a lâmpada possuir gás, por isso o espectro é contínuo (conclusão). Depois temos também o filamento (dado fornecido), por isso (justificativa) temos o espectro contínuo e discreto (conclusão).

Essa argumentação permite que notemos a confusão por parte de A3, já que ela mesma, no turno 559 em resposta ao professor, associou a lâmpada de filamento ao espectro contínuo e agora está associando a presença do gás a esse espectro.

Utilizando o modelo de Van Eemeren et al. (1987) adaptado por Villani e Nascimento (2003), podemos afirmar que a fala de A3 representa um discurso interpretado (O') a partir da fala do professor ao longo da sequência em que tenta associar os tipos de lâmpadas (gás e filamento) aos tipos de espectro (discreto e contínuo). Essa fala do professor praticamente teve início no turno 549, quando ele afirma que a lâmpada é mista e questiona o que ela está misturando, e é concluída no turno 563 quando ele explica o que acontece com lâmpada que tem seu filamento aquecido e este vai aquecendo o gás também. Podemos dizer que o conjunto dessas falas constitui o discurso (D) do locutor, no caso, o professor.

As falas do professor, alguns comentários dos alunos e as observações constituem o contexto determinado para elaboração do discurso interpretado por parte da ouvinte (L), aqui representada por $\mathrm{A} 3$.

Notamos na fala, incorreta, de A3 que ela associa o espectro contínuo à lâmpada com gás, mas, em seguida, diz que esse espectro ocorre "quando apaga a luz" (da sala), portanto, além da fala do professor, ela levou em conta também a sua própria observação no início do 
trabalho com a lâmpada mista. Pode ter considerado também as falas e observações dos demais alunos da sala.

Esse discurso interpretado é extremamente importante, pois mostra de forma clara toda a confusão de A3 na observação e análise dos espectros da lâmpada mista, o que parece refletir a situação dos demais integrantes do grupo também, já que ninguém se opõe à fala dela.

Seria importante uma intervenção por parte do professor ou mesmo de outro aluno para tentar sanar essa confusão.

Importante também analisarmos neste momento da aula como a fala do professor está retornando dos alunos. Seria interessante se tivéssemos mais retornos elaborados de outros alunos.

Em relação aos indicadores de alfabetização científica, continuamos com os alunos $\underline{\text { organizando, }}$ classificando, , com alguns exemplos de justificativas e também com exemplo de explicação e raciocínio lógico.

Temos o indicador organização nas seguintes formas:

$\checkmark$ Organização para realização da atividade: os alunos continuam se preparando para a atividade como um todo. Neste momento esse indicador aparece com menor intensidade, afinal os alunos já fizeram outras observações antes, mas ainda temos como exemplos os turnos: 490 quando A1 pergunta sobre a lâmpada que vão observar; 500, em que A2 pergunta novamente que tipo de lâmpada estão observando; 573, 574 e 577, A3 indica no caderno o local onde A4 deve anotar que a lâmpada incandescente é a que tem filamento; 586, A3 indica para A4 a região no caderno na qual deve anotar a lâmpada fluorescente; 633, 634 e 635 quando, após pergunta do professor, os alunos afirmam que ele pode apagar a lâmpada mista.

$\checkmark$ Organização para observação com os espectroscópios: os alunos buscam a melhor forma para realizarem as observações. Embora já tenham realizado outras observações anteriormente, ainda encontramos alguns exemplos nesse momento, como nos turnos: 515, A3 ao pedir licença ao professor para conseguir realizar suas observações; 517, A4 faz solicitação semelhante; 539 quando um aluno não identificado tenta indicar onde está vendo o amarelo pelo espectroscópio, após A1 ter afirmado que o amarelo e verde estão separados; 540 em que A4 parece solicitar nova observação.

$\checkmark$ Organização para classificação dos espectros: como faz parte da atividade classificar o espectro como contínuo ou discreto, este tipo de organização aparece com destaque e temos os turnos: 514 quando A3 pergunta se querem que ele fale das cores; 531, A5 
pede diferenciação dos espectros contínuos e discretos para realizar suas classificações; 535, A1 tenta organizar suas ideias ao observar que a lâmpada tem gás; 537, A1, após ter afirmado que o espectro é contínuo no turno 535, observa e organiza suas ideias e percebe que a cor verde e a amarela estão separadas, fato indicativo de um espectro discreto; 570, A3 afirma que a lâmpada tem gás e filamento, tentando organizar a classificação do espectro conforme solicitação do professor; 580 um aluno não identificado organiza as cores que está vendo respondendo ao questionamento do professor que visa a classificação do espectro observado; 581 e 585 o mesmo ocorre com A5; 621, A3 afirma que está vendo o espectro discreto e uma parte não muito definida que representa o espectro contínuo conforme observação do professor.

$\checkmark$ Organização para classificar a cor que representa a maior ou menor banda do espectro observado: só aparece em praticamente em dois turnos, mas é interessante notarmos que surgiu sem uma solicitação explícita do professor: 625 e 627 quando A3 organiza dentre as cores que está vendo qual é a que "aparece mais forte ou mais fraca" para classificar a maior e menor banda.

$\checkmark$ Organização buscando associação de variáveis: do turno 542 ao 563 o professor faz questionamentos visando uma associação entre os tipos de espectros e as lâmpadas. Embora os alunos não percebam toda classificação e organização que realizaram entre esses turnos, pode ser considerado de uma forma geral uma grande organização buscando associar a lâmpada de filamento com o espectro contínuo e lâmpada com gás ao espectro discreto.

O indicador classificação recebe destaque nas seguintes formas:

$\checkmark$ Classificação do tipo de espectro - em função principalmente dos questionamentos do professor, esse indicador aparece praticamente em todo esse momento da aula, como nos turnos: 493, 494 e 495, em que vários alunos classificam o espectro como contínuo; 496 e 497 quando um aluno não identificado discorda da classificação feita nos turnos anteriores; 511, A3 discorda do raciocínio de A4 que diz não ter enxergado nenhum espectro porque a lâmpada é mista, aqui A3 classifica o espectro observado como contínuo também; 519, A3 classifica como contínuo; 520 vários alunos repetem a classificação de A3. Nesses dois turnos os alunos classificam não pela observação e sim pela associação com o tipo de lâmpada. O professor questionou sobre a lâmpada com gás, portanto a resposta deles estava errada e foi corrigida pelo professor no turno 521; 522, A3 parece discordar da classificação do professor; 524 vários alunos classificam o espectro da lâmpada com filamento como contínuo após questionamento 
do professor, agora classificam corretamente; 526, A4 confirma que é contínuo; 527, A3 diz que é discreto; 528, A4 afirma novamente que é contínuo; 530 Ani classifica como contínuo, mas aprece responder a indagação do professor em relação ao momento que começaram a observar, quando de fato era contínuo; 535, A1 classifica como contínuo, porém com ressalvas; 536, A5 classifica como contínuo; 543 vários alunos classificam como discreto, após o professor questionar novamente sobre o espectro dessa lâmpada; 546, A5 classifica como contínuo; 547 outro aluno não identificado afirma que são os dois espectros juntos; 548,A5 diz que é contínuo; 551, A2 classifica como discreto; 606 e 607 aluno não identificado e A2 respectivamente classificam como discreto, mesmo sem um questionamento do professor ou de outro aluno; 609 outro aluno não identificado classifica como contínuo; 611 A2 classifica como "discretínuo" remetendo à ideia que temos os dois espectros juntos; 612 um aluno não identificado diz que é contínuo; 613 outro aluno não identificado classifica como mista, embora não fique explícito se classifica o espectro ou a lâmpada; 617 vários alunos repetem a classificação como mista; 618 vários alunos afirmam que é contínuo; 623 aluno não identificado acha que é contínuo; 628, A1 classifica como discreto.

$\checkmark$ Classificação relacionada ao tamanho da banda dos espectros - aqui os alunos classificam quais as cores que representam a maior e a menor banda do espectro observado. Por não ter uma solicitação direta temos como exemplos apenas o turno: 626 quando A3 classifica a cor verde como a banda mais larga.

Classificação do tipo de lâmpada - aqui esse tipo de classificação manifesta-se muito. Num momento inicial aparece apenas uma identificação do tipo de lâmpada e da luz que ela emite, num momento posterior o professor procura associar a lâmpada de filamento com o espectro contínuo e a com gás ao espectro discreto, com o objetivo que eles raciocinem o que ocorre com a lâmpada. Como exemplos, citamos os turnos: 492, A5 afirma que é "luz de poste amarelo" como dissemos anteriormente, essa classificação parece ser uma referência a um tipo de lâmpada que observou na atividade para casa; 501, A5 novamente classifica como "luz de poste amarelo"; 505, A5 classifica a lâmpada como de gás mercúrio ou "de outra coisa lá"; 506, A5 afirma que é vapor de mercúrio, em seguida, o professor afirma que tem outra coisa, já que ela é mista; 510, A5 insiste como "luz de poste amarela"; 555, após o professor solicitar o tipo de lâmpada que tem espectro discreto, A2 classifica a lâmpada como fluorescente; 556 vários alunos repetem a classificação de A2; 557 aluno não 
identificado classifica como fluorescente e enfatiza que é a lâmpada com gás; 559, A3 classifica a lâmpada com filamento a que possui espectro contínuo após questionamento do professor; 561 aluno não identificado responde "gás e filamento" como sendo o tipo de lâmpada que estão observando depois da pergunta do professor que ainda afirmou ser uma lâmpada mista; 562 vários alunos repetem a classificação; 570, A3 afirma que é gás e filamento, embora o professor tenha solicitado no turno 568 o tipo de espectro que estão observando naquele instante; 574, A3 classifica a incandescente como a que possui filamento, mas sua fala é para A4 anotar no caderno; 624 no meio de uma classificação de cores A3 utiliza o termo fluorescente também.

$\checkmark$ “Classificação das cores"- pode ocorrer seja para identificação das mesmas no espectro observado, seja para classificação dos espectros ou ainda para definição da menor ou maior banda, e como exemplos desses casos, temos: 512 e 513 aluno não identificado classifica as cores que está vendo enquanto outros respondem o tipo de espectro; 580 aluno não identificado informa as cores que está vendo, depois que o professor pergunta quantas cores os alunos enxergam; 581, A5 também classifica as cores que enxerga; 585, A5 afirma que existe um monte de cores no espectro que está olhando; 587, 588, 589, 591 e 591 alguns alunos citam algumas cores; 595, A2 afirma que não vê o azul discordando de outros alunos; 596 um aluno cita a cor anil que não havia sido citada ainda; 597 um aluno não identificado afirma que as cores que está vendo são bem definidas; 598 outro aluno diz que vê mais clarinho; 599, A3 afirma que aparece um "flashinho" uma provável referência ao flash da câmara para indicar claridade; 601 aluno não identificado respondendo ao professor que perguntou qual cor aparece mais espalhada, indica a cor vermelha; 602 outro aluno cita o verde; 603 um terceiro cita o vermelho; 604 outro menciona o verde claro e o amarelo; 622, A3 afirma que a cor violeta aparece "mais forte"; 624, A3 cita a cor violeta novamente, a verde e a amarela; 625 e 626, A3 afirma que a verde é a cor que representa a banda mais larga.

O indicador "classificação dos espectros" é muito importante nesse momento da aula, pois mostra bem as dificuldades e confusões por parte dos alunos; já o indicador "classificação das lâmpadas" mostra a associação que A5 faz em relação à atividade de campo, embora isso não seja explorado; e por fim no indicador "classificação das cores", notamos novamente muita dificuldade em definirem as cores que enxergam e não conseguem chegar a um consenso. 
O indicador "justificativa" aparece nos turnos 564 e 565 quando A3 justifica sua classificação em espectro contínuo devido à presença do gás, embora esteja incorreta, em seguida justifica a presença do espectro contínuo e discreto por causa da presença (também) do filamento, embora tenha feito confusão, apresenta justificativas; essa sequência também pode ser considerada como "explicação", porque A3 utiliza informações já levantadas para completar seu raciocínio.

\section{Outras informacões relevantes:}

Novamente predomina a interação P/T, com algumas interações A/A e Ax/Ay.

Nesse momento da aula A4 reduz muito sua participação e A3 tem um destaque maior em relação ao momento anterior. A1, A5 e A6 também aparecem, porém o destaque fica mesmo para participação de A3.

Aqui apesar das tentativas do professor, os alunos acabam confundindo a classificação dos espectros e sentem dificuldades em realizar as associações que o professor deseja.

Nessa sequência os alunos acabam respondendo aos questionamentos do professor e apresentam poucas interações diferentes do que está sendo solicitado pelo mesmo. 


\section{Episódio 1 - atividade de observação de lâmpadas diversas para identificação de seus espectros}

\section{Momento 5 - observação da $4^{\mathrm{a}}$ lâmpada (dicróica) e $5^{\mathrm{a}}$ lâmpada (dicróica com filtro azul)}

Ver tabela de transcrição e análise (anexo p. 274).

\section{Descrição da aula:}

Este momento representa a observação de uma lâmpada dicróica e de uma lâmpada dicróica com filtro azul.

A observação dessas lâmpadas ocorre imediatamente após a observação da lâmpada mista. Parte desse momento ocorre com pouca iluminação, o que dificulta a identificação de alguns alunos quando falam e também a observação dos gestos e manipulação dos espectroscópios.

Podemos dividir esse momento em duas etapas distintas:

- $\quad$ Observação da lâmpada dicróica (do turno 636 ao 679).

- $\quad$ Observação da lâmpada dicróica com filtro azul (do turno 680 ao 750).

Segue uma rápida descrição dessas etapas:

Do turno 636 ao 679:

No turno 636, A5 afirma que a nova lâmpada "é da hora" numa forma de demonstrar seu interesse. Logo no turno seguinte o professor informa que a lâmpada é dicróica e tem foco dirigido.

A5 associa essa lâmpada à de farol de carro e também à "luz de motel".

No turno 646, A3, mesmo sem ser solicitado, começa a identificar a quantidade de cores que está vendo e no turno 654, A1 classifica o espectro como contínuo, também sem ser solicitado.

No turno 656, A3 pergunta o tipo da lâmpada, ele mesmo responde que é dicróica e depois tem sua fala confirmada pelo professor. 
No turno 661 o professor pergunta se já terminaram. No turno 666 ele pergunta, caso a lâmpada tenha espectro contínuo, quais as cores que devem aparecer e A1 responde que todas, enquanto A4 vai informando as cores que está enxergando.

Nos turnos 672 e 673, A5 destaca as cores que aparecem mais e menos, A3 por sua vez cobra do professor o tempo de aula, que segundo ele já extrapolou. A5 fica surpreso com a atitude de A3. A4 está preocupado com as anotações, e A5 pede uma lâmpada de luz negra para o professor que está trocando a lâmpada.

\section{Do turno 680 ao 750 :}

Aluno não identificado pergunta se é luz branca para o professor no turno 680, e obtém como resposta que é lâmpada dicróica com filtro azul.

Já no turno 683 aluno não identificado cita algumas cores e novamente cita outras cores no turno 686.

O professor pergunta sobre o espectro dessa lâmpada no turno 687. Os alunos continuam citando as cores que estão vendo e as que faltam.

No turno 693 o professor fornece uma nova informação sobre a caracterização dos espectros. No turno 694, A3 quer saber que tipo de lâmpada dicróica é essa.

No turno 698 o professor pergunta sobre o tipo de espectro da lâmpada. Já nos turnos 703 e 705 ele questiona se existem linhas no meio do espectro; no 708 se dá para ver o formato da lâmpada e se as cores aparecem separadas. Os alunos mostram indecisão sobre a classificação do espectro. No turno 716 o professor solicita nova classificação, e obtém como resposta que o espectro é discreto, e as cores estão todas misturadas.

Turno 717: Ani: É contínuo.

Turno 718: Ani2: Tá tudo junto...

Turno 721: A2: Tá tudo misturado professor.

Na sequência seguinte (a partir do turno 722), o professor questiona sobre o filtro azul e o que ele traz como consequência. Essa sequência com interação com os alunos segue até o turno 750 .

\section{Análises:}

Em relação ao envolvimento com a atividade, logo no início deste momento, notamos a empolgação de A5 com a lâmpada:

Turno 635: A5: Essa outra é da hora. 
Importante observarmos essa empolgação, pois com a lâmpada mista os alunos já demonstravam cansaço e muita dificuldade na identificação dos espectros.

A5 também busca associar a lâmpada dicróica com outras, citando a de farol de carro e a de "luz de motel".

Como indicativos de envolvimento com a atividade temos ainda:

Os alunos não necessitam de uma solicitação direta do professor para organizarem suas observações, como no caso de A1 no turno 646 que já começa a contar as cores que está observando e no turno 655 começa sua classificação do espectro observado:

\section{Turno 655: A1: Ela é contínua.}

A busca por melhores condições ou posições para realizarem a observação, como no turno 648 quando um aluno não identificado pede que o professor deixe a caixa com a lâmpada em determinada posição, ou ainda no turno 650 quando A3 solicita que o professor vire a lâmpada para seu lado.

A prontidão nas respostas às perguntas que o professor faz, como no turno 672 em que o professor comenta sobre quais as cores não aparecem, qual aparece mais (maior banda) e qual aparece menos (menor banda) e obtém resposta de A5. Também serve de exemplo o turno 705 quando o professor pergunta se aparecem linhas no meio do espectro e vários alunos respondem que não. Destacamos ainda o turno 708, o professor questiona se as cores estão separadas e obtém como resposta, "não". Do turno 722 ao 745, o professor procura destacar a função do filtro utilizado na lâmpada dicróica e faz várias perguntas aos alunos, estabelecendo uma relação dialógica.

Percebemos também alguns fatos que demonstram cansaço e uma dispersão por parte de alguns alunos na realização da atividade:

$\checkmark \quad$ Muita conversa e gritos durante a observação que parecem indicar uma dispersão por parte dos alunos. Apenas destacamos que, por possuir um foco dirigido, a lâmpada dicróica ilumina mais alguns pontos da sala e a escuridão durante a observação pode ter contribuído para que os alunos fizessem um pouco mais de barulho.

Do turno 662 ao 665, A4 e A5 realizam uma conversa que não está relacionada à atividade, bem no momento em que os demais alunos realizam suas observações e após um pedido do professor para que realizassem rapidamente as observações e anotações.

No turno 674, A3 questiona o professor sobre o tempo da aula, que segundo ele já estaria muito longo. E o mesmo A3, de forma dispersa, pede que o professor tire a lâmpada no turno 677. 
Em relação às linguagens, a manipulação dos espectroscópios continua e podemos notar, nos momentos em que a iluminação permite, que os alunos continuam com o espectroscópio no olho realizando suas observações, e nos turnos 648 e 650 quando procuram melhores posições para observação, com certeza é para observação com o espectroscópio.

Devido à sala permanecer com pouca iluminação durante a maior parte desse momento não tivemos a imagem para confirmar a intensa manipulação dos espectroscópios, mas de uma forma indireta, podemos perceber essa manipulação nos momentos em que eles identificam as cores ou a quantidade de cores que estão observando, como nos turnos: 646, A1 afirma que vê três cores; 669, A4 destaca as cores que está observando; 672, A5 ressalta a cor que aparece mais e a que aparece menos; 683, A2 também destaca as cores que está enxergando já com a lâmpada dicróica com filtro azul; 686 e 688 um aluno não identificado também comenta as cores que está enxergando; 689 aluno não identificado destaca a cor que está faltando; 691 outro aluno destaca outra cor que está faltando; 704 quando os alunos respondem que não parecem linhas no espectro, após pergunta do professor; 706 dizem ao professor que não há linhas no espectro; 709 e 711 respondem que as cores não estão separadas; 718 aluno não identificado afirma que (as cores) estão todas juntas. Portanto, podemos dizer que a linguagem oral neste caso foi muito importante para constatarmos a manipulação dos espectroscópios.

Em relação manipulação de materiais, temos como exemplos os turnos: 678 quando A4 solicita que A3 fale as cores e realize as anotações para depois conferirem; 719, A3 solicita que A4 anote as cores que ele está observando. A ausência de iluminação também reduz nossa observação em relação às anotações que os alunos realizam.

A linguagem oral é imprescindível neste momento da atividade, principalmente devido à falta de iluminação que dificulta a observação de outras linguagens, como a manipulação de materiais e gestual. Como dissemos anteriormente a linguagem oral contribuiu inclusive, de uma forma indireta, para notarmos a manipulação dos espectroscópios.

Aparecem interações P/T e A/A também com Ax/Ay.

Como alguns exemplos importantes de linguagem oral para realização da atividade, destacamos os turnos: 638 e 644 quando A5 busca associar a lâmpada dicróica com outros tipos de lâmpadas; 646, A1 ao identificar quantas cores está enxergando no espectro; 655 A1 classifica o espectro como contínuo; 656, A3 indaga sobre o nome "da luz", ou seja, sobre o tipo de lâmpada que estão observando; do turno 666 ao 671 o professor questiona sobre as cores que devem aparecer num espectro contínuo e quais as que os alunos estão enxergando, bem como as que aparecem mais e menos no espectro, nessa sequência os alunos respondem 
diretamente ao professor; 680 um aluno não identificado pergunta se a nova lâmpada (a dicróica com filtro azul) corresponde à (luz) branca e obtém resposta do professor que afirma se tratar de uma lâmpada dicróica ainda, porém com um filtro azul; 683 um aluno já começa a organizar as cores que está enxergando; 686 um aluno não identificado também destaca as cores que está enxergando; 687 o professor interroga sobre o espectro da lâmpada, porém os alunos destacam as cores como no turno 688 e as cores que faltam nos turnos 689 e 691 .

No turno 693 o professor fornece mais informações sobre as características dos tipos de espectros a fim de buscar facilitar a classificação dos alunos, porém não obtendo respostas, o professor inicia uma sequência de falas do turno 703 ao 716 em que, por meio da ausência ou presença de linhas entre as cores, ele busca a classificação por parte dos alunos. Finalmente obtém como resposta, no turno 717, um aluno não identificado que o espectro é contínuo e tal fala é reforçada por outro aluno no turno 718 quando afirma que estão todas (as cores) juntas.

Do turno 722 ao 745, o professor estabelece um diálogo com os alunos com o objetivo de destacarem a finalidade do filtro azul utilizado nessa lâmpada.

Podemos afirmar também que a linguagem oral foi muito importante para acompanharmos a forma como os alunos estão se apropriando dos conhecimentos, na observação de importantes aspectos epistemológicos.

Sobre a linguagem gestual não contamos com imagens relevantes devido à ausência de iluminação.

Em relação à apropriacão de termos técnicos notamos A1 no turno 655 classificando rapidamente o espectro da lâmpada como contínuo, porém sem apresentar justificativas para tal classificação, que não é contestada, mas no turno 666 o professor pergunta sobre quais cores devem aparecer se o espectro for contínuo e os alunos respondem que todas as cores. Em seguida, no turno 671 o professor questiona quais as cores que não aparecem (lembramos que no turno 646, A1 afirmara ter observado apenas três cores), quais aparecem mais e menos.

Com isso o professor parece ter a intenção de colocar em dúvida a classificação de A1 como espectro contínuo, já que os alunos afirmam que um espectro contínuo deve apresentar todas as cores conforme informação fornecida anteriormente, e em suas observações, percebem a ausência de algumas.

Notamos os alunos destacando as cores que aparecem mais e menos, embora discordem delas, porém não observamos eles destacarem qual cor não se evidencia. Também 
não temos um retorno do professor antes da troca da lâmpada dicróica pela dicróica com filtro azul no turno 680 .

No turno 687 o professor pergunta sobre o espectro da lâmpada dicróica com filtro azul. Como resposta um aluno não identificado cita as cores vermelha, verde e violeta; outro aluno diz que falta a cor amarela e um terceiro diz não ter a cor vermelha.

Não obtendo a resposta sobre a classificação do espectro, o professor inicia uma série afirmações e de questionamentos no turno 693, tentando facilitar a classificação por parte dos alunos.

No turno 693 o professor apresenta uma nova informação sobre a caracterização dos espectros:

Turno 693: P: Pessoal, se tem, presta atenção, se tem todas as cores, isso indica que o espectro provavelmente seja contínuo, o contrário não é verdadeiro.

Com essa fala o professor procura mostrar que a presença de todas as cores é uma característica do espectro contínuo, no entanto a ausência de cores não identifica um espectro discreto. Essa informação é nova e importante para o momento da aula.

No turno 698 o professor pergunta novamente sobre o espectro da lâmpada e não conseguindo resposta objetiva, nos turnos 703 e 705 pergunta se aparecem linhas no espectro e os alunos respondem que não. Nos turnos 708 e 710 o professor indaga se dá para ver o formato da lâmpada e se as cores estão separadas. Os alunos respondem que não.

No turno 714 um aluno não identificado afirma que o espectro é contínuo, porém A2 no turno seguinte diz que é discreto, surgindo dúvidas por parte dos alunos em relação à classificação do espectro da lâmpada dicróica.

No turno 716 o professor questiona novamente sobre o espectro da lâmpada. No turno 717 um aluno não identificado diz que é contínuo e no turno 718 outro aluno consolida essa classificação afirmando que (as cores) estão juntas:

Turno 714: Ani: É contínuo.

Turno 715: Ani: Tá tudo junto...

No turno 721 A2 ainda comenta que "está tudo misturado".

Não obtemos uma confirmação nem uma resposta definitiva por parte do professor. Ficamos sem saber se os alunos realmente compreenderam que mesmo com algumas cores faltando, o espectro é contínuo, pois não possui linhas separando as cores, ou seja, elas aparecem "juntas" de forma contínua; ou se ainda estão confusos sobre o fato de que não aparecendo todas as cores, o espectro deveria ser discreto. Sentimos a necessidade de mais 
diálogos e questões sobre esse momento Entretanto, verificamos uma sequência em que o professor procura destacar a função do filtro azul.

Nos turnos seguintes, mais precisamente do turno 722 ao 745 , o professor busca trabalhar com os alunos a função do filtro azul. No turno 722 quando questiona o que o filtro faz, obtém as seguintes respostas nos turnos: 723 A3 afirma que acaba com as luzes; 724 A5 diz que fica azul (a luz); 726, A2 afirma que a s cores ficam mais próximas; 727 A5 confirma que (a luz) fica mais azul.

No turno 728 o professor pergunta se a luz vermelha passa pelo filtro azul e adquire as seguintes respostas nos turnos: 729, A3 afirma que não passa; 730, A4 diz que ficará preto, depois que não sabe ao certo que cor ficará; 731, A3 diz que vai ficar preto.

Interessante que neste momento A2 contraria a fala de seus colegas afirmando que enxergou o vermelho:

Turno 732: A2: Não. Mas aí dá para ver o vermelho.

A2 confia em sua observação para contrariar as afirmações de A3 e A4. A3 ainda fala que não dá para ver, porém o professor solicita que observe de novo e no turno 735, A3 acaba concordando com A2 que realmente consegue enxergar a cor vermelha.

Nos turnos seguintes até o turno 745, o professor relembra com os alunos que em outras lâmpadas a cor vermelha sempre aparecia com grande destaque, geralmente representando a maior banda, já com a presença do filtro azul, quase não enxergamos a cor vermelha. Conclui afirmando que o filtro não funciona $100 \%$, apesar disso, consegue diminuir bastante as frequências mais distantes do azul que passam pelo filtro.

Em relação aos termos técnicos os alunos utilizam normalmente os termos "contínuo" e "discreto", porém não ficam à vontade para classificarem o espectro da lâmpada dicróica e nem da dicróica com filtro azul. Embora não apresentem uma justificativa explícita, os alunos destacam não enxergar todas as cores, no entanto enxergam as cores juntas e não percebem linhas entre elas. Como as informações que os alunos tinham anteriormente afirmavam que a presença de todas as cores caracterizava o espectro contínuo, a ausência de algumas delas deve ter levado a acharem que o espectro é discreto, mas ao mesmo tempo não perceberam linhas entre as cores, uma caracterização do espectro contínuo. Isso parece ter levado a uma confusão que refletiu com poucos alunos classificando a lâmpada e ainda com algumas discordâncias.

Com relação à função do filtro azul, parecem ter compreendido por ter concordado com aquilo que observaram.

Faltaram questões que esclarecessem melhor as classificações que fizeram. 
No que diz respeito aos conceitos envolvidos, percebemos os alunos ficarem um pouco confusos em relação às características que definem o espectro contínuo e o discreto, devido as suas observações, já que não enxergavam todas as cores (característica que acreditavam ser do espectro discreto) e ao mesmo tempo não enxergavam linhas separando as mesmas (característica do espectro contínuo). Apesar das explicações do professor e da última classificação ter sido correta, não podemos afirmar que os alunos realmente tenham compreendido, pois não apresentam justificativas ou argumentos elaborados nessas classificações.

Também não temos nenhuma referência aos motivos que levam a um tipo ou outro de espectro.

Sobre argumentacão quase não temos falas que representem exemplos, segundo Toulmin (1958), porque os alunos em geral respondem a questionamentos do professor, porém sem apresentarem justificativas. Uma exceção, mas mesmo assim considerando de forma coletiva, acontece nos turnos 717 quando um aluno não identificado afirma que o espectro da lâmpada é contínuo e no 718 outro aluno diz que (as cores) estão separadas. Nesses turnos podemos identificar o dado representado pela observação que fizeram com o espectroscópio, portanto um dado obtido e empírico (Jiménez Aleixandre, 1998). A conclusão é apresentada no turno 717 quando um aluno afirma que (o espectro) é contínuo, já a justificativa aparece no turno seguinte, outro aluno explica que (as cores) estão todas juntas, praticamente confirmando a classificação do espectro como contínuo.

É interessante notarmos que durante todo esse momento o professor busca a classificação do espectro da lâmpada dicróica ou da dicróica com filtro azul e como os alunos demonstram dificuldades e dúvidas na classificação, ele fornece informações como se fossem "pistas" para que os alunos cheguem a uma conclusão.

Podemos considerar o momento como um exemplo de argumentação (Toulmin, 1958) se considerarmos as observações como dados obtidos e empíricos (Jiménez Aleixandre, 1998) e informações como no turno 693 quando o professor afirma que a presença de todas as cores indica que o espectro é contínuo, mas a ausência de algumas não indica que seja discreto, como dados fornecidos (Jiménez Aleixandre, 1998). A conclusão pode ser considerada a afirmação no turno 717 quando o aluno afirma que o espectro é contínuo e as justificativas aparecem nas falas em que os alunos com a ajuda do professor afirmam ver as cores juntas (turno 718), e nos turnos nos quais afirmam que não enxergam as linhas no meio do espectro e que as cores não estão separadas. Portanto, um exemplo de argumentação construída coletivamente. 
Utilizando o modelo de Van Eemeren et al. (1987) adaptado por Villani e Nascimento (2003) podemos observar de uma forma geral um discurso (D) do locutor representado pela fala do professor (S), seja na sequência em que busca a classificação do espectro feita pelos alunos, seja na sequência que procura explicar a função do filtro azul na lâmpada dicróica.

As falas e informações do professor, as falas e observações dos alunos representam o contexto que contribui para o discurso interpretado (D') por parte dos alunos que são os ouvintes (L). Teríamos mais condições de analisar como o conhecimento é assimilado pelos alunos caso tivéssemos mais perguntas específicas sobre suas afirmações e falas, como por que classificaram o espectro como contínuo, ou alguma pergunta para verificar se entenderam a função do filtro adequadamente.

Em relação aos indicadores de alfabetizacão científica, predominam organização e classificação.

O indicador organização aparece nas seguintes formas:

Organização para realização da atividade: temos poucos exemplos neste momento, pois os alunos já estão mais acostumados com as observações, mesmo assim, identificamos alguns turnos, como: 640 quando A3 pergunta se a lâmpada observada tem gás ou filamento; 656, A3 pergunta sobre o nome da lâmpada; 678, A4 pede que A3 vá falando e anotando para que eles possam conferir depois; 680 aluno não identificado pergunta se a nova lâmpada (dicróica com filtro azul) é luz branca.

Organização para observação com os espectroscópios: os alunos buscam a melhor forma para realizarem as observações. Ainda encontramos alguns exemplos nesse momento, como nos turnos: 648 um aluno não identificado solicita ao professor que deixe a caixinha (de luz) em determinada posição para que realize suas observações; 650 quando A3 pede para virar a caixa em uma posição que facilite sua observação; 668, A5 também solicita que vire (a lâmpada) em sua direção; 732 quando A2 afirma que dá para ver (a cor vermelha) “aí" (do espectro que aparece no espectroscópio).

Organização para classificação dos espectros: continua aparecendo afinal continuamos com a classificação dos espectros. Destacamos os turnos: 646, A1 cita a presença de três cores; 667, A1 afirma que para um espectro ser contínuo devem aparecer todas as cores, após pergunta do professor; 704 e 706 quando vários alunos respondem ao professor que não aparecem linhas no meio do espectro; 711 vários alunos respondem ao professor que as cores não aparecem separadas; 718 quando aluno não identificado afirma que as cores estão todas juntas; 721, A2 fala que as cores estão misturadas. 
Organização buscando associação de variáveis: aparece nos turnos: 638 quando A5 associa a luz da lâmpada dicróica com a luz de farol de carro; 644, A5 associa a luz da lâmpada com a "luz de motel".

Organização para compreensão a função do filtro azul: é um novo tipo de organização que identificamos em que os alunos organizam ideias e observações anteriores com auxílio do professor, visando entenderem a ação do filtro azul. Ocorre praticamente na sequência final desse momento, como nos turnos: 732 quando A2 afirma que é possível enxergar a cor vermelha no canto do espectro; 738, 740, 742 e 744, A1 e A3 respondem ao professor que nas outras observações o espectro relacionado ao vermelho não era pouco, era forte, representava a maior banda e era muito larga; 744, A3 diz ao professor que agora (com a presença do filtro azul) "não dá nem para aparecer".

O indicador classificação aparece nas seguintes formas:

Classificação do tipo de espectro: esse indicador aparece nos seguintes turnos: 655, A1 classifica o espectro como contínuo; 714 aluno não identificado classifica como contínuo; 715, A2 classifica como discreto; 717 aluno não identificado classifica como contínuo também; 718 outro aluno não identificado ao afirmar que (as cores) estão todas juntas parece classificar como contínuo o espectro, confirmando a classificação do turno anterior. A baixa incidência desse indicador contribui para percepção de que os alunos demonstram insegurança para classificação desse espectro.

Classificação relacionada ao tamanho da banda dos espectros aparece muito pouco, praticamente nos turnos: 672 quando A5 afirma que a cor que aparece mais é a verde e a que aparece menos é a azul; 673 A5 contrariando sua fala anterior afirma agora que a cor verde aparece menos.

$\checkmark \quad$ Classificação do tipo de lâmpada: talvez pela importância da classificação do tipo de lâmpada na tentativa de associar ao tipo de espectro apresentado no momento anterior (com a lâmpada mista), turno 640, A3 questiona se a lâmpada tem gás ou filamento; no turno 656 A3 questiona sobre o nome da lâmpada e no turno 658 o próprio A3 comenta ser dicróica e obtém a confirmação do professor no turno 659 e no 660 repete sua afirmação. No turno 680 um aluno não identificado questiona se a lâmpada dicróica com filtro azul representa uma "luz branca". Temos ainda outros exemplos nos turnos: 694 quando A3 quer saber tipo de lâmpada dicróica estão observando; 695 e 696, A5 afirma que é "azul”; 697 o próprio A3 afirma que é com filtro azul (dicróica com filtro azul).

Classificação das cores: pode ocorrer, seja para identificação das mesmas no espectro observado, seja para classificação dos espectros, ou ainda para definição da menor ou 
maior banda, e como exemplos desses casos temos: 669, A4 classifica as cores que está observando: vermelha, azul, lilás e amarela; 670 aluno não identificado destaca a cor laranja; 672 A5 além de falar as cores que aparecem mais e menos, parece indicar as cores que está observando destacando a azul, verde e vermelha; 683 um aluno não identificado, mesmo sem ser solicitado, já comenta as cores que está observando no espectro da lâmpada dicróica com filtro azul: verde, azul, anil e violeta; 686 aluno não identificado destaca as cores vermelha, verde e violeta; 689 afirma que a cor amarela está faltando; 691 após o professor dizer que faltam duas cores, um aluno não identificado diz que não enxergou a cor vermelha; 719 e 720 A3 e A4 destacam as cores que devem anotar: violeta e azul.

O indicador "classificação das cores" é importante, pois demonstra que de uma forma geral os alunos conseguiram enxergar e perceber as cores que se destacaram no espectro da lâmpada dicróica com filtro azul, já que citam as cores: verde, azul, anil e violeta e também destacam não enxergarem a cor amarela e vermelha. Pela explicação construída com o professor, vimos que o filtro apesar de não ser $100 \%$, realmente dificulta a passagem das frequências mais afastadas do azul, por isso a dificuldade em ver as cores mais próximas do vermelho.

Já o indicador "classificação dos espectros" demonstra insegurança e dificuldade por parte dos alunos em definirem o tipo de espectro observado, provavelmente por acreditarem que o espectro possuía características tanto do espectro discreto (já que não apareciam todas as cores) e do contínuo (já que não existiam linhas separando as cores). O professor tentou resolver o impasse destacando que a presença de todas as cores indica um espectro contínuo, porém a ausência de algumas não indica necessariamente que ele seja discreto e sugeriu a classificação pela presença ou ausência das linhas entre as cores observadas.

Com a "classificação das lâmpadas", notamos A5 buscando associar a lâmpada observada na sala com outras, mas tal fato novamente não é aproveitado.

Nesse momento da aula sentimos a ausência de mais indicadores "justificativa", pois seria muito interessante verificar de uma forma mais direta e com a ajuda da linguagem oral como os alunos estão assimilando seus conhecimentos e elaborando suas falas e ideias, entretanto a ausência de perguntas relacionadas a "como" e "porque" deram suas respostas, praticamente impossibilitaram a presença desse indicador.

Apenas no turno 718 temos um aluno não identificado que justifica a fala do turno anterior, que classificava o espectro como contínuo, ao afirmar que as (cores) estão todas juntas, já que essa é uma característica do espectro contínuo. 


\section{Outras informaç̃es relevantes:}

Predomina a interação P/T, com poucas interações A/A e Ax/Ay.

Notamos uma boa participação de A2, principalmente quando afirma ver a cor vermelha enquanto seus colegas de grupo acabavam de falar que não dava para enxergar essa cor. Por sua vez A3, apesar de continuar participando, demonstra cansaço.

Talvez preocupado com o tempo restante da aula, o professor não deixou muito espaço para que os alunos apresentassem mais suas ideias e eles próprios se limitaram a responder aos questionamentos sem discutirem muito sobre o que estavam observando. 


\section{Episódio 1 - atividade de observação de lâmpadas diversas para identificação de seus espectros}

\section{Momento 6 - observação da 6 âampada (luz negra) \\ Ver tabela de transcrição e análise (anexo p. 280).}

\section{Descricão da aula:}

Este momento representa a observação de uma lâmpada de luz negra. Praticamente essa observação ocorre do turno 751 ao turno 787.

Segue uma rápida descrição desse momento:

No turno 751 o professor avisa que vai trocar a lâmpada e em seguida coloca a nova lâmpada e informa se tratar da luz negra. No turno 754, A5 pede que alguém dê um sorriso numa brincadeira com referência ao efeito da luz na cor branca dos dentes.

Logo em seguida um aluno não identificado e A1 afirmam que só dá para enxergarem a cor roxa (correspondente ao violeta). No turno 757 o professor pergunta qual o tipo de espectro. A5 responde que é roxo e o professor repete a sua pergunta, destacando se é contínuo ou discreto. A5 em tom de brincadeira responde que é "continuamente roxo". No turno 762 um aluno não identificado classifica o espectro como discreto.

No turno 764 pergunta se já observaram as cores que aparecem nesse espectro. No turno 765 um aluno fala que tinha dito ter a cor verde; em seguida uma aluna não identificada afirma que dá para ver o "arco-íris" todo, A4 diz não ver nada, A5 comenta ver a cor branca, verde e laranja e logo a seguir um aluno não identificado pergunta ao professor se não tem a cor laranja.

Um aluno não identificado reclama que já passaram duas aulas (turno 775). E no turno 777, A4 insiste na visualização da cor laranja.

Temos muitas brincadeiras durante a observação da lâmpada, algumas relacionadas à iluminação da mesma e outras sem vínculo com a atividade. No turno 783 o professor lembra que os alunos precisam finalizar o relatório a ser entregue e avisa que na próxima aula falará sobre as características de cada lâmpada observada bem como seus espectros (turno 783).

Nesse momento da aula a iluminação também prejudica um pouco a observação, mas é mais clara do que com a lâmpada dicróica que tinha um foco dirigido. A observação dessa lâmpada foi muito rápida e sem tempo para muitas discussões. 


\section{Análises:}

Em relação ao envolvimento com a atividade, no início da observação com a luz negra notamos euforia por parte dos alunos e alguns comentários sobre ela e sobre o que brilha sob a luz negra. No turno 754, A5 solicita que alguém dê um sorriso numa referência ao efeito da luz negra sobre a cor branca.

A3 expressa sua alegria no turno 761 ao afirmar que essa lâmpada é legal:

Turno 761: A3: Olha que legal!

No início da observação, nos turnos 755 e 756, um aluno não identificado e A1 afirmam que só dá para ver o roxo (violeta) mesmo antes de qualquer pergunta do professor. Após o professor perguntar sobre o espectro da lâmpada, os alunos procuram destacar as cores que estão observando.

Porém, durante a troca da lâmpada, observamos muito barulho e brincadeiras não relacionadas à atividade, e durante a observação temos muitas conversas paralelas. No turno 759 o professor pergunta se o espectro é contínuo ou discreto e obtém como resposta de A5, que é "continuamente roxo", numa brincadeira que embora faça referência à atividade e a cor que estão observando, está errada, já que o espectro é discreto. Tais atitudes demonstram que os alunos estão mais dispersos e menos atentos às observações.

No turno 775 um aluno não identificado chama a atenção do professor em relação ao tempo de aula e no turno 778, A3 reclama que a (observação da) luz dá dor de cabeça.

A observação da luz negra dura praticamente seis minutos e parece ter sido uma boa estratégia do professor deixar essa lâmpada para o final, pois os alunos já demonstram cansaço e estão mais dispersos, porém a luz negra e seus efeitos chamam a atenção. Também após a lâmpada mista, é apresentada uma lâmpada com espectro contínuo (dicróica), e agora outra com espectro discreto (luz negra).

Essa última observação não traz muitas discussões.

Em relação às linguagens, a manipulação dos espectroscópios é notada durante o momento em que os alunos destacam as cores que estão observando e no turno 777, A4 indica uma posição no espectroscópio onde está vendo a cor laranja:

\section{Turno 777: A4: Tá vendo ali é laranja, não é? É laranja mesmo!}

Entre os turnos 781 e 787 os alunos estão agitados, alguns sentam em bancos atrás do grupo, outros estão em pé brincando, mas mesmo assim, percebemos que A1 continua com o espectroscópio em mãos e um aluno atrás dele ainda observa com o espectroscópio.

Nesta sequência de turnos notamos A1 organizando suas folhas, o que representa um exemplo de manipulação de materiais. 
A linguagem oral recebe destaque, pois com a pouca luz na sala, fica difícil a observação dos gestos. É por meio dessa linguagem que percebemos certa dificuldade na identificação das cores.

Inicialmente A1 e um aluno não identificado afirmam ver a cor roxa (violeta), em seguida, outro aluno não identificado faz referência à cor verde no turno 765 . No turno 767 uma aluna não identificada afirma que dá para ver o "arco-íris", ou seja, suas sete cores; outro aluno não identificado afirma que só vê a cor roxa. No turno 769, A4 diz não ver nada e no turno 772, A5 afirma ver a cor branca, verde e laranja. A cor laranja ainda é citada por um aluno não identificado no turno 773 em que solicita a confirmação do professor para presença dessa cor e no turno 777 quando A4 afirma que estava vendo mesmo a cor laranja e chega a indicar verbalmente a posição da cor no espectro.

Nesse momento predominam as interações A/A, mas também temos a interação P/T.

Sobre a linguagem gestual não contamos com imagens relevantes devido à ausência de iluminação. O pouco tempo dedicado a essa observação e falta de questionamentos e discussões também podem ter contribuído para ausência da linguagem gestual, pois, em geral, essa linguagem tem sido utilizada para cooperar com a linguagem verbal.

Em relação à apropriação de termos técnicos, observamos apenas um aluno não identificado classificando o espectro como discreto em resposta dada ao professor, porém não temos nenhuma justificativa para essa classificação. Ao longo da observação, notamos que são citadas apenas algumas cores: roxa (violeta), verde e laranja, o que representa uma característica do espectro discreto, no entanto em nenhum momento os alunos ou o professor estabelecem uma associação entre a classificação e as cores observadas.

Não temos outros exemplos de utilização de termos técnicos nesse momento.

Não conseguimos indício ou referência a conceitos envolvidos neste momento da aula.

Sobre argumentacão não temos nenhuma fala mais organizada que constitua uma argumentação propriamente dita. Nesse momento os alunos apenas classificam as cores e organizam suas ideias e não utilizam nenhum tipo de justificativa.

Com relação aos indicadores de alfabetização científica, notamos a utilização apenas dos indicadores organização e classificação.

O indicador organização aparece nas seguintes formas:

$\checkmark$ Organização para realização da atividade: ainda aparecem exemplos como no turno 752 quando A5 pergunta se pode desligar a lâmpada dicróica com filtro azul para trocar pela lâmpada de luz negra; no turno 785, A3 pergunta se depois poderão mexer 
na internet, provavelmente numa referência à atividade com espectros de estrelas e sobre espectros contínuos e discretos para utilizar o site da Universidade do Rio Grande do Sul, que estaria previsto para aulas seguintes; e por fim, no turno 786, A2 lembra a todos que eles não sabem se na próxima sexta terão aulas, o que impediria a realização da atividade. Esses dois últimos turnos já representam uma organização para próxima atividade, portanto vão além da observação da luz negra.

$\checkmark$ Organização para observação com os espectroscópios: ainda encontramos um exemplo nesse momento. Os alunos buscam melhorar suas observações como no turno: 777 quando A4 afirma ver a cor laranja e indica "ali" como sendo o local em que vê a cor citada no espectroscópio. Essa fala mostra que ele precisou olhar de novo e atentamente, buscando a cor em outra posição no espectro observado. Destacamos que, com lâmpada de luz negra, as cores do espectro aparecem bem distantes, e a cor laranja aparece realmente numa faixa muito fina.

$\checkmark$ Organização para classificação dos espectros: ocorre no momento em que os alunos destacam ou classificam as cores que estão observando, como nos turnos: 755 e 756 quando um aluno não identificado e A1 afirmam que só conseguem ver a cor roxa; 765, um aluno afirma ter notado a presença da cor verde; 767 uma aluna não identificada afirma que a luz apresenta todas as cores do "arco-íris"; 772, A5 destaca as cores branca, verde e laranja; 773 um aluno não identificado pergunta ao professor se tem realmente a cor laranja; 777 quando A4 destaca eufórico que realmente enxergou a cor laranja em determinado local do espectro observado. Embora essa organização de cores possa ser utilizada para classificação dos espectros, não encontramos evidências da associação entre elas e o tipo de espectro observado.

O indicador classificação aparece nas seguintes formas:

$\checkmark$ Classificação do tipo de espectro: evidencia-se quando os alunos tentam responder ao questionamento do professor sobre o tipo de espectro e aparece apenas em alguns turnos como no 758 em que A5 afirma que é roxo, com isso A5 acaba usando uma classificação do espectro baseada na cor que aparece mais. Aqui devemos ter em mente que o espectro da lâmpada de luz negra realmente destaca a cor "roxa" (violeta) logo no início e aos poucos, e com mais atenção observamos outras cores numa faixa bem fina, o que justifica a classificação de A5. Diante de tal classificação, o professor torna sua pergunta mais específica ao questionar se é contínuo ou discreto. Nesse instante A5 faz uma brincadeira, afirmando que é "continuamente roxo". Esse fato mostra certa familiaridade com o termo contínuo, porém a classificação está errada, já 
que o espectro é discreto, mas não temos como saber se neste momento ele apenas enxergou a cor roxa e isso teria confundido sua classificação, ou se somente fez uma brincadeira despretensiosa sem significado maior. Por fim, no turno 762 um aluno não identificado fornece a classificação correta ao afirmar que o espectro é discreto, sem apresentar justificativas. Depois desta classificação o professor não questiona mais sobre o tipo de espectros. A presença de apenas determinadas cores que os alunos destacam pode ser um indicativo que o espectro seja discreto, porém não necessariamente. Não aparece em nenhum momento a citação que as cores estariam separadas que seria a justificativa para classificação como espectro discreto.

$\checkmark$ Classificação das cores: pode ocorrer seja para identificação das mesmas no espectro observado ou para classificação dos espectros, e como exemplos desses casos temos os mesmos turnos apresentados no descritor "organização para classificação dos espectros". Nesse caso os alunos apenas classificam as cores, embora essa classificação tenha potencial para contribuir na nomeação do espectro observado isso não ocorre.

O pouco tempo para essa observação e ausência de questionamentos e discussões dificultou o surgimento do indicador "justificativa".

\section{Outras informações relevantes:}

Predomina a interação A/A, com poucas interações P/A e Ax/Ay. É um momento diferente nesse aspecto, já que o professor fala muito pouco, parece preocupado com a finalização da aula. Porém, as interações entre os alunos também não fornecem muitas informações para compreendermos a organização de suas ideias.

Chama atenção a aluna não identificada no turno 767 que afirma conseguir ver as cores do arco-íris, pois nenhum outro aluno cita mais do que três cores em sua observação. Aqui também não conseguimos identificar o motivo que levou a aluna a realizar tal comentário.

Notamos que os alunos identificam a cor em destaque inicialmente como a roxa. Nos outros momentos eles utilizavam a cor violeta para tal faixa de frequência, porém o motivo pela utilização da palavra "roxo" no lugar de "violeta" deve estar associado ao fato dessa faixa de frequência aparecer em destaque no espectro dessa lâmpada sem aparecer ao lado do azul e anil e aparentemente estar mais escura. 


\title{
Episódio 1 - atividade de observação de lâmpadas diversas para identificação de seus espectros
}

\author{
Momento 7 - final da aula \\ Ver tabela de transcrição e análise (anexo p. 281).
}

\section{Descricão da aula:}

Este momento representa o final da aula com a atividade de observação dos espectros das lâmpadas. Praticamente ocorre do turno 788 ao turno 812. É caracterizado por ser uma aula expositiva, na qual predomina a fala do professor que utiliza uma apresentação em Power point para sistematizar alguns pontos da atividade e fornecer algumas informações novas. São poucas as falas dos alunos nesse momento.

Segue uma descrição desse momento:

No turno 788 o professor solicita aos alunos que, se sentem e fiquem calmos, já que, ao final da observação com a lâmpada de luz negra, os alunos ficaram muito agitados e chegaram inclusive a levantar e mudar de local como no caso de A6 e A7 que sentam nos bancos atrás da bancada onde estavam; A3 encontra-se em pé brincando com o grupo, A2 brinca com A5, A3 senta no seu lugar e A6 volta ao lado de A1 que organiza suas folhas. Nesse instante temos muitos gritos e barulhos.

No turno 790 o professor solicita que terminem o relatório e lembra que este deve ser entregue no final desta aula. Nesse instante o professor liga o Power point e começa a citar as lâmpadas que observaram, iniciando com a lâmpada incandescente e pede para que olhem a temperatura que o filamento pode atingir. No turno 791, A3 responde que o filamento pode atingir até 2500 graus Celsius.

No turno seguinte (792) o professor confirma a informação de A3 e explica que, além da luz visível, essa lâmpada emite infravermelho que está associado ao calor, exemplificando também com a radiação que sentimos quando aproximamos a palma da mão do rosto. Portanto, a lâmpada incandescente, além de iluminar, também esquenta o ambiente.

O professor ainda informa que para uma lâmpada de $60 \mathrm{~V}$ e $100 \mathrm{~W}, 14 \%$ da energia é convertida em luz e $80 \%$ ou um pouco mais é convertida em calor, trabalhando a idéia de potência e rendimento e destacando que na lâmpada incandescente a maior parte da energia é perdida na forma de calor. Nesse instante os alunos já estão sentados olhando para televisão 
que está conectada ao computador e que passa a apresentação em Power point. Apesar da baixa eficiência, o professor destaca que a lâmpada incandescente dá uma boa sensação para quem está num ambiente iluminado por ela, pois apresenta um espectro contínuo, mas não justifica tal afirmação.

Após essa fala, o professor comenta sobre as lâmpadas a gás que duram um tempo maior (cerca de 3000 horas) e sobre os efeitos benéficos das radiações, como no caso de crianças que nascem com icterícia e os rins não funcionam adequadamente para eliminar a substância do sangue das crianças, o que resulta numa cor amarelada nelas. O professor comenta que existe um nível que é considerável aceitável para isso.

Até esta parte da aula, os alunos estavam em silêncio e atentos a fala do professor, inclusive A4 o observava atentamente, e A1 presta atenção enquanto arruma suas folhas de caderno. Porém, nesse instante os alunos voltam a falar um pouco e o professor solicita silêncio novamente. A4 aproveita para notar uma lâmpada do teto com outro espectroscópio com diâmetro pequeno.

Em seguida, o professor continua sua informação sobre a icterícia, avisando que, ao levarem o bebê para casa, os pais precisam dar banho de sol nelas, para auxiliar o funcionamento dos órgãos com o objetivo de eliminar essa substância e diminuir a icterícia. Ainda informa que acima de 15 pontos de intensidade, a criança precisa tomar banho de luz no hospital.

Neste instante no turno 794 uma aluna não identificada comenta que sua sobrinha tomou esse banho de luz durante 15 dias. Tal comentário demonstra que os alunos estão atentos.

No turno 795 o professor complementa a observação da aluna comentando que provavelmente o nível estava muito elevado. Em seguida, ele explica que quem tem forro pode utilizar a lâmpada dicróica com filtro azul, pois o calor não passa pelo filtro e vai para cima do forro, enquanto a parte de baixo recebe mais luz e menos infravermelho. Após comentar o fato de não esquentar tanto o ambiente, o professor comenta que a lâmpada dicróica é aquela com foco dirigido e uma lâmpada fluorescente de $11 \mathrm{~W}$ pode emitir a mesma luz propiciada por uma incandescente de $100 \mathrm{~W}$, procurando mostrar que a fluorescente possui um rendimento maior que a incandescente. Nesse mesmo turno o professor pergunta se a lâmpada que está mostrando é fluorescente ou fosforescente e obtém como resposta que é fluorescente, em seguida questiona sobre qual a diferença entre lâmpada fluorescente e fosforescente. A resposta aparece na fala de um aluno não identificado: 
Turno 798: Ani: Fosforescente é aquela que acende quando tudo está apagado, por causa da energia recebida.

O turno seguinte o professor parabeniza Ani e logo depois acrescenta que a lâmpada fluorescente recebe energia e logo emite, enquanto a fosforescente recebe energia mais lentamente e mesmo depois que para de receber, continua emitindo luz. Em seguida professor e alunos citam exemplos como interruptor e "enfeites de quarto" que são colocados em tetos ou paredes.

No turno 804 o professor fala sobre as lâmpadas de vapor de mercúrio ou sódio, utilizadas em iluminação pública. Comenta que a lâmpada de mercúrio possui um "tom" mais esbranquiçado enquanto a de sódio, uma luz mais amarela. Explica que a cor amarela está relacionada ao gás que emite radiações cujo espectro está mais próximo das frequências amarela e laranja.

No turno 805, A5 pergunta qual das duas lâmpadas é a melhor. Lembramos que A5 sempre falava da "luz de poste amarelo" durante as observações dos espectros, provavelmente se referindo a uma lâmpada de sódio.

No turno 806 o professor parece responder que as duas lâmpadas são boas, porém sua fala é interrompida por uma aluna não identificada que nota que já passaram duas aulas.

No turno 808 o professor pede mais um minuto de atenção e fala sobre as linhas dos espectros:

Turno 808: P: Só mais um detalhe: nós olhamos algumas lâmpadas a gás e algumas tinha linha aí no meio do espectro, essas linhas são como a impressão digital do gás, se tem tais linhas é mercúrio, se tem outras tais é hidrogênio, outras tais linhas ... então, cada gás emite uma certa quantidade de linhas e certas cores, e foi isso que fizemos aqui hoje. Estávamos distinguindo o tipo de substância que tem dentro da lâmpada. Então nós voltamos e faremos outra atividade parecido com isso. Pessoal, muito obrigado. Foi muito bom... (Aplausos).

Com essa fala o professor praticamente deixou um "gancho" para a atividade do “Astrônomo Mirim” que será desenvolvida na próxima aula, além de levantar a questão da identificação de substâncias e elementos por meio da análise dos espectros das lâmpadas.

Nos turnos seguintes alguns alunos perguntam se é para deixar o relatório e se podem levar o espectroscópio.

Mesmo após o final da aula, um aluno procura o professor para mostra sua pesquisa de campo e tentar tirar algumas dúvidas.

\section{Análises:}


Em relação ao envolvimento com a atividade, devemos destacar que para realização dessa atividade o professor precisou trabalhar com duas salas ao mesmo tempo, pois as demais classes da escola foram dispensadas e não teria sentido que uma classe aguardasse para ter a última aula. Era uma sexta-feira no período noturno e mesmo nos instantes finais, após o término da aula, os alunos permaneceram em silêncio para ouvir o professor, no final aplaudiram e ainda saíram de forma organizada, enquanto alguns alunos ainda ficaram para conversar com o professor.

Com certeza isso demonstra um comprometimento dos alunos com o professor e com a atividade realizada. Lembramos que, com a dinâmica intensa da aula, apenas na análise das lâmpadas dicróicas alguns alunos começaram a reclamar do horário, ainda em número muito pequeno (dois ou três alunos).

Nessa parte final temos também momentos como no turno 792, que os alunos olham atentamente e prestam atenção nas falas do professor e do mesmo modo organizam suas folhas e anotações. Temos ainda como exemplos o turno 794 quando uma aluna não identificada comenta do caso de icterícia de sua sobrinha, e no turno 805 quando A5 pergunta sobre qual lâmpada seria a melhor, a de mercúrio ou de sódio. Esses turnos demonstram envolvimento dos alunos com a atividade.

Em alguns instantes o professor precisou solicitar silêncio, mas obteve um rápido e bom retorno por parte dos alunos na aula.

Em relação às linguagens, a manipulação dos espectroscópios poderia nem aparecer nesse momento, porém ainda flagramos A4 olhando para lâmpada do teto com um espectroscópio com diâmetro pequeno, enquanto o professor falava sobre lâmpadas a gás e sobre icterícia no turno 793.

A manipulação de materiais aparece na forma de organização das folhas e cadernos que realizaram as anotações, como no caso de A1 que também no turno 792 arruma as folhas de seu caderno enquanto presta atenção à fala do professor.

A linguagem oral prevalece nesse momento, com predomínio da fala do professor. Ocorrem algumas interações P/A. Por meio da linguagem oral,1 notamos que os alunos estão atentos e envolvidos com a aula, como no caso em que A3 fala a temperatura do filamento da lâmpada incandescente no turno 791; 794 quando aluna não identificada comenta que sua sobrinha teve icterícia; 798 aluno não identificado responde ao professor o que é uma lâmpada fosforescente, após, no turno anterior, ter classificado a lâmpada com o professor como fluorescente; ou ainda no 805, A5 pergunta qual lâmpada é melhor: de mercúrio ou de sódio. 
A linguagem gestual não apresenta destaque nesse momento da aula.

Em relação à apropriacão de termos técnicos, observarmos que o professor faz questão de diferenciar a lâmpada fluorescente da fosforescente, embora no transcorrer da atividade não tenhamos identificado nenhuma fala referente a essa lâmpada. No turno 798 um aluno não identificado fornece uma boa definição sobre lâmpada fosforescente e nos turnos seguintes, com os exemplos do interruptor e dos "enfeites de quarto", parecem assimilar bem a ideia da lâmpada fosforescente.

Não aparecem nesse momento outras referências à assimilação de termos técnicos.

Em relação aos conceitos envolvidos o professor procura explicar a diferença entre a lâmpada fosforescente e a fluorescente, e que parece ser bem assimilado pelos alunos pelos seus comentários nos turnos 798, 801 e 803. Embora não aprofunde na explicação, são discutidas ideias como rápida ou lenta absorção de energia e rápida ou lenta emissão da mesma, por parte das lâmpadas.

No final desse momento o professor fala também que as cores e linhas de cada espectro estão associadas ao tipo de substância ou elemento responsáveis por eles. Não temos retorno dos alunos sobre tal fato, já que essa informação é fornecida nos instantes finais da aula.

Em relação ao tamanho das bandas e ao motivo da aparência dos espectros não temos nenhuma indicação.

Sobre argumentacão percebemos que, apesar da fala do professor predominar nesse momento temos um exemplo de argumentação básica, segundo Toulmin (1958), no turno 798 quando um aluno não identificado responde ao professor o que é uma lâmpada fosforescente.

Nesse turno de fala o aluno fornece a conclusão quando afirma que lâmpada fosforescente é a que "acende quando tudo está apagado" e como justificativa diz que isso ocorre "por causa da energia recebida". Podemos considerar o dado a observação do aluno de que a lâmpada permanece brilhando quando tudo está apagado, portanto um dado obtido e empírico (Jiménez Aleixandre, 1998). A própria justificativa parece ser utilizada a partir de um conhecimento básico do aluno.

Como se trata de uma aula expositiva e com pouca interação, é normal que praticamente não apareçam estruturas de argumentação.

Em relação aos indicadores de alfabetização científica, notamos a utilização dos indicadores organização e classificação e justificativa. 
No turno 796 um aluno não identificado realiza uma classificação quando o professor pergunta se a lâmpada que está com ele é fosforescente ou fluorescente, e ele responde que é fluorescente.

No turno 798 um aluno não identificado, ao responder para o professor o que é a lâmpada fosforescente, realiza uma classificação e apresenta uma justificativa para essa classificação ao responder que é por causa da energia que a lâmpada fosforescente permanece acesa, mesmo depois que outras lâmpadas estão apagadas.

No turno 801 quando A5 cita que possui uns "negocinhos" em seu quarto está organizando seus exemplos de materiais fosforescentes.

No turno 807 quando uma aluna não identificada avisa que já passaram duas aulas, e no turno 809 quando A3 pergunta se é para entregar as anotações, temos exemplos de organização da atividade.

\section{Outras informacões relevantes:}

Essa parte final da aula é importante, porque o professor apresenta características e informações relevantes sobre as lâmpadas, porém seria interessante que já nessa sequência ele falasse sobre os espectros de cada uma delas.

Considerando a atividade completa em sala de aula, podemos observar as dificuldades e as evoluções dos alunos para identificarem os espectros contínuos e discretos, assim como para identificarem as cores. No entanto, comparando as atividades de campo que foram entregues, reparamos uma evolução durante a realização da atividade.

As atividades que continham os desenhos dos espectros são as que nos permitem fazer essa observação (ver anexo atividade de campo $3^{\circ} \mathrm{D}$ e $3^{\circ} \mathrm{G}$ ).

Nas atividades dos alunos do $3^{\circ} \mathrm{G}$, notamos que eles até identificam espectros com quantidades de cores diferentes, mas consideram que todos são contínuos e não desenharam nenhuma linha entre as cores. A ideia de espectros discretos é nova para os alunos, portanto é razoável que numa primeira observação realizada distante do professor eles não tenham distinguido ou destacado a presença das linhas.

Nas atividades dos alunos do $3^{\circ} \mathrm{D}$ também é possível observar que identificam espectros com quantidades de cores diferentes e classificam a maior parte deles como discretos, porém não conseguimos identificar pelos desenhos diferenças com o desenho do espectro contínuo que possam levar a essa diferenciação.

Aqui os alunos destacam a maior e menor banda presente em cada espectro. 
Alguns alunos, como o n $^{\circ}$ 02, números 18 e 29 e outro que está sem identificação na frente, mas corresponde ao $\mathrm{n}^{\mathrm{o}} 25$ (anotação no verso), apresentam desenhos com contornos de separação de cores, porém parece que utilizaram esses contornos apenas para facilitar a visão da separação das mesmas, pois até o espectro contínuo aparece com esse contorno.

Praticamente antes da atividade, os alunos "enxergavam" os espectros da mesma forma, apenas com possibilidade de quantidades diferentes de cores.

Outra consideração que fazemos ao final dessa atividade com os espectros das lâmpadas é que podemos considerar o fato dos alunos terem ficado para realizar a atividade, enquanto toda escola foi dispensada, como um indicativo de envolvimento e comprometimento com a mesma. 


\title{
Episódio 2 - análise da atividade do astrônomo mirim:
}

\author{
Momento 1 - início da aula $-\mathbf{1}^{\text {a }}$ análise \\ Ver tabela de transcrição e análise (anexo p. 285).
}

\section{Descrição da aula:}

A parte inicial desta aula é utilizada pelo professor para fornecer informações gerais sobre a atividade, e os próprios alunos, em grupo, buscam uma organização para registro das atividades e do material que vão entregar ao professor.

Segue uma descrição mais detalhada desse momento inicial que consideramos até o turno de fala 38:

Os alunos já estão sentados em grupos, em volta de carteiras que foram agrupadas, enquanto o professor dá instruções gerais na frente da sala. Temos três grupos com aproximadamente seis alunos em cada um deles.

No turno de fala 01, A5 explica para A1 sobre a atividade que entregaram na aula anterior na qual deviam registrar as cores presentes nos espectros de algumas lâmpadas que deveriam observar em casa ou nas ruas. Esse diálogo ocorre, pois A1 não esteve presente na aula anterior.

No turno 02 o professor praticamente apresenta o objetivo da aula e destaca que estão trabalhando com duas atividades: primeiro, a observação dos espectros das lâmpadas que fizeram na aula anterior com os espectroscópios, destacando que elas possuíam linhas em posições diferentes e cores também diferentes, em seguida destaca que com a atividade a ser desenvolvida pretende explicar o aparecimento das linhas e até calcular suas posições.

Turno 02: P: (...) Hoje nós, segunda parte da aula, vamos explicar por que aparece cada uma dessas linhas, inclusive até calcular a posição dessas linhas. (...).

No turno 03 o professor explica que a luz, ao passar por elementos distintos, no estado gasoso, apresentará espectros diferentes. Enquanto fala dos espectros de diversos gases, o professor mostra a folha com os espectros de diferentes elementos que os alunos irão utilizar na aula e faz uma analogia para explicar que o espectro é uma característica única de cada elemento. 
Turno 03: P: (...) Então isso é como se fosse a digital do elemento, o alumínio tem essas linhas, sempre. O alumínio sempre terá essas linhas, carbono essas linhas, ferro essas linhas, cada elemento tem linhas bem definidas. (...).

$\mathrm{Na}$ sequência o professor informa aos alunos que podem verificar uma tabela periódica com os elementos e seus respectivos espectros na internet no site que lhes foi passado (na verdade uma página do site da Universidade Federal do Rio Grande do Sul).

No turno de fala 06 o professor explica que por meio da espectroscopia é possível determinar e identificar os elementos que estão presentes na atmosfera de um planeta ou em uma estrela, para tanto basta captar a luz refletida por um deles e permitir que ela passe por um espectroscópio com rede de difração. Com o espectro obtido, basta compará-lo com o espectro de cada elemento para verificar os que estão presentes no planeta ou na estrela. Neste instante, enquanto fornece uma explicação geral, o professor mostra uma transparência com o espectro que representa uma estrela hipotética elaborado para essa atividade.

Na sequência o professor explica como farão a atividade: com o espectro da estrela hipotética basta colocá-la sobre o espectro dos elementos e procurar as linhas que coincidem e caso coincidam todas as linhas do elemento significa que ele está presente naquela estrela. Nesse instante o professor mostra como devem colocar a transparência com o espectro da estrela hipotética sobre os espectros dos elementos. É um instante fundamental, pois define como devem desenvolver a atividade.

Turno 06: P: (...) Então eu tenho as linhas dos elementos que eu conheço na Terra e tenho o espectro da estrela, então eu vou colocar um sobre o outro e procurar os que as linhas coincidem. Se as linhas todas do elemento, do alumínio estiverem todas na estrela 3, quer dizer que nessa estrela que eu estou observando, lá tem alumínio.

No turno seguinte o professor explica como a atividade será organizada, informando que entregará um conjunto com estrelas (espectros em transparências) numeradas para identificação e também uma tabela com espectros de alguns elementos (espectros de vários elementos em uma folha de sulfite). Na sequência informa que terão que comparar esses conjuntos de espectros para verificarem quais os elementos que estão presentes em cada estrela. Após a verificação deverão registrar em uma folha o número da estrela e o símbolo de cada elemento que ela apresente.

Durante a sequência de explicação do professor, os alunos do grupo prestam atenção, embora no momento em que o professor fala do site com a tabela de elementos e espectros, A4 converse com A6 e A1 diz que não vai procurar essas informações no site.

Os alunos não fazem nenhum tipo de questionamento sobre a atividade. 
Do turno 08 ao 14 os alunos brincam e definem quem fará as anotações, no caso, A4 se prontifica. No turno 12 o professor deixa um conjunto de folhas com os espectros dos elementos para A1 e no turno 15 informa que vai deixar dois conjuntos com cada grupo, entregando o segundo conjunto de folhas para A2, enquanto A1 observa o que recebeu anteriormente. Do turno 18 ao 37 A4 indaga e registra o número de cada aluno do grupo. A4 faz esse registro brincando com os colegas do grupo enquanto no turno 28 o professor informa que entregou as folhas com os espectros dos elementos e que vai entregar o espectro das estrelas agora. Durante esse tempo alguns alunos do grupo já começam a observar os espectros das folhas.

Aproximadamente no turno 31 o professor entrega cinco espectros de estrela para o grupo. A2 e A3 começam a comparar os espectros das estrelas e dos elementos emparelhando a estrela com os espectros dos elementos.

No turno 38 A5 se manifesta em relação à maneira como devem observar.

\section{Análise:}

Em relação ao envolvimento com a atividade, podemos destacar que mesmo no início da aula os alunos buscam uma organização para o que estão fazendo, como no caso em que A5 explica para A1 sobre a atividade que entregaram na aula anterior (pesquisa de campo):

Turno 01: A5: Diego, esse aí era outro, que você tinha que olhar lá e marcar as cores no papel você vê a (inaudivel) que você tava olhando. (inaudível). Já entregou pra ele?Então já era.

A5 busca acalmar A1 que não esteve presente na aula anterior e está um pouco confuso em relação ao que farão.

A preocupação de A4 para realizar as anotações, bem como para anotar os números de todos do grupo também, demonstra envolvimento com a atividade (entre os turnos 09 e 37). Outro indicativo de envolvimento ocorre quando o professor entrega os espectros das estrelas para o grupo e imediatamente A2 e A3 começam a comparar os espectros bem, como A5 fala como devem fazer.

Turno 38: Tem que deixar na reta.

Consideramos também a atenção que prestaram durante toda a fala do professor (turno 02 ao turno 07), quase sem conversas paralelas. 
Porém, o fato de não existirem perguntas sobre a atividade não permite saber se eles realmente compreenderam o que deveriam fazer.

Em relação às linguagens, esse início de aula apresenta predominantemente falas do professor que explica a atividade com alguns gestos aparecendo durante essa explicação, porém nosso foco está nos alunos e nesse momento eles não se manifestam muito. De qualquer forma, notamos a manipulação dos espectros (das estrelas e dos elementos) bem como a manipulação dos materiais (cadernos e canetas).

A manipulação dos espectros ocorre no turno 15 quando o professor entrega o segundo conjunto de folhas com espectros dos elementos para A2, e A1 observa as folhas que recebeu anteriormente; outro exemplo ocorre no turno 31 quando o professor entrega os espectros das estrelas, possibilitando que A2 e A3 comparem os espectros dos elementos emparelhando o espectro da estrela com os espectros dos elementos.

A manipulação dos materiais ocorre no turno 08 quando A5 solicita uma caneta e a partir do turno 18 quando A4 começa a perguntar os números dos integrantes do grupo e a anotá-los para posterior entrega do trabalho ao professor.

A linguagem oral aparece praticamente apenas nas interações entre os alunos do grupo. Essas ocorrem logo após o professor passar as informações sobre a atividade. No turno 09, A4 assume a responsabilidade de realizar as anotações; do turno 18 ao 37, A4 questiona os números dos alunos do grupo e eles respondem.

Destacamos ainda a fala de A5, que ao ver A2 e A3 manipulando os espectros, afirma que eles devem ficar "na reta", ou seja, utiliza a linguagem verbal para auxiliar a manipulação dos espectros por parte de A2 e A3.

Em relação à apropriação de termos técnicos, não temos nenhuma fala dos alunos utilizando termos específicos. O professor faz uso das palavras "espectro" e "espectroscopia" e explica novamente o que o espectroscópio faz com a luz que passa por ele (turno 06), mas não vemos manifestação dos alunos em relação a esses termos.

Para os conceitos envolvidos, o professor destaca que cada elemento possui um espectro específico e relembra que o espectroscópio possui uma rede de difração. Tais conceitos não são questionados nem comentados pelos alunos.

Em relação à argumentação, não há nenhuma fala dos alunos em destaque com os elementos básicos da argumentação, segundo o modelo de Toulmin (1958).

Em relação aos indicadores de alfabetizacão científica, predomina-se o indicador “organização", seja para realização da atividade em si, como no turno 09 quando A4 assume a 
responsabilidade me realizar as anotações, ou para realização da observação no turno 38 quando A5 sugere que (os espectros da estrela e dos elementos) devem ficar na reta.

\section{Outras informacões relevantes:}

No turno 02 enquanto o professor explica a atividade que realizarão, associando-a à atividade anterior sobre observação dos espectros das lâmpadas, ele acaba apresentando uma perspectiva negativa ao dizer que talvez os alunos não gostem muito da atividade:

Turno 02: P: (...) Isso é um trabalho que, talvez, vocês considerem um pouco mais... não muito agradável.

Embora não tenhamos uma reação direta dos alunos, essa fala chama a atenção, pois o professor sempre procurou estimular a participação dos alunos, e aqui neste instante, a sua fala parece refletir uma preocupação em relação à postura dos alunos, pois esta atividade parece ser menos dinâmica que a anterior. A preocupação é válida já que as atividades apresentam uma dinâmica diferente, no entanto esta fala poderia gerar desconfiança e desestimular os alunos.

Temos o predomínio da interação Professor/Turma, coerente, por ser um momento inicial no qual os alunos ouvem atentamente as informações fornecidas pelo professor para realização da atividade. Também temos algumas interações Aluno/Aluno do mesmo grupo na organização da realização da atividade.

A5 é o único integrante do grupo analisado anteriormente na atividade dos espectros das lâmpadas. A1 parece ser o único aluno que não estava presente na aula anterior.

Os alunos não fazem nenhum tipo de questionamento para o professor sobre a realização da atividade ou sobre as informações fornecidas.

Nesse momento uma grande quantidade de informações é apresentada aos alunos. 


\section{Episódio 2 - análise da atividade do astrônomo mirim:}

\section{Momento 2 - Alunos começam a fazer a atividade \\ Ver tabela de transcrição e análise (anexo p. 288).}

\section{Descricão da aula:}

Consideramos essa parte como um momento distinto, pois marca o início efetivo da atividade por parte dos alunos. Praticamente três etapas marcam esse momento:

- Do turno 39 ao 101 os alunos fazem a atividade apenas com as instruções gerais do professor.

- A partir do turno 102 contam com uma intervenção direta do professor que explica como devem realizar a atividade e continuam fazendo até o turno 334.

- Turno 335 quando o professor retorna ao grupo para verificar o que estão fazendo, até o turno 361. Nessa etapa o professor identifica que os alunos não estão realizando a atividade da forma como foi solicitada.

Segue uma descrição mais detalhada das etapas citadas:

Do turno 39 ao turno 101:

No turno 39 o professor ainda solicita atenção aos alunos, mas não conseguimos compreender sua fala. Já no turno 40, A2, A3 e A5 estão tentando fazer a atividade.

No turno 41, A2 e A3 tentam comparar os espectros com a ajuda de A5, enquanto são observados por A1. A partir desse turno os alunos buscam a melhor forma para compararem os espectros bem como a identificação das linhas e das cores.

Turno 41: A5: Também não; é a de baixo.

Turno 42: A2: É a de baixo.

Turno 47: A3: Tem amarela aqui, ó.

Turno 48: A5: Não pode pôr em cima, tem que ver aqui.

Essa interação dialógica entre os alunos segue até o final dessa etapa e merecem destaque alguns turnos:

Turno 53: A4: Essa aqui é.

Turno 54: A5: Não. A linha tem que tá igual.

Turno 55: A4: Idêntico, idêntico?

Turno 56: $A 5: E$. 
Nessa sequência de turnos notamos que A4 parece ter identificado uma linha presente em algum elemento e também na estrela que estão observando, porém A5 refuta sua observação, justificando que a linha não está idêntica, portanto é necessário que a linha esteja toda parecida para confirmar a presença do elemento na estrela. Destacamos ainda que eles não fazem nenhum comentário sobre as várias linhas presentes em um espectro. O diálogo é em torno de uma linha apenas.

No turno 61, A5 reclama que os demais integrantes do grupo estão utilizando a folha inadequadamente, "ao contrário".

A6 praticamente não comenta nada, inclusive A4 solicita que ela fale algo no turno 67, mas não consegue retorno. Os demais alunos estão atentos e manipulando os espectros constantemente.

Do turno 68 ao 73 os alunos continuam organizando suas observações e buscando identificar as linhas e percebemos que eles fazem a atividade de forma contrária à sugerida pelo professor: eles mudam a estrela para cada elemento na folha de sulfite, eles olham um elemento e verificam se cada estrela possui aquele elemento. Tal atitude é contrária à proposta, de mostrar como os cientistas trabalham, já que na realidade eles conseguem o espectro de uma estrela e em seguida identificam os elementos presentes nela.

No turno 74 o professor entrega mais uma folha de sulfite. Os alunos seguem suas observações e comparações, e no turno 83 o professor reforça a necessidade de compararem todos os elementos.

$\mathrm{Na}$ sequência de turnos notamos que os alunos apresentam dificuldades para chegar a uma conclusão única sobre a identificação dos elementos.

Turno 84: A1: Já achou a... Achou uma?

Turno 85: A5: A estrela dois, então tem alumínio.

Turno 86: A3: É alumínio.

Turno 87: Não é ó!

Turno 88: A2: Nossa, mas parece.

Turno 90: A5: Como é que vai responder vai colocar...?

Quando A4 pergunta sobre a estrela 2 para realizar suas anotações, A5 responde que ela tem alumínio e A3 comenta ter mais uma, mas não classifica qual. Nos turnos 97, 98 e 99, A6, A1 e A5 iniciam uma conversa sobre dança, mas essa conversa logo para.

No turno 101 o professor informa que cada estrela apresenta aproximadamente três ou quatro elementos. 
Turno 101: P: Pessoal, é o seguinte: cada estrela tem 3 ou 4 elementos. Pode ter até alguma outra que tem mais ou alguma outra que tem menos, mas não é um único elemento...

\section{Do turno 102 ao 334:}

Após a informação sobre a provável quantidade de elementos presentes em cada estrela, o professor sugere que o grupo se organize para fazer uma comparação por vez e, numa interação direta, questiona se acharam algum elemento. A5 responde que acharam e A4 cita a estrela 2 que para eles possui alumínio. O professor pergunta por que identificaram o alumínio:

\section{Turno 113: P: Tem alumínio. Por que tem alumínio?}

Turno 115: P: Mostra aí.

A resposta é fornecida com A4 que afirma que (as linhas) estão batendo, ou seja, são idênticas, indicando no espectro as linhas:

Turno 116: A4: Bate aqui ó!

O professor confirma que está bom e pergunta se é só o alumínio que está presente na estrela. Em seguida, A3 pergunta se é necessário verificar com os outros elementos enquanto mostra o conjunto de espectros e gesticula com a mão, segurando uma caneta e apontando para as linhas das estrelas e dos elementos. O professor aproveita quando ela passa sobre o Cálcio e reforça a informação que é essencial coincidir tudo para que tenha o elemento e em seguida pergunta se ele está presente na estrela em questão.

Turno 120: P: Péra aí, para aí, sobre o cálcio. Tem que fazer coincidir o começo e o fim. Bom, tem cálcio?

A4 e A3 respondem que não e A3 justifica sua resposta após solicitação do professor:

Turno 126: A3: Não tem as mesmas linhas.

A resposta é confirmada e reforçada pelo professor:

Turno 127: P: As linhas não coincidem.

O professor faz o mesmo questionamento em relação ao Carbono e ao Hélio e indica que deverão fazer o mesmo em relação aos demais elementos. No turno 137, A2 pergunta o que significa " $\mathrm{H}$ " e o professor responde se tratar do Hidrogênio e informa novamente que podem marcar só o símbolo.

Nesse instante o grupo apresenta uma divisão nítida: A3 e A4 verificam juntos, enquanto A1, A2 e A5 examinam outro espectro e apenas A6 observa. A partir desse instante, enquanto o grupo continua suas comparações, o professor vai a outro grupo. Os alunos seguem até o turno 211 sem a presença direta do professor. 
No turno 149, A2 comenta que vai deixar uma estrela de lado e pergunta se já acharam o elemento que ela possui. A5 responde que ainda não e mesmo que tivessem achado um, teriam que verificar cada um dos outros elementos.

Turno 149: A2: Deixa aqui de lado. Já achou essa daqui?

Turno 150: A5: Não, mas tem que ver com essa, mesmo você achando tem que ver aqui se tem.

Nesse turno A5 demonstra que assimilou a informação do professor sobre verificar todos os elementos.

Do turno 161 ao turno 177, A1, que não estava presente na aula anterior, busca informações sobre a filmagem da aula com o professor e com A5. No turno 177, A5 relembra o grupo do qual fez parte na atividade de análise dos espectros das lâmpadas. Durante essa sequência os demais alunos do grupo continuam suas observações e comparações, principalmente A2 e A3. Após A5 falar com A1, ele volta sua atenção para A2 e A3 e, depois de observá-las, parece reformular sua ideia sobre como considerar quando a estrela possui determinado elemento. A partir desse instante A5 passa a considerar que basta uma linha coincidir para indicar a presença do elemento, seguindo a opinião do grupo.

Em seguida, os alunos continuam verificando as estrelas 8 e 9 e A5 e A2 explicam para A1 como ele deve fazer para identificar os elementos, informando que precisa colocar os espectros juntos para ver se estão "na mesma" linha, que devem "ter linha igual". Interessante que nesse instante A2 comenta que existem mais linhas e A5 reforça, se tiver uma linha só batendo, já indica a presença do elemento.

Turno 202: A5: Mas uma linha não ta batendo? Então.

Turno 204: A5: Você vê do começo. Se tiver uma linha batendo tem o (inaudível) lá, Hélio, Hidrogênio.

Logo A3 e A4 concordam inicialmente sobre uma observação em relação à presença do azul e discordam sobre a presença das linhas evidentes na cor amarela. Nesse instante A1 pergunta ao professor se todas as linhas devem bater, mostrando uma interpretação contrária ao seu grupo.

Turno 212: A1: Tem que bater todas as linhas né, professor?

O professor aproveita para falar a todos da sala que todas as linhas do elemento devem estar presentes na estrela. Essa fala ocorre no turno 215 e é repetida no turno 217 quando chama a atenção de A4, mas não vemos maiores consequências em relação a essa observação, tanto A1 quanto A4 não questionam a interpretação do grupo. 
Os turnos seguintes mostram os alunos comparando os espectros, manipulando-os e até comemorando quando identificavam a presença de algum elemento na estrela.

Em alguns instantes também notamos a preocupação em relação às anotações que estão fazendo e como vão entregar ao professor, como A1 no turno 256 que se preocupa com a explicação que devem dar para identificação do elemento. O mesmo A1 pergunta ao professor como falar o nome dos elementos no turno 264, e como resposta, o professor dá os nomes, mas indica que podem colocar apenas o símbolo nas respostas.

Até o turno 286 temos uma interação e dinâmica muito intensas entre os membros do grupo que manipulam os espectros, realizam as observações, fazem comparações, organizam a atividade e classificam os elementos presentes em cada estrela.

No turno 287 o professor pergunta se já terminaram e A1 pede mais tempo. Continuam realizando a atividade e em momentos como no turno 310 todos observam o mesmo espectro, com exceção de A6. Podemos observar A3 passando detalhadamente a estrela sobre os espectros dos elementos no turno 329. Esta situação mostra que seguiram a orientação do professor para identificarem todos os elementos presentes em determinada estrela para depois verificarem outra.

Do turno 335 ao 361 :

No turno 335 o professor vem verificar como o grupo está trabalhando e solicita conferir a estrela 8. Ele considera que os alunos identificaram muitos elementos para essa estrela, pois ela deveria no máximo ter cinco. Com essa fala os alunos já percebem que fizeram algo errado. O professor refaz a verificação da estrela 8 com os alunos:

Turno 351: P: Mg. Tem Mg? Não, não tem. Olha as linhas do Mg. Essas linhas verdes não estão na estrela, então não tem.

Em seguida conferem o Nitrogênio:

Turno 355: P: Tá. Então N, vamos ver se tem N. Não tem $N$.

Turno 356: Val: Por quê??

Turno 357: P: Porque olha aqui ó, o monte de linhas no verde e não tem aqui. Essas duas não têm aqui, essas não tem. Tem que bater praticamente todas.

Turno 358: A4: Ah então foi isso que nós fez...

A4 demonstra ter entendido o que fizeram de errado e o professor confirma no turno seguinte:

Turno 360: P: Vocês pegaram se tivesse uma, duas. Não! Essa sim bate todas ó: todas vermelhas, todas amarelas, todas verdes, as azuis, anil. Aqui bate todas. 
O professor explica detalhadamente como devem fazer e vai mostrando as linhas com a ponta de uma caneta.

\section{$\underline{\text { Análise: }}$}

Em relação ao envolvimento com a atividade, podemos destacar a constante manipulação dos espectros pelos alunos do grupo que ocorre praticamente durante todo momento e por todos os alunos, com exceção de A6 que algumas vezes parecia dispersa em relação à atividade. Logo no início do turno, enquanto o professor ainda fala, A3 e A5 já começam a fazer a atividade e A2 e A3 tentam comparar os espectros com ajuda de A5. Essa sequência de manipulação e tentativa de identificação dos elementos ocorre por todo o restante de turnos.

Consideramos também o número reduzido de conversas paralelas como um indicador de envolvimento com a atividade. Estas ocorrem de forma breve em alguns turnos, como no início, quando A2 conversa com A6, mas rapidamente volta a sua atenção para comparação dos espectros. Do turno 97 ao 99, A1, A5 e A6 falam sobre dança, mas logo em seguida A5 está atento ao trabalho do grupo novamente. Mesmo durante os turnos 161 até 177, enquanto A1 pede informações para o professor e para A5 sobre a filmagem da aula, os demais alunos continuam empenhados na realização da atividade.

A alegria e comemorações quando identificam algum elemento ou quando compreendem algo também é um indicativo de envolvimento com a atividade. Isso ocorre nitidamente nos turnos destacados a seguir:

Turno 225: A3: Tem esse azul, tem sim.

Turno 226: A1: Aleluia.

Turno 227: A2: Tem sim.

Durante esses turnos A1 e A2 batem palmas por acreditarem que identificaram um elemento. Também nos turnos a seguir:

Turno 247: A4: Essa aí tem.

Turno 248: A2: Agora entendi.

Turno 249: Val: Êeeeeeee!

Durante esses turnos A1 cumprimenta A5 batendo em suas mãos. Os alunos ficam empolgados com a identificação que fizeram e com o fato de A2 ter compreendido. 
Por fim consideramos também um indicativo de envolvimento com a atividade a preocupação com as anotações e registro que devem ser feitos e com a melhor forma de identificar os elementos.

Seguem exemplos de preocupação com as anotações e registro: o turno 139 quando A4 pergunta o que significa "H" e o professor responde que é Hidrogênio, mas que podem marcar só o símbolo; no turno 193, A5 solicita que A1 vá anotando enquanto citam as estrelas que já foram; no turno 232, A3 pede que os demais falem os elementos para ela repassar para A4 que está anotando, e no turno 264, A1 pergunta sobre como classificar os elementos e o professor responde o nome de cada um, mas avisa que podem anotar apenas os símbolos.

Exemplos com a preocupação com a melhor forma de identificar os elementos ocorrem praticamente durante todo o momento analisado e destacamos alguns: turno 48 quando A5 afirma que não pode pôr em cima (os espectros) e indica onde precisam ver; turno 116 A4 justifica para o professor a presença do alumínio ao mostrar que as linhas do elemento estão "batendo" com as da estrela. A sequência do turno 178 até 184 quando A5 interpreta, após observar A2 e A3 identificando um elemento, que a presença de uma linha coincidente, já indica a presença do elemento. Essa ideia é confirmada por A3 e retomada por A5 no turno 204 quando explica para A1, e A2 reforça essa fala no turno 321:

Turno 321: A2: Não precisa ter todas, basta uma linha só.

No turno 234, A3 afirma que a estrela observada tem Alumínio e mostra para A2 como ir deslizando a estrela (transparência com espectro da estrela hipotética) sobre os espectros dos elementos para comparação. No turno 329, A3 após comentar que existe Hélio, passa detalhadamente a estrela sobre os espectros dos elementos.

Em relação às linguagens, percebemos um predomínio da manipulação dos espectros que ocorre praticamente durante todo o momento analisado com o objetivo de identificarem os elementos presentes em cada estrela observada. Em menor escala também temos a manipulação de materiais como a folha onde os alunos registram suas observações para entregarem ao professor. No caso A4 é o responsável pelas anotações que serão entregues.

Nesse momento a linguagem oral é muito significativa, pois é por meio dela que conseguimos perceber aspectos cognitivos. Nos diálogos a seguir podemos entender o raciocínio utilizado por A5 e pelo grupo para identificarem os elementos nas estrelas.

Turno 178: A5: Ah tá! Peraí, se tiver um só igual aí marca?

Turno 179: A3: $E$.

Turno 180: A5: Ah então. Empresta aqui. A 2 já fez, né. Então entendi.

Turno 181: A3: A 2 jáfez... 
Turno 182: A5: Agora eu entendi. Porque eu achei que tinha que ser igual todo no total.

Turno 183: A3: Ah é?

Turno 184: A5: É só comparar a linha. Se tiver linha igual.

Nessa sequência de turnos observamos as conclusões de A5 após ver as identificações feitas por A2 e A3. Notamos também que suas conclusões são confirmadas sempre por A3. Nesse instante A5 passa a interpretar que o espectro não precisa ser igual em sua totalidade e sim possuir apenas linha igual para indicar a presença do elemento na estrela. Essa é a forma como o grupo interpretou as informações do professor sobre a identificação dos elementos. Vale ressaltar que A5 parecia ter interpretado corretamente as informações do professor, porém acabou seguindo a opinião do grupo.

A5 e A2 confirmam essa ideia para A1 nos turnos 197 e 198:

Turno 197: A5: Vê do começo se tiver uma linha assim, por exemplo, essa aqui ó... tem que deixar na mesma linha.

Turno 198: A2: Tipo tem que (ter) linha igual, entendeu?

Turno 204: P: Você vê do começo. Se tiver uma linha só batendo tem o (inaudível) lá, Hélio, Hidrogênio.

Esses turnos indicam como o grupo está pensando, com exceção de A1 que parece confuso e A6 que não manifesta opinião. A1 posteriormente questiona ao professor se todas as linhas devem coincidir:

Turno 212: A1: Tem que bater todas as linhas né, professor?

A1 recebe a confirmação do professor nos turnos 213 e 217 e 219:

Turno 213: P: Todas as linhas do elemento têm que estar na estrela.

Turno 217: P: Todas as linhas do elemento têm que estar na estrela. Não pode ser apenas uma linha.

Turno 218: A4: Mais de uma?

Turno 219: P: Todas as linhas que estão no elemento têm que estar na estrela.

Aqui embora o professor seja enfático em afirmar que todas as linhas devem coincidir e A4 demonstrar que está atento a essa fala, não temos nenhuma mudança no comportamento do grupo que continua classificando os elementos como presentes na estrela com apenas uma linha do espectro coincidindo com outra da estrela. A1 e A4 não levam a afirmação do professor para o grupo. Essa ideia ainda aparece no turno 321 com A2:

Turno 321: A2: Não precisa ter todas, basta uma linha só. 
Esse pensamento só vai começar a ser modificado no turno 343 quando o professor pede para ver os elementos presentes na estrela 8 e nota que existem muitos elementos. $\mathrm{O}$ professor explica detalhadamente como devem observar e afirmar que todas as linhas do espectro dos elementos devem coincidir com as do espectro da estrela, para que o elemento esteja presente nela. Na sequência A4 fala e demonstra que olharam apenas uma linha:

Turno 358: A4: Ah, então foi isso (não conferimos todas as linhas) que nós fez...

O professor, pela fala dos alunos e pelas anotações que apresentaram, consegue identificar como fizeram a comparação:

Turno 359: P: Vocês pegaram se tivesse uma, duas. Não!...

No turno 344, A4 já perguntava se teriam que fazer de novo, portanto essa sequência foi muito importante para os alunos compreenderem em que momento estavam errando.

A linguagem oral também foi essencial para os alunos expressarem suas preocupações com as anotações e para indicar como estavam fazendo as comparações.

Nesse momento temos a linguagem gestual muito utilizada para mostrar as posições das cores e das linhas dos espectros. Dessa forma os gestos continuam cooperando com a linguagem oral (Carmo, 2006).

Alguns exemplos:

Turno 57: A3: A (linha) que aparece é essa aqui.

Ao mesmo tempo em que fala, aponta com o dedo para folha com os espectros dos elementos indicando a referida linha. A3 repete o gesto no turno 82.

No turno 115 quando o professor solicita que os alunos mostrem porque tem alumínio A4 indica que as linhas batem e mostra apontando para os espectros. No turno 170, A4 pergunta se tem a cor verde e A3 responde que sim, indicando para a posição onde está enxergando a cor verde no espectro. Os alunos não utilizam os gestos para descrever suas ideias, nem suas observações como no caso da atividade dos espectros das lâmpadas.

Em relação à apropriação dos termos técnicos, notamos que alguns alunos se confundem um pouco com os símbolos que representam os elementos, como A2 no turno 137:

Turno 137: A2: O que é isso aqui? H?

Turno 138: A3: Hidrogênio; acho que é hidrogênio, né professor?

Interessante percebermos que A3 responde, mas busca a confirmação do professor. Como a confirmação não vem, A4 questiona:

Turno 139: A4: Professor, "H” é Hidrogênio? 
O professor nesse instante apenas responde que devem marcar o símbolo "H". No turno 264 A1 também demonstra dúvidas em relação aos elementos:

Turno 264: A1: Professor, faz favor. Então como se fala ferro, Mg, tal...? Aí vai.

Turno 265: P: Você pode escrever só o símbolo. É Lítio, Magnésio, Neônio, Hidrogênio, Oxigênio, Sódio e Xenônio. Mas pode colocar só o símbolo.

O professor responde falando o nome dos elementos, mas avisa novamente que podem registrar apenas o símbolo, demonstrando que no momento está mais preocupado com maneira como os alunos estão comparando as linhas e espectros.

Além dos nomes dos elementos, não observamos a utilização de nenhum termo específico por parte dos alunos.

Em relação aos conceitos envolvidos, não notamos nenhuma referência que indique se tratam a luz como onda ou partícula. Nenhum outro conceito aparece nesse momento da aula. A preocupação é identificar os elementos que estão presentes nas estrelas, assim como os cientistas fazem com espectroscópios e estrelas reais.

Em relação à argumentação encontramos algumas estruturas com elementos básicos da argumentação, conforme modelo de Toulmin (1958).

$1^{\text {o }}$ exemplo:

No turno 113 o professor pergunta por que tem Alumínio, ou seja, por que os alunos indicaram que determinada estrela possui Alumínio, e no turno 115 pede para os alunos mostrarem. A resposta aparece com A4 no turno 116:

\section{Turno 116: A4: Bateu aqui ó!}

A4 utiliza gestos para indicar a posição onde as linhas coincidem no espectro. Em sua resposta a conclusão aparece implícita: “(tem Alumínio porque) bateu aqui ó!”. Já a justificativa ocorre quando afirma que "bateu aqui", isso é, que aquelas linhas que estão indicando com os gestos coincidem e é necessária a coincidência entre as linhas da estrela e do elemento para indicar que este está presente na mesma. O $\underline{\text { dado é obtido e empírico }}$ (Jiménez Aleixandre, 1998) por meio da observação e comparação entre o espectro da estrela e do elemento.

$2^{\circ}$ exemplo:

$\mathrm{Na}$ sequência o professor, após afirmar que devem coincidir começo e fim, pergunta se a estrela que estão analisando possui Cálcio. A resposta obtida é que não possui, porém sem justificativas, então o professor questiona o motivo no turno 123 e A3 responde no turno 126:

Turno 126: A3: Não tem as mesmas linhas. 
A estrutura aqui apresentada é praticamente a mesma que apareceu na fala de A4 anteriormente: Em sua resposta a conclusão aparece implícita: “(não tem Cálcio porque) não tem as mesmas linhas.". Já a justificativa ocorre quando afirma que "não tem as mesmas linhas”, seria necessária a coincidência entre as linhas da estrela e do elemento para indicar

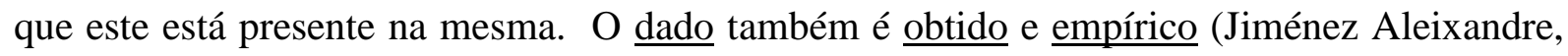
1998) por meio da observação e comparação entre o espectro da estrela e do elemento.

Na sequência o professor confirma a informação e torna a fala mais precisa ao afirmar que "as linhas não coincidem".

$3^{\circ}$ exemplo:

Nos turnos de fala a seguir, A5 constrói seu argumento a partir da observação do trabalho desenvolvido por A2 e A3:

Turno 178: A5: Ah tá! Peraí, se tiver um só igual aí marca?

Turno 179: A3: É.

Turno 180: A5: Ah então. Empresta aqui. A 2 já fez, né. Então entendi.

Turno 181: A3: A 2 já fez...

Turno 182: A5: Agora eu entendi. Porque eu achei que tinha que ser igual todo no total.

Turno 183: A3: Ah é?

Turno 184: A5: É só comparar a linha. Se tiver linha igual.

O dado foi obtido e empírico (Jiménez Aleixandre, 1998) observando-se o trabalho e comparações feitas por A2 e A3, com isso A5 concluiu que se tiver linha igual deve marcar, mesmo que seja uma linha apenas e justifica o fato de não ter marcado, pois considerava que (o espectro) tinha que ser igual em sua totalidade.

Tal raciocínio não está correto, mas é um exemplo de estrutura de argumentação construída ao longo de alguns turnos e com a colaboração de A3 confirmando as conclusões e ideias de A5. Estrutura semelhante ocorre com A2 no turno 321 quando se apropria do mesmo raciocínio.

É interessante utilizarmos aqui de uma forma geral o modelo de Van Eemeren et al. (1987) adaptado por Villani e Nascimento (2003), para entendermos a fala de A5.

Temos um discurso do professor (Locutor) que ocorreu no momento anterior (ver turno de fala 06 - atividade astrônomo mirim - momento 1) afirmando que todas as linhas deveriam coincidir (bater) e que inicialmente também era a ideia de A5 (Ouvinte) conforme afirma no turno 182. Ao observar a manipulação dos espectros e as classificações de A3 e A2 (Contexto), A5 apresenta outra ideia ao considerar que basta uma linha para indicar a 
presença do elemento conforme turno 178. A nova fala de A5 constitui, dessa forma, um discurso interpretado (O’).

Esse exemplo destaca a importância do Contexto para a constituição do discurso interpretado numa sala de aula.

Os argumentos são importantes e é por meio deles que conseguimos entender como os alunos constroem seu conhecimento, permitindo a intervenção do professor para reforçar a ideia, no caso, correta ou contrariando, a fim de buscar um novo raciocínio por parte dos alunos. Os dois primeiros exemplos são resultados de um questionamento direto do professor, já o terceiro está ligado ao objetivo da atividade que é identificar os espectros dos elementos que estão presentes na estrela, ou seja, está associado a uma questão mais geral e ao interesse de A5 em aprender como identificar esses elementos na estrela.

Em relação aos indicadores de alfabetizacãa científica, temos basicamente a utilização dos indicadores organização, classificação e um pouco de justificativa.

Em relação ao indicador organização, há dois tipos: organização para realização da atividade e organização para comparação dos espectros.

Como exemplo de organização para realização da atividade, podemos citar os turnos: 73 quando A4 indica a folha em que anotarão as respostas; 193 quando A5 solicita que A1 anote as comparações; 232 quando A3 pede para que os demais alunos do grupo falem os elementos presentes para ela ir repassando para A4 que está anotando, e 264 quando A1 pergunta para o professor como se fala os nomes dos elementos e o professor responde, mas informa que podem anotar apenas o símbolo; do turno 273 ao 275 A3, A2 e A1 questionam se determinada estrela é a 06 ou a 09.

Como exemplo de organização para comparação dos espectros, temos os turnos: 48 quando A5 afirma que não podem colocar (os espectros) em cima e indica de onde precisam olhar; turno 61 quando o próprio A5 avisa que os demais alunos do grupo estão usando a folha ao contrário; 150 em que, A5, ao responder para A2 que não achou o que ela estava indicando, mas, mesmo que achasse, deveria conferir todos os outros elementos; a sequência dos turnos 178 ao 185 quando A5 muda sua ideia sobre como identificar se determinado elemento está presente na estrela; 197, A5 reafirma que é necessária apenas uma linha coincidindo para indicar a presença do elemento; 204, A5 explica que devem olhar desde o começo para verificar se alguma linha bate; 212 quando A1 pergunta para o professor se todas as linhas precisam bater; 234, A3 afirma que a estrela possui Alumínio mostra para A2 como deslizar a estrela sobre os espectros; e 321, A2 afirma novamente que não precisa ter todas as linhas. 
O indicador classificação surge quando os alunos indicam os elementos que estão presentes na estrela como nos turnos: 85, A5 fala que a estrela 2 tem Alumínio; 86, A3 confirma a presença do Alumínio; 143, A3 acha ter identificado o Lítio; 220, A5 comenta que a estrela 1 tem Alumínio; 252, A3 afirma que tem Lítio e não tem Magnésio; 254, A3 volta em sua classificação e A2 cita o Magnésio; 267, A3 e A2 indicam o Sódio; 268 A3 mostra o Xenônio; 283, A3 observa o Níquel; 293, A3 indica o Neônio; 296, A3 e A2 citam o Nitrogênio; 299, A3 cita o Sódio; 301, A3 mostra o Xenônio; 302, A5 o Alumínio; 305, A2 cita o Cálcio; 329, A3 o Hélio; 331, A3 o Hidrogênio; 332, A1 o Ferro; e 350, A4 o Lítio para estrela 8 .

Observamos que a maioria das classificações é feita por A3 e não conseguimos identificar exatamente de quais estrelas eles estão falando em alguns casos.

O indicador Justificativa aparece nos turnos em que os alunos justificam e explicam suas respostas para o professor ou quando explicam o raciocínio que estão utilizando para verificar se determinado elemento está presente em determinada estrela. Podemos citar os turnos: 126 quando A3 responde ao professor que a estrela não tem Cálcio, porque não tem as mesmas linhas; 204, A5 explica para A1 que é necessário apenas uma linha para indicar a presença de determinado elemento na estrela; e do turno 178 ao 184, A5 justifica a maneira com passou identificar a presença de um elemento após observar A2 e A3.

\section{Outras informacões relevantes:}

Pela própria natureza da aula, temos interações do tipo P/T, A/A e P/G. O professor fornece informações e explicações gerais para toda sala, os alunos do grupo interagem entre si durante a observação e comparação dos espectros e, por sua vez, o professor procura observar as dificuldades de cada grupo bem como responder a questionamentos que eles fazem.

Notamos nitidamente que os alunos iniciam esse momento passando todas as estrelas em cada elemento ao contrário das instruções do professor, em seguida retomam as comparações, verificando todos os elementos para cada estrela, após explicação direta do professor. Porém, indicam a presença do elemento quando pelo menos uma linha do espectro confere e só no final da atividade com a presença do professor, é que reconhecem que estavam fazendo de forma errada.

Podemos dizer que o grupo apresentou dificuldades em compreender as instruções básicas fornecidas pelo professor. Provavelmente por ser a primeira vez que realizam a atividade e pela quantidade de informações passadas no início da aula. 


\section{Episódio 2 - análise da atividade do astrônomo mirim:}

\section{Momento 3 - Alunos começam a refazer a atividade \\ Ver tabela de transcrição e análise (anexo p. 301).}

\section{Descricão da aula:}

Consideramos essa sequência como um momento distinto, porque representa a retomada da atividade pelos alunos do grupo, após o professor ter constatado que eles estavam utilizando a ideia de que com apenas uma linha coincidindo deveriam considerar a presença do elemento na estrela. Após explicação do professor informando que devem coincidir todas as linhas, os alunos reiniciam suas comparações.

Esse momento vai do turno 362 até o 556.

Chama a atenção que o tempo para fazerem a correção é pequeno e o professor acaba por ajudá-los com os primeiros elementos como o Sódio, Xenônio, Cálcio, Carbono, Hidrogênio e mais um ou dois elementos que não conseguimos compreender quais seriam. A presença do professor no grupo ocorre até o turno 398 em que solicita ao grupo que para conferir. No turno 399 o professor se dirige à sala destacando que as estrelas hipotéticas devem ter quatro ou cinco elementos e jamais dez:

Turno 399: P: Pessoal, as estrelas devem ter aí quatro ou cinco elementos. Não tem dez elementos, não tem, não tem. Não está correto.

A partir do turno 400 os alunos do grupo iniciam uma intensa revisão de suas anotações, comparando novamente os espectros das estrelas com os espectros dos elementos, até o turno 556 quando o professor passa recolhendo as folhas com as anotações.

\section{Análise:}

Em relação ao envolvimento com a atividade, podemos observar a participação de praticamente todo o grupo durante a revisão das anotações. Apenas A6 não participa efetivamente da atividade, pois não emite opiniões nem realiza questionamentos. Outro indicativo que consideramos é o número reduzido de conversas paralelas ou brincadeiras não relacionadas com a atividade que ocorrem durante esse momento. Podemos notar essas conversas e brincadeiras nos turnos: 372 quando A4 conversa e brinca com um aluno de outro grupo; 381, A6 e A5 brincam enquanto A1 acerta uma classificação, observado pelo professor 
e demais integrantes do grupo; e no turno 544 quando A1 brinca enquanto o grupo realiza as últimas classificações.

Vale ressaltar que consideramos indicativo de envolvimento com a atividade a preocupação com as anotações e registros que devem ser feitos, como no turno 376 quando A4 solicita que A1 vá riscando da folha de anotações os elementos que não estão presentes em determinada estrela; o pedido é repetido várias vezes durante esse momento, bem como alguns pedidos para deixarem os elementos que realmente constam na estrela de acordo com a nova análise. No turno 555, A2 pergunta ao professor se é necessário "passar a limpo" a folha onde fizeram as anotações e no turno seguinte A5 pede para passarem a caneta.

Outro indicativo é a preocupação com a melhor forma de identificar os elementos que ocorre nos turnos: 414 quando A4 explica para A5 como deve comparar os espectros; e 502, A1 reclama da dificuldade em constatar a presença do Ferro. A manipulação dos espectros por sua vez ocorre durante todo o momento analisado, mostrando também o envolvimento e empenho dos alunos.

Em relação às linguagens, temos um predomínio da manipulação dos espectros que ocorre praticamente durante todo o momento analisado com o objetivo de revisarem toda identificação completa feita anteriormente em relação aos elementos presentes em cada estrela observada. Em menor escala também temos a manipulação de materiais como a folha onde os alunos corrigem as anotações registradas anteriormente e que entregarão ao professor.

A linguagem verbal é importante para acompanharmos o desenvolvimento da atividade por parte dos alunos e para identificarmos as estrelas e elementos que estão analisando. Para acompanharmos a análise, utilizamos a linguagem oral deles com as transcrições das falas e também a linguagem escrita representada pela folha com as anotações que fizeram e entregaram ao professor (ver anexo).

No acompanhamento da atividade, observamos que no início, mesmo com a ajuda do professor, os alunos ainda classificam incorretamente a presença dos elementos como nos turnos 363 e 369. Nos dois casos o professor explica como devem fazer a comparação. Nos turnos 374 e 380 a classificação é feita corretamente pelos alunos do grupo e o professor também explica o motivo pelo qual podem afirmar que os elementos estão presentes. $\mathrm{O}$ fato se repete no turno 388 e depois temos as classificações que os alunos fazem já sem a presença do professor.

Comparando as falas das transcrições com a folha entregue ao professor, percebemos que com o auxílio do professor comparam os elementos presentes na estrela 8 onde riscaram 
os elementos: N, Na, Xe, Ca e Fe e confirmaram: Li, O, C e H. Isso ocorreu entre os turnos 362 e 399.

A partir do turno 399 até o 454, verificam os elementos presentes na estrela 9, conforme a fala de A4 no turno 400:

Turno 400: A4: Nove. Esse aqui tem?

Interessante observarmos que A5 no turno 410 solicita que risquem o Carbono, mas logo em seguida A4 informa que este elemento não estava anotado na folha. No turno 425, A5 cita que o Lítio não está presente na estrela, mas este elemento também não havia sido registrado anteriormente. Novamente comparando os turnos de fala com as anotações das estrelas, notamos que para a estrela 9 os alunos riscaram os elementos: $\mathrm{Mg}, \mathrm{Ne}, \mathrm{Na}, \mathrm{Xe}, \mathrm{Al}$, $\mathrm{Ca}$ e Fe e confirmaram: $\mathrm{N}$ e $\mathrm{O}$. Ainda riscaram o $\mathrm{He}$ e confirmaram o $\mathrm{H}$, porém tal informação só aparece na folha com as anotações.

Do turno 458 até o turno 492 eles verificam a estrela 3.

Turno 459: A5: Qual que é essa? É a três.

No início A1 afirma que a estrela tem Ferro e Carbono que não estão anotados na lista, mas logo em seguida A5 indica que não, pois está sobrando a cor vermelha. Com a comparação verificamos que os alunos riscaram: $\mathrm{Li}, \mathrm{Mg}, \mathrm{Ne}, \mathrm{N}, \mathrm{Xe}$ e He e confirmaram: $\mathrm{Al}$, $\mathrm{Ca}$ e H.

Embora não façam nenhuma referência explícita, do turno 508 ao turno 535 os alunos parecem verificar a estrela 1. Observamos que pelos turnos de fala fica difícil identificar a transição da estrela 3 para estrela 1, isso só foi possível com o auxílio da folha com as anotações. Para esta estrela os alunos riscaram: $\mathrm{Ca}, \mathrm{Li}, \mathrm{Mg}, \mathrm{Ne}$ (que na folha estava anotado $\mathrm{Me}$, conforme os próprios alunos percebem nos turnos 523, 524 e 525), $\mathrm{Na}$ e Xe e confirmaram: C, H e Fe (na folha o elemento foi indicado como F).

$\mathrm{O}$ elemento $\mathrm{Al}$ permanece registrado na folha, porém não percebemos nenhuma referência a sua presença ou não nos turnos de fala.

Os alunos ainda citam alguns elementos que não estão presentes na estrela 1 , mas que já não constavam na folha de registros: He e Ne.

Do turno 536 ao turno 554 os alunos verificam a estrela 2. Para esta estrela os alunos riscam: Li e Xe e confirmam a presença de: Al, He e H.

Ainda comentam outros elementos que não estão presentes na estrela 2, mas que já não constavam na folha de registros: $\mathrm{Mg}, \mathrm{Ne}$ e $\mathrm{N}$.

Durante toda revisão realizada pelo grupo, verificamos algumas divergências antes do posicionamento final, o que demonstra claramente a dificuldade na comparação dos espectros 
e que serve de indicativo que esta não é uma atividade simples de ser bem realizada. Alguns exemplos de divergências sobre a presença dos elementos nas estrelas podem ser encontrados nas sequências de turnos: 362 ao 372 em que as observações dos alunos não conferem com as do professor; 474 ao 477 alunos divergem sobre a presença do Xe na estrela 3; 483 ao 485 sobre a presença do $\mathrm{C}$ também na estrela 3; 488 ao 492 divergem sobre a presença do $\mathrm{H}$ na estrela 3; 503 ao 505 sobre a presença de Al na estrela 1; 548 ao 552 divergem sobre as presenças do He e $\mathrm{H}$ na estrela 2.

Embora o grupo assuma um posicionamento final único, essas divergências indicam o grau de dificuldade da atividade, mesmo os alunos revisando as observações que já realizaram com as instruções do professor, não foi uma tarefa simples.

Praticamente não temos a linguagem gestual que só aparece em alguns instantes em que os alunos apontam e indicam onde se encontra determinado espectro, cor ou linha no conjunto que estão analisando.

Em relação à apropriação dos termos técnicos, notamos que os alunos utilizam os nomes e símbolos dos elementos químicos de forma mais espontânea, inclusive no turno 523, A5 percebe que foi anotado erroneamente na folha o símbolo de $\mathrm{Ne}$ :

Turno 523: A5: Quem colocou esse aqui, ó? "Me”?

E A3 rapidamente confirma se tratar do símbolo Ne anotado incorretamente:

Turno 524: A3: É Ne! Pode riscar.

Se não podemos garantir que se apropriaram totalmente dos termos dos elementos químicos, podemos dizer que caminham para isso.

Em relação aos conceitos envolvidos, não observamos nenhuma referência que indique se tratam a luz como onda ou partícula. Nenhum outro conceito aparece nesse momento da aula. Essa situação é coerente com o momento anterior, já que este é uma consequência direta daquele.

Em relação à argumentação, encontramos algumas estruturas com elementos básicos dela.

No turno 411, A4 afirma que não tem Carbono e no turno 412, A5 confirma que não tem (carbono), (pois) sobrou um monte (de linhas). E novamente A4 no turno 414 confirma que "não pode sobrar em cima".

Turno 410: A5: Risca o C aí.

Turno 411: A4: C não tem, não tem.

Turno 412: A5: Não, sobrou um monte (inaudivel).

Turno 413: A5: Esse resto de linha pra continuar amarelo aí. 
Turno 414: A4: Não só vale aqui de cima para baixo. Não pode sobrar em cima viu? Essa aí tem.

Novamente temos um exemplo de argumento construído coletivamente. Conforme o modelo de Toulmin (1958) temos: o dado obtido por meio da observação e da comparação dos espectros da estrela com os espectros dos elementos caracterizando o dado como obtido e empírico (Jiménez Aleixandre, 1998); a conclusão é que (a estrela analisada) não tem Carbono e a justificativa utilizada para essa conclusão é "que sobraram linhas" na comparação entre os espectros e não podem sobrar linhas (todas devem coincidir).

Estruturas semelhantes a essa podem ser encontradas nos turnos: 439 quando A5 justifica a ausência do elemento por causa do azul que está sobrando; 461 quando justifica pela sobra do vermelho, episódio que se repete no turno 471; 515 quando A2 justifica que (as linhas) não bateram para o Li.

Com essas estruturas de argumentação, observamos que os alunos compreenderam a fala do professor informando que todas as linhas devem coincidir para afirmarmos que um determinado elemento está presente na estrela analisada.

Pelo modelo de Van Eemeren et al. (1987) adaptado por Villani e Nascimento (2003) podemos afirmar que, depois da intervenção direta do professor ao notar que os alunos do grupo estavam identificando os elementos de forma errada (Contexto), o discurso do grupo que corresponde ao discurso interpretado finalmente se aproximou do discurso do locutor no caso o professor. Isso só foi possível dentro de um contexto no qual o professor chegou inclusive a identificar alguns elementos com os alunos.

Em relação aos indicadores de alfabetizacão científica, novamente temos a utilização dos indicadores organização, classificação e alguma justificativa.

Em relação ao indicador organização, temos dois tipos: organização para realização da atividade e organização para comparação dos espectros.

Como exemplo de organização para realização da atividade, podemos citar os turnos: 376 quando A4 solicita que A1 vá riscando os elementos que não estão presentes na estrela, mas estão anotados na folha de atividades, fato que se repete em outros turnos como no 384, 402, 405,483 a pedido de A5, no 531, entre outros ao longo do momento analisado; 555 quando A2 pergunta se é necessário passar a limpo; e 556 quando A5 solicita que passe a caneta.

Como exemplo de organização para comparação dos espectros, os alunos buscam a melhor forma para analisar os espectros, seja manipulando o conjunto de espectros, ou explicando como devem fazer para identificar a presença do elemento, temos os turnos: 414; 
417; 518 entre outros, já que constantemente manipulam o conjunto de espectros buscando melhor visualização das linhas.

O indicador classificação surge quando os alunos indicam os elementos que estão, ou não presentes na estrela. Como este momento é para verificação das classificações feitas anteriormente, ele aparece praticamente durante toda a situação analisada, como nos turnos: $367,373,405,419,462,524,547,549$ e 552 entre tantos outros.

$\mathrm{O}$ indicador Justificativa aparece nos turnos em que os alunos justificam e explicam suas respostas para o professor ou quando explicam o raciocínio que estão utilizando para verificar se determinado elemento está presente em determinada estrela. Podemos citar os turnos: 412, 414, 439, 471 e 515. 


\title{
Episódio 2 - análise da atividade do astrônomo mirim:
}

\section{Momento 4 - Explicação/sistematização e apresentação de novos problemas pelo professor}

\author{
Ver tabela de transcrição e análise (anexo p. 308).
}

\section{Descrição da aula:}

Essa sequência é considerada um momento singular, cuja característica principal é o predomínio da fala do professor que traz informações e busca sistematizar a aula, além de apresentar dois novos problemas aos alunos. É nesse momento que o professor introduz o modelo de Bohr para explicar os espectros e suas linhas.

Segue uma descrição detalhada desse momento:

No turno 557, A4 entrega a folha com as anotações dos elementos presentes nas estrelas analisadas. Os alunos do grupo conversam entre si.

No turno 558 e 562 o professor busca organizar a sequência da aula, informando que pretende fornecer uma pequena explicação e apresenta um texto com seis perguntas das quais destacará duas para os alunos responderem. Este fato ocorre devido à proximidade do final da aula e também do ano letivo, conforme destaca um aluno não identificado no turno 559, respondendo que eles fariam dia 20 (de dezembro). O professor é obrigado a priorizar as questões que pretende trabalhar. Enquanto explica o que pretende fazer, ele entrega os textos de apoio para os grupos. A5 canta durante a entrega dos textos.

No turno 563 o professor entrega o texto de apoio para o grupo que estamos acompanhando enquanto A5 faz uma brincadeira com ele e em seguida volta a cantar, agora com a companhia de A4.

No turno 565 o professor apresenta um contexto histórico para estudos sobre os espectros e destaca que a Ciência não surgiu pronta e imutável, mas sim que ela passa por mudanças e evoluções ao longo dos anos em função de novas descobertas.

O professor também comenta que as linhas dos espectros já eram conhecidas desde 1800 e alguns avanços ocorreram nos anos seguintes como com Hook em 1856, mas não sabiam explicar porque as linhas apareciam. Em seguida, destaca o texto que entregou aos alunos (ver anexo - Modelo Atômico de Bohr) que mostra na primeira página basicamente 
três tipos de espectros: o espectro contínuo de um filamento que é obtido quando a luz resultante do aquecimento do filamento passa por um prisma ou por uma rede de difração; um gás ou uma lâmpada com gás, quando aquecida, emitirá luz que ao passar pelo prisma ou pela rede de difração também apresentará um espectro (no texto consta a informação que é um espectro de emissão); por fim, cita o espectro de absorção que é obtido quando a luz (de outra fonte) passa através de um gás e na sequência ao sofrer refração em um prisma, apresentará um espectro diferente. O professor destaca que maiores informações podem ser obtidas no site da UFRGS e mostra o nome do site que já estava na lousa. O mesmo lamenta o pouco tempo restante.

No turno 568 o professor relata que as ideias sobre o surgimento das linhas nos espectros começam a ficar mais claras com o modelo atômico de Bohr. Em seguida comenta que existiram outros modelos atômicos antes daquele proposto por Bohr.

É a primeira vez que cita o modelo de Bohr.

O próximo modelo citado pelo professor é o de Thompson. Enquanto explica como era o modelo, o professor desenha na lousa. A2 e A3 olham atentamente para o texto de apoio, enquanto A1, A4 e A5 olham para lousa, apenas A6 mexe com seu celular de forma dispersa. Depois apresenta o modelo de Rutherford e, para isso, descreve o experimento de espalhamento no qual lançou partículas alfas, constituídas por dois prótons e dois nêutrons, em uma lâmina bem fina de ouro, onde supunha que os átomos estivessem um ao lado do outro. Nesse momento o professor utiliza analogias para explicar o que ocorreu com o experimento realizado por Rutherford. O professor também utiliza desenhos na lousa para descrever esse modelo. A5 está disperso durante a explicação do professor, ele conversa e brinca com o microfone enquanto fala com A6.

Nos turnos seguintes o professor continua fazendo analogia para descrever o experimento realizado por Rutherford, até a apresentação do modelo atômico elaborado por ele no turno 585. Durante esse período, A5 demonstra impaciência ao observar a hora. O professor conta com a colaboração de alguns alunos quando utiliza sua analogia.

Logo após apresentar o modelo de Rutherford, destaca o problema dos elétrons girando ao redor de um núcleo que deveriam emitir energia e com o tempo colapsar com o núcleo. Continua usando a lousa para representar o modelo de Rutherford.

No turno 590 o professor começa a falar do modelo de Bohr, apresentando a solução proposta por ele para resolver o problema do colapso do elétron (o elétron gira sem irradiar energia) e novamente utiliza desenho na lousa para mostrar o elétron girando em sua órbita. Em seguida começa a falar das posições que os elétrons podem ocupar e das transições que 
realizam. Neste instante os alunos brincam com o professor e distraem um pouco. No turno 597 o professor aproveita o desenho que tinha feito na lousa para indicar com gestos os níveis de energia onde podem ser encontrados. Durante a fala sobre as mudanças de posições dos elétrons, o professor conta com a ajuda dos alunos, principalmente de um determinado aluno de outro grupo.

No turno 601 o professor é obrigado a pedir atenção em virtude das conversas paralelas dos alunos.

Já no turno 603 o professor explica que os elétrons só podem ocupar órbitas inteiras (quantização de energia) e apresenta uma nova questão para sala: se o átomo de hidrogênio possui apenas um elétron, por que aparecem tantas linhas no espectro desse elemento?

Esta questão é uma das duas que o professor selecionou dentre as seis que aparecem no texto de apoio.

Neste turno o professor faz uso da palavra "fóton", mas não chega a fornecer explicação sobre ela.

No turno 605 o professor continua utilizando desenhos na lousa para suas explicações e fornece pista sobre a resposta:

Turno 605: P: A única coisa que você pode utilizar para tentar elaborar sua resposta é que existem várias possibilidades de posição do elétron. Ele pode estar no nível 1, no nível 2, no nível 3, no nível 4, mas o importante é que só tem um elétron. Quando você excita...

No turno 608 o professor explica que quando o elétron se encontra num nível de energia maior, ele emite um fóton que vai marcar o espectro. Essa fala é importante, pois justifica a presença das linhas no espectro, em seguida afirma que o elétron emite luz e "desce" ao nível anterior. No mesmo turno o professor repete a questão sobre a quantidade de linhas presentes no espectro. Notamos que nesse turno o professor utiliza a palavra "fóton" e "luz" para descrever a mesma situação. A2 comenta que faltam apenas 15 minutos para acabar a aula, e o professor olha para o relógio.

No turno 613 o professor explica que, quando excitado (recebe energia), o elétron sobe para um nível de energia maior, mas fica numa posição que não é estável. Em seguida, emite luz, uma onda eletromagnética, um fóton e quando ele volta para o nível anterior, aparece uma linha. Neste momento o professor usa a palavra "luz", "onda eletromagnética" e "fóton" para descrever a mesma situação, porém essa classificação não é comentada pelo professor nem questionada pelos alunos.

Nos turnos seguintes o professor segue explicando que o elétron pode subir e descer várias vezes para mesma posição, no caso, citando do segundo nível para o terceiro e a volta 
para o segundo, mas continua sendo apenas um elétron e marcando sempre a mesma linha. Continua utilizando desenhos na lousa para suas explicações.

Os alunos tentam responder. A3 parece ter interpretado a mudança de um nível para outro como uma reflexão, como se o elétron "batesse" em um nível e voltasse para outro, resultando no número maior de linhas.

Já um aluno de outro grupo parece associar as cinco linhas com a quantidade de níveis de energia que estavam desenhadas na lousa. $\mathrm{O}$ professor destaca que podem existir mais níveis de energia e solicita que o aluno explique seu raciocínio. A4 retoma a fala de A3, mas também não justifica. Vários alunos falam ao mesmo tempo.

No turno 632, A3 comenta que outra linha deve surgir quando o elétron muda de posição entre outros níveis de energia, como por exemplo, entre os níveis três e quatro. $\mathrm{O}$ professor complementa a resposta de $\mathrm{A} 3$, afirmando que na verdade a outra linha surgirá quando o elétron que inicialmente veio do $4^{\circ}$ nível chegar ao $2^{\circ}$.

Turno 633: P: Se ele sobe para o 4 e desce para o 3, ele emite uma outra onda eletromagnética... As linhas espectrais na verdade vão aparecer quando ele descer para o 2, do 4 para o 2, então vai aparecer uma segunda linha.

Segue a discussão: A3 questiona o que acontece quando do nível três para o quatro, ou seja, muda apenas um nível, mas entre níveis diferentes. O professor explica que também ocorrerá a emissão de onda eletromagnética, mas que não será observado no espectro. Apenas observaremos a nova linha quando mudar do $4^{\circ}$ para o $2^{\circ}$. E nova linha surgirá quando mudar do $5^{\circ}$ para o $2^{\circ}$ e assim por diante. A3 questiona se só aparecem linhas quando a mudança é para o nível 2. O professor responde que as radiações visíveis são as que ocorrem entre o $2^{\circ}$ e outros níveis de energia. As demais transições não conseguimos enxergar.

No turno 649 o professor apresenta a segunda questão para os alunos: qual o motivo de aparecerem linhas mais nítidas que outras no mesmo espectro? Os alunos seguem tentando explicar, porém notamos a classe agitada com a proximidade do término da aula. No turno 666 o professor destaca que num gás teremos milhões de átomos e elétrons e que para cada transição de um elétron, por exemplo, voltando do nível três para o dois, indicará a mesma linha, mesmo que para átomos distintos (e elétrons distintos também). No turno 667 um aluno não identificado comenta que as cores seriam diferentes.

A fala do professor parece caminhar para conclusão de que um número maior de elétrons voltando de um mesmo nível para o outro resulta em uma linha mais nítida, no entanto nestes instantes finais não temos o áudio e logo vemos os alunos se despedindo no final da aula. O encerramento é tranquilo e os alunos parecem felizes com a aula. 


\section{Análise:}

Destacamos que embora seja uma aula de sistematização/explicação com predomínio da fala do professor, nosso foco continua sendo os alunos no grupo observado, claro que sempre considerando também a interação com o professor.

Em relação ao envolvimento com a atividade, os alunos seguem atentos às falas do professor e interagem à medida que as perguntas são feitas pelo mesmo. Apenas notamos que A5, cuja participação sempre foi relevante neste momento final da aula está disperso e brinca muito, não participando das principais discussões. Entre os turnos 660 e 663, a dispersão de A5 chama a atenção do professor que chega a brincar com ele e o próprio aluno comenta que não consegue raciocinar.

Como exemplos de participação dos alunos, podemos destacar a participação de A4 e um aluno não identificado quando o professor utiliza analogia para descrever o experimento de espalhamento de Rutherford que ocorre entre os turnos 572 e 585 . Também chama a atenção a participação de um aluno de outro grupo durante a discussão sobre as transições do elétron nos níveis de energia que ocorre entre os turnos 591 e 607. Quando o professor apresenta a primeira questão no turno 603 e repete no turno 607, vários alunos de grupos distintos tentam responder e destacamos a participação de A3, do aluno de outro grupo que participou das discussões sobre os níveis de energia e de A4.

Os momentos que os alunos acompanham atentos a fala do professor, os desenhos e explicações que apresenta na lousa e mesmo quando olham para os textos de apoio, também consideramos indicativos do envolvimento com a atividade.

Em relação às linguagens, temos o predomínio da linguagem oral por parte dos alunos. Nesse momento da aula praticamente todas as interações são por meio de falas e em tentativas de respostas aos questionamentos do professor. Destacamos a seguinte sequência de turnos:

Turno 581: P: Quando ele fez essa experiência, as partículas alfa, algumas delas batiam e voltavam. Pra chegar a bater e voltar isso aqui não pode ser uma bola de futebol, esse caminhão bateu no quê? Pra bater e chegar a voltar?

Turno 582: A4: Uma montanha.

Turno 583: P: Deve ser uma montanha, deve ser pelo menos outro caminhão.

Turno 584: A4: O Douglas.

O professor continua explicando o que aconteceu com as partículas alfa ao serem jogadas na lâmina de ouro e continua utilizando analogia para tanto. A4 responde com a ideia 
que teria de ser algo grande, maior que o caminhão. $O$ professor aproveita a resposta do aluno, mas torna a informação mais precisa ao afirmar que pelo menos outro caminhão seria necessário para que o primeiro batesse e retornasse. A4 repete a brincadeira remetendo à ideia de algo grande, porém sem precisar o quanto.

Nesse exemplo, conseguimos acompanhar como o conhecimento está sendo construído e presenciamos um caso no qual o professor utiliza a resposta do aluno, mas acrescentando uma informação mais precisa a ela, ele "especializa" a fala do aluno com sua própria fala.

A sequência entre os turnos 619 e 648 também são um exemplo onde a linguagem oral nos permite observar e compreender como os alunos estão raciocinando em relação ao questionamento do professor sobre a quantidade de linhas que observamos nos espectros, embora tenhamos apenas um elétron para o caso do Hidrogênio.

A manipulação de materiais é notada apenas no início do momento quando o professor começa sua explicação e comenta sobre os tipos de espectros que aparecem na primeira página do texto de apoio e quando começa a falar dos modelos atômicos. Nesses instantes alguns alunos buscam acompanhar a fala do professor observando o texto de apoio.

Apesar de o foco ser os alunos, destacamos que o professor utiliza muito a linguagem escrita na lousa para complementar suas explicações. Os alunos praticamente receberam informações e explicações por meio da linguagem oral até este momento, depois adquiriram também, por meio de desenhos e representações feitas pelo professor na lousa.

Com relação à apropriacão dos termos técnicos, os alunos parecem assimilar a ideia de mudança de níveis apresentada no modelo de Bohr, conforme os turnos 637 e 638. Embora o professor utilize o termo "fóton", os alunos não fazem nenhuma referência a ele e não temos a utilização de nenhum outro termo novo.

Em relação aos conceitos envolvidos, os alunos não fazem nenhum questionamento a respeito dos postulados de Bohr sobre o elétron que gira ao redor do núcleo sem irradiar energia e sobre a quantização dos níveis de energia, inclusive em suas falas não indicam a possibilidade do elétron ocupar níveis fracionários em nenhum momento.

O professor utiliza a ideia de onda eletromagnética e de fóton (partícula) para luz em vários momentos da aula, como nos turnos 603, 608, 613 (quando utiliza ao mesmo tempo as duas interpretações para luz - onda e partícula) e 641. Embora não fique claro o motivo pelo qual o professor utiliza as duas interpretações ao mesmo tempo, os alunos não fazem nenhuma referência a elas e não parecem ter notado a utilização desses conceitos pelo professor. 
Quanto à argumentação, encontramos um exemplo no turno 632:

Turno 632: A3: Mas se ele sobe pro 4 e cai pro 3 é outra linha.

Nessa fala podemos identificar os elementos básicos da argumentação, segundo Toulmin (1958): a conclusão aparece quando A3 afirma que terá outra linha, e ela será diferente; a justificativa para essa diferença é o fato (do elétron) subir para o $4^{\circ}$ e cair para o $3^{\circ}$, ou seja, transições entre níveis diferentes; e o dado parece ser um dado fornecido (Jiménez Aleixandre, 1998) já que o professor no turno 605 informa que os elétrons podem ocupar vários níveis de energia. Interessante notar que esse dado também pode ser um dado obtido por meio das observações do aluno em relação aos desenhos que o professor faz na lousa, em que são apresentados cinco níveis de energia, ou até mesmo uma combinação dos dois tipos de dado.

Embora o raciocínio do aluno esteja correto, o professor informa que essa nova linha não será observada porque não está na faixa de frequências visíveis (turno 641), porém destaca que realmente a justificativa para presença de um número maior de linhas é a transição entre níveis diferentes, desde que relacionadas ao $2^{\circ}$ nível (turno 633).

Nos turnos 637 e 638 um aluno de outro grupo e A2, respectivamente, justificam a presença de outras linhas com a subida para outros níveis, no caso, comentado pelo aluno do outro grupo, que a quantidade de vezes é a responsável pelo número de linhas. Como vimos tal raciocínio não é correto, entretanto, aqui temos uma conclusão que é indicada pelo aparecimento de várias linhas; uma justificativa, a subida para outro nível de energia, no caso, explicado por A2, e o número de subidas, argumentado pelo aluno de outro grupo. $\mathrm{O}$ dado também pode ser resultado das observações ou ainda da fala do professor no turno 605 .

Em relação aos indicadores de alfabetizacão científica, lembramos que esse momento é utilizado pelo professor para organizar e apresentar explicações e justificativas. Não sobra muito espaço para ações dos alunos, que na maior parte do momento, prestam atenção às explicações do professor e respondem as suas perguntas. Nos instantes em que os alunos dão respostas, aparecem, em alguns casos, o indicador justificativa, como observamos nos turnos 632, 637 e 638. Tal fato é coerente com o momento da aula.

\section{Outras informacões relevantes:}

Neste momento da aula, notamos que, diferentemente dos momentos anteriores a esse episódio, em que os alunos interagiam apenas com os outros integrantes do próprio grupo, as interações ocorrem entre todos os grupos e com o professor. Também observamos um processo coletivo de construção de conhecimento com participação efetiva do professor 
fornecendo informações e apresentando questionamentos e de vários alunos, inclusive de grupos diferentes, buscando respostas e tentando compreender as situações apresentadas. 


\section{Capítulo VI - Considerações finais}




\section{Consideracões finais e conclusões:}

Com esse trabalho buscamos verificar "se" e "como' os alunos se apropriam da linguagem científica partindo de conceitos falados ou outras formas de linguagem científica e se essa apropriação pode ser um indicativo de evolução conceitual, em uma sequência de Ensino de Física Moderna para o Ensino Médio que trabalhasse com atividades práticas.

Ainda buscamos observar se essas atividades práticas apresentaram alguma contribuição para apropriação da linguagem científica e da evolução conceitual, caso ela ocorresse.

Trabalhamos com duas atividades práticas: primeiro, análise dos espectros de lâmpadas com espectroscópio construído com redes de difração de $\mathrm{CD}$, e segundo, astrônomo mirim, cujo objetivo era que os alunos verificassem se uma estrela hipotética possuía determinados elementos químicos por meio de comparação de espectros. Consideramos cada atividade como um Episódio de Ensino que foram divididos em momentos distintos.

Após um estudo de referenciais sobre Linguagens da Ciência no Ensino e argumentação em sala de aula, definimos alguns instrumentos para nossa análise que foi realizada com uma estrutura na qual verificamos: as linguagens científicas presentes; a presença de estruturas de argumentação; indicadores de Alfabetização Científica; apropriação de termos técnicos; envolvimento dos alunos com a atividade; e verificação da presença ou não de conceitos nas linguagens dos alunos.

A seguir destacamos alguns aspectos importantes da análise e fazemos algumas considerações:

Em relação ao envolvimento com a atividade:

Episódio 1:

Constante e intensa manipulação dos espectroscópios no primeiro episódio. Mesmo não prestando muita atenção ao que o professor fala, os alunos já manipulavam os espectroscópios no momento 1 .

A maior parte das falas é voltada para atividade, o mesmo ocorrendo com as ações. Alunos eufóricos com as observações.

Durante o momento 4 os alunos demonstram cansaço com a análise da lâmpada mista, mas no momento 5, nova empolgação com a lâmpada dicróica e também no momento 6 , com a lâmpada de luz negra. 
Busca pela melhor forma de realizar as observações.

Preocupação com a descrição correta das características dos espectros como identificação das cores presentes, classificação das bandas e classificação em contínuo ou discreto.

Interações dialógicas permeiam todo o momento 2, quando os alunos discordam e questionam a classificação feita pelo professor.

Intensa discussão do grupo para definição de qual é a menor banda.

Iniciativa para as atividades, algumas vezes os alunos já classificam a lâmpada ou o espectro mesmo sem solicitação explícita do professor.

No momento 2 destacam a diferença entre as duas lâmpadas observadas (incandescente e fluorescente).

Aparece classificação do tipo de espectro com justificativa a partir do momento 2 .

Poucas falas que atrapalham o professor. Apenas nos momentos 5 e 6 notamos muitas conversas e brincadeiras não relacionadas à atividade. Também no momento 5 questionam sobre o tempo de duração da aula.

Participação efetiva dos alunos durante a realização da atividade.

Episódio 2:

Busca pela organização da atividade.

Atenção às informações fornecidas pelo professor por meio da fala ou de desenhos na lousa, embora no momento 1 não façam perguntas.

Constante manipulação dos espectros.

Poucas conversas não relacionadas à aula.

Euforia com as identificações e com a atividade.

Preocupação com os registros da aula e com a melhor forma de identificar os elementos.

Participação efetiva de praticamente todos os alunos do grupo. Apenas A6 tem uma participação discreta ao longo da atividade, e A5 fica dispersa no momento 4.

Em relação às linguagens científicas:

\section{Episódio 1:}

Predomínio da manipulação dos espectroscópios que reflete o interesse dos alunos e a busca pela melhor forma para observação. As dificuldades com a manipulação dos espectros para observação vão diminuindo durante os momentos. Esta manipulação ocorre mesmo antes 
da solicitação do professor no momento 1 e até durante a explicação no momento 7. Também contribui para identificarmos algumas dificuldades que os alunos encontram com a atividade.

Observamos a manipulação de materiais para registro das observações como folhas e cadernos.

A linguagem oral possibilita a observação das interações bem como perceber os questionamentos e dificuldades dos alunos. Permite notarmos que as maiores interações dialógicas ocorrem nos momentos 2 e 3 . Nos momentos 5 e 6 praticamente só contamos com a linguagem oral, já que a iluminação era pouca.

A linguagem gestual está mais presente e relacionada com a atividade a partir do momento 3 sempre cooperando com a linguagem oral. Nos turnos 5 e 6 com a falta de iluminação e pouco tempo para atividade, não registramos gestos relevantes.

\section{Episódio 2:}

Predomínio da linguagem oral. Prevalece a fala do professor no momento 1. Permite a observação de aspectos cognitivos. Temos a linguagem escrita também, com a folha de respostas do grupo.

Constante manipulação dos espectros (das estrelas hipotéticas e dos elementos).

A linguagem gestual aparece com menor intensidade e geralmente para indicar a posição das linhas, cores ou espectros. Continua cooperando com a linguagem oral.

\section{Em relação à apropriação de termos técnicos:}

\section{Episódio1:}

Utilização e apropriação do termo "contínuo" e do termo "discreto" e suas características conforme o desenvolvimento da atividade. Ficam confusos a partir do momento 4 com a lâmpada mista, e a confusão persiste com a lâmpada dicróica e dicróica com filtro. As novas situações de análises, informações e questionamentos realizados pelo professor contribuem para confusão dos alunos.

Não utilizam muito o termo "maior banda" ou "menor banda", preferem usar "o que aparece mais" ou "o que aprece menos", ou simplesmente "maior" ou "menor".

\section{Episódio 2:}

Os alunos confundem os nomes e símbolos que representam os elementos químicos, porém no decorrer da atividade, passam a utilizá-los com maior espontaneidade indicando que, se não se apropriaram dos símbolos e nomes, pelo menos caminham nesse sentido.

Parecem ter assimilado a ideia de mudanças de níveis. 
Em relação aos conceitos envolvidos:

\section{Episódio 1:}

A questão dos conceitos aparece pela fala do professor, mas não temos retornos dos alunos em relação a eles.

Quando fala sobre distribuição de frequências, o professor remete a ideia de luz como onda no momento 2 .

No momento 3 quando troca a expressão "maior banda" por "mais intensa", parece existir uma confusão de conceitos.

Apenas no momento 7 , quando o professor faz questão de diferenciar a lâmpada fosforescente da lâmpada fluorescente, temos retorno dos alunos e surge a questão da rápida e lenta absorção e emissão de luz.

No momento 7 o professor destaca que as cores e linhas estão associadas a determinadas substâncias.

\section{Episódio 2:}

No momento 1 o professor destaca que cada elemento possui um espectro específico.

Apresenta o Modelo Atômico de Bohr e alguns de seus postulados, mas não temos como identificar se os alunos realmente entenderam ou não. Um detalhe chama a atenção: os alunos não questionam a possibilidade de posicionamento de elétrons entre os níveis apresentados, porém não temos como afirmar que isso foi resultado da compreensão da quantização dos níveis de energia.

No momento 4 para definir a luz emitida quando os elétrons "descem" de nível, o professor utiliza o conceito de luz como partícula (fóton) e também como onda eletromagnética, entretanto não apresenta nenhuma explicação ou comentário sobre os dois conceitos. Os alunos não comentam. É a primeira vez que ouvimos a palavra fóton ser utilizada na aula.

Em relação à ârgumentação:

\section{Episódio 1:}

Temos um número relativamente pequeno de argumentos e com estruturas básicas.

Surgem alguns exemplos de argumentação a partir do momento 2.

No momento 3 temos um exemplo de construção coletiva de argumento e podemos considerar o momento 5 todo como uma estrutura básica de argumento.

Os momentos 6 e 7 não apresentam estruturas básicas de argumentação.

\section{Episódio 2:}


Encontramos estruturas básicas de argumentação a partir do momento 2 .

No momento 2 temos um exemplo de como a fala do professor parece modificada devido ao contexto da aula na fala do aluno.

No momento 3 temos estrutura coletiva de argumento. Notamos que após a intervenção do professor, a fala do grupo passa a se identificar com a fala inicial do professor no começo do episódio.

Em relação aos Indicadores de Alfabetização Científica:

\section{Episódio 1:}

Pela natureza da atividade e pela ausência de perguntas que levem ao desenvolvimento da argumentação, predominam os indicadores "organização" e "classificação" e o indicador "justificativa" aparecendo nas estruturas mais elaboradas de fala.

Para nossas análises e pelas características particulares das atividades, sentimos a necessidade de especificar ainda mais o indicador "organização", precisamos de maior exatidão, conforme a atividade foi se desenvolvendo. Dessa forma no momento 1 temos "organização para realização da atividade" e "organização para observação com os espectroscópios".

No momento 2 surgem também “organização para classificação dos espectros”, já que os alunos iniciam as identificações, "organização para classificação das bandas" e "organização buscando associação de variáveis". Neste contexto temos também "classificação" e "justificativa". O indicador "classificação" também necessitou de maior precisão: "classificação do tipo de espectro", "classificação do tamanho das bandas" e "classificação das cores".

No momento 4 o indicador "classificação" é fundamental, pois reflete as discordâncias e confusões presentes no grupo em relação à análise dos espectros. Utilizamos "classificação do tipo de lâmpada". Surge um exemplo de "explicação" que está diretamente ligado ao indicador "justificativa".

No decorrer da atividade notamos que a "organização para observação" diminui, e isto demonstra que os alunos já se apropriaram da manipulação dos espectroscópios. Surge “organização para compreensão da função do filtro azul" e na classificação dos tipos de espectros, percebemos insegurança por parte dos alunos que reflete as dificuldades que passaram a ter a partir da análise da lâmpada mista.

No momento 6 não temos o indicador "justificativa".

\section{Episódio 2:}


Aparece “organização" no momento 1.

Nos momentos 2 e 3 temos "organização", "classificação" e "justificativa". Também utilizamos classificações mais precisas para “organização" e "classificação".

No momento 4 apenas o indicador "justificativa" nos instantes que os alunos apenas respondem aos questionamentos do professor.

Em relação a outras informações relevantes:

\section{Episódio 1:}

Predominam as interações P/T, mas aparecem bastante A/A e algumas vezes Ax/Ay. Apenas no momento 6 predominam interações A/A.

Notamos a participação de vários alunos no decorrer da atividade e em cada momento um ou dois alunos acabam tendo uma participação maior.

Pela natureza da atividade existe a interação com outros grupos.

\section{Episódio 2:}

Predominam as interações P/T, aparecendo também P/A e A/A. Pela natureza da atividade, não temos interação entre alunos de grupo diferentes enquanto comparam os espectros.

O professor apresenta preocupação no início da atividade em virtude da mudança de dinâmica da aula em relação à atividade anterior.

Partindo desses aspectos destacados e das análises realizadas, verificamos que existe sim apropriação da linguagem científica durante a realização das atividades. Inclusive acompanhando a manipulação dos espectroscópios e dos espectros das estrelas, notamos que os alunos apresentam dificuldades iniciais que vão se resolvendo com o desenvolvimento das atividades.

A utilização das linguagens científicas e a presença dos indicadores de alfabetização científica apontados nas análises indicam que os alunos estão inseridos num processo de construção de conhecimentos científicos dentro da realidade escolar. A utilização dos termos técnicos de forma mais espontânea e uma compreensão dos mesmos inseridos no contexto da atividade reforçam essa conclusão.

Observamos também que os indicadores e as linguagens são importantes para identificarmos as estruturas de argumentação presentes nos episódios e são esses argumentos que permitem um acompanhamento maior dos aspectos cognitivos presentes nas aulas. Com os argumentos conseguimos entender como os alunos estão desenvolvendo sua estrutura de pensamento e percebemos muitas vezes uma estrutura maior construída coletivamente. 
Entretanto, os argumentos surgem com questionamentos feitos pelo professor ou pelos próprios alunos durante a atividade. Nesse sentido sentimos a falta de mais perguntas e questões elaboradas e estrategicamente inseridas com o objetivo de buscar entender como os alunos estão pensando e elaborando seus raciocínios. Essas perguntas elaboradas com essa finalidade facilitam um acompanhamento mais preciso por parte do professor possibilitando que ele realize intervenções que colaborem com o processo ensino-aprendizagem dos alunos.

O professor faz algumas perguntas que possibilitam o aparecimento de argumentos e também intervenções. Porém, uma aula estruturada com mais questões para serem utilizadas em momentos específicos e com o objetivo de permitirem a elaboração de argumentos por parte dos alunos contribuirá muito para o processo ensino-aprendizagem e pode evitar certas confusões, como as ocorridas durante as análises dos espectros das lâmpadas mista e dicróica com filtro.

Podemos afirmar também que as atividades, pelas suas características e dinâmicas, conseguiram um excelente nível de envolvimento dos alunos e isso com certeza contribuiu muito para apropriação das linguagens científicas. A utilização da linguagem "manipulação dos materiais" foi ótima para despertar o interesse dos alunos.

Já em relação à evolução conceitual não temos indicativos por parte dos alunos que ela tenha ocorrido. Com as atividades, da forma que foram desenvolvidas, não percebemos que modelo os alunos utilizam para luz e nem a presença de outros conceitos.

O máximo que conseguimos foi acompanhar como os alunos estavam identificando e distinguindo as características dos espetros contínuos e discretos.

Durante a apresentação do modelo atômico de Bohr, o professor chega a utilizar ao mesmo tempo a ideia de luz como onda e como partícula, mas os alunos parecem nem perceber isso. Portanto, não podemos afirmar que as atividades contribuam de forma imediata para evolução dos conceitos.

Vale ressaltar que a explicação dos espectros de emissão e absorção, a necessidade da utilização do modelo de Bohr para essa explicação podem contribuir para as questões conceituais, principalmente para questão dualidade onda-partícula para luz, porém durante a realização das atividades, na qual estava focada nossa proposta de análise, os alunos não apresentam indicativos em relação aos conceitos.

Outras considerações:

Durante a análise de dados praticamente realizamos um mapeamento das aulas baseados nas falas, ações e interações do grupo que acompanhamos. Tal mapeamento, além 
de permitir que chegássemos a considerações sobre os nossos problemas de pesquisa, ainda propiciou outras considerações.

Como dissemos anteriormente, os argumentos foram extremamente importantes para o acompanhamento do processo cognitivo dos alunos. E mesmo as falas que não apresentavam estruturas de argumentação básica contribuíram para mostrar as dificuldades que os alunos encontraram para realização das tarefas que lhes foram estabelecidas. O mesmo ocorrendo com as imagens obtidas.

Relembramos a seguir alguns fatos relevantes desse mapeamento:

Em relação ao Episódio 1:

No momento 1 os alunos estão manipulando os espectroscópios, enquanto o professor fornece informações gerais sobre a atividade e explica que ela servirá como nova oportunidade para aqueles que não fizeram a pesquisa de campo, e também para os que fizeram tirarem suas dúvidas e aperfeiçoarem suas observações e interpretações. Durante essa fala, alguns alunos terminam a construção dos espectroscópios, outros já realizam observação da lâmpada no teto da sala e outros relatam sobre a atividade de campo. Há alunos não tão atentos à fala do professor.

No momento 2 o professor inicia a atividade com uma lâmpada fluorescente compacta. Os alunos iniciam suas observações e começam a classificar os espectros como contínuos ou discretos, mas demonstram dúvidas em relação à classificação e não justificam as mesmas. Rapidamente o professor troca de lâmpada a fim de que os alunos notem a diferença entre os espectros. A lâmpada utilizada agora é uma incandescente.

Aqui a estratégia do professor foi bem sucedida, já que vários alunos mostram perceber a diferença entre os espectros observados (fluorescente com espectro discreto e incandescente com espectro contínuo).

O professor aproveita para destacar as características que os alunos devem observar para classificar os espectros durante a observação da lâmpada fluorescente: a presença de todas as cores indicando que é contínuo e a presença de linhas indicando que é discreto.

Surge a primeira classificação com justificativa por parte dos alunos.

Com a lâmpada incandescente, além da classificação dos espectros, o professor solicita também a identificação da maior e da menor banda.

Apresentam dificuldades na identificação das cores como vermelho e laranja, anil e azul entre outras.

Buscam melhores condições para observação com o espectroscópio, desde o posicionamento em relação à lâmpada até identificação sobre qual lado do espectroscópio 
deve ser utilizado para observação e onde devem olhar dentro do mesmo para enxergarem os espectros. A busca vai sendo aprimorada durante o desenvolvimento da atividade.

Grande preocupação com os registros das observações.

No momento 3 o professor volta a utilizar a lâmpada fluorescente, agora solicitando uma observação mais detalhada: a classificação dos espectros, a identificação das bandas e ainda buscando associar o tamanho e formato das fendas do espectroscópio aos espectros observados. No caso, como o espectro da lâmpada fluorescente é discreto, com alguns espectroscópios os alunos observavam linhas escuras separando as cores, tudo num formato retangular, e com outros conseguiram enxergar o desenho do formato exato das lâmpadas separadas por regiões escuras.

Os alunos utilizam gestos para reforçarem a ideia de como estão vendo os espectros. Utilizam expressões como "tudo pontilhado" e "uns quadradinhos" para descreverem o espectro discreto.

Ainda buscam melhorar a forma para realizarem as observações com os espectroscópios.

Os alunos utilizam a ausência de algumas cores e o fato delas aparecerem separadas para classificarem o espectro como discreto. O professor insiste que devem classificar justificando pela presença de linhas, porém os alunos preferem apenas falar que as cores estão separadas, tal fato pode ter sido uma consequência de que em alguns espectros os alunos observavam o desenho das lâmpadas separadas cada uma com uma cor.

No momento 4 o professor utiliza uma lâmpada mista que inicialmente possui um espectro contínuo devido ao aquecimento de seu filamento (como o que ocorre com a lâmpada incandescente) e à medida que vai aquecendo, temos um espectro discreto devido à presença do gás em seu interior (como ocorre com a lâmpada fluorescente).

Os alunos realizam uma rápida observação inicial enquanto o espectro é contínuo e depois outra com o espectro discreto. A estratégia inicial utilizada pelo professor consiste em buscar associar o tipo de lâmpada com o tipo de espectro observado considerando que os alunos já viram uma lâmpada com filamento e outra com gás, no entanto, os alunos se mostraram muito confusos em relação às observações e classificação dos espectros. Na sequência o professor muda de estratégia, buscando destacar o significado da palavra "mista" para os alunos tentarem compreender o que estava ocorrendo.

A confusão continua e notamos que alguns alunos tinham uma expectativa de enxergar nitidamente os dois espectros ao mesmo tempo. 
As divergências nas classificações e dúvidas levam a algumas estruturas de argumentação por parte dos alunos durante a apresentação de suas ideias.

Demonstram os primeiros sinais de cansaço.

No momento 5 o professor utiliza uma lâmpada dicróica (cuja luz é dirigida para região de foco específico) e uma lâmpada dicróica com filtro azul.

Os alunos demonstram um pouco de insegurança na classificação dos espectros, provavelmente até pela observação da lâmpada anterior (mista).

O professor traz uma nova informação quando afirma que a ausência de algumas cores não significa necessariamente que o espectro seja discreto. Essa informação parece surgir pela presença do filtro que não deixa passar totalmente algumas cores. De qualquer forma é uma informação que entra em conflito com o que os alunos vinham fazendo: utilizando a presença de cores para classificar o tipo de espectro considerando que a presença de todas as cores indicava uma espectro contínuo, logo a ausência de algumas seria um indicativo do espectro discreto.

Essa informação reforça a classificação pela presença ou ausência de linhas, mas parece deixar os alunos inseguros em suas classificações.

O professor procura deixar bem claro a função do filtro utilizado.

O professor começa a se preocupar com o tempo restante de aula. O tempo reduzido não permite que os alunos apresentem muito suas ideias como nos momentos anteriores e se limitam a responder as indagações do professor.

No momento 6 o professor utiliza a última lâmpada: lâmpada de luz negra.

A estratégia de deixar essa lâmpada para o final da aula é boa, visto que ela chama a atenção dos alunos que já demonstravam sinais de cansaço, porém o pouco tempo restante não permite novamente que os alunos apresentem totalmente suas idéias.

Notamos outra vez a dificuldade na identificação das cores: os alunos identificam a cor roxa, mas divergem e mostram dificuldade no reconhecimento da cor verde e da cor laranja. Também é interessante observarmos que para os outros espectros os alunos utilizam lilás no lugar de roxo e que essa é a única vez que a cor roxa aparece sem a presença da azul e anil ao seu lado. Pela tonalidade mais escura que parece ter em relação às outras vezes que apareceu nos demais espectros, os alunos parecem ter optado pela classificação como cor roxa.

No momento 7 o professor apresenta informações sobre as lâmpadas e no final afirma que as linhas presentes nos espectros estão associadas ao tipo de gás utilizado e cada um 
possui linhas específicas. Com isso o professor deixa um "gancho" para a atividade seguinte do astrônomo mirim.

Com as informações aqui relatadas e as mais específicas apresentadas nas análises, podemos dizer que a atividade não pode ser considerada simples, pois apresenta uma grande quantidade de informações: análise de um espectro discreto $\rightarrow$ análise de um espectro contínuo $\rightarrow$ presença de todas as cores indica espectro contínuo $\rightarrow$ presença de linhas indica espectro discreto $\rightarrow$ nova análise de um espectro discreto $\rightarrow$ associação do tamanho das fendas com a imagem do espectro formada no espectroscópio $\rightarrow$ análise de uma lâmpada que possui inicialmente espectro contínuo e com o aquecimento de um gás passa a ter espectro discreto $\rightarrow$ análise de uma lâmpada que possui espectro contínuo, mas que tem um filtro de cor $\rightarrow$ a ausência de cores não significa necessariamente que o espectro seja discreto.

As dificuldades para identificação e distinção de cores que são próximas no espectro como no caso do vermelho, laranja e amarelo ou do azul, anil e violeta, também representam indicativos da complexidade da atividade. Lembramos que a distinção das cores e suas tonalidades depende muito da percepção de quem está observando e pode realmente variar de observador para observador.

Outro fato relevante é que a faixa de frequência para determinada cor pode ser pequena para certo elemento, o que também pode dificultar a observação, principalmente dos alunos que estão fazendo isso pela primeira vez e, consequentemente, não sabem de forma exata o que esperar das observações. Lembramos que durante a análise da lâmpada mista no turno 619, o professor destaca a presença de um espectro discreto bem nítido e parece que comentará sobre a presença de um espectro contínuo por trás deste, porém o áudio não permite confirmarmos tal impressão. De qualquer forma, nenhum aluno faz referência a essa superposição de espectros, o que exige um olhar muito mais experiente para percebê-lo ou algum aluno que esteja atento, de uma forma muito precisa, a detalhes.

Além da dificuldade com a identificação das cores, temos também as dificuldades com a maneira como devem observar com o espectroscópio: qual a melhor posição em relação à lâmpada; dúvidas, se precisam olhar diretamente para lâmpada ou não; qual o lado do espectroscópio deve ser utilizado para observar (se devem olhar pelo lado que possui o pedaço de $\mathrm{CD}$ ou lado da fenda sem o CD); qual a posição que devem olhar dentro do espectroscópio para enxergarem a melhor imagem do espectroscópio; e por fim, as diferenças que notam quando olham por espectroscópios com fendas diferentes resultando em espectros com "desenhos" diferentes.

Em relação ao Episódio2: 
No momento 1 o professor explica os objetivos da aula e informa que cada elemento possui um espectro único que funciona como sua digital, ou seja, os espectros servem para identificar os elementos. Informa que esta situação foi utilizada por pesquisadores e cientistas para identificarem elementos presentes em estrelas e planetas.

Sobre a atividade que os alunos vão realizar, o professor destaca que receberão o espectro hipotético de algumas estrelas em folhas de transparências, bem como os espectros de algumas estrelas em papel sulfite. Com esse conjunto de materiais deverão verificar quais os elementos presentes em cada estrela. Essa determinação deve ser feita comparando os espectros dos elementos com o espectro hipotético de cada estrela: os alunos devem pegar o espectro de uma estrela e verificar os elementos que ela possui e em seguida repetir o processo com outra estrela. $\mathrm{O}$ professor também informa que devem considerar que a estrela possui determinado espectro quando todas as linhas do elemento coincidirem com as da estrela.

No momento 2 os alunos começam a identificação dos elementos, porém eles pegam um elemento e passam as estrelas por ele, até que o professor perceba o ocorrido e solicite que peguem uma estrela e verifiquem todos os elementos nela contidos.

Os alunos buscam a melhor forma de compararem os espectros, a melhor forma para emparelharem os espectros e compararem as linhas.

Nesse momento percebemos que um aluno (A5) tinha interpretado corretamente as solicitações do professor, considerando que todas as linhas deveriam coincidir para que o elemento estivesse presente na estrela. Entretanto, ao observar a maneira como outros alunos realizam a comparação (no caso A2 e A3), ele acaba mudando sua interpretação e considera que a presença de apenas uma linha já seria suficiente para confirmar a presença do elemento. A3 confirma essa ideia que passa a ser o critério de classificação utilizado pelo grupo.

Tal fato só é percebido pelo professor no fim do momento quando nota que os alunos do grupo encontraram uma quantidade bem maior do que a esperada para cada estrela.

No momento 3 o professor ajuda os alunos a reverem algumas de suas identificações, reforçando que é necessário que todas as linhas do elemento estejam presentes na estrela observada para que ele esteja presente na mesma.

Logo em seguida os alunos iniciam uma rápida e intensa verificação de todas as estrelas e elementos, agora utilizando o critério correto.

No momento 4 o professor explica que a presença das linhas no espectro está relacionada às transições dos elétrons nos níveis de energia apresentados no modelo atômico de Bohr, mais especificamente as transições que envolvem o $2^{\circ}$ nível de energia. Também 
informa que o número de linhas não está relacionado ao número de elétrons e sim às diferentes transições envolvendo o $2^{\circ}$ nível de energia, por exemplo, a transição do $3^{\circ}$ para o $2^{\circ}$ nível resulta em uma linha, e a do $4^{\circ}$ para o $2^{\circ}$ nível resulta em outra linha.

No final da aula o professor ainda tenta falar sobre a diferença de nitidez de algumas linhas do espectro, mas não consegue desenvolver adequadamente o tema por falta de tempo e não temos o áudio dos instantes finais.

Também neste caso, com as informações aqui relatadas e as mais específicas apresentadas nas análises, podemos dizer que a atividade não pode ser considerada simples.

Presenciamos a dificuldade dos alunos para descobrirem a melhor forma de emparelhar os espectros a fim de comparar as linhas dos espectros dos elementos com as linhas dos espectros das estrelas.

Os alunos apresentaram dificuldades em compreender que numa tentativa didática de aproximar a atividade ao que os cientistas fazem, deveriam utilizar primeiro uma estrela e verificar a presença ou ausência de elementos nela e depois repetir o processo com outras estrelas. Afinal, na realidade, uma estrela é descoberta e na sequência, tentam identificar os elementos nela presentes e não o inverso.

Também tiveram dificuldades em compreender que para confirmar a presença de um determinado elemento na estrela todas as linhas deveriam coincidir, apresentando um discurso diferente daquele utilizado pelo professor, e mesmo com a intervenção deste, compatibilizando os discursos, ainda não foi eliminada outra dificuldade: a de observação e comparação das linhas.

Essa dificuldade pode ser percebida pelas constantes divergências entre os integrantes do grupo em relação à presença ou ausência dos elementos e as diferenças na maneira que enxergavam as linhas. O grupo sempre apresentou um posicionamento final único, apesar das muitas divergências que notamos pelas falas, manipulação dos espectros e discursos dos alunos.

Além disso, nessa atividade foi apresentado o modelo atômico de Bohr, com alguns de seus postulados para explicar a presença das linhas nos espectros discretos e também o número de linhas presentes em cada espectro, constituindo, dessa forma, um grande número de informações para os alunos.

Estas dificuldades, presentes nas duas atividades, mostram a importância e a necessidade de acompanhamento, por parte do professor, da forma como os alunos estão estruturando suas ideias e construindo seus conhecimentos, para que ele possa intervir na hora que for necessária e decidir por qual tipo de intervenção deve optar dentro do contexto escolar 
(tempo de aula, objetivos a serem atingidos, respeito à individualidade dos alunos e eventuais decisões estruturais que afetem as aulas).

Isto reforça nossa conclusão sobre a importância de questões previamente elaboradas que levem os alunos a elaborar argumentos que permitam um acompanhamento e avaliação do processo cognitivo, possibilitando intervenções que resultem numa otimização do processo de ensino-aprendizagem.

A importância da intervenção do professor pode ser exemplificada com o caso em que notou os alunos identificando erroneamente a presença dos elementos na estrela e realizou algumas identificações com eles, explicando que todas as linhas deveriam coincidir, antes de deixar que retomassem a atividade sem sua presença direta.

O professor que trabalha com atividades como estas, além de dominar os conceitos, nunca deve subestimar o grau de dificuldades que ela apresenta para os alunos. O cuidado com a estrutura de formação de conhecimentos é essencial para que os objetivos da aula possam ser alcançados sem causar danos ao aprendizado dos alunos.

A sequência de atividades parece representar uma boa escolha, pois conseguiu um envolvimento muito bom por parte dos alunos. Buscou uma adaptação didática para atividades realizadas por cientistas, e que mostram aspectos presentes numa pesquisa de investigação, inclusive a importância do erro para o aprendizado, como no caso em que os alunos, após serem informados que estavam identificando os elementos de forma incorreta, não desanimaram e retomaram suas análises buscando a correção.

A sequência com a observação de espectros, classificação e caracterização em espectros contínuos e discretos, uma demonstração prática de utilização dessas informações, bem como a necessidade e apresentação do modelo de Bohr para explicar a presença das linhas nos espectros e a quantidade dessas linhas, representa não o único, mas um caminho interessante e coerente para introdução aos estudos da Física Moderna. Permite também aulas dinâmicas e envolventes, além de uma sequência didática lógica e coerente para transição da Física Clássica para a chamada Física Moderna.

É importante ressaltar que não se espera que os problemas, como da determinação de elementos em um gás, uma estrela ou planeta, do colapso dos elétrons ou da quantização de energia, estimulem os alunos como aconteceu com físicos e cientistas no passado. Porém, eles apresentam uma razão coerente para sequência de estudos adotada, destacando características de pesquisas científicas e um contexto histórico, além dos conhecimentos físicos.

A sequência que analisamos representa o início dessa transição. Ela mostra uma razão para apresentação do modelo de Bohr e seus postulados. Na sequência prevista o próximo 
assunto, depois de trabalharem melhor o modelo de Bohr, com o texto de apoio no qual temos mais questões e exercícios, seria o efeito fotoelétrico em que a luz é descrita como partícula conhecida hoje como fóton e com energia proporcional à frequência da luz. Por fim, é discutida a questão da dualidade onda-partícula com atividade baseada no interferômetro de Mach-Zehnder e quatro interpretações para luz: ondulatória, corpuscular, dualista realista e da complementaridade.

Não podemos deixar de comentar as dificuldades estruturais como a dispensa inesperada dos alunos ou alguma outra atividade extraclasse que sem dúvida podem ter dificultado o professor em relação ao cumprimento de seu cronograma.

Nas atividades que acompanhamos, tivemos dificuldades em antecipar o horário de gravação nas aulas dos espectros das lâmpadas, que seriam as duas últimas, porém por motivo de dispensa dos alunos, as aulas foram antecipadas e essa informação só foi fornecida a todos no próprio dia da aula.

Também na sequência analisada, o professor precisou fazer escolhas: na análise dos espectros das lâmpadas, dedicou pouco tempo para a lâmpada de luz negra e não teve como retomar passo a passo o espectro de cada lâmpada ao final da atividade.

A visita ao site da Universidade Federal do Rio Grande do Sul, prevista no planejamento da sequência didática para ser realizada logo após a atividade com os espectros das lâmpadas, acabou como uma indicação de pesquisa para os alunos fazerem em casa e não foi retomada formalmente na aula.

Durante a apresentação e explicação do modelo de Bohr, o professor apresenta os postulados que falam sobre os elétrons e sua órbita circular ao redor do núcleo; sobre as órbitas específicas que podem ocupar e sobre o fato de não emitirem radiação eletromagnética enquanto giram. Porém, não chega a falar sobre a relação entre frequência e energia quando o elétron muda de órbita. Também não fala detalhadamente sobre os espectros de emissão e absorção.

Estas informações constam no texto de apoio sobre o Modelo Atômico de Bohr (ver anexo), mas não houve tempo para o professor trabalhar detalhadamente e mantendo uma coerência com as atividades realizadas, ele optou por explicar a presença das linhas no espectro e pelo número de linhas presentes, utilizando para tanto as informações necessárias e escolhendo questões da lista de exercícios para discutirem em sala de aula.

Considerando todas essas circunstâncias que podem ocorrer nas escolas, reforçamos mais ainda a necessidade de entendermos o processo cognitivo dos alunos para que as decisões tomadas pelo menos minimizem as perdas resultantes de situações similares a esta. 
Uma sugestão de continuidade e aprofundamento do trabalho, aqui apresentado, é a análise da apropriação de linguagem científica e desenvolvimento da argumentação nas atividades propostas na sequência (inclusive com a sistematização final destas aulas) com efeito fotoelétrico e dualidade onda-partícula e analisar o desenvolvimento dessa apropriação em comparação com essas atividades para introdução ao modelo de Bohr. 


\section{Bibliografia}




\section{Referências Bibliográficas:}

ABDALLA, M.C.B. Niels Bohr O Arquiteto da Mecânica Quântica. Scientific American Apresenta Gênios da Ciência - Duetto Editorial. p. 32 - 43. 2005.

ABRAhÃO, T. C.; CARVAlHO, A. M. P. 2003 Do Pensamento Hipotético-Dedutivo na Ciência ao Hipotético-Dedutivo no Ensino - Análise da Reflexão dos Professores In: Anais do IV ENPEC. Bauru: UNESP/Bauru v. 1, p. 1486-1496 2003.

AUSUBEL, D. P. 1978 Psicología educativa. Um punto de vista cognoscitivo. México, Trilhas, cap. 141978 apud CARVALHO, A.M.P.; PÉREZ, D.G. Formação de Professores de Ciências 2a edição, Cortez Editora 1995.

AXT, R. O papel da experimentação no ensino de ciências, in MOREIRA, M. A. \& AXT, R. Tópicos em ensino de ciências, Sagra, 1991 apud KANBACH, B. G.; LABURU, C. E.; SILVA, O.H.M. Razões para a não utilização de atividades práticas por professores de Física no Ensino Médio. XVI Simpósio Nacional de Ensino de Física (SNEF). 2005.

BAKHTIN, M. 1981 The dialogic imagination, ed. Por Michael Holquist. Austin: University of Texas Press, 1981 apud CAPECCHI, M.C.V.M. Aspectos da Cultura Científica em Atividades de Experimentação nas Aulas de Física. Tese (Doutorado) - Faculdade de Educação, Universidade de São Paulo, São Paulo 2004.

BORGES, A. T. 2002 Novos rumos para o laboratório escolar de ciências. Caderno Brasileiro de Ensino de Física, v. 19, n. 3, 2002 apud KANBACH, B. G.; LABURU, C. E.; SILVA, O.H.M. Razões para a não utilização de atividades práticas por professores de Física no Ensino Médio. XVI Simpósio Nacional de Ensino de Física (SNEF). 2005.

BOUDA, N. \& WEIL-BARAIS, A. 2001 Contextes social et interactionnel d'activités expérimentales à l'école primaire. Rapport de Recherche INRP, 2001 apud VILLANI, C.E.P.; NASCIMENTO, S., S. A Argumentação e o Ensino de Ciências: uma Atividade Experimental no Laboratório Didático de Física do Ensino Médio. Investigações em Ensino de Ciências. Porto Alegre. V. 8, no 3. 2003. 
BOULTER, C. J. ; GILBERT, J. K. 1995 Argument and science education. In: Costello, P.J. M. e Mitchell, S. (edts). Competing and Consensual voices: the theory and pratice of argument. Multilingual Matters LTD, Cap.6, p. 84 - 98, 1995 apud MONTEIRO, M. A. A.; TEIXEIRA, O. P. B. Uma Análise das Interações Dialógicas em Aulas de Ciências nas Séries Iniciais do Ensino Fundamental. Investigações em Ensino de Ciências. Porto Alegre. V. 9. no 3. 2004.

BRAZ JUNIOR, DULCIDIO Física Moderna - Tópicos para o Ensino Médio. Editora Companhia da Escola, Campinas - São Paulo - 2002.

BRETON, P. 1996 A argumentação na comunicação. $1^{\mathrm{a}}$ ed. Bauru SP: EDUSC, 1999. (Tradução do original francês L'argumentation dans la communication, Paris, Éditions La Découverte 1996) apud VILLANI, C.E.P.; NASCIMENTO, S., S. A Argumentação e o Ensino de Ciências: uma Atividade Experimental no Laboratório Didático de Física do Ensino Médio. Investigações em Ensino de Ciências. Porto Alegre. V. 8, nº 3. 2003.

BRISCOE, C. 1991 "The dynamic interactions among beliefs, role methaphores and teaching pratics. A case study of teacher change”, Science Education, 75 (2), p. 185-199, 1991 apud CARVALHO, A.M.P.; PÉREZ, D.G. Formação de Professores de Ciências $2^{\mathrm{a}}$ edição, Cortez Editora 1995.

BROCKINGTON, G. A Realidade Escondida: A Dualidade Onda-partícula para Estudantes do Ensino Médio. 2005. Dissertação (Mestrado) - Instituto de Física e Faculdade de Educação, Universidade de São Paulo, São Paulo 2005.

CANDELA, A. A construção discursiva de contextos argumentativos no ensino de ciências. In: Coll, C.; Edwards, D. (Org.). Ensino, Aprendizagem e Discurso em Sala de Aula. Artmed, Porto Alegre. 1998. p. 143 - 169.

CAPECCHI, M.C.V.M. Aspectos da Cultura Científica em Atividades de Experimentação nas Aulas de Física. Tese (Doutorado) - Faculdade de Educação, Universidade de São Paulo, São Paulo 2004. 
CAPECCHI, M.C.V.M.; CARVALHO, A. M. P. 2000 Argumentação na aula de ciências a partir de uma atividade de conhecimento físico com crianças na faixa de oito a dez anos. Investigações em Ensino de Ciências, vol. 5, n. 3, [http://www.if.ufrgs.br/public/ensino/revista.htm], dezembro de 2000 (a) apud CAPECCHI, M.C.V.M. Aspectos da Cultura Científica em Atividades de Experimentação nas Aulas de Física. Tese (Doutorado) - Faculdade de Educação, Universidade de São Paulo, São Paulo 2004.

CAPECCHI, M.C.V.M.; CARVALHO, A. M. P. 2000 Interações discursivas na construção de explicações para fenômenos físicos em sala de aula. VII Encontro de Pesquisa em Ensino de Física, Florianópolis, março de 2000 (b) apud CAPECCHI, M.C.V.M. Aspectos da Cultura Científica em Atividades de Experimentação nas Aulas de Física. Tese (Doutorado) Faculdade de Educação, Universidade de São Paulo, São Paulo 2004.

CAPECCHI, M. C. V. M.; CARVALHO, A. M. P.; SILVA, D. Relações entre o Discurso do Professor e a Argumentação dos Alunos em uma Aula de Física. ENSAIO - Pesquisa em Educação em Ciências - V. 2 / $\mathrm{n}^{\mathrm{o}} 2$ - dezembro. 2002. Disponível em: < http://www.fae.ufmg.br/ensaio/v2_2/mariacandida.PDF >. Acesso em agosto de 2007.

CARMO, A.B. A Linguagem Matemática em uma Aula Experimental de Física. 2006. Dissertação (Mestrado) - Instituto de Física e Faculdade de Educação, Universidade de São Paulo, São Paulo 2006.

CARMO, A.B.; CARVALHO, A.M.P. Contemplando a Cultura Científica na sala de aula: Um olhar sobre os alunos. XVI Simpósio Nacional de Ensino de Física (SNEF). 2005.

Disponível em: 〈http://www.sbf1.sbfisica.org.br/eventos/snef/xvi/cd/resumos/T0470-1.pdf $\rangle$. Acesso em julho de 2007.

CARVALHO, A. M. P. Ensinar Física e Promover uma Enculturação Científica. Direcional Escolas - A Revista do Educador - agosto 2006.

CARVALHO, A. M. P. Introduzindo os Alunos no Universo das Ciências. - In: Werthein, J.; Cunha, C. (Orgs.). Educação Científica e Desenvolvimento: O que pensam os Cientistas. UNESCO, Instituto Sangari. Brasília. Novembro de 2005. p. 61 - 67. 
CARVALHO, A.M.P. Uma Metodologia de Pesquisa para Estudar os Processos de Ensino e Aprendizagem em Salas de Aula - In: Santos, F. M. T.; Greca, I. M.(Orgs.). Pesquisa em Ensino de Ciências no Brasil e suas Metodologias - Unijui - RS - Editora Unijui da Universidade Regional do Noroeste do Estado do Rio Grande do Sul, 2006, p 13 - 48.

CARVALHO, A. M. .P. 2004 Building up explanations in physics teaching International Journal of Science Education v. 26 (2) p. 225-237 2004 apud CARVALHO, A.M.P. Uma Metodologia de Pesquisa para Estudar os Processos de Ensino e Aprendizagem em Salas de Aula - In: Santos, F. M. T.; Greca, I. M.(Orgs.). Pesquisa em Ensino de Ciências no Brasil e suas Metodologias - Unijui - RS - Editora Unijui da Universidade Regional do Noroeste do Estado do Rio Grande do Sul, 2006, p 13 - 48.

CARVAlHO, A. M. P.; CAPECCHI, M. C. V. M. Atividade de laboratório como instrumento para a abordagem de aspectos da cultura científica em sala de aula. Proposições, Campinas - SP. v. 17. n. 1. 2006. p. 137-153.

CARVAlHO, A. M. P.; GARRIDO, E.; LABURU, C. E.; MOURA, M. O.; SANTOS, M.; SILVA, D.; AVIVI, M. L.; CASTRO, R.; ITACARAMBI, R. R.; GONÇALVES, M. E. 1993 a História da Ciência, a Psicogênese e a Resolução de Problemas na Construção do Conhecimento em Sala de Aula... Revista da Faculdade de Educação (USP) São Paulo, v.19, n 2, p. $245-256$.

CARVALHO, A.M.P.; PÉREZ, D.G. Formação de Professores de Ciências $2^{\mathrm{a}}$ edição, Cortez Editora 1995.

CARVAlHO, A.M.P.; SANTOS, E.; AZEVEDO, M.C.; DATE, M.; FUJII, S. \& NASCIMENTO, V.B. Termodinâmica: um ensino por investigação. São Paulo, Faculdade de Educação da Universidade de São Paulo. 1999.

COMPIANI, M. 1996 As geociências no ensino fundamental: um estudo de caso sobre o tema: "A formação do Universo". Campinas, SP, 1996.(Tese de Doutorado) - Faculdade de Educação, Universidade Estadual de Campinas, 1996 apud MONTEIRO, M. A. A.; TEIXEIRA, O. P. B. Uma Análise das Interações Dialógicas em Aulas de Ciências nas Séries 
Iniciais do Ensino Fundamental. Investigações em Ensino de Ciências. Porto Alegre. V. 9. no 3. 2004.

COSTA, ISA; SANTOS, MARLY 1999, A Física moderna e contemporânea na sala de aula da escola média. In: XIII SIMPÓSIO NACIONAL DE ENSINO DE FÍSICA, 1999, Brasília apud PIETROCOLA, M.P. Projeto para melhoria do Ensino Público - Atualização dos Currículos de Física no Ensino Médio de Escolas Estaduais: A Transposição das Teorias Modernas e Contemporâneas para Sala de Aula - 2003 - Faculdade de Educação da Universidade de São Paulo e FAPESP 2003 / 00146 -3.

CROWDER, E. 1996 Gestures at work in sense-making science talk, The journal of the learning sciences, 5 (3), 173-208, 1996 apud CAPECCHI, M.C.V.M. Aspectos da Cultura Científica em Atividades de Experimentação nas Aulas de Física. Tese (Doutorado) Faculdade de Educação, Universidade de São Paulo, São Paulo 2004.

DRIVER, R.; ASOKO, H.; LEACH, J.; MORTIMER, E.; SCOTT, P. 1994, Constructing Scientific Knowledge in the Classroom. Paper prepared for submission to Educational Research, May 1994 apud CAPECCHI, M.C.V.M. Aspectos da Cultura Científica em Atividades de Experimentação nas Aulas de Física. Tese (Doutorado) - Faculdade de Educação, Universidade de São Paulo, São Paulo 2004.

DRIVER, R.; NEWTON, P. 1997 Establishing the norms of scientific argumentation in classrooms. Paper prepared for presentation at the ESERA Conference, 2 - 6 September, 1997, Rome, 1997 apud CAPECCHI, M.C.V.M. Aspectos da Cultura Científica em Atividades de Experimentação nas Aulas de Física. Tese (Doutorado) - Faculdade de Educação, Universidade de São Paulo, São Paulo 2004.

EDWARDS, D.; MERCER, N. 1987 Common knowledge: the development of understanding in the classroom. Londres: Methuen, 1987 apud CAPECCHI, M.C.V.M. Aspectos da Cultura Científica em Atividades de Experimentação nas Aulas de Física. Tese (Doutorado) Faculdade de Educação, Universidade de São Paulo, São Paulo 2004.

ERICKSON, F. Audiovisual Records as a Primary Data Source - Sociological Methods \& Research-Vol. 11 No 2. November 1982. Sage Publications Inc. 1982. p. 212 - 233. 
ERICKSON, FREDERICK. 1998 Qualitative Research Methods for Science Education, in B. J. Fraser \& K. G. Tobin (eds), International Handbook of Science Education, Kluver Academic Publishers, Great Britain, PP. 1155-1173 1998 apud CARVALHO, A.M.P. Uma Metodologia de Pesquisa para Estudar os Processos de Ensino e Aprendizagem em Salas de Aula - In: Santos, F. M. T.; Greca, I. M.(Orgs.). Pesquisa em Ensino de Ciências no Brasil e suas Metodologias - Unijui - RS - Editora Unijui da Universidade Regional do Noroeste do Estado do Rio Grande do Sul, 2006, p 13 - 48.

FERNANDES, F.; LUFT, C. P.; GUIMARÃES, F. M. Dicionário Brasileiro Globo $23^{\mathrm{a}}$ Edição. Editora Globo. 1992.

FRANKS, A.; JEWITT, C. 2001 The meaning of action in learning and teaching, British Educational Research Journal, vol. 27, n. 2, 2001 apud CAPECCHI, M.C.V.M. Aspectos da Cultura Científica em Atividades de Experimentação nas Aulas de Física. Tese (Doutorado) Faculdade de Educação, Universidade de São Paulo, São Paulo 2004.

GRANDY, R. E.; DUSCHL, R. A. Reconsidering the Character and Role of Inquiry in School Science: Analysis of a Conference - Science and Education. V. 16. $\mathrm{n}^{\circ} 2$. fevereiro 2007. p. $141-166$.

GONÇALVES, M. E. R. 1997 Atividades de Conhecimento Físico na Formação de Professores das Séries Iniciais. Tese de Doutorado, Faculdade de Educação da Universidade de São Paulo 1997.

HERZBERG, G. Atomic Spectra \& Atomic Structure. New York - Dover Publications Second Edition. 1944. p. $01-70$.

JIMÉNEZ ALEIXANDRE, M. P.; DÍAZ de BUSTAMANTE, J. Discurso de Aula Y Argumentación Em La Clase de Ciências: Cuestiones Teóricas Y Metodológicas. Enseñanza de Las Ciências. 2003. p. 359 - 370. 
JIMÉNEZ ALEIXANDRE, M. P.; DIAZ DE BUSTAMANTE, J.; DUSCHL, R. A. 1998 Scientific culture and school culture: epistemic and procedural components Trabalho apresentado no Encontro Anual da National Association for Research in Science Teaching (NARST), San Diego, CA, abril 1998 (b) apud CAPECCHI, M.C.V.M. Aspectos da Cultura Científica em Atividades de Experimentação nas Aulas de Física. Tese (Doutorado) Faculdade de Educação, Universidade de São Paulo, São Paulo 2004.

JIMÉNEZ ALEIXANDRE, M. P.; REIGOSA, CASTRO, C.; ÁLVAREZ PÉREZ, V. 1998 Argumentación em el Laboratório de Física. Trabalho apresentado no VI Encontro de Pesquisa em Ensino de Física, 26 a 30 de outubro, Florianópolis, 1998 (a) apud CAPECCHI, M.C.V.M. Aspectos da Cultura Científica em Atividades de Experimentação nas Aulas de Física. Tese (Doutorado) - Faculdade de Educação, Universidade de São Paulo, São Paulo 2004.

JIMÉNEZ ALEIXANDRE, M. P.; RODRÍGUEZ, B.; DUSCHL, R. A. “Doing the Lesson”or "Doing Science": Argument in High School Genetics. Science Education. V. 84. Novembro de 2000. p. $757-792$.

KANBACH, B. G.; LABURU, C. E.; SILVA, O.H.M. Razões para a não utilização de atividades práticas por professores de Física no Ensino Médio. XVI Simpósio Nacional de Ensino de Física $2005 . \quad$ Disponível em: <http://www.sbf1.sbfisica.org.br/eventos/snef/xvi/cd/resumos/T0373-1.pdf.>. Acesso em: julho de 2007.

KLÜSENER, R. 1998 Ler, escrever e compreender a matemática, ao invés de tropeçar nos símbolos. In: NEVES, I. C. B.; SOUZA, J. V.; SCHÄFFER, N. O. et. al. (orgs). Ler e escrever: compromisso de todas as áreas. Porto Alegre: UFRGS, p.175-89 1998 apud CARMO, A.B. A Linguagem Matemática em uma Aula Experimental de Física. 2006. Dissertação (Mestrado) - Instituto de Física e Faculdade de Educação, Universidade de São Paulo, São Paulo 2006.

KUHN, D. 1993 Science as argument: implications for teaching and learning scientific thinking. Science Education, v.77, n.3, p.319-337, 1993 apud MONTEIRO, M. A. A.; TEIXEIRA, O. P. B. Uma Análise das Interações Dialógicas em Aulas de Ciências nas Séries 
Iniciais do Ensino Fundamental. Investigações em Ensino de Ciências. Porto Alegre. V. 9. no 3. 2004.

LEMKE, J. L. Multiplying Meaning: Visual and Verbal Semiotics in Scientific Text. In: Martin, J.; Veel, R. (Eds.). Reading Science. Londres: Routledge). 1998.

LEMKE, J. L. 1990, Talking science, language, learning and values. Norwood, New Jersey: Ablex Publishing Corporation apud VILLANI, C.E.P.; NASCIMENTO, S., S. A Argumentação e o Ensino de Ciências: uma Atividade Experimental no Laboratório Didático de Física do Ensino Médio. Investigações em Ensino de Ciências. Porto Alegre. V. 8, no 3. 2003. Disponível em: 〈http://www.if.ufrgs.br/public/ensino/vol8/n3/v8_n3_a1.html>. Acesso em abril de 2007.

LEMKE, J. L. 1997 Aprender a Hablar Ciência: lenguaje, aprendizaje y valores. Espanha, Editora Paidós, 1997 (Originalmente publicado sob o título: Talking science: language, learning and values, em 1990) 1997 apud CAPECCHI, M.C.V.M. Aspectos da Cultura Científica em Atividades de Experimentação nas Aulas de Física. Tese (Doutorado) Faculdade de Educação, Universidade de São Paulo, São Paulo 2004.

LÜDKE, M.; ANDRÉ, M. 1986 Pesquisa em Educação: Abordagens Qualitativas Editora pedagógica e universitária - EPU, São Paulo 1986.

MÁRQUEZ, C. IZQUIERDO, M. \& ESPINET, M. 2003 Comunicación Multimodal en la Clase de Ciencias: El Ciclo Del Agua. Enseñanza de las Ciencias, v.21, n.3, p. 371-386, 2003 apud CARMO, A.B. A Linguagem Matemática em uma Aula Experimental de Física. 2006. Dissertação (Mestrado) - Instituto de Física e Faculdade de Educação, Universidade de São Paulo, São Paulo 2006.

MARTINS, R. de A. O Nascimento de uma Nova Física. Scientific American Apresenta Gênios da Ciência - Duetto Editorial. p. 6 - 13. 2005.

MONTEIRO, M. A. A.; TEIXEIRA, O. P. B. Uma Análise das Interações Dialógicas em Aulas de Ciências nas Séries Iniciais do Ensino Fundamental. Investigações em Ensino de 
Ciências. Porto Alegre. V. 9. $\mathrm{n}^{\mathrm{o}}$ 3. 2004. Disponível em: <http://www.if.ufrgs.br/public/ensino/vol9/n3/v9_n3_a2.htm>. Acesso em: abril de 2007.

MORTIMER, E.F. 1994 Evolução do Atomismo em Sala de Aula: Mudança de Perfis Conceituais. Tese (Doutorado) - Faculdade de Educação, Universidade de São Paulo, São Paulo, 1994 apud CARMO, A.B. A Linguagem Matemática em uma Aula Experimental de Física. 2006. Dissertação (Mestrado) - Instituto de Física e Faculdade de Educação, Universidade de São Paulo, São Paulo 2006.

MORTIMER, E. F.\& MACHADO, A. H. 1996 A linguagem numa aula de ciência,. Presença Pedagógica, v. 2, n. 11, p. 49-57, 1996 apud CARMO, A.B. A Linguagem Matemática em uma Aula Experimental de Física. 2006. Dissertação (Mestrado) - Instituto de Física e Faculdade de Educação, Universidade de São Paulo, São Paulo 2006.

MORTIMER, E. F.; SCOTT, P. H. 2000 Analyse discourse in the science classroom. In: LEACH, J.; MILLAR, R.; OSBORNE, J. (eds) Improving Science Education: The contribuition of research.. MILTON KEYNES: Open University Press, 2000 apud CAPECCHI, M.C.V.M. Aspectos da Cultura Científica em Atividades de Experimentação nas Aulas de Física. Tese (Doutorado) - Faculdade de Educação, Universidade de São Paulo, São Paulo 2004.

MORTIMER, E. F.; SCOTT, P. H. Atividades Discursivas nas Salas de Aula de Ciências: Uma Ferramenta Sociocultural para Analisar e Planejar o Ensino - Investigações em Ensino de Ciências. Porto Alegre. V. 7. nº 3. 2003. Disponível em: <www.if.ufrgs.br/public/ensino/vol7/n3/v7_n3_a7.htm>. Acesso em: abril de 2007.

MORTIMER, E. F.; SCOTT, P. H. 2002 Discursive activity on the social plane of high school science classrooms: a tool for analysing and planning teaching interactions. Artigo apresentado no Annual Meeting da AERA, New Orleans,USA, 2002. (versão em português publicada em Investigações em Ensino de Ciências) apud CAPECCHI, M.C.V.M. Aspectos da Cultura Científica em Atividades de Experimentação nas Aulas de Física. Tese (Doutorado) - Faculdade de Educação, Universidade de São Paulo, São Paulo 2004.

MORTIMER, E. F.; SCOTT, P. H. Making Meaning in Secondary Science Classrooms. 
Open Univ. Press. Maidenhead, UK. 2003.

NASCIMENTO, V. B. 2003 Visões de Ciência e Ensino por Investigação: Aspectos de História e Filosofia da Ciência, em busca de uma Alfabetização Científica Universidade de São Paulo, Faculdade de Educação. Dissertação de mestrado 2003.

OLDENBERG, Introduction to Atomic Physics. Second Edition - McGraw-Hill Book Company, INC - New York, Toronto, London. p. 99 - 175. 1954.

OLIVEIRA, F.F. O Ensino de Física Moderna com Enfoque CTS: Uma Proposta Metodológica para o Ensino Médio usando o Tópico Raios X. 2006. Dissertação (Mestrado) Faculdade de Educação, Universidade Federal do Rio de Janeiro, Rio de Janeiro 2006.

ORIENTAÇÕES CURRICULARES PARA O ENSINO MÉDIO - Ciências da Natureza, Matemática e suas Tecnologias. - Ministério da Educação - Secretaria de Educação Básica. Brasília 2006.

OSTERMANN, F.; CAVALCANTI, C.J.H. 1999, Física moderna e contemporânea no ensino médio: elaboração de material didático, em forma de pôster, sobre partículas elementares e interações fundamentais. Caderno Catarinense de Ensino de Física, v. 16, n. 3, p. 267-286, dez. 1999 apud PIETROCOLA, M.P. Projeto para melhoria do Ensino Público Atualização dos Currículos de Física no Ensino Médio de Escolas Estaduais: A Transposição das Teorias Modernas e Contemporâneas para Sala de Aula - 2003 - Faculdade de Educação da Universidade de São Paulo e FAPESP 2003 / 00146 -3.

OSTERMANN, F.; MOREIRA, M. A. 1998, Tópicos de física contemporânea na escola média brasileira: um estudo com a técnica Delphi. In: Encontro de Pesquisa em Ensino de Física, VI, Atas, UFSC, 19p Seção de comunicações orais, Florianópolis, 1998 apud PIETROCOLA, M.P. Projeto para melhoria do Ensino Público - Atualização dos Currículos de Física no Ensino Médio de Escolas Estaduais: A Transposição das Teorias Modernas e Contemporâneas para Sala de Aula - 2003 - Faculdade de Educação da Universidade de São Paulo e FAPESP 2003 / 00146 -3. 
OSTERMANN, F.; MOREIRA, M. A. 2001, Uma revisão bibliográfica sobre a área de pesquisa "Física Moderna e Contemporânea no Ensino Médio", Investigações em Ciências, vol. 5, $\mathrm{n}^{\mathrm{o}}$ 1, UFRGS, Porto Alegre, 2001 apud PIETROCOLA, M.P. Projeto para melhoria do Ensino Público - Atualização dos Currículos de Física no Ensino Médio de Escolas Estaduais: A Transposição das Teorias Modernas e Contemporâneas para Sala de Aula 2003 - Faculdade de Educação da Universidade de São Paulo e FAPESP 2003 / 00146 -3.

PCN - PARÂMETROS CURRICULARES NACIONAIS - ENSINO MÉDIO. Ministério da Educação - Secretaria de Educação Média e Tecnológica. Brasília 1999.

PCN + ENSINO MÉDIO - Orientações Educacionais Complementares aos Parâmetros Curriculares Nacionais. Linguagens Códigos e sua Tecnologias. - Secretaria de Educação Média e Tecnológica. Brasília: MEC; SEMTEC, 2002.

PESSOA, O. F.; GEVERTZ, R.; SILVA, A.G. 1985, Como ensinar ciências v. 104, $5^{\text {a }}$ Edição, Companhia Editora Nacional, São Paulo - SP Brasil, 1985 apud KANBACH, B. G.; LABURU, C. E.; SILVA, O.H.M. Razões para a não utilização de atividades práticas por professores de Física no Ensino Médio. XVI Simpósio Nacional de Ensino de Física (SNEF). 2005.

PIETROCOLA, M. P. A matemática como estruturante do conhecimento físico. Caderno Brasileiro do Ensino de Física, v.17, n.1, p.93-114, 2002 apud CARMO, A.B. A Linguagem Matemática em uma Aula Experimental de Física. 2006. Dissertação (Mestrado) - Instituto de Física e Faculdade de Educação, Universidade de São Paulo, São Paulo 2006.

PIETROCOLA, M.P. Projeto para melhoria do Ensino Público - Atualização dos Currículos de Física no Ensino Médio de Escolas Estaduais: A Transposição das Teorias Modernas e Contemporâneas para Sala de Aula - 2003 - Faculdade de Educação da Universidade de São Paulo e FAPESP 2003 / 00146 -3.

PINTO, ALEXANDRE CUSTÓDIO; ZANETIC, JOÃO 1999, É possível levar a Física Quântica para o ensino médio? Caderno Catarinense de Ensino de Física, Florianópolis, v. 16, n. 1, p. 7-34, abr. 1999 apud PIETROCOLA, M.P. Projeto para melhoria do Ensino Público - Atualização dos Currículos de Física no Ensino Médio de Escolas Estaduais: A 
Transposição das Teorias Modernas e Contemporâneas para Sala de Aula - 2003 Faculdade de Educação da Universidade de São Paulo e FAPESP 2003 / 00146 -3.

ROTH, W-M 2002 Science, culture and the emergence of language. Science Education, vol. 86 (3): 368-385, 2002 (a) apud CAPECCHI, M.C.V.M. Aspectos da Cultura Científica em Atividades de Experimentação nas Aulas de Física. Tese (Doutorado) - Faculdade de Educação, Universidade de São Paulo, São Paulo 2004.

SASSERON, L.H.; CARVALHO, A.M.P. Almejando a Alfabetização Científica no Ensino Fundamental: A proposição e a Procura de Indicadores do Processo - Investigações em Ensino de Ciências - V 13 (3), pp 333 - 352, 2008. Disponível em:

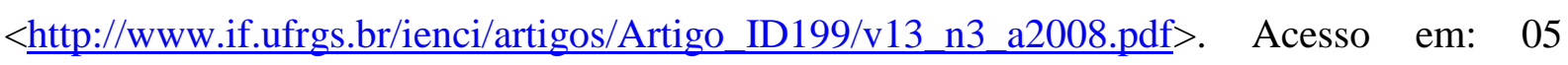
janeiro 2009.

SCOTT, P. 1997 Developing Science Concepts in Secondary Classroom: An Analysis of Epdagogical Interactions from a Vygotskian Perspective, tese de doutorado não publicada, Reino Unido: Universidade de Leeds, 1997 apud CAPECCHI, M.C.V.M. Aspectos da Cultura Científica em Atividades de Experimentação nas Aulas de Física. Tese (Doutorado) Faculdade de Educação, Universidade de São Paulo, São Paulo 2004.

SEED - Schlumberger Excellence in Educational Development - Um programa Schumberger de desenvolvimento comunitário sem fins lucrativos - A descoberta dos Fulerenos Espectroscopia. Disponível em: $<$ http://www.seed.slb.com/pt/scictr/watch/fullerenes/spectro.htm>. Acesso em 01 fevereiro 2007.

STUDART, N. Max Planck O Revolucionário Conservador. Scientific American Apresenta Gênios da Ciência - Duetto Editorial. p. 14 - 19. 2005.

THOMAZ, M. F. 2000 “A experimentação e a formação de professores: uma reflexão”. Cad. Cat. Ens. Fís. V. 17, n. 3: p. 360-369 apud KANBACH, B. G.; LABURU, C. E.; SILVA, O.H.M. Razões para a não utilização de atividades práticas por professores de Física no Ensino Médio. XVI Simpósio Nacional de Ensino de Física (SNEF). 2005 
TIPLER, PAUL Física Volume 4 - Ótica e Física Moderna. Terceira Edição - Editora Guanabara Koogan S.A. 1995. p. 179- 199.

TOULMIN, S. 1958 The uses of argument. Cambridge University Press, 1958 apud CAPECCHI, M.C.V.M. Aspectos da Cultura Científica em Atividades de Experimentação nas Aulas de Física. Tese (Doutorado) - Faculdade de Educação, Universidade de São Paulo, São Paulo 2004.

UFF - Universidade Federal Fluminense. Instituto de Física. Laboratório de Plasma e Espectroscopia Atômica. A espectroscopia. Disponível em: <http://www.if.uff.br/plasma/espectroscopia.htm>. Acesso em 01 fevereiro 2007.

UFRGS - Universidade Federal do Rio Grande do Sul. Departamento de Astronomia do Instituto de Física da UFGRS. Espectroscopia. Disponível em: <http://astro.if.ufrgs.br/rad/espec/espec.htm>. Acesso em: 01 fevereiro 2007.

UFRGS - Universidade Federal do Rio Grande do Sul. Instituto de Física. A Física do século XX - A. Surgimento da Física Moderna - Espectros de radiação. Disponível em: $<$ http://www.if.ufrgs.br/ betz/iq_XX_A/espRad/aEspRadText.htm>. Acesso em: 01 fevereiro 2007.

VAN EEMEREN, F. H.; GROOTENDORST, R.; KRUIGER, T. 1987 Handbook of Argumentation Theory : A Critical Survey of Classical Backgrounds and Modern Studies. Foris Publications Holland, 1987 apud VILLANI, C.E.P.; NASCIMENTO, S., S. A Argumentação e o Ensino de Ciências: uma Atividade Experimental no Laboratório Didático de Física do Ensino Médio. Investigações em Ensino de Ciências. Porto Alegre. V. 8, no 3. 2003.

VILLANI, C.E.P.; NASCIMENTO, S., S. A Argumentação e o Ensino de Ciências: uma Atividade Experimental no Laboratório Didático de Física do Ensino Médio. Investigações em Ensino de Ciências. Porto Alegre. V. 8, $\mathrm{n}^{\mathrm{o}}$ 3. 2003. Disponível em: <http://www.if.ufrgs.br/public/ensino/vol8/n3/v8_n3_a1.html>. Acesso em abril de 2007. 
Anexos 


\section{Tabela com as transcrições}

Tabela com transcrições, linguagens, indicadores, tipos de interação e comentários: Atividade de análise de espectros de lâmpadas - aula de 10/11/2006 - aproximadamente 52 minutos de gravações $-3^{\mathrm{a}}$ série $\mathrm{G}$ - Ensino Médio (sala que acompanhamos para análise) com presença da $3^{\mathrm{a}}$ série $\mathrm{D}$ - Ensino Médio.

Observação: Ani = aluno não identificado e Val = vários alunos.

\section{Episódio 1 - análise da atividade de observacão dos espectros das lâmpadas:}

\section{Momento 1 - início da aula}

\begin{tabular}{|c|c|c|c|c|}
\hline $\begin{array}{l}\text { Turno } \\
\text { De } \\
\text { fala }\end{array}$ & $\begin{array}{l}\text { Linguagem verbal (oral ou } \\
\text { escrita) }\end{array}$ & $\begin{array}{l}\text { Outras } \\
\text { linguagens } \\
\text { Ações/gestos/ } \\
\text { Manipulação de } \\
\text { materiais }\end{array}$ & Indicadores & $\begin{array}{l}\text { Tipos de } \\
\text { Interação/Comentários }\end{array}$ \\
\hline 01 & $\begin{array}{l}\text { A2: Ô Vanda, onde está o } \\
\text { corte?...o amarelo. }\end{array}$ & & Organização & $\mathrm{A} / \mathrm{A}$ \\
\hline 02 & A3: Cadê...cadê. & & Organização & $\mathrm{A} / \mathrm{A}$ \\
\hline 03 & $\begin{array}{l}\text { P: Pessoal, vamos adiantar aí os } \\
\text { trabalhos... }\end{array}$ & & Organização & $\mathrm{P} / \mathrm{T}$ \\
\hline 04 & $\begin{array}{l}\text { A1: Dá um pedacinho para o } \\
\text { Maurício. }\end{array}$ & & Organização & $\mathrm{A} / \mathrm{A}$ \\
\hline 05 & $\begin{array}{l}\text { P: Hoje vocês deveriam estar } \\
\text { fazendo o espectroscópio. Não } \\
\text { sei se todos conseguiram fazer... }\end{array}$ & & Organização & $\mathrm{P} / \mathrm{T}$ \\
\hline 06 & $\begin{array}{l}\text { A4: Pega mais uns três pedaços } \\
\text { aí Ricardo. }\end{array}$ & & Organização & $\mathrm{A} / \mathrm{A}$ \\
\hline 07 & $\begin{array}{l}\text { P: Mas se (...) por ventura não } \\
\text { conseguirem fazer eu tenho aqui } \\
\text { alguns que vou fornecer para } \\
\text { que a gente faça a nossa } \\
\text { atividade que estaremos } \\
\text { filmando. }\end{array}$ & & Organização & $\mathrm{P} / \mathrm{T}$ \\
\hline 08 & A5: Maurício... & & & $\mathrm{A} / \mathrm{A}$ \\
\hline 09 & A4:Peraí, peraí! Ricardo! & & & $\begin{array}{l}\text { A/A Do turno } 09 \text { ao } 14 \text { as } \\
\text { falas são simultâneas. }\end{array}$ \\
\hline 10 & A4: Chega né!? & & & \\
\hline 11 & A1: E o Léo? E o Léo? & & & $\mathrm{A} / \mathrm{A}$ \\
\hline
\end{tabular}




\begin{tabular}{|c|c|c|c|c|}
\hline 12 & $\begin{array}{l}\text { P: Vocês deveriam, também ter } \\
\text { feito uma pesquisa de campo. }\end{array}$ & & Organização & $\mathrm{P} / \mathrm{T}$ \\
\hline 13 & $\begin{array}{l}\text { Muitos (inaudível)... quem fez } \\
\text { aqui? }\end{array}$ & & Organização & $\mathrm{P} / \mathrm{T}$ \\
\hline 14 & $\begin{array}{l}\text { P: Alguns fizeram. Os que } \\
\text { fizeram, por favor, me passem. } \\
\text { Os que não fizeram, nós } \\
\text { faremos aqui. Nós vamos } \\
\text { aproveitar já a experiência }\end{array}$ & $\begin{array}{l}\text { Nesse momento, } \\
\text { enquanto o } \\
\text { professor fala, os } \\
\text { alunos (deste } \\
\text { grupo) estão com } \\
\text { os } \\
\text { espectroscópios } \\
\text { em mãos e cada } \\
\text { um mostrando o } \\
\text { seu para o outro } \\
\text { do grupo. }\end{array}$ & Organização & $\begin{array}{l}\mathrm{P} / \mathrm{T} \text { e } \mathrm{A} / \mathrm{A} \text {. Neste momento os } \\
\text { alunos parecem prestar mais } \\
\text { atenção ao que o professor } \\
\text { fala, porém continuam } \\
\text { interagindo entre si, o que é } \\
\text { demonstrado quando mostram } \\
\text { o espectroscópio um para o } \\
\text { outro. }\end{array}$ \\
\hline 15 & A4: Enxergou Ricardo? & & Organização & $\mathrm{A} / \mathrm{A}$ \\
\hline 16 & $\begin{array}{l}\text { A1: Agora Gustavo querido } \\
\text { empresta sua caneta. }\end{array}$ & & Organização & $\mathrm{A} / \mathrm{A}$ \\
\hline 17 & $\begin{array}{l}\text { P: Os que já não enxergam nós } \\
\text { vamos aproveitar a experiência } \\
\text { (inaudível) deste estado das } \\
\text { figuras para gente fazer aqui. (?) } \\
\text { Eu tenho algumas lâmpadas... }\end{array}$ & & Organização & $\mathrm{P} / \mathrm{T}$ \\
\hline 18 & A4: Hã? & & & \\
\hline 19 & A1: Obrigado. & & & $\begin{array}{l}\text { A/A. A1 agradece a caneta } \\
\text { emprestada. }\end{array}$ \\
\hline 20 & $\begin{array}{l}\text { A3: Isso não serve... Ô ta } \\
\text { pensando que eu sou o que? }\end{array}$ & $\begin{array}{l}\text { Manipulação de } \\
\text { material para } \\
\text { construção do } \\
\text { espectroscópio. }\end{array}$ & Organização & $\begin{array}{l}\text { A/A. Fala enquanto passa a } \\
\text { fita adesiva para A4 arrumar } \\
\text { seu espectroscópio. }\end{array}$ \\
\hline 21 & $\begin{array}{l}\text { A5: Você não descolou as cor } \\
\text { não? }\end{array}$ & & & $\mathrm{A} / \mathrm{A}$ \\
\hline 22 & P: Então, lâmpada mista,... & & & $\mathrm{P} / \mathrm{T}$ \\
\hline 23 & Ani: Tem amarelo aí professor? & & & $\mathrm{P} / \mathrm{T}$ \\
\hline 24 & 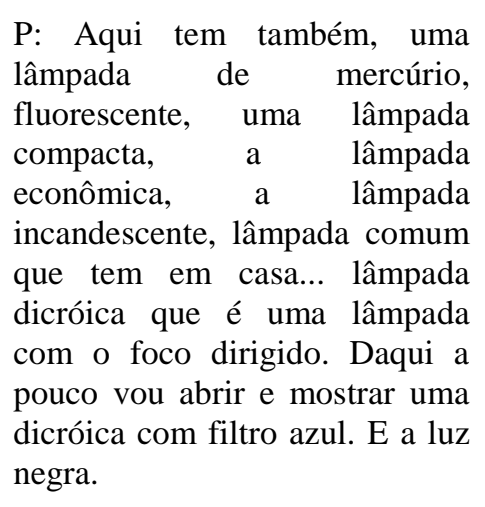 & & Organização & $\mathrm{P} / \mathrm{T}$ \\
\hline 25 & A2: Não tem amarelo, não; & & & A/A. A2 fala se dirigindo ao \\
\hline
\end{tabular}




\begin{tabular}{|c|c|c|c|c|}
\hline & trazer de sua casa. & & & $\begin{array}{l}\text { A4. Do turno } 25 \text { ao } 34 \text { as falas } \\
\text { dos alunos são simultâneas à } \\
\text { fala do professor no turno } 24 \text {. }\end{array}$ \\
\hline 26 & A4 & $\begin{array}{l}\text { Gestos e } \\
\text { manipulação do } \\
\text { espectroscópio. }\end{array}$ & Organização & $\begin{array}{l}\text { A/A. A4 sinaliza colocando o } \\
\text { dedo na boca indicando } \\
\text { silêncio e em seguida dá uns } \\
\text { tapinhas no espectroscópio. }\end{array}$ \\
\hline 27 & A2: Cê é bobo Hein?... & $\begin{array}{l}\text { Manipulação do } \\
\text { espectroscópio e } \\
\text { cadernos. }\end{array}$ & & $\begin{array}{l}\text { A/A. Enquanto A2 fala o } \\
\text { restante do grupo está } \\
\text { manuseando } \\
\text { espectroscópios e cadernos. }\end{array}$ \\
\hline 28 & A1: Muito obrigado. & $\begin{array}{l}\text { Manipulação de } \\
\text { caneta e do } \\
\text { espectroscópio. }\end{array}$ & Organização & $\begin{array}{l}\text { A/A. A1 devolve a caneta e } \\
\text { agradece e depois coloca o } \\
\text { espectroscópio na bancada. }\end{array}$ \\
\hline 29 & A3: Cadê o meu? O meu é esse? & & Organização & $\begin{array}{l}\text { A/A } \\
\text { A3 dá a volta na bancada e } \\
\text { fica ao lado de A2, em seguida } \\
\text { levanta para pegar o } \\
\text { espectroscópio. }\end{array}$ \\
\hline 30 & $\begin{array}{l}\text { A1: E o seu não tem nome não? } \\
\text { Não vai por nome não? }\end{array}$ & & Organização & $\begin{array}{l}\text { A/A. A1 segura o } \\
\text { espectroscópio, } \\
\text { para A1. }\end{array}$ \\
\hline 31 & A2: (inaudível) & & Organização & $\begin{array}{l}\text { A/A } \\
\text { A2 responde acenando com a } \\
\text { cabeça de forma negativa, } \\
\text { enquanto abre seu caderno. }\end{array}$ \\
\hline 32 & A1: Por quê? & & & $\mathrm{A} / \mathrm{A}$ \\
\hline 33 & A3: (inaudível) & & & $\mathrm{A} / \mathrm{A}$ \\
\hline 34 & $\mathrm{~A} 2$ & $\begin{array}{l}\text { Ação: bate com } \\
\text { as duas mãos na } \\
\text { mesa e vira. }\end{array}$ & & $\begin{array}{l}\text { A/A } \\
\text { A ação de A2 ocorre ao } \\
\text { mesmo tempo em que A3 } \\
\text { pronuncia algo que não } \\
\text { conseguimos escutar. }\end{array}$ \\
\hline 35 & $\begin{array}{l}\text { P: Vamos começar, aqui é a luz } \\
\text { negra. }\end{array}$ & & & $\mathrm{P} / \mathrm{T}$ \\
\hline 36 & A1: Ai que emoção... & & & $\begin{array}{l}\text { A/A } \\
\text { A1 parece falar com ironia, } \\
\text { aparentemente chateada com } \\
\text { A3; pega o espectroscópio e } \\
\text { fica olhando para ele. }\end{array}$ \\
\hline 37 & A5: & & & $\begin{array}{l}\text { Com as mãos mexendo no } \\
\text { microfone utilizado para } \\
\text { gravação. }\end{array}$ \\
\hline 38 & $\begin{array}{l}\text { P: Então vamos ver como fica o } \\
\text { espectro destas lâmpadas. }\end{array}$ & & Organização & $\mathrm{P} / \mathrm{T}$ \\
\hline 39 & Ani: Cadê que eu não achei & & & \\
\hline
\end{tabular}




\begin{tabular}{|c|c|c|c|c|}
\hline & nada? & & & \\
\hline 40 & $\begin{array}{l}\text { P: Você utiliza as lâmpadas, a } \\
\text { intenção é que... a gente } \\
\text { conseguisse reproduzir a } \\
\text { claridade da luz solar, no } \\
\text { mínimo com essa finalidade... }\end{array}$ & & Organização & $\begin{array}{l}\text { P/T } \\
\text { Enquanto o professor fala, A3 } \\
\text { coloca uma caneta na mesa e } \\
\text { mexe com o caderno após ter } \\
\text { anotado, provavelmente, o } \\
\text { nome no espectroscópio. A2 } \\
\text { abre o caderno e pega uma } \\
\text { folha solta de A1 e olha } \\
\text { atentamente para ela. }\end{array}$ \\
\hline 41 & $\begin{array}{l}\text { P: ...vocês vão notar que as } \\
\text { lâmpadas têm certo (inaudível) } \\
\text { têm algumas especialidades, } \\
\text { então antes, por favor... } \\
\text { espectroscópio. Quem fez } 3^{\circ} \mathrm{D} \text { ? } \\
3^{\circ} \mathrm{D} \text { espectroscópio quem fez? }\end{array}$ & & Organização & $\mathrm{P} / \mathrm{T}$ \\
\hline 42 & Ani: Ô doido! & & & $\begin{array}{l}\text { P/T. Alguém exclama no } \\
\text { momento em que não } \\
\text { conseguimos ouvir o professor } \\
\text { no turno 41. Todos do grupo } \\
\text { estão atentos ao caderno e } \\
\text { folhas sobre a bancada. }\end{array}$ \\
\hline 43 & A5: Anderson. Não Vanderson. & & Organização & $\mathrm{A} / \mathrm{A}$ \\
\hline 44 & A1: É Wanderson! & & Organização & $\mathrm{A} / \mathrm{A}$ \\
\hline 45 & A2: É com "W". & & Organização & $\mathrm{A} / \mathrm{A}$ \\
\hline 46 & $\begin{array}{l}\text { A3: Opa!Pode falar. } \\
\text { [respondendo a pergunta do } \\
\text { professor]. Ih perdi a folha. } \\
\text { Anda aí [procurando no meio do } \\
\text { caderno]. }\end{array}$ & & & $\mathrm{P} / \mathrm{T}$ \\
\hline 47 & A4: Manda aí. & & Organização & $\mathrm{P} / \mathrm{T}$ \\
\hline 48 & $\begin{array}{l}\text { A1: Você está com minha folha } \\
\text { aí. }\end{array}$ & & & $\begin{array}{l}\text { A/A. A1 fala apontando para } \\
\text { pessoa que está do outro lado } \\
\text { da bancada. }\end{array}$ \\
\hline 49 & $\begin{array}{l}\text { A1: A minha também taí. Essa } \\
\text { (inaudível) é do Gabriel e essa é } \\
\text { do Léo!Leandro de alguma } \\
\text { coisa, acho que "da Silva". }\end{array}$ & & Organização & $\begin{array}{l}\text { A/A. A1 pronuncia algo com o } \\
\text { espectroscópio em mãos. }\end{array}$ \\
\hline 50 & A4: Minha folha não ta lá. & & Organização & $\mathrm{A} / \mathrm{A}$ \\
\hline 51 & $\begin{array}{l}\text { A3: Mano acabei de perder aqui, } \\
\text { fui fechar o caderno. }\end{array}$ & & & $\begin{array}{l}\text { A3 fala folheando seu } \\
\text { caderno. }\end{array}$ \\
\hline 52 & $\mathrm{~A} 2$ & $\begin{array}{l}\text { Manipulação do } \\
\text { espectroscópio. }\end{array}$ & Organização & $\begin{array}{l}\text { A2 olhando para o alto através } \\
\text { do espectroscópio. }\end{array}$ \\
\hline 53 & $\begin{array}{l}\text { A4: Ô Gabi empresta sua } \\
\text { matéria de física aí. }\end{array}$ & & & 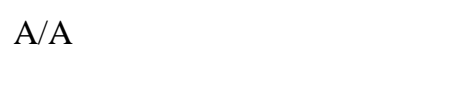 \\
\hline
\end{tabular}




\begin{tabular}{|c|c|c|c|c|}
\hline 54 & A1: Não trouxe o caderno. & & & $\mathrm{A} / \mathrm{A}$ \\
\hline 55 & $\begin{array}{l}\text { A5: E esse aí de quem ? Esse } \\
\text { outro é de quem? }\end{array}$ & & & $\mathrm{A} / \mathrm{A}$ \\
\hline 56 & A1: Ih...(inaudível) & & & \\
\hline 57 & $\begin{array}{l}\text { A4: Ô Maurício empresta seu } \\
\text { caderno aí. (inaudível). Cadê o } \\
\text { Léo? }\end{array}$ & & & $\begin{array}{l}\text { A/A. A3 continua atento ao } \\
\text { caderno, folheando-o. A5 tenta } \\
\text { pegar o espectroscópio de A1 } \\
\text { que defendendo da investida } \\
\text { de A6 agarra o espectroscópio } \\
\text { junto ao corpo. } \\
\text { Várias falas simultâneas } \\
\text { (incompreensível). }\end{array}$ \\
\hline 58 & $\begin{array}{l}\text { Ani: Eu já tinha dormido na } \\
\text { mesa. }\end{array}$ & $\begin{array}{l}\text { Manipulação de } \\
\text { materiais. }\end{array}$ & & $\begin{array}{l}\text { A/A. Enquanto A4 fala, alunos } \\
\text { manuseiam o que parece ser a } \\
\text { folha da pesquisa de campo, } \\
\text { solicitada em aula anterior. A3 } \\
\text { abre o caderno com o desenho } \\
\text { de uma tabela e a } \\
\text { decomposição da luz após } \\
\text { passar por um prisma. } \\
\text { Enquanto o grupo conversa } \\
\text { entre si, o professor fala } \\
\text { novamente, mas não dá para } \\
\text { entender. } \\
\text { Aluna de outro grupo chama o } \\
\text { professor. }\end{array}$ \\
\hline 60 & $\mathrm{P}: 3^{\circ} \mathrm{E} !$ & & & \\
\hline 61 & A4: Deixa de ser egoísta. & & & $\begin{array}{l}\text { A/A. Aluno de outro grupo } \\
\text { levanta e entrega um caderno } \\
\text { para A3. Grupo agitado. }\end{array}$ \\
\hline 62 & P: Números. & & Organização & $\begin{array}{l}\text { P/G. O professor vem até o } \\
\text { grupo fazer uma pergunta. }\end{array}$ \\
\hline 63 & Onde, onde cadê? & & Organização & $\begin{array}{l}\text { P/G. O professor está } \\
\text { registrando quem fez o } \\
\text { trabalho de campo. }\end{array}$ \\
\hline 64 & P: Onde, cadê? & & Organização & 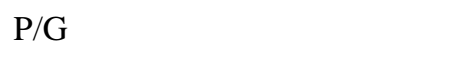 \\
\hline 65 & $\mathrm{~A} 1: 21,43, \ldots$ & & Organização & $\mathrm{P} / \mathrm{G}$ \\
\hline 66 & P: certo. & & & $\mathrm{P} / \mathrm{G}$ \\
\hline 67 & Ani: Vamos fazer na ordem. & & & $\mathrm{A} / \mathrm{A}$ \\
\hline 68 & $\mathrm{~A} 1: 42,45$. & & & $\mathrm{P} / \mathrm{G}$ \\
\hline 69 & P: Cadê?! & & Organização & $\mathrm{P} / \mathrm{G}$ \\
\hline 70 & $\begin{array}{l}\text { A1: Ta aqui ó! } \\
\text { A5: Ta tudo aí, junta tudo aí. }\end{array}$ & & Organização & $\begin{array}{l}\text { PG. A1 mostra todos os } \\
\text { espectroscópios sobre a mesa. } \\
\text { P/G }\end{array}$ \\
\hline
\end{tabular}




\begin{tabular}{|c|c|c|c|c|}
\hline 72 & A1: (inaudível) & & & \\
\hline 73 & $\begin{array}{l}\text { A3: Não, não mistura o meu } \\
\text { não. O meu é profissional. }\end{array}$ & & & $\begin{array}{l}\text { A3 pega seu espectroscópio de } \\
\text { volta. }\end{array}$ \\
\hline 74 & A1: O meu é no 22 & & & $\begin{array}{l}\text { P/G. A1 fala mostrando seu } \\
\text { espectroscópio. }\end{array}$ \\
\hline 75 & P: Oh! É isso? & & & \\
\hline 76 & Ani: 33. & & & \\
\hline 77 & $\begin{array}{l}\text { A3: } \quad \text { Então (inaudível) } \\
\text { esqueceram de mim? }\end{array}$ & & & $\mathrm{P} / \mathrm{G}$ \\
\hline 78 & P: Não... está aqui. & & & $\begin{array}{l}\text { P/G. O professor responde a } \\
\text { pergunta de A3 e se afasta do } \\
\text { grupo sorrindo com suas } \\
\text { anotações. }\end{array}$ \\
\hline 79 & P: Quem fez a pesquisa? & & Organização & 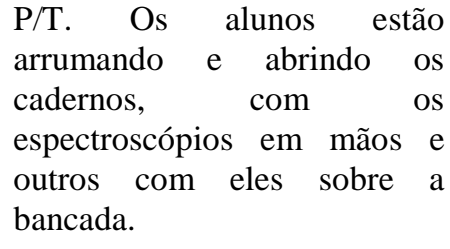 \\
\hline 80 & $\begin{array}{l}\text { A3: Ô Gabi! Saiu olhando na } \\
\text { rua? }\end{array}$ & & Organização & $\mathrm{A} / \mathrm{A}$ \\
\hline 81 & $\begin{array}{l}\text { A1: Não, só olhei no postezinho } \\
\text { lá perto de casa, só que é branca, } \\
\text { amarela não tinha mais nada. }\end{array}$ & & Organização & $\mathrm{A} / \mathrm{A}$ \\
\hline 82 & $\begin{array}{l}\text { A5: Da varanda do meu quarto } \\
\text { pegou uma "luzona" amarela } \\
\text { assim ó! }\end{array}$ & Gestos. & Organização & $\begin{array}{l}\text { A/A. A5, fala abrindo os } \\
\text { braços. }\end{array}$ \\
\hline 83 & $\begin{array}{l}\text { A1: Já pensou aí ó, indo lá } \\
\text { embaixo na outra rua que eu não } \\
\text { conheço ninguém? }\end{array}$ & & & $\mathrm{A} / \mathrm{A}$ \\
\hline 84 & $\begin{array}{l}\text { A5: Não tenho nem vontade de } \\
\text { sair da varanda para olhar a } \\
\text { Amanda. }\end{array}$ & & & $\mathrm{A} / \mathrm{A}$ \\
\hline 85 & $\begin{array}{l}\text { A3: Falta (inaudível) pro } \\
\text { Wanderson né veio? }\end{array}$ & & Organização & $\mathrm{A} / \mathrm{A}$ \\
\hline 86 & $\begin{array}{l}\text { A5: Aquela luz enche o saco, } \\
\text { deixa eu pegar um estilete, "cê" } \\
\text { vai ver ela... }\end{array}$ & & & $\begin{array}{l}\text { A/A. Aluno de outro grupo } \\
\text { vem até este e pega uma } \\
\text { cadeira. Senta entre o A3 e } \\
\text { A4. O grupo parece bem } \\
\text { agitado. }\end{array}$ \\
\hline 87 & $\begin{array}{l}\text { A3: (inaudível) } \quad \ldots \quad \text { forró } \\
\text { universitário. }\end{array}$ & & & 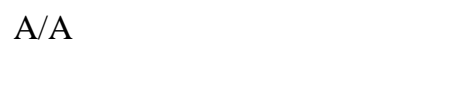 \\
\hline 88 & A5: Que é que tem isso? & & & \\
\hline
\end{tabular}




\begin{tabular}{|c|c|c|c|}
\hline 89 & $\begin{array}{l}\text { A3: Música (inaudível) forró } \\
\text { universitário. }\end{array}$ & & A3 cantando. \\
\hline 90 & 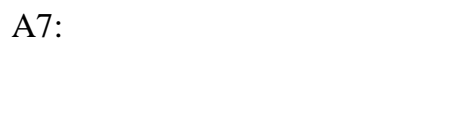 & & $\begin{array}{l}\text { O aluno que chegou ao grupo } \\
\text { retira algo da mão do A5 e } \\
\text { leva até embaixo da bancada. }\end{array}$ \\
\hline 91 & A5: "Cê" pára de ser chato! & & Fala para A7. \\
\hline 92 & A4: Falou professor prazer. & & $\begin{array}{l}\text { Fala para A3 afastando sua } \\
\text { mão. }\end{array}$ \\
\hline 93 & $\begin{array}{l}\text { A4: Tá gostando né? Só porque } \\
\text { os outros viu, você parou... }\end{array}$ & & $\begin{array}{l}\text { A4 põe a mão nas costas do } \\
\text { A7. }\end{array}$ \\
\hline 94 & $\begin{array}{l}\text { A1: Professor, o senhor tinha } \\
\text { falado uma lâmpada só... }\end{array}$ & Organização & $\begin{array}{l}\text { P/T. A1 gesticula mostrando } \\
\text { um dedo, indicando a } \\
\text { quantidade de lâmpada, } \\
\text { enquanto olha para o } \\
\text { professor. A4 rasga uma folha } \\
\text { do caderno. }\end{array}$ \\
\hline 95 & A5: Ô Wanderson... & Organização & $\begin{array}{l}\text { A/A. A5 gesticula com as } \\
\text { mãos chamando atenção de } \\
\text { A3. }\end{array}$ \\
\hline 96 & $\begin{array}{l}\text { A3: Pediram a fita, eu fui e } \\
\text { enrolei. }\end{array}$ & & $\begin{array}{l}\text { A/A. A3 mostra o } \\
\text { espectroscópio } \\
\text { aparentemente está envolvido } \\
\text { por fita isolante. O professor } \\
\text { vem e recolhe as folhas do } \\
\text { grupo. }\end{array}$ \\
\hline 97 & $\begin{array}{l}\text { A4: Ô professor... tem luz } \\
\text { vermelha aí? Só falta esse. }\end{array}$ & Organização & 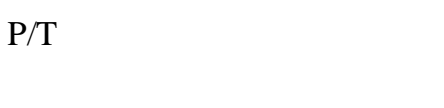 \\
\hline 98 & A3: Professor... & & $\mathrm{P} / \mathrm{T}$ \\
\hline 99 & $\begin{array}{l}\text { A4: Tem luz vermelha aí? Só } \\
\text { falta esse para mim. }\end{array}$ & Organização & $\mathrm{P} / \mathrm{T}$ \\
\hline 100 & P: Não precisa ter todos. & Organização & $\begin{array}{l}\text { P/T. A fala do professor é } \\
\text { geral, embora responda ao } \\
\text { questionamento de A4. }\end{array}$ \\
\hline 101 & $\begin{array}{l}\text { A4: Não!? Então fazendo } \\
\text { beleza. }\end{array}$ & Organização & $\begin{array}{l}\mathrm{P} / \mathrm{T} \text {. Professor estende o braço } \\
\text { direito para recolher a folha. } \\
\mathrm{A} 4 \text {, ao ouvir a resposta do } \\
\text { professor, interpreta que não } \\
\text { precisa fazer com todas as } \\
\text { lâmpadas, basta fazer com } \\
\text { algumas. }\end{array}$ \\
\hline 102 & A4: Quer que eu tire isso daqui? & Organização & $\mathrm{P} / \mathrm{T}$ \\
\hline 103 & P: Não depois eu tiro. & Organização & $\begin{array}{l}\mathrm{P} / \mathrm{T} \text {. Professor recolhe as } \\
\text { folhas. }\end{array}$ \\
\hline 104 & A4: Obrigado professor. & & $\mathrm{P} / \mathrm{T}$. Professor se dirige a \\
\hline
\end{tabular}




\begin{tabular}{|c|c|c|c|c|}
\hline & & & & $\begin{array}{l}\text { outros grupos e este } \\
\text { permanece agitado. } \\
\text { A5 joga um dos vários } \\
\text { espectroscópios de A1 que } \\
\text { gira o rosto assustada e depois } \\
\text { ri. }\end{array}$ \\
\hline 105 & $\begin{array}{l}\text { P: Olha nós vamos fazer o } \\
\text { seguinte (inaudível) nem muitos } \\
\text { fizeram, provavelmente alguns } \\
\text { erros então nós...vamos } \\
\text { provavelmente fazer a correção } \\
\text { destes erros. Nós vamos fazer a } \\
\text { observação de algumas } \\
\text { lâmpadas. Quem não tem } \\
\text { espectroscópio? }\end{array}$ & & Organização & $\begin{array}{l}\mathrm{P} / \mathrm{T} \text {. O professor volta a falar } \\
\text { para sala. A1 conversa com } \\
\text { A2 que está ao seu lado e A3 } \\
\text { conversa com A4 mostrando } \\
\text { seu caderno. Em ambos os } \\
\text { casos não dá para ouvir o que } \\
\text { estão falando. }\end{array}$ \\
\hline 106 & A3: Faz então para mim. & & & $\begin{array}{l}\text { A/A. A3 pede para A4 rindo, } \\
\text { para em seguida fechar o } \\
\text { caderno e pegar as canetas. }\end{array}$ \\
\hline 107 & A3: Certo. & & & $\mathrm{A} / \mathrm{A}$ \\
\hline 108 & $x^{2}$ & $\begin{array}{l}\text { Manipulação do } \\
\text { espectroscópio. }\end{array}$ & Organização & $\begin{array}{lr}\text { A/A. A3 pede para A4. } \\
\text { Enquanto o professor pergunta } \\
\text { quem não } & \text { tem } \\
\text { espectroscópio, A7 } & \text { manuseia } \\
\text { atentamente } & \\
\text { espectroscópio. } & \end{array}$ \\
\hline 109 & Ani: Ricardo (inaudível) & & & \\
\hline 110 & $\begin{array}{l}\text { A5: Professor! Oh! Os do } \\
\text { professor é moderno! }\end{array}$ & & & $\begin{array}{l}\text { P/T e A/A. Após a fala A5, A7 } \\
\text { bate nos braços de A3 } \\
\text { chamando sua atenção para } \\
\text { que este observe seu } \\
\text { espectroscópio, após A3 ter } \\
\text { retirado uma folha do } \\
\text { cadernos do A7, que fala algo } \\
\text { que não conseguimos } \\
\text { compreender. A3 olha para A7 } \\
\text { atentamente. }\end{array}$ \\
\hline 111 & A3: É. & & & $\begin{array}{l}\text { A/A. A7 gesticula apontando } \\
\text { para o espectroscópio e } \\
\text { pronuncia algo que não } \\
\text { compreendemos. A3 responde, } \\
\text { mas também } \\
\text { compreendemos e gesticula } \\
\text { apontando para } \\
\text { espectroscópio nas mãos do } \\
\text { A7. Parece explicar como } \\
\text { observar. }\end{array}$ \\
\hline 112 & $\begin{array}{l}\text { A7: (inaudível)... usar aquelas } \\
\text { coloridas? Aquele trabalho no } \\
\text { negócio? }\end{array}$ & & Organização & $\mathrm{A} / \mathrm{A}$ \\
\hline 113 & $\begin{array}{l}\text { A3: Não porque o professor foi } \\
\text { buscar. }\end{array}$ & & Organização & $\mathrm{A} / \mathrm{A}$ \\
\hline
\end{tabular}




\begin{tabular}{|c|c|c|c|c|}
\hline 114 & A3: Quem fez este foi eu, meu... & Gestos. & Organização & $\begin{array}{l}\text { A/A. A3 gesticula apontando } \\
\text { para si, em seguida aponta } \\
\text { para o espectroscópio na mão } \\
\text { do amigo. }\end{array}$ \\
\hline 115 & $\begin{array}{l}\text { A3: A fita isolante e esse } \\
\text { negócio (inaudível)... eu fiz na } \\
\text { sala mesmo. }\end{array}$ & Gestos. & Organização & $\begin{array}{l}\text { A/A. A3 aponta para parte } \\
\text { onde está o pedaço do CD no } \\
\text { espectroscópio. }\end{array}$ \\
\hline 116 & A7: Aqui ó... & $\begin{array}{l}\text { Manipulação do } \\
\text { espectroscópio. }\end{array}$ & Organização & $\begin{array}{l}\text { A/A. A7 manuseia e olha para } \\
\text { o espectroscópio. }\end{array}$ \\
\hline 117 & A3: Aqui ó, você olha por aqui. & $\begin{array}{l}\text { Manipulação do } \\
\text { espectroscópio. }\end{array}$ & Organização & $\begin{array}{l}\text { A/A. A3 aponta e indica no } \\
\text { espectroscópio a região onde a } \\
\text { observação deve ser feita. }\end{array}$ \\
\hline 118 & $\begin{array}{l}\text { A7: ...(inaudível) bastante fita } \\
\text { isolante... por dentro que põe? }\end{array}$ & $\begin{array}{l}\text { Manipulação do } \\
\text { espectroscópio. }\end{array}$ & Organização & $\begin{array}{l}\text { A/A. A7 aponta para dentro do } \\
\text { espectroscópio. } \\
\text { Durante esse tempo o } \\
\text { professor continua dirigindo } \\
\text { sua fala para todos os grupos } \\
\text { enquanto se movimenta pela } \\
\text { sala. Muitas conversas } \\
\text { simultâneas, difíceis de serem } \\
\text { compreendidas. }\end{array}$ \\
\hline 119 & $\begin{array}{l}\text { P: Pessoal... todos têm? Olha } \\
\text { vou deixar mais alguns aqui. }\end{array}$ & & Organização & $\begin{array}{l}\mathrm{P} / \mathrm{T} \text { e } \mathrm{P} / \mathrm{G} \text {. O professor passa e } \\
\text { deixa vários espectroscópios } \\
\text { para este grupo. }\end{array}$ \\
\hline 120 & Ani: Dá um pro rapaz aqui! & & Organização & $\mathrm{P} / \mathrm{A}$ \\
\hline 121 & $\begin{array}{l}\text { A4: Deixa eu ver, deixa eu ver } \\
\text { este aqui! }\end{array}$ & $\begin{array}{l}\text { Manipulação do } \\
\text { espectroscópio. }\end{array}$ & Organização & $\begin{array}{l}\text { A/A. A4 leva aos olhos um } \\
\text { dos espectroscópios } \\
\text { "coloridos" que o professor } \\
\text { trouxe e deixou na bancada. } \\
\text { Vira, observa de novo e coloca } \\
\text { o dedo em um dos lados do } \\
\text { espectroscópio, } \\
\text { novamente e põe o dedo na } \\
\text { outra extremidade e observa a } \\
\text { lâmpada do teto com o } \\
\text { espectroscópio. }\end{array}$ \\
\hline 122 & $\begin{array}{l}\text { A5: Esse aqui é da hora, só um } \\
\text { cortezinho... }\end{array}$ & & Organização & $\begin{array}{l}\text { A/A. Ao mesmo tempo A7 } \\
\text { parece perguntar algo, mas } \\
\text { não dá para entender. }\end{array}$ \\
\hline 123 & $\begin{array}{l}\text { A3: Tem! Porque o preto lá não } \\
\text { tinha um pedacinho. Só tinha o } \\
\text { marrom. }\end{array}$ & $\begin{array}{l}\text { Manipulação do } \\
\text { espectroscópio. }\end{array}$ & Organização & $\begin{array}{l}\text { A/A. As falas do turno } 123 \text { ao } \\
\text { turno } 125 \text { ocorrem } \\
\text { simultaneamente. } \\
\text { A7 sorri para A3 e volta a } \\
\text { olhar para o professor que } \\
\text { neste momento faz uma } \\
\text { explicação geral. A3 diz algo } \\
\text { para A7. A3 e A7 continuam } \\
\text { conversando enquanto o } \\
\text { professor explica para sala, A2 } \\
\text { e A1 e demais manuseiam os } \\
\text { espectroscópio e também }\end{array}$ \\
\hline
\end{tabular}




\begin{tabular}{|c|c|c|c|c|}
\hline & & & & $\begin{array}{l}\text { olham através dele em direção } \\
\text { às lâmpadas do teto. }\end{array}$ \\
\hline 124 & $\begin{array}{l}\text { A1: È, mas esse aqui também dá } \\
\text { para ver. Ó... }\end{array}$ & $\begin{array}{l}\text { Manipulação do } \\
\text { espectroscópio. }\end{array}$ & Organização & $\begin{array}{l}\text { A/A. A1 segurando um } \\
\text { espectroscópio maior, fala e } \\
\text { mostra ao colega à sua } \\
\text { esquerda. Praticamente todos } \\
\text { alunos do grupo manuseiam os } \\
\text { espectroscópios, trocam } \\
\text { espectroscópios entre eles e } \\
\text { realizam observações com as } \\
\text { lâmpadas do teto. }\end{array}$ \\
\hline 125 & $\begin{array}{l}\text { P: Pessoal, eu coloquei mais } \\
\text { alguns sobre a mesa, } \\
\text { dependendo da observação que } \\
\text { vocês já fizeram com os seus, } \\
\text { tenta aí com outro } \\
\text { primeiro...(inaudível)...o que } \\
\text { estiver melhor você faz a } \\
\text { observação. A observação das } \\
\text { lâmpadas que faremos aqui } \\
\text { será... (inaudível)... Já estão } \\
\text { organizados os grupos aí? }\end{array}$ & & Organização & $\mathrm{P} / \mathrm{T}$ \\
\hline 126 & Ani: De quantos? & & Organização & $\mathrm{P} / \mathrm{T}$ \\
\hline 127 & $\begin{array}{l}\text { P: Nós temos que fazer } \\
\text { exatamente a tabela que vocês } \\
\text { fizeram, } \\
\text { escrevam...(inaudível)...quem } \\
\text { não tiver lápis ou giz colorido } \\
\text { então anotem. }\end{array}$ & $\begin{array}{l}\text { Manipulação de } \\
\text { espectroscópio. }\end{array}$ & Organização & $\begin{array}{l}\mathrm{P} / \mathrm{T} \text {. A2 observa a lâmpada no } \\
\text { teto com o espectroscópio e } \\
\text { presta atenção a fala de A1. } \\
\text { Fala algo enquanto mostra seu } \\
\text { espectroscópio para A1 que } \\
\text { acaba pegando-o. A1 observa } \\
\text { a lâmpada do teto com o } \\
\text { espectroscópio de A2. A3 } \\
\text { observa atenta e longamente } \\
\text { através de seu espectroscópio. }\end{array}$ \\
\hline 128 & $\begin{array}{l}\text { A1: Esse aqui não é de CD não } \\
\text { hein? O Leonardo que pegou } \\
\text { para fazer. }\end{array}$ & $\begin{array}{l}\text { Manipulação do } \\
\text { espectroscópio. }\end{array}$ & Organização & $\begin{array}{l}\text { A/A. A1 vira e observa pelos } \\
\text { dois lados do espectroscópio. } \\
\text { Passa para o aluno à sua } \\
\text { esquerda. }\end{array}$ \\
\hline 129 & A1: Não dá para ver nada. & Gestos. & & $\begin{array}{l}\text { P/T e A/A. A1 balança a } \\
\text { cabeça negativamente, por não } \\
\text { conseguir ver. }\end{array}$ \\
\hline 130 & $\begin{array}{l}\text { Aba: Professor eu vou ganhar a } \\
\text { luz negra depois? }\end{array}$ & $\begin{array}{l}\text { Manipulação do } \\
\text { espectroscópio. }\end{array}$ & & $\begin{array}{l}\text { P/A e A/A. Todos observam a } \\
\text { luz do teto atentamente. }\end{array}$ \\
\hline 131 & $\begin{array}{l}\text { A5: Professor eu vou ganhar a } \\
\text { luz negra? }\end{array}$ & & & $\begin{array}{l}\text { P/T. Muito ruído na sala, } \\
\text { muitos alunos falando ao } \\
\text { mesmo tempo. }\end{array}$ \\
\hline 132 & $\begin{array}{l}\text { P: Então vocês têm que fazer } \\
\text { um quadro ou fazer um relatório } \\
\text { e anotar...as mesmas coisas que } \\
\text { deveriam ter feito na pesquisa } \\
\text { de campo. (inaudível)... a a }\end{array}$ & & Organização & $\mathrm{P} / \mathrm{T}$ \\
\hline
\end{tabular}




\begin{tabular}{|c|c|c|c|c|}
\hline & primeira lâmpada fluorescente... & & & \\
\hline 133 & A5: Dá uma folha aí. & & & $\begin{array}{l}\text { A/A. A5 fala ao mesmo tempo } \\
\text { que o professor. }\end{array}$ \\
\hline 134 & $\begin{array}{l}\text { P: ...Tem que anotar o que? } \\
\text { Lembra o quadro? Nome da } \\
\text { lâmpada: fluorescente compacta. } \\
\text { Espectro: se é discreto ou } \\
\text { contínuo. Alex, por favor, } \\
\text { abaixe a lâmpada. }\end{array}$ & & Organização & $\mathrm{P} / \mathrm{T}$. \\
\hline 135 & A5: Me empresta uma folha aí! & $\begin{array}{l}\text { Manipulação do } \\
\text { espectroscópio. }\end{array}$ & Organização & $\begin{array}{l}\text { A/A. A5 manuseando o } \\
\text { espectroscópio. }\end{array}$ \\
\hline 136 & A4: Tá louco é? & & & $\begin{array}{l}\text { A/A. A5 arranca uma folha de } \\
\text { seu caderno. }\end{array}$ \\
\hline 137 & A5: Tô pegando uma folha. & $\begin{array}{l}\text { Manipulação do } \\
\text { espectroscópio. }\end{array}$ & Organização & $\begin{array}{l}\text { A3 mostra o espectroscópio } \\
\text { que está manuseando para A4. } \\
\text { Abre um lado do } \\
\text { espectroscópio para olhar } \\
\text { dentro dele. }\end{array}$ \\
\hline 139 & Ani: É para fazer o quê? & & Organização & $\mathrm{P} / \mathrm{T}, \mathrm{P} / \mathrm{A}$ \\
\hline 140 & A5: (inaudível). & & & \\
\hline 141 & A5: Ele falou pega aí, eu peguei. & & & $\mathrm{A} / \mathrm{A}$ \\
\hline 142 & Val: gritos. & & & P/T. A luz da sala é apagada. \\
\hline
\end{tabular}

\section{Momento 2 - 0bservação da lâmpada fluorescente compacta e da lâmpada incandescente}

\begin{tabular}{|l|l|l|l|l|}
\hline $\begin{array}{l}\text { Turno } \\
\text { De } \\
\text { fala }\end{array}$ & $\begin{array}{l}\text { Linguagem verbal (oral ou } \\
\text { escrita) }\end{array}$ & $\begin{array}{l}\text { Outras linguagens } \\
\text { Ações/gestos/ } \\
\text { Manipulação de } \\
\text { materiais }\end{array}$ & Indicadores & $\begin{array}{l}\text { Tipos } \\
\text { Interação/Comentários }\end{array}$ \\
144 & Ani: Professor! & & & P: Oi! \\
145 & Ani1: Tô vendo nada! & & P/T. O professor se dirige à \\
146 & Olha... & $\begin{array}{l}\text { bancada onde a lâmpada está } \\
\text { acesa. } \\
\text { A/A }\end{array}$ \\
147 & $\begin{array}{l}\text { A3: Olha... Vou olhar e vou } \\
\text { falando. }\end{array}$ & \\
\hline
\end{tabular}




\begin{tabular}{|c|c|c|c|c|}
\hline 148 & A5: Professor cê tá na frente! & & & $\mathrm{P} / \mathrm{T}$. \\
\hline 149 & A4: É professor assim não dá. & & Organização & $\mathrm{P} / \mathrm{T}$ \\
\hline 150 & $\begin{array}{l}\text { P: Pessoal,...ó esse trabalho no } \\
\text { final da aula eu vou recolher } \\
\text { (muitas falas ao mesmo } \\
\text { tempo)...então alguém do grupo } \\
\text { tem que estar anotando. }\end{array}$ & $\begin{array}{l}\text { Manipulação do } \\
\text { espectroscópio. }\end{array}$ & Organização & $\begin{array}{l}\mathrm{P} / \mathrm{T} \text {. Ao mesmo tempo que o } \\
\text { professor fala os alunos } \\
\text { começam a observar e falar as } \\
\text { cores. }\end{array}$ \\
\hline 151 & $\begin{array}{l}\text { A3: Violeta, verde, verde-claro. } \\
\text { Laranja. Vermelho. Não azul } \\
\text { não to vendo. }\end{array}$ & & & A/A. \\
\hline 152 & A5: Quem ta anotando? & & Organização & $\begin{array}{l}\text { A/A.. A5 levanta e fica no } \\
\text { meio de A3 e A4, quando faz } \\
\text { a pergunta. }\end{array}$ \\
\hline 153 & $\begin{array}{l}\text { P: Esta lâmpada fluorescente } \\
\text { compacta. Segunda coisa, o } \\
\text { espectro aqui é discreto ou } \\
\text { contínuo? }\end{array}$ & & Organização & $\mathrm{P} / \mathrm{T}$. \\
\hline 154 & A3: É contínuo! & $\begin{array}{l}\text { Manipulação do } \\
\text { espectroscópio }\end{array}$ & Classificação & $\begin{array}{l}\text { P/T. A3 fala enquanto observa } \\
\text { a lâmpada com o } \\
\text { espectroscópio. Outros alunos } \\
\text { falam ao mesmo tempo, mas } \\
\text { alguém confirma que é } \\
\text { contínuo. } \\
\text { A5 sussurra algo para A3. }\end{array}$ \\
\hline 155 & P: Observem a lâmpada. & & Organização & $\mathrm{P} / \mathrm{T}$. \\
\hline 156 & A2: É discreto. & & Classificação & $\begin{array}{l}\mathrm{P} / \mathrm{T} \text {. Alguns alunos dizem que } \\
\text { é discreto. }\end{array}$ \\
\hline 157 & A1: Azul. & $\begin{array}{l}\text { Manipulação de } \\
\text { materiais. }\end{array}$ & Classificação & Fala enquanto faz anotações. \\
\hline 158 & A3: Então é que você errou. & & & $\mathrm{A} / \mathrm{A}$ \\
\hline 159 & A5: Anota aí Raxixi. & & Organização & $\begin{array}{l}\text { A/A. Fala apontando para o } \\
\text { caderno de A3. }\end{array}$ \\
\hline 160 & $\begin{array}{l}\text { A3: Ô Gabi você está aí } \\
\text { anotando? }\end{array}$ & & Organização. & $\mathrm{A} / \mathrm{A}$ \\
\hline 161 & A1: & & & $\begin{array}{l}\text { A/A. Gesticula com a cabeça } \\
\text { de forma negativa. }\end{array}$ \\
\hline 162 & Val: Não?! Eu não. & Gestos. & & $\begin{array}{l}\text { A/A. Gesticula negativamente } \\
\text { com a cabeça também. }\end{array}$ \\
\hline 163 & A4: Eu to anotando. & & Organização & A/A. \\
\hline 164 & A3: Tá anotando? & & Organização & $\begin{array}{l}\text { A/A. A3 fala enquanto olha o } \\
\text { caderno de A5. }\end{array}$ \\
\hline 165 & $\begin{array}{l}\text { A5: Tá anotando?! Anota aí, } \\
\text { anota aí. Eu vou falando. }\end{array}$ & & Organização & $\mathrm{A} / \mathrm{A}$ \\
\hline
\end{tabular}




\begin{tabular}{|c|c|c|c|c|}
\hline 166 & $\begin{array}{l}\text { P: Aparecem todas as cores? As } \\
\text { sete aí? }\end{array}$ & & Organização & $\mathrm{P} / \mathrm{T}$. \\
\hline 167 & Val: Professor! Não! & & & \\
\hline 168 & $\begin{array}{l}\text { P: Então isso já é um indício que } \\
\text { o espectro não é contínuo. }\end{array}$ & & Justificativa & $\mathrm{P} / \mathrm{T}$. \\
\hline 169 & $\begin{array}{l}\text { A5: Roxo, azul e verde. Roxo, } \\
\text { azul e verde. }\end{array}$ & & Classificação & $\begin{array}{l}\text { A/A. A5 fala para A4 anotar. } \\
\text { Sua fala é simultânea a do } \\
\text { professor. }\end{array}$ \\
\hline 170 & A1: Ah, então eu fiz errado. & & Organização & $\mathrm{P} / \mathrm{T}$. \\
\hline 171 & $\begin{array}{l}\text { P: Segunda coisa... olha como é } \\
\text { que você distingue um espectro } \\
\text { do outro? Pessoal! (grito),... }\end{array}$ & & Organização & $\begin{array}{l}\text { P/T. Enquanto fala dos } \\
\text { quadros reforçados, vai } \\
\text { gesticulando com as mãos } \\
\text { reforçando aquilo que diz. }\end{array}$ \\
\hline 172 & Val:Oi! & & & $\begin{array}{l}\text { Vários alunos gritam após o } \\
\text { grito do professor, antes dele } \\
\text { retomar a fala. }\end{array}$ \\
\hline 173 & $\begin{array}{l}\text { P....(calmamente) Você vê uma } \\
\text { tarja colorida e nesta tarja se } \\
\text { aparecem linhas ou quadros } \\
\text { reforçados com destaque maior } \\
\text { mais intenso parecem várias } \\
\text { linhas, então este espectro é } \\
\text { discreto e não contínuo. }\end{array}$ & $\begin{array}{l}\text { Manipulação dos } \\
\text { espectroscópios. }\end{array}$ & $\begin{array}{l}\text { Classificação } \\
\text { e justificativa }\end{array}$ & $\begin{array}{l}\text { retomar a fala. } \\
\text { Os alunos continuam olhando } \\
\text { para lâmpada acesa, fazem } \\
\text { anotações e comentam uns } \\
\text { com os outros. }\end{array}$ \\
\hline 174 & A5: Cores! & $\begin{array}{l}\text { Manipulação do } \\
\text { espectroscópio. }\end{array}$ & Organização. & $\begin{array}{l}\text { A/A. } \\
\text { A5 faz anotações e fala em } \\
\text { voz alta, após ter feito outra } \\
\text { observação com } \\
\text { espectroscópio. }\end{array}$ \\
\hline 175 & $\begin{array}{l}\text { P: Então observem esta lâmpada. } \\
\text { Espectro é discreto ou contínuo? }\end{array}$ & & $\begin{array}{l}\text { Organização/ } \\
\text { classificação. }\end{array}$ & $\mathrm{P} / \mathrm{T}$. \\
\hline 176 & Val: Discreto. & & Classificação & $\mathrm{P} / \mathrm{T}$. \\
\hline 177 & P: Discreto. & $\begin{array}{l}\text { Manipulação de } \\
\text { materiais. }\end{array}$ & Classificação & $\begin{array}{l}\text { P/T. O professor, confirma a } \\
\text { fala dos alunos, mas sem } \\
\text { justificativas. }\end{array}$ \\
\hline 178 & A4: Azul né? & & Organização & $\begin{array}{l}\text { A/A } \\
\text { A4 fala para A1, enquanto ela } \\
\text { escreve n o caderno. }\end{array}$ \\
\hline 179 & A3: Azul, eu não to vendo azul. & & Organização & $\begin{array}{l}\text { A/A. A4 toca A3 enquanto } \\
\text { este fala. }\end{array}$ \\
\hline 180 & $\begin{array}{l}\text { A4: Caramba Ricardo! Você não } \\
\text { enxerga? Abre o olho, } \\
\text { abre!Primeiro abre o olho! } \\
\text { Agora põe o cano no olho. }\end{array}$ & $\begin{array}{l}\text { Manipulação do } \\
\text { espectroscópio. }\end{array}$ & Organização & $\begin{array}{l}\text { A/A. A4 fala enquanto } \\
\text { continua olhando fixamente } \\
\text { com o espectroscópio. } \\
\text { A2 ri quando A4 pede para A3 } \\
\text { colocar o espectroscópio no } \\
\text { olho. }\end{array}$ \\
\hline 181 & A3: Licença aí professor! & $\begin{array}{l}\text { Manipulação do } \\
\text { espectroscópio. }\end{array}$ & Organização & $\begin{array}{l}\text { P/T. A3 fala enquanto abaixa } \\
\text { o espectroscópio. }\end{array}$ \\
\hline 182 & P: Então para percebermos a & Manipulação da & Organização & $\mathrm{P} / \mathrm{T}$ \\
\hline
\end{tabular}




\begin{tabular}{|c|c|c|c|c|}
\hline & diferença... & lâmpada. & & \\
\hline 183 & A3: Certo. & & Organização & $\begin{array}{l}\mathrm{P} / \mathrm{T} \text {. Tudo escuro, o professor } \\
\text { está trocando a lâmpada. }\end{array}$ \\
\hline 184 & $\begin{array}{l}\text { Ani: Professor tem que anotar o } \\
\text { nome das cores professor? }\end{array}$ & & Organização & $\mathrm{P} / \mathrm{T}$ \\
\hline 185 & $\begin{array}{l}\text { Ani1: Saí do meio aí professor } \\
\text { fazendo favor. }\end{array}$ & & Organização & $\mathrm{P} / \mathrm{T}$ \\
\hline 186 & $\begin{array}{l}\text { A5: Ô professor eu não consigo } \\
\text { (não dá para compreender)... O } \\
\text { senhor vai deixar rolar ou não? }\end{array}$ & & Organização & $\begin{array}{l}\mathrm{P} / \mathrm{T} \text {. Vários alunos falam ao } \\
\text { mesmo tempo. }\end{array}$ \\
\hline 187 & $\begin{array}{l}\text { A3: E aí professor vai deixar } \\
\text { anotar ou não? }\end{array}$ & & Organização & $\begin{array}{l}\mathrm{P} / \mathrm{T} \text {. O professor fala algo que } \\
\text { não dá para compreender. }\end{array}$ \\
\hline 188 & A5: Já mudou? & $\begin{array}{l}\text { Manipulação da } \\
\text { lâmpada. }\end{array}$ & Organização & $\begin{array}{l}\text { P/T. Temos uma lâmpada } \\
\text { acesa. }\end{array}$ \\
\hline 189 & $\begin{array}{l}\text { P: Observem esta... Não eu vou } \\
\text { voltar esta. }\end{array}$ & $\begin{array}{l}\text { Manipulação da } \\
\text { lâmpada. }\end{array}$ & Organização & $\begin{array}{l}\mathrm{P} / \mathrm{T} \text {. O professor fala erguendo } \\
\text { a lâmpada anterior com a mão } \\
\text { esquerda. }\end{array}$ \\
\hline 190 & $\begin{array}{l}\text { P: Mas observe para você } \\
\text { perceber a diferença entre o } \\
\text { espectro discreto e o contínuo. }\end{array}$ & $\begin{array}{l}\text { Manipulação da } \\
\text { lâmpada. }\end{array}$ & Organização & $\mathrm{P} / \mathrm{T}$ \\
\hline 191 & $\begin{array}{l}\text { A3: É mesmo. Vai esse é linha } \\
\text { reta ó! }\end{array}$ & Gestos. & Organização. & $\begin{array}{l}\text { P/T. A3 ergue a mão direita } \\
\text { enquanto fala. }\end{array}$ \\
\hline 192 & $\begin{array}{l}\text { A4: Ó que "look" essa fita aí } \\
\text { mano! }\end{array}$ & Gestos. & & $\begin{array}{l}\text { A/A. A4 "bate" com seu } \\
\text { espectroscópio em A3. }\end{array}$ \\
\hline 193 & A3: dá hora! & & & A/A. Diz virando para A4. \\
\hline 194 & P: Esse espectro é contínuo. & & Classificação & $\begin{array}{l}\text { P/T. A1 fala algo para A2, } \\
\text { enquanto ele escreve sem eu } \\
\text { caderno, porém não dá para } \\
\text { compreender. } \\
\text { Vários alunos falam ao mesmo } \\
\text { tempo e notamos euforia na } \\
\text { sala com a atividade. }\end{array}$ \\
\hline 195 & A4: Essa é da hora! & & Organização & $\mathrm{P} / \mathrm{A}, \mathrm{A} / \mathrm{A}$ \\
\hline 196 & A5: Esse é garantido. & $\begin{array}{l}\text { Manipulação dos } \\
\text { espectroscópios. }\end{array}$ & & $\begin{array}{l}\text { P/A, A/A. Os alunos observam } \\
\text { a lâmpada com seus } \\
\text { espectroscópios, inclusive A1 } \\
\text { inclina-se para frente para } \\
\text { observar melhor. }\end{array}$ \\
\hline 197 & P: (inaudível) Pessoal! & & Organização & $\mathrm{P} / \mathrm{T}$ \\
\hline 198 & $\begin{array}{l}\text { A4: Como chama essa } \\
\text { lâmpada? }\end{array}$ & & Organização & $\mathrm{P} / \mathrm{T}$ \\
\hline 199 & A5: Incandescente. & & Classificação & $\mathrm{A} / \mathrm{A}$ \\
\hline
\end{tabular}




\begin{tabular}{|c|c|c|c|c|}
\hline 200 & $\begin{array}{l}\text { A3: Lâmpada incandescente... } \\
\text { ou não? Você não sabe? }\end{array}$ & & $\begin{array}{l}\text { Classificação } \\
\text { /organização }\end{array}$ & A/A. A3 fala olhando para A4. \\
\hline 201 & A4: É lâmpada amarela. & & Classificação & $\mathrm{A} / \mathrm{A}$ \\
\hline 202 & A4: Espectro contínuo. & & Classificação & $\mathrm{A} / \mathrm{A}$ \\
\hline 203 & $\begin{array}{l}\text { A3: Não, não é contínuo, não } \\
\text { aparece todas as cores. Contínuo } \\
\text { é quando aparece todas. }\end{array}$ & & $\begin{array}{l}\text { Classificação } \\
\text { /Justificativa/ } \\
\text { Explicação }\end{array}$ & $\mathrm{A} / \mathrm{A}$ \\
\hline 204 & $\begin{array}{l}\text { P: Põe o lado do plástico da lente } \\
\text { encostado no olho. E o fundo } \\
\text { aponta para lâmpada. }\end{array}$ & & Organização & $\begin{array}{l}\mathrm{P} / \mathrm{T} \text {. Nesse momento o } \\
\text { professor, que continuava a } \\
\text { falar em baixo tom, fala para } \\
\text { toda classe. }\end{array}$ \\
\hline 205 & A4: O cara manja. & & & \\
\hline 206 & Ani: Professor! & & & $\mathrm{P} / \mathrm{A}$ \\
\hline 207 & $\begin{array}{l}\text { A1: Tales! Qual é o seu número } \\
\text { mesmo? }\end{array}$ & & Organização & A/A. A1 pergunta para A5. \\
\hline 208 & A5: 11 & & Organização & $\mathrm{A} / \mathrm{A}$ \\
\hline 209 & $\begin{array}{l}\text { A4: (inaudível)... ô Tales sai do } \\
\text { meio velho. }\end{array}$ & & & $\begin{array}{l}\text { Vários alunos falando ao } \\
\text { mesmo tempo. }\end{array}$ \\
\hline 210 & $\begin{array}{l}\text { A4: Põe essa mão cheia de dedos } \\
\text { na frente não enxergo (?) coisa } \\
\text { nenhuma. }\end{array}$ & & & \\
\hline 211 & A5: Você enxerga antes? & $\begin{array}{l}\text { Manipulação do } \\
\text { espectroscópio e } \\
\text { de materiais. }\end{array}$ & & $\begin{array}{l}\text { A/A. A5 fala rindo e } \\
\text { colocando a mão no ombro de } \\
\text { A4. } \\
\text { A4 observa com seu } \\
\text { espectroscópio, enquanto A2 } \\
\text { fala algo para A1 que realiza } \\
\text { anotações em seu caderno. }\end{array}$ \\
\hline 212 & $\begin{array}{l}\text { P: Aí mais ou menos onde você } \\
\text { está segurando na lateral aparece } \\
\text { uma tarjinha colorida... }\end{array}$ & & Organização & $\mathrm{P} / \mathrm{T}$ \\
\hline 213 & Ani: Professor! & & & P/A \\
\hline 214 & P: Conseguiu ver? & & Organização & $\mathrm{P} / \mathrm{A}$ \\
\hline 215 & A3: É. Uh, uh!!! & $\begin{array}{l}\text { Manipulação do } \\
\text { espectroscópio. }\end{array}$ & Organização & $\begin{array}{l}\text { P/A. A3 demonstra expressão } \\
\text { de felicidade e observando } \\
\text { com o espectroscópio } \\
\text { comemora sem tirá-lo do olho. } \\
\text { Continua na mesma posição } \\
\text { de observação. }\end{array}$ \\
\hline 216 & Ani: Posso olhar na lâmpada? & $\begin{array}{l}\text { Manipulação do } \\
\text { espectroscópio. }\end{array}$ & Organização & P/A \\
\hline 217 & $\begin{array}{l}\text { P: Qual o espectro desta } \\
\text { lâmpada? }\end{array}$ & & $\begin{array}{l}\text { Organização/ } \\
\text { classificação. }\end{array}$ & $\mathrm{P} / \mathrm{T}$ \\
\hline
\end{tabular}




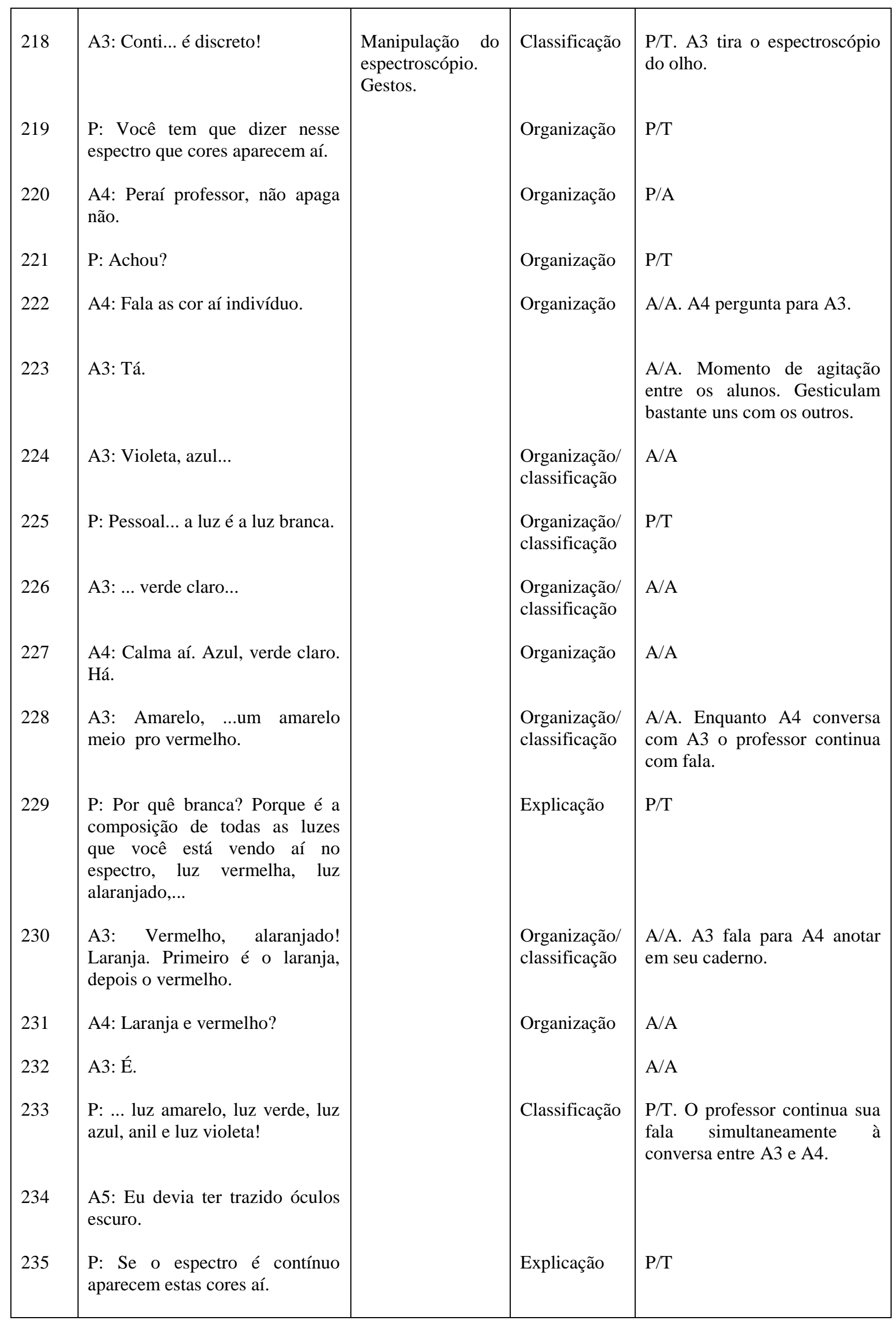




\begin{tabular}{|c|c|c|c|c|}
\hline 236 & A4: Quais cores? & & & $\mathrm{P} / \mathrm{T}$ \\
\hline 237 & $\begin{array}{l}\text { P: Vermelho, alaranjado, } \\
\text { amarelo, verde, azul, anil, } \\
\text { violeta. }\end{array}$ & & Explicação & $\begin{array}{l}\mathrm{P} / \mathrm{T} \text {. Embora responda um } \\
\text { aluno o professor fala para } \\
\text { toda classe. }\end{array}$ \\
\hline 238 & $\begin{array}{l}\text { A3: Podes crê, é vi... é isso aí } \\
\text { mesmo. }\end{array}$ & Gestos. & & $\begin{array}{l}\text { A/A P/A. A3 gesticula } \\
\text { fazendo sinal de positivo com } \\
\text { a mão e fala ainda com o } \\
\text { espectroscópio nos olhos. } \\
\text { A4 ri, pronuncia algo que não } \\
\text { compreendemos e põe a mão } \\
\text { no ombro de A3. } \\
\text { A1 permanece quieta olhando } \\
\text { em direção à lâmpada, mas } \\
\text { sem espectroscópio. } \\
\text { Todos falam na sala, mas em } \\
\text { baixo tom. }\end{array}$ \\
\hline 239 & A4: Que cor é anil? & $\begin{array}{l}\text { Manipulação do } \\
\text { espectroscópio. }\end{array}$ & Organização & $\begin{array}{l}\text { P/A. A4 fala com o } \\
\text { espectroscópio no olho } \\
\text { observando a lâmpada. }\end{array}$ \\
\hline 240 & $\begin{array}{l}\text { A3: O que? Como é que é? } \\
\text { (inaudível)... }\end{array}$ & Gestos. & & $\begin{array}{l}\text { A/A. A3 gesticula mostrando } \\
\text { indignação. }\end{array}$ \\
\hline 241 & $\begin{array}{l}\text { A2: Você viu não, se tava } \\
\text { separado não? }\end{array}$ & & & $\mathrm{A} / \mathrm{A}$ \\
\hline 242 & $\begin{array}{l}\text { P: Olha o azul, ele tem uma } \\
\text { tonalidade que nós ... }\end{array}$ & & Organização & $\mathrm{P} / \mathrm{T}$ \\
\hline 243 & A3: E o anil? & & Organização & $\mathrm{A} / \mathrm{A}$ \\
\hline 244 & $\begin{array}{l}\text { P: ... na linguagem comum nós } \\
\text { diríamos que ele, (inaudível)... } \\
\text { um pouco mais claro. Então o } \\
\text { azul e o azul claro. }\end{array}$ & & Explicação & $\mathrm{P} / \mathrm{T}$ \\
\hline 245 & A4: Anil é o azul piscina? & & Organização & $\begin{array}{l}\text { P/A. Na sala ouvimos alguns } \\
\text { risos, mas em baixo tom. }\end{array}$ \\
\hline 246 & A3: O anil professor?... & & & $\mathrm{P} / \mathrm{T}$ \\
\hline 247 & P: O anil é o azul escuro. & & Classificação & $\mathrm{P} / \mathrm{T}$ \\
\hline 248 & A4: Azul escuro. & & & $\mathrm{P} / \mathrm{T}$ \\
\hline 249 & $\begin{array}{l}\text { A3: Ah eu sabia é que eu tava } \\
\text { querendo confirmar. }\end{array}$ & Gestos. & & $\begin{array}{l}\mathrm{P} / \mathrm{T} \text {. A3 gesticula com o } \\
\text { espectroscópio em mãos em } \\
\text { tom meio irônico. }\end{array}$ \\
\hline 250 & A4: Ah... cala tua boca vai. & & & $\mathrm{A} / \mathrm{A}$ \\
\hline 251 & $\begin{array}{l}\text { P: Bom, então o que vocês têm } \\
\text { que anotar? Nome da lâmpada, } \\
\text { que lâmpada é essa? } \\
\text { Incandescente. Espectro dessa } \\
\text { lâmpada? }\end{array}$ & & Organização & $\mathrm{P} / \mathrm{T}$ \\
\hline
\end{tabular}




\begin{tabular}{|c|c|c|c|c|}
\hline 252 & A3: Isso aí, isso aí, é... & & & $\mathrm{A} / \mathrm{A}$ \\
\hline 253 & $\begin{array}{l}\text { A4: Tu é burro mesmo hein? } \\
\text { Você falou violeta mano. }\end{array}$ & & & $\mathrm{A} / \mathrm{A}$ \\
\hline 254 & A3: E não é violeta não? & $\begin{array}{l}\text { Manipulação do } \\
\text { espectroscópio. }\end{array}$ & & $\begin{array}{l}\mathrm{A} / \mathrm{A} \text {. O diálogo entre } \mathrm{A} 3 \text { e } \mathrm{A} 4 \\
\text { ocorre simultaneamente à fala }\end{array}$ \\
\hline 255 & A4: É anil cavalo! & & & $\begin{array}{l}\text { do professor no turno } 251 \text {. } \\
\text { Nesse momento os demais } \\
\text { alunos do grupo estão olhando } \\
\text { para a lâmpada novamente } \\
\text { com o espectroscópio. }\end{array}$ \\
\hline 256 & Ani: Contínuo. & & Classificação & $\mathrm{P} / \mathrm{T}$ \\
\hline 257 & Ani1: Discreto. & & Classificação & $\mathrm{P} / \mathrm{T}$ \\
\hline 258 & P: Contínuo. & & Classificação & $\mathrm{P} / \mathrm{T}$ \\
\hline 259 & Ani1: Contínuo aí ó. & & Classificação & P/T. Risos gerais. \\
\hline 260 & P: Vê de trás. & & & $\begin{array}{l}\text { P/A. O professor entrega um } \\
\text { espectroscópio para um aluno. }\end{array}$ \\
\hline 261 & Ani2: Aí pegô feio hein? & & & $\mathrm{P} / \mathrm{A}$ \\
\hline 262 & A3: Ficou mal agora. & & Explicação & $\mathrm{A} / \mathrm{A}$ \\
\hline 263 & P: As cores!? Tem todas! & & & $\begin{array}{l}\mathrm{P} / \mathrm{T} \text {. Alunos falam ao mesmo } \\
\text { tempo, mas não dá para } \\
\text { compreender. }\end{array}$ \\
\hline 264 & P: E aí no quadro... & & Organização & $\mathrm{P} / \mathrm{T}$ \\
\hline 265 & Ani: Professor fez? & & & $\mathrm{P} / \mathrm{A}$ \\
\hline 266 & P: Não. & & & $\mathrm{P} / \mathrm{A}$ \\
\hline 267 & $\begin{array}{l}\text { P: As duas últimas anotações do } \\
\text { quadro. Qual é a maior banda? }\end{array}$ & $\begin{array}{l}\text { Manipulação do } \\
\text { espectroscópio e } \\
\text { manipulação de } \\
\text { materiais. }\end{array}$ & Organização & $\begin{array}{l}\mathrm{P} / \mathrm{T} \text {. Enquanto o professor fala } \\
\text { alguns alunos observam com o } \\
\text { espectroscópio e A1 mexe } \\
\text { com uma folha de caderno que } \\
\text { está em suas mãos. }\end{array}$ \\
\hline 268 & A3: Maior banda? Do Gustavo. & & & $\begin{array}{l}\text { P/T. A3 fala em tom de } \\
\text { gozação. Risos gerais. }\end{array}$ \\
\hline 269 & $\begin{array}{l}\text { P: No caso a mais larga. } \\
\text { Vermelho. }\end{array}$ & & Classificação & $\mathrm{P} / \mathrm{T}$ \\
\hline 270 & Ani: Verde. & & Classificação & $\mathrm{P} / \mathrm{T}$ \\
\hline 271 & A3: Não. Não é. É o verde. & & Classificação & $\begin{array}{l}\mathrm{P} / \mathrm{T} \text {. A3 recebe um empurrão } \\
\text { de } \mathrm{A} 4 \text {. }\end{array}$ \\
\hline 272 & A5: Explode. & & & $\mathrm{P} / \mathrm{T}$. \\
\hline 273 & A3: Rá... É o verde pô. & & Classificação & $\begin{array}{l}\text { P/T. A3 ri e dá um "tapa" em } \\
\text { A4. }\end{array}$ \\
\hline
\end{tabular}




\begin{tabular}{|c|c|c|c|c|}
\hline 274 & $\begin{array}{l}\text { P: Maior distribuição } \\
\text { frequêencias, aí o vermelho. }\end{array}$ & & Classificação & $\mathrm{P} / \mathrm{T}$ \\
\hline 275 & $\begin{array}{l}\text { A1: Professor, mas o verde } \\
\text { também tem. }\end{array}$ & $\begin{array}{l}\text { Manipulação do } \\
\text { espectroscópio. }\end{array}$ & Classificação & $\begin{array}{l}\text { P/A. A1 fala tirando o } \\
\text { espectroscópio dos olhos. } \\
\text { Uma aluna devolve um } \\
\text { espectroscópio aparentemente } \\
\text { para o professor. }\end{array}$ \\
\hline 276 & $\begin{array}{l}\text { Ani: } \mathrm{O} \text { verde também tem } \\
\text { professor. }\end{array}$ & & Classificação & $\mathrm{P} / \mathrm{A}$ \\
\hline 277 & A5: Ah tá véio. & & & $\mathrm{A} / \mathrm{A}$ \\
\hline 278 & $\begin{array}{l}\text { A1: O verde e o vermelho ta na } \\
\text { média. }\end{array}$ & Gestos. & Classificação & $\begin{array}{l}\text { P/A. A1 gesticula com a mão } \\
\text { direita sinalizando "mais ou } \\
\text { menos" para indicar a idéia de } \\
\text { média. }\end{array}$ \\
\hline 279 & A3: É o verde. & $\begin{array}{l}\text { Manipulação com } \\
\text { o espectroscópio. }\end{array}$ & Classificação & $\begin{array}{l}\text { P/A. A3 fala olhando com o } \\
\text { espectroscópio novamente. }\end{array}$ \\
\hline 280 & A3: Não. É o verde! & & Classificação & $\mathrm{P} / \mathrm{A}$ \\
\hline 281 & A5: É o verde. & & Classificação & $\mathrm{P} / \mathrm{A}$ \\
\hline 282 & $\begin{array}{l}\text { P: Qual é o menor, o que aparece } \\
\text { menos? }\end{array}$ & & Organização & $\mathrm{P} / \mathrm{T}$ \\
\hline 283 & $\begin{array}{l}\text { Val: É o amarelo. } \\
\text { Verde. } \\
\text { Amarelo. }\end{array}$ & & Classificação & $\begin{array}{l}\mathrm{P} / \mathrm{T} \text {. Vários alunos respondem } \\
\text { ao mesmo tempo. Alguns } \\
\text { falam que é o amarelo e outros } \\
\text { o verde. }\end{array}$ \\
\hline 284 & A3: É o verde. & & Classificação & P/T. A3 grita que é o verde. \\
\hline 285 & A5: É o lilás. & & Organização & $\mathrm{P} / \mathrm{T}$ \\
\hline 286 & Val: Amarelo. & & Classificação & $\mathrm{P} / \mathrm{T}$ \\
\hline 287 & A2: É o amarelo ô. & & Classificação & A/A. A2 fala olhando para A3. \\
\hline 288 & A3: É não, o amarelo é o menor. & & Classificação & A/A. A3 fala para A2. \\
\hline 289 & A2: É o que aparece menos. & & & $\mathrm{A} / \mathrm{A}$ \\
\hline 290 & $\begin{array}{l}\text { A3: Ah menor. Menos é o La... } \\
\text { La... o laranja. }\end{array}$ & & Classificação & $\mathrm{A} / \mathrm{A}$ \\
\hline 291 & $\begin{array}{l}\text { A3: Ô. Menos aparece é o } \\
\text { laranja. }\end{array}$ & $\begin{array}{l}\text { Manipulação do } \\
\text { espectroscópio. }\end{array}$ & Classificação & $\begin{array}{l}\text { A/A. A3 fala para A4 que está } \\
\text { observando com } \quad \text { o } \\
\text { espectroscópio. }\end{array}$ \\
\hline 292 & Ani: Laranja professor. & & Classificação & $\mathrm{P} / \mathrm{T}$ \\
\hline 293 & Val: Laranja. & & Classificação & $\begin{array}{l}\mathrm{P} / \mathrm{T} \text {. Vários alunos repetem ao } \\
\text { mesmo tempo. }\end{array}$ \\
\hline 294 & A3: Laranja é o menor. & & Classificação & $\mathrm{P} / \mathrm{T}$ \\
\hline
\end{tabular}




\begin{tabular}{|c|c|c|c|c|}
\hline 295 & A4: Maior banda é qual? & & Organização & $\mathrm{P} / \mathrm{T}$ \\
\hline 296 & P: Então anotem. & & Organização & $\mathrm{P} / \mathrm{T}$ \\
\hline 297 & A3: Maior a sua. & & & $\begin{array}{l}\text { A/A. Parece um comentário } \\
\text { irônico. A } 3 \text { e A4 riem. }\end{array}$ \\
\hline 298 & $\begin{array}{l}\text { P: Que aparece mais. Maior } \\
\text { banda e a menor banda. }\end{array}$ & & Organização & $\mathrm{P} / \mathrm{T}$ \\
\hline 299 & $\begin{array}{l}\text { Ani: Pára, pára. Fala a menor aí } \\
\text { gata. }\end{array}$ & & Organização & A/A. Estão rindo. \\
\hline 300 & $\begin{array}{l}\text { A4: De pé Wanderson, seu } \\
\text { grampola. }\end{array}$ & & & $\mathrm{A} / \mathrm{A}$ \\
\hline 301 & A5: Menor é raxixe mesmo. & $\begin{array}{l}\text { Manipulação de } \\
\text { materiais. }\end{array}$ & & $\begin{array}{l}\text { A/A. Risos gerais. } \\
\text { continua anotando em } \\
\text { caderno. }\end{array}$ \\
\hline 302 & $\begin{array}{l}\text { A1: Menor é o laranja ou o } \\
\text { amarelo? Decide gente! }\end{array}$ & & Organização & $\begin{array}{l}\text { A/A. A1 fala e ri. Vários } \\
\text { alunos falando ao mesmo } \\
\text { tempo. }\end{array}$ \\
\hline 303 & A2: Né gente? & & & $\begin{array}{l}\text { A/A. Fala olhando para outro } \\
\text { grupo. }\end{array}$ \\
\hline 304 & $\begin{array}{l}\text { A3: Grudados. Peraí que eu to... } \\
\text { Ta mostrando meu cabelo. }\end{array}$ & & & $\mathrm{A} / \mathrm{A}$ \\
\hline 305 & P: Tudo bem pessoal. & & Organização & $\mathrm{P} / \mathrm{T}$ \\
\hline 306 & A4: Qual é a maior? & & Organização & A/A. A4 pergunta para A3. \\
\hline 307 & $\begin{array}{l}\text { P: Terminaram para esta } \\
\text { lâmpada? }\end{array}$ & & Organização & $\mathrm{P} / \mathrm{T}$ \\
\hline 308 & A3: Peraí. & & Organização & $\mathrm{P} / \mathrm{T}$ \\
\hline 309 & Ani: Calma. & & Organização. & $\mathrm{P} / \mathrm{T}$ \\
\hline 310 & $\begin{array}{l}\text { A3: Não! Peraí! To tentando } \\
\text { aqui. }\end{array}$ & & Organização. & $\mathrm{P} / \mathrm{T}$ \\
\hline 311 & A4: Laranja é a menor... banda. & & Classificação & $\begin{array}{l}\text { P/T. Vários alunos falando ao } \\
\text { mesmo tempo. }\end{array}$ \\
\hline 312 & Val: É laranja... & & Classificação & $\mathrm{P} / \mathrm{T}$ \\
\hline 313 & Ani: É amarelo... (inaudível). & & Classificação & $\mathrm{P} / \mathrm{T}$ \\
\hline 314 & A3: Lara... Amarelo, amarelo. & & Classificação & $\mathrm{P} / \mathrm{T}$ \\
\hline 315 & $\begin{array}{l}\text { A4: É laranja Ricardo. Pára é } \\
\text { laranja, por que cê tá falando } \\
\text { amarelo véio?! }\end{array}$ & & Classificação & $\mathrm{A} / \mathrm{A}$ \\
\hline 316 & $\begin{array}{l}\text { A3: É amarelo! Amarelo! É } \\
\text { amarelo. }\end{array}$ & & Classificação & $\mathrm{A} / \mathrm{A}$ \\
\hline
\end{tabular}




\begin{tabular}{|c|c|c|c|c|}
\hline 317 & $\begin{array}{l}\text { A1: Ô Ricardinho, é porque o } \\
\text { amarelo e o laranja tão junto. }\end{array}$ & Gestos. & Justificativa. & $\begin{array}{l}\text { A/A. A1 gesticula com as } \\
\text { mãos indicando proximidade. }\end{array}$ \\
\hline 318 & A3: Então... $\operatorname{argh!!!~}$ & Gestos. & Organização & $\begin{array}{l}\text { A/A. A3 gesticula } \\
\text { demonstrando irritação. }\end{array}$ \\
\hline 319 & A3: É isso aí mesmo. & & Organização & A/A. A3 fala olhando para A1. \\
\hline 320 & A4: Oh... Quem tem certeza aí? & & Organização & $\begin{array}{l}\mathrm{A} / \mathrm{A}, \mathrm{P} / \mathrm{T} \text {. A1 pronuncia para } \\
\mathrm{A} 2 \text { algo que não } \\
\text { compreendemos. }\end{array}$ \\
\hline 321 & A5: É o laranja. & & Classificação & $\mathrm{P} / \mathrm{T}$ \\
\hline 322 & A3: Para mim é o amarelo. & & Classificação & $\mathrm{P} / \mathrm{T}$ \\
\hline 323 & $\begin{array}{l}\text { A4: É laranja. Já escrevi laranja } \\
\text { e vai ser laranja. }\end{array}$ & & Classificação & $\mathrm{P} / \mathrm{T}, \mathrm{A} / \mathrm{A}$ \\
\hline 324 & $\begin{array}{l}\text { A3: Não, mas eu acho que tem } \\
\text { que fazer o certo. }\end{array}$ & & & $\mathrm{A} / \mathrm{A}$ \\
\hline 325 & A4: Então. Vamos lá. & & & $\mathrm{A} / \mathrm{A}$ \\
\hline 326 & A3: Vamos lá é o amarelo. & & & $\mathrm{A} / \mathrm{A}$ \\
\hline 327 & $\begin{array}{l}\text { P: Bem quem vier na próxima } \\
\text { aula eu vou apresentar o total de } \\
\text { espectros. }\end{array}$ & & Organização & $\begin{array}{l}\mathrm{P} / \mathrm{T} \text {. O professor fala enquanto } \\
\mathrm{A} 3 \mathrm{e} \text { A } 4 \text { discutem. O } \\
\text { professor fala em baixo tom. }\end{array}$ \\
\hline 328 & A4: Professor! & & & $\mathrm{P} / \mathrm{T}$ \\
\hline 329 & 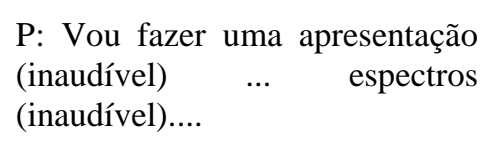 & & & $\begin{array}{l}\mathrm{P} / \mathrm{T} \text {. Os alunos do grupo falam } \\
\text { em alto tom e ao mesmo } \\
\text { tempo. }\end{array}$ \\
\hline 330 & $\begin{array}{l}\text { A2: Cês tão fazendo com grupo } \\
\text { diferente é? }\end{array}$ & & Organização & A/A. A2 fala para A3 e A4. \\
\hline 331 & A3: Eu não sei. & & Organização & $\mathrm{A} / \mathrm{A}$ \\
\hline 332 & $\begin{array}{l}\text { A2: É ...a Gabi já tá fazendo } \\
\text { aqui. }\end{array}$ & & Organização & $\mathrm{A} / \mathrm{A}$ \\
\hline 333 & $\begin{array}{l}\text { A3: Ela falou que não tava } \\
\text { escrevendo aí. Ô Gustavo... }\end{array}$ & Gestos. & Organização & $\begin{array}{l}\text { A/A. A3 gesticula apontando } \\
\text { para A4. }\end{array}$ \\
\hline 334 & $\begin{array}{l}\text { A1: Eu coloquei o número do } 3^{\circ} \\
\mathrm{G} \text { todo. }\end{array}$ & & Organização & $\mathrm{A} / \mathrm{A}$ \\
\hline 335 & A4: Hã...(?) & & & \\
\hline 336 & A3: Você falou... & & & $\mathrm{A} / \mathrm{A}$ \\
\hline 337 & A1: Só tem nós do $3^{\circ} \mathrm{G}$. & Gestos. & Organização & $\begin{array}{l}\text { A/A. A1 gesticula abrindo os } \\
\text { braços. }\end{array}$ \\
\hline 338 & A4: Sem graça. & & & $\begin{array}{l}\text { A/A. O professor continua } \\
\text { falando em baixo tom, não } \\
\text { compreendemos. }\end{array}$ \\
\hline
\end{tabular}




\begin{tabular}{|c|c|c|c|c|}
\hline 339 & $\begin{array}{l}\text { P: Ok, pessoal, posso mudar a } \\
\text { lâmpada? }\end{array}$ & & Organização & $\mathrm{P} / \mathrm{T}$ \\
\hline 340 & $\begin{array}{l}\text { Ani: Calma } \\
\text { (inaudível)... deixa um pouco } \\
\text { ainda! }\end{array}$ & Gestos. & Organização & $\begin{array}{l}\text { P/T. Ani fala gesticulando } \\
\text { com os braços. }\end{array}$ \\
\hline 341 & A5: Já apaguei tá Aline? & $\begin{array}{l}\text { Manipulação de } \\
\text { materiais. }\end{array}$ & Organização & $\begin{array}{l}\text { A/A. A3 pega uma folha de } \\
\text { caderno de A4 e coloca sobre } \\
\text { seu caderno. }\end{array}$ \\
\hline 342 & $\begin{array}{l}\text { A3: Não, nós vai continuar } \\
\text { fazendo. }\end{array}$ & $\begin{array}{l}\text { Manipulação de } \\
\text { materiais. }\end{array}$ & Organização & $\begin{array}{l}\text { A/A. A4 pega a folha das } \\
\text { mãos de A3 e amassa. }\end{array}$ \\
\hline 343 & A4: Já era. & & Organização & $\mathrm{A} / \mathrm{A}$ \\
\hline 344 & $\begin{array}{l}\text { A3: Cê vai desperdiçar trabalho } \\
\text { feito? }\end{array}$ & & Organização & $\mathrm{A} / \mathrm{A}$ \\
\hline 345 & A4: A Gabi ta fazendo, já era. & & Organização & $\mathrm{A} / \mathrm{A}$ \\
\hline 346 & A3: Mas e aí? & & Organização & $\begin{array}{l}\text { A/A. Durante esse diálogo } \\
\text { entre A3 e A4 a sala toda está } \\
\text { conversando. }\end{array}$ \\
\hline 347 & $\begin{array}{l}\text { A4: Ô Gabi obrigado por me } \\
\text { avisar. }\end{array}$ & & Organização & $\mathrm{A} / \mathrm{A}$ \\
\hline 348 & A1: De nada. & & & A/A. A3 olha para A1. \\
\hline 349 & $\begin{array}{l}\text { A3: Oh... E se erra agora? Nós } \\
\text { põe (inaudível)... }\end{array}$ & & Organização & $\begin{array}{l}\text { A/A. No início de sua fala A3 } \\
\text { olha para A4 e depois começa } \\
\text { a prestar atenção no professor } \\
\text { antes de encerrar a frase. }\end{array}$ \\
\hline 350 & $\begin{array}{l}\text { P: Eu preciso que vocês façam. } \\
\text { Faz a observação e anota. }\end{array}$ & & Organização & $\mathrm{P} / \mathrm{T}$ \\
\hline 351 & A4: O quê? Ah peraí. & $\begin{array}{l}\text { Manipulação de } \\
\text { materiais. }\end{array}$ & Organização & $\begin{array}{l}\text { P/T. A4 coloca na mesa o } \\
\text { espectroscópio que estava } \\
\text { segurando. } \\
\text { A3 volta a olhar para A4, A1 } \\
\text { também olha e ambos riem. }\end{array}$ \\
\hline 352 & A3: Você vai desperdiçar pô?! & $\begin{array}{l}\text { Manipulação de } \\
\text { materiais. }\end{array}$ & Organização & $\begin{array}{l}\text { A/A. A3 e A2 novamente } \\
\text { estão com o espectroscópio } \\
\text { olhando para a lâmpada. }\end{array}$ \\
\hline 353 & Ani: Pronto professor. & & Organização & P/T. Alguns alunos riem. \\
\hline 354 & $\begin{array}{l}\text { A5: Ô professor põe aquela } \\
\text { primeira lá que você tirou. }\end{array}$ & & Organização & $\mathrm{P} / \mathrm{T}$ \\
\hline 355 & P: Pronto. Pronto. & & & $\mathrm{P} / \mathrm{T}$ \\
\hline 356 & A3: Põe a primeira. & & Organização & $\mathrm{P} / \mathrm{T}$ \\
\hline 357 & A1: Ah a do Léo é da hora. & & & $\begin{array}{l}\text { P/T, A/A. Após a fala de A1, } \\
\text { A2 passa o espectroscópio }\end{array}$ \\
\hline
\end{tabular}




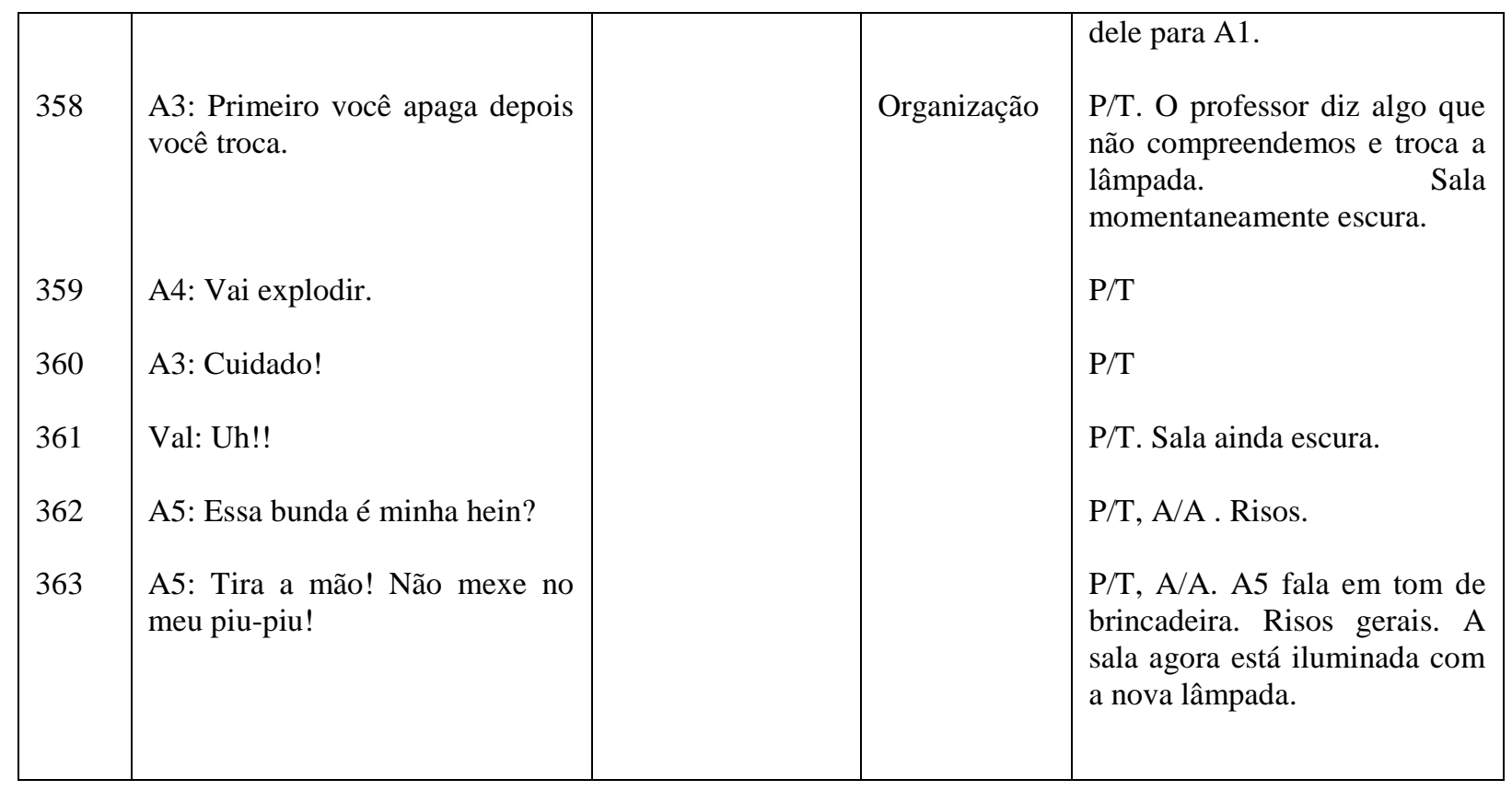

\section{Momento 3 - Nova observação da lâmpada fluorescente compacta}

\begin{tabular}{|c|c|c|c|c|}
\hline $\begin{array}{l}\text { Turno } \\
\text { De } \\
\text { fala }\end{array}$ & $\begin{array}{llll}\begin{array}{l}\text { Linguagem } \\
\text { escrita) }\end{array} & & & \\
\end{array}$ & $\begin{array}{l}\text { Outras linguagens } \\
\text { Ações/gestos/ } \\
\text { Manipulação de } \\
\text { materiais }\end{array}$ & Indicadores & $\begin{array}{ll}\text { Tipos } & \text { de } \\
\text { Interação/Comentários } & \end{array}$ \\
\hline 364 & $\begin{array}{l}\text { P: Pessoal! Vamos lá! Segunda } \\
\text { lâmpada. }\end{array}$ & $\begin{array}{l}\text { A sala está } \\
\text { iluminada com a } \\
\text { nova lâmpada. }\end{array}$ & & $\mathrm{P} / \mathrm{T}$ \\
\hline 365 & P: A segunda lâmpada é esta. & & & $\begin{array}{l}\text { Apresentação: o professor está } \\
\text { organizando a aula }\end{array}$ \\
\hline 366 & Ani: Fluorescente. & & Organização & $\begin{array}{l}\text { Ocorre a identificação da } \\
\text { lâmpada a ser analisada }\end{array}$ \\
\hline 367 & P: Fluorescente compacta. & $\begin{array}{l}\text { Manipulação de } \\
\text { materiais. }\end{array}$ & Organização & $\begin{array}{l}\text { A menina na extremidade } \\
\text { esquerda levanta e grita com } \\
\text { alguém (não é possível } \\
\text { compreender). } \\
\text { Os alunos estão com o } \\
\text { espectroscópio no olho } \\
\text { observando a lâmpada, com } \\
\text { exceção do A7 que está com a } \\
\text { mão no queixo olhando, mas } \\
\text { sem o espectroscópio. }\end{array}$ \\
\hline 368 & A3: Aparece preta também. & & Organização & $\mathrm{A} / \mathrm{A}$ \\
\hline 369 & $\begin{array}{l}\text { P: (inaudível)... Vocês utilizam } \\
\text { também em residência. }\end{array}$ & & & $\mathrm{P} / \mathrm{T}$ \\
\hline
\end{tabular}




\begin{tabular}{|c|c|c|c|c|}
\hline 370 & A4: Nossa. & & & $\mathrm{A} / \mathrm{A}$ \\
\hline 371 & A3: Tudo pontilhado sabe? & $\begin{array}{l}\text { A3 fala para A4, } \\
\text { gesticulando com } \\
\text { o braço para cima } \\
\text { e para baixo. }\end{array}$ & Organização & \\
\hline 372 & A4: Aparece preto, velho. & & Organização & \\
\hline 373 & A7: É ô. & & & \\
\hline 374 & $\begin{array}{l}\text { P: Parece que todos terminaram. } \\
\text { Como é que é o espectro dessa } \\
\text { lâmpada? }\end{array}$ & & & $\begin{array}{l}\text { P/T. O professor questiona } \\
\text { com a intenção que apareçam } \\
\text { organização e classificação. }\end{array}$ \\
\hline 375 & A3: Não ó. Olha para ele. & & & $\mathrm{A} / \mathrm{A}$ \\
\hline 376 & A4: Discreto! & $\begin{array}{lr}\text { A4 fala } \\
\text { respondendo } \\
\text { professor. }\end{array}$ & Classificação & $\mathrm{P} / \mathrm{T}$ \\
\hline 377 & Val: Discreto. & & Classificação & $\mathrm{A} / \mathrm{A}$ \\
\hline 378 & Isso mesmo. & & Classificação & $\mathrm{A} / \mathrm{A}$ \\
\hline 379 & P: Por que é discreto? & & & $\mathrm{P} / \mathrm{T}$ \\
\hline 381 & $\begin{array}{l}\text { A4: porque não aparece todas as } \\
\text { cores! } \\
\text { Val: Porque tá separado. }\end{array}$ & $\begin{array}{l}\text { Outros alunos } \\
\text { também falam ao } \\
\text { mesmo tempo e } \\
\text { alguns repetem. }\end{array}$ & Justificativa & \\
\hline 382 & A3: Não aparece todas as cores. & & Justificativa & \\
\hline 383 & A4: Tem as bolinhas lá. & & Organização & $\mathrm{A} / \mathrm{A}$ \\
\hline 384 & A3: Vai aparecer umas bolinhas. & & Organização & $\mathrm{A} / \mathrm{A}$ \\
\hline 385 & $\begin{array}{l}\text { P: Não aparecem todas. O que } \\
\text { mais?... }\end{array}$ & & Organização & $\mathrm{P} / \mathrm{T}$ \\
\hline 386 & A4: Tem uns quadradinhos. & & Organização & \\
\hline 387 & $\begin{array}{l}\text { A3: Uns quadradinhos assim ó } \\
\text { pulando. }\end{array}$ & $\begin{array}{l}\text { A3 gesticula com } \\
\text { o braço para cima } \\
\text { e para baixo. }\end{array}$ & Organização & \\
\hline 388 & Ani: É tá separado não é? & & Organização & \\
\hline 389 & A5: Olha com esse. & $\begin{array}{l}\text { Manipulação do } \\
\text { espectroscópio. }\end{array}$ & Organização & $\begin{array}{l}\text { A/A. Várias falas entre os } \\
\text { alunos que ainda observam } \\
\text { (alguns com espectroscópio). }\end{array}$ \\
\hline 390 & $\begin{array}{l}\text { A3: Ó Gustavo, eu não sei se é } \\
\text { seis... }\end{array}$ & & & $\mathrm{A} / \mathrm{A}$ \\
\hline 391 & A4: Nossa não dá para ver nada. & $\begin{array}{l}\text { Manipulação de } \\
\text { materiais }\end{array}$ & Organização & $\begin{array}{l}\text { A/A e A/M. Após o } \\
\text { comentário A4 troca o lado de } \\
\text { observação do espectroscópio. }\end{array}$ \\
\hline 392 & A3: Olha depois do verde claro. & & Organização. & A/A. A3 fala ao mesmo tempo \\
\hline
\end{tabular}




\begin{tabular}{|c|c|c|c|c|}
\hline 393 & $\begin{array}{l}\text { P: Pessoal. Pergunta para vocês. } \\
\text { Algum de vocês (inaudível) em } \\
\text { qual espectro vocês estão vendo } \\
\text { linhas? Alguém tem o espectro } \\
\text { que aparece linha, bem feito? (?) }\end{array}$ & & Organização & $\begin{array}{l}\text { em que o professor retoma sua } \\
\text { fala. } \\
\mathrm{P} / \mathrm{T}\end{array}$ \\
\hline 394 & $\begin{array}{l}\text { A3: Depois do verde claro pula. } \\
\text { E o lilás, aparece um } \\
\text { quadradinho do lilás (inaudível). }\end{array}$ & Gestos. & & $\begin{array}{l}\text { A/A. A3 gesticula com a mão } \\
\text { direita para cima e para baixo, } \\
\text { enquanto a outra mão segura o } \\
\text { espectroscópio. A3 continua } \\
\text { falando ao mesmo tempo que } \\
\text { o professor. }\end{array}$ \\
\hline 395 & A4: Tesc, tesc... Não tem essa... & Gestos. & Organização & $\begin{array}{l}\text { A/A. A4 sinaliza de forma } \\
\text { negativa. A7 olha em direção } \\
\text { a lâmpada sem o } \\
\text { espectroscópio. }\end{array}$ \\
\hline 396 & $\begin{array}{l}\text { P: Algum dos espectroscópios aí } \\
\text { dá para ver o formato da } \\
\text { lâmpada? }\end{array}$ & & Organização & $\mathrm{P} / \mathrm{T}$ \\
\hline 397 & Ani: Ele separa, ele separa! & & Organização & $\mathrm{P} / \mathrm{T}$ \\
\hline 398 & Ani1: Dá. & & & \\
\hline 399 & P: Observem esse formato. & & Organização & \\
\hline 400 & Val: Ele separa, ele separa. & & Organização & $\begin{array}{l}\mathrm{P} / \mathrm{T} \text {. Vários alunos falam ao } \\
\text { mesmo tempo em que o } \\
\text { professor. }\end{array}$ \\
\hline 401 & $\begin{array}{l}\text { Ani: Eles estão separados por } \\
\text { causa disto... }\end{array}$ & & Explicação. & $\begin{array}{l}\text { P/T. Aqui o aluno apresenta } \\
\text { uma tentativa de explicação, } \\
\text { que não mostra base de } \\
\text { sustentação. Não é uma } \\
\text { explicação cientifica. }\end{array}$ \\
\hline 402 & $\begin{array}{l}\text { P: Mas dá para ver o formato da } \\
\text { lâmpada? }\end{array}$ & & Organização & $\begin{array}{l}\text { Neste momento o professor } \\
\text { tenta organizar a próxima } \\
\text { etapa da aula. }\end{array}$ \\
\hline 403 & A4: Dá para ver a lâmpada não? & & & $\begin{array}{l}\text { A/A. A4 comenta em baixo } \\
\text { tom para o grupo. Parece falar } \\
\text { com A3. }\end{array}$ \\
\hline 405 & $\begin{array}{l}\text { P: Dá. Algum dá para ver o } \\
\text { formato? }\end{array}$ & & & $\begin{array}{l}\text { Do turno } 47 \text { ao } 51 \text { estão } \\
\text { falando sobre o manuseio de } \\
\text { material. } \\
\mathrm{P} / \mathrm{T}\end{array}$ \\
\hline 406 & Val: Dá. Dá para ver. & & & \\
\hline 407 & Ani: Vê a lâmpada. & & & \\
\hline 408 & Ani1: É verdade. & $\begin{array}{l}\text { Manipulação do } \\
\text { espectroscópio. }\end{array}$ & & $\begin{array}{ll}\mathrm{P} / \mathrm{T} \text {. Continuam observando a } \\
\text { lâmpada com }\end{array}$ \\
\hline
\end{tabular}




\begin{tabular}{|c|c|c|c|c|}
\hline 409 & $\begin{array}{l}\text { P: Bobe! Dá para ver linhas } \\
\text { Bobe? }\end{array}$ & & Organização & $\begin{array}{l}\text { espectroscópio. } \\
\mathrm{P} / \mathrm{T} \text {, pois apesar de chamar por } \\
\text { determinado aluno, a conversa } \\
\text { é com toda sala. }\end{array}$ \\
\hline 410 & A8: Dá para ver linhas. & $\begin{array}{l}\text { Bobe } \\
\text { respondendo ao } \\
\text { professor. }\end{array}$ & Organização & $\mathrm{P} / \mathrm{T}$ \\
\hline 411 & $\begin{array}{l}\text { P: Como é que é a entrada do } \\
\text { seu espectroscópio? } \\
\text { Ani: É redonda! }\end{array}$ & $\begin{array}{l}\text { Manipulação de } \\
\text { materiais. }\end{array}$ & Organização & $\begin{array}{l}\text { P/T. Risos gerais. Agitação } \\
\text { geral, mas continuam sentados } \\
\text { na bancada, com } \\
\text { espectroscópio na mão ou nos } \\
\text { olhos. Não dá para entender o } \\
\text { que falam, pois vários se } \\
\text { pronunciam ao mesmo tempo. }\end{array}$ \\
\hline 413 & $\begin{array}{l}\text { P: Ô Robson! Como é a entrada } \\
\text { aí do espectroscópio? }\end{array}$ & & Organização & $\begin{array}{l}\text { P/T. Apesar da pergunta } \\
\text { específica para determinado } \\
\text { aluno, aqui a interação é com a } \\
\text { classe toda também. Risos. }\end{array}$ \\
\hline 415 & $\begin{array}{l}\text { A5: Volumíca! } \quad \text { Uma... } \\
\text { (inaudível) } \\
\text { P: Pessoal como é que é a fenda } \\
\text { Bobe? É grande? Pequena? } \\
\text { Quadrada? }\end{array}$ & & Organização & \\
\hline 416 & Ani: Pequena. & & Organização & \\
\hline 417 & $\begin{array}{l}\text { A5: Depende da inspiração. } \\
\text { Notô? }\end{array}$ & & & \\
\hline 418 & A4: Já anotou? & & Organização & A/A. A4 fala par A3. \\
\hline 419 & Ani: (inaudível) & & & \\
\hline 420 & $\begin{array}{l}\text { P: Em qual espectroscópio dá } \\
\text { para ver o formato da lâmpada? }\end{array}$ & & Organização & $\mathrm{P} / \mathrm{T}$ \\
\hline 421 & Ani: Opa! & & & \\
\hline 422 & A5: Esse daqui dá ó. & & Organização & \\
\hline 423 & Ani: Esse aqui. & & Organização & \\
\hline 424 & P: Como é que é a fenda aí? & & Organização & \\
\hline 425 & A4: Quadrada. & & Organização & Sussurros de vários alunos. \\
\hline 426 & $\begin{array}{l}\text { P: O tamanho da fenda mais ou } \\
\text { menos? }\end{array}$ & & Organização & \\
\hline 427 & $\begin{array}{l}\text { A5: Aqui é um retângulo } \\
\text { professor. }\end{array}$ & & Organização & \\
\hline 428 & $\begin{array}{l}\text { P: Retangular. Mas que } \\
\text { tamanho? }\end{array}$ & & $\begin{array}{l}\text { Organização/ } \\
\text { Classificação }\end{array}$ & \\
\hline 429 & Ani1: Do meu dedo. & & Organização & \\
\hline
\end{tabular}




\begin{tabular}{|c|c|c|c|c|}
\hline 430 & Ani2: Um centímetro. & & Organização & \\
\hline 431 & Ani3: Uma estrela. & & & \\
\hline 432 & $\begin{array}{l}\text { P: Um centímetro mais ou } \\
\text { menos. A entrada aí do } \\
\text { espectroscópio. }\end{array}$ & $\begin{array}{l}\text { Gesticula com as } \\
\text { mãos indicando o } \\
\text { tamanho } \\
\text { aproximado. }\end{array}$ & Organização & \\
\hline 433 & A5: Um centímetro? & & Organização & \\
\hline 434 & P: Pessoal! & & Organização & \\
\hline 435 & A5: Não tenho paciência hein? & & Organização & \\
\hline 436 & Ani3: Silêncio! & & Organização & $\begin{array}{l}\text { Ax/Ax. } 3^{\text {a }} \text { aluna a esquerda de } \\
\text { A1 grita reforçando o } \\
\text { "pessoal" do professor. }\end{array}$ \\
\hline 437 & $\begin{array}{l}\text { P: Vamos lá. Vamos Quando o } \\
\text { espectroscópio tem a fenda } \\
\text { muito grande, muito aberta, dá } \\
\text { para ver aí o formato da } \\
\text { lâmpada. }\end{array}$ & $\begin{array}{l}\text { Manipulação dos } \\
\text { espectroscópios. }\end{array}$ & $\begin{array}{l}\text { Organização/ } \\
\text { classificação }\end{array}$ & $\begin{array}{l}\text { P/T. Alguns alunos estão com } \\
\text { o espectroscópio no olho } \\
\text { observando a lâmpada } \\
\text { enquanto o professor fala. }\end{array}$ \\
\hline 438 & A4: Verde claro. & & Organização & $\begin{array}{l}\text { A/A. A4 fala em baixo tom e } \\
\text { observando a lâmpada. Como } \\
\text { se fosse um comentário para } \\
\text { ele mesmo. }\end{array}$ \\
\hline 439 & $\begin{array}{l}\text { P: Então você vai ver várias } \\
\text { lâmpadas com cores diferentes. }\end{array}$ & & Organização & $\begin{array}{l}\text { P/T. A5 continua observando e } \\
\text { anotando em seu caderno } \\
\text { enquanto o professor vai } \\
\text { explicando. }\end{array}$ \\
\hline 440 & $\begin{array}{l}\text { P: Quem tem o espectroscópio } \\
\text { com a fenda muito fina então } \\
\text { você vai ver linhas no meio do } \\
\text { espectro. }\end{array}$ & & $\begin{array}{l}\text { Organização/ } \\
\text { Classificação }\end{array}$ & $\begin{array}{l}\mathrm{P} / \mathrm{T} \text { A/A. Enquanto } \mathrm{o} \\
\text { professor realiza seus } \\
\text { comentários A3 gesticula e } \\
\text { apontando para lâmpada fala } \\
\text { para A4 a sua direita, que } \\
\text { observa a lâmpada com } \\
\text { espectroscópio. }\end{array}$ \\
\hline 441 & $\begin{array}{l}\text { P: No espectro (inaudível) } \\
\text { espectro colorido e no meio dele } \\
\text { uma linha fina (inaudível). }\end{array}$ & & $\begin{array}{l}\text { Organização/ } \\
\text { classificação }\end{array}$ & \\
\hline 443 & $\begin{array}{l}\text { A1: Bem no cantinho ali ó. } \\
\text { (inaudível). As corezinhas, cada } \\
\text { cor fica num lugar (inaudível)... } \\
\text { As lâmpadas, são várias } \\
\text { lâmpadas uma de cada cor. } \\
\text { P: Ó! Pessoal! Eu acho que vou } \\
\text { ter que deixar alguns alunos para } \\
\text { gente voltar pra fazer em } \\
\text { dezembro. }\end{array}$ & Gestos. & Organização & $\begin{array}{l}\text { A/A. A1 gesticula com as } \\
\text { mãos. } \\
\text { Uma risada abafa o som da } \\
\text { menina que explica para A6. } \\
\text { Vários alunos falando ao } \\
\text { mesmo tempo. }\end{array}$ \\
\hline 444 & Val: Na, não. & & & $\begin{array}{l}\mathrm{P} / \mathrm{T} \text {. Vários falam ao mesmo } \\
\text { tempo. }\end{array}$ \\
\hline
\end{tabular}




\begin{tabular}{|c|c|c|c|c|}
\hline 445 & $\begin{array}{l}\text { A5: Seria uma boa idéia, hein } \\
\text { professor. }\end{array}$ & & & \\
\hline 446 & Ay: Ah, professor. & & & \\
\hline 448 & $\begin{array}{l}\text { Ani: Vamos fazer silêncio aí. } \\
\text { Ay: Silêncio gente! }\end{array}$ & & Organização & $\begin{array}{l}\text { Ax/Ay. } 3^{\mathrm{a}} \text { menina à esquerda, } \\
\text { gritando novamente. Pedindo } \\
\text { silêncio. }\end{array}$ \\
\hline 449 & $\begin{array}{l}\text { P: Vamos lá! Vamos lá. Qual é a } \\
\text { maior ... Não vamos colocar a } \\
\text { maior banda, vamos qual é a } \\
\text { mais intensa agora. Anote } \\
\text { (inaudível) qual é a mais intensa. }\end{array}$ & & Organização & $\begin{array}{l}\mathrm{P} / \mathrm{T} \text {. Neste momento parece } \\
\text { que o professor tenta substituir } \\
\text { a notação comum ("maior } \\
\text { banda") por uma notação } \\
\text { científica ("a mais intensa"). } \\
\text { Porém os conceitos parecem } \\
\text { estar confusos. }\end{array}$ \\
\hline 450 & Ani: “Ssssssssssss" & & & $\begin{array}{l}\text { Algum aluno chiando. } \\
\text { Brincadeira sem vínculo com } \\
\text { a aula. }\end{array}$ \\
\hline 451 & $\begin{array}{l}\text { P: Qual é a mais intensa? O que } \\
\text { aparece mais, o que aparece } \\
\text { menos? }\end{array}$ & & Organização & $\mathrm{P} / \mathrm{T}$ \\
\hline 452 & A4: A verde clara. & & Classificação & $\begin{array}{l}\text { Alguém fala provavelmente } \\
\text { com a mão na boca. }\end{array}$ \\
\hline 453 & A3: Verde claro. & & Classificação & A3 fala repetindo. \\
\hline 454 & P: Anotem aí. & & & \\
\hline 455 & $\begin{array}{l}\text { A5: O que aparece mais aqui é o } \\
\text { azul. }\end{array}$ & & Classificação & $\mathrm{P} / \mathrm{T}$ \\
\hline 456 & A3: Não! & & Classificação & \\
\hline 457 & Ani : É o verde claro. & & Classificação & \\
\hline 458 & A7: E a menos é a lilás. & & Classificação & $\begin{array}{l}\text { A4 realiza anotações em seu } \\
\text { caderno. }\end{array}$ \\
\hline 459 & $\begin{array}{l}\text { A4: Aires não tem nem } \\
\text { espectroscópio para ver. }\end{array}$ & & & A/A. Risos. \\
\hline 460 & A3: Anota aí. & & Organização & \\
\hline 461 & A4: Qué esperá? & & & \\
\hline 462 & A5: Ó como é que ele segura. & $\begin{array}{l}\text { Manipulação de } \\
\text { materiais. }\end{array}$ & Organização & \\
\hline 463 & Ax: A minha é a violeta! & & & \\
\hline 464 & A3: Não precisava não ô? & & & \\
\hline 465 & $\begin{array}{l}\text { A2: Professor! Não é que } \\
\text { aparece menos depois? }\end{array}$ & $\begin{array}{l}\text { Manipulação dos } \\
\text { espectroscópios e } \\
\text { manipulação de } \\
\text { materiais. }\end{array}$ & Organização & $\begin{array}{l}\mathrm{P} / \mathrm{T} \text { Comenta com } \\
\text { espectroscópio em mãos e A1 } \\
\text { ao seu lado atenta realizando } \\
\text { anotações. }\end{array}$ \\
\hline 466 & A2: Professor dá uma licencinha & Gestos. & & \\
\hline
\end{tabular}




\begin{tabular}{|c|c|c|c|c|}
\hline & aí. & & & \\
\hline 467 & P: Vamos lá. & & & \\
\hline 468 & Ani: Próxima aula. & & & \\
\hline 469 & $\begin{array}{l}\text { A3: Professor dá um tempinho, } \\
\text { por favor. }\end{array}$ & & & $\begin{array}{l}\text { Gesticula com as mãos } \\
\text { indicando sinal de solicitação } \\
\text { de tempo usado nos esportes, } \\
\text { como no caso de vôlei. }\end{array}$ \\
\hline 470 & Ax: A minha é violeta. & & & $\begin{array}{l}\mathrm{P} / \mathrm{T} \mathrm{Ax} / \mathrm{Ay} .3^{\mathrm{a}} \text { menina à } \\
\text { esquerda de } \mathrm{A} 1 \text {, repetindo o } \\
\text { que disse anteriormente. }\end{array}$ \\
\hline 471 & $\begin{array}{l}\text { A4: Põe uma de cada vez aí, } \\
\text { professor. Apareceu dois } \\
\text { espectroscópios aqui. }\end{array}$ & & Organização & \\
\hline 472 & $\begin{array}{l}\text { A5: Liga as duas professor. Vê } \\
\text { se dá. Liga as duas rapidão. }\end{array}$ & & Organização & \\
\hline 473 & Ani: Violeta ... & & Classificação & \\
\hline 474 & Ani1: Não! & & & $\begin{array}{l}\text { O segundo aluno à esquerda } \\
\text { de A1, larga o espectroscópio } \\
\text { e passa a mão na cabeça como } \\
\text { se estivesse cansado. }\end{array}$ \\
\hline 475 & A4: Pára de aloprar Caio! & & & A/A \\
\hline 476 & $\begin{array}{l}\text { A2: Professor liga as duas pra } \\
\text { mim ver. }\end{array}$ & & & $\mathrm{P} / \mathrm{A}$ \\
\hline 477 & P: Pessoal, pronto? & & Organização & \\
\hline 478 & A4: Não! & & & \\
\hline 479 & $\begin{array}{l}\text { A5: Liga as duas para mim ver } \\
\text { como é que fica! }\end{array}$ & & & $\begin{array}{l}\text { P/T. A2 com espectroscópio } \\
\text { no olho observando a } \\
\text { lâmpada. }\end{array}$ \\
\hline 480 & $\begin{array}{l}\text { A4: Qual que é a menor dessa } \\
\# * \$ \$ @ \text { aí? }\end{array}$ & & Organização & \\
\hline 481 & Ani: Não, não, não, não. & & & \\
\hline 482 & A4: Pergunta pra ele só, depois. & & & $\mathrm{A} / \mathrm{A}$ \\
\hline 483 & $\begin{array}{l}\text { A4: Quando ele tiver sozinho na } \\
\text { sala. }\end{array}$ & & & $\begin{array}{l}\text { Enquanto fala, está encostado } \\
\text { com braço esquerdo no A3 e } \\
\text { segurando um espectroscópio } \\
\text { com a mão direita. }\end{array}$ \\
\hline 484 & Ani: Vai. & & & \\
\hline 485 & A5: Licença, aí professor. & & & $\mathrm{P} / \mathrm{T}$. \\
\hline 486 & A4: Qual é a menor? & & Organização & A/A. A4 sussurrando para A3. \\
\hline 487 & A3: (inaudível). & Manipulação de & & A3 pega o espectroscópio que \\
\hline
\end{tabular}




\begin{tabular}{|l|l|l|l|}
\hline 488 & materiais. & & $\begin{array}{l}\text { estava na bancada e passa a } \\
\text { observar a lâmpada } \\
\text { novamente. }\end{array}$ \\
Ani: Volta esse bolhão. & $\begin{array}{l}\text { Pisos. } \\
\text { Fica tudo escuro novamente. } \\
\text { Gritos. }\end{array}$ \\
\hline
\end{tabular}

\section{Momento 4 - Observação da lâmpada mista}

\begin{tabular}{|c|c|c|c|c|}
\hline $\begin{array}{l}\text { Turno } \\
\text { De } \\
\text { fala }\end{array}$ & $\begin{array}{l}\text { Linguagem verbal (oral ou } \\
\text { escrita) }\end{array}$ & $\begin{array}{l}\text { Outras linguagens } \\
\text { Ações/gestos/ } \\
\text { Manipulação de } \\
\text { materiais }\end{array}$ & Indicadores & $\begin{array}{ll}\text { Tipos } & \text { de } \\
\text { Interação/Comentários } & \end{array}$ \\
\hline 489 & $\begin{array}{l}\text { P: Rapidamente observe o } \\
\text { espectro desta. }\end{array}$ & & Organização & $\begin{array}{l}\mathrm{P} / \mathrm{T} . \quad \mathrm{O} \text { professor está } \\
\text { organizando a observação da } \\
\text { nova lâmpada. }\end{array}$ \\
\hline 490 & A1: Essa daí é o que? & $\begin{array}{l}\text { Manipulação de } \\
\text { materiais. }\end{array}$ & Organização & $\begin{array}{l}\text { Os alunos tentam identificar o } \\
\text { tipo de lâmpada enquanto o } \\
\text { professor } \quad \text { solicita }\end{array}$ \\
\hline 491 & P: É discreto? É contínuo? & & Classificação & $\begin{array}{l}\text { classificação do espectro. } \\
\text { Os alunos classificam o }\end{array}$ \\
\hline 492 & A5: É luz de poste amarelo. & & & $\begin{array}{l}\text { espectro em resposta ao } \\
\text { professor. }\end{array}$ \\
\hline 493 & Ani: Contínuo. & & & \\
\hline 494 & Val: É contínuo. & & & \\
\hline 495 & Val: Contínuo. & & & \\
\hline 496 & Ani: Não. & & & $\begin{array}{l}\text { Vários alunos comentam ao } \\
\text { mesmo tempo. }\end{array}$ \\
\hline 497 & Ani1: Contínuo é embaçado. & & & \\
\hline 498 & P: Então anotem aí. È contínuo. & & $\begin{array}{l}\text { Organização/ } \\
\text { classificação }\end{array}$ & \\
\hline 499 & $\begin{array}{l}\text { A4: Olhei sem querer (inaudível) } \\
\text { que coisa mais chata. }\end{array}$ & $\begin{array}{l}\text { Manipulação de } \\
\text { materiais. }\end{array}$ & & $\begin{array}{l}\text { A4 fala em baixo tom de voz. } \\
\text { Abaixa o espectroscópio e } \\
\text { anota em seu caderno. } \\
\text { Não ocorre interação, o aluno } \\
\text { parece expressar um } \\
\text { pensamento para ele mesmo. }\end{array}$ \\
\hline 500 & $\begin{array}{l}\text { A2: Professor! Qual lâmpada é } \\
\text { essa aí? }\end{array}$ & & Organização & $\begin{array}{l}\mathrm{P} / \mathrm{T} \\
\text { Os alunos continuam tentando } \\
\text { identificar o tipo de lâmpada. }\end{array}$ \\
\hline 501 & A5: Luz de poste amarelo. & & Classificação & $\begin{array}{l}\text { O professor solicita que } \\
\text { anotem (organizem) o tipo de }\end{array}$ \\
\hline
\end{tabular}




\begin{tabular}{|c|c|c|c|c|}
\hline 502 & P: Então anotem aí! & & Organização & espectro observado. \\
\hline 503 & $\begin{array}{l}\text { A1: Não, não é ela tem um } \\
\text { nome. }\end{array}$ & & Classificação & $\mathrm{A} / \mathrm{A}$ \\
\hline 504 & P: É a lâmpada mista. & & & $\begin{array}{l}\mathrm{P} / \mathrm{T} \text {, em seguida o professor } \\
\text { responde tratar-se de uma } \\
\text { lâmpada mista. } \\
\text { Os alunos continuam } \\
\text { discutindo sobre o tipo de } \\
\text { lâmpada baseados no fato de } \\
\text { ser "mista". }\end{array}$ \\
\hline 505 & $\begin{array}{l}\text { A5: É gás de mercúrio ou de } \\
\text { outra coisa lá? }\end{array}$ & . & Classificação & $\begin{array}{l}\text { Vários alunos falam ao mesmo } \\
\text { tempo. Não dá para } \\
\text { compreender. }\end{array}$ \\
\hline 506 & $\begin{array}{l}\text { A5: Vapor de mercúrio... Vapor } \\
\text { de mercúrio... }\end{array}$ & & & \\
\hline 507 & P: Tem outra coisa, ela é mista. & & $\begin{array}{l}\text { Classificação } \\
\text { /organização }\end{array}$ & \\
\hline 508 & A1: Então se a palavra é mista... & & Justificativa & $\mathrm{A} / \mathrm{A}$ \\
\hline 509 & $\begin{array}{l}\text { A4: Então não enxergo espectro } \\
\text { nenhum? }\end{array}$ & & & \\
\hline 510 & A5: Luz de poste amarela. & & Classificação & \\
\hline 511 & A3: Não! Contínuo. & $\begin{array}{l}\text { Manipulação de } \\
\text { espectroscópio. }\end{array}$ & $\begin{array}{l}\text { Classificação } \\
\text { Justificativa. }\end{array}$ & $\begin{array}{lr}\text { A/A e A/M } & \text { Continuam } \\
\text { manipulando } & \text { o } \\
\text { espectroscópio. } & \text { A3 } \\
\text { observando } & \text { com } \\
\text { espectroscópio, vira para A4 e } \\
\text { realiza seu comentário. } \\
\text { Vários alunos falando ao } \\
\text { mesmo tempo. }\end{array}$ \\
\hline 512 & $\begin{array}{l}\text { Ani: Verde claro, azul, vermelho } \\
\text { e amarelo. }\end{array}$ & & Classificação & $\begin{array}{l}\text { Um aluno começa a falar das } \\
\text { cores que estão observando. }\end{array}$ \\
\hline 513 & Ani: Vermelho e amarelo. & & & $\begin{array}{l}\text { Parece repetir o que foi dito } \\
\text { anteriormente. }\end{array}$ \\
\hline 514 & $\begin{array}{l}\text { A3: Qué que eu vá falando as } \\
\text { cores? }\end{array}$ & & Organização. & A3 fala em baixo tom. \\
\hline 515 & $\begin{array}{l}\text { A3: Professor dá licença aí } \\
\text { professor, fazendo favor! Cê tá } \\
\text { atrapalhando aí. }\end{array}$ & & Organização. & $\begin{array}{l}\mathrm{P} / \mathrm{T} \text {. A3 solicita (gritando) que } \\
\text { o professor fique em outra } \\
\text { posição para observar melhor } \\
\text { a lâmpada. }\end{array}$ \\
\hline 516 & A5: Pode ser Raxixi...? & & Organização. & \\
\hline 517 & $\begin{array}{l}\text { A4: Tira o bracinho aí fazendo o } \\
\text { favor! }\end{array}$ & . & & $\begin{array}{l}\text { A/A. A2 fala rindo e olhando } \\
\text { para A3. }\end{array}$ \\
\hline 518 & $\begin{array}{l}\text { P: Pessoal essa lâmpada tem gás. } \\
\text { Espectro discreto ou contínuo? }\end{array}$ & & Classificação & $\begin{array}{l}\mathrm{P} / \mathrm{T} . \quad \mathrm{O} \text { professor está } \\
\text { organizando a classificação do } \\
\text { espectro em função do tipo de }\end{array}$ \\
\hline
\end{tabular}




\begin{tabular}{|c|c|c|c|c|}
\hline 519 & A3: Contínuo. & & & $\begin{array}{l}\text { lâmpada. Primeiro questiona o } \\
\text { fato de a lâmpada ter gás e em }\end{array}$ \\
\hline 520 & Val: Contínuo. & & & $\begin{array}{l}\text { seguida o fato de ter } \\
\text { filamento. }\end{array}$ \\
\hline 521 & P: Discreto. & & & \\
\hline 522 & A3: Não... & & & \\
\hline 523 & $\begin{array}{l}\text { P: Essa lâmpada tem filamento. } \\
\text { Espectro discreto ou contínuo? }\end{array}$ & & & \\
\hline 524 & Val: Contínuo. & & & \\
\hline 525 & $\begin{array}{l}\text { P: Contínuo. O espectro que } \\
\text { você está vendo aí. }\end{array}$ & & & \\
\hline 527 & $\begin{array}{l}\text { A4: Contínuo. } \\
\text { A3: Discreto! }\end{array}$ & & Classificação & $\begin{array}{l}\mathrm{P} / \mathrm{T} \text {. Os alunos continuam } \\
\text { classificando, mas sem } \\
\text { apresentarem justificativas. }\end{array}$ \\
\hline 528 & A4: Contínuo. & & & \\
\hline 529 & $\begin{array}{l}\text { P: Quando começaram a ver } \\
\text { (inaudível) observem se esse } \\
\text { ainda é contínuo. }\end{array}$ & & Organização. & \\
\hline 530 & Ani: É contínuo. & Gestos. & Classificação & $\begin{array}{l}\mathrm{P} / \mathrm{T} . \quad \text { Ani } \quad \text { acenando } \\
\text { positivamente com a cabeça. }\end{array}$ \\
\hline 531 & $\begin{array}{l}\text { A5: Quem sabe a diferença de } \\
\text { discreto e contínuo lá? }\end{array}$ & & Organização. & $\begin{array}{l}\text { A/A. A2 procura explicação } \\
\text { para diferenciar os dois tipos } \\
\text { de espectro. }\end{array}$ \\
\hline 532 & $\begin{array}{l}\text { A3: Eu sei. Lá é (inaudível) aí } \\
\text { tem gás. }\end{array}$ & $\begin{array}{lr}\text { A3 } & \text { fala } \\
\text { esfregando } & \text { os } \\
\text { olhos. } & \end{array}$ & Organização. & $\begin{array}{l}\text { A/A. A3 fala esfregando os } \\
\text { olhos. }\end{array}$ \\
\hline 533 & P: Observa novamente. & & & $\mathrm{P} / \mathrm{T}$ \\
\hline 534 & A4: Tem gás, mas é ... & & & \\
\hline 535 & A1: É contínuo mas tem um ... & $\begin{array}{l}\text { Gestos. } \\
\text { Manipulação do } \\
\text { espectroscópio. }\end{array}$ & $\begin{array}{l}\text { Organização/ } \\
\text { manipulação } \\
\text { de materiais. }\end{array}$ & $\begin{array}{l}\text { A1 acena e gesticula com os } \\
\text { dedos da mão direita enquanto } \\
\text { segura o espectros- } \\
\text { cópio com a mão esquerda. }\end{array}$ \\
\hline 536 & A5: É contínuo. & & Classificação & A6 confirmando a fala de A1. \\
\hline 537 & $\begin{array}{l}\text { A1: ...Um verde e um amarelo } \\
\text { meio separadinho. }\end{array}$ & & $\begin{array}{l}\text { Organização/ } \\
\text { classificação }\end{array}$ & $\begin{array}{l}\text { Apesar de classificarem como } \\
\text { contínuo, afirmam que as } \\
\text { cores estão meio separadas. }\end{array}$ \\
\hline 538 & A3: É ô. & & & \\
\hline 539 & Ani: Ali tá passando o amarelo! & & Organização & $\begin{array}{l}\text { A/A. Vários alunos falam e } \\
\text { observam ao mesmo tempo. }\end{array}$ \\
\hline 540 & A4: Ô então bota de novo! & & & \\
\hline 541 & A5: Professor se eu ficar cego & & & \\
\hline
\end{tabular}




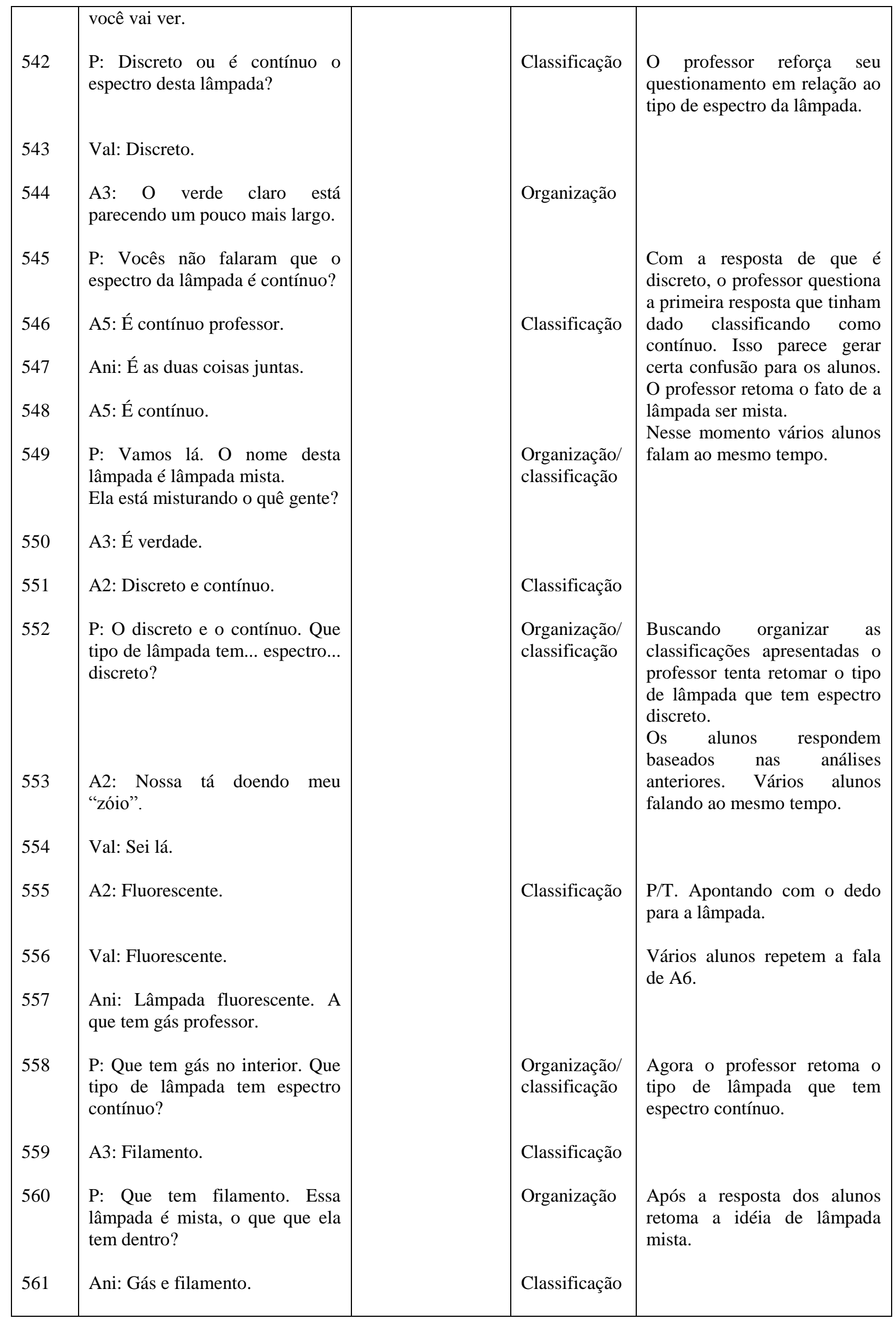




\begin{tabular}{|c|c|c|c|c|}
\hline 562 & Val: Gás e filamento. & & & $\begin{array}{l}\text { P/T. Vários alunos repetem a } \\
\text { fala anterior. }\end{array}$ \\
\hline 563 & $\begin{array}{l}\text { P: Ela tem filamento. } \\
\text { Quando acendemos ela o } \\
\text { filamento acendeu e foi } \\
\text { aquecendo o gás. } \\
\text { Ela estava a princípio um tanto } \\
\text { amarelada, olha só a claridade, } \\
\text { agora (inaudível) }\end{array}$ & $\begin{array}{l}\text { Manipulação do } \\
\text { espectroscópio e } \\
\text { manipulação de } \\
\text { materiais. }\end{array}$ & & $\begin{array}{l}\text { O professor inicia uma } \\
\text { explicação sobre a lâmpada } \\
\text { observada. A2: Fala bem alto } \\
\text { e ao mesmo tempo em que o } \\
\text { professor. } \\
\text { Enquanto o professor realiza } \\
\text { sua fala explicativa: } \\
\text { alguns alunos continuam } \\
\text { observando a lâmpada com } \\
\text { espectroscópio; } \\
\text { outros falam ao mesmo tempo } \\
\text { e anotam no caderno. }\end{array}$ \\
\hline 564 & $\begin{array}{l}\text { A3: ... agora é filamento } \\
\text {...espectro contínuo e discreto ... } \\
\text { E (inaudível). }\end{array}$ & $\begin{array}{l}\text { A3 fala para A4 } \\
\text { que anota em seu } \\
\text { caderno. }\end{array}$ & Justificativa & $\begin{array}{l}\text { A/A. Nesse momento A3 tenta } \\
\text { explicar para A4 o tipo de } \\
\text { espectro observado. A3 fala } \\
\text { para A4 que anota em seu } \\
\text { caderno. } \\
\text { Momento em que A5 grita. }\end{array}$ \\
\hline 566 & $\begin{array}{l}\text { A5: Agora tá claro que é uma } \\
\text { beleza! }\end{array}$ & & & $\begin{array}{l}\text { A5 grita superpondo a fala do } \\
\text { professor e do A3. }\end{array}$ \\
\hline 567 & $\begin{array}{l}\text { Ani: Graciliano devolve } \\
\text { (inaudível) }\end{array}$ & & & \\
\hline 568 & P: O espectro agora é o quê? & & $\begin{array}{l}\text { Organização/ } \\
\text { classificação }\end{array}$ & $\begin{array}{l}\mathrm{P} / \mathrm{T} \text {. O professor pergunta qual } \\
\text { o tipo de espectro observado } \\
\text { neste momento. }\end{array}$ \\
\hline 569 & A5: Nossa. & & & \\
\hline 570 & A3: Gás e filamento. & & $\begin{array}{l}\text { Classificação } \\
\text { /organização }\end{array}$ & $\begin{array}{l}\text { P/T. A3 fala para A4 que } \\
\text { continua anotando em seu } \\
\text { caderno. }\end{array}$ \\
\hline 571 & A2: Ela se soltou. & & & A2 fala em voz alta. \\
\hline 572 & P: Discreto. & & Classificação & $\begin{array}{l}\text { P/T. Como a resposta obtida } \\
\text { não é suficiente o professor } \\
\text { afirma tratar-se de um } \\
\text { espectro discreto. } \\
\text { A3 observa } \\
\text { espectroscópio e vira para A4 } \\
\text { que está anotando. }\end{array}$ \\
\hline 573 & A4: Tô com dor de cabeça. & & & $\begin{array}{l}\text { A/A. A4 fala olhando para } \\
\text { frente e pára de escrever por } \\
\text { um instante. }\end{array}$ \\
\hline 574 & $\begin{array}{l}\text { A3: A incandescente tem } \\
\text { filamento. }\end{array}$ & & Classificação & $\begin{array}{l}\text { Vários alunos falando ao } \\
\text { mesmo tempo. }\end{array}$ \\
\hline 575 & A3: É aqui! & & Organização. & A3 aponta para o caderno. \\
\hline
\end{tabular}




\begin{tabular}{|c|c|c|c|c|}
\hline 576 & $\begin{array}{l}\text { A3: Cê não anotou? } \\
\text { Incandescente ó. }\end{array}$ & & & $\begin{array}{l}\text { A3 aponta para outra região } \\
\text { do caderno. }\end{array}$ \\
\hline 577 & A3: Aqui embaixo ó. & & & $\begin{array}{l}\text { A4 coloca a mão onde A3 } \\
\text { indicou. }\end{array}$ \\
\hline 578 & $\begin{array}{l}\text { P: Quantas cores vocês estão } \\
\text { vendo nesse espectro? }\end{array}$ & & Organização & $\mathrm{P} / \mathrm{T}$ \\
\hline 579 & A2: Quatro. & & Classificação & \\
\hline 580 & $\begin{array}{l}\text { Ani: Vermelho, alaranjado... } \\
\text { (inaudível). }\end{array}$ & & & $\mathrm{A} / \mathrm{A}$ \\
\hline 581 & $\begin{array}{l}\text { A5: Eu to vendo azul, } \\
\text { verde,laranja, vermelho, azul e } \\
\text { roxo (inaudível). }\end{array}$ & $\begin{array}{l}\text { Manipulação do } \\
\text { espectroscópio }\end{array}$ & $\begin{array}{l}\text { Organização/ } \\
\text { classificação }\end{array}$ & $\begin{array}{l}\mathrm{P} / \mathrm{T} . \text { O professor fala ao } \\
\text { mesmo tempo em que } \mathrm{A} 2 .\end{array}$ \\
\hline 582 & P: Aqui estão os destaques aí. & & Organização & \\
\hline 583 & Ani2: Cinco. & & Organização & \\
\hline 584 & Ani3: Cinco. & & & \\
\hline 585 & A5: Tem um monte cores aqui. & & & $\begin{array}{l}\text { A3 continua observando A4 } \\
\text { realizar suas anotações. }\end{array}$ \\
\hline 586 & A3: A fluorescente você põe lá. & $\begin{array}{l}\text { Manipulação dos } \\
\text { espectroscópios e } \\
\text { manipulação dos } \\
\text { materiais. }\end{array}$ & Organização & $\begin{array}{l}\text { A3 aponta para outra região } \\
\text { do caderno. } \\
\text { Em seguida A3 volta a olhar } \\
\text { para lâmpada com o } \\
\text { espectroscópio. A4 também } \\
\text { olha, mas sem espectroscópio. } \\
\text { A4 pára de realizar anotações } \\
\text { por um instante. }\end{array}$ \\
\hline 587 & Ani: Vermelho. & & Classificação & \\
\hline 588 & Ani1: Laranja. & & & \\
\hline 589 & Ani2: Amarelo... & & & \\
\hline 590 & $\begin{array}{l}\text { P: Essas cores que vocês estão } \\
\text { vendo... }\end{array}$ & & Organização & \\
\hline 591 & Ani: Azul e lilás. & & Classificação & \\
\hline 592 & Ani1: Cinco! & & & \\
\hline 593 & $\begin{array}{l}\mathrm{P}: \ldots \text { todas aparecem bem } \\
\text { definidas? }\end{array}$ & & $\begin{array}{l}\text { Organização/ } \\
\text { classificação }\end{array}$ & \\
\hline 594 & Val: Não! & & & $\begin{array}{l}\text { A4 também passa a observar a } \\
\text { lâmpada com o } \\
\text { espectroscópio. Vários alunos } \\
\text { falam ao mesmo tempo. }\end{array}$ \\
\hline 595 & A2: O azul não. & & Classificação & \\
\hline 596 & Ani: $\mathrm{O}$ anil. & & & \\
\hline
\end{tabular}




\begin{tabular}{|c|c|c|c|c|}
\hline 597 & $\begin{array}{l}\text { Ani2: Ah, a minha tá bem } \\
\text { definida. }\end{array}$ & & & \\
\hline 598 & Ani3: Eu tô vendo mais clarinho. & & & \\
\hline 599 & $\begin{array}{l}\text { A3: O meu aparece um } \\
\text { "fleschinho". }\end{array}$ & $\begin{array}{l}\text { Manipulação de } \\
\text { espectroscópios }\end{array}$ & & $\mathrm{P} / \mathrm{T} \mathrm{A} / \mathrm{A}$. \\
\hline 600 & $\begin{array}{l}\text { P: Algumas delas aparece } \\
\text { espalhada no (inaudível). }\end{array}$ & & Organização & \\
\hline 602 & $\begin{array}{l}\text { Ani: O vermelho! } \\
\text { Ani2: É o verde ... o verde mais } \\
\text { claro. }\end{array}$ & & Classificação & $\begin{array}{l}\text { Os alunos respondem ao } \\
\text { professor e indicam várias } \\
\text { cores aparecendo espalhadas. }\end{array}$ \\
\hline 603 & Ani3: O vermelho. & & & \\
\hline 604 & Ani4: O verde claro e o amarelo. & & Classificação & $\begin{array}{l}\text { Praticamente todos estão com } \\
\text { o espectroscópio no olho. } \\
\text { Observam a lâmpada. }\end{array}$ \\
\hline 605 & $\begin{array}{l}\text { P: Como é o espectro dessa } \\
\text { lâmpada? }\end{array}$ & & & \\
\hline 606 & Ani: É discreto. & & & \\
\hline 607 & A2:Discreto. & & & \\
\hline 608 & A5: É zuado. & & & \\
\hline 609 & Ani2: Contínuo. & & & \\
\hline 610 & Ani3: Legal. & & & \\
\hline 611 & A2: É “discretínuo". & & & $\begin{array}{l}\text { A2 deita a cabeça sobre a } \\
\text { bancada e olha para A1. }\end{array}$ \\
\hline 612 & Ani: É contínuo. & & & \\
\hline 613 & Ani2: É mista. & & & \\
\hline 614 & $\begin{array}{l}\text { A4: Essa lâmpada tá difícil pra } \\
\text { \#@*@/\&*. }\end{array}$ & & & $\begin{array}{l}\text { A/A. A4 fala passando a mão } \\
\text { na cabeça. Após as respostas } \\
\text { diversas A4 manifesta sua } \\
\text { dificuldade em identificar o } \\
\text { espectro da lâmpada. }\end{array}$ \\
\hline 615 & A3: Tá mesmo. & & & $\begin{array}{l}\text { A/A. A } 3 \text { e A4 voltam a olhar } \\
\text { através do espectroscópio. }\end{array}$ \\
\hline 616 & A5: É um espectro gente fina. & & & \\
\hline 617 & Val: É mista. & & & \\
\hline 618 & Val: É contínua. & & & \\
\hline 619 & $\begin{array}{l}\text { P: Tem uma parte que é discreto } \\
\text { tem aí bem definido, tem uma } \\
\text { parte que é } \\
\text { (inaudível) }\end{array}$ & & $\begin{array}{l}\text { Organização/ } \\
\text { classificação }\end{array}$ & $\begin{array}{l}\text { P/T. O professor tenta auxiliar } \\
\text { os alunos na classificação e } \\
\text { identificação do espectro } \\
\text { observado. }\end{array}$ \\
\hline
\end{tabular}




\begin{tabular}{|c|c|c|c|c|}
\hline 620 & A4: Tô vendo nada. & & & $\begin{array}{l}\text { A4 demonstra sua dificuldade } \\
\text { novamente. }\end{array}$ \\
\hline 621 & $\begin{array}{l}\text { A3: Tô vendo a minha. A minha } \\
\text { tá parecendo umas flechinhas. }\end{array}$ & & $\begin{array}{l}\text { Organização/ } \\
\text { classificação. }\end{array}$ & $\begin{array}{l}\text { A3 demonstra euforia por ter } \\
\text { conseguido observar. }\end{array}$ \\
\hline 622 & $\begin{array}{l}\text { A3: A violeta tá parecendo mais } \\
\text { forte. }\end{array}$ & & Classificação & \\
\hline 623 & Ani: Acho que é contínuo. & & & \\
\hline 624 & $\begin{array}{l}\text { A3: Ó a violeta, a verde } \\
\text { fluorescente e a amarela ó ... }\end{array}$ & & & \\
\hline 625 & $\begin{array}{l}\text { A3: ... é das umas que tá } \\
\text { aparecendo mais forte. }\end{array}$ & & & $\begin{array}{l}\text { Vários alunos falando ao } \\
\text { mesmo tempo. }\end{array}$ \\
\hline 626 & $\begin{array}{l}\text { A3: A banda mais larga é a } \\
\text { verde forte e ... }\end{array}$ & & & \\
\hline 627 & $\begin{array}{l}\text { A3: ...o vermelho é o que ...tá } \\
\text { maior... Tá fraco. }\end{array}$ & & & \\
\hline 628 & A1: Discreto. & Gestos. & & $\begin{array}{l}\mathrm{P} / \mathrm{T} \text { A/A. A1 fala balançando a } \\
\text { cabeça positivamente para A6. } \\
\text { O professor fala em baixo tom } \\
\text { com alguns alunos da sala. } \\
\text { Vários alunos conversam ao } \\
\text { mesmo tempo. }\end{array}$ \\
\hline 629 & A5: Meu bumbum ta quadrado. & & & \\
\hline 630 & $\begin{array}{l}\mathrm{P}: \ldots \text { nós faremos isso nas } \\
\text { próximas aulas (inaudível) } \\
\text { vezes. }\end{array}$ & & Organização & \\
\hline 631 & Ani: Hoje? & & & \\
\hline 632 & P: Posso apagar? & & & \\
\hline 633 & Val: Pode! & & & \\
\hline 634 & A3: É, vai. & Gestos. & & $\begin{array}{l}\text { A3 fala com a mão na cabeça } \\
\text { e com o corpo meio inclinado. }\end{array}$ \\
\hline 635 & Ani: Claro que pode. & & & \\
\hline
\end{tabular}

\section{Momento 5 - Observação da lâmpada dicróica e dicróica com filtro azul}




\begin{tabular}{|c|c|c|c|c|}
\hline $\begin{array}{l}\text { Turno } \\
\text { De } \\
\text { fala }\end{array}$ & $\begin{array}{llll}\begin{array}{l}\text { Linguagem } \\
\text { escrita) }\end{array} & \text { verbal } & \text { (oral ou } \\
\end{array}$ & $\begin{array}{l}\text { Outras linguagens } \\
\text { Ações/gestos/ } \\
\text { Manipulação de } \\
\text { materiais } \\
\end{array}$ & Indicadores & $\begin{array}{ll}\text { Tipos } & \mathrm{de} \\
\text { Interação/Comentários }\end{array}$ \\
\hline 636 & A5: essa outra é da hora. & & & $\begin{array}{llll}\text { Realizada } & \text { a } & \text { troca } & \text { das } \\
\text { lâmpadas. } & & & \end{array}$ \\
\hline 637 & $\begin{array}{l}\text { P: Fazer em duas etapas essa } \\
\text { aqui é a lâmpada dicróica. Ela } \\
\text { tem foco dirigido. }\end{array}$ & & Organização & $\mathrm{P} / \mathrm{T}$ \\
\hline 638 & A5: É a de farol de carro né? & & Organização & $\begin{array}{l}\text { A5 busca associar a lâmpada } \\
\text { observada com outra. }\end{array}$ \\
\hline 639 & $\begin{array}{l}\text { P: ... ela tem o mesmo sistema, } \\
\text { mas essa aqui... }\end{array}$ & & & \\
\hline 640 & A3: Essa tem gás e filamento? & & Classificação & \\
\hline 641 & $\begin{array}{l}\text { P: ... e o calor sai por aqui. Aqui } \\
\text { ela permite passar... as ondas } \\
\text { luminosas. }\end{array}$ & & & \\
\hline 642 & A5: liga aí! & & Organização & $\mathrm{P} / \mathrm{T}$. \\
\hline 643 & A5: Essa aí é fraquinha. & & & Sala muito escura. \\
\hline 644 & $\begin{array}{l}\text { A5 :É luz motel... que fica em } \\
\text { cima da cama redonda.. }\end{array}$ & & & \\
\hline 645 & $\begin{array}{l}\text { P: Olha! Dá uma olhada ela está } \\
\text { iluminando muito pouco. }\end{array}$ & & Organização & \\
\hline 646 & A1: Tem 3 cores. & $\begin{array}{l}\text { Manipulação do } \\
\text { espectroscópio. }\end{array}$ & & \\
\hline 647 & P: Ela é bem intensa. & & & \\
\hline 648 & $\begin{array}{l}\text { Ani: } \hat{O} \text { professor deixa a } \\
\text { caixinha ai... }\end{array}$ & & & \\
\hline 649 & $\begin{array}{l}\text { P: Pra verificar o espectro dela, } \\
\text { como o foco é dirigido... }\end{array}$ & & & \\
\hline 650 & A3: vira aqui professor & & Organização & \\
\hline 651 & P: Já vou... calminha. & & & \\
\hline 652 & A5: Espera haxixe... & & & \\
\hline 653 & $\begin{array}{l}\text { P: Sejam rápidos para que eu } \\
\text { possa ... }\end{array}$ & & & \\
\hline 654 & P: Dicróica. & & Classificação & \\
\hline 655 & A1: Ela é continua... & & & \\
\hline 656 & $\begin{array}{l}\text { A3: Qual o nome da luz } \\
\text { professor? }\end{array}$ & & & \\
\hline
\end{tabular}




\begin{tabular}{|c|c|c|c|c|}
\hline 657 & Ani: Alice, $1 .$. & & & \\
\hline 658 & A3: Dicróica. & & & \\
\hline 659 & P: Dicróica. & & & \\
\hline 660 & A3: Dicróica, dicróica. & & & \\
\hline 661 & P: Pronto? & & & \\
\hline 662 & $\begin{array}{l}\text { A5: Três conselhos: não zoa ela } \\
\text { porque ela é nervosa, não zoa ela } \\
\text { porque o namorado dela é maior } \\
\text { que eu. }\end{array}$ & & & $\mathrm{A} / \mathrm{A}$ \\
\hline 663 & A4: Ninguém ta zoando ela. & & & \\
\hline 664 & $\begin{array}{l}\text { A5: Não zoa ela porque ela é } \\
\text { minha amiga. }\end{array}$ & & & \\
\hline 665 & A4: To zoando o trabalho dela. & & & \\
\hline 666 & $\begin{array}{l}\text { P: Se for continuo que cores } \\
\text { aparece? }\end{array}$ & & & $\mathrm{P} / \mathrm{T}$ \\
\hline 667 & A1: todas. & & Organização & \\
\hline 668 & A5:Ô vira pra cá que é legal. & $\begin{array}{l}\text { Manipulação dos } \\
\text { espectroscópios. }\end{array}$ & & 17 \\
\hline 669 & $\begin{array}{l}\text { A4: Vermelho, azul, lilás, } \\
\text { amarelo. }\end{array}$ & & Classificação & \\
\hline 670 & Ani: Laranja. & & & \\
\hline 671 & $\begin{array}{l}\text { P: ... qual não aparece, qual } \\
\text { aparece mais, qual aparece } \\
\text { menos. }\end{array}$ & & & \\
\hline 672 & $\begin{array}{l}\text { A5: Azul, verde, vermelho. A } \\
\text { que aparece menos é azul, a que } \\
\text { aparece mais é a verde. Preciso } \\
\text { fumar um cigarro professor! }\end{array}$ & $\begin{array}{l}\text { Manipulação dos } \\
\text { espectroscópios e } \\
\text { manipulação de } \\
\text { materiais. }\end{array}$ & & $\begin{array}{l}\text { A1, A2 e A7 atentos a } \\
\text { observação e anotando no } \\
\text { caderno. }\end{array}$ \\
\hline 673 & $\begin{array}{l}\text { A5: É a verde que aparece } \\
\text { menos ... }\end{array}$ & & & \\
\hline 674 & $\begin{array}{l}\text { A3: Ah, professor o senhor falou } \\
\text { que era } 50 \text { minutos e já passou } \\
\text { uma hora. }\end{array}$ & & Organização & A3 disperso. \\
\hline 675 & A5: Você ta cronometrando? & & & \\
\hline 676 & $\begin{array}{l}\text { A5: O professor, cega todo } \\
\text { mundo... }\end{array}$ & & & \\
\hline 677 & $\begin{array}{l}\text { A3: Tira essa lâmpada aí } \\
\text { professor. }\end{array}$ & & & Sala muito escura. \\
\hline 678 & A4: Você vai falando e a vai & & & \\
\hline
\end{tabular}




\begin{tabular}{|c|c|c|c|c|}
\hline & $\begin{array}{l}\text { anotando... e aí a gente } \\
\text { confere,.... aí é a parte daltônica, } \\
\text { e aí também. }\end{array}$ & & & A/A. A4 fala para A3. \\
\hline 679 & $\begin{array}{l}\text { A5: Professor você vai me } \\
\text { descolar uma lâmpada de luz } \\
\text { negra? }\end{array}$ & & & $\mathrm{P} / \mathrm{T}$ \\
\hline 680 & $\begin{array}{l}\text { Ani: O que que é isso daí, é } \\
\text { branca, professor? }\end{array}$ & & Classificação & \\
\hline 681 & $\begin{array}{l}\text { P: Essa é dicróica também, só } \\
\text { que tem um filtro de cor azul. }\end{array}$ & & & $\begin{array}{l}\text { Lâmpada dicróica com filtro } \\
\text { azul. }\end{array}$ \\
\hline 682 & P: Pessoal... & & & Muitas falas e barulhos. \\
\hline 683 & Ani: Verde azul, anil e violeta. & & Classificação & \\
\hline 684 & P: Ok pessoal? & & & \\
\hline 685 & A5: É o sol nascente... & & & \\
\hline 686 & Ani:Vermelho verde, violeta. & & & \\
\hline 687 & P: E ai o espectro dessa? & & & \\
\hline 688 & Ani:Vermelho verde, violeta. & Manipulação de & Classificação & $\mathrm{D} / \mathrm{T}$ \\
\hline 689 & Ani: Ta faltando o amarelo. & & & \\
\hline 690 & P: Tá faltando dois... & & & \\
\hline 691 & $\begin{array}{l}\text { Ani: Eu não to vendo vermelho } \\
\text { não. }\end{array}$ & & & \\
\hline 692 & A5: É porque você é daltônica. & & & \\
\hline 693 & $\begin{array}{l}\text { P: Pessoal, se tem presta } \\
\text { atenção, se tem todas as cores, } \\
\text { isso indica que o espectro } \\
\text { provavelmente seja continuo, o } \\
\text { contrario não é verdade... }\end{array}$ & & & $\begin{array}{l}\text { Muitas conversas não } \\
\text { relacionadas à atividade. Sala } \\
\text { escura. }\end{array}$ \\
\hline 694 & $\begin{array}{l}\text { A3: Professor é lâmpada } \\
\text { dicróica o que? }\end{array}$ & & & \\
\hline 695 & A5: Azul. & & & \\
\hline 696 & A5: Azul. & & & \\
\hline 697 & A3: É com filtro azul. & & & \\
\hline 698 & $\begin{array}{l}\text { P: pessoal como é o espectro } \\
\text { dessa lâmpada? }\end{array}$ & & & \\
\hline 699 & $\begin{array}{l}\text { A5: Eu não sei você não virou } \\
\text { pra cá. }\end{array}$ & & & \\
\hline 700 & P: Dicróica. & & & \\
\hline
\end{tabular}




\begin{tabular}{|c|c|c|c|c|}
\hline 701 & Ani: A outra também. & & & \\
\hline 702 & $\begin{array}{l}\text { A5: Não sei, ele não virou pra } \\
\text { cá. }\end{array}$ & & & \\
\hline 703 & $\begin{array}{l}\text { P: Estão aparecendo linhas no } \\
\text { meio do espectro? }\end{array}$ & & & \\
\hline 704 & Val: Não, não. & & Organização & \\
\hline 705 & $\begin{array}{l}\text { P: Tem linhas aí no meio do } \\
\text { espectro? }\end{array}$ & & & \\
\hline 706 & Val: Não. & & & \\
\hline 707 & $\begin{array}{l}\text { A5: será que o professor fica } \\
\text { vendo linhas o dia todo? }\end{array}$ & & & $\mathrm{A} / \mathrm{A}$ \\
\hline 708 & $\begin{array}{l}\text { P: dá pra ver o formato da } \\
\text { lâmpada. Dá pra ver as cores } \\
\text { separadas? }\end{array}$ & & & $\mathrm{P} / \mathrm{T}$ \\
\hline 709 & Val: não. & & & \\
\hline 710 & P: As cores estão separadas? & & & \\
\hline 711 & Val: Não. & $\begin{array}{l}\text { Manipulação dos } \\
\text { espectroscópios. }\end{array}$ & Organização & \\
\hline 712 & $\begin{array}{l}\text { A5: esse povo não sabe calar a } \\
\text { boca. }\end{array}$ & & & \\
\hline 713 & P: Pessoal! & & & $\mathrm{P} / \mathrm{T}$ \\
\hline 714 & $\begin{array}{l}\text { Ani: É continuo o que aparece } \\
\text { mais é o... }\end{array}$ & & Classificação & $\begin{array}{l}\text { Muito barulho e conversas não } \\
\text { relacionadas à atividade. }\end{array}$ \\
\hline 715 & A2: É discreto & & & \\
\hline 716 & $\begin{array}{l}\text { P: E aí pessoal como é o } \\
\text { espectro dessa lâmpada? }\end{array}$ & & & \\
\hline 717 & Ani: É Contínuo. & & Classificação & \\
\hline 718 & Ani2:Tá tudo junto ... & & Justificativa & \\
\hline 719 & $\begin{array}{l}\text { A3: Anota as cores ai, Gustavo: } \\
\text { Violeta. }\end{array}$ & & Organização & \\
\hline 720 & A4: Azul. & & & \\
\hline 721 & A2: Tá tudo misturado professor. & & & \\
\hline 722 & $\begin{array}{l}\text { P: O que que faz o filtro? o que } \\
\text { que faz o filtro azul? }\end{array}$ & & & O professor inicia um diálogo \\
\hline 723 & A3: Acaba com as luzes. & & Explicação & $\begin{array}{l}\text { explicar a função do filtro } \\
\text { azul. }\end{array}$ \\
\hline 724 & A5: deixa azul. & & Explicação & \\
\hline 725 & P: Não entendi. & & & \\
\hline
\end{tabular}




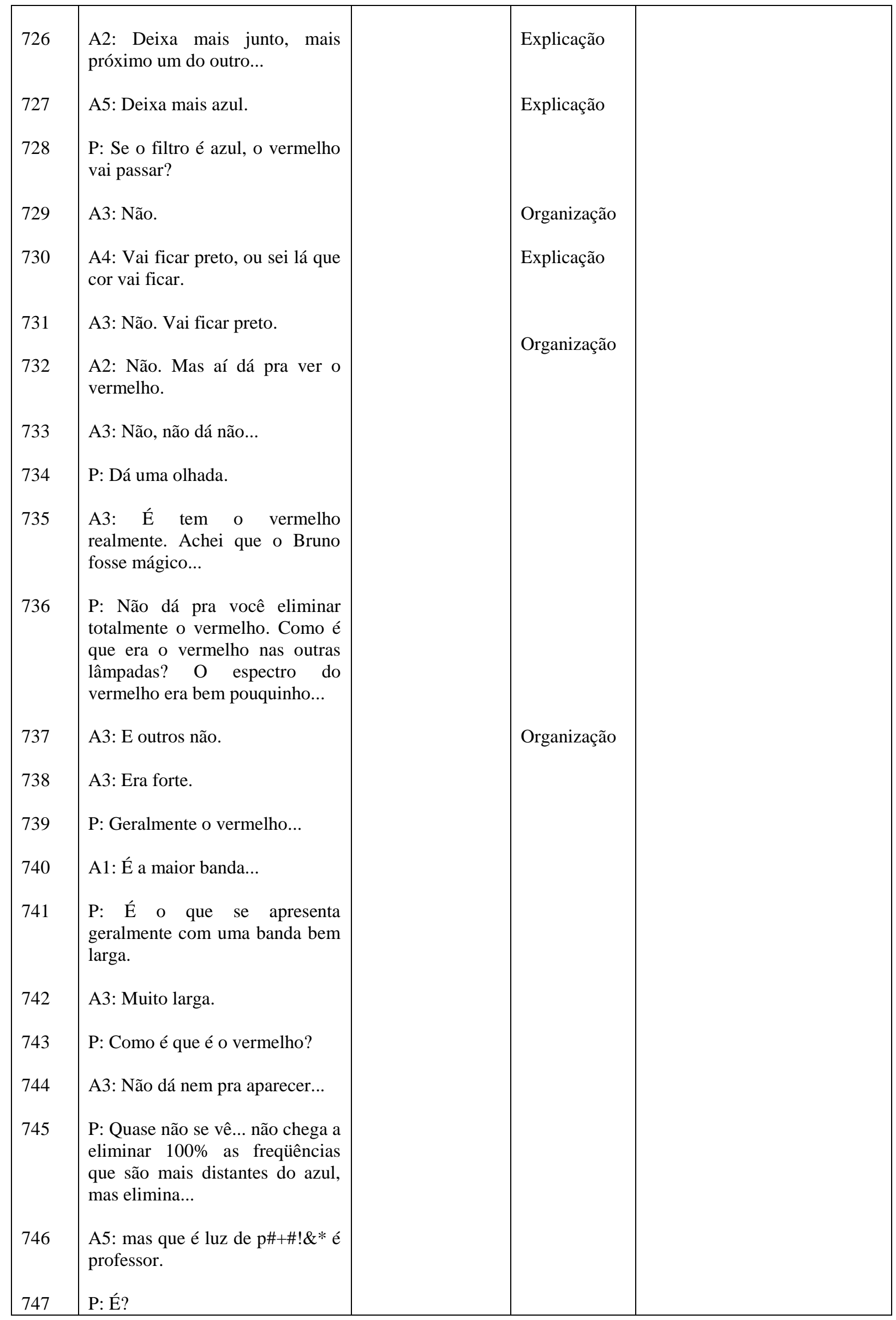




\begin{tabular}{|l|l|l|l|l|}
\hline 748 & G: É. & & \\
749 & A3: O professor sabe disso. & & & \\
750 & Ani: Já acabou professor? & & & \\
\hline
\end{tabular}

\section{Momento 6 - Observação da lâmpada de luz negra}

\begin{tabular}{|c|c|c|c|c|}
\hline $\begin{array}{l}\text { Turno } \\
\text { De } \\
\text { fala }\end{array}$ & $\begin{array}{llll}\text { Linguagem } & \text { verbal } & \text { (oral ou } \\
\text { escrita) } & & & \end{array}$ & $\begin{array}{l}\text { Outras linguagens } \\
\text { Ações/gestos/ } \\
\text { Manipulação de } \\
\text { materiais }\end{array}$ & Indicadores & $\begin{array}{ll}\text { Tipos } & \mathrm{de} \\
\text { Interação/Comentários } & \end{array}$ \\
\hline 751 & $\begin{array}{l}\text { P: Pessoal, vou colocar a luz } \\
\text { negra. }\end{array}$ & & & $\begin{array}{l}\text { Troca da lâmpada. Professor } \\
\text { coloca a Lâmpada de luz }\end{array}$ \\
\hline 752 & A5: Posso desligar aqui? & & & $\begin{array}{l}\text { negra. } \\
\text { Muito barulho. Alunos imitam }\end{array}$ \\
\hline 753 & P: Pessoal , luz negra. & & & $\begin{array}{l}\text { animais como gatos e cães. } \\
\text { Muitas conversas paralelas. }\end{array}$ \\
\hline 754 & A5: Dá um sorrisinho alguém aí. & & & \\
\hline 755 & Ani: Só dá para ver roxo. & & $\begin{array}{l}\text { Organização/ } \\
\text { classificação }\end{array}$ & \\
\hline 756 & A1: Só da pra ver roxo. & & & \\
\hline 757 & $\begin{array}{l}\text { P: Como é que é o espectro } \\
\text { dessa lâmpada? }\end{array}$ & & & \\
\hline 758 & A5: Roxo. & & Classificação & \\
\hline 759 & P: Contínuo ou discreto? & & & \\
\hline 760 & A5: Continuamente roxo. & $\begin{array}{l}\text { Manipulação dos } \\
\text { espectroscópios. }\end{array}$ & Classificação & \\
\hline 761 & A3: Olha que legal! & & & \\
\hline 762 & Ani: Discreto. & & & \\
\hline 763 & Ani2: Ta brilhando. & & & \\
\hline 764 & $\begin{array}{l}\text { P: Ok pessoal, já viram aí as } \\
\text { cores que aparecem? }\end{array}$ & & & $\begin{array}{l}\text { Os alunos comentam sobre os } \\
\text { efeitos da luz negra. }\end{array}$ \\
\hline 765 & Ani: Falei que tinha verde... & & Organização & \\
\hline 766 & A5: Você vê a cor. & & & \\
\hline 767 & $\begin{array}{l}\text { Ani: Ah gente, dá para ver o } \\
\text { arco-íris todo... }\end{array}$ & & & \\
\hline 768 & Ani2: Eu só vejo o roxo! & & Classificação & \\
\hline 769 & A4: Não to vendo nada . & & & \\
\hline
\end{tabular}




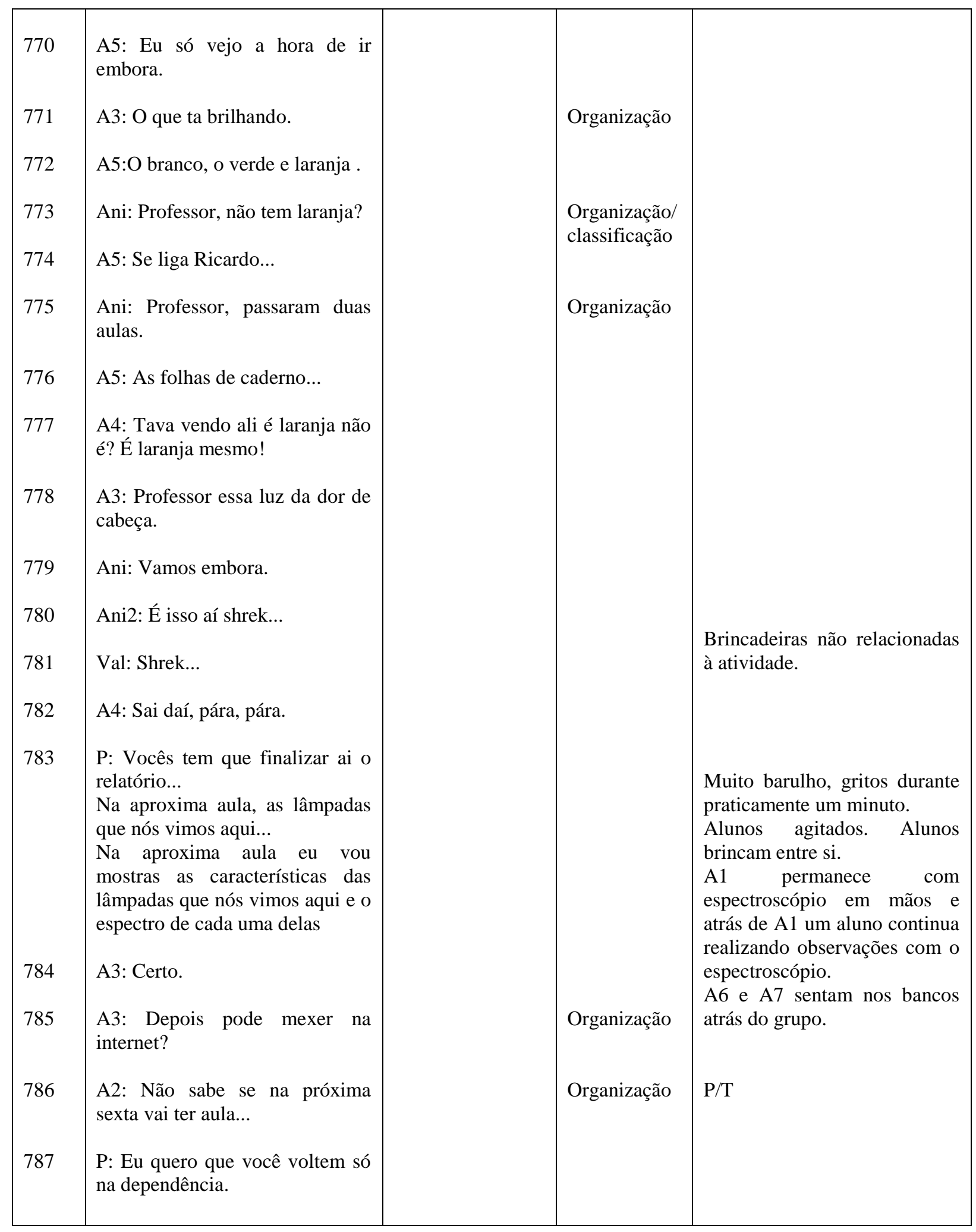

\section{Momento 7 - Final da atividade de observação dos espectros das lâmpadas}




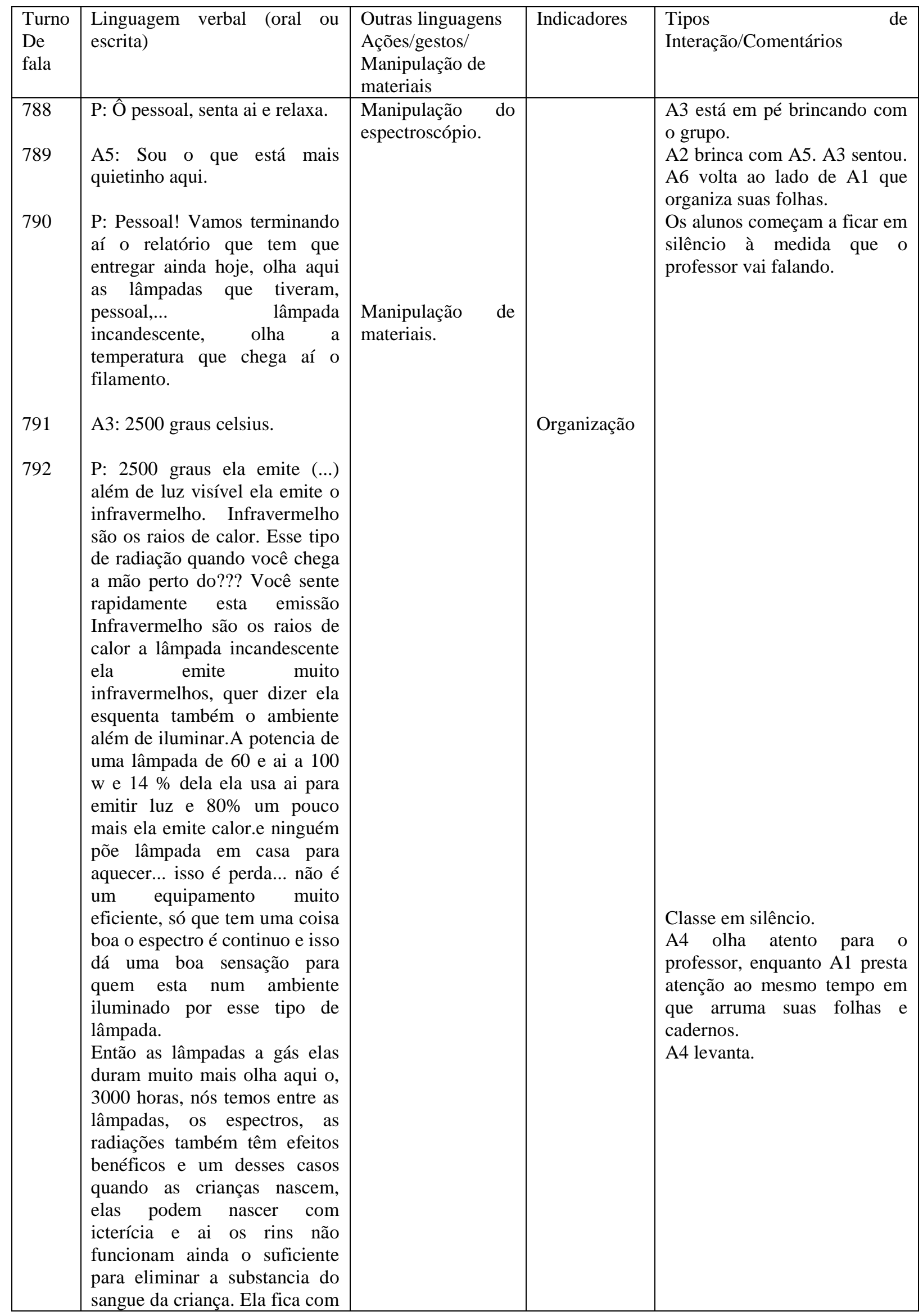




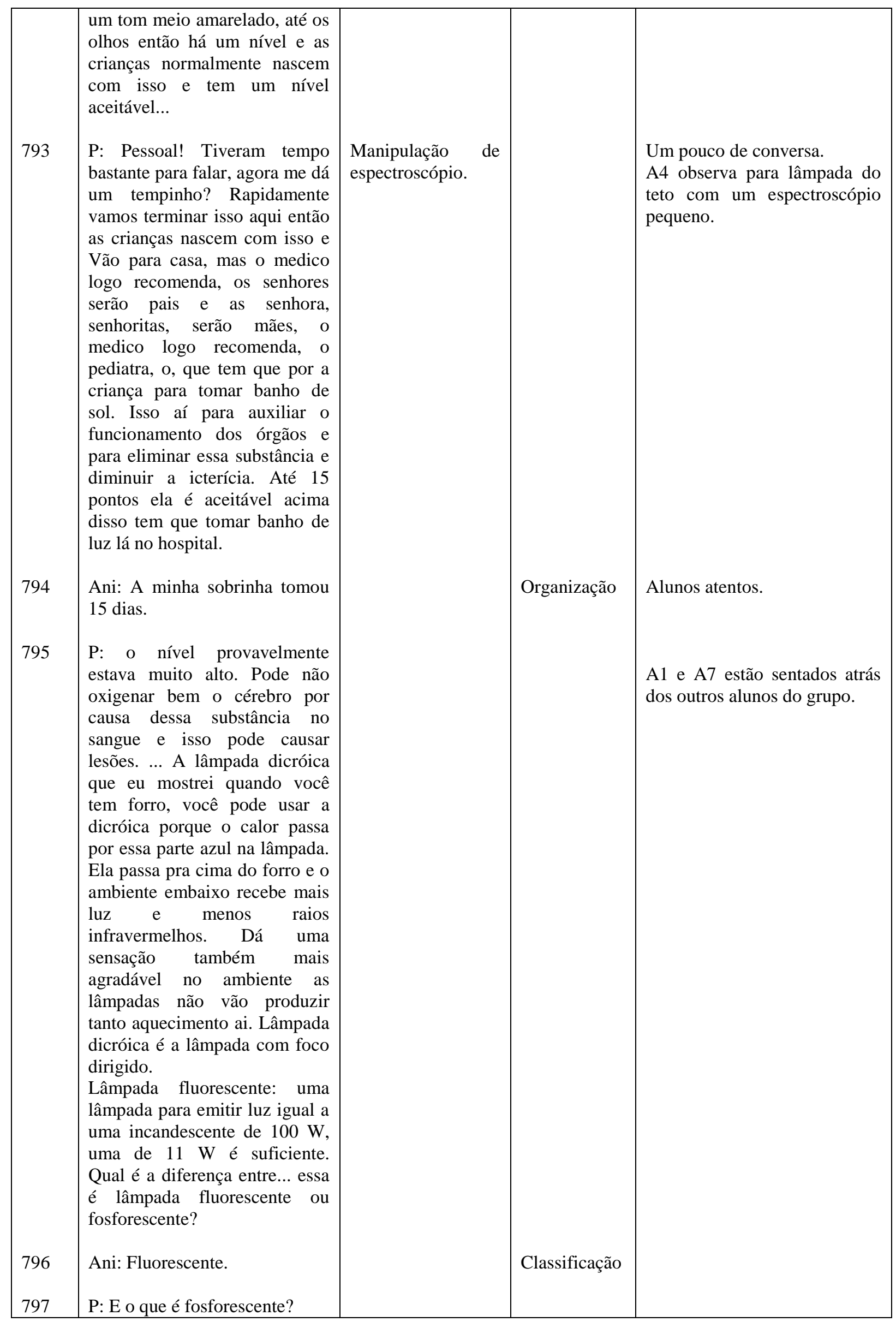




\begin{tabular}{|c|c|c|c|}
\hline 798 & $\begin{array}{l}\text { Ani: Fosforescente é aquela } \\
\text { que acende quando tudo está } \\
\text { apagado, por causa da energia } \\
\text { recebida. }\end{array}$ & Explicação & \\
\hline 799 & P: Muito bem. É isso mesmo. & & \\
\hline 800 & $\begin{array}{l}\text { P: Lâmpada fluorescente } \\
\text { recebe a energia e logo ela } \\
\text { emite. Substâncias que são } \\
\text { fosforescente recebe a energia } \\
\text { mais lentamente e depois que } \\
\text { para de receber energia ela } \\
\text { continua a emitir luz um } \\
\text { exemplo são os interruptores, } \\
\text { eles são... eles tem materiais } \\
\text { fosforescentes. }\end{array}$ & & \\
\hline 801 & $\begin{array}{l}\text { A: Aqueles negocinhos no teto } \\
\text { do quarto. }\end{array}$ & Organização & \\
\hline 802 & $\begin{array}{l}\text { P: Se você deixar o interruptor, } \\
\text { com a lâmpada acesa o dia } \\
\text { inteiro, ele fica recebendo } \\
\text { energia por causa da luz. } \\
\text { Quando você apaga à noite, o } \\
\text { ambiente se apaga e você olha } \\
\text { o interruptor e da pra ver, } \\
\text { porque ele ainda esta emitindo } \\
\text { luz. Ele é fosforescente, esse } \\
\text { tipo de lâmpada é fluorescente }\end{array}$ & & Toca o sinal. \\
\hline 803 & $\begin{array}{l}\text { A6: É que nem as estrelinhas } \\
\text { no... }\end{array}$ & & \\
\hline 804 & $\begin{array}{l}\text { P: A lâmpada a vapor de } \\
\text { mercúrio ou sódio, nós já } \\
\text { havíamos comentado, são } \\
\text { lâmpadas que são usada em } \\
\text { iluminação publica tem um tom } \\
\text { mais esbranquiçado e o sódio é } \\
\text { aquela lâmpada que parece que } \\
\text { esta velha, é uma lâmpada } \\
\text { meio amarelada. } \\
\text { O amarelo da lâmpada não é } \\
\text { que ela esta velha é o tipo e gás } \\
\text { que tem ali, ele emite } \\
\text { radiações, emite raios que, o } \\
\text { espectro dele está mais } \\
\text { próximo das frequiências do } \\
\text { amarelo e do alaranjado por } \\
\text { isso que ele tem... }\end{array}$ & & Aiunos atentos. \\
\hline 805 & $\begin{array}{l}\text { A5: Qual é a melhor: a de } \\
\text { mercúrio ou a de sódio? }\end{array}$ & Classificação & \\
\hline 806 & P: Não as duas são... & & \\
\hline 807 & Ani: É professor eram duas & Organização & \\
\hline
\end{tabular}




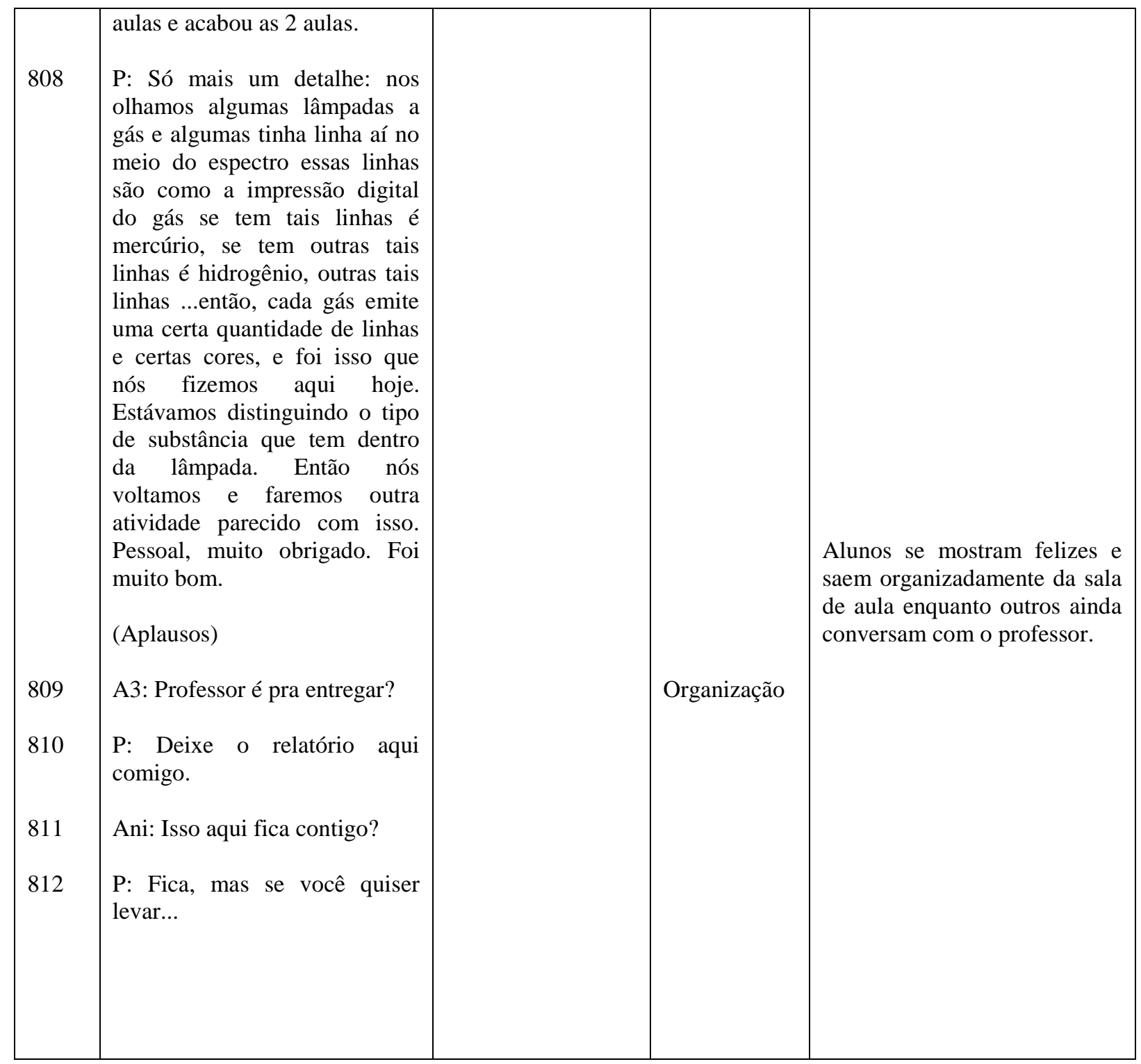

Tabela com transcrições, linguagens, indicadores, tipos de interação e comentários: Atividade do astrônomo mirim - aula de 01/12/2006 - aproximadamente 60 minutos de gravações - $3^{\text {a }}$ série $\mathrm{G}$ - Ensino Médio.

\section{Episódio 2 - análise da atividade do astrônomo mirim:}

\section{Momento 1 - início da aula}

\begin{tabular}{|l|l|l|lr|}
\hline $\begin{array}{l}\text { Turno } \\
\text { de } \\
\text { fala }\end{array}$ & Linguagem verbal (oral ou escrita) & $\begin{array}{l}\text { Outras linguagens } \\
\text { Ações/gestos/ } \\
\text { Manipulação de } \\
\text { materiais }\end{array}$ & $\begin{array}{l}\text { Indicadores/ Tipos } \\
\text { Interação/Comentários }\end{array}$ \\
\hline 01 & A5: Diego, esse aí era outro, que você & & Organização. A/A. Classe \\
\hline
\end{tabular}




\begin{tabular}{|c|c|c|c|}
\hline & $\begin{array}{l}\text { tinha que olhar lá e marcar as cores no } \\
\text { papel você vê a (inaudível) que você tava } \\
\text { olhando. (inaudível). Já entregou pra } \\
\text { ele?Então já era. }\end{array}$ & & $\begin{array}{l}\text { arrumada em } \\
3 \text { grupos com } 6 \text { alunos. } \\
\text { Alunos falam enquanto o } \\
\text { professor pega folhas com } \\
\text { espectro dos elementos. }\end{array}$ \\
\hline 02 & $\begin{array}{l}\text { P: Pessoal, pessoal, então nós temos duas } \\
\text { atividades, duas atividades. Primeiro nós } \\
\text { fizemos um trabalhinho, o espectroscópio, } \\
\text { observamos as lâmpadas. Cada lâmpada } \\
\text { tinha um espectro diferente: apareciam } \\
\text { linhas em posições e em cores diferentes, } \\
\text { vocês observaram isso. Hoje nós, segunda } \\
\text { parte da aula, vamos explicar por que } \\
\text { aparece cada uma dessas linhas, inclusive } \\
\text { até calcular a posição dessas linhas. Isso é } \\
\text { um trabalho que, talvez, vocês considerem } \\
\text { um pouco mais... não muito agradável. }\end{array}$ & & $\begin{array}{l}\text { Organização. P/T. Alunos } \\
\text { sentados ao redor de carteiras } \\
\text { agrupadas. } \\
\text { Professor apresenta o objetivo } \\
\text { da aula. }\end{array}$ \\
\hline 03 & $\begin{array}{l}\text { P: Então esses elementos... olha aqui cada } \\
\text { elemento, cada elemento quando você tem } \\
\text { lá o gás de certo elemento, processa ele } \\
\text { torna ele gás e depois faz com que luz } \\
\text { passe por ele e ele emita luz você vai ver } \\
\text { um espectro diferente. } \\
\text { Então isso é como se fosse a digital do } \\
\text { elemento (1) o alumínio tem essas linhas, } \\
\text { sempre. O alumínio sempre terá essas } \\
\text { linhas, carbono essas linhas, } \\
\text { ferro essas linhas cada elemento tem } \\
\text { linhas bem definidas. Se tiverem, } \\
\text { quiserem um outro momento verificar } \\
\text { isso, tem uma tabela periódica completa } \\
\text { na internet, com as linhas espectrais de } \\
\text { cada elemento. Eu já até citei para vocês o } \\
\text { site. }\end{array}$ & $\begin{array}{lr}\text { Gestos. O professor } \\
\text { mostra o papel com os } \\
\text { espectros } r \\
\text { elementos. }\end{array}$ & $\begin{array}{l}\text { Organização. P/T. Quando fala } \\
\text { sobre o site, o professor } \\
\text { escreve o endereço na lousa. }\end{array}$ \\
\hline 04 & $\begin{array}{l}\text { A1: Até parece que eu vou procurar isso } \\
\text { na internet. }\end{array}$ & & $\mathrm{A} / \mathrm{A}$ \\
\hline 05 & $\begin{array}{l}\text { P: ... site da universidade federal do Rio } \\
\text { Grande do Sul, espectroscopia. Põe lá em } \\
\text { qualquer site de busca, com essa } \\
\text { informação ele vai abrir lá uma página que } \\
\text { tem todos os elementos e todas as linhas } \\
\text { espectrais... }\end{array}$ & & $\begin{array}{l}\text { Organização. P/T. Alunos do } \\
\text { grupo prestam atenção } \\
\text { enquanto A4 fala com A6. }\end{array}$ \\
\hline 06 & $\begin{array}{l}\text { P: Então de vez em quando nós ouvimos } \\
\text { é... informações, jornais, pegamos alguma } \\
\text { revista que diz que tal estrela, tal planeta } \\
\text { tem atmosfera. Ora como eles sabem... } \\
\text { que gás, que atmosfera tem no planeta ou } \\
\text { numa estrela? Através da luz pelo planeta } \\
\text { refletida ou pela luz emitida por uma } \\
\text { estrela. Aqui eu tenho o espectro de uma } \\
\text { estrela. Põe um telescópio e na chegada da } \\
\text { luz ele põe um espectroscópio com uma } \\
\text { rede de difração e tira o espectro da } \\
\text { estrela. Então este é o espectro de uma } \\
\text { estrela. Que elementos são estes que deixa }\end{array}$ & Gestos do professor. & $\begin{array}{l}\text { Organização/explicação. P/T. } \\
\text { O professor mostra a } \\
\text { transparência com o espectro } \\
\text { que representa uma estrela } \\
\text { hipotética. }\end{array}$ \\
\hline
\end{tabular}




\begin{tabular}{|c|c|c|c|}
\hline 07 & $\begin{array}{l}\text { estas linhas? } \\
\text { Então eu tenho as linhas dos elementos } \\
\text { que eu conheço na Terra e tenho o } \\
\text { espectro da estrela, então eu vou colocar } \\
\text { um sobre o outro e procurar os que as } \\
\text { linhas coincidem. Se as linhas todas do } \\
\text { elemento, do alumínio estiverem todas na } \\
\text { estrela } 3 \text {, quer dizer que nessa estrela que } \\
\text { eu estou observando, lá tem alumínio. } \\
\text { P: Então o que eu vou fazer? Vou entregar } \\
\text { um conjunto para vocês de estrelas: estrela } \\
3,7 \text {, 4, e vou entregar a tabela de alguns } \\
\text { elementos que há nestas estrelas. Vocês } \\
\text { vão ter que simplesmente comparar e vão } \\
\text { me entregar uma folha dizendo a estrela } 3 \\
\text { tem e marcar o símbolo dos elementos que } \\
\text { lá tem. É um trabalho bem tranqüilo, mas } \\
\text { é o que exatamente fazem aí... }\end{array}$ & & 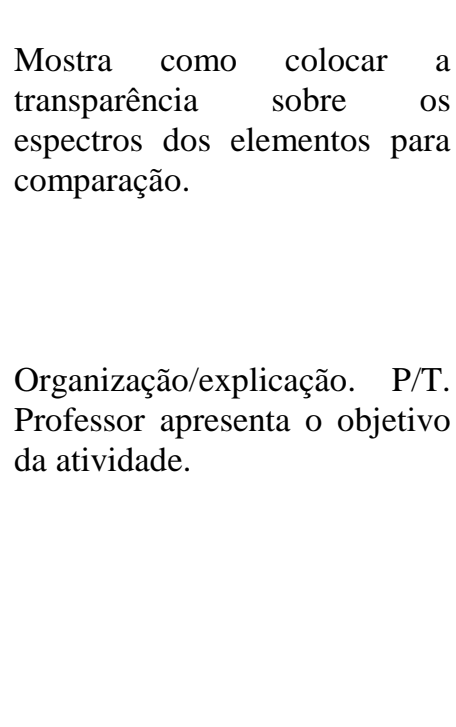 \\
\hline 08 & A5: Quem tem caneta ai? & & Organização. A/A. \\
\hline 09 & A4: Eu escrevo. & & \\
\hline 10 & $\begin{array}{l}\text { P: O grupo de vocês, aí... já temos aí os } \\
\text { grupos formados. }\end{array}$ & & $\mathrm{P} / \mathrm{T}$. \\
\hline 11 & $\begin{array}{l}\text { A5: Enquanto você escreve é nós aí, nós } \\
\text { zoa o trabalho. }\end{array}$ & & $\mathrm{A} / \mathrm{A}$. \\
\hline 12 & $\begin{array}{l}\text { A4: Olha a folha que você me dá, toda } \\
\text { suja aí seu porco. }\end{array}$ & & $\begin{array}{l}\text { Nesse instante o professor } \\
\text { entrega as folhas do grupo para } \\
\text { A1. }\end{array}$ \\
\hline 13 & A5: Você que é. & & \\
\hline 14 & A4: Inseto mesmo. & & \\
\hline 16 & $\begin{array}{l}\text { P: Eu vou deixar dois conjuntos com cada } \\
\text { grupo. } \\
\text { A3: O professor tá na Globo agora hein?... }\end{array}$ & $\begin{array}{l}\text { Manipulação de } \\
\text { materiais/manipulação } \\
\text { dos espectros. }\end{array}$ & $\begin{array}{l}\text { Organização. } \mathrm{P} / \mathrm{T} \text {. Professor } \\
\text { entrega o } 2^{\circ} \text { conjunto de folhas } \\
\text { para } \mathrm{A} 2 \text {, enquanto } \mathrm{A} 1 \text { observa } \\
\text { as que recebeu anteriormente. }\end{array}$ \\
\hline 17 & A4: Oh professor tá importante... & & \\
\hline 19 & A4: Que número você é haxixe? & $\begin{array}{l}\text { Manipulação de } \\
\text { materiais/manipulação } \\
\text { dos espectros. }\end{array}$ & $\begin{array}{l}\text { Após o professor entregar o } \\
\text { material, em cada grupo dois } \\
\text { ou mais alunos já começam a } \\
\text { fazer a atividade. }\end{array}$ \\
\hline 20 & A4: Seis? & & \\
\hline 21 & A5: Não três três. & & \\
\hline 22 & A2: Igual a seis. & & \\
\hline 23 & A5: Não é. Igual a 33 & & \\
\hline 24 & A2: Que número você é Marli? & & \\
\hline 25 & A6: Não sei. & & \\
\hline
\end{tabular}




\begin{tabular}{|c|c|c|}
\hline 26 & A4: E você? & \\
\hline 27 & A3: Oito. & \\
\hline 28 & $\begin{array}{l}\text { P: O que vocês receberam são os espectros } \\
\text { dos elementos. Agora eu vou entregar os } \\
\text { das estrelas que vocês têm que verificar. }\end{array}$ & Organização. P/T. \\
\hline 29 & A4: Seu nome é... & Organização. A/A. \\
\hline 30 & A2: Ariana. & \\
\hline 31 & A4: Número. & $\begin{array}{ll}\text { Organização. } \quad \mathrm{P} / \mathrm{T} ; & \mathrm{A} / \mathrm{A} . \quad \mathrm{O}\end{array}$ \\
\hline 32 & A2: Sete. & de estrelas. \\
\hline 33 & P: Estrela 1,2, 3,4 e 5. & $\begin{array}{l}\text { A2 e A3 começam a comparar } \\
\text { os espectros das estrelas e dos } \\
\text { elementos }\end{array}$ \\
\hline 34 & A4: Diego, que número você é? & $\begin{array}{l}\text { (emparelham a estrela com o } \\
\text { espectro). }\end{array}$ \\
\hline 35 & A1: Treze. & \\
\hline 36 & A2: RG de cada um aí, por favor. & \\
\hline 37 & $\begin{array}{l}\text { A6: Eu não tenho número ouviu Léo. } \\
\text { Esqueci em casa e não sei de cor. Esqueci } \\
\text { em casa. }\end{array}$ & \\
\hline 38 & A5: Tem que deixar na reta. & \\
\hline
\end{tabular}

Episódio 2 - análise da atividade do astrônomo mirim:

Momento 2 - alunos começam a fazer a atividade

\begin{tabular}{|l|l|l|l|}
\hline $\begin{array}{l}\text { Turno } \\
\text { de } \\
\text { fala }\end{array}$ & Linguagem verbal (oral ou escrita) & $\begin{array}{l}\text { Outras linguagens } \\
\text { Ações/gestos/ } \\
\text { Manipulação de } \\
\text { materiais }\end{array}$ & $\begin{array}{l}\text { Indicadores/ Tipos de } \\
\text { Interação/Comentários }\end{array}$ \\
\hline 39 & $\begin{array}{l}\text { P: Pessoal espera um minuto que eu } \\
\text { (inaudível). }\end{array}$ & $\begin{array}{l}\text { A4: Se eu sou policial já tinha jogado } \\
\text { você num camburão e sua mãe ia buscar } \\
\text { você na delegacia. }\end{array}$ & $\begin{array}{l}\text { P/T. } \\
\text { Enquanto A2 conversa } \\
\text { paralelamente com A6, A2, A3 } \\
\text { e A5 estão tentando fazer a } \\
\text { atividade. } \\
\text { Organização. A/A. A2 e A3 } \\
\text { tentam comparar os espectros } \\
\text { com a ajuda de A5. A1 } \\
\text { observa. }\end{array}$ \\
41 & A5: Também não; é a debaixo. & Manipulação \\
43 & A2: É a de baixo. & A5: Tem essas folhas aí também. & \\
44 & A2: Tem essas também... & \\
\hline
\end{tabular}




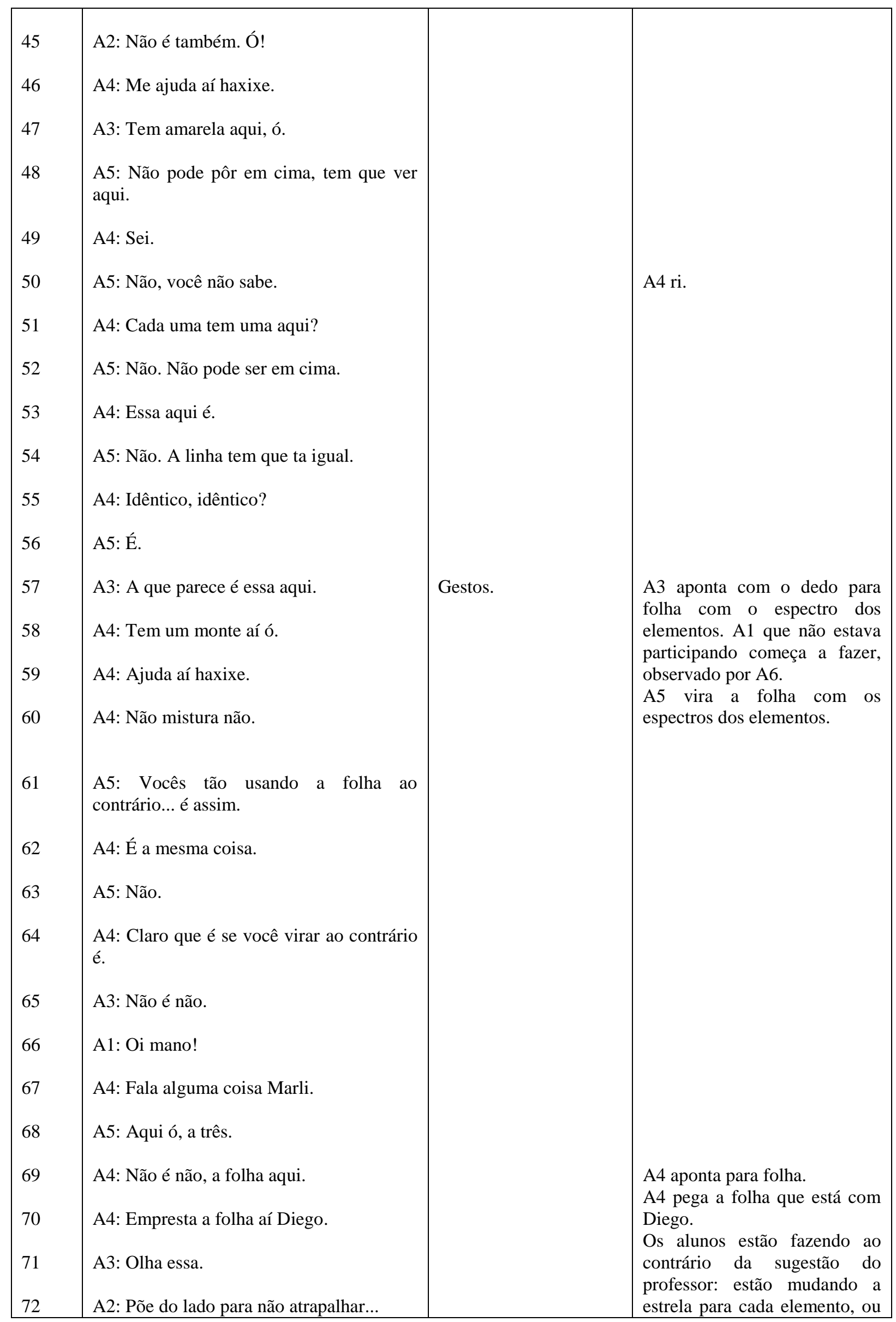




\begin{tabular}{|c|c|c|c|}
\hline 74 & $\begin{array}{l}\text { A4: Nesta folha é a resposta. } \\
\text { P: Aqui para próxima. }\end{array}$ & & $\begin{array}{l}\text { seja, em cada elemento eles } \\
\text { vão passando todas as estrelas. } \\
\text { P/T. O professor entrega uma } \\
\text { folha de sulfite. }\end{array}$ \\
\hline 75 & A3: É um desses. & & \\
\hline 76 & A4: Essa aqui ó. & & \\
\hline 77 & Ani: Aí, achou? & & \\
\hline 78 & Ani: É parecido. & & \\
\hline 79 & A4: Segura aqui. & & \\
\hline 80 & A3: To a caneta. & & \\
\hline 81 & A5: Já viu essa daí? & & $\begin{array}{l}\text { A5 fala para A3 enquanto } \\
\text { passa duas estrelas para A1. }\end{array}$ \\
\hline 83 & $\begin{array}{l}\text { A3: Essa aqui,é essa ó! } \\
\text { P: Tem que comparar todos os elementos. }\end{array}$ & Gestos. & $\begin{array}{l}\text { Fala para A2 enquanto segura } \\
\text { estrelas e aponta para espectros } \\
\text { dos elementos. }\end{array}$ \\
\hline 85 & $\begin{array}{l}\text { A1: Já achou a... achou uma? } \\
\text { A5: A estrela } 2 \text { então tem alumínio. }\end{array}$ & $\begin{array}{l}\text { Manipulação dos } \\
\text { espectros. }\end{array}$ & $\begin{array}{l}\text { Organização/classificação. } \\
\text { A/A. A2 pega estrelas da mão } \\
\text { de A1. }\end{array}$ \\
\hline 86 & A3: É alumínio & & $\begin{array}{l}\text { Nesse instante os alunos } \\
\text { observam e A1 manipula um } \\
\text { conjunto com A2; A3 com A4; }\end{array}$ \\
\hline 87 & Ani: Não é ó! & & $\begin{array}{l}\text { A5 sozinho e A6 só olha. } \\
\text { Alunos atentos. }\end{array}$ \\
\hline 88 & A2: Nossa, mas parece. & & A3 olha para conjunto de A2. \\
\hline 89 & A3: (Inaudível). & & $\begin{array}{l}\text { A3 aponta para o conjunto de } \\
\text { transparências e folhas com os }\end{array}$ \\
\hline 90 & $\begin{array}{l}\text { A5: Como é que vai responder vai } \\
\text { colocar... }\end{array}$ & & $\begin{array}{l}\text { espectros como se tivesse } \\
\text { achado um elemento. }\end{array}$ \\
\hline 91 & P: Cadê? Mostra aí. & & \\
\hline 92 & A4: Estrela $2 ? \ldots$ & & \\
\hline 93 & A5: A estrela 2 tem alumínio. & & \\
\hline 94 & A3: Tem mais uma aqui ó. & & \\
\hline 95 & A4: Como é que é Haxixe? Estrela 2. & & \\
\hline 96 & A5: Estrela $2 \ldots$ alumínio. & & \\
\hline 97 & $\begin{array}{l}\text { A6: Vocês nem contaram pra gente que } \\
\text { vocês tavam dançando. }\end{array}$ & & $\begin{array}{l}\text { Conversa paralela entre A6, } \\
\text { A1 e A5. }\end{array}$ \\
\hline 98 & $\begin{array}{l}\text { A1: Eu dancei e não me reconheci, velho, } \\
\text { dançando. }\end{array}$ & & \\
\hline 99 & $\begin{array}{l}\text { A5: Você não dançou, ficou balançando o } \\
\text { corpo. }\end{array}$ & & \\
\hline 100 & A4: Essa aqui já foi, né? & & A4 põe uma estrela de lado. \\
\hline
\end{tabular}




\begin{tabular}{|c|c|c|c|}
\hline 101 & $\begin{array}{l}\text { P: Pessoal, é o seguinte: cada estrela tem } 3 \\
\text { ou } 4 \text { elementos. Pode ter até alguma outra } \\
\text { que tem mais ou alguma outra que tem } \\
\text { menos, mas não é um único elemento... }\end{array}$ & & Organização. P/T. \\
\hline 102 & A5: Aqui não é. & & \\
\hline 103 & $\begin{array}{l}\text { P: Cadê ó, é bom vocês se organizarem e } \\
\text { fazerem uma de cada vez se não vão ter } \\
\text { um nó. }\end{array}$ & & Organização. P/G. \\
\hline 104 & P: Vai lá. & & \\
\hline 105 & P: E aí achou algum elemento? & & \\
\hline 106 & A5: Achamos. & & \\
\hline 107 & P: Cadê? & & \\
\hline 108 & A4: Cadê a 2. Esse aqui ó! & & \\
\hline 109 & A5: O 2. & & \\
\hline 110 & A5: A 2 tem alumínio. & & Classificação. \\
\hline 111 & P: Estrela 2 o que tem na estrela $2 ?$ & & \\
\hline 112 & A4: Alumínio. & & \\
\hline 113 & P: Tem alumínio. Por que tem alumínio? & & Classificação/organização. \\
\hline 114 & Aniy: Professor, faz favor! & & \\
\hline 115 & P: Mostra aí. & & \\
\hline 116 & A4: Bate aqui, ó! & $\begin{array}{l}\text { Gestos. Manipulação } \\
\text { dos espectros. }\end{array}$ & \\
\hline 117 & P: Tá bom. Só alumínio? & & \\
\hline 118 & A4: Como assim professor? & & \\
\hline $\begin{array}{l}119 \\
120\end{array}$ & $\begin{array}{l}\text { A3: Tem que testar nos outro, professor? } \\
\text { P: Péra aí, para aí, sobre o cálcio. Tem que } \\
\text { fazer coincidir o começo e o fim. Bom, } \\
\text { tem cálcio? }\end{array}$ & & $\begin{array}{l}\text { Mostra o conjunto e gesticula } \\
\text { com a mão segurando uma } \\
\text { caneta! Duas vezes, apontando } \\
\text { para as linhas da estrela e dos } \\
\text { elementos. }\end{array}$ \\
\hline 121 & A4: Não. & & \\
\hline 122 & A3: Não. & & \\
\hline 123 & P: Por que não? & & \\
\hline 124 & A3: porque as linhas não... (inaudível). & Gestos. & \\
\hline 125 & P: Oi? & & \\
\hline 126 & A3: Não tem as mesmas linhas & & \\
\hline
\end{tabular}




\begin{tabular}{|c|c|c|c|}
\hline 127 & P: As linhas não coincidem & & Explicação/Justificativa. \\
\hline 128 & A3: É. & & \\
\hline 129 & P: Desce, vamos pro debaixo. & $\begin{array}{l}\text { Manipulação dos } \\
\text { espectros. }\end{array}$ & $\begin{array}{l}\text { Mostra com gesto que não há } \\
\text { continuidade. }\end{array}$ \\
\hline 130 & P: Tem carbono? & & \\
\hline 131 & A5: Não, não dá não. & & \\
\hline 132 & $\begin{array}{l}\text { P: Não, não coincide. O de baixo tem } \\
\text { Hélio? }\end{array}$ & & \\
\hline 133 & A5: Vocês não viram essa? & & \\
\hline 134 & P: Mostra pra mim que coincide. Aonde? & & \\
\hline 135 & A3: Ah é. & & \\
\hline 136 & $\begin{array}{l}\text { P: Não tem Hélio, continua vocês vão ver } \\
\text { hidrogênio, ferro, depois muda de folha, e } \\
\text { compara lítio, magnésio, todos os } \\
\text { elementos. }\end{array}$ & & $\begin{array}{l}\text { A5 mostra com a caneta sobre } \\
\text { o conjunto que o professor } \\
\text { manipula. }\end{array}$ \\
\hline 137 & A2: O que essa aqui? $\mathrm{H}$ ? & & \\
\hline 138 & $\begin{array}{l}\text { A3: Hidrogênio; acho que é hidrogênio, né } \\
\text { professor? }\end{array}$ & & \\
\hline 139 & A4: Professor, "H" é hidrogênio? & & \\
\hline 140 & $\begin{array}{l}\text { P: Pode marcar só o símbolo, "H”, marca } \\
\text { "H". }\end{array}$ & & \\
\hline 141 & $\begin{array}{l}\text { Aniy: Professor, todos estes aqui que tem } \\
\text { que achar? }\end{array}$ & & $\begin{array}{l}\text { Organização/classificação. } \\
\text { A/A. A3 e A4 verificam } \\
\text { juntos. A1, A2 e A5 também } \\
\text { fazem enquanto A6 só observa. } \\
\text { A5 dá outra estrela para A4. }\end{array}$ \\
\hline 142 & A4: Péra aí tem que trocar de folha. & & $\begin{array}{l}\text { Os alunos comparam os } \\
\text { espectros sem falar nada. }\end{array}$ \\
\hline 143 & A3: Eu acho que é lítio, né? & & \\
\hline 144 & A5: Não achei nada meu. & & $\begin{array}{l}\text { Mostra a estrela em relação ao } \\
\text { gabarito }\end{array}$ \\
\hline 145 & A2: Esse daí é cheio de listinha ó. & & \\
\hline 146 & $\begin{array}{l}\text { A5: Esses aí não tem, esses aí não tem } \\
\text { essas estrelas. }\end{array}$ & & \\
\hline 147 & $\begin{array}{l}\text { A2: O tipo tem folha aí que agente não } \\
\text { tem. }\end{array}$ & & $\begin{array}{l}\text { Enquanto eles trabalham o } \\
\text { professor fala com outro } \\
\text { grupo. } \\
\text { A5 passa a folha para A2. }\end{array}$ \\
\hline 148 & A5: Vê essa aqui ó! & & \\
\hline 149 & $\begin{array}{l}\text { A2: Deixa essa aqui de lado. Já achou essa } \\
\text { aqui? }\end{array}$ & & \\
\hline 150 & $\begin{array}{l}\text { A5: Não, mas tem que ver com essa, } \\
\text { mesmo você achando tem que ver aqui se }\end{array}$ & & $\begin{array}{l}\text { A3 pega folha que estava com } \\
\text { A2. }\end{array}$ \\
\hline
\end{tabular}




\begin{tabular}{|c|c|c|c|}
\hline & tem. & & \\
\hline 151 & A5: Achou bastante? & & \\
\hline 152 & A4: A gente já viu, é Li. & & \\
\hline 153 & A3: Deixa eu ver? Acho que é tudo igual. & & Devolve a folha para Aa 2 \\
\hline 154 & A4: É que ele deu duas folhas. & & \\
\hline 155 & A5: Ele deu duas folhas por grupo. & & \\
\hline 156 & A4: Então terminou. & & \\
\hline 157 & A5: todas? & & \\
\hline 158 & A3: Terminou só a 2. & & \\
\hline 159 & A4: De uma estrela. & & \\
\hline 160 & A3: Terminou ó a 2. & & \\
\hline 161 & A1: Tem um documentário aí vai mostrar. & & \\
\hline 162 & A5: Sei não. & & \\
\hline 163 & $\begin{array}{l}\text { A1: Ô Professor! Vai ter um } \\
\text { documentário, e tal... alguma coisa? Como } \\
\text { é que é o esquema? }\end{array}$ & & $\begin{array}{l}\text { P/T. A1 faz referência à } \\
\text { filmagem da aula. }\end{array}$ \\
\hline 164 & $\begin{array}{l}\text { P: Não entendi. } \\
\text { A1: (Inaudível). }\end{array}$ & & $\begin{array}{l}\mathrm{P} \text { e A1 conversam sobre a } \\
\text { filmagem. } \\
\text { A1 fala a ouvido do } \\
\text { professor. }\end{array}$ \\
\hline 166 & P: (Inaudível). & & \\
\hline 167 & $\begin{array}{l}\text { A1: (inaudível)... que moral hein, } \\
\text { professor? }\end{array}$ & & \\
\hline 168 & P: (inaudível)... uma aula mais dinâmica. & & \\
\hline 169 & A1: Só nossa sala? & & \\
\hline 170 & A4: Verde? & & \\
\hline 172 & $\begin{array}{l}\text { A3: Verde tem aqui ó! } \\
\text { A1: O professor disse que nossa sala ficou } \\
\text { bacana sabia? Da hora. }\end{array}$ & Gestos. & $\begin{array}{l}\text { A3 aponta com o dedo a } \\
\text { posição da linha verde. } \\
\text { A5, A1 e A6 olham enquanto } \\
\text { A2 faz. }\end{array}$ \\
\hline 173 & A5: Foi legal, mesmo. & & \\
\hline 174 & A1: Só o nosso? & & $\begin{array}{l}\text { A4 e A3 continuam fazendo a } \\
\text { comparação entre os espectros. }\end{array}$ \\
\hline 175 & A5: Não, tem mais uma sala só. & & \\
\hline 176 & $\begin{array}{l}\text { A1: Nossa que tá tipo mandando bem. } \\
\text { Tipo ele escolheu e tal? }\end{array}$ & & \\
\hline 177 & A5: Ele mandou montar o grupo aí. O & & A5 volta a observar A3 e A4. \\
\hline
\end{tabular}




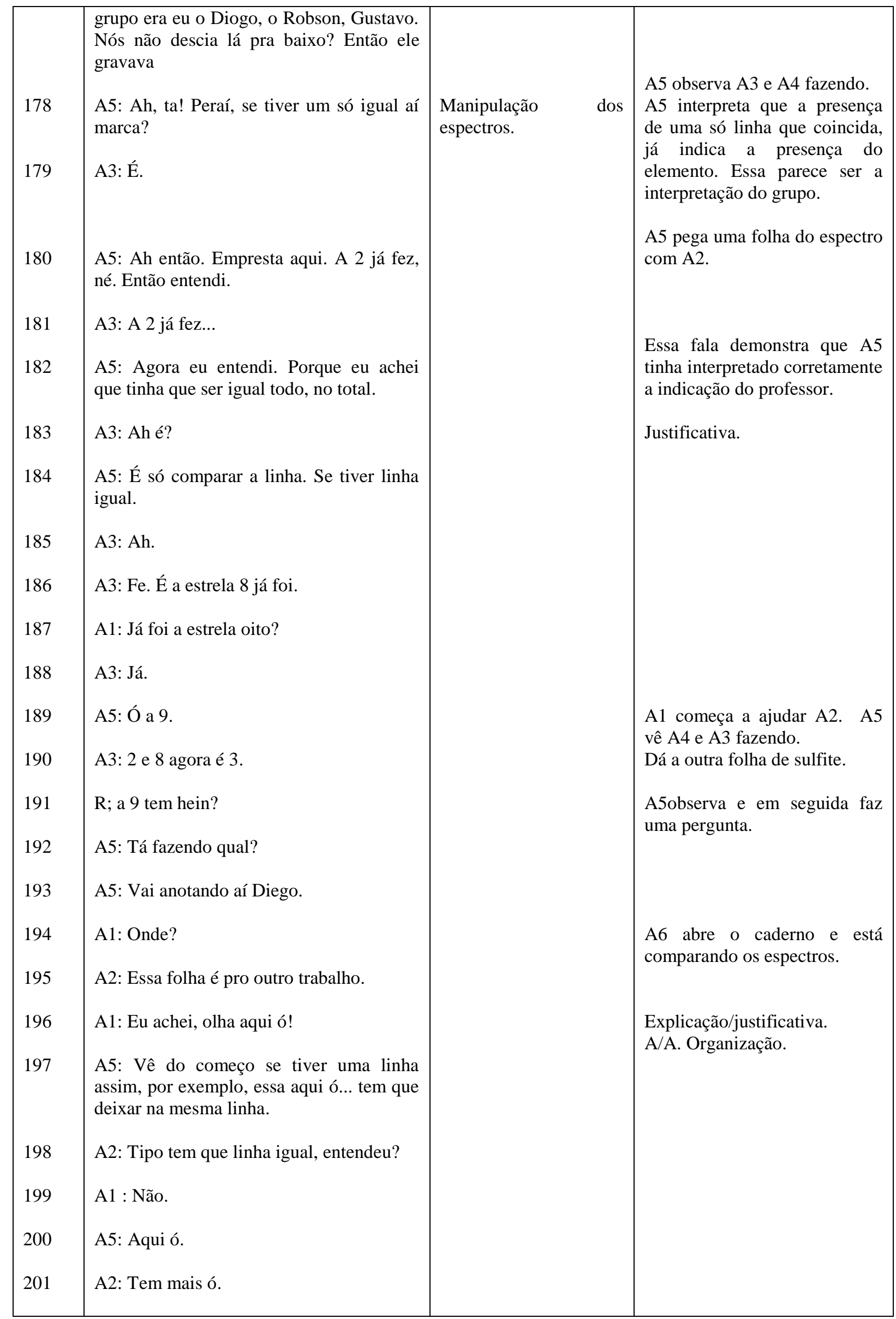




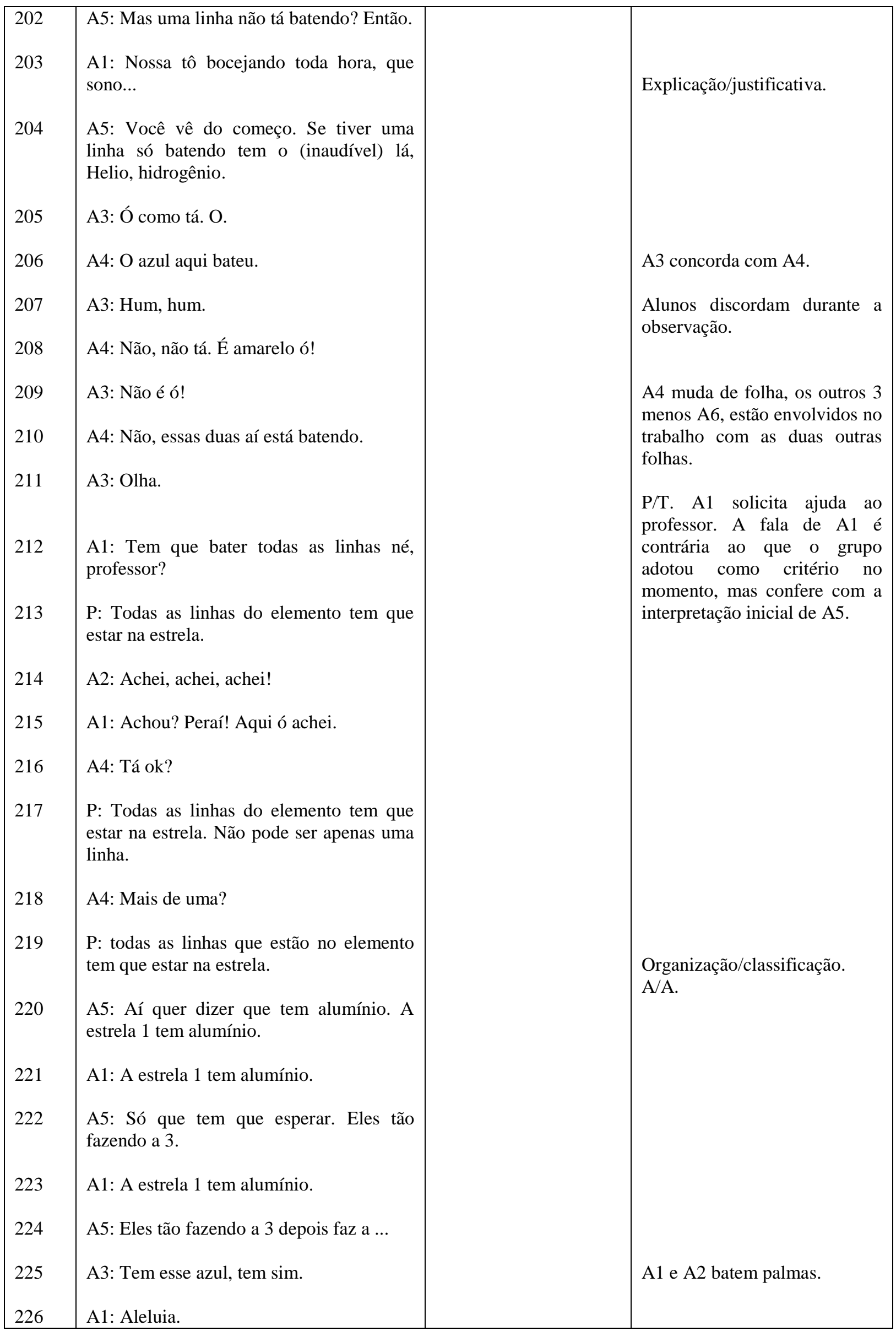




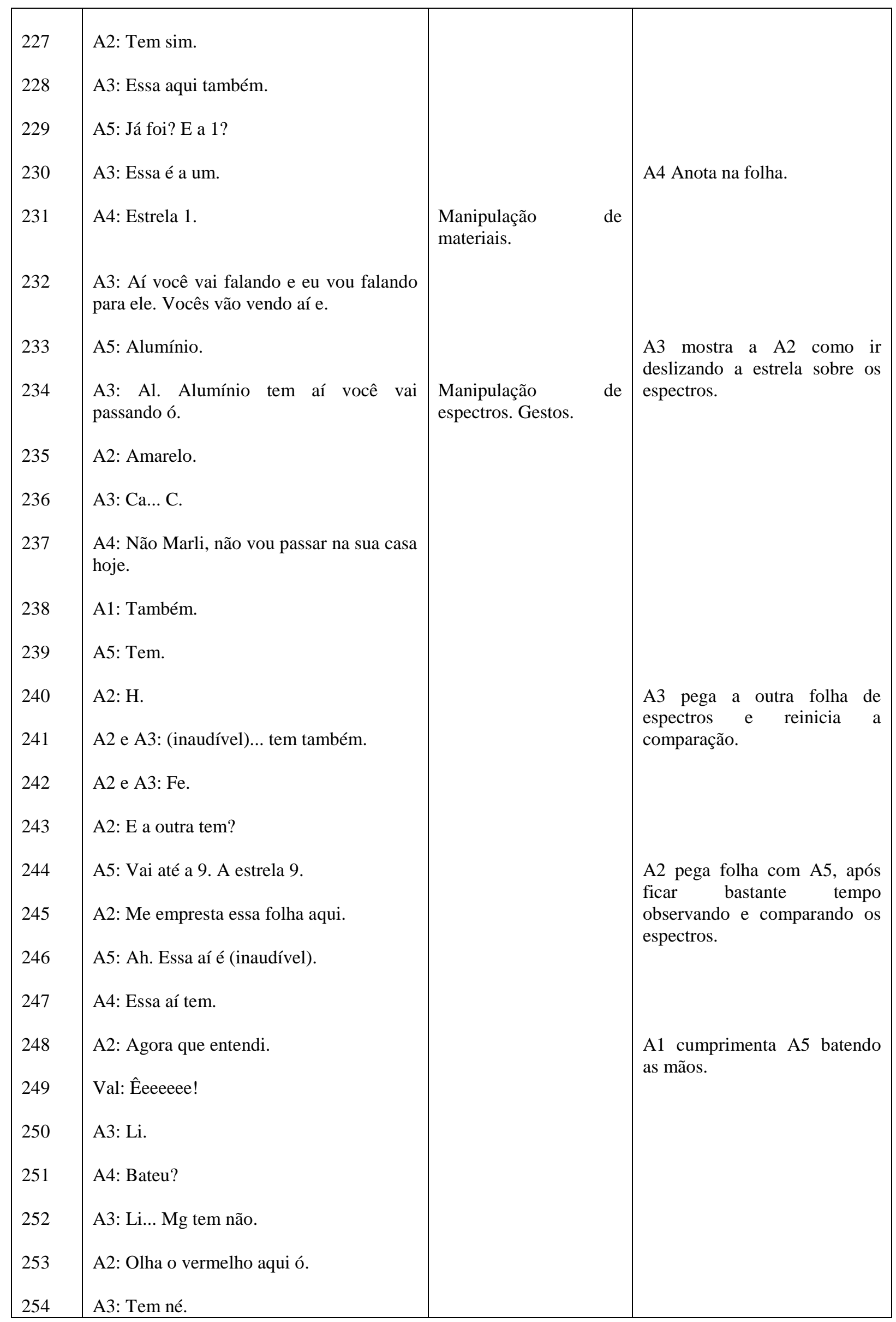




\begin{tabular}{|c|c|c|c|}
\hline 255 & A2: $\mathrm{Mg}$. & & \\
\hline 256 & $\begin{array}{l}\text { A1: Tem que dar a explicação, como vai } \\
\text { dar a explicação? Como vai falar se e } \\
\text { ferro. Como que é... }\end{array}$ & & \\
\hline 257 & A4: Então né, mas (inaudível). & & $\begin{array}{l}\text { A1 vira em direção ao outro } \\
\text { grupo. }\end{array}$ \\
\hline 258 & $\begin{array}{l}\text { A5: É só pra ver e anotar que tem, acho. } \\
\text { Depois ele vai mostrar no trabalho. }\end{array}$ & & A3 concorda com A4. \\
\hline 259 & A4: Tem esse amarelo aí do meio. & & \\
\hline 260 & A4: Não. & & \\
\hline 261 & A1: Professor. & & \\
\hline 262 & A3: Tem esse aqui. & & \\
\hline 263 & A3 e A2: Né? & & \\
\hline 264 & $\begin{array}{l}\text { A1: Professor, faz favor. Então como se } \\
\text { fala ferro, } \mathrm{Mg} \text {, tal...? Aí vai. }\end{array}$ & & \\
\hline 265 & $\begin{array}{l}\text { P: Você pode escrever só o símbolo. É } \\
\text { lítio, magnésio, neônio, hidrogênio, } \\
\text { oxigênio, sódio e xenônio. Mas pode } \\
\text { colocar só o símbolo. }\end{array}$ & & Repete fazendo gestos. \\
\hline 266 & A2: É... bate. & Gestos. & \\
\hline 267 & A3 e A2: Na. & & \\
\hline 268 & A3: É Xe. & & $\begin{array}{l}\text { A5 troca estrela com A3. } \\
\text { Ergue e mostra a estrela }\end{array}$ \\
\hline 269 & A1: Aí. Agora sim. Tava difícil. & & \\
\hline 270 & A2: Agora esse daqui ó! & $\begin{array}{l}\text { Manipulação dos } \\
\text { espectros. }\end{array}$ & \\
\hline 271 & A3: A 1 já foi. & & \\
\hline 272 & A2: E esse daqui? & & \\
\hline 273 & A3: É 6 ou 9? & & \\
\hline 274 & A1: 9 & & $\begin{array}{l}\text { Organização/classificação. P/G } \\
\text { e A/A. Todos menos A6 estão }\end{array}$ \\
\hline 275 & A1: Professor, é 6 ou 9? ... 6? ... 9? 6? & & $\begin{array}{l}\text { envolvidos com o trabalho. A1 } \\
\text { fez sua pergunta depois de }\end{array}$ \\
\hline 276 & P: Não. 9. & & $\begin{array}{l}\text { observar atentamente } \\
\text { espectros. }\end{array}$ \\
\hline 277 & A1: É 9. & & \\
\hline 278 & A5: 9 tem que colocar do lado da outra. & & \\
\hline 279 & $\begin{array}{l}\text { A1: É nove, nossa, péra aí, péra aí... não; } \\
\text { não bateu. }\end{array}$ & & \\
\hline 280 & A4: Não deu não. Tem que dá retinho. & & A5 fala em tom de brincadeira. \\
\hline
\end{tabular}




\begin{tabular}{|c|c|c|c|}
\hline 281 & A5: Diego você não deu não. & \multirow{27}{*}{$\begin{array}{l}\text { Manipulação dos } \\
\text { espectros. }\end{array}$} & \multirow{27}{*}{$\begin{array}{l}\text { Organização. P/T. } \\
\text { Classificação/organização. } \\
\text { A/A. Os alunos estão } \\
\text { marcando se tem } 1 \text { linha em } \\
\text { comum e não quando bate o } \\
\text { espectro inteiro. }\end{array}$} \\
\hline 282 & A4: A verde eu acho que deu. & & \\
\hline 283 & A3: Essa verde deu ó, é Ni. & & \\
\hline 284 & A5: Cadê? Qual é a verde? & & \\
\hline 285 & $\begin{array}{l}\text { A5: Só que a linha não é da mesma } \\
\text { grossura. }\end{array}$ & & \\
\hline 286 & A5: Bateu não. & & \\
\hline 287 & $\begin{array}{l}\text { P: Pessoal, estamos terminando? Vamos } \\
\text { para a segunda atividade? }\end{array}$ & & \\
\hline 288 & $\begin{array}{l}\text { A1: Não professor, pêra aí, estamos } \\
\text { acabando, é uma aula, dá um tempo. }\end{array}$ & & \\
\hline $\begin{array}{l}289 \\
290\end{array}$ & $\begin{array}{l}\text { A5: Não esse aqui foi o que já... } \\
\text { A4: Você bateu a vermelho aí. }\end{array}$ & & \\
\hline 291 & A3: Ah é, a vermelha, essa aqui. & & \\
\hline 292 & A3: Essa também ó. & & \\
\hline 293 & $\mathrm{~A} 3: \mathrm{Ne}$ & & \\
\hline 294 & A2: Essa bateu. & & \\
\hline 295 & A1: Bateu aqui também. & & \\
\hline 296 & A3 e A2: N. & & \\
\hline 297 & A3: Vermelha também... Ne. & & \\
\hline 298 & A4: O que? & & \\
\hline 299 & A3: Na. & & \\
\hline 300 & A2: Aqui também ó. & & \\
\hline 301 & A3: Xe. & & \\
\hline 302 & A5: Agora vem o alumínio. & & \\
\hline 303 & A3: Essa não a verde só... (inaudível). & & \\
\hline 304 & $\begin{array}{l}\text { A1: Ficou legal as fotos né Marli? Dá hora } \\
\text { né? Só passando assim! }\end{array}$ & & \\
\hline 305 & 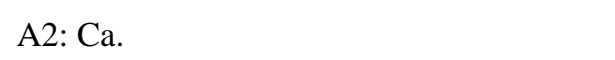 & & \\
\hline 306 & A1: Peraí, peraí, não. & & \\
\hline 307 & A2: Ca ó! & & \\
\hline 308 & A1: Não, não, não, olha aqui Priscila. & & \\
\hline
\end{tabular}




\begin{tabular}{|c|c|c|}
\hline 309 & A2: Como não, aqui ó. & $\begin{array}{l}\text { Os alunos do grupo olham para } \\
\text { mesmo espectro com }\end{array}$ \\
\hline 310 & A5: Essa linha está meio dividida ó... & exceção de A6. \\
\hline 311 & A1: É tá dividida. & \\
\hline 312 & $\begin{array}{l}\text { A5: Aqui tem dois verdes junto, aqui só } \\
\text { tem um. }\end{array}$ & \\
\hline 313 & A1: Tem não. & \\
\hline 314 & A5: Tem não. & \\
\hline 315 & A4: Tem um aqui ó,... & \\
\hline 316 & A3: Tem não. & \\
\hline 317 & A4: Ó, eu achei essa aqui! & \\
\hline 318 & A3: É, é S. & \\
\hline 319 & A1: Como essa daqui tem aqui. & \\
\hline 320 & A3: O verde aqui ó! & \\
\hline 321 & $\begin{array}{l}\text { A2: Não precisa ter todas, basta uma linha } \\
\text { só. }\end{array}$ & \\
\hline 322 & $\begin{array}{l}\text { A1: Não. Basta uma linha, mas aqui... } \\
\text { peraí. }\end{array}$ & \\
\hline 323 & A5: Põe direito, tá torto. & \\
\hline 324 & A2: Torto. & \\
\hline 325 & A3: Tá vendo. & \\
\hline 326 & A5: Já num tá quase na reta. & \\
\hline 327 & A2: É... tem diferença né? Também não. & \\
\hline 328 & A5: Nem essa. & $\begin{array}{l}\text { A3 passa detalhadamente a } \\
\text { estrela sobre os espectros }\end{array}$ \\
\hline 329 & A3: É, He. & $\begin{array}{l}\text { depois de afirmar que é He, em } \\
\text { seguida vão para outro }\end{array}$ \\
\hline 330 & A5: Tá errado? & espectro e afirmam que é $\mathrm{H}$. \\
\hline 331 & A3: H. & $\begin{array}{l}\text { A4 continua anotando as } \\
\text { respostas. }\end{array}$ \\
\hline 332 & A1: Ferro. & \\
\hline 333 & A2: Acabou né. & \\
\hline 334 & A1: Cabo? Deixa eu ver. & $\begin{array}{l}\text { Organização. P/G. O professor } \\
\text { vem verificar como os alunos }\end{array}$ \\
\hline 336 & $\begin{array}{l}\text { P: Estrela } 8 \text {, cadê? ... Pega a estrela } 8 \text { aí e } \\
\text { vamos conferir essa estrela } 8 \text {. } \\
\text { A1: Ah, professor. }\end{array}$ & $\begin{array}{l}\text { estão fazendo e considera que } \\
\text { tem muitos elementos para } \\
\text { cada estrela. Com a fala do } \\
\text { professor os alunos percebem }\end{array}$ \\
\hline
\end{tabular}




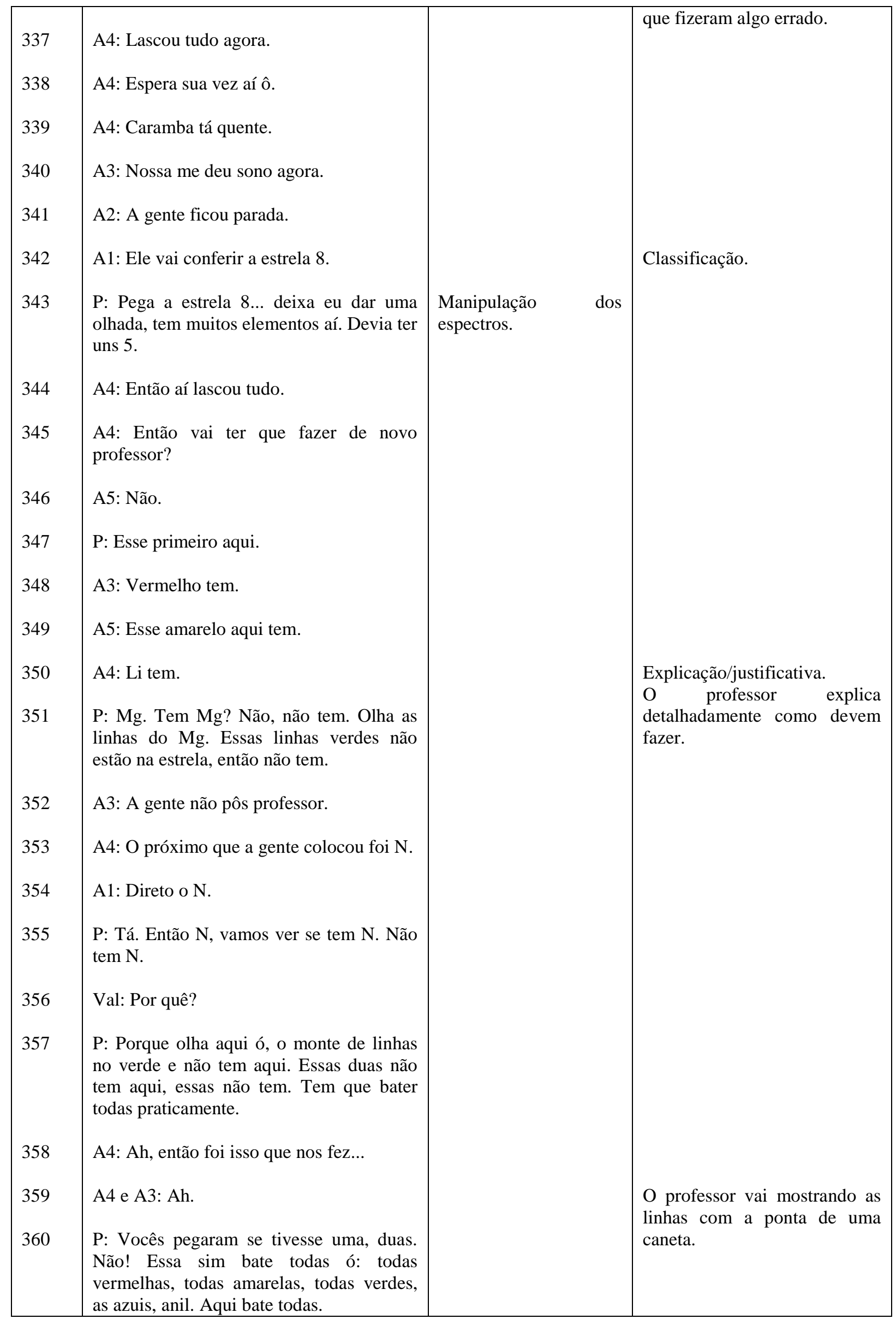




\begin{tabular}{|l|l|l|l|}
\hline 361 & A3: Ô, tem. & & \\
\hline
\end{tabular}

Episódio 2 - análise da atividade do astrônomo mirim:

\section{Momento 3 - alunos começam a refazer a atividade}

\begin{tabular}{|c|c|c|c|}
\hline $\begin{array}{l}\text { Turno } \\
\text { de } \\
\text { fala }\end{array}$ & Linguagem verbal (oral ou escrita) & $\begin{array}{l}\text { Outras linguagens } \\
\text { Ações/gestos/ } \\
\text { Manipulação de } \\
\text { materiais } \\
\end{array}$ & $\begin{array}{lcc}\text { Indicadores/ } & \text { Tipos } & \text { de } \\
\text { Interação/Comentários } & \end{array}$ \\
\hline 362 & $\begin{array}{l}\text { P: Vocês vão ter que conferir. Vocês vão } \\
\text { ter que ser um pouco mais rápidos. Tem } \\
\mathrm{Na} \text { ? }\end{array}$ & $\begin{array}{l}\text { Manipulação dos } \\
\text { espectros. }\end{array}$ & $\begin{array}{l}\text { Organização/classificação. } \\
\text { P/G. }\end{array}$ \\
\hline 363 & A3: Tem. & & $\begin{array}{l}\text { Os alunos ainda classificam } \\
\text { incorretamente. }\end{array}$ \\
\hline 364 & P: Não tem. Não tem. & & \\
\hline 365 & A3: Nem aqui? & & \\
\hline 366 & $\begin{array}{l}\text { P: Porque esse amarelo tá aqui. Até tem } \\
\text { um vermelho aqui que parece, mas olha } \\
\text { aqui no... tem um laranja tem umas linhas } \\
\text { que não tem, linhas no verde que não tem, } \\
\text { linhas que não tem. }\end{array}$ & & Explicação/justificativa. \\
\hline 367 & A4: Não tem Na, certo? & & \\
\hline 368 & A3: Xe tem aí? & & \\
\hline 369 & A4: Xe. & & \\
\hline 370 & P: Xenônio, tem xenônio? & & \\
\hline 371 & $\begin{array}{l}\text { P: Nem pensar. Tem milhões de linhas no } \\
\text { xenônio, quer dizer uma centena aí olha aí } \\
\text { não tem nada dessas linhas aqui. }\end{array}$ & & \\
\hline 372 & $\begin{array}{l}\text { A4: Tá me xingando aí? O que é que você } \\
\text { tá falando aí o comedor de cachorro? }\end{array}$ & & $\begin{array}{l}\text { A/A. A4 fala para um aluno do } \\
\text { outro grupo. }\end{array}$ \\
\hline 373 & A1: Ca. & & \\
\hline 374 & A3: Esse também não tem. & & A3 acerta a classificação. \\
\hline 375 & $\begin{array}{l}\text { P: Não. Você tem as linhas aqui do verde } \\
\text { e do vermelho que não tem. }\end{array}$ & & \\
\hline 376 & A4: Vai riscando aí Diego. & $\begin{array}{l}\text { Manipulação } \\
\text { materiais. }\end{array}$ & Organização. \\
\hline 377 & Val: Ca. & & \\
\hline
\end{tabular}




\begin{tabular}{|c|c|c|c|c|}
\hline 378 & $\begin{array}{l}\text { P: Tem um verde aí que não tem, então já } \\
\text { não tem. }\end{array}$ & & & \\
\hline 379 & P: Carbono tem? & & & \\
\hline 380 & A1: Aqui tem, tem aqui ó. & $\begin{array}{l}\text { Manipulação } \\
\text { espectros. }\end{array}$ & $\operatorname{dos}$ & \\
\hline 381 & $\begin{array}{l}\text { P: Vermelho tem, amarelo, amarelo tem, } \\
\text { verde, verde tem, azul, azul tem, anil tem, } \\
\text { carbono tem. }\end{array}$ & & & $\begin{array}{l}\text { A1 acertou a classificação. } \\
\text { A6 e A5 estão brincando. }\end{array}$ \\
\hline 382 & P: Tem esse? & & & \\
\hline 383 & A4: Não. & & & \\
\hline 384 & A4: H não. H você risca aí. & & & $\begin{array}{l}\text { Classificação/organização. } \\
\text { A/A. }\end{array}$ \\
\hline 385 & P: Tem este? & & & \\
\hline 386 & A3: Na não tem. & & & Classificação. P/G, A/A. \\
\hline 387 & P: Tem ou não? & & & \\
\hline 388 & A4:Tem. & & & \\
\hline 389 & P: Por que tem? & & & \\
\hline 390 & A4: $\mathrm{O}$ azul. & & & \\
\hline 391 & P: É isso aí. É tem. Esse aqui? & & & \\
\hline 392 & Val: Tem, não tem. & & & \\
\hline 393 & $\begin{array}{l}\text { A4: Esse vermelho, tá sobrando um monte } \\
\text { de linha em cima aí.Tá peraí. }\end{array}$ & & & \\
\hline 394 & P: Esses vermelhos. Tá. E agora? & & & \\
\hline 395 & A5: Ó amarelo? & & & \\
\hline 396 & P: Não bate. & & & \\
\hline 397 & $\begin{array}{l}\text { P: Até aparece aqui ó, tem duas linhas do } \\
\text { verde que aqui não tem, uma linha do azul } \\
\text { que não tem,mais duas do azul que não } \\
\text { tem. Sejam um pouco mais rápidos e tem } \\
\text { que dar uma olhada. }\end{array}$ & & & $\begin{array}{l}\text { Organização. P/G. O professor } \\
\text { solicita que sejam mais rápidos } \\
\text { e que confiram aqueles já } \\
\text { feitos. }\end{array}$ \\
\hline 398 & P: Confira, agora. & & & \\
\hline 399 & $\begin{array}{l}\text { P: Pessoal, as estrelas devem ter aí quatro } \\
\text { ou cinco elementos. Não tem dez } \\
\text { elementos, não tem, não tem. Não está } \\
\text { correto. }\end{array}$ & & & Organização. P/T. \\
\hline 400 & $\begin{array}{l}\text { A4: Nove. Esse aqui tem? } \\
\text { A5: Tem não. }\end{array}$ & $\begin{array}{l}\text { Manipulação } \\
\text { espectros. }\end{array}$ & & $\begin{array}{l}\text { Organização/classificação. } \\
\text { A/A. }\end{array}$ \\
\hline 402 & A4: Risca lá. & Manipulação & dos & \\
\hline
\end{tabular}




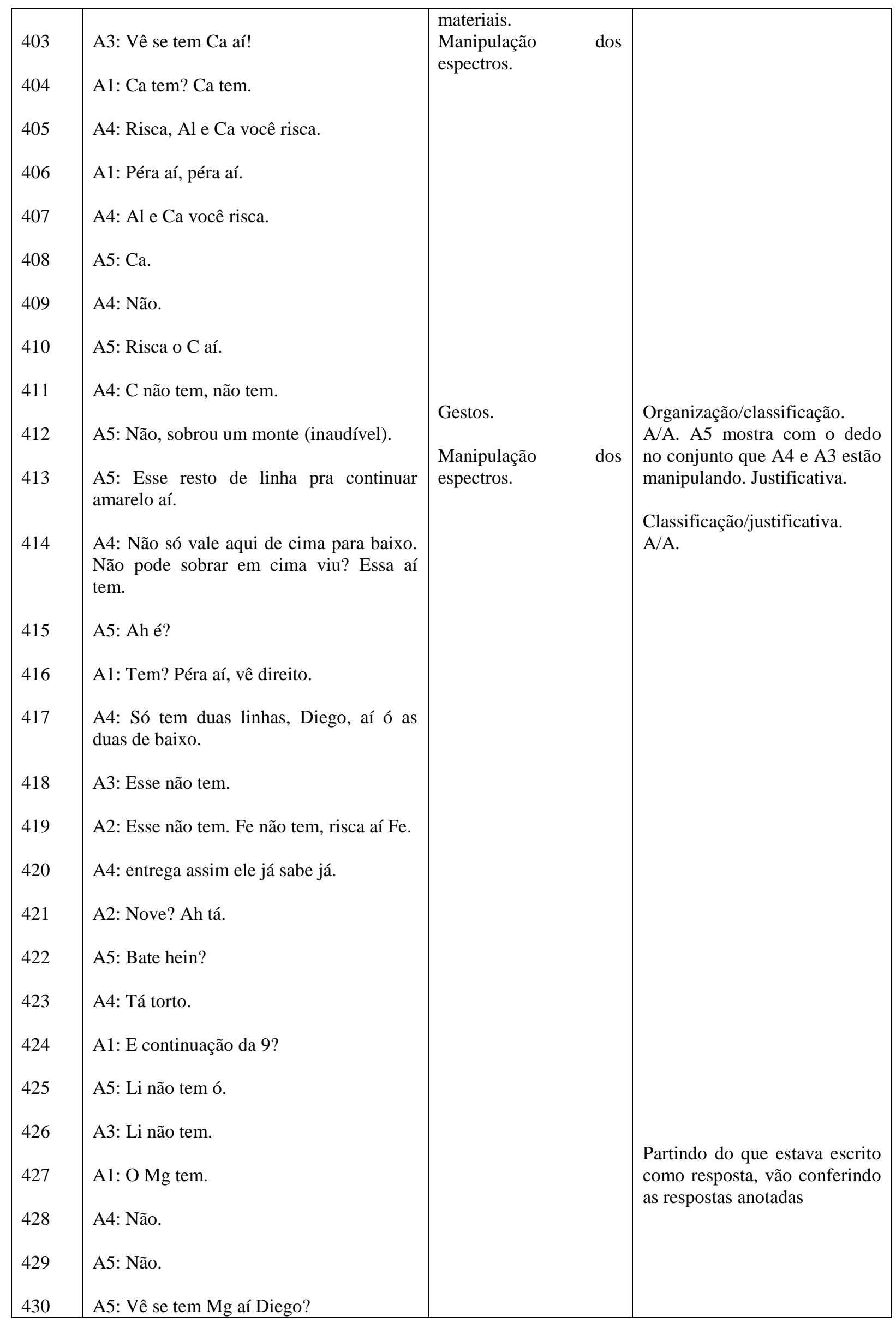




\begin{tabular}{|c|c|c|c|}
\hline 431 & A3: Tá torto olha é aqui ó! & & \\
\hline 432 & A1: Desculpa então. & & \\
\hline 433 & A2: Tem o MG aí? & & \\
\hline 434 & A5: Risca. & $\begin{array}{l}\text { Manipulação dos } \\
\text { materiais. }\end{array}$ & $\begin{array}{l}\text { Organização/classificação. } \\
\text { A/A. }\end{array}$ \\
\hline 435 & A4: Ne também não. & $\begin{array}{l}\text { Manipulação } \quad \text { dos } \\
\text { espectros. }\end{array}$ & \\
\hline 436 & A1: Risca também? & & \\
\hline 437 & A5: Risca. & & \\
\hline 438 & A1: Aqui bate. Bate aqui as três aqui ó? & & $\begin{array}{lll}\mathrm{Na} \text { conversa } & \text { dos } & \text { alunos } \\
\text { percebemos } & \text { uma } & \text { grande }\end{array}$ \\
\hline 440 & $\begin{array}{l}\text { A5: Não. É a azul que esta sobrando } \\
\text { aqui?... E o Ne. } \\
\text { A1: Já foi. N. }\end{array}$ & & $\begin{array}{l}\text { interação e também a } \\
\text { dificuldade em classificar os } \\
\text { elementos presentes em cada } \\
\text { estrela. }\end{array}$ \\
\hline 441 & A4: $\mathrm{N}$ bate. & & \\
\hline 442 & A2: Esse aí bate. & & \\
\hline 443 & A1: Certíssimo. & & \\
\hline 444 & A1: Ô. & & \\
\hline 445 & A4: Esse bate também. & & \\
\hline 446 & A1: Bate. & & \\
\hline 447 & A5: E o azul? & & \\
\hline 448 & A2: É esse não bate. & & \\
\hline 449 & A5: $\mathrm{Na} ?$ & & \\
\hline 450 & A4: Na risca. & & \\
\hline 451 & A1: É a 9 essa daí? & & \\
\hline 452 & A5: É. & & \\
\hline 453 & A2: Essa também não. & & \\
\hline 454 & A3: Xe. & & \\
\hline 455 & $\begin{array}{l}\text { A5: É aqui ó. Essa? A de cima também. } \\
\text { Não, não acabou. }\end{array}$ & & \\
\hline 456 & A3: Não. & & \\
\hline 457 & A2: Não, não, não acabou. & & \\
\hline 458 & A1: Aqui tem esse Ferro aqui, carbono. & & \\
\hline 459 & A5: Qual que é essa? É a três. & & \\
\hline
\end{tabular}




\begin{tabular}{|c|c|c|c|}
\hline 460 & A5: Passa pra três aí. & & \\
\hline 461 & A5: Não porque o vermelho sobra ó. & & Justificativa. A/A. \\
\hline 462 & A2: Li não tem, Li não tem. & & Classificação. \\
\hline 463 & A1: A três. & $\begin{array}{l}\text { Manipulação dos } \\
\text { espectros. }\end{array}$ & Classificação/organização. \\
\hline 464 & A5: Risca? & & \\
\hline 465 & A3: Risca. & & \\
\hline 466 & A2: Mg. & & \\
\hline 467 & A3: Mg também não. & & \\
\hline 468 & A2: Mg risca. & & \\
\hline 469 & A5: Vê se tem $\mathrm{Ne}$. & & \\
\hline 470 & A4: Também não. Ne risca. & & \\
\hline 471 & $\begin{array}{l}\text { A5: No vermelho aqui sobra ó. Aqui o } \\
\text { vermelho sobra. }\end{array}$ & & \\
\hline 472 & A4: Sobra amarelo também. & & \\
\hline 473 & A5: Sobrou esse vermelho. & & \\
\hline 474 & A3: Na não tem aí não. Xe tem. & & \\
\hline 475 & A5: Só que sobra. & & \\
\hline 476 & A4: Sobra aqui ó. & & \\
\hline 477 & A3: É. & & \\
\hline 478 & A2: Tira. & & \\
\hline 479 & A5: Esse aí bateu. & & \\
\hline 480 & A4: Deixa, deixa. & & \\
\hline 481 & A4: Bateu também. & & \\
\hline 482 & A2: Ca deixa. & & \\
\hline 483 & A5: Essa não risca aí o C tá. & & \\
\hline 484 & A1: Onde? C não tem. & & \\
\hline 485 & A2: Essa não tem. Essa aí qual que é? & & \\
\hline 486 & A5 e A3: He! & & \\
\hline 487 & A2: He você tira. & & \\
\hline 488 & A4: $\mathrm{H}$ tem. & & \\
\hline
\end{tabular}




\begin{tabular}{|c|c|c|c|}
\hline 489 & A3: $\mathrm{H}$ tem. & & \\
\hline 490 & A1: H não tem. & & \\
\hline 491 & A4: $\mathrm{H}$ tem, deixa. & & \\
\hline 492 & A2: H tem aqui ó! & $\begin{array}{l}\text { Manipulação dos } \\
\text { espectros. }\end{array}$ & \\
\hline 493 & A4: Essa bateu. & & \\
\hline 494 & A2: Essa bateu. & & \\
\hline 495 & A1: Essa bateu, ferro bateu. & & \\
\hline 496 & A5: Deixa. & & \\
\hline 497 & A2: Fe, ferro. & & \\
\hline 498 & A5: Deixa ô. & & \\
\hline 499 & A1: Estou cego cara. & & \\
\hline 500 & A4: Diego é uma comédia cara. & & \\
\hline 501 & A1: Sou cego cara. & & \\
\hline 502 & $\begin{array}{l}\text { A1: Professor, não vi ferro aqui não cara, } \\
\text { sou ceguinho! }\end{array}$ & & $\begin{array}{l}\text { Organização/classificação. } \\
\text { P/G. A1 relata ao professor sua } \\
\text { dificuldade para identificar a }\end{array}$ \\
\hline 503 & A2 e A3: Al. & & presença do elemento $\mathrm{Fe}$. \\
\hline 504 & A5: Essa é a estrela 8. & & Classificação. A/A. \\
\hline 505 & A3: Al não tem. & & \\
\hline 506 & A2: Essa não tem Ca né? & & \\
\hline 507 & A3: É Ca não tem. & & \\
\hline 508 & A5: Essa daí. & & \\
\hline 509 & A5: Bateu, bateu. & & \\
\hline 510 & A3: C tem né? & & \\
\hline 511 & A2: Esse não, He não tem também. & & \\
\hline 512 & A4: $\mathrm{H}$ bateu. & & \\
\hline 513 & A3: Essa bateu. & & \\
\hline 514 & A4: Não bateu. & & $\begin{array}{l}\text { Neste instante A4 já faz } \\
\text { referência a outro elemento. }\end{array}$ \\
\hline 515 & A2: Nem tem aqui, Li não bateu. & & \\
\hline 516 & A1: Tô ceguinho cara. & & \\
\hline 517 & A3: Li tira? Tira, tira também Mg. & & \\
\hline 518 & A5: Não tem ó o vermelho aqui. & & Justificativa. A/A. Ao fornecer \\
\hline
\end{tabular}




\begin{tabular}{|c|c|c|c|}
\hline 520 & $\begin{array}{l}\text { P: Tem Ne? } \\
\text { A5: Ne, tem } \mathrm{Ne} ?\end{array}$ & & $\begin{array}{l}\text { sua explicação A5 indica a } \\
\text { posição da cor vermelha que } \\
\text { não está presente nos dois } \\
\text { espectros observados. }\end{array}$ \\
\hline 521 & A5: Tem não. É esse aqui ó. & & \\
\hline 522 & P: Tem neônio? & $\begin{array}{l}\text { Manipulação dos } \\
\text { espectros. }\end{array}$ & $\begin{array}{l}\text { P/G. } \\
\text { Classificação/organização. }\end{array}$ \\
\hline 523 & A5: Quem colocou esse aqui ó? "Me"? & & \\
\hline 524 & A3: É Ne! Pode riscar. & & \\
\hline 525 & A5: Esse $\mathrm{Ne}$, ta errado de riscar. & & \\
\hline 526 & A3: N também não. & & O professor observa o grupo. \\
\hline 527 & P: Tem nitrogênio? & & \\
\hline 528 & Val: Não. & & \\
\hline 529 & A4: Esse aí. & & \\
\hline 530 & $\begin{array}{l}\text { A2: Não. O (oxigênio) também pode } \\
\text { riscar na... }\end{array}$ & & \\
\hline 531 & A4: Pode riscar. & & \\
\hline 532 & A4: Essa também. & & \\
\hline 533 & A2: Esse também, Na, não. & & \\
\hline 534 & A5: Não tem Xe, essa aqui tá certo? & & \\
\hline 535 & A5: A cinco aí hein? & & \\
\hline 536 & A5: E a dois? & & \\
\hline 537 & A4: Li pode riscar, $\mathrm{Mg}$. & & \\
\hline 538 & A2: Mg não tem. & & \\
\hline 539 & A3: Essa também não. & & \\
\hline 540 & A5: Não bate, o Ne. & & \\
\hline 541 & A5: Ne não bateu. & & \\
\hline 542 & $\begin{array}{l}\text { A2: Também não em } \mathrm{N} \text { é nitrogênio não } \\
\text { é? }\end{array}$ & & \\
\hline 543 & A4: Também não. & & \\
\hline 544 & A1: Charlie Brown Jr. Charlie Brown. & & $\begin{array}{l}\text { A1 brinca um pouco durante a } \\
\text { realização da atividade. }\end{array}$ \\
\hline 545 & A2: É nóis. & & \\
\hline 546 & A2: Bate. & & \\
\hline 547 & A3 e A5: Alumínio bateu. & & \\
\hline
\end{tabular}




\begin{tabular}{|l|l|l|l|}
\hline 548 & A3: Não tem Helio e hidrogênio. & & \\
549 & A2: Só tem Helio e hidrogênio. & & \\
550 & A3: Essa também não. & & \\
551 & A5: Helio bate. & & \\
552 & A2: Então Hélio e hidrogênio. & & \\
553 & A5: K? & A2: Agora vai pro hidrogênio cabô. & \\
554 & $\begin{array}{l}\text { A2: Professor chega aí. Precisa passar a } \\
\text { limpo ou da pra... }\end{array}$ & & \\
556 & A5: Passa a caneta sim ô. & $\begin{array}{l}\text { Organização. P/G. Professor } \\
\text { recolhe as folhas referentes à } \\
\text { atividade. }\end{array}$ \\
\hline
\end{tabular}

Episódio 2 - análise da atividade do astrônomo mirim:

Momento 4 - professor inicia explicação/sistematização e apresenta novos problemas

\begin{tabular}{|l|l|l|l|}
\hline $\begin{array}{l}\text { Turno } \\
\text { de } \\
\text { fala }\end{array}$ & Linguagem verbal (oral ou escrita) & $\begin{array}{l}\text { Outras linguagens } \\
\text { Ações/gestos/ } \\
\text { Manipulação de } \\
\text { materiais }\end{array}$ & $\begin{array}{l}\text { Indicadores/ Tipos de } \\
\text { Interação/Comentários }\end{array}$ \\
\end{tabular}




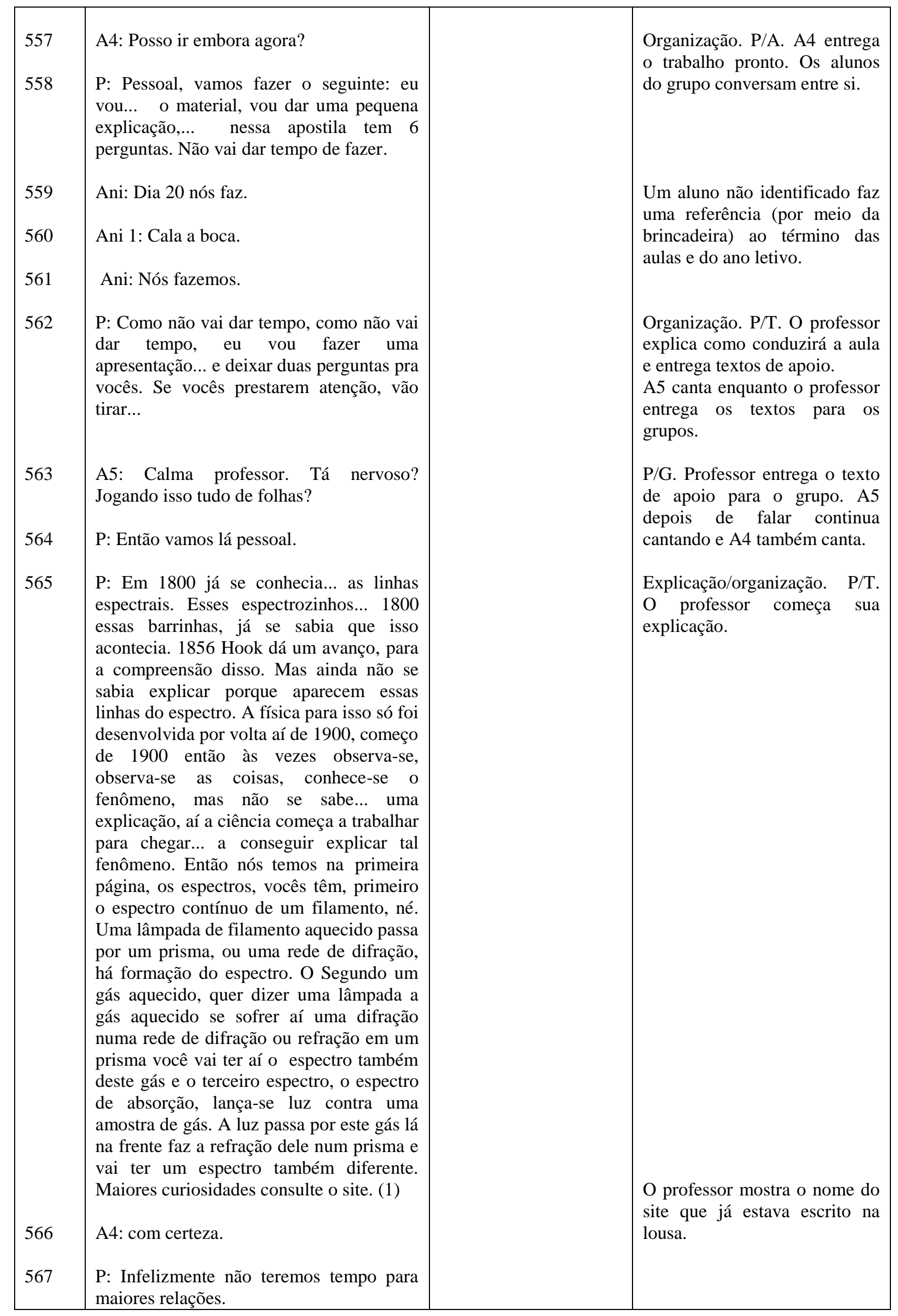



relato simples. Quem deixa um pouco mais claro o surgimento das linhas... elas ficam mais claras com os trabalhos de Bohr... O que o Bohr propõe? Ele propõe o modelo atômico, que nós tivemos os três principais modelos atômicos. Antes dele. Primeiro o de Thompson: ele pensava que o átomo era como um pudim de ameixas, ele era todo uma massa com carga positiva e as ameixas seriam os elétrons, mas na época ainda não sabia, havia como se fosse a ameixa de cargas negativas, proposta do Thompson.

Depois o aluno dele, Rutherford assume o laboratório e acha que a idéia dele está errada sobre o átomo. E vai pesquisar, tentar encontrar/testar esse átomo. O que ele fez? Pegou o ouro laminou numa folha bem fininha. Ele pensou deve ter aqui quase um átomo, um ao lado do outro.

569 A5: Eu mereço.

570 P: De tão fina que estava a folha de ouro...

571 A5: Pára aí Marli, pára.

572 P: Ele lançou uma partícula chamada partícula alfa, partícula alfa tem dois prótons e dois nêutrons. Uma partícula grande. $\mathrm{O}$ elétron é muito menor do que o próton e tem dois prótons e dois nêutrons ela é muito maior do que o elétron. Ele jogou essa partícula contra... o ouro, uma folha de ouro laminada. Isso aqui é como jogar um caminhão, (inaudível) o que que nós vamos colocar aqui?

P: Uma bola de futebol?

$574 \quad$ Ani: Ignorante esse cara...

575 P: Que que acontece vai... uma carreta contra uma bola de futebol. O que espera que acontece?

Ani: A bola de futebol vai bem alto.

577 P: E o caminhão vai parar? A pancada pára? O que acontece?

Ani: Se for o Douglas pára.

Primeira vez que o professor cita Bohr.

$\mathrm{P} / \mathrm{T}$. Professor desenha na lousa e fala sobre o modelo de Thompson.

A2 e A3 olham atentamente para o texto de apoio. A1, A4 e A5 olham para lousa. A6 mexe com seu celular.

Professor fala sobre o modelo de Rutherford.

Para auxiliar sua explicação, o professor vai desenhando na lousa.

A5 conversa enquanto o professor explica.

A5 brinca com o microfone, enquanto fala com A6.

Utiliza a lousa novamente na explicação do modelo de Rutherford.

Um aluno responde à indagação do professor, que faz nova pergunta agora focando o que acontece com o caminhão.

Apesar do tom de brincadeira o Ani responde que precisa de algo grande (no caso o aluno Douglas) para que o caminhão também pare. 


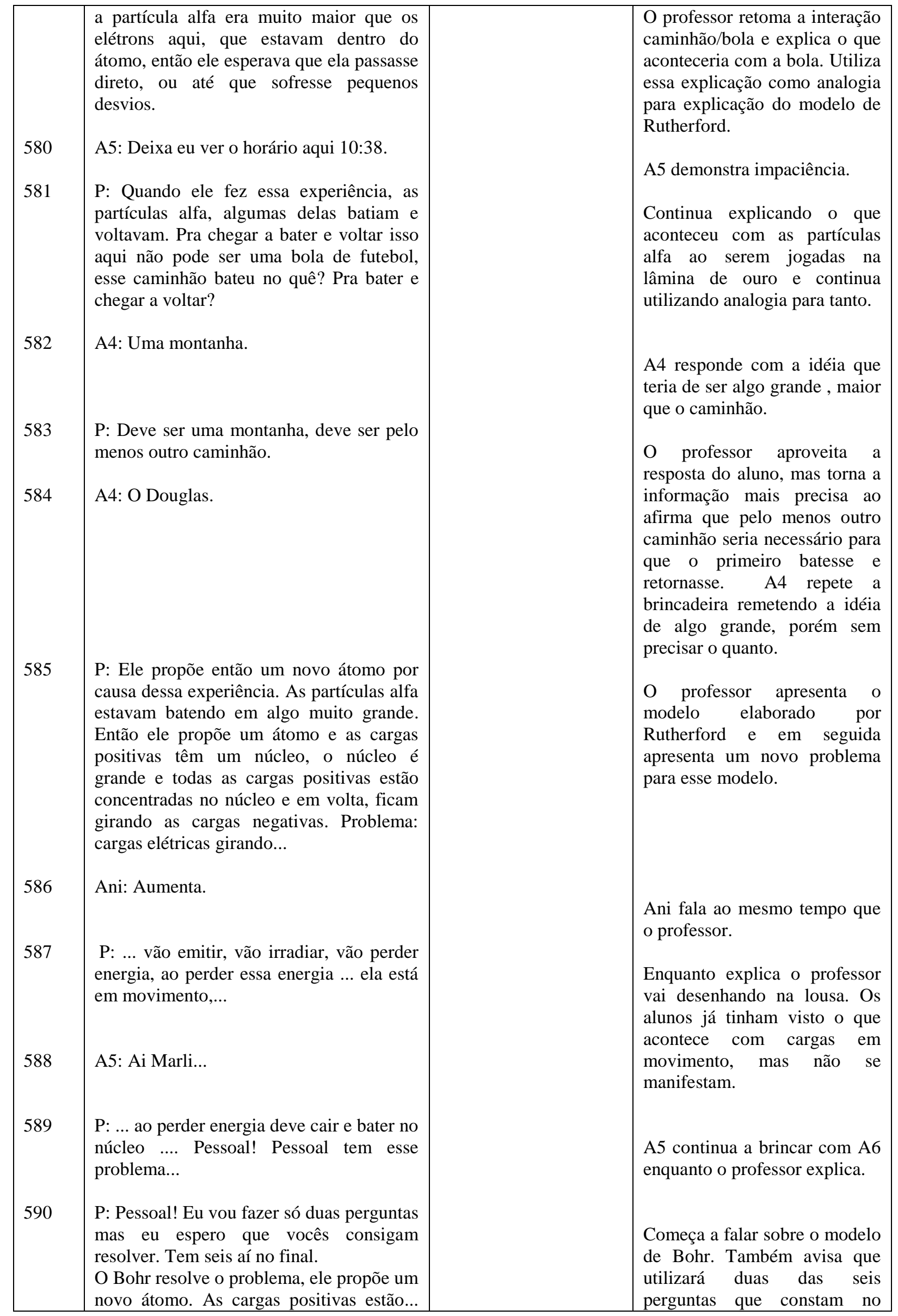




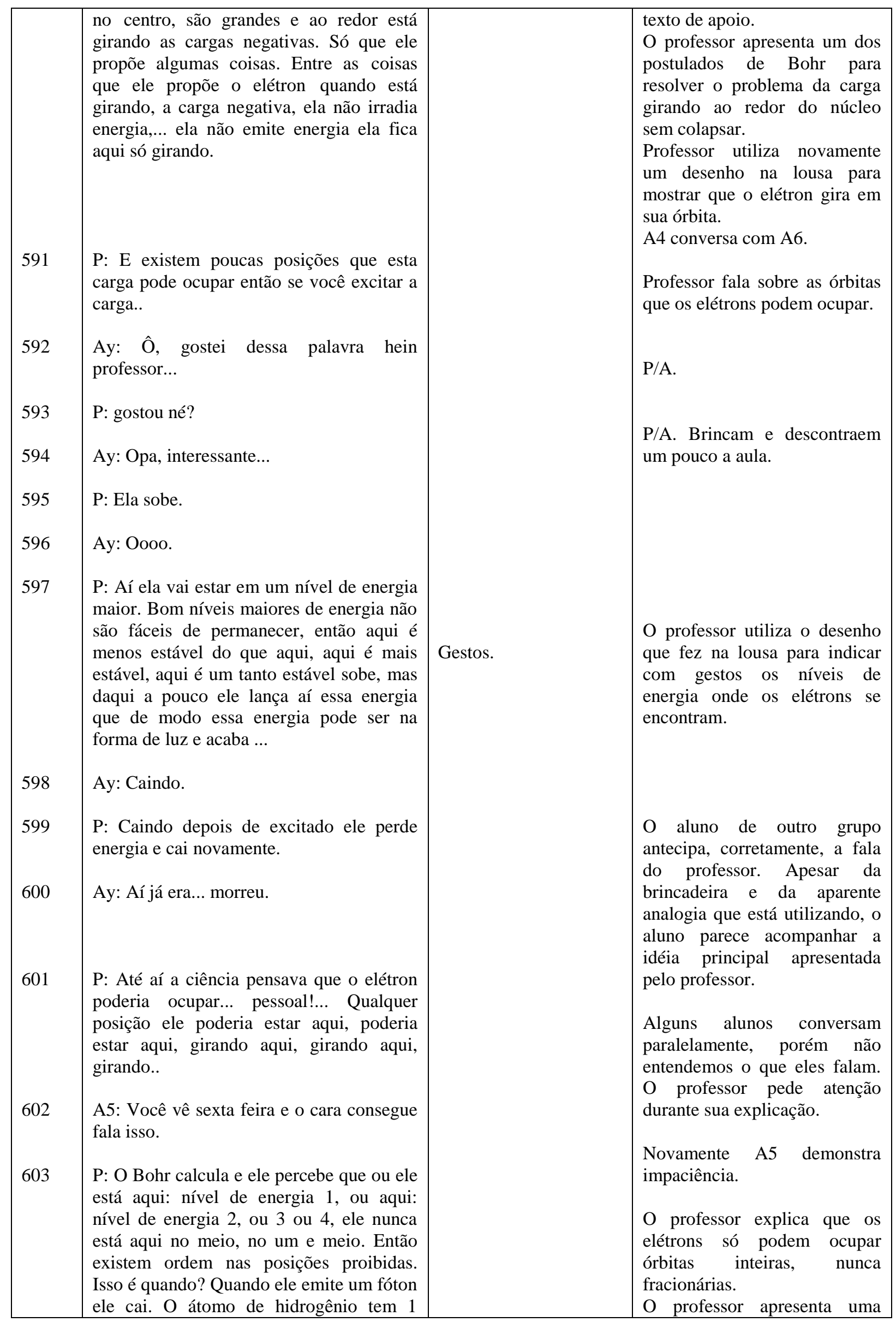




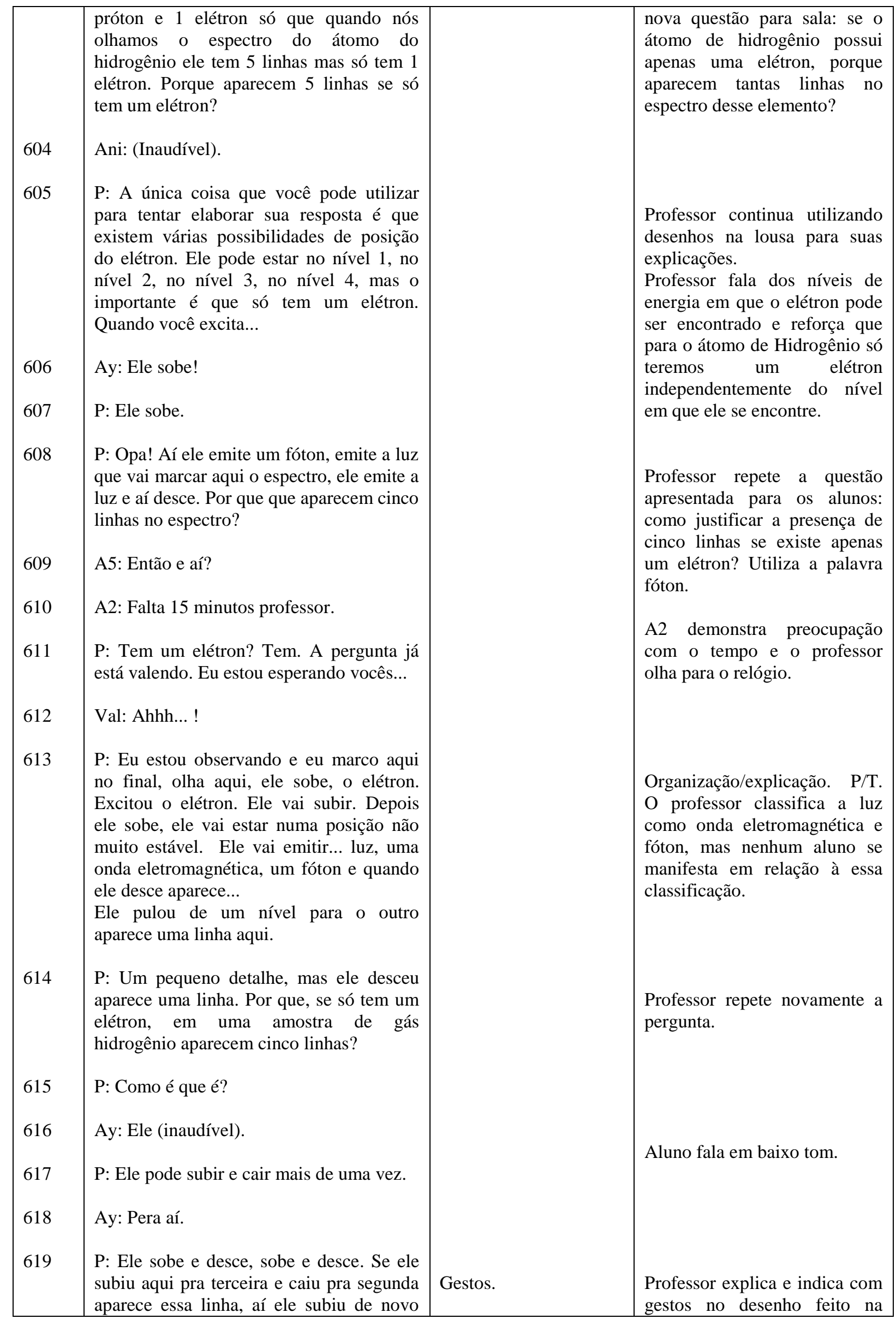




\begin{tabular}{|c|c|c|}
\hline & $\begin{array}{l}\text { pra terceira, desceu pra segunda, continua } \\
\text { a linha, subiu pra terceira caiu na } \\
\text { segunda... da terceira pra segunda é essa } \\
\text { linha. E as outras?... Por que que aparece } \\
5 \text { linhas? }\end{array}$ & $\begin{array}{l}\text { lousa a transição do elétron e } \\
\text { destaca a linha que aparece em } \\
\text { virtude dessa transição, } \\
\text { enfatizando que é sempre a } \\
\text { mesma linha quando muda do } \\
\text { nível dois para o três e vice- } \\
\text { versa, não importando a } \\
\text { quantidade de vezes que faça } \\
\text { isso. }\end{array}$ \\
\hline 620 & A3: Porque ele reflete professor? & Os alunos tentam responder. \\
\hline 621 & Ay: Porque tem cinco... & $\begin{array}{l}\text { A3 parece ter interpretado a } \\
\text { mudança de um nível para } \\
\text { outro como uma reflexão }\end{array}$ \\
\hline 623 & $\begin{array}{l}\text { P: Cinco, o que? } \\
\text { Ay: Tem cinco círculos em volta do } \\
\text { nucleo... }\end{array}$ & $\begin{array}{l}\text { outro como uma reflexão. } \\
\text { Como se o elétron "batesse" } \\
\text { em um nível e voltasse para } \\
\text { outro resultando no número } \\
\text { maior de linhas. }\end{array}$ \\
\hline 624 & P: Cinco níveis de energia... & $\begin{array}{l}\text { Já Ay parece associar as cinco } \\
\text { linhas com a quantidade de }\end{array}$ \\
\hline 625 & Ay: Isso! & $\begin{array}{l}\text { níveis de energia que estavam } \\
\text { desenhadas na lousa. O }\end{array}$ \\
\hline 626 & $\begin{array}{l}\text { P: Tem até mais. Mas digamos que tenha } \\
5 \text { níveis de energia. E aí? }\end{array}$ & $\begin{array}{l}\text { professor destaca que podem } \\
\text { existir mais níveis de energia e } \\
\text { solicite que o aluno explique }\end{array}$ \\
\hline 627 & A4: Ele bate e volta. & $\begin{array}{l}\text { seu raciocínio. } \\
\text { A4 retoma a fala de } \mathrm{A} 3 \text {, mas }\end{array}$ \\
\hline 628 & Ani: Aparece... (inaudível). & $\begin{array}{l}\text { também não justifica. } \\
\text { Vários alunos falam ao mesmo }\end{array}$ \\
\hline 629 & $\begin{array}{l}\text { P: Só tem, só tem um elétron. Ele já falou } \\
\text { que... por que que aparecem várias linhas? } \\
\text { Ele falou por que ele é excitado várias } \\
\text { vezes e emite luz e desce várias vezes. Aí } \\
\text { eu falei: Só que ele sobe, é excitado, sobe } \\
\text { para o nível } 3 \text {, caí para o nível } 2 \text { aparece } \\
\text { essa linha. Aí de novo, ele é excitado, } \\
\text { sobe para o } 3 \text {, desce para o } 2 \text {, é a mesma } \\
\text { linha. }\end{array}$ & tempo. \\
\hline 630 & Ani: Mas se ele... (inaudível). & \\
\hline 631 & $\begin{array}{l}\text { P: Sobe para o } 3 \text { desce para o } 2 \text {, é a } \\
\text { mesma linha. }\end{array}$ & \\
\hline 632 & $\begin{array}{l}\text { A3: Mas se ele sobe pro } 4 \text { e cai pro } 3 \text { é } \\
\text { outra linha. }\end{array}$ & $\begin{array}{l}\text { A3 justifica que outra linha } \\
\text { deve surgir quando o elétron } \\
\text { muda de posição entre outros } \\
\text { níveis de energia, como por } \\
\text { exemplo, entre os níveis três e } \\
\text { quatro. }\end{array}$ \\
\hline 633 & $\begin{array}{l}\text { P: Se ele sobe para o } 4 \text { e desce para o } 3 \text {, } \\
\text { ele emite uma outra onda } \\
\text { eletromagnética... As linhas espectrais na } \\
\text { verdade vão aparecer quando ele descer } \\
\text { para o } 2 \text {, do } 4 \text { para o } 2 \text { então, vai aparecer } \\
\text { uma segunda linha. }\end{array}$ & $\begin{array}{l}\text { Professor complementa a } \\
\text { resposta de A3 afirmando que } \\
\text { na verdade a outra linha } \\
\text { surgirá quando o elétron que } \\
\text { inicialmente veio do } 4^{\circ} \text { nível } \\
\text { chegar ao } 2^{\circ} \text {. }\end{array}$ \\
\hline 634 & $\begin{array}{l}\text { A3: Você quer saber por quê... existe a } \\
\text { linha? }\end{array}$ & \\
\hline
\end{tabular}




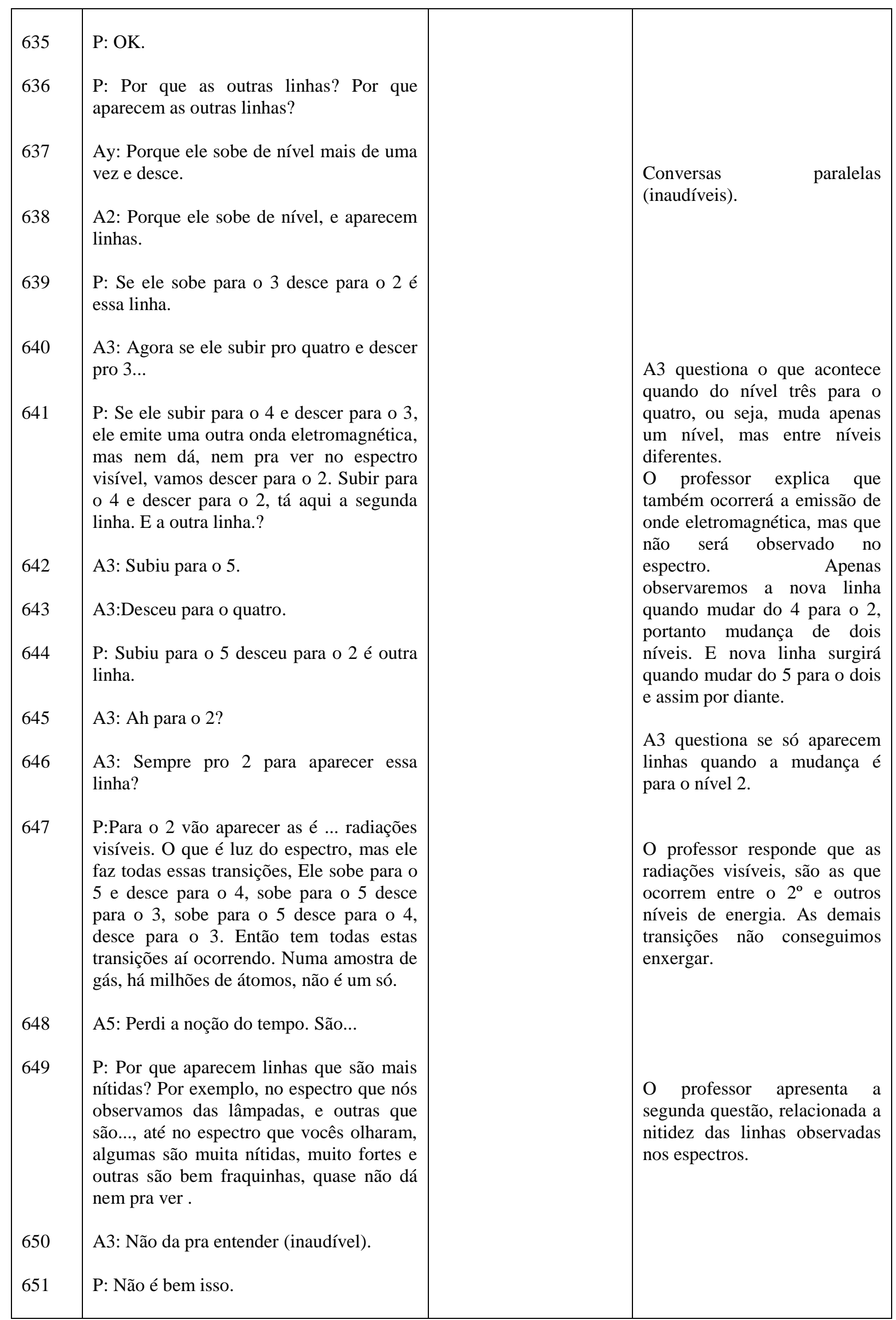




\begin{tabular}{|c|c|c|}
\hline 652 & $\begin{array}{l}\text { A4: (inaudível)... Aquele tipo de } \\
\text { cruzadinha que você vira de ponta cabeça }\end{array}$ & \\
\hline 653 & $\begin{array}{l}\text { P: Veja aqui. Tá aparecendo muito. O azul } \\
\text { aqui é muito fraquinho, apagado. } \\
\text { Por que tem umas que a aparecem tão } \\
\text { nitidamente e outras quase não aparecem? }\end{array}$ & \\
\hline 654 & Ani: (inaudível)? & \\
\hline 655 & Ani: Como é que é? & $\begin{array}{l}\text { O professor tenta atender os } \\
\text { alunos de outro grupo que } \\
\text { estão tentando responder. A5 }\end{array}$ \\
\hline 656 & Ani: Ele sobe e desce (inaudível). & $\begin{array}{l}\text { volta a cantar Rap no } \\
\text { microfone da gravação. }\end{array}$ \\
\hline 657 & P: Ele emite onda e não emite luz. & \\
\hline 658 & $\begin{array}{l}\text { Ani: (inaudível) quando está subindo... ? } \\
\text { (inaudível). }\end{array}$ & \\
\hline 659 & P: Quando ele tá subindo (inaudível). & \\
\hline 660 & $\begin{array}{l}\text { A5: Não tô conseguindo raciocinar, é o } \\
\text { calor professor. }\end{array}$ & $\begin{array}{l}\text { A5 disperso e acaba chamando } \\
\text { a atenção do professor. }\end{array}$ \\
\hline 661 & P: Ficou excitado, caiu e ficou quieto... & P/A. O professor faz uma \\
\hline 662 & $\begin{array}{l}\text { A4: Tá preocupado com o leite que tem } \\
\text { que levar pras crianças em casa. }\end{array}$ & $\begin{array}{l}\text { brincadeira com A5. } \\
\text { A4 aproveita para brincar com } \\
\text { A5 também. }\end{array}$ \\
\hline 663 & $\begin{array}{l}\text { A5: Tô preocupado com o jantar, minha } \\
\text { mulher. }\end{array}$ & \\
\hline 665 & $\begin{array}{l}\text { P: Não. E aí? Porque que umas linhas... } \\
\text { essa parte é importante hein... } \\
\text { A4: É ultimo dia e o senhor... }\end{array}$ & $\begin{array}{l}\text { Organização/explicação. } \mathrm{P} / \mathrm{T} \text {. } \\
\text { Professor retoma a questão } \\
\text { para sala. }\end{array}$ \\
\hline 666 & $\begin{array}{l}\text { P: Uma amostra... Pessoal vamos! Uma } \\
\text { amostra de gás você tem milhões de } \\
\text { átomos, milhões de elétrons . Subiu para } \\
\text { o } 3 \text { desceu para o } 2 \text {, apareceu essa linha. } \\
\text { Um outro átomo subiu para o } 3 \text { desceu } \\
\text { para o } 2 \text { é a mesma linha. } \\
\text { Um outro átomo subiu para... é a mesma } \\
\text { linha. }\end{array}$ & \\
\hline 667 & Ani: Só que cores diferentes. & \\
\hline 668 & P: Agora... & \\
\hline
\end{tabular}


Material de apoio utilizado durante as atividades: A seguir temos o roteiro para construção do espectroscópio e para pesquisa de campo. Esses roteiros foram utilizados em uma aula logo após a atividade com os espectros das lâmpadas e imediatamente antes da aula do astrônomo mirim.

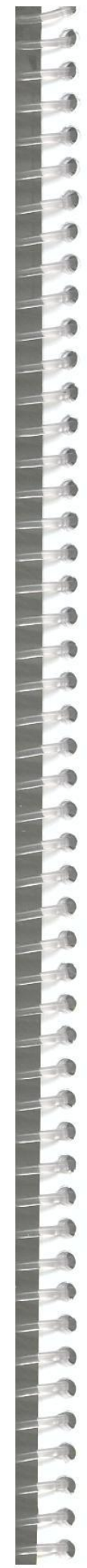

BLOCO VIII- ESPECTROSCOPIA

ROTEIRO PARA CONSTRUÇÃO DE UM ESPECTROSCÓPIO.

Materiais necessários:

Fita isolante, cartolina na cor preta fosca, $\mathrm{CD}$, cola e tesoura.

Montagem:

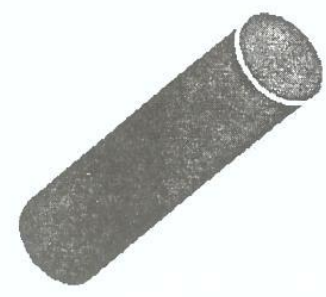

Construa um cilindro com a cartolina com aproximadamente $4 \mathrm{~cm}$ de diâmetro e $7 \mathrm{~cm}$ a $10 \mathrm{~cm}$ de comprimento.

Este tubo poderá ser de PVC ou uma caixa de pasta de dente, mas revestido internamente com a cartolina preta fosca.

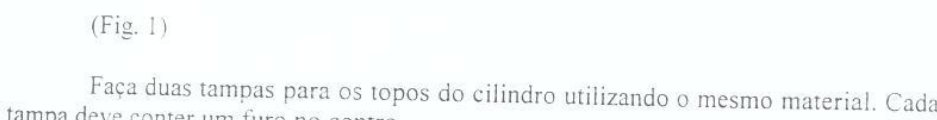

Faça duas tampas para os topos do cilindro utilizando o mesmo material. Cad tampa deve conter um furo no centro.
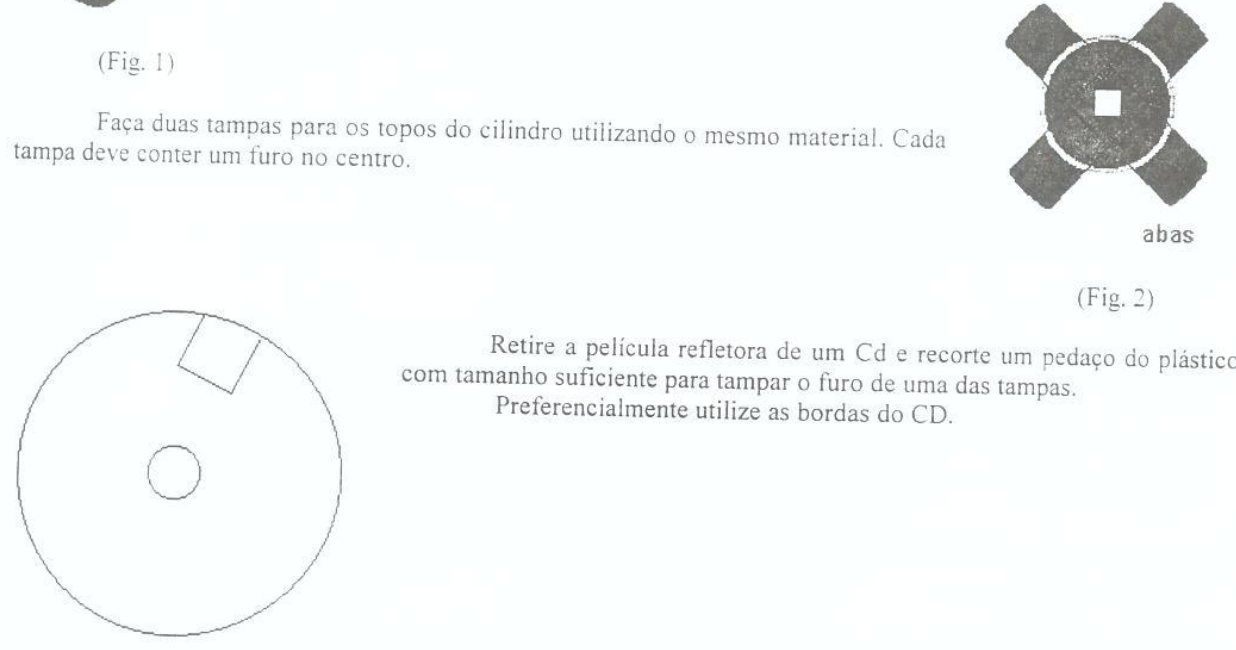

(Fig. 2

(Fig. 3)

Cole o "recorte de CD" em uma das tampas.

plático do $\mathrm{CD}$

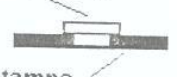

tampa

(Fig. 4)

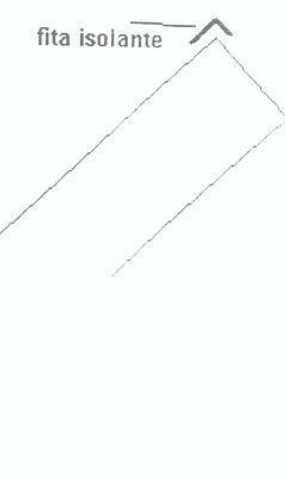

Cole as tampas no cilindro.

É recomendável que o plástico do $\mathrm{CD}$ esteja no interior do cilindro.

Para evitar que a luz penetre no interior do tubo por eventuais frestas utilize fita-isolante para vedar os pontos de união entre o cilindro e as tampas. 
Nome:

série prof.

\section{ROTEIRO DE OBSERVACÃO USANDO O ESPECTROSCÓPIO}

Objetivo: Analisar a luz emitida por várias fontes luminosas. observando o espectro de cores formado através do espectroscópio construído em sala de aula.

Procedimento: Escolha um tipo de lâmpada e observe-a através do espectroscópio. Você deverá procura uma posiçào de observação através do espectroscópio em que consiga enxergar "cores" no interior do tubo. Para certeza que as cores observadas são referentes à determinada làmpada. basta tampá-la com o dedo, por exemplo. e ver se as cores desaparecem. Procure evitar direcionar o espectroscópio a posições que estejam entre duas ou mais lâmpadas. Em seguida realize suas anotações de acordo com as questões a seguir:

a) Qual o tipo de lâmpada que você está observando?

b) Como as cores se apresentam? Faça um desenho indicando o que você está observando.

b) Existem cores que se destacam? Em caso afirmativo. quais são elas?

c) Existe algum tipo de separação entre as cores ou elas estão juntas?

\begin{tabular}{|c|c|c|c|}
\hline Lâmpada & Desenho & Cores que se destacam? & Separação \\
\hline Incandescente & & & $\begin{array}{l}\text { ( ) Separadas } \\
\text { ( ) Juntas }\end{array}$ \\
\hline Fluorescente & & & $\begin{array}{l}\text { ( ) Separadas } \\
\text { ( ) Juntas }\end{array}$ \\
\hline Lâmpada de mercúrio & & & $\begin{array}{l}\text { ( ) Separadas } \\
\text { ( ) Juntas }\end{array}$ \\
\hline Luz negra & & & $\begin{array}{l}\text { ( ) Separadas } \\
\text { ( ) Juntas }\end{array}$ \\
\hline Vela & & & $\begin{array}{l}\text { ( ) Separadas } \\
\text { ( ) Juntas }\end{array}$ \\
\hline $\begin{array}{l}\text { Mercúrio (presente nos } \\
\text { postes de iluminação } \\
\text { pública) }\end{array}$ & & & $\begin{array}{l}\text { ( ) Separadas } \\
\text { ( ) Juntas }\end{array}$ \\
\hline $\begin{array}{l}\text { Sódio (também presente } \\
\text { nos postes, mas é de cor } \\
\text { amarelada) }\end{array}$ & & & $\begin{array}{l}\text { ( ) Separadas } \\
\text { ( ) Juntas }\end{array}$ \\
\hline $\begin{array}{l}\text { Néon (letreiros } \\
\text { luminosos) }\end{array}$ & & & $\begin{array}{l}\text { ( ) Separadas } \\
\text { ( ) Juntas }\end{array}$ \\
\hline $\begin{array}{l}\text { Lanternas traseiras de } \\
\text { carros }\end{array}$ & & & ( ) Separadas \\
\hline \multirow[t]{2}{*}{$\begin{array}{l}\text { Sol (CUIDADO!!! Não } \\
\text { olhe diretamente para } \\
\text { ele!) }\end{array}$} & & & $\begin{array}{l}\text { ( ) Separadas } \\
\text { ( ) Juntas }\end{array}$ \\
\hline & & & $\begin{array}{l}\text { ( ) Separadas } \\
\text { ( ) Juntas }\end{array}$ \\
\hline
\end{tabular}

Textos de apoio fornecidos na aula de análise dos espectros das lâmpadas e na atividade do astrônomo mirim: 


\section{ESPECTROSCÓPIO}

A luz é uma onda eletromagnética que possui várias freqüéncias e conseqüentemente vários comprimentos de onda $(\lambda)$ associados a ela. A luz visível corresponde a um pequeno trecho do espectro eletromagnético (com freqüências compreendidas aproximadamente entre $3.8 .10^{14} \mathrm{~Hz}$ e $8.3 .10^{14} \mathrm{~Hz}$ ) e os diferentes tipos de luzes monocromáticas se distribuem da seguinte forma: luz vermelha, alaranjada, amarela, verde, azul, anil e violeta com os comprimentos de onda variando de $700 \mathrm{~nm}$ (vermelho) a $400 \mathrm{~nm}$ (violeta) ${ }^{1}$.

Um espectroscópio é um aparelho que dispersa a luz emitida por uma fonte a fím de determinar os comprimentos de onda $(\lambda)$ que a compõem, ou seja, é um aparelho que faz com que a luz que passa sobre ele seja decomposta em várias cores (aquelas possiveis do espectro citado acima). Para realizar essa dispersão o espectroscópio pode ser construido com um prisma ou com uma rede de difracão.

Verifiquemos o funcionamento básico dos espectroscópios citados:

\section{Espectroscópio com uma rede de difracão:}

Com o conceito, já estudado, de difração podemos estudar os fenômenos associados ao desvio da propagação da luz ao atravessar uma pequena fenda ou um obstáculo à sua frente. Deve-se lembrar que os efeitos da difração são notados apenas quando os obstáculos e fendas são de dimensões comparáveis ao comprimento de onda em questão. (Por isso o som. que é uma onda mecânica, consegue contornar obstáculos de tamanhos razoáveis e ser notado de forma praticamente uniforme ao redor do obstáculo, pois seu comprimento de onda é em torno de centenas de metros, enquanto a luz visivel é da ordem de $500 \mathrm{~nm}$, ou seja, para verificarmos a difração da luz. precisamos de fendas muito pequenas).

Uma rede de difração é constituida de um vidro com muitas fendas paralelas e próximas entre si. A luz atravessa o espaço ocupado pelas fendas e à frente delas formam-se franias claras e escuras. Estas franjas referemse às interferências construtivas e destrutivas. São as diferenças de caminho percorrido pelas ondas que atravessaram cada uma das fendas que provocam essas interferencias.
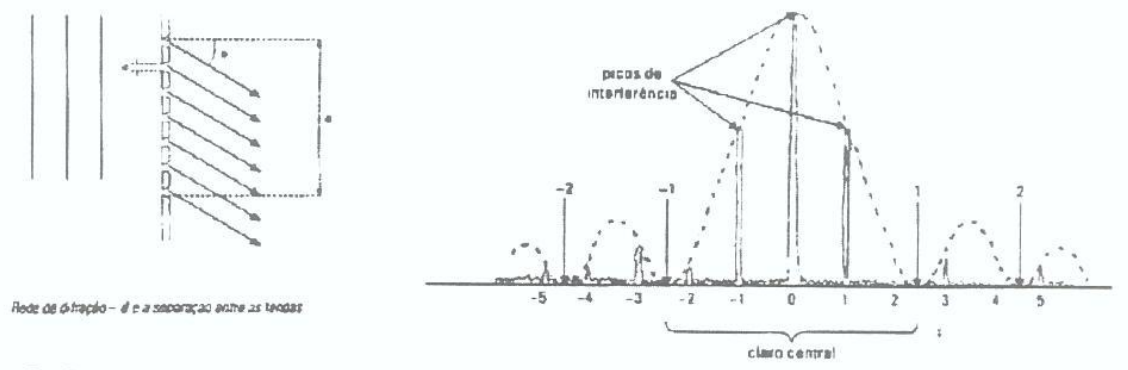

Gráfico da intensidade da luz ao atravessar uma rede de difração. A difração devida à largura total da

fenda esta representada na linha pontilhada e a interferência devido às fendas intermediárias está representada

nas linhas cheia.

(Fig. 6, Fonte: GASPAR, Alberto. Fisica V.2, pag. 248)

As franjas produzidas são resultado das interferências construtivas que associam cada frequiência (ou comprimento de onda $(\lambda)$ ) da luz que passa por uma fenda, com a mesma freqüência( $v)$ ou comprimento de onda $(\lambda)$ da luz que passa pelas outras fendas. Dessa forma, o azul interfere construtivamente com o proprio azul de outra fenda, o vermelho com o próprio vermelho e assim por diante. destacando cada cor do espectro separadamente. Assim, temos a decomposição da luz branca nas suas luzes coloridas do espectro eletromagnético.

Embora existam espectroscópios sofisticados, o nosso é feito utilizando um pedaço de CD conforme indicado nos procedimentos do experimento. É o CD que vai difratar a luz para a formação das interferências. pois é constituido por uma sucessão de minúsculas cavidades que têm a mesma largura e profundidade. mas comprimentos diferentes e distâncias variadas². São essas finissimas trilhas de cavidades concêntricas que decompõem a luz branca em diversas cores. Portanto o CD difrata a luz ao passar por suas pequenas cavidades (ou sulcos) para em seguida refleti-la. Por fim, do encontro de suas diferentes reflexões resulta a interferència citada acima, o que leva à separação das cores. Como essas cavidades são circulares. no CD. utilizamos pedaços quadrados retirados próximos à borda, pois ai as cavidades estão mais paralelas entre si.

\section{$1 \mathrm{~nm}=1.10^{-9} \mathrm{~m}$}

"O comprimento médio das cavidades é de aproximadamente 0.4 "micron $"$ e a distância media entre duas cavidades

sucessivas é de cerca de 1.6 micron ( 1 micron $=10^{-6} \mathrm{~m}$ ). 


\section{Espectroscónio com prisma}

Um prisma ${ }^{3}$ também dispersa a luz. decompondo-a em suas respectivas cores do espectro eletromagnético de acordo com a freqüência (ou comprimento de onda) de cada cor. Porem. aqui a decomposição não é feita por difração e sim por refração. Sabemos que no vácuo todas as ondas componentes da luz se propagam com a mesma velocidade(c) e que nos meios materiais cada componente vai ter uma velocidade de propagação (v) diferente das demais. Desta forma. todas as componentes da luz que antes de atravessarem o prisma se propagavam na mesma direção (mesmo ângulo de incidência), com a mesma velocidade. durante a passagem pelo prisma sofrem refração em seguida cada componente se propagará numa direção diferente. pois cada uma delas terá um ângulo de refração próprio. ocorrendo, portanto, a dispersão da luz. O prisma produz uma segunda refração, quando a luz sai do prisma para o ar, fazendo com que as cores se afastem ainda mais.

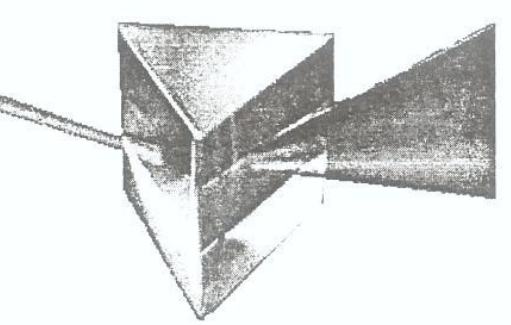

Dispersão em cores da luz branca (

(Fig. 7. Fonte: Adaptação do site www.ino.it www_inoa/ images/sitiprisma.jpg)

Ao atravessar um prisma, a luz vermelha. de menor freqüência. é a que sofre o menor desvio. O maior desvio é sofrido pela luz violeta, de maior freqüência.

Vimos, portanto, que tanto o prisma como uma rede de difração, podem ser utilizados como elemento dispersor de um espectroscópio. Porém o prisma apresenta baixa resolução sendo mais apropriada a utilização das redes de difraçào.

Quando a luz passa pela fenda estreita, para atingir o prisma ou a rede de difração, verificamos a formação de uma imagem diferente da fenda para cada cor. As imagens coloridas obtidas se superpõem parcialmente. dando origem a uma única faixa colorida chamada espectro contínuo. Num espectro continuo, a passagem de uma cor para a outra não se faz bruscamente. é gradual, formando então as sete tonalidades conhecidas como as cores do arco-íris. Isso ocorre quando a luz que incide no espectroscópio é formada por todas as cores do espectro. No entanto, se a luz utilizada para iluminar a fenda for constituida por um número discreto de luzes monocromáticas, ou seja, não apresentar as sete tonalidades do espectro, teremos a formação de imagens de acordo com o numero de cores que compõem essa luz e observaremos apenas a quantidade de cores presentes e ainda separadas por regiões escuras, formando um espectro de raias (ou bandas).

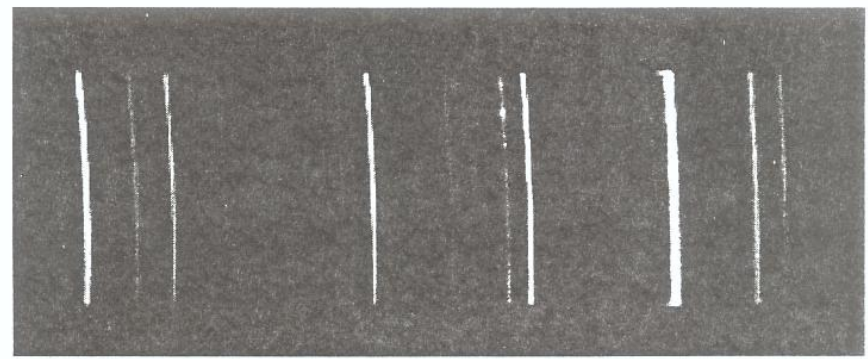

Exemplo de um espectro ca raias do Hélic

Qualquer meio transparente. Isotropo e imitado por duas superi z es planas nao daralelas 
(Fig 8, Fonte: http://www. ifi.unicamp.br/ accosta/f429-18.html, 20/dez/2005)

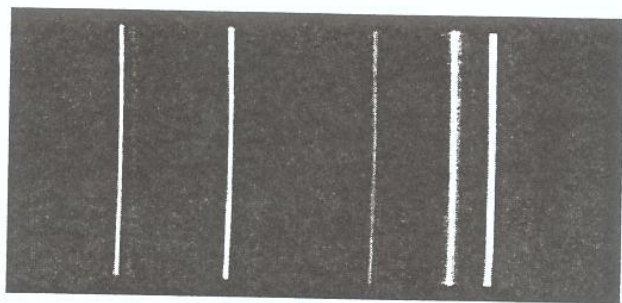

Exemplo de um espectro de raias do Mercúrio.

(Fig 9, Fonte: http://www.ifi.unicamp.br/ accosta/f429-18.html, 20/dez/2005)

Fontes de linhas espectrais: são as fontes que emitem a maior parte de sua radiacão em comprimentos de onda discretos.

As fontes de linhas são usadas como padrões de comprimentos de onda para calibração de diversos equipamentos ópticos.

Lâmpadas:

Quando chega a noite, as lâmpadas fazem parte de nosso cotidiano, e se não temos a iluminação que elas nos fornecem, sentimos um grande desconforto.

Existe uma grande variedade de lâmpadas, com formatos e cores diferentes, que procuram imitar o Sol, tarefa dificil dada a continuidade do espectro do Sol.

Essas lâmpadas podem ser classificadas em dois tipos diferentes: as lâmpadas incandescentes e as lâmpadas de descarga elétrica em um gás.

a) Lâmpadas incandescentes:

As lâmpadas incandescentes consta

incandescência pela passagem dis duas ou três vezes, que é levado a inerte ou vácuo dentro do tubo que contém eletrica. A oxidação do filamento é evitada pela presença de um gás

industriais foram fabricadas em 1881 .

As lâmpadas incandescentes atualmente utilizam filamento de tungstênio, que atinge $2500^{\circ} \mathrm{C}$.

apesar de não ser visivel ao olho sentimos ao aproximarmos nossa mão de uma lâmpada desse tipom nossa pele, sendo a responsável pelo calor que

A pálida luz da lâmpada incandescente modifica nossa percepção da cor dos objetos. Se a temperatura do filamento pudesse ser maior, teriamos uma iluminação próxima da solar, mas isso é dificil porque as ligas condutoras costumam se romper em altas temperaturas. Esse tipo de lâmpada desperdiça uma parcela importante da energia elétrica, na produção de infravermelho, que não serve para iluminação.

b) Lâmpadas de descarga elétrica: As modernas lâmpadas de descarga são constituidas por um tubo contendo gases ou vapores, através dos
quais se estabelece um arco elétrico. Os gases mais utilizados são o argônio, o neônio, o xenónio, o hélio ou o criptônio e os vapores de mercúrio, e sódio. Esses gases ou vapores podem estar à baixa, média ou aita pressão. As
de vapor de mercúrio e de xenónio são de alta pressão.

1. Lâmpada fluorescente tubular: É uma làmpada de baixa pressão na qual a luz e produzida por pós fluorescentes (cristais de fósforo) que
recobrem a superficie interna do tubo. Quando a corrente elétrica passa pelo gás ele emite ondas na faixa do ultravioleta, que são absorvidas pelo pó, que reemite numa distribuição de radiaçōes visiveis. 


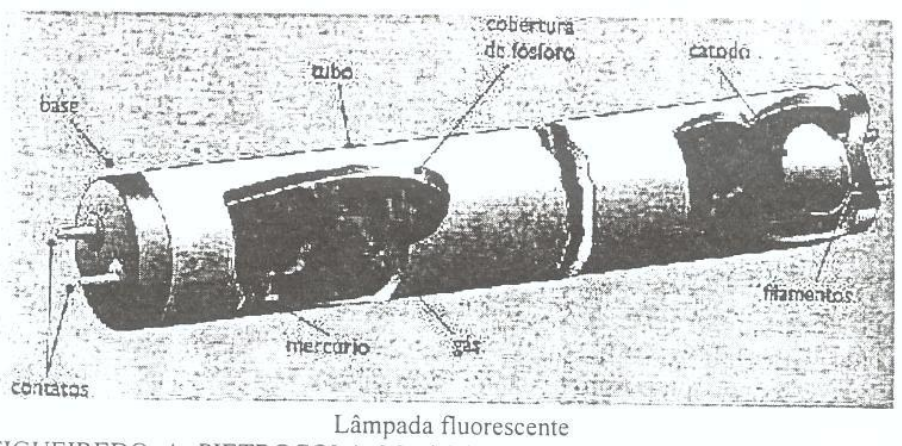

Fig. 10, Fonte: FIGUEIREDO, A; PIETROCOLA, Mauiricio;Luz e Cores-Física um outro lado. Pág. 48.)

A lâmpada, geralmente em forma de tubo longo com um eletrodo de tungstênio em cada extremidade contém o vapor de mercúrio ou argônio a baixa pressão. Dessa forma, pouca radiação é emitida fora da faixa visivel, por isso essas lâmpadas têm alto rendimento e baixo consumo de energia elétrica.

Abaixo, veja o gráfico do espectro das lâmpadas fluorescentes:

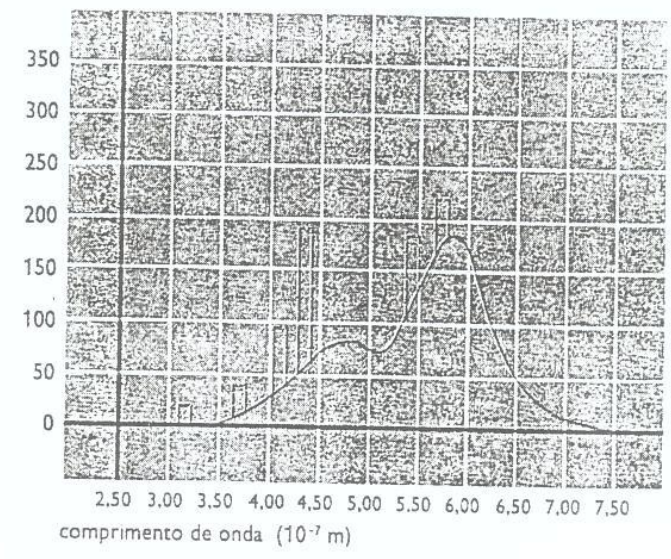

Espectro da Lâmpada fluorescente

Fig. 10, Fonte: FIGUEIREDO, A; PIETROCOLA. Mauiricio; Luz e Cores-Física um outro lado. Pág. t9.)

2. Lâmpada de vapor de mercúrio e de vapor de sódio:

As lâmpadas de vapor de mercúrio e de sódio contêm um tubo de descarga feito de quartzo para suportar elevadas temperaturas. O gás está à baixa pressão. Quando a lâmpada é ligada, o gás fíca submetido a uma tensão elétrica que obriga os ions a acelerarem e chocarem entre si. Esses choques provocam a emissão de radiacão.

Cada gás emite freqüências diferentes. conforme os gráficos abaixo: 


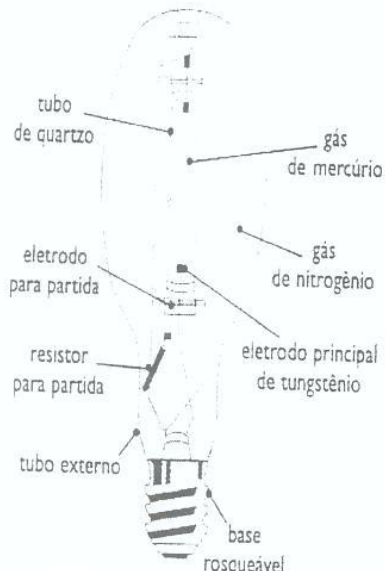

poder de radiação (escala relativa)

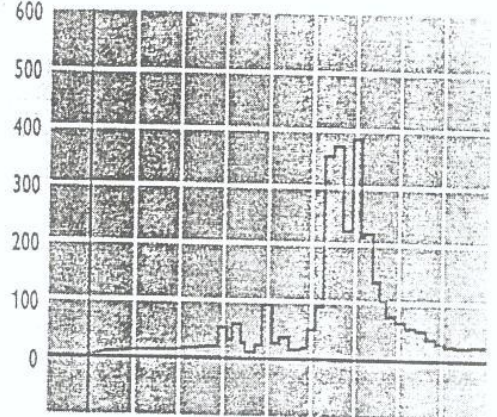

$3,00 \quad 3,50 \quad 4,00 \quad 4,50 \quad 5,00 \quad 5,50 \quad 6.00 \quad 6.50 \quad 7,007.50$

Fig. 11, Fonte: FIGUEIREDO, A: PIETROCOLA, Mauirício; Luz e Cores- Física um outro lado. Pág. 45.
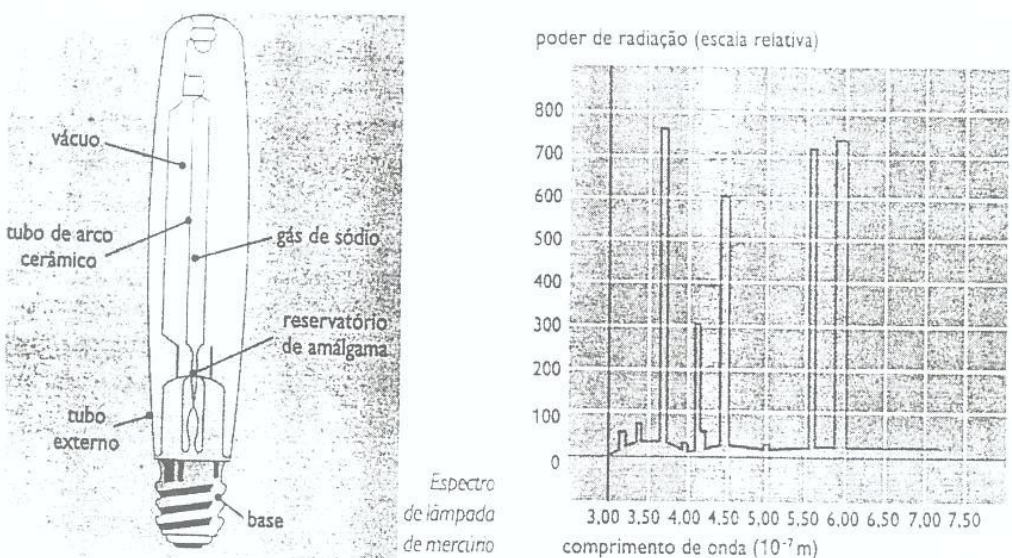

Espectro da Lâmpada fluorescente

Fig. 12, Fonte: FIGUEIREDO, A; PIETROCOLA, Mauiricio; Luz e Cores- Fisica um outro lado. Pág 45 e t6

BIBLIOGRAFIA:

www. ifi.unicamp.br/ accosta/f429-18 html-29k-

DULCIDIO Braz Júnior. Fisica moderna - Tópicos para o Ensino Médio. Editora Companhia da Escola. Campinas. São

SCHAUM/VANDER MERWE. Fisica Geral, Editora Mc Graw-Hill,1979

FIGUEIREDO, A:PIETROCOLA. Mauiricio: Luz e Cores- Física um outro lado São Paulo, Ed. FTD 2000

(Gráfico extraido de GASPAR. Alberto. Fisica V.2. São Paulo, Editora Ática. 2001.) 


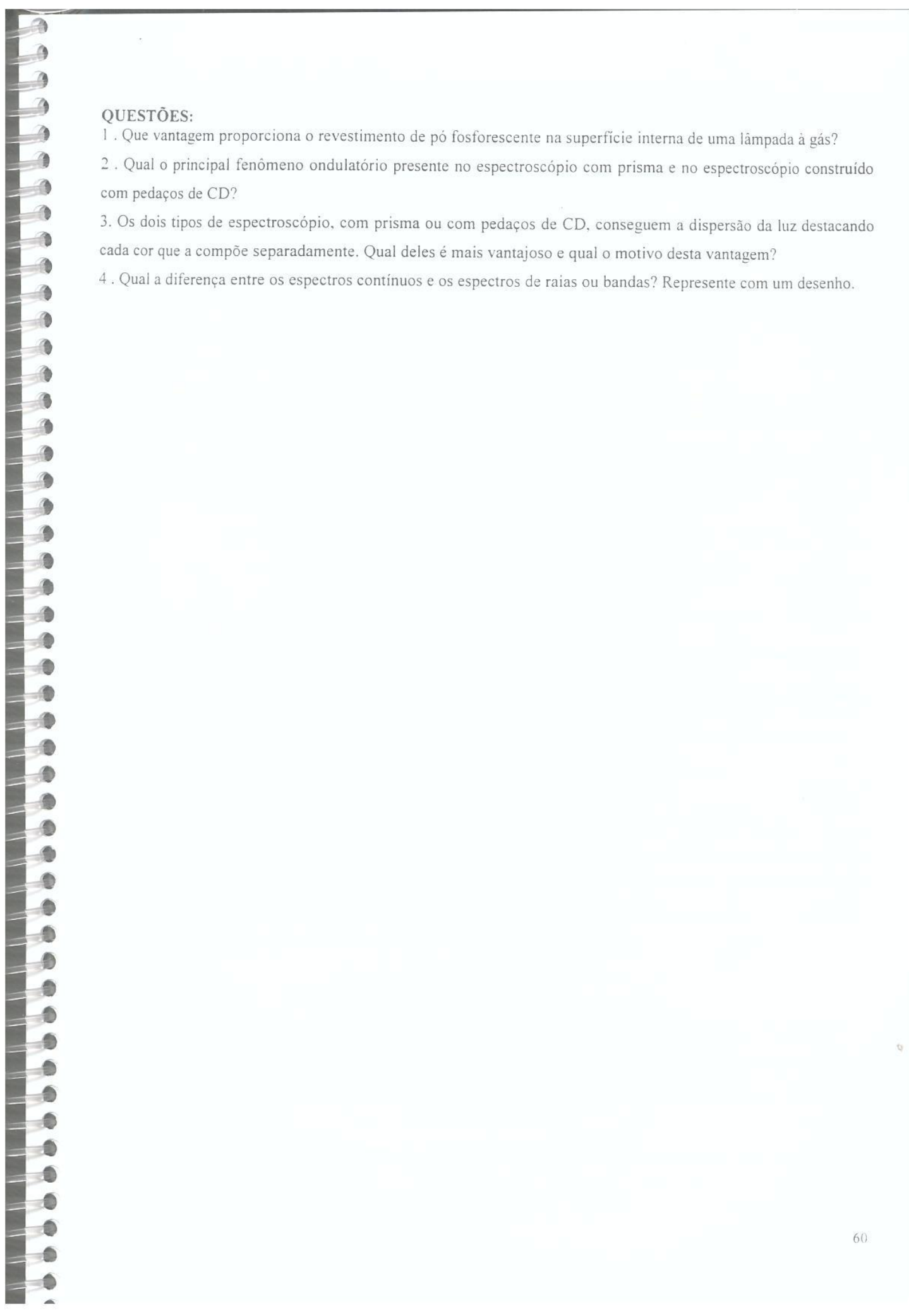




\section{BLOCO IX - O MODELO ATÔMICO DE BOHR}

\section{$\underline{\text { Roteiro da Atividade na Sala de Informática: }}$}

Na classe observamos diferentes lâmpadas com o espectroscópio e vimos que há espectros diferentes para as diferentes lâmpadas. Vamos investigar como é a emissão de luz pelos diferentes elementos quimicos e o que são os espectros de emissão e absorção.

Entrar no site :http://astro.if.ufrgs.br/rad/espec/espec.htm. Se não conseguir. entrar pelo site http://astro.if.ufrgs.br/index.htm Do lado esquerdo da tela aparece uma lista de assuntos de astrofisica. Procure 0 link ESPECTROSCOPIA. Clicando nele, vai chegar ao mesmo lugar.

Ler os dois primeiros parágrafos.

Após o título HISTÓRICO, ler o $1^{\circ}$ parágrafo e pular para o parágrafo após as duas fotos que começa com: Em 1856 o químico Robert.

Ler até a figura "Simulação das linhas".

Responda à questão abaixo em folha à parte:

1. O que é espectro de emissão e espectro de absorção?

Clicar no escrito simulação das linhas. Ler as instruções que aparecem acima da tabela periódica. Observe os espectros de emissão e absorção do Hidrogênio(H) e depois do Hélio(He).

Responda à questão abaixo na folha à parte:

2. Vocês percebem alguma semelhança entre os dois tipos de espectros para um mesmo elemento, isto é os espectros de emissão e absorção do $\mathrm{H}$ têm alguma semelhança? E os do $\mathrm{He}$ ?

Veja agora os espectros de emissão do hidrogênio $(\mathbf{H})$,

$$
\text { neônio }(\mathrm{Ne}) \text {, }
$$

xenônio $(\mathrm{Xe})$

sódio (Na),

$$
\begin{gathered}
\text { mercúrio }(\mathrm{Hg}), \\
\text { oxigênio }(\mathrm{O}) \text {. }
\end{gathered}
$$

3. Qual desses espectros apresenta um número maior de linhas?

4. Qual apresenta o menor número de linhas?

Volte ao texto clicando em espectroscopia e leia os parágrafos 4 e 5 após a figura simulação das linhas, que começa: EM 1862

5. Você já conhecia esse fato? O que achou de saber que se pode conhecer do que é feita uma estrela, estando a milhões de anos -luz de distância?

\section{"BRINCANDO DE ASTRONOMO"}

Vamos descobrir de que elementos químicos se compõe uma estrela?

Cada grupo receberá uma folha com os espectros de diferentes elementos quimicos.

As transparências numeradas correspondem a estrelas simplificadas. Anote o número da sua estrela. Compare o espectro da sua estrela com os espectros dos diferentes elementos. Se o espectro da estrela apresentar todas as linhas correspondentes ao elemento, é por que este é um dos constituintes da estrela.

Compare com cuidado, pois cada estrela tem pelo menos 3 elementos componentes.

\section{Modelo Atômico de Bohr}

Retomando os espectros de emissão e absorção

Em 1856, o químico alemão Robert Wilhelm Bunsen (1811-1899) inventou o bico de gás que leva seu nome Quando um elemento quimico era colocado sobre a chama do gás, as cores emitidas eram as da substância e não as da chama. Seu discipulo. Kirchoff sugeriu que as cores seriam mais bem distinguidas se passassem por un prisma. Com isso, eles passaram a identificar as linhas com os elementos quimicos. Os gases quentes observados por Kirchoff e Bunsen nào emitiam um espectro continuo. Descobriram que cada elemento gerava uma série de linhas diferentes.

Estas linhas eram todas brilhantes.

De suas experiências. Kirchhoff formulou as très leis empiricas da espectroscopia. para determinar a composição de uma mistura de elementos. 


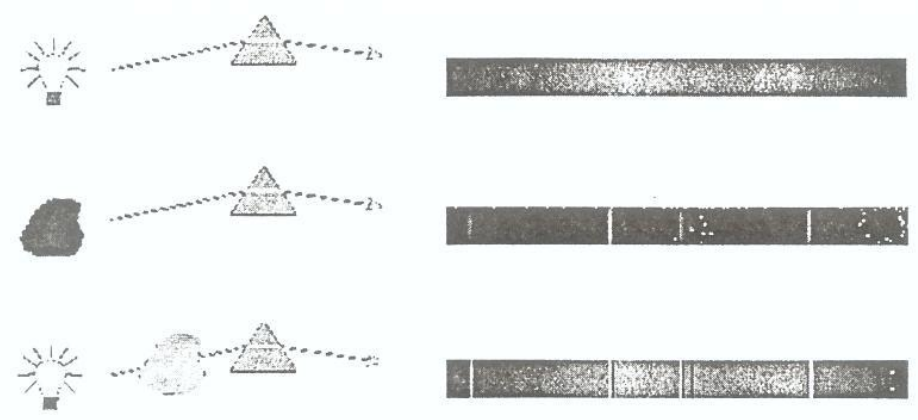

(fig. 1: Fonte: http://astro.if.ufrgs.br/rad/espec/espec.htm)

1) Um corpo opaco quente, sólido, líquido ou gasoso, emite um espectro contínuo.

2) Um gás transparente produz um espectro de linhas brilhantes (de emissão). O número e a posição destas linhas depende dos elementos químicos presentes no gás.

3) Se um espectro continuo passar por um gás à temperatura mais baixa, o gás frio causa a presença de linhas escuras (absorção). O número e a posição destas linhas dependem dos elementos químicos presentes no gás.

Embora um átomo só emita um comprimento de onda, muitos átomos comprimidos juntos num material emitem radiação formando uma série de linhas.

Quase toda informação sobre as propriedades físicas das estrelas é obtida direta ou indiretamente de seus espectros, principalmente suas temperaturas, densidades e composições.

A observação dos espectros estelares tomou impulso em $1860 \mathrm{com}$ Giovanni Battista Donati (1826-1873) em Florença. Em 1862, o astrônomo sueco Anders Jonas Ångström (1814-1874), aumentando a precisão de medida do comprimento de onda, identificou as linhas de hidrogênio no Sol. A identificação do elemento hidrogênio já havia sido feita em 1766 pelo físico e químico inglês Henry Cavendish (1731-1810).

Em 1868, o astrônomo inglês Sir Joseph Norman Lockyer (1836-1920) descobriu uma linha inexplicada no espectro do Sol, que ele identificou com um novo elemento químico, hélio, do grego helios, Sol.

Somente 27 anos mais tarde o elemento hélio foi descoberto na Terra, pelo quimico inglês Sir William Ramsay (1852-1916) quando o espectro de um minério de urânio contendo hélio produziu uma linha na posição exata daquela encontrada por Lockyer no espectro do Sol. Hoje em dia sabemos que o hélio é o segundo elemento mais abundante no Universo. O primeiro é o hidrogênio.

\section{A Origem das Linhas Espectrais: átomos e luz}

No início do século XX, os cientistas começaram a estabelecer as bases para a compreensão da formação dos espectros à medida que eles começaram a aprender mais sobre a estrutura dos atomos e a natureza da luz.

Os experimentos de Ernest Rutherford (1871-1937) em 1909, auxiliado por Hans Geiger (1882-1945) e Ernest Marsden (1889-1970), bombardeando folhas de ouro com partículas alfa (ions de hélio), demonstraram que os átomos são compostos de um pequeno núcleo, com carga elétrica positiva, rodeado por uma nuvem de elétrons. com carga elétrica negativa. Esses elétrons não poderiam estar parados, pois eles cairiam em direção ao núcleo devido à atração coulombiana, então Rutherford propôs que os elétrons estariam girando em torno do núcleo em órbitas circulares.

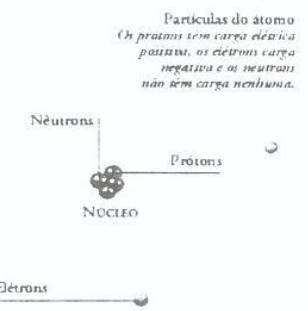

(fig. 2. Fonte: http://www.algosobre.com.br/img2/Image195.gif)

No entanto, isso não resolvia o problema da estabilidade do núcieo. pois cargas elétricas aceleradas emitem energia, e a perda de energía faria os elétrons espiralarem rapidamente em direça ao nucleo. emitindo radiacào em todos os comprimencs de onda e tornando os atomos instaveis. 
Esse modelo atômico não era satisfatório, pois os átomos obviamente são estáveis, além do mais era conhecido. através dos estudos dos espectros de emissão, que quando os átomos emitem radiação, eles o fazem somente em certos comprimentos de onda. específicos de cada elemento, e não em todos os comprimentos de onda.

\section{Mas como explicar as linhas espectrais?}

O Modelo atômico de Bohr

Em 1900, o físico Max Planck (1858-1957) havia apresentado um trabalho com idéias que permitiram uma melhor compreensão dos fenômenos de absorção e emissão de radiações em um corpo negro, ao considerar a energia, na emissão e na absorção, diretamente proporcional à freqüencia da radiação $(v)$ e sempre ocorrendo em pacotes, chamados quanta: $\mathrm{E}=\mathrm{h} . \mathrm{v}$, sendo h denominado constante de Planck e tendo valor: $\mathrm{h}=6.63 .10^{-34} \mathrm{~J} . \mathrm{s}$.

Em 1913. Niels Bohr propôs alguns postulados, a fim de fazer uma correção ao modelo atômico de Rutherford. levando em consideração a quantização de Planck e cujo significado foi elucidado por Einstein.

\section{$1^{\circ}$ POSTULADO DE BOHR}

Um elétron em um átomo se move numa órbita circular em torno do núcleo sob influência da atração de natureza elétrica, entre o elétron e o núcleo, obedecendo às leis da mecânica clássica.

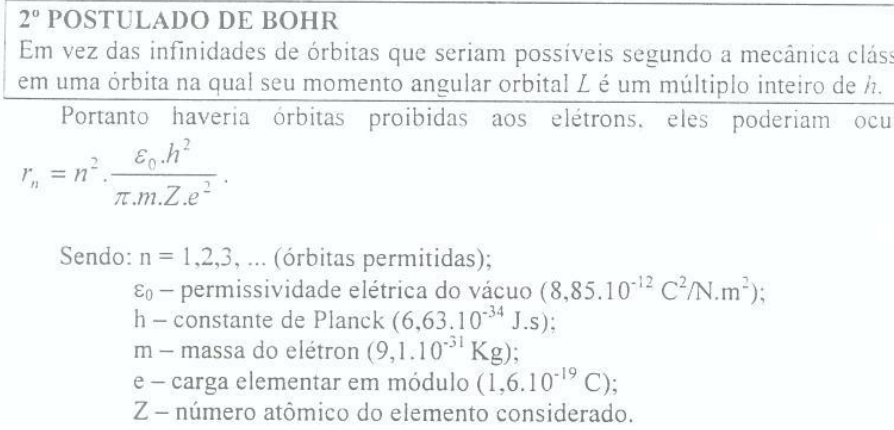
em uma órbita na qual seu momento angular orbital $L$ é um múltiplo inteiro de $h$. $r_{n}=n^{2} \cdot \frac{\varepsilon_{0} \cdot h^{2}}{\pi \cdot m \cdot Z \cdot e^{2}}$.

Sendo: $\mathrm{n}=1,2,3, \ldots$ (órbitas permitidas); $\varepsilon_{0}$ - permissividade elétrica do vácuo $\left(8,85.10^{-12} \mathrm{C}^{2} \mathrm{~N} \cdot \mathrm{m}^{2}\right)$;

h - constante de Planck $\left(6,63.10^{-34} \mathrm{~J} . \mathrm{s}\right)$;

$\mathrm{m}$ - massa do elétron $\left(9,1.10^{-31} \mathrm{Kg}\right)$;

e - carga elementar em módulo $\left(1,6.10^{-19} \mathrm{C}\right)$;

$\mathrm{Z}$ - número atômico do elemento considerado.

Em vez das infinidades de órbitas que seriam possiveis segundo a mecânica clássica. um elétron só pode se mover

Portanto haveria órbitas proibidas aos elétrons. eles poderiam ocupar apenas orbitas com raro:

\section{$3^{\circ}$ POSTULADO DE BOHR}

Apesar de estar constantemente acelerado, o elétron que se move numa dessas órbitas possiveis não emite radiação eletromagnética. Portanto, sua energia total $E$ permanece constante.

Os valores da energia nestas órbitas, seriam:

$$
E_{n}=-\frac{1}{n^{2}} \cdot \frac{m \cdot Z^{2} \cdot e^{4}}{8 \cdot \varepsilon_{0}{ }^{2} \cdot h^{2}}=\frac{E_{1}}{n^{2}}=-\frac{13.60}{n^{2}} .
$$

A unidade de energia ao fazer o cálculo é em Joule (J), no Sistema Internacional de Medidas. Também podemos usar como unidade de energia o elétron-volt (eV), onde: $1 \mathrm{eV}=1.6 .10^{-17} \mathrm{~J}$ ou $1 \mathrm{~J}=6.25 \cdot 10^{18} \mathrm{eV}$. Desta forma podemos obter a constante de Planck em eV.s: $h=6,63 \cdot 10^{-34} \cdot 6 \cdot 25 \cdot 10^{18} \mathrm{eV} . \mathrm{s}=4 \cdot 1 \cdot 10^{-15} \mathrm{eV} . \mathrm{s}$

Para que o valor da energia em eV seja convertida em J (Joule). o valor em eV deve ser multiplicado por $1,6.10^{-19} \mathrm{~J}$, pois por definição $\mathrm{l}$ eV (elétron-volt) é a energia que um elétron recebe ao ser acelerado por meio de uma diferença de potencial $\mathrm{U}=1 \mathrm{~V}$.

Para o átomo de Hidrogênio, em que $Z=1$ :

\begin{tabular}{|c|cc|}
\hline $\mathrm{N}$ (órbitas) & $\mathrm{r}_{\mathrm{n}}(\mathrm{A})$ & $\mathrm{E}_{\mathrm{n}}(\mathrm{eV})$ \\
\hline $\mathrm{n}=1$ (estado fundamental) & 0.52 & -13.60 \\
\hline $\mathrm{n}=2$ & 2.08 & -3.40 \\
\hline $\mathrm{n}=3$ & 4.68 & -1.51 \\
\hline
\end{tabular}

Lembrar que um angstron ( $1 \mathrm{~A}$ ) equivale a $10^{-14} \mathrm{~m}$. 

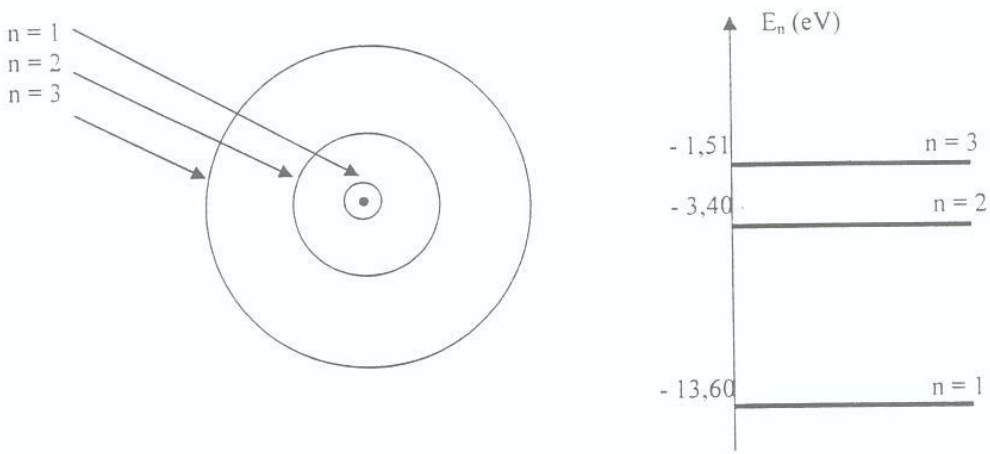

(fig. 3)

\section{$4^{\circ}$ POSTULADO DE BOHR}

É emitida radiação eletromagnética se um elétron que se move inicialmente sobre uma órbita de energia total $E_{l}$, muda seu movimento descontinuamente de forma a se mover numa órbita de energia total $E_{\%}$. A frequêencia da radiação emitida (v) é igual a: $E_{i}-E_{f} / h$.

Assim, no lugar do modelo planetário de átomo, com elétrons orbitando em volta do núcleo, no modelo atômico de Bohr os elétrons estão distribuidos em niveis de energia caracteristicos de cada elemento. Ao absorver energia, um elétron pode pular para outro nivel e depois voltar a seu nivel original. emitindo a mesma energia que recebeu Veremos brevemente que esta energia não poderá ter qualquer valor, ou seja, ela só poderá ser absorvida ou emitida por um elétron em valores bem definidos, discretos. Estes "pacotes" de energia são chamados de fótons.

Explicando os espectros atômicos com o modelo atômico de Bohr

Se fizermos a luz de uma lâmpada comum (de filamento incandescente) passar através de um prisma, ela será decomposta em várias cores, que são popularmente conhecidas como arco-iris. Cientificamente, o que se obtém é chamado de espectro da luz visível.

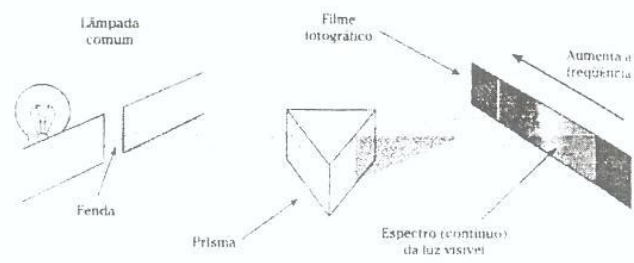

(fig. 4. Fonte: TITO, Cantor. Quimica Básica)

Contudo, se repetirmos essa experiência utilizando a luz proveniente de uma lâmpada de gás, não obteremos o espectro completo. Apenas algumas linhas estarão presentes, correspondendo somente a algumas freqüências das ondas de luz visivel. Essas linhas formam o espectro de linhas ou espectro atômico.

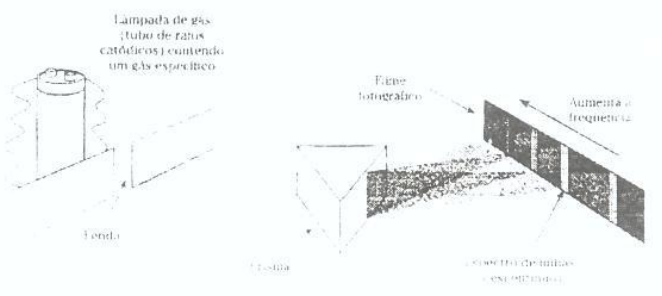

(fịg. 5. Fonte: TITO. Cantor. Quimuca Básica) 
Alguns exemplos de espectros atômicos aparecem na figura abaixo. Como você pode perceber. as linhas obtidas dependem do elemento utilizado e são descontínuas. E extremamente intrigante por que isso acontece. O fato é que acontece!

Utilizando o modelo atômico de Bohr pode-se explicar o mistério dos espectros atômicos. Conforme em seus postulados, os elétrons ao serem excitados por uma fonte externa de energia, saltam para um nivel de maior energia e ao retornarem aos niveis de menor energia, liberam energia na forma de luz (fótons). Como a cor da luz emitida depende da energia entre os niveis envolvidos na transição e como essa diferença varia de elemento para elemento, a luz apresentara cor característica para cada elemento quimico.

Dentre os espectros atômicos, vale ressaltar que existe o espectro de emissão quando o elétron perde energia emitindo um fóton e o espectro de absorção quando o elétron ganha energia absorvendo um fóton.

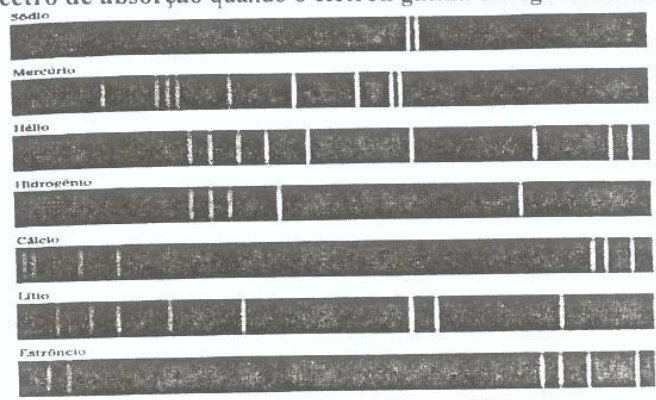

(fig. 6. Fonte: TITO, Cantor. Química Básica)

Espectro Atômico de alguns elementos

Espectro de Emissão
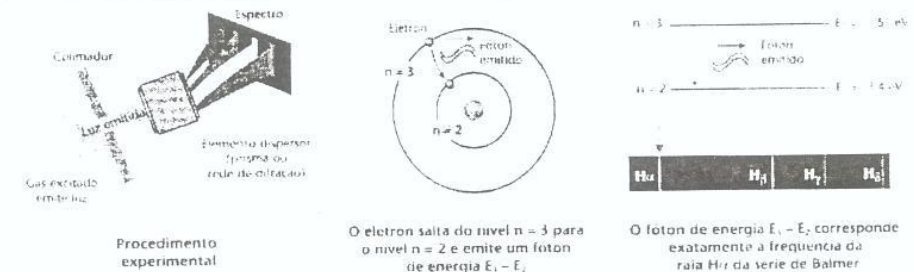

(fig. 7. Fonte: JÚNIOR, Dulcídio Braz. p.52)

Supondo que acima temos uma amostra de hidrogênio que de alguma forma foi excitada. podemos observar que um elétron saltou do nivel 2 para o nivel 3. Em seguida, ele retorna para seu estado inicial $n=2$. emitindo um fóton. No estado $n=3$ a energia é $E_{3}=-1,51 \mathrm{eV}$ e no estado $n=2$, a energia é $E_{2}=-3.40 \mathrm{eV}$. Desta forma, podemos calcular a freqüência do fóton emitido:

$$
\begin{aligned}
& \Delta E=h \cdot v \Rightarrow v=\frac{\Delta E}{h}=\frac{E_{3}-E_{2}}{h} \\
& v=\frac{-1.51-(-3.40)}{4,1 \cdot 10^{-15}} \Rightarrow v=4.6 \cdot 10^{14} \mathrm{~Hz}
\end{aligned}
$$

Utilizando uma chapa fotográfica podemos registrar essa linha e outras que sejam emitidas. Como houve emissão de energia pelo átomo. esse espectro recebe o nome de espectro de emissão. 


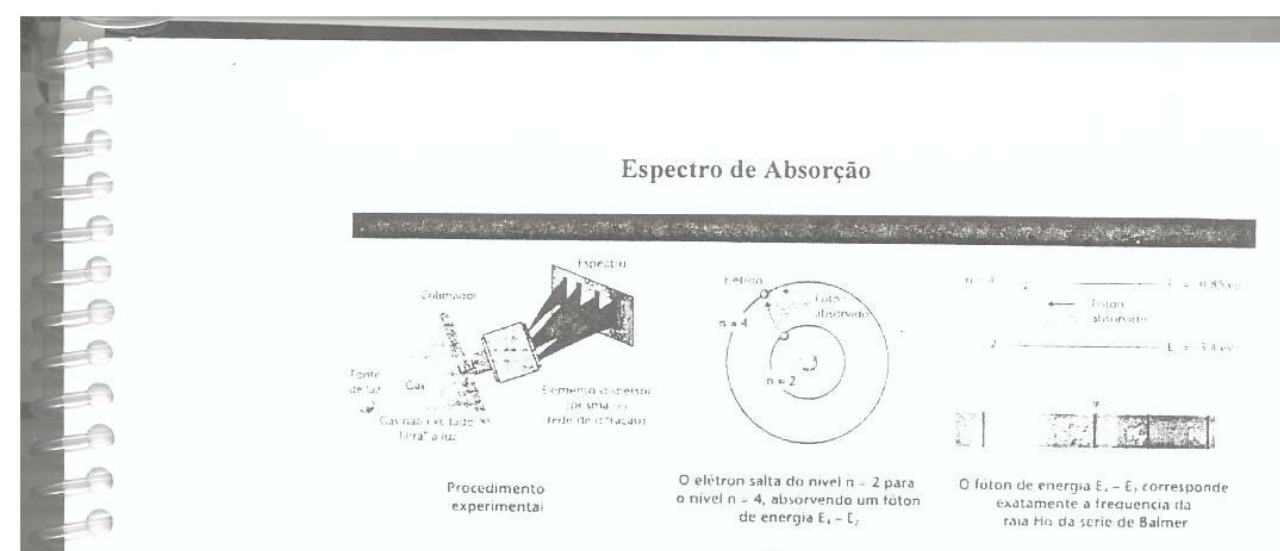

(fig. 8. Fonte: JÚNIOR, Dulcidio Braz. p.53)

Supondo que agora a amostra de hidrogênio é atravessada por um feixe de luz, os elétrons do gas podem absorver a energia da luz incidente, ou melhor, os fótons. Entretanto não é qualquer fóton que interessa para os elétrons, mas apenas aqueles cuja energia for suficiente para proporcionar um salto quântico entre os niveis de energia permitidos. Assim, alguns fótons de certa energia (freqüência) serão absorvidos. enquanto outros passarão e não serão absorvidos pelo gás.

Imaginando que um elétron que esteja ocupando o nivel $\mathrm{n}=2$. com energia $\mathrm{E}_{2}=-3.40 \mathrm{eV}$, absorva um determinado fóton do feixe incidente, saltando para uma órbita mais afastada. por exemplo $n=4$. com energia $E_{4}=$ $-0,85 \mathrm{eV}$, a freqüência do föton absorvido será:

$$
\begin{aligned}
& \Delta E=h \cdot v \Rightarrow v=\frac{\Delta E}{h}=\frac{E_{4}-E_{2}}{h} \\
& v=\frac{-0.85-(-3,40)}{4,1 \cdot 10^{-15}} \Rightarrow v=6,2 \cdot 10^{14} \mathrm{~Hz}
\end{aligned}
$$

Mais uma vez, utilizando uma chapa fotográfica podemos registrar esse espectro. Só que agora teremos um espectro diferente do espectro de emissão, pois aparecerão linhas escuras, relativas à luz de certas freqüências convenientes e que foram absorvidas do feixe incidente. Como houve absorção de energia, esse espectro recebe o nome de espectro de absorção.

Assim, os espectros de emissão e absorção ocupam a mesma posição, pois estão associados a uma mesma freqüência, sendo que a diferença fundamental é que as linhas de emissão correspondem a fötons emitidos num salto quântico ao passo que as linhas escuras de absorção correspondem a fótons absorvidos durante um salto quântico.

\section{BIBLIOGRAFIA:}

JÚNIOR, Dulcídio Braz. Tópicos de Fisica Moderna. Campinas, SP. Ed. Companhia da Escola. 2002.

TITO, Cantor. Ouimica Básica. São Paulo. Ed. Moderna, 2004

http://www.algosobre.com.br

http://astro.if.ufrgs.br

Questões:

1-) Calcule a energia no nivel energético $\mathrm{n}=4$ para o átomo de hidrogênio.

2-) Considere que o elétron no átomo de hidrogênio "salte" do nivel de energia $n=3$ para o estado fundamental (nivel $\mathrm{n}=1$ ). Baseando-se no diagrama de niveis para o átomo de hidrogênio, responda:

a) Ao realizar esse "salto", o elétron absorveu ou emitiu energia? Qual o valor dessa energia envolvida. em elétron-volt.?

b) Qual o valor da energia envolvida. em Joule. e a freqüência da luz emitida nessa transição de niveis?

3-) Suponha que no átomo de hidrogênio. um eletron do nivel de energia $n=2$. volte para o estado fundamental. Baseando-se no diagrama de niveis para o átomo de hidrogênio. responda:

a) Ao realizar essa transição. o elétron absorveu ou emitiu energia? Qual o valor dessa energia. em elétron-volt?

b) Qual o valor da energia envolvida. em Joule. e a freqüencia da luz emitida nessa transicão de niveis? 
4-) Com base no modelo atômico de Bohr, seus postulados e os espectros atômicos, procure justificar porque no espectro de emissão do hidrogênio existem 5 raias visiveis (ver figura do espectro atômico de alguns elementos), se ele é um elemento que possui apenas um elétron em seu estado fundamental.

5-) (PUCRS) Um átomo excitado emite energia, muitas vezes em forma de luz visível, porque:

a) um de seus elétrons foi arrancado do átomo.

b) um dos elétrons desloca-se para níveis de energia mais baixos, aproximando-se do núcleo.

c) um dos elétrons desloca-se para níveis de energia mais altos, afastando-se do núcleo.

d) os elétrons permanecem estacionários em seus níveis de energia.

e) os elétrons se transformam em luz. segundo Einstein.

6-) (UFJF 2001) A presença de um elemento atômico em um gás pode ser determinada verificando-se as energias dos fótons que são emitidos pelo gás, quando este é aquecido. No modelo de Bohr para o átomo de hidrogênio, as energias dos dois níveis de menor energia são: $\mathrm{E} 1=-13,6 \mathrm{eV}$ e E2 $=-3,40 \mathrm{eV}$. Considerando-se essas informações, um valor possivel para a energia dos fótons emitidos pelo hidrogênio aquecido é:
a) $-17,0 \mathrm{eV}$.
b) $-3,40 \mathrm{eV}$.
c) $8,50 \mathrm{eV}$.
d) $10,2 \mathrm{eV}$.

\section{Exercícios e questões complementares sobre Modelo de Bohr:}

1. O que ocorre quando a luz branca do Sol atravessa um prisma?

2. O que é um espectro contínuo?

3. Em que consiste a espectroscopia?

4. Os cientistas Bunsen e Kirchoff fizeram muitas observações que forneceram subsídios para o estudo da espectroscopia. Que observações foram essas?

5. Quando um gás é introduzido no interior de uma lâmpada, ficando a baixa pressão e sofrendo descargas elétricas, ele emite uma luz que apresenta que tipo de espectro: contínuo ou descontínuo?

6. O espectro de luz solar (visível) compreende que faixas de comprimento de onda aproximadamente? E de frequiências?

7. $O$ que representa em termos físicos a expressão de Max Planck $E=h$. f para uma onda eletromagnética?

8. Pensando no espectro de luz branca e lembrando que a primeira cor deste espectro é o vermelho (maior comprimento de onda) e a última é o violeta (menor comprimento de onda), qual destas luzes tem a maior freqüência? E a maior energia?

9. O modelo atômico de Rutherford apresentava um problema de estabilidade do núcleo. Explique que problema é esse.

10. Bohr substituiu o modelo de Rutherford para o átomo. Como se define o modelo de Bohr?

11. Quais são os postulados de Bohr?

12. O que significa dizer que o átomo está excitado?

13. Quando estudamos os espectros, vimos que há espectros continuos e discretos, e que o modelo atômico de Rutherford não explicava o espectro discreto. Como se explica a existência desse tipo de espectro usando o modelo de Bohr?

14. O que é um espectro de emissão? Explique usando o modelo atômico de Bohr.

15. Qual a diferença entre o espectro de emissão e o de absorção?

16. É correto afirmarmos que no modelo atômico de Bohr aplicado ao átomo de hidrogênio o elétron pode apresentar qualquer valor de energia? Justifique.

17. "Uma amiga sua sugere que, para o bom funcionamento. os átomos de gás neônio no interior de um tubo deveriam ser periodicamente substituídos por átomos frescos, pois a energia dos átomos tende a se exaurir com a continua excitação dos mesmos. produzindo uma luz cada vez mais fraca. como vemos nas lâmpadas fluorescentes." Você concorda ou discorda dessa afirmação? Justifique.

18. Um feixe de raios $\mathrm{X}$ é totalmente absorvido por uma placa de chumbo. Se a energia desse raio $\mathrm{X} e ́$ $E_{1}$ e sua frequêencia é $v_{1}$, podemos afirmar que:

a) Essa energia faz o elétron da placa se aproximar do nucieo. 
b) Após essa absorção, a placa de chumbo vai emitir um raio $\mathrm{X}$ de freqüência $v_{1}$

c) Após essa absorção, o chumbo pode emitir um raio $\mathrm{X}$ de freqüência menor que $v$

d) Essa energia faz o elétron saltar de uma órbita mais próxima para uma mais afastada do núcleo.

19. Por que não brilhamos no escuro?

20. Calcule a energia para o átomo de hidrogênio para o nível energético:
a) $n=2$
b) $n=3$
c) $\mathrm{n}=4$

21. Através da expressão $E n=-13,6 / \mathrm{n}^{2}$, podemos calcular a energia (E) no modelo atômico de Bohr. Com base nisso responda:

a) $\mathrm{O}$ que "n" representa nesta expressão?

b) Qual a unidade de medida de energia neste caso? Existem outras? Cite-as.

c) Qual o valor da energia quando $n=1$ ? O que este valor representa?

22. O átomo de hidrogênio possui número atômico $1(Z=1)$. De acordo com o modelo atômico de Bohr, responda: Qual a raio do átomo $\mathrm{H}$, em angstrom para $\mathrm{n}=1$ ? E em metros?

23. Calcule a energia recebida pelo elétron na transição do nivel 2 para o 3. Qual a freqüência da onda absorvida? Se esse elétron voltar para o nivel 2, qual será a freqüência da onda emitida?

24. Ionizar um átomo é fazer com que seu elétron seja "desligado" de seu núcleo, isto é, que o átomo "perca" aquele elétron. Considerando o diagrama de energia do hidrogênio, ao lado, quanto de energia é necessário fornecer a um elétron no estado fundamental/(n=1) para ionizar esse átomo? Isso corresponde ao elétron ser atingido por uma onda de que freqüência?

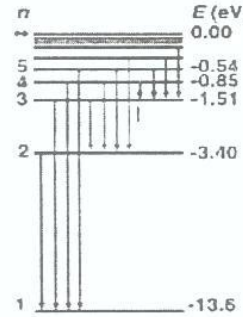


Trabalhos dos alunos: Trabalho de observação com espectroscópio - pesquisa de campo - exemplos com desenhos:

$3^{\circ} \mathrm{G}$ :

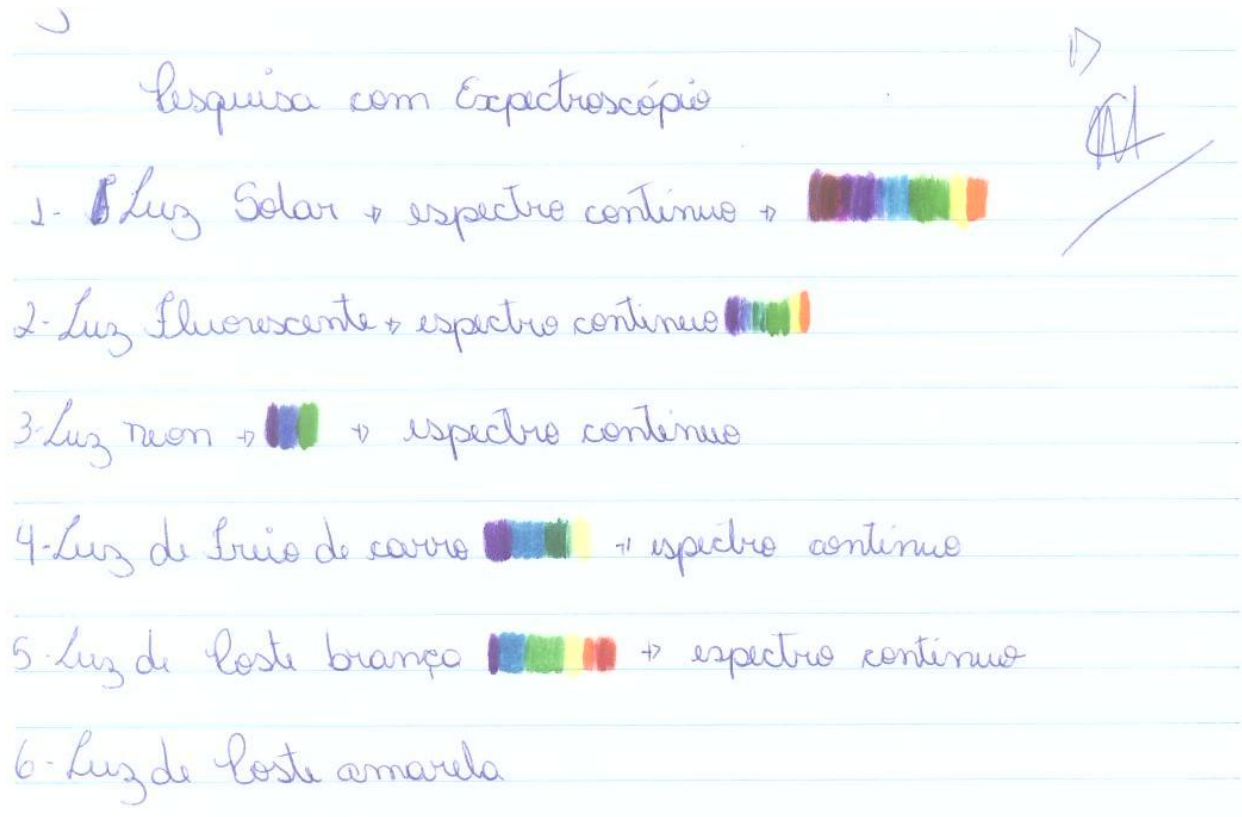


Pesquisa com Espectrascópio

IV $\rightarrow$ luz do Sol espectrocontinuo 1 luz de Neon espectac continuo

1: li: luz de paste branca "I " "I - luz liverescente "F " "I

*iili luz de Freio de carro "I "I II 


\section{"Fisica}

and II luz solar=expectro conténuc

Eate $\rightarrow$ luz neon = expectro continuo

Will II luz die peste branco (laper de mercirio lespectro continuo

Iill I liz Shorescente = espectro continuo

WAll treio de Carro = espectro continuo 


\begin{tabular}{l} 
PESqUISA \\
\hline LUZ \\
NEON \\
SOLARECTRO
\end{tabular}


$3^{\circ} \mathrm{D}$ :

$48,36 \quad 3 D$

\begin{tabular}{|c|c|c|c|c|}
\hline \multicolumn{7}{|c|}{ Pesquisa de Campo: Espectros e Luzes } \\
\hline $\begin{array}{c}\text { Luzes e } \\
\text { Lampadas }\end{array}$ & $\begin{array}{c}\text { Espelho Continuo } \\
\text { ou Discreto }\end{array}$ & $\begin{array}{c}\text { Frequências (cores } \\
\text { no espetro) }\end{array}$ & Maior Banda & Menor Banda \\
\hline 1 - Luz Solar & & & & \\
\hline 2-Incandescente & 0 & & & \\
\hline 3- Fluorescente & & & & \\
\hline 4- Luz de Freio & & & & \\
\hline 5 - Xenônio & & & & \\
\hline
\end{tabular}

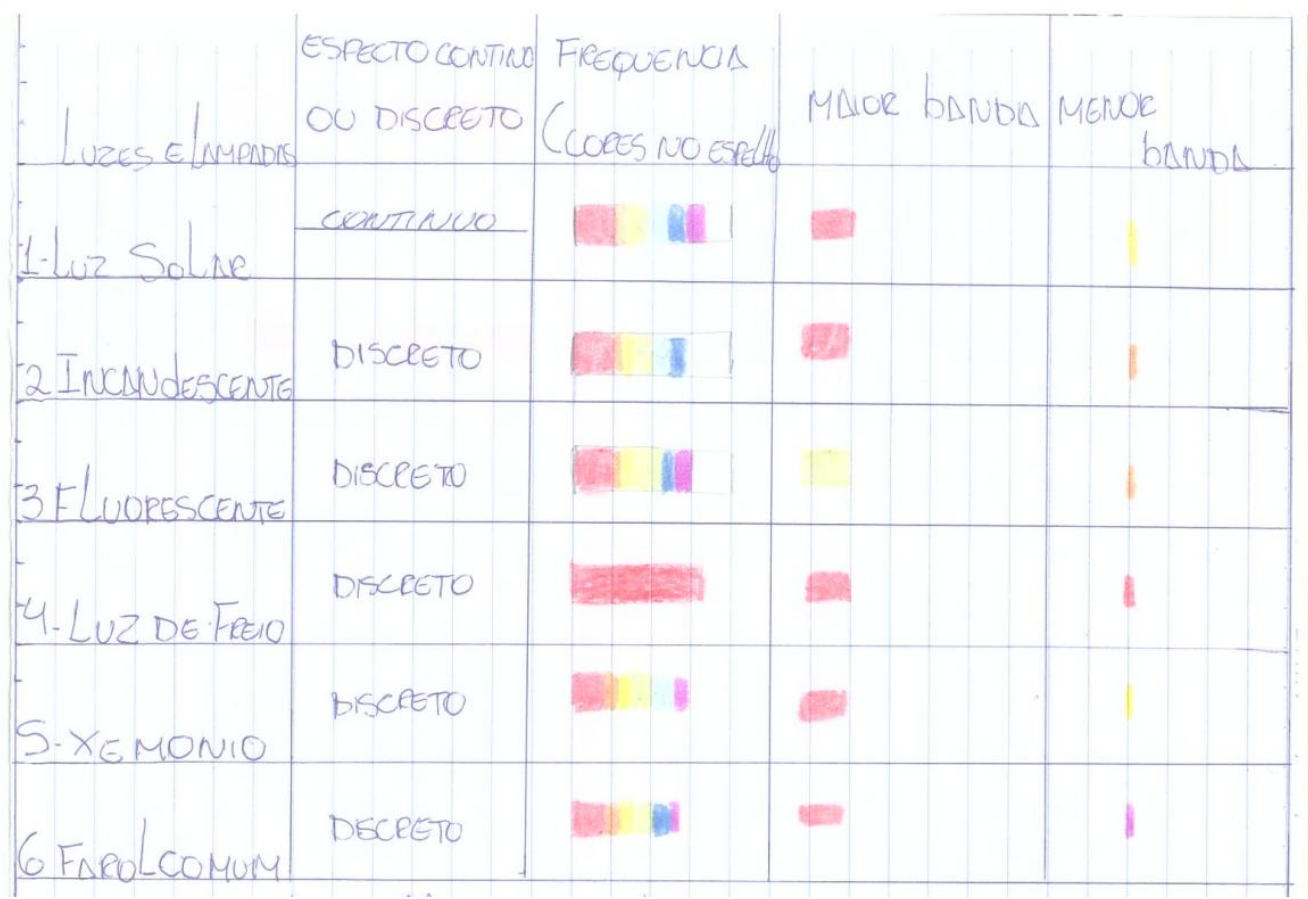




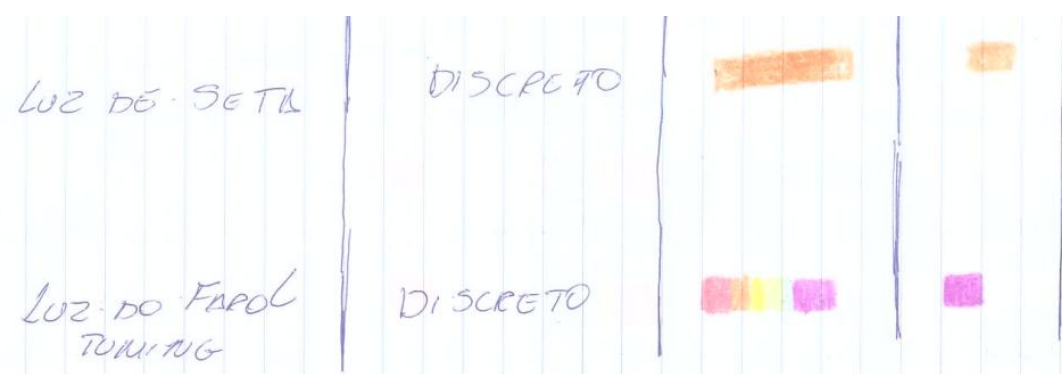

\begin{tabular}{|c|c|c|c|c|}
\hline Luzor a Lompader & $\begin{array}{l}\text { eapecto contiriud } \\
\text { sun dhesereto }\end{array}$ & 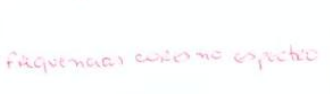 & 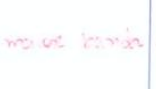 & mercict Lant? \\
\hline$\ldots 7$ SoLar & conthoo & & & \\
\hline Incandscente & Dincrecto & & & \\
\hline furosencente & Viscreto & & & \\
\hline Frilo & buecricto & & 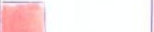 & t \\
\hline Xenonio & 1) secareto & & 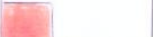 & \\
\hline farol (womiun) & & & & (7) \\
\hline $\operatorname{Ln} 7$ Seta & & & 2 & $\sqrt{1+1}$ \\
\hline Lut de faro? (JNing) & $x+2=2,6+0$ & & & \\
\hline
\end{tabular}




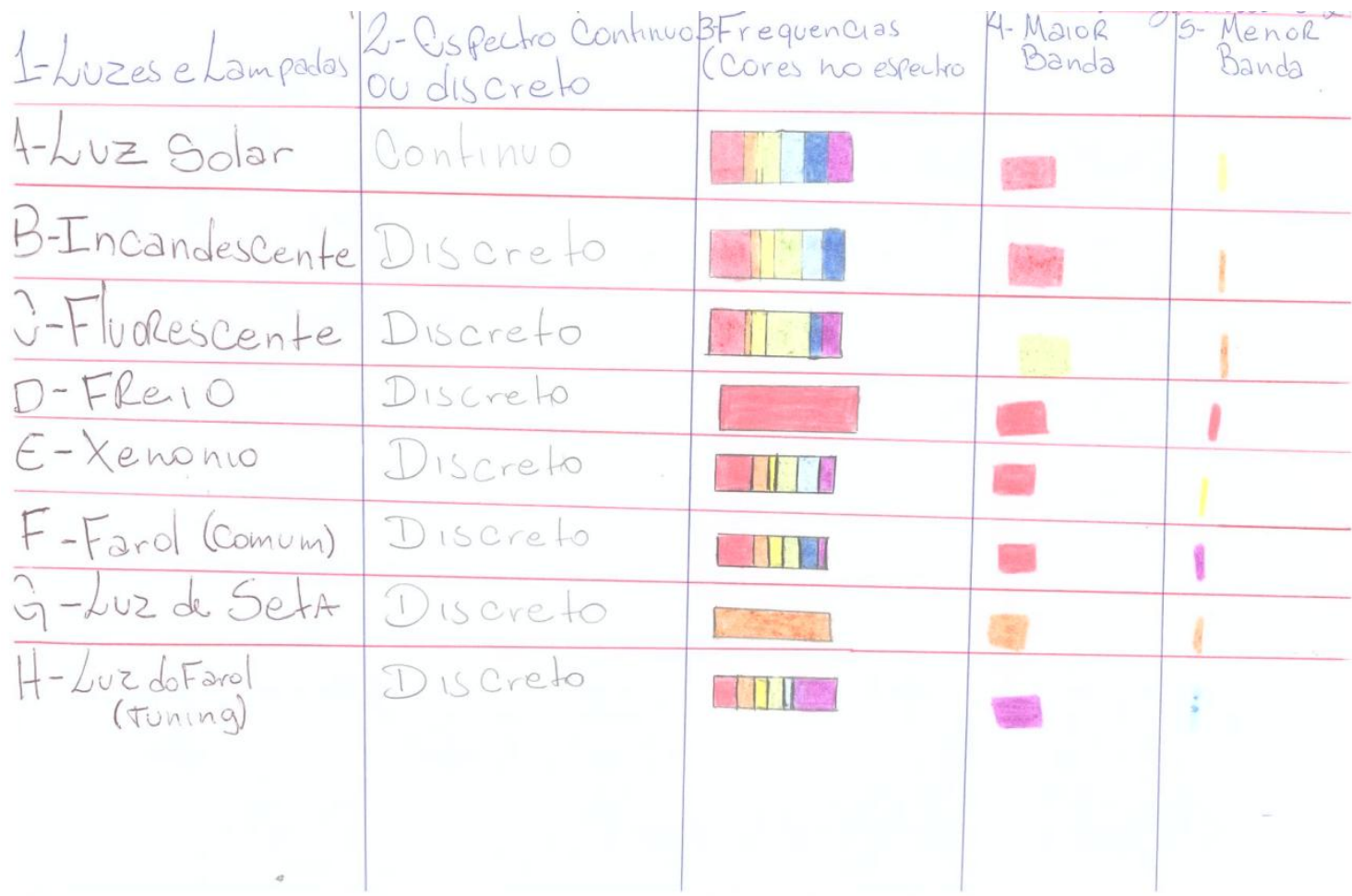

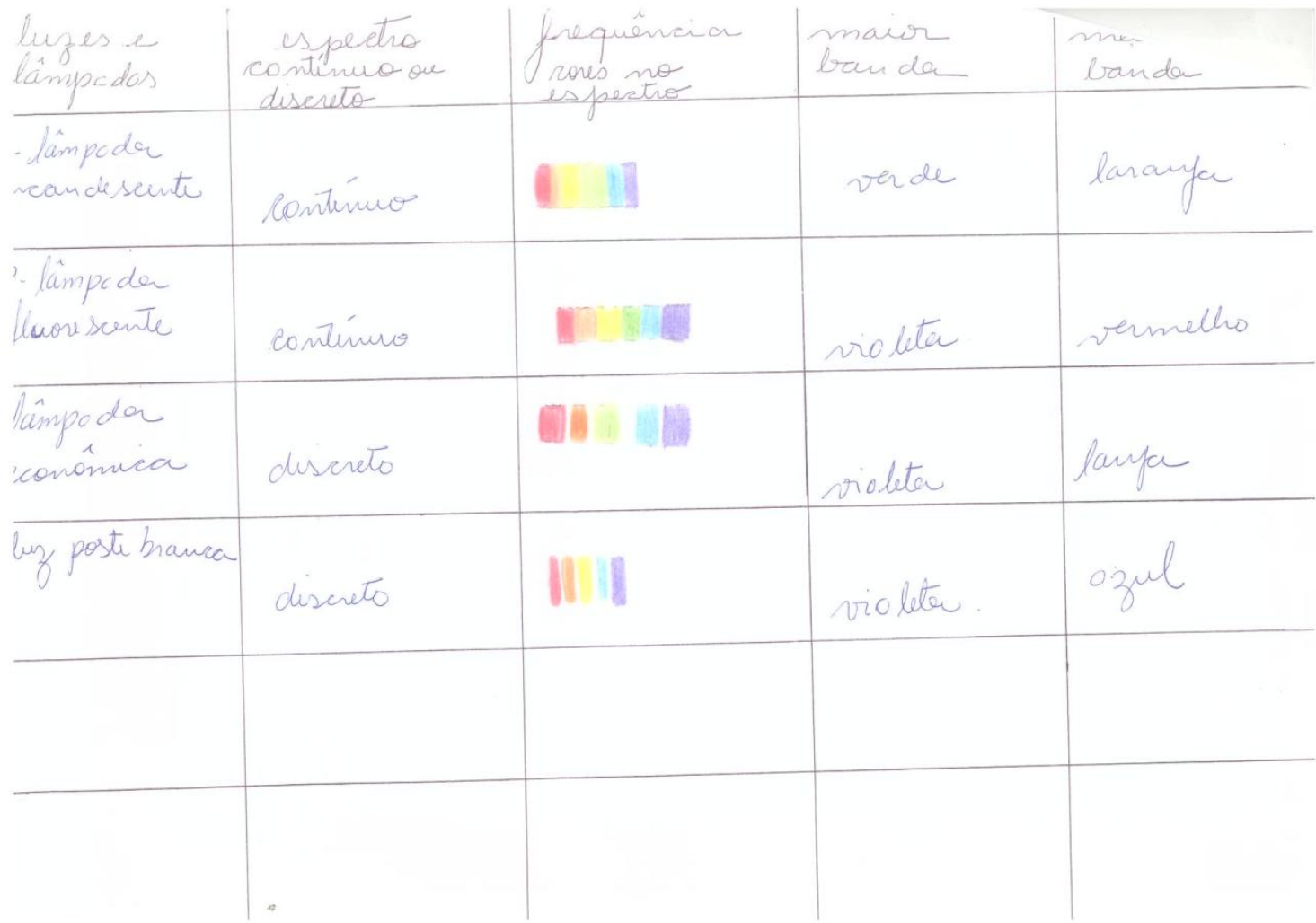




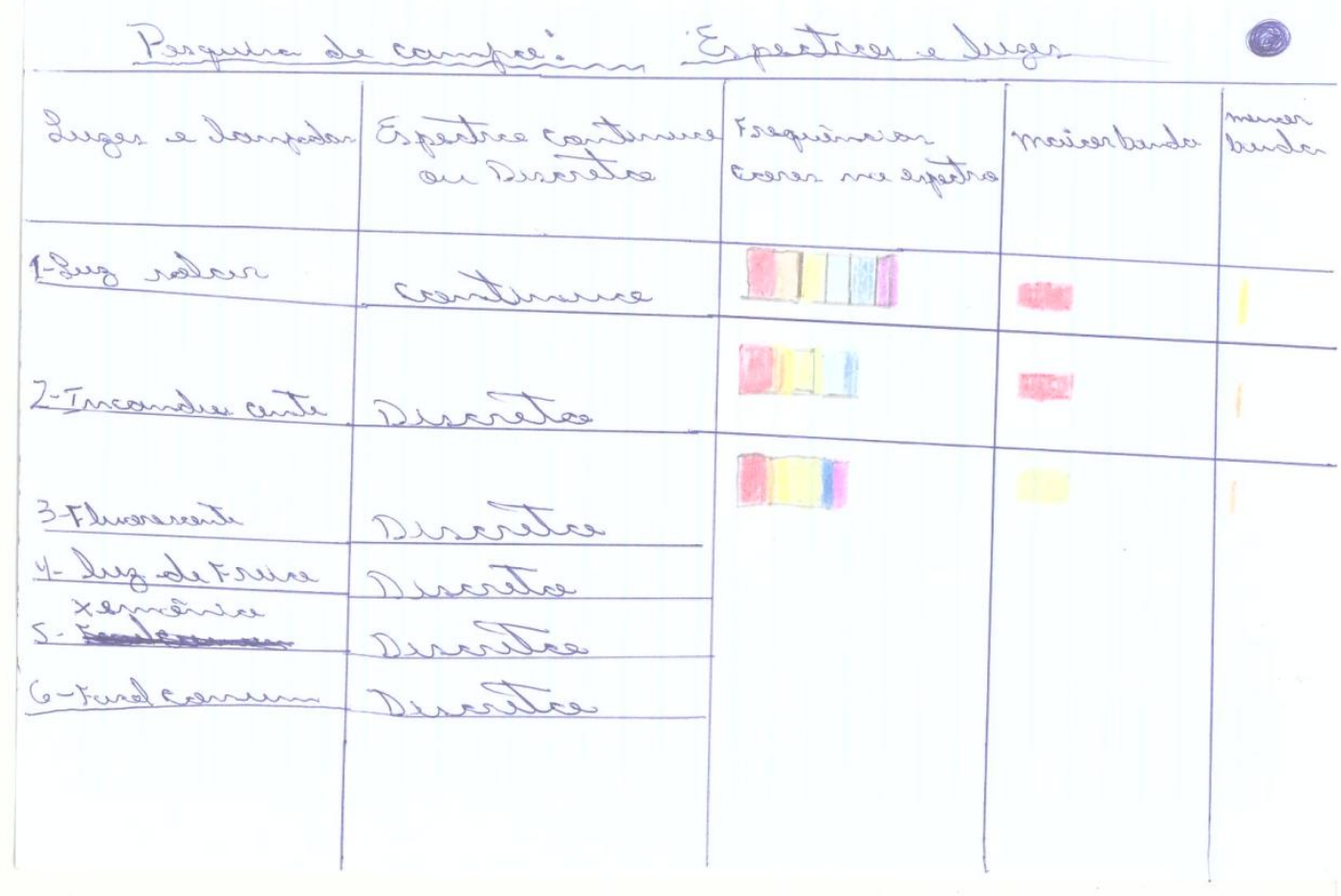

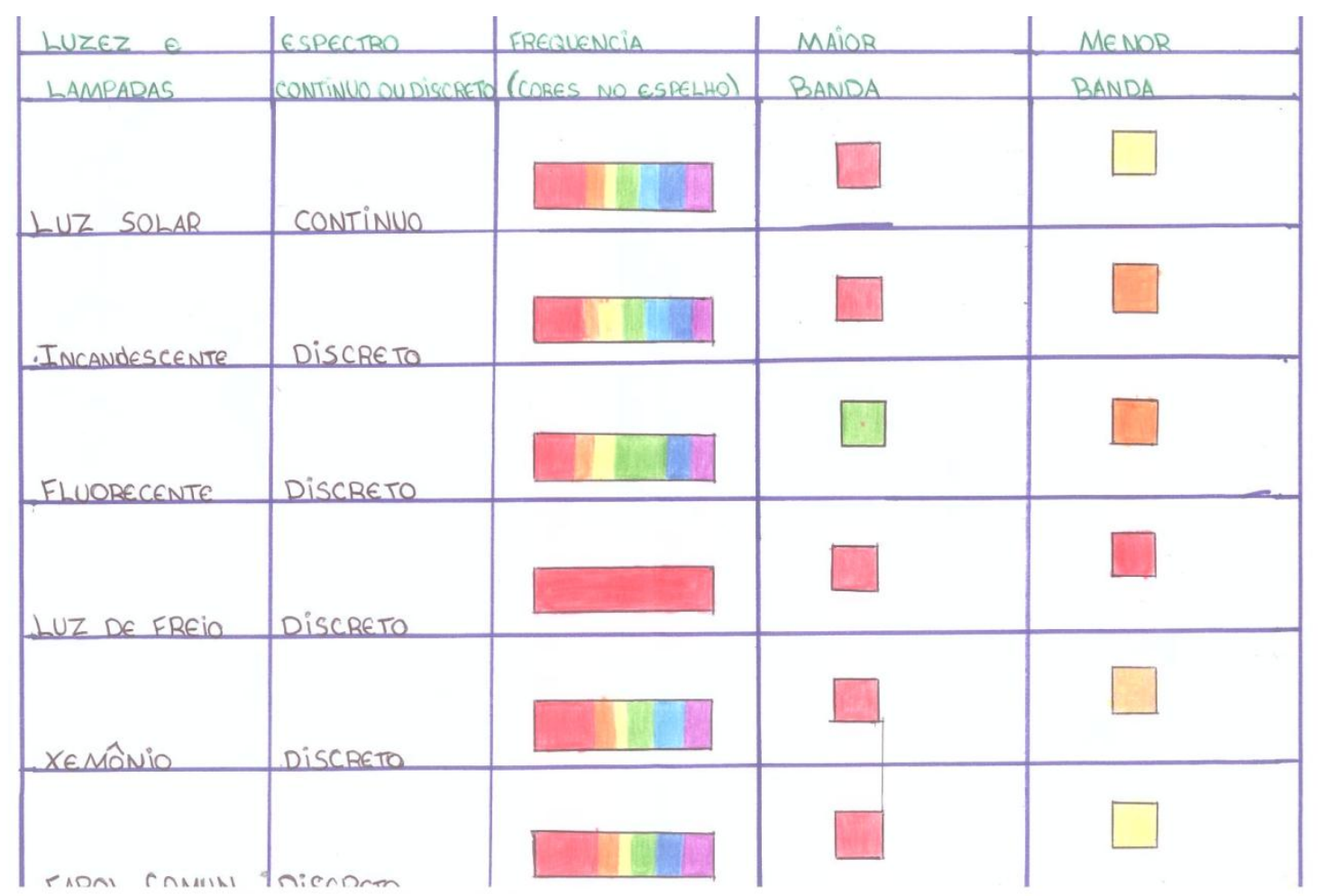


Trabalho astrônomo mirim entregue pelo grupo observado $-3^{\circ} \mathrm{G}$

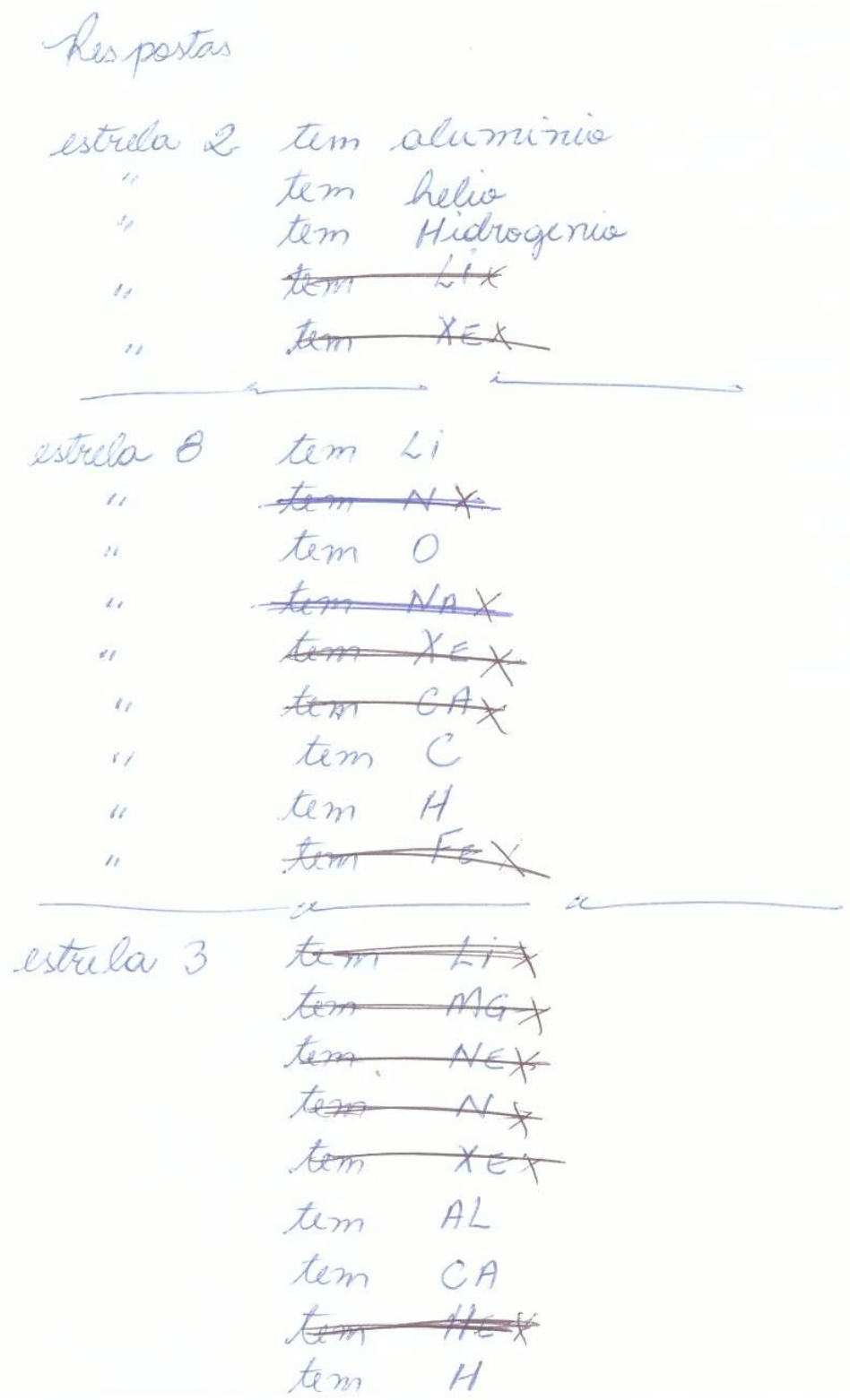




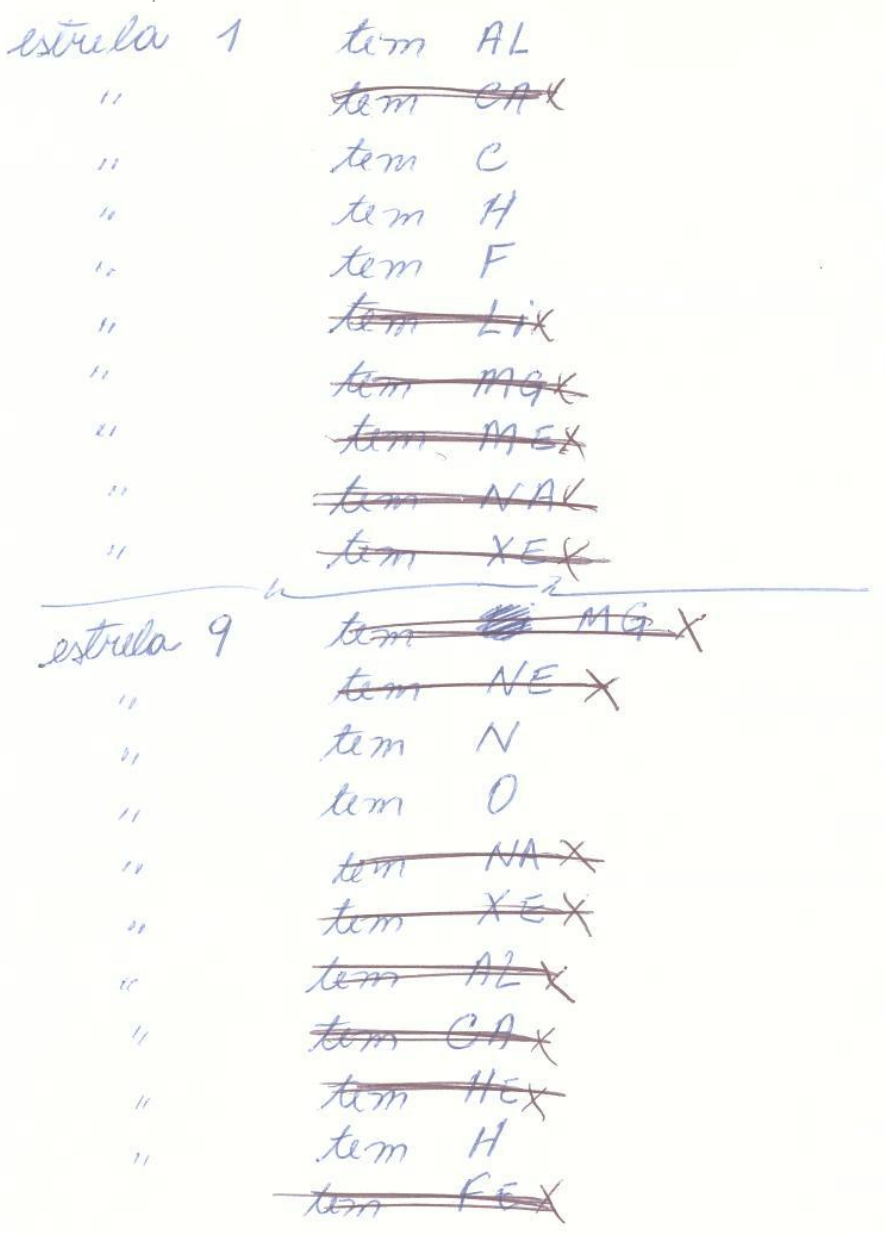

